UNIVERSIDADE DE SÃO PAULO

FACULDADE DE FILOSOFIA, LETRAS E CIÊNCIAS HUMANAS

DEPARTAMENTO DE HISTÓRIA

PROGRAMA DE PÓS-GRADUAÇÃO EM HISTÓRIA SOCIAL

\title{
O emergir do corpo neurológico no corpo paulista: Neurologia, Psiquiatria e Psicologia em São Paulo a partir dos periódicos médicos paulistas. (1889-1936)
}

Afonso Carlos Neves

Tese apresentada ao Programa de Pós-Graduação em História Social, do Departamento de História da Faculdade de Filosofia, Letras e Ciências Humanas da Universidade de São Paulo, para obtenção de título de Doutor em Ciências.

Orientadora: Profa. Dra. Maria Amélia Mascarenhas Dantes

V. 1

São Paulo

2008 
AUTORIZO A REPRODUÇÃO E DIVULGAÇÃO TOTAL OU PARCIAL DESTE TRABALHO, POR QUALQUER MEIO CONVENCIONAL OU ELETRÔNICO, PARA FINS DE ESTUDO E PESQUISA, DESDE QUE CITADA A FONTE.

Serviço de Biblioteca e Documentação da Faculdade de Filosofia, Letras e Ciências Humanas da Universidade de São Paulo

Neves, Afonso Carlos
N518 O emergir do corpo neurológico no corpo paulista : Neurologia, Psiquiatria e Psicologia em São Paulo a partir dos periódicos médicos paulistas (1889-1936) / Afonso Carlos Neves ; orientadora Maria Amélia Mascarenhas Dantes. -- São Paulo, 2008.

2 v. : il.

Tese (Doutorado -- Programa de Pós-Graduação em História Social. Área de concentração: História Social) --Departamento de História da Faculdade de Filosofia, Letras e Ciências Humanas da Universidade de São Paulo.

1. Neurologia - São Paulo (1889-1936). 2. Psiquiatria - São Paulo (1889-1936). 3. Psicologia - São Paulo (1889-1936). I. Título. 
Dedicatória

Este trabalho é dedicado a

Daisy, Raquel e Tomaz. 


\section{Agradecimentos}

À Profa. Dra. Maria Amélia Mascarenhas Dantes, que orientou este trabalho de forma meticulosa, minuciosa, disciplinada e paciente, tornando, assim, possível uma navegação entre os métodos da história e os meandros da ciência médica.

À historiadora Márcia Regina de Barros Silva, por sua valiosa ajuda nas buscas bibliográficas, bem como nas dicas a respeito da elaboração de um trabalho de história social.

Ao historiador Luis Antonio Coelho Ferla, pelas sugestões e perguntas em torno de questões deste trabalho, bem como em apresentar-me os estudos do espanhol Huertas.

Ao Prof. Dr. Alberto Alain Gabbai, chefe da Disciplina de Neurologia da Unifesp, por apoiar a realização deste trabalho.

À Profa. Dra. Maria Regina Simões de Paula, por alimentar minha curiosidade histórica em tempos de medicina, de modo que me faz lembrar Marc Bloch ao dizer que "história é ciência com poesia”.

A minha esposa Daisy, à minha filha Raquel e a meu filho Tomaz, por tolerarem a ocupação do tempo e do espaço doméstico com tantos livros, papéis, computadores, narrativas, etc.

A meus pais Odail e Lourdes por minha formação. 
“A ciência é a auxiliar da ação. E a ação visa a um resultado.

A inteligência científica pergunta, pois o que deverá ser feito para que um certo resultado desejado seja obtido, ou, mais geralmente, que condições são necessárias para que um certo fenômeno se produza. Ela vai de um arranjo de coisas a um rearranjo, de uma simultaneidade a uma simultaneidade. Necessariamente ela negligencia o que se passa no intervalo; ou, se disto se ocupa, é para aí considerar outros arranjos, simultaneidades ainda. Com métodos destinados a apreender o feito, ela não saberia, em geral, penetrar no que se faz, seguir o movimento, adotar o devir que é a vida das coisas. Esta tarefa pertence à filosofia. Enquanto o cientista, constrangido a tomar do movimento aspectos imóveis e a colher repetições ao longo do que não se repete, pronto para dividir comodamente a realidade sobre planos sucessivos em que ela se desenvolve a fim de submetê-la à ação do homem, é obrigado a astuciar com a natureza, a adotar em relação a ela uma atitude de desconfiança e de luta, o filósofo a trata como camarada. A regra da ciência é aquela posta por Bacon: obedecer para comandar. O filósofo não obedece nem comanda; ele procura simpatizar”.

Henri Bergson 


\section{$\underline{\text { Resumo }}$}

Nesta pesquisa estudamos o estabelecimento das áreas científicas neurologia, psiquiatria e psicologia, em São Paulo, no período entre 1889 e 1936, principalmente através de artigos científicos em periódicos médicos paulistas. A partir da instalação da República, iniciou-se um movimento médico de organização da sociedade e promoção da ciência que se expressou nas áreas em questão através de Franco da Rocha e de sua obra no Hospício do Juquery. Tanto ele quanto seus sucessores criaram o que se pode chamar de “escolas paulistas” em torno das disciplinas estudadas. A partir de uma conceituação de corpo neurológico elaborada por Foucault, constatamos que a elaboração desse corpo pelos estudiosos realinhou fronteiras entre neurologia, psiquiatria e psicologia, com a migração de moléstias entre esses grupos. Esse corpo neurológico adquiriu características próprias paulistas, em momento de afirmação de São Paulo no fim do período estudado.

\section{$\underline{\text { Abstract }}$}

With this research, we studied the stablishment of neurology, psychiatry and psychology in São Paulo, between 1889 and 1936, mainly by articles in scientific journals of São Paulo. Since the Republic starting, a medical movement tried to organize the society and promote science. This factors had expression in the concerned areas by Franco da Rocha and his work in Juquery Asylum. He and his followers created something that we can call "schools of São Paulo" around the studied scentific fields. With a conception of neurologic body elaborated by Foucault, we observed that the researchers rearranged the frontiers among neurology, psychiatry and psychology, with the migration of diseases from one to other of these disciplines. The neurologic body received its own caracterization of São Paulo, in a moment of reinforcement of that place in the end of the focused period. 
Índice

Prefácio. .11

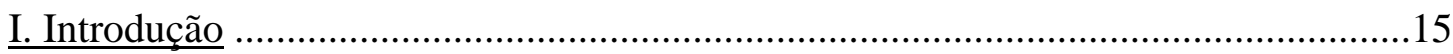

I. 1 - Apresentação do tema ……………………………………………………......15

I. 2 - São Paulo como palco das ciências enfocadas ……………………………….....16

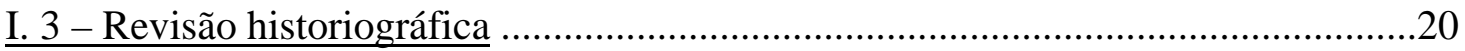

I. 3. 1 - Origem dos termos psicologia, neurologia e psiquiatria ..................................20

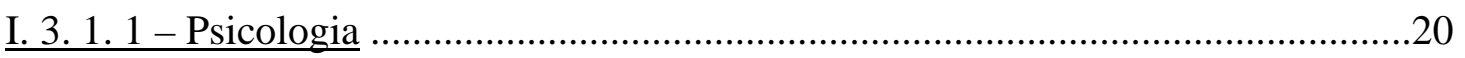

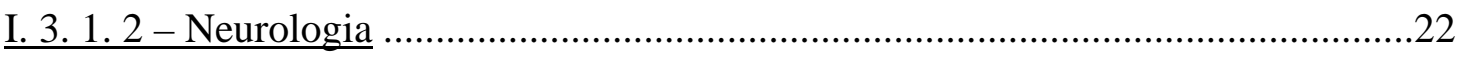

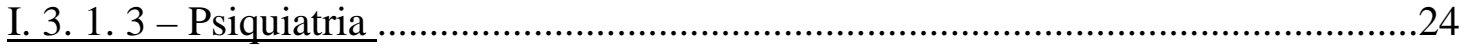

I. 3.2 - Estudos historiográficos mais recentes ..........................................................26

I. 3. 2. 1. - A história da história da psiquiatria..............................................................26

I. 3. 2. 2. - Foucault e os conceitos de "corpo neurológico" e de outros corpos............34

I. 3. 2. 3 - Rafael Huertas e o corpo social .................................................................41

I. 3. 3. - Historiografia sobre psiquiatria, psicologia e neurologia no Brasil

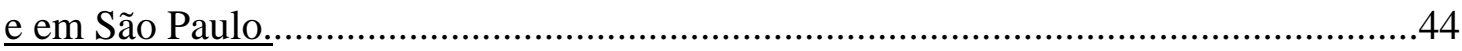

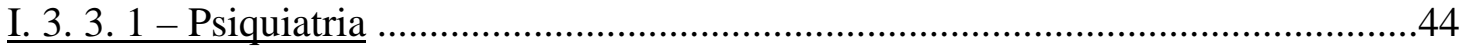

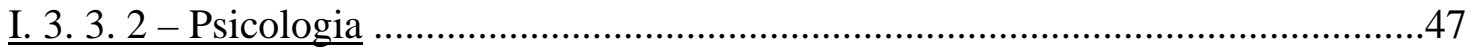

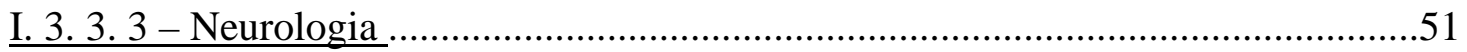

I. 4 - Fontes e Método................................................................................................51

Capitulo 1 - Considerações gerais sobre as áreas enfocadas e personagens relacionadas às mesmas. ………………………………......54

1.1 - Caracterização das áreas em questão a partir de alguns trabalhos e personagens brasileiros.......................................... 56

1.1.1 - Um achado: o livro de Teixeira Brandão ………………………………….......57

1.1. 2 - Claro Homem de Mello e Franco da Rocha: primeiros psiquiatras em São Paulo.................................................................... 63

1. 1. 3 - Algumas obras iniciais de Franco da Rocha. ................................................65

1. 1. 3. 1 - A tese inaugural de Franco da Rocha ................................................................65 
1. 1. 3. 2. - Uma obra de Franco da Rocha do início do século XX ..........................70

1. 2 - Linguagens, nomes, classificações...................................................................77

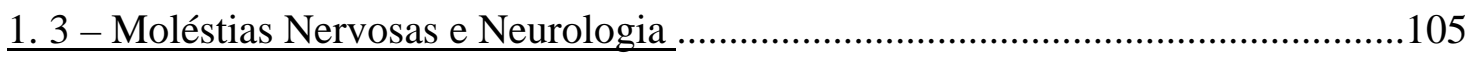

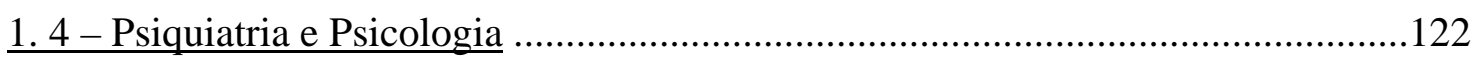

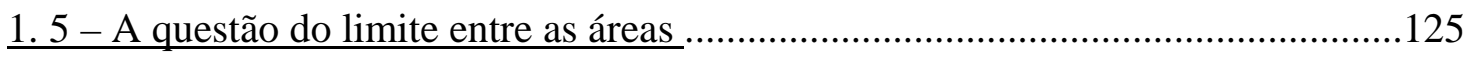

1. 6 - Intersecção com outras áreas científicas e com outros setores ..........................131

1. 7 - Osório César e sua obra, interface entre psiquiatria e arte: um outro retrato do Juquery. .........................................................................134

1.8 - A década de 1880 - período de transições ................................................... 148

Capítulo $2-1^{\circ}$ Período - 1889-1898:

Do Império à República, da Ladeira do Tabatingüera para as margens do Juquery:

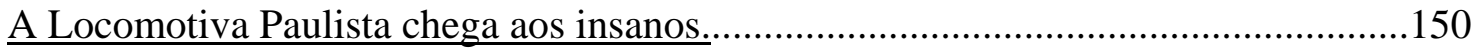

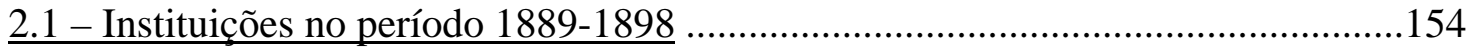

2. 1. 1. - Assistência a Alienados em São Paulo antes do Juquery ...............................158

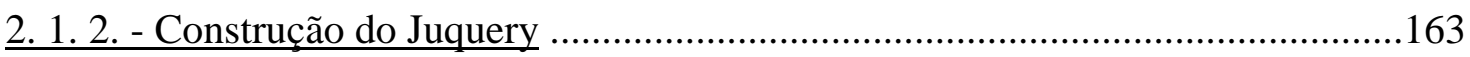

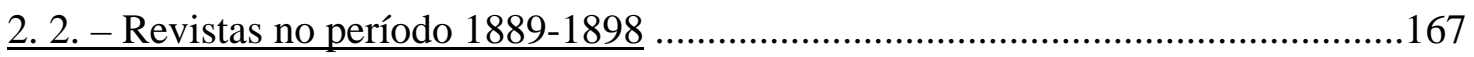

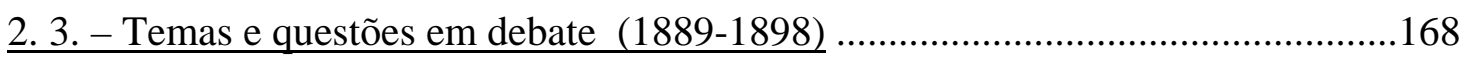

2. 3. 1. - Os debates presentes na Revista Medica de S. Paulo em 1889 ....................169

2. 3. 2. - Classificações de doenças psiquíatricas. (1889-1898)..............................170

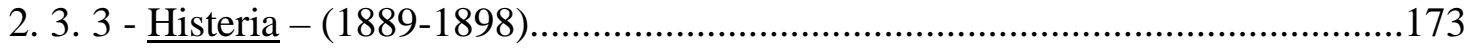

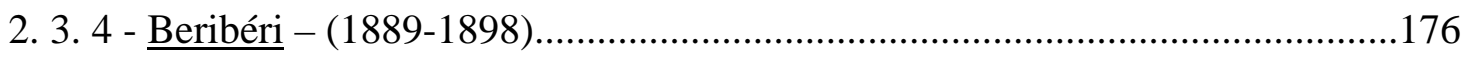

2. 3.5 - Doutrina do neurônio - (1889-1898)...............................................................178

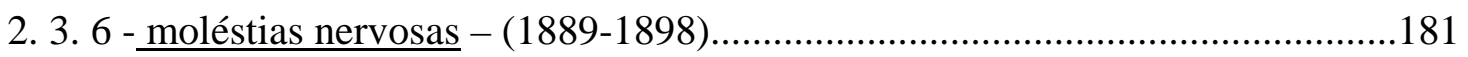

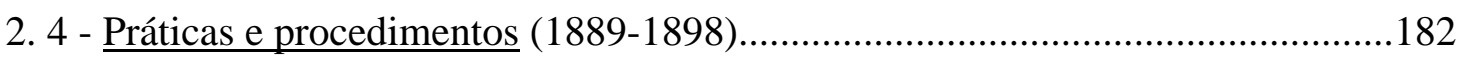

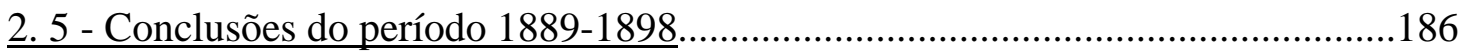

Capítulo 3 - 20 Período: 1899-1912.

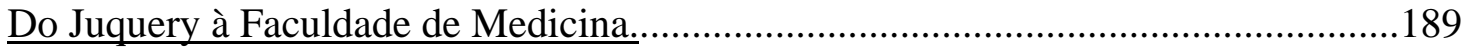

3.1 - Instituições médicas (1899-1912) ....................................................................189

3.1.1 - Hospício da capital e Hospício do Juquery (1899-1912)................................189

3.1.2 - Faculdade de Medicina e instituições similares (1899-1912)..........................192

3.2 - Revistas médicas (1899-1912) ......................................................................199 


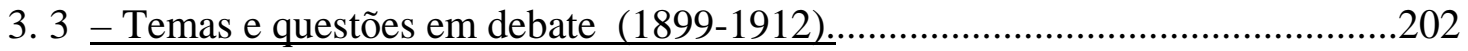

3. 3. 1 - Classificações das doenças - $(1899$ - 1912).................................................202

3. 3. 1.1 - Classificações: Paranóia (1899-1912)......................................................221

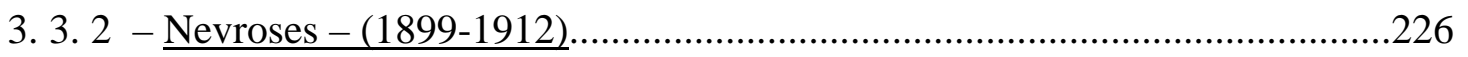

3. 3. 2. 1. - Nevroses: Histeria e neurastenia (1899-1912)..........................................226

3. 3. 2. 2. - Nevroses: Moléstia de Parkinson (1899-1912)........................................243

3. 3. 2. 3. - Nevroses: Coréia (1899-1912).................................................................247

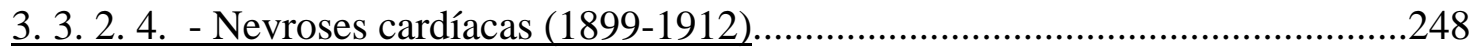

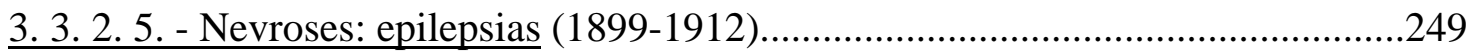

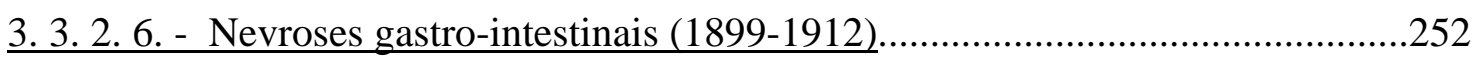

3. 3. 2. 7. - Nevroses: asma; nevroses reflexas nasais (1899-1912)........................... 253

3. 3.3 - Sífilis do sistema nervoso. (1899-1912).....................................................254

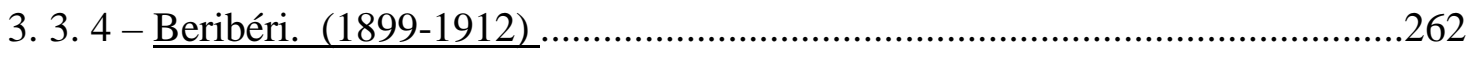

3. 3.5 - Doutrina do neurônio.(1899-1912)................................................................265

3. 3. 6. - Diagnóstico Diferencial (1899-1912)_............................................................270

3. 3. 7. Localização e centros cerebrais (1899-1912)..................................................279

3. 3.8 - Manifestações psíquicas e neurológicas de doenças sistêmicas (1899-1912).283

3. 3. 9. - Concepções e mecanismos de moléstias do sistema nervoso (1899-1912)....288

3. 3. 10. - Concepções sobre a relação entre cérebro e mente (1899-1912)..................297

3. 3. 11. - Concepções em moléstias psiquiátricas (1899-1912) …...............................300

3. 3. 12 - Concepções psicológicas e noções sobre o sistema nervoso (1899-1912)...309

3. 3. 13 - Modernidade, sociedade, cérebro e mente (1899-1912) ….............................316

3. 3. 14 - Medicina e Direito: debates sobre alienismo. (1899-1912)..........................324

3. 3.15 - Afirmação de São Paulo. (1899-1912)..........................................................331

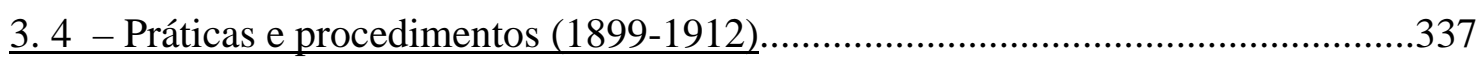

3. 4. 1. - Psicologia experimental, psicoterapia e similares (1899-1912).....................337

3. 4. 2. - Laboratório Clínico (1899-1912) ……............................................................342

3. 4. 3. - Práticas nos hospícios e outros estabelecimentos (1899-1912) ....................343

3. 4. 4. - Tratamentos medicamentosos (1899-1912) …..............................................353

3. 4. 5. - Tratamento cirúrgico (1899-1912) …...........................................................357

3. 4. 6. - Assistência a alienados delinqüentes (1899-1912) .....................................358

3. 4. 7. - Exame e tratamento por coleta de líquido cefalorraquiano (1899-1912)......359

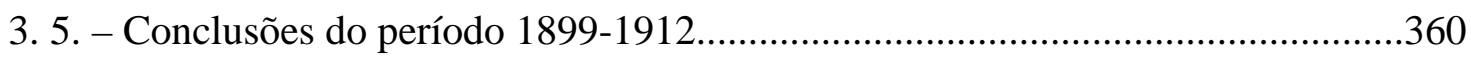


Capítulo $4-3^{\circ}$ período: 1913-1932

Da Faculdade para a diversidade:

de um tempo de certezas ao fim da era federativa;

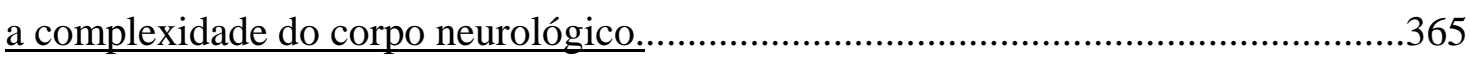

4. 1 - Instituições e personagens (1913-1932) …..........................................................365

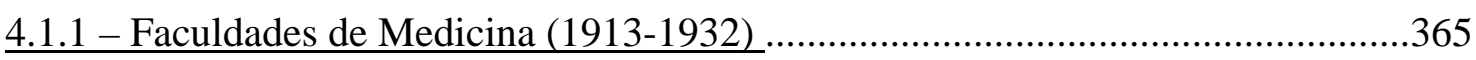

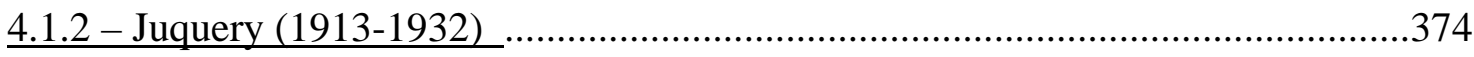

4.1.3 - Associações, Sociedades, Ligas (1913-1932) ................................................375

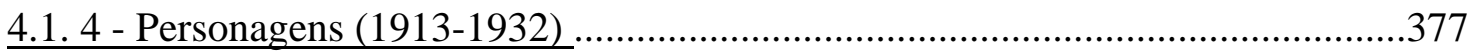

4. 1. 5 - Instituições internacionais (1913-1932) ……................................................379

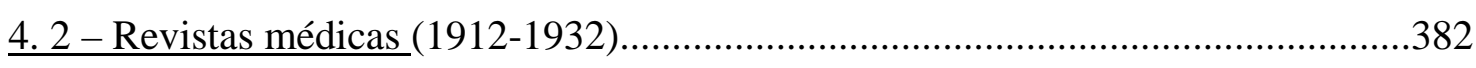

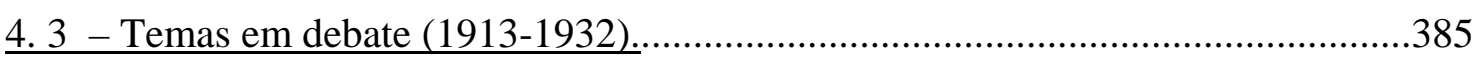

4. 3.1 - Classificação das moléstias (1913-1932) .......................................................385

4. 3. 2. - Sífilis do sistema nervoso (1913-1932)..........................................................389

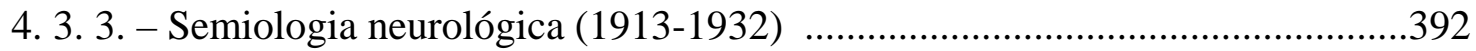

4. 3. 4. - Nevroses e neuroses (1913-1932) ................................................................401

4. 3. 4. 1. - Neurastenia e psicastenia (1913-1932) ..................................................402

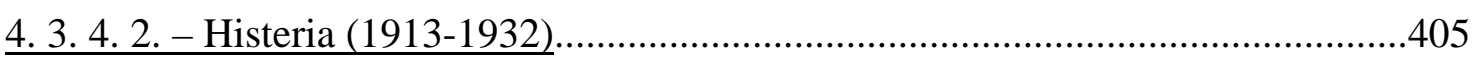

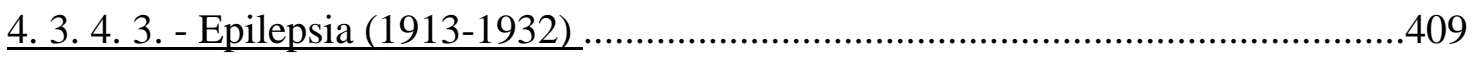

4. 3. 4. 4. - Moléstia de Parkinson (1913-1932) ...............................................................411

4. 3. 5. Manifestações psíquicas e neurológicas de doenças sistêmicas(1913-1932)...413

4. 3. 6. Concepções em moléstias do sistema nervoso (1913-1932) ……......................414

4. 3. 7. Encefalite letárgica (1913-1932) ….............................................................417

4. 3. 8. Concepções em psiquiatria (1913-1932) …......................................................420

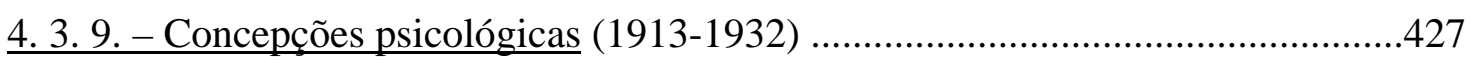

4. 3. 10. - Debates em torno de Espiritismo e Psicologia (1913-1932).........................432

4. 3. 11. - Modernidade, sociedade, cérebro e mente (1913-1932) .............................433

4. 4 - Práticas e procedimentos (1913-1932).............................................................435

4. 4. 1. - Psicoterapia e práticas similares (1913-1932) .................................................435

4. 4. 2. - Terapêutica medicamentosa (1913-1932) _...................................................441

4. 5. - Conclusões do período 1913-1932 ….............................................................444 
Capítulo 5 - $3^{\circ}$ Período - 1933-1936.

Da Faculdade e da Escola à Universidade e às Cátedras:

O corpo neurológico delimitado no corpo paulista ferido. .......................................448

5. 1 - Instituições (1933-1936)............................................................................448

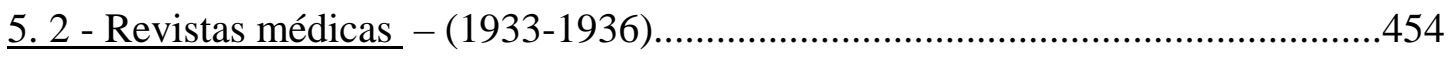

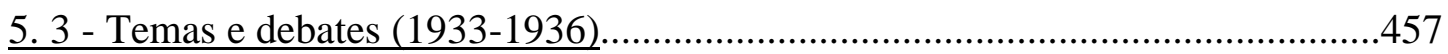

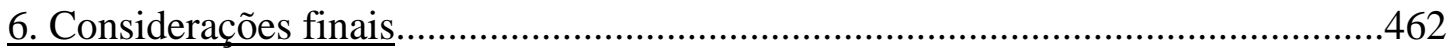

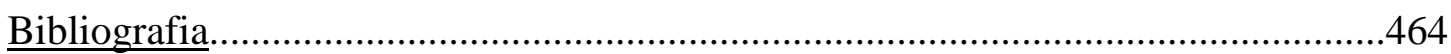

Fontes documentais: Periódicos e Anais de Congressos............................................464

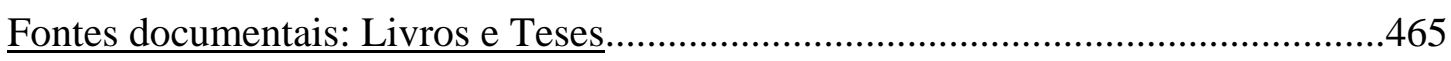

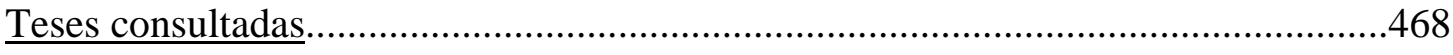

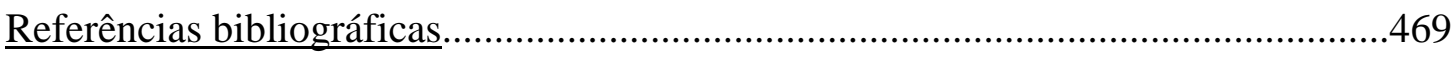

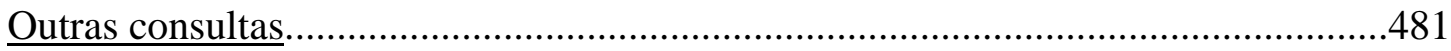

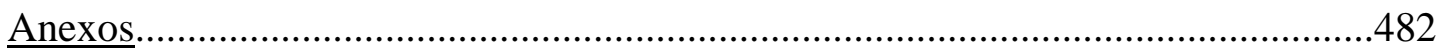

$\underline{\text { Anexo }} 1$ - Decreto $\mathrm{n}^{\circ} 132$ de 22 de dezembro de 1903............................................483

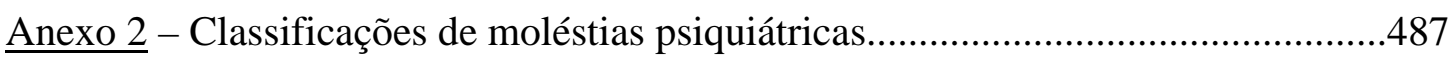

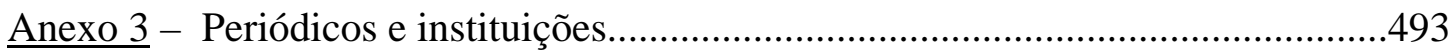


$\underline{\text { Prefácio }}$

Ao interessar-me pela história da neurologia em São Paulo, principalmente em relação aos processos anteriores à instalação das disciplinas desse campo - na Escola Paulista de Medicina, virtualmente, em 1933 (na prática em 1938), e na Faculdade de Medicina da Universidade de São Paulo, em 1935 -, encontrei apenas informações factuais, em fontes provindas de registros dos próprios especialistas, e nenhum trabalho que procurasse discutir esses processos.

Além disso, ao consultar periódicos, livros e outros registros médicos desse período, observei a área de neurologia entremeada com a psiquiatria, e com o que então era considerada como psicologia - uma área intermediária entre a medicina, a filosofia, a sociologia e a pedagogia - além de intersecções com outras áreas médicas e científicas.

Encontrei no livro de Michel Foucault intitulado O Poder Psiquiátrico ${ }^{1}$, um estudo sobre o processo de formação da neurologia, em torno do que ele chama de “corpo neurológico”, que me pareceu bastante apropriado à minha pesquisa. Ele aborda o acima dito espaço intermediário entre as áreas enfocadas, onde ele considera que a neurologia, no fim do século XIX e começo do século XX, não corresponde nem ao dispositivo clínico e nem ao dispositivo psiquiátrico para abordagem do doente, mas a um método que fica entre ambos.

Foucault também assinala que, no mesmo período, na comparação com a psiquiatria, a qual procura obter respostas verbais do sujeito, a neurologia procura obter respostas “do corpo” do sujeito. Além disso, ele lembra que é própria da neurologia, a possibilidade dos fenômenos poderem ser escalonados em diferentes graus de evolução.

Esse livro corresponde a aulas dadas por Foucault em 1973 e 1974. Consta em rodapé uma nota a respeito do manuscrito dessa aula, a frase: “De 1850 a 1870, a emergência de um novo corpo”.

Esse "novo corpo" é o corpo neurológico, que emerge a partir da elaboração de uma prática e de um pensamento com certas características que vão sendo elaboradas até certa altura do século XX.

1 FOUCAULT, M. O Poder Psiquiátrico. Editado por Jacques Legrange. Editora Martins Fontes, 2006, p. 387-419. 
Um fator em especial, que chama minha atenção para a leitura que Foucault faz do corpo neurológico, é que ela traduz uma percepção que ainda se tem na prática médica, quanto à diferenciação da neurologia em relação às outras áreas.

No período estudado, os processos de estruturação da neurologia se correlacionam com fatores sociais, culturais e de outros campos de estudo.

Desse modo, o estudo do estabelecimento da neurologia, ou ainda de um “corpo neurológico” em São Paulo, passa também pelo estudo do estabelecimento da psiquiatria e da psicologia, entremeadas pelo processo de formação de um "corpo social” urbano paulistano.

Esse “corpo neurológico e social” corresponde ao corpo que no fim do século XIX apresenta manifestações, por exemplo, da histeria, e que no século XX passa a apresentar outros quadros em substituição a esse, acompanhando novos ditames científicos, concomitantes às transformações urbanas e novidades modernas.

Quando falamos de corpo neurológico, estamos nos referindo ao resultado do entendimento neurológico do organismo humano, em torno do qual se forma a especialidade neurologia. Na medida em que esta especialidade se configura, também psiquiatria e psicologia tomam formas próprias, até definirem seus contornos e intersecções.

Em relação aos estudos históricos e sociológicos já existentes sobre psiquiatria e psicologia em São Paulo, no período em questão, pretendemos antes acrescentar novos elementos, que foram pouco ou não registrados, do que confrontar visões. Não é nosso objetivo desconstruir, mas sim acrescentar ou debater. Nosso trabalho diz respeito, em grande parte a uma "arqueologia” a respeito dessas diferentes áreas, nas publicações médicas paulistas, principalmente de elementos ainda pouco enfocados.

Sobre a minha posição pessoal diante das questões levantadas, não posso evitar o fato de ter imbuída em minha formação a medicina e a neurologia, ao mesmo tempo em que tenho especial interesse em entender a história dessas ciências inserida nos contextos sociais e culturais.

Também quero ressaltar o uso da palavra “emergir”, utilizada no título deste trabalho, que pode ser tomada em dois sentidos, que podem ser complementares.

Emergir pode indicar algo que se superficializa, que aparece, que se configura, que passa a ser visualizado, como Foucault utiliza, conforme dito anteriormente, ao falar da emergência de um novo corpo. 
Além disso, emergir também lembra “emergência, urgência, emergente, urgente”, sentido esse que pode tornar mais perceptível a movimentação urbana, a pressa, a velocidade, a aceleração, o movimento, o confronto, o enfrentamento entre o indivíduo e a cidade, que se move cada vez mais rápida, a partir da segunda metade do século XIX e início do século XX. Essa rapidez, inclusive, pode ser evidenciada, por exemplo, pelo aumento dos acidentes urbanos, cada vez mais envolvendo pessoas feridas em meio à movimentação das ruas, a partir de determinado momento do século XIX.

O olhar do estudioso habitualmente dirigido a esse período, ao focalizar temas médicos e relativos à saúde e doença, em geral, aponta questões como: higiene, saúde pública, doutrina pasteuriana, epidemias, e outros temas políticos, econômicos e sociais. Pouco se fala sobre o surgimento de urgência e emergência, que acompanham a inserção da prática médica “em uma corrida contra o tempo".

O “emergir” do corpo neurológico ocorre em um período apontado por Foucault - início da segunda metade do século XIX - que corresponde também ao momento de outras inovações do campo médico, que são a anestesia e a antissepsia. A partir destas duas novas aquisições para a prática médica, a medicina passa a "correr contra o tempo" no tratamento de certas condições, por serem possíveis novos cuidados que se valem de anestesia e antissepsia. Assim como "a velocidade, a aceleração e a rapidez” são incorporadas em outros campos da sociedade, também na medicina esses fatores se fazem presentes ${ }^{2}$. É nesse cenário urbano que se configura o corpo neurológico envolvido também no contexto do "moderno", que transita entre o ambiente social e o científico.

Também quero assinalar que, assim como se ensina no curso médico que "não existem doenças e sim doentes”, eu vejo os sistemas do corpo e seu funcionamento como construções oriundas do objetivo de entender o organismo, fazendo uso de determinada linguagem, em certas circunstâncias. Assim, também o corpo neurológico

\footnotetext{
${ }^{2}$ Também sobre a "pressa" no início do século XX, podemos ler, no prefácio do livro de Franco da Rocha, "O Pansexualismo na doutrina de Freud", de 1920: "Não é facil obter uma intuição correta da Psicoanalise. Para isso é preciso ler e estudar muito um assunto que não dá resultado prático imediato. A pressa de acabar, estado d'alma que tem invadido actualmente a sociedade inteira, não permite a qualquer homem um trabalho penoso, só por amor do saber" (itálicos de Franco da Rocha).

ROCHA, F. O Pansexualismo na Doutrina de Freud. Typographia Brasil de Rothschild \& Cia. S. Paulo, 1920, p. III.
} 
não é um dado absoluto a ser desvendado, mas uma elaboração ocorrida dentro das condições estudadas neste trabalho.

Este estudo tem correlações com o que ocorre atualmente entre as diferentes áreas enfocadas. A partir dos anos 1990, passa-se a usar o termo "neurociências” para se referir a uma ampliação da área de estudos sobre o sistema nervoso. Concomitantemente o termo "neuropsiquiatria”3 voltou a ser usado para se referir a todo um novo campo de trabalho com publicações específicas, bem como cursos de formação e associações de especialistas ${ }^{4}$. Por sua vez, a ampliação e intersecção entre essas áreas não compromete a existência dos mais variados ramos da psicologia, que mantém seu espaço no âmbito profissional e científico, inclusive também reconfigurando suas intersecções com as outras duas áreas, como, por exemplo, em neuropsicologia, ou em psicologia cognitiva, ou em psicologia experimental, etc., ao mesmo tempo em que continuam em plena atividade os ramos derivados das idéias psicanalíticas.

\footnotetext{
${ }^{3} \mathrm{O}$ processo de desdobramentos e modificações da, assim chamada, neuropsiquiatria não seguiu exatamente os mesmos caminhos em diferentes países. Conforme Robert Castel, a psiquiatria, na França, separou-se institucionalmente da neuropsiquiatria em 1968, como uma espécie de libertação da especialidade psiquiátrica em relação a um poder da neurologia, para depois cair sob o poder da psicanálise. Castel refere que a doutrina de Freud passou a ser mais aceita na França só após a Segunda Guerra Mundial, pois contrária a ela havia o apego dos franceses a Pierre Janet, e certa aversão à Alemanha, entre outros fatores. Diferentemente dos franceses, os americanos se interessaram pela psicanálise desde seus primórdios. Assim, o paradigma psicanalítico não foi sincrônico na França e nos Estados Unidos. Isso pode ter ocorrido também em outros países.

CASTEL, R. A Gestão dos riscos: da antipsiquiatria à psicanálise. Livraria Francisco Alves Editora, (1981) 1987.

${ }^{4}$ YUDOFSKY, S. C.; HALES, R. E. Neuropsiquiatria e Neurociências na prática clínica. $4^{\mathrm{a}}$ edição, Artmed Editora, 2006.
} 


\section{$\underline{\text { I - Introdução }}$}

\section{1. - Apresentação do tema}

O tema desta pesquisa corresponde aos processos de estabelecimento das áreas científicas, que acabaram sendo nomeadas como neurologia, psiquiatria e psicologia, na cidade de São Paulo.

O período a ser estudado vai do ano de 1889 ao ano de 1936.

A fonte principal deste trabalho é constituída pelas palavras dos médicos e cientistas presentes nos periódicos científicos de então.

Para dialogar com esses registros também recorremos a livros e anais de congressos do período.

Esses três termos, neurologia, psiquiatria e psicologia, desde que foram incorporados pela ciência médica, foram freqüentemente usados para designar campos similares de estudo e trabalho, por vezes sendo adotados de forma associada ou modificada, como, por exemplo, nos termos “neuropsiquiatria” e “neuropatologia”, “neuropsicologia” entre outros.

A partir de agora, para evitar repetições, toda vez que falarmos em corpo neurológico, estaremos nos referindo ao corpo neurológico conceituado por Foucault.

Consideramos que o processo de estabelecimento dessas áreas, em São Paulo, se deu de modo que cada uma delas se desenvolveu no espaço das outras duas. A nossa hipótese é de que a formação do corpo neurológico permitiu delimitar neurologia, psiquiatria e psicologia. Em um triângulo que contenha essas três áreas, psiquiatria e psicologia têm sua respectiva história social; o ângulo correspondente à neurologia pode ser preenchido a partir de um estudo em torno do processo de elaboração do corpo neurológico.

Também queremos, neste trabalho, chamar a atenção para pessoas ou eventos ignorados ou pouco citados na historiografia, e que foram encontrados em nosso levantamento.

Embora pareça óbvio, queremos frisar que, ao focalizarmos esses processos em São Paulo, devemos observar que eles não ocorrem de forma isolada na cidade, de 
modo que há contatos com outras cidades do Estado, bem como com outros Estados e outros países.

A periodização adotada baseia-se na criação, em São Paulo, de algumas instituições ligadas às áreas estudadas e à medicina em geral.

$1^{\text {o }}$ período - 1889-1898 - corresponde ao início da República, bem como ao surgimento das primeiras instituições científicas médicas em São Paulo, além do início da construção do Juquery, até o início de seu funcionamento em 1898.

$2^{\circ}$ período - 1899-1912 - período que vai desde o ano seguinte ao início do funcionamento das primeiras instalações do Juquery, até a fundação da Faculdade de Medicina e Cirurgia de São Paulo.

$3^{\circ}$ período - 1913-1932 - do início da Faculdade de Medicina e Cirurgia de São Paulo até o ano que precede a fundação da Escola Paulista de Medicina.

$4^{\text {o }}$ período - 1933-1936 - esse período compreende: a fundação e o início das atividades na Escola Paulista de Medicina, em 1933, com as disciplinas Neurologia e Psiquiatria em separado (mas com início das aulas dessas áreas em 1938); a fundação da Universidade de São Paulo em 1934; a instalação em separado das disciplinas de Psiquiatria e Neurologia na Faculdade de Medicina da Universidade de São Paulo, em 1935/1936. Em 1934, iniciam-se aulas de Psicologia na FFLCH - USP.

\section{2 - São Paulo como palco das ciências enfocadas}

Na cidade de São Paulo, o estabelecimento das atividades médicas tem diversas particularidades já apontadas por outros trabalhos, relacionadas com seu rápido desenvolvimento associado à cultura do café no Estado e aos seus desdobramentos, além da instalação do regime republicano, bastante atuante em São Paulo, onde procura deixar uma marca de progresso que se sobressaía, em comparação ao regime anterior ${ }^{5}$.

O recorte inicial deste trabalho é o ano de 1889, por ser o ano da proclamação da República, além de também ser o ano em que surge o primeiro periódico médico científico em São Paulo, a Revista Médica de São Paulo.

5 Em relação a esse aspecto ver os trabalhos:

SILVA, M.R.B. O mundo transformado em laboratório: ensino médico e produção de conhecimento em São Paulo de 1891 a 1933. Tese de Doutorado, FFLCH, USP, 2003.

TELAROLLI JUNIOR, R. Poder e Saúde: as epidemias e a formação dos serviços de saúde em São Paulo. Editora Unesp, 1996. 
Essa publicação pode ser considerada como uma das primeiras instituições científicas médicas na cidade, que pode ter assinalado uma nova fase de institucionalização da medicina em São Paulo .

Essa institucionalização segue passos iniciais diferentes das cidades de Rio de Janeiro e Salvador, que já contam com cursos médicos desde a vinda da família real para o Brasil em 1808.

A questão das políticas públicas, que se seguem à instalação da República, tem, em São Paulo, sua interface com o Estado que prospera. Em 1889, a cidade de São Paulo ainda está recente em sua fase de crescimento, acompanhando a economia do café.

Conforme o historiador E. Simões de Paula, nos anos de 1872-1875 ocorre uma “segunda fundação de São Paulo”, em virtude das transformações pelas quais passa a cidade nessa ocasião ${ }^{7}$, em grande parte associadas à gestão do presidente da Província João Teodoro Xavier de Mattos ${ }^{8}$, entre outros fatores.

Simões de Paula também assinala que, em 1872, ocorre a inauguração da estrada de ferro Jundiaí-Campinas pela Companhia Paulista, cinco anos após o início de atividades da linha Santos-Jundiaí, a primeira da província. Acentua que João Teodoro, nesse período, modifica ruas, estradas, largos, a Várzea do Carmo, para atrair fazendeiros e capitalistas do interior e seus investimentos. Também nessa década a colonização e a imigração são organizadas pela Associação de Colonização e Imigração, fundada em 1871. Assim, Simões de Paula registra um aumento considerável de habitantes entre 1872 e 1886 (de 26.040 para 47.697) ${ }^{9}$. Ressalte-se também que, nessa década, ocorre o início do movimento republicano no Estado.

Conforme a autora Frehse, além desse marco da década de 1870 em São Paulo, o estudioso americano Richard Morse sugere que décadas anteriores a 1870

6 A esse respeito ver:

FERREIRA, L.O. O nascimento de uma instituição científica: o periódico médico brasileiro da primeira metade do século XIX. Tese de doutorado, FFLCH, USP, 1996.

Ver também o trabalho de Silva, M.R.B. já citado.

7 PAULA, E. S. Contribuição monográfica para o estudo da segunda fundação de São Paulo, 1936 apud “A cidade de São Paulo - estudos de geografia urbana” - organizado por Aroldo de Azevedo, vol. II, a Evolução Urbana, Companhia Editora Nacional, 1958.

8 A esse respeito ver:

QUEIROZ, S.R.R. Política e poder público na Cidade de São Paulo:1889-1954. In: PORTA, P., História da Cidade de São Paulo, volume 3, Editora Paz e Terra, 2004.

SEGAWA, H. São Paulo, veios e fluxos: 1872-1954. In: PORTA, P., História da Cidade de São Paulo, volume 3, Editora Paz e Terra, 2004.

9 FREHSE, F. O Tempo das Ruas na São Paulo de fins do Império. Edusp, 2005, p. 51-53. 
configuraram o que passa a acontecer a partir dessa data. Assim, ele propõe mais um marco delimitante da formação de São Paulo em 1828, com a fundação da Academia de Direito do Largo São Francisco; ele acrescenta também a chegada da imprensa a partir dos anos 1820, a vinda de imigrantes e a mudança dos legisladores a respeito do conceito de urbano ${ }^{10}$.

A autora destas citações, Fraya Frehse, refere outros tantos estudiosos como Gilberto Freyre, Sérgio Buarque de Holanda, Florestan Fernandes, Ernani da Silva Bruno, Odilon Nogueira de Mattos, Maria Odila Leite da Silva Dias, para dizer que "a São Paulo de fins do século XIX aparece como locus cuja marca maior é a simultaneidade entre continuidade e ruptura"11 (itálicos da autora).

É esta última frase que nos chama a atenção, e à qual queremos chegar com essas últimas citações.

É no ambiente da transição entre os séculos XIX e XX, na cidade de São Paulo, caracterizado por esse paradoxo de "continuidade e ruptura", que vamos estudar os processos de estabelecimento das áreas científicas enfocadas por nosso trabalho.

Dos anos 1870, mais especificamente 1872, até o ano da proclamação da República, passam-se dezessete anos. Nesse período há tentativas de organização dos médicos paulistas, como em 1878 (último ano da administração de João Teodoro), quando caminha razoavelmente a promoção de um Congresso Médico, inclusive anunciado pela imprensa. Existe até mesmo certo comprometimento de médicos de várias cidades do interior da província de São Paulo, que prometem participação nesse evento. Isso demonstra a presença desses profissionais em diversas cidades paulistas, sinalizando o desenvolvimento econômico desses locais, acompanhando a cultura do café. No entanto, esse congresso não chega a acontecer. Isso pode indicar dificuldades para a institucionalização da medicina em São Paulo, no transcorrer desses anos.

Em 1889, além do lançamento do primeiro periódico médico paulista, ocorre a primeira tentativa de fundar-se uma Sociedade de Medicina e Cirurgia de S. Paulo, que não chega a perdurar. Em 1895 ocorre a fundação de uma sociedade com esse mesmo nome, sendo que, desta vez, perdura. 
Esses podem ser alguns exemplos da fragilidade de algumas instituições médicas em São Paulo, nessa fase de transição de regimes políticos, nessa recente "nova São Paulo” que se configura.

Mas, por outro lado, algumas iniciativas referentes à higiene ganham grande impulso, logo nos primeiros anos da República, neste caso com instituições mais estáveis, colocando a cidade entre as primeiras no país a implantar práticas ligadas aos conceitos científicos de higiene, em saúde pública, com a criação do Serviço Sanitário. No que diz respeito ao ensino da medicina, a Santa Casa é um espaço onde já acontece certa forma de aprendizado, antes de haver faculdade de medicina na cidade ${ }^{12}$.

A leitura da Revista Medica de São Paulo mostra que, nos artigos científicos de 1889, os médicos paulistas incluem, de modo geral, alguns assuntos que dizem respeito às áreas de psiquiatria e de moléstias nervosas, relatados por médicos generalistas ou traduzidos de artigos internacionais, não havendo ainda algum profissional que se identifique como mais ligado às áreas de psiquiatria, psicologia, ou moléstias nervosas em São Paulo.

Como veremos mais adiante, somente a partir da vinda, para São Paulo, de Claro Homem de Mello, no início dos anos 1890, e principalmente de Franco da Rocha, em 1892, é que passa a haver a presença de médicos com formação específica em psiquiatria e moléstias nervosas na cidade ${ }^{13}$.

No transcorrer de todo o período estudado, observamos configurações variáveis das áreas e termos estudados, sendo que, a partir de 1933, na Escola Paulista de Medicina, e a partir de 1936 na Faculdade de Medicina da Universidade de São Paulo, passam a existir separadamente as disciplinas de neurologia e psiquiatria.

Quanto à psicologia, há registros de que, no transcorrer do século XIX e início do século XX, consta de estudos da Faculdade de Direito ou de outros cursos, em uma linha próxima da filosofia e da pedagogia. Em medicina, a psicologia é mais freqüentemente chamada de “psicologia médica” e se aproxima de uma psicologia

12 A esse respeito ver:

TELAROLLI JUNIOR, R. Poder e Saúde - As epidemias e a formação dos Serviços de Saúde em São Paulo. Editora Unesp, 1996.

SILVA, M.R.B. O mundo transformado em laboratório: ensino médico e produção de conhecimento em São Paulo, de 1891 a 1933. Tese de Doutorado, USP, 2003.

13 Podemos lembrar que Franco da Rocha é citado, quase sempre, como psiquiatra ou como alienista, e praticamente nunca isoladamente ou destacadamente, como especialista em "moléstias nervosas", que é um termo correspondente a moléstias do sistema nervoso, nesse período. 
experimental. A partir da criação da Sociedade Brasileira de Psicanálise, em 1927, em São Paulo, a psicologia toma, aos poucos, uma configuração diferenciada e separada da medicina, embora persista a psicologia médica como um campo inserido na medicina, até os tempos atuais.

\section{3. Revisão historiográfica}

\section{3. 1 - Origem dos termos psicologia, neurologia e psiquiatria.}

Há estudos que consideram como primeiros registros a respeito dessas áreas, certos textos gregos ou mesmo de outros povos da antigüidade ${ }^{14}$.Optamos por abordar o aparecimento dos nomes propriamente ditos dos campos em questão, como uma forma de acompanhar os processos que configuram essas áreas.

As origens dos termos psicologia, neurologia, psiquiatria e outros termos correlatos, ou derivados, ou associados, nem sempre são claras ou fáceis de evidenciar, havendo algumas divergências.

\section{3. 1.1 - Psicologia}

A respeito do aparecimento do termo psicologia fazemos uso principalmente do texto de 1964, do autor $\operatorname{Krstic}^{15}$, da então Iugoslávia ${ }^{16}$. Esse texto relata os três indivíduos de origem germânica que são mais comumente relacionados como tendo usado primeiro a palavra psicologia. A esses nomes, o autor acrescenta outro, de um escritor de seu próprio país, que teria usado essa palavra antes dos referidos germânicos.

Assim, a origem da palavra psicologia é mais comumente associada a esses germânicos do século dezesseis: Rudolf Göckel, Otto Casmann e Filip Melanchton.

Rudolf Göckel (1547-1628) é mais conhecido sob o nome latino Goclenius. Foi professor de física, matemática, lógica e ética na Universidade de Marburg. Além de

\footnotetext{
${ }^{14}$ Isso pode ser visto, por exemplo, no livro “Textos Básicos de História da Psicologia” organizados por Herrnstein, R. J. \& Boring, E. G. da Edusp, 1971. Embora sob o nome de psicologia, alguns desses textos podem também ser considerados como de neurologia, ou como de psiquiatria, pois abordam temas como localização cerebral, função visual, etc, desde a antigüidade até o século XX.

15 Não temos dados sobre esse autor.

16 KRSTIC, K. Marco Marulic: the autor of the therm "Psychology". Acta Instituti Psycologici Universitatis Zagrabiensis, 1964, n. 36, pp. 7-13.
} 
vários tratados sobre lógica e um dicionário filosófico, Göckel publica um tratado, em Marburg em 1590, intitulado Psicologia hoc est de hominis perfectione, anima, ortu. Esse trabalho é supostamente o mais antigo livro impresso preservado que contém a palavra psicologia, sendo que, nessa obra, a palavra está escrita com letras gregas.

Otto Casmann (1562-1607) pertence aos filósofos protestantes liberais do fim do século dezesseis. Entre seus trabalhos, de filosofia, teologia e ciências naturais, há um chamado Psychologia anthropologica, impresso em Hanau em 1594.

As diferentes enciclopédias e tratados se dividem entre considerar Goclenius ou Casmann como o primeiro a usar o termo, dependendo de suas fontes de informação, embora Goclenius tenha publicado primeiro.

Por outro lado, várias outras publicações atribuem o termo a Melanchton, que supostamente usa essa palavra em suas palestras em torno de 1530 e 1550, ou seja, oralmente (sua obra De anima é de 1530).

Além desses autores, há um estudioso menos citado. Pelo menos 66 anos antes de Göckel o termo psicologia foi usado pelo humanista e poeta Marko Marulic (14501524) em um de seus tratados em latim, cujo título, Psichiologia de ratione animae humanae, foi preservado em uma lista de trabalhos de Marulic feita pelo poeta, seu contemporâneo e amigo, Bozicevic-Natalis, em sua “Vida de Marco Marulic” (Vita Marci maruli Spalatensis).

De qualquer forma, considera-se a difusão do termo psicologia a partir de Leibniz (1646-1716) e Christian Wolff (1679-1754); este com os trabalhos "Pensamentos racionais sobre Deus, o mundo e a alma do homem, assim como sobre todas as coisas em geral” (1719) ${ }^{17}$, Psychologia empirica e Psychologia rationalis (1732-1734). Com essas duas obras de Wolff, aparece a idéia de psicologia no sentido moderno, a psicologia racional constitui um discurso tradicional sobre a alma, enquanto a psicologia empírica apresenta-se como independente da filosofia e fundamenta-se na observação das faculdades da alma ${ }^{18}$, e vai ter maior influência em desdobramentos posteriores no que vai se constituir como psicologia propriamente dita ${ }^{19}$.

17 CAYGILL, H. Dicionário Kant. Jorge Zahar Editor, 1994, p. 265.

Lê-se nesse livro que Christian Wolff influenciou Kant em seus conceitos sobre psicologia em Crítica da Razão Pura, onde Kant faz considerações sobre Psicologia racional e Psicologia empírica. À pagina 266, cita-se que Kant escreveu sobre doença mental em "Ensaio sobre as enfermidades da cabeça", em 1764.

${ }^{18}$ Em Psychologia Empírica, Wolff lança a palavra "psicometria”, aventando a possibilidade de se ter um conhecimento matemático do espírito humano.

BRAUNSTEIN, J. F.; PEWZNER, E. - História da Psicologia. Instituto Piaget, 2003, p. 42.

${ }^{19}$ Idem, p. 39-40. 
Na França, a palavra psicologia aparece no Essai de psychologie de Charles Bonnet $^{20}$, em 1754 e passa a ser largamente usada a partir de Maine de Biran (1766$1824)^{21}$.

O psicólogo Hans Thomae ${ }^{22}$ discute se a psicologia originou-se da filosofia ou da fisiologia. Esse autor considera que essas duas influências têm seus papéis nessa origem, dizendo que é comumente aceito que a psicologia, adjetivada como científica, remonta à fundação do primeiro laboratório de psicologia pelo médico Wilhelm Wundt (1832-1920), em Leipzig, entre os anos de 1874 e 1883 (conforme várias etapas dessa fundação).

Por outro lado, os autores franceses Braunstein e Pewzner dizem que essa menção a Wundt deve-se, em boa parte, aos historiadores atuais da psicologia, principalmente os anglo-saxões, que dão muita importância aos aspectos institucionais da história ${ }^{23}$.

\section{3. 1.2 - Neurologia}

O termo neurologia foi introduzido pelo inglês Thomas Willis (1621-1675), provindo da palavra grega "neuro" usada para designar tendão ${ }^{24}$. Willis foi autor de outros diversos termos que se tornaram de uso consagrado em neurologia, sendo ele considerado como o primeiro a estudar o cérebro de modo mais detalhado, em sua obra Cerebri anatome, de $1664^{25}$. Para ele, esse termo era algo como o estudo do cérebro e dos nervos.

Há uma distância razoável no tempo, entre Thomas Willis ${ }^{26}$ e $\operatorname{Charcot}^{27}$, que é habitualmente considerado como o criador da primeira cátedra de doenças do sistema

\footnotetext{
${ }^{20}$ Ibidem, p. 41.

21 KRSTIC, K. Marko Marulic: the author of the term "Psychology". Acta Instituti Psychologici Universitatis Zagrabiensis, 1964, n. 36, pp 7-13.

22 THOMAE, H. Abordagem social: o surgimento da Psicologia científica como disciplina independente. In: BROZEK, J.; MASSIMI, M., Historiografia da Psicologia Moderna, Edições Loyola, 1998, p. 375387.

${ }^{23}$ BRAUNSTEIN, J. F.; PEWZNER, E. História da Psicologia. Instituto Piaget, 2003, p. 119.

24 Os gregos consideravam tendões e nervos como estruturas similares.

25 FINGER, S. Origins of Neuroscience: a History of Explorations into Brain Function. Oxford University Press, 1994, p. 24.

26 Raymond Vieussens (1641-1716) foi um equivalente francês de Willis, sendo que publicou "Neurographia universalis" em 1685, tendo sido influenciado por Willis.

FINGER, S. Origins of Neuroscience, p. 209-210.

27 Jean-Martin Charcot (1825-1893), médico da Universidade de Sorbonne, em 1862 foi designado para dirigir o Hospício de Salpêtrière, o qual conta com mais de cinco mil pacientes nessa ocasião. Nesse local 22
} 
nervoso, em 1882, em Paris, após lançar em 1880 o periódico “Archives de Neurologie”.

No intervalo entre Willis e Charcot, são usados termos mais próximos a “moléstias nervosas” ou ainda a "doenças do sistema nervoso"28 do que propriamente neurologia, para designar essa área da medicina.

Em relação a isso, nesse período, podemos citar o alemão Moritz Romberg (1795-1873) da Universidade de Berlim, que nos anos 1840-1846 escreve e publica o livro Leherbuch der Nervenkrankheiten, ou seja, "Manual de Moléstias Nervosas”, sendo assim um dos primeiros livros sobre essas moléstias. Em 1820, Romberg traduz para o alemão a obra do inglês Andrew Marshall (1742-1813), intitulada Anatomia Mórbida do Cérebro e, anos depois, do inglês Charles Bell (1774-1842), O Sistema Nervoso do Corpo Humano ${ }^{29}$, que podem tê-lo influenciado.

Charles Bell era um estudioso de Anatomia e um artista, de modo que, em 1806 publica Ensaios sobre Anatomia da Expressão na Pintura, obra que influencia Darwin em seus estudos sobre a expressão humana das emoções ${ }^{30}$. Em 1811, Bell escreve Idéia de uma nova Anatomia do Cérebro submetida às observações de seus amigos, em forma de 100 folhetos distribuídos a seus amigos, onde estuda as raízes nervosas. Por isso, muitos atribuem a Bell a "fundação" da neurologia como campo de estudo, correlacionando anatomia e clínica. Alguns estudiosos divergem sobre essa primazia de Bell, supondo que talvez ele não tivesse noção da inovação de seu estudo, o que teria atrasado suas publicações. Posteriormente às publicações do francês Magendie, em 1822, sobre o mesmo assunto, Bell faz publicação em 1824, segundo alguns, adaptando seu texto para reforçar sua primazia ${ }^{31}$.

ele desenvolve estudos de moléstias do sistema nervoso e de moléstias mentais. Entre essas, elabora conceituações de histeria e de nevrose que se tornam bastante influentes. Além disso, diversas moléstias neurológicas estão ligadas a seu nome. Seus estudos sobre hipnose atraem a atenção da sociedade de Paris para além da classe médica.Alguns de seus discípulos depois ficam famosos, entre eles Sigmund Freud.

ALEXANDER, F.G.; SELESNICK, S. T. História da Psiquiatria. Ibrasa, 1966, p. 231-233.

FINGER, S. Origins of Neuroscience: a History of Explorations into Brain Function. Oxford University Press, 1994, p. 224-225.

${ }^{28}$ O conceito de "sistemas" no organismo é principalmente atribuído a Bichat, em 1801, em sua obra "Anatomie générale".

FOUCAULT, M. O Nascimento da Clínica. Editora Forense Universitária, (1980) 2006, p. 142-143.

29 PEARCE, J.M.S. Romberg and his sign. European Neurology, 53: 210-213, 2005.

30 FINGER, S. - Origins of Neuroscience. Oxford University Press, 1994, p. 266-267.

31 FINGER, S. - Origins of Neuroscience. Oxford University Press, 1994, p. 28-29.

23 
O sucessor de Romberg na Universidade de Berlim foi Wilhelm Griesinger (1817-1868), sendo um dos primeiros a ter o título de professor de Psiquiatria e Moléstias Nervosas ${ }^{32}$.

Outros estudiosos são relatados como ligados a diversos processos inerentes à neurologia, mas citá-los nos levaria para além desta apresentação ${ }^{33}$.

\section{3. 1.3 - Psiquiatria}

A palavra psiquiatria aparece em 1808, com Johann Christian Reil (17591813), com o formato em alemão de Psychiaterie, mais tarde passando a Psychiatrie ${ }^{34}$.

Devemos notar que é comumente admitido Philippe Pinel (1745-1826) como o “fundador” da psiquiatria, por escrever o Tratado médico-filosófico da alienação da alma ou mania (publicado em 1801), além de dirigir os asilos de Bicêtre (1793) e Salpêtrière (1795), de maneira inovadora.

No entanto, nesse momento, não existe ainda o termo “psiquiatria”. Além disso, outros autores publicam, antes dele, livros sobre doenças mentais: Batt, em Londres, publica, em 1758, a obra Tratado da Loucura; Vicenzo Chiarugi, em Florença, publica Tratado médico analítico da loucura em geral e em particular, em $1794^{35}$. Além desses, eventualmente são citados outros estudiosos anteriores a Pinel ${ }^{36}$.

De qualquer modo, Pinel é comumente considerado como fundador de uma medicina mental ou alienista, como uma área independente, a partir do isolamento terapêutico dos alienados em Bicêtre e Salpêtrière.

32 ALEXANDER, F.G.; SELESNICK, S.T. História da Psiquiatria. Ibrasa, 1966.

33 Entre esses há Franz Joseph Gall (1758-1828), médico alemão que estabeleceu a frenologia: uma teoria que atribui a cada área do cérebro uma função, baseado nas saliências e reentrâncias da superfície do crânio. Sua polêmica doutrina fez sucesso entre o fim do século XVIII e início do século XIX. Seu seguidor Johann Spurzheim (1776-1832) ampliou essa teoria. Essas idéias tiveram forte oposição do francês Marie-Jean-Pierre Flourens (1794-1867) que fez experimentos em cérebros de animais, com resultados desfavoráveis à frenologia.

FINGER, S. Origins of Neuroscience: A History of explorations into brain function. Oxford University Press, 1994, p. 32-36.

FEINBERG, T.E.; FARAH M.J. Behavioral Neurology and Neuropsychology. McGraw-Hill, 1997, p.5-7. 34 HAAK, H.P.; HAAK, C. Die Entwicklung der Psychiatrie. Em: <http://www.entwicklung-derpsychiatrie.de> Acessado em 10 de junho de 2006.

35 PAIM, I. História da Psicopatologia. E.P.U., 1993, p. 1-2.

36 Quanto a isso ver:

LAIGNEL-LAVASTINE, M. et VINCHON, J. Les maladies de l'esprit et leur médecins du XVIe au XIXe siècle: Les étapes des conaissances psychiatriques de la Renaissance à Pinel. Éditions Médicales Norbert Malone, Paris, Editions A. Chaine, 1930. 
Royer-Collard faz coisa semelhante na Maison Nationale de Chareton, onde se torna médico chefe em 1805, mesmo ano em que Esquirol, discípulo de Pinel, defende sua tese "Paixões consideradas como causas, sintomas e meios curativos da alienação mental”. Em 1816, Royer-Collard torna-se professor de Medicina Legal na Faculdade de Medicina de Paris, e em 1821, passa a ser também o primeiro titular da cátedra de Medicina Mental.

Royer-Collard e Esquirol têm como discípulos Calmeil, que estuda a paralisia nos alienados, e Bayle, que conceitua a moléstia paralisia geral ${ }^{37}$.

Johann Christian August Heinroth (1773-1843), em 1811, estabelece a primeira cátedra denominada como de Psiquiatria, em Leipzig; ele também cunha o termo “psicossomático”38.

O médico austríaco Barão Ernst von Feuchtersleben (1806-1849), em seu livro traduzido para o inglês como "Principles of Medical Psychology”(1847), de 1845, introduz as palavras “psicose” e “psicopatologia”39. Nesse livro, o autor menciona o inconsciente como força geradora dos sonhos ${ }^{40}$. Podemos ver que o título de seu livro, em inglês, assume um título referente à psicologia médica e não propriamente à psiquiatria.

37 CANGUiLHEM, G. Études D'Histoire et de Philosophie des Sciences. Librairie Philosophique J. Vrin, Paris, 1975, p. 375.

38 PEARCE, J.M.S. Romberg and his sign. European Neurology, 53: 210-213, 2005.

39 Conforme o psiquiatra brasileiro Isaias Paim, não é fácil descobrir a origem do termo psicopatologia, mas ele o atribui a Jeremy Bentham (1748-1832) em 1817, sob a forma "psychological pathology". Ele considera Karl Jaspers (1883-1969) como fundador da Psicopatologia como disciplina autônoma, a partir da publicação de "Psicopatologia Geral” em 1913, usando o método fenomenológico em suas pesquisas clínicas.

PAIM, I. História da Psicopatologia. E.P.U., 1993, p.1 e p. 41.

40 FINGER, S. Origins of Neuroscience. Oxford University Press, 1994, p. 262. 


\section{3. 2. - Estudos historiográficos mais recentes}

Esgotar um estudo historiográfico sobre as áreas em questão é tarefa inexeqüível para os objetivos deste trabalho. Assim, vamos comentar alguns textos que são de interesse para abordarmos a interface entre neurologia, psiquiatria e psicologia.

Por serem pertinentes a uma metodologia que discuta os processos em torno da elaboração das disciplinas científicas enfocadas, e por estarmos trabalhando dentro de história social, nesta seção vamos nos deter mais demoradamente em textos de três obras: Discovering the History of Psychiatry, editado por Mark S. Micale e Roy Porter; “O Poder Psiquiátrico”, de Michel Foucault e El siglo de la Clinica - para una teoria de práctica psiquiátrica, de Rafael Huertas.

\section{3. 2.1 - $\underline{\text { A história da história da psiquiatria. }}$}

Em termos de historiografia, consideramos a obra editada por Mark S. Micale e Roy Porter, Discovering the History of Psychiatry ${ }^{41}$, que citamos a seguir, como uma referência central, em relação às áreas estudadas, de um modo geral, e não apenas como historiografia sobre o Brasil ou sobre São Paulo, por abordar questões que perpassam o nosso trabalho. Micale é historiador do Departamento de História da Yale University e Roy Porter é historiador do Wellcome Institute for the History of Medicine de Londres.

O fato de esse livro tratar de psiquiatria e não diretamente de neurologia ou psicologia, não tira sua importância para o nosso trabalho, pois sua abordagem metodológica de visão de processo em história da ciência pode se estender às outras áreas, já que as três são interligadas.

A seguir fazemos comentários sobre a introdução, intitulada: "Reflexões sobre a Psiquiatria e suas Histórias”.

Na introdução, os editores, Porter e Micale, frisam, que nos últimos trinta anos (até 1994), a história da psiquiatria tem sido das áreas que mais cresceram e mais atraíram a atenção e geraram controvérsias. Eles apresentam temas que têm chamado a atenção dos estudiosos: a ascensão e queda do asilo psiquiátrico; a história do confinamento compulsório e dos processos contrários à institucionalização; a origem, a

41 PORTER, R.; MICALE, M.S.(edits.) Discovering the History of Psychiatry. Oxford University Press, 1994. 
validade científica e eficácia terapêutica da teoria freudiana; os méritos dos modelos biológicos da mente, opostos aos modelos psicodinâmicos; o uso de tratamentos físicos extremos para distúrbios mentais, como lobotomia e eletrochoque; os processos de controle social sobre mulheres, trabalhadores e minorias.

Assim, Porter e Micale apontam que, nesses trinta anos, são feitos trabalhos originais, por vezes apaixonados e polêmicos, em todas essas áreas. Esses estudiosos acentuam também que esses debates atravessam os limites de seus campos específicos, atingindo outros campos sociais. Citam que, figuras notáveis, especialmente Michel Foucault, são consagradas menos como comentadoras de um ramo da história médica e mais como ícones culturais e sociais.

Conforme os editores, nos anos 1960 e 1970 crescem os questionamentos, sobre o uso da psiquiatria, feitos pelos mais diversos regimes políticos e condicionamentos sociais. Eles frisam que a politização da história da psiquiatria, nos anos recentes, tem sido acompanhada por um crescimento explosivo dessa história como uma disciplina acadêmica; assim, têm-se uma diversidade de discursos e abordagens sobre a história da psiquiatria.

Porter e Micale prosseguem, relatando que: teóricos sociais e culturais; sociólogos; historiadores da ciência e da medicina; historiadores sociais, culturais e intelectuais; historiadores da mulher; críticos de arte e literatura; psiquiatras, neurologistas, psicanalistas e psicólogos clínicos; todos têm sua palavra sobre a psiquiatria e seu famoso passado.

Sendo assim, - continuam os editores - não é surpresa que os historiadores da psiquiatria tenham variado enormemente e tenha havido diferentes histórias da psiquiatria. Desse modo, desde meados do século XX, a assim rotulada "história da psiquiatria” tem sido configurada conforme seus autores: como progresso linear de humanitarismo e ciência médica; descoberta gradual, pelos séculos, do inconsciente; luta dialética sem fim, entre teorias e terapias da mente, biológicas e psicológicas; história da emergência, formulação e difusão das idéias de Freud; o domínio psicológico e social do racionalismo autoritário burguês; a manipulação das mulheres por médicos homens; antigo esforço para medicalizar doenças não orgânicas.

Conforme Porter e Micale, a lista pode ser aumentada, e cada uma dessas linhas inspirou e estimulou revisões e contra-revisões. Eles consideram que essa é uma das áreas da ciência em que há menos consenso e mais debates na atualidade. 
Os editores frisam que, de modo similar a outros campos, a psiquiatria também tem sua vertente de história linear e cumulativa, que procura seus precursores e fundadores, e que forma memórias idealizadas; esse tipo de história serve para socializar os principiantes nas disciplinas e ligá-los aos profissionais atuais e aos grandes nomes do passado. Acrescentam que isso também serve às delimitações interdisciplinares e intradisciplinares, bem como, nos períodos de conflito paradigmático, servem para legitimar ou deslegitimar teorias e metodologias; além disso, essa história também colabora com uma imagem favorável para o público, a mídia e fontes de financiamento institucional.

Ainda conforme os editores, nos anos 1930, 1940 e 1950 proliferam os estudos sobre psiquiatria cunhados dentro da historiografia Whig, que consideram a história da psiquiatria sob o ponto de vista da atualidade, e apontam sempre uma evolução da ignorância dos antigos para o esclarecimento gradual até os tempos atuais. Esse período coincide com um grande prestígio da psiquiatria na Europa e na América do Norte.

Nos anos 1960, continuam os editores, acompanhando as inovações da década, aparecem quatro textos chave: Asylums de Erving Goffman, The Divided Self de R. D. Laing, The Myth of Mental Ilness de Thomas Szasz ${ }^{42}$ e Histoire de la folie de Michel Foucault. Todos eles questionam as asserções oficiais de benignidade fundamental da psiquiatria. A seguir, há uma noção resumida do trabalho desses quatro estudiosos, a partir do livro de Porter e Micale.

Laing, trabalhando no Reino Unido, afirma que a esquizofrenia e as outras doenças mentais não são doenças, mas uma designação diagnóstica arbitrariamente fixada pela sociedade e confirmada pelos psiquiatras.

Goffman, um sociólogo americano, sensibilizado pelos escritos de Bruno Bettelheim sobre campos de concentração, retrata o moderno hospital-dia como uma “instituição total” que degrada pessoas e efetivamente cria comportamento louco.

Szasz começa da premissa de que a psiquiatria institucional é um empreendimento insustentável, por basear-se na noção de doença mental, que é por si só, uma ficção; ele considera a história da psiquiatria uma fantasia.

42 Thomas S. Szasz também escreveu “A Fabricação da Loucura”, em 1971, onde compara o movimento de Saúde Mental à Inquisição, considerando os psiquiatras como produtores de loucos.

SZASZ, T.S. A fabricação da loucura: um estudo comparativo entre a Inquisição e o movimento de saúde mental. Zahar Editores, (1971) 1978. 
De modo similar, em Loucura e Civilização, Foucault argumenta que o crescimento da psiquiatria institucional não é uma fonte de progresso, mas uma técnica de alienação; ele transforma os heróis dos Whig em vilões. Assim, a família Tuke em York nos anos 1770 e 1780, e Pinel no hospital Bicêtre nos anos 1790, não liberam os loucos, mas apenas forjam-lhes "cadeias mais sinistras”, “o aprisionamento moral gigante” do asilo insano.

Ainda conforme os editores, no fim dos anos 1960, as idéias de Goffman, Laing, Szasz e Foucault combinam com as psicologias marxistas da Alemanha e da França, o sentimento anti-psicoanalítico britânico, a teoria crítica feminista e movimentos de liberação de doentes mentais, em um ataque a práticas e instituições modernas de saúde mental. Um poderoso movimento de “anti-psiquiatria” está a caminho.

A seguir, referem os editores que, nos anos 1970, ocorrem vários estudos aplicando os esquemas gerais da anti-psiquiatria a países específicos. Enquanto os autores da literatura Whig se apresentam como historiadores médicos, os novos revisionistas críticos são psicoterapeutas desafetos ou sociólogos radicais e historiadores das universidades. Bürger und Irre de Klaus Doerner, The Discovery of the Asylum de David Rothman, L'ordre psychiatrique de Robert Castel, e Museums of Madness de Andrew Scull, trazem as idéias de Laing, Foucault, Goffman e Szasz, respectivamente para a história da psiquiatria alemã, americana, francesa e britânica do século dezenove. Eles têm uma preferência pelo estudo das instituições.

Conforme os editores, a grande revisão das últimas três décadas coloca os historiadores médicos amadores como autores de uma ingênua história intelectual internalista da psiquiatria, contra historiadores profissionais que produzem uma pesquisa mais sofisticada em método e sociologicamente orientada. Mas, ainda conforme os autores, um exame não tendencioso revela que essa polarização profissional é, em grande grau, ficcional. Por exemplo, o primeiro grande historiador da psiquiatria americana, freqüentemente citado hoje como Whig, foi Albert Deutsch e seu The Mentally Ill in America de 1937. Mas Deutsch, conforme se vê no ensaio de George Mora, nesse livro, não é nem médico, nem historiador, mas um servidor público autodidata, do movimento de higiene mental do Estado de New York, que era manifestamente reformista. Além disso, seu livro é farto em fontes de dados. Similarmente, como indica Edward Morman, em seu capítulo neste livro, George 
Rosen, que se doutora em medicina e sociologia, é pioneiro no conceito de "sociologia histórica da doença mental”, contemporaneamente aos escritos de Goffman, Laing, Foucault e Szasz.

Os editores acentuam que, nas últimas duas décadas, diminui a psiquiatria hospitalar tradicional em poder e prestígio. No entanto, ao mesmo tempo ocorre a expansão e influência da visão de mundo através da psicologia. As pessoas se voltam para as psicociências para organizar seus relacionamentos, educar suas crianças, para interpretar a arte, para melhorar a vida sexual, para nos dizer porque estamos infelizes, deprimidos, ansiosos ou fatigados. Essas necessidades psicológicas produziram uma imensa estrutura profissional. Micale e Porter chamam esse processo de "revolução psicológica”, e consideram essa a maior transformação cultural do século XX.

Falando da estrutura do livro, os editores dizem que seus autores são das ciências médicas, das ciências sociais e das humanidades. Frisam que o conteúdo vai além dos estudos do mundo anglo-saxão e aborda também outras culturas. O livro tem vinte capítulos, agrupados em cinco partes.

A primeira parte diz respeito aos trabalhos iniciais sobre história da psiquiatria, com um capítulo intitulado "Início da historiografia psiquiátrica na Alemanha do século XIX”, por Otto M. Marx e outro capítulo chamado "Primeiros historiadores americanos de psiquiatria: 1910-1960”, por George Mora.

A segunda parte desse livro explora o trabalho de cinco indivíduos: Richard Hunter, Ida Macalpine, George Rosen, Henri Ellenberger e Jean Starobinski. Respectivamente pelos autores: Roy Porter, Edward T. Morman, Mark S. Micale, Fernando Vidal. Conforme Micale e Porter, esses personagens estão entre os mais poderosos e originais intérpretes históricos da psiquiatria no século $\mathrm{XX}$. Todos eles receberam treinamento médico, sendo que Hunter e Ellenberger praticaram psiquiatria institucional. Esses e outros psiquiatras, ainda conforme os editores, trazem valorosas contribuições à história da psiquiatria. Na França, a primeira análise crítica do mito fundador de Pinel é da psiquiatra Gladys Swain.

A terceira parte chama-se “Corrente psicoanalítica” e tem os capítulos "História das biografias de Freud”, por Elisabeth Young-Bruehl; "Um clima de opinião: reescrevendo a história da psicanálise”, por John Forrester; “Philip Rieff: a crítica da psicanálise como teoria cultural”, por Kenneth S. Piver. 
A quarta parte chama-se “Temas e tópicos de história”, com os capítulos: “Os mitos de origem na história da psiquiatria”, por P. Vandermeersch; “O gesto de Pinel: a história do mito psiquiátrico”, por D. B. Weiner; “A história da psiquiatria na Itália: um século de estudos”, por P. Guarnieri; “A história do asilo revisitada: reflexões pessoais”, por G. N. Grob; “Psiquiatria alemã, psicoterapia e psicanálise durante o período nazista: reflexões historiográficas", por G. Coks; "Heróis e não-heróis: temas recorrentes na historiografia da psiquiatria russo-soviética”, por J. V. Brown.

A quinta parte chama-se "Críticas da Psiquiatria”, com os capítulos: "O paradigma retórico na história da psiquiatria: Thomas Szasz e o mito da doença mental”, por R. E. Vatz e L. S. Weinberg; “Fenomenologia dos espíritos doentes de Michel Foucault”, por G. Gutting; “Histórias feministas da psiquiatria”, por N. Tomes; “História e anti-psiquiatria na França”, por J. Postel e D. F. Allen; “Psiquiatria e antipsiquiatria nos Estados Unidos”, por N. Dain.

Continuando, então, os editores acentuam que alguns dos revisionistas podem ser criticados com os mesmos métodos que eles usam para criticar a historiografia Whig. Eles, os revisionistas, alegam que a história dos profissionais foi moldada para servir a seus interesses e os acusam de "presentismo”. No entanto, conforme Micale e Porter, os revisionistas também aplicam valores de julgamento do fim do século vinte a médicos, administradores e políticos que viveram em outras condições no passado.

Os editores dizem ainda suspeitar que historiadores sociais da psiquiatria, radicalmente orientados, estavam cientes de suas orientações ideológicas e metas políticas. No entanto, parece que não estavam tão conscientes de que sua agenda política serviu para selecionar seus assuntos, modelar suas metodologias, suas interpretações e predeterminar suas conclusões. Ainda conforme os editores, esses historiadores da psiquiatria centraram-se em narrativas que levaram a análises econômicas, sociais e políticas, mais do que científicas ou clínicas. Em adição, sua desmistificação das idealizações Whig acabou gerando heróicas remistificações neomarxistas e foucaultianas. A reforçada divisão entre historiador amador e profissional, a conceituação programaticamente externalista da disciplina, e metodologias apropriadas para tal conceitualização, que foi ruidosamente anunciada nos anos 1970, foram calculadas para privilegiar a autoridade explanatória do historiador social e do cientista social sobre o médico. 
Micale e Porter acentuam que dizemos que a história Whig foi escrita para os psiquiatras. Mas, os revisionistas também escreveram para indivíduos da sua corporação, intelectuais não médicos da academia, que compartilham a mesma ideologia. Assim, os editores dizem que: “para entender a história da psiquiatria escrita pelos profissionais é preciso conhecer os vínculos dos psiquiatras; do mesmo modo, para entender a história da psiquiatria escrita pelos historiadores é necessário conhecer os seus vínculos”.

Reforçam os editores que o propósito desse livro não é levantar vantagens do lado Whig ou do lado revisionista, nem alimentar o confronto, mas ressaltar que ambos os lados faltaram com uma auto-crítica e auto-reflexão, e ambos os lados se politizaram substancialmente.

A seguir fazemos mais algumas considerações a respeito de certos temas tratados nessa obra de Micale e Porter, que, entre os capítulos citados, são de interesse para o nosso trabalho.

Um desses temas diz respeito aos mitos de origem, ou de fundação da psiquiatria. Em um capítulo a esse respeito, o autor Vandermeersch, ao estudar os mitos de origem em ciências, relata que a função desses mitos é de legitimizar o presente. Assinala que, nos relatos históricos da psiquiatria, há certas referências que podem ser consideradas mais como mitos, tal como a "liberação das correntes" dos alienados de Bicêtre por Pinel, supostamente ocorrido em 1794.

Vandermeersch cita outro autor, J. Postel, que, por sua vez, assinala que o pintor Tony Robert-Fleury “imortalizou” a cena desse acontecimento na conhecida pintura de 1878, de maneira um tanto fantasiosa, similarmente a tantas outras construções artísticas do passado.

Em outro capítulo sobre o assunto de mitos de fundação, Weiner cita o trabalho de história da psiquiatria feito pela psiquiatra francesa Gladys Swain, no qual essa autora refere que o filho mais velho de Pinel (1745-1826), o médico Scipion Pinel (1795-1859), juntamente com o discípulo favorito e herdeiro acadêmico de Pinel, o médico Esquirol (1772-1840), iniciaram o processo de construção de um símbolo sentimental, que se tornou o "mito de Pinel como libertador dos alienados"43.

43 WEINER, D.B. "Le geste de Pinel”: The History of a Psychiatric Myth. In: PORTER, R.; MICALE, M.S, (edits), Discovering the History of Pyschiatry, Oxford University Press, 1994. 
Weiner amplia a visão sobre Pinel, para além do estudo do mito fundador, e discute o mito em torno de sua figura, que foi oportunamente usado em várias circunstâncias, em debates entre direita e esquerda francesa no século XIX. Essa autora considera que o mito encobriu feitos valorizáveis de Pinel no cuidado aos pacientes, considerando que a origem da atenção especial de Pinel aos pacientes pode ter advindo de sua religiosidade - um fato esquecido -, mais do que do próprio espírito da revolução francesa; essa religiosidade não teria sido um dado de interesse daqueles que politizaram os feitos de Pinel.

Em relação a Freud, em capítulo escrito por Young-Buehl, intitulado A history of Freud Biographies, a autora faz uma análise crítica de várias biografias de Freud. Comentando sobre a psicanálise, ela considera essa uma ciência singular entre as ciências, por três razões: a primeira por ser uma ciência “praticada” sobre seus futuros executores, não sendo aprendida e sim incorporada; segundo, por ser uma ciência, onde, conforme diz, "não há um Einstein para esse Newton”, acrescentando que a ciência de Freud tornou-se mais uma espécie de literatura sobre Freud, sem sucessor à altura ou que o superasse; em terceiro, considera que a psicanálise é uma ciência sem maiores contribuições à sua própria história como ciência, pois é centrada na biografia de Freud, sendo que ele mesmo, "sem cerimônia” (palavras da autora), escreveu em 1914 o livro “Sobre a História do Movimento Psicanalítico”, centrado na sua própria biografia.

Gutting, em outro capítulo do livro de Micale e Porter, aprofunda uma análise crítica das considerações de Foucault sobre a loucura, e faz algumas avaliações de estudiosos que se opõem, e dos que são favoráveis a Foucault, deixando em aberto a necessidade de melhor aprofundamento sobre essas questões ${ }^{44}$. Esses debates giram em torno da dimensão e significado do "confinamento”, tão enfatizado por Foucault, bem como sobre sua rejeição veemente em ver como progresso o tratamento médico clássico que, conforme Gutting, levou a se considerar os loucos como doentes mentais e não como criminosos, o que, para alguns, foi um fator favorável aos doentes ${ }^{45}$.

44 GUTTING, G. Michel Foucalt’s “Phänomenologie des Krankengeistes”. In: PORTER, R.; MICALE, M.S. (edits), Discovering the History of Psychiatry, Oxford University Press, 1994.

45 Entre outras obras, pode-se ver as idéias de Foucault sobre psiquiatria em:

FOUCAULT, M. História da Loucura na idade clássica. Editora Perspectiva (1972), 1989. 


\section{3. 2. 2. - Foucault e os conceitos de "corpo neurológico" e de outros corpos}

Um autor sabidamente marcante no estudo da história da psiquiatria e campos afins é Michel Foucault. O seu entendimento a respeito da psiquiatria configurou um verdadeiro paradigma sobre uma determinada maneira de ver a loucura, as doenças mentais e seus estudos, de modo que ele passou a ser uma referência obrigatória em trabalhos sobre esses assuntos. Por outro lado, têm sido feitos trabalhos de reavaliação desses conceitos e nem todos são concordes a respeito de suas idéias ${ }^{46}$.

Uma forma de aprofundarmos o entendimento do tema em questão pode ser através do conceito de Michel Foucault a respeito de “corpo neurológico” presente no livro “O Poder Psiquiátrico”, referente a uma copilação das aulas dadas por ele em Paris, nos anos de 1973 e 1974.

A primeira menção de “corpo neurológico” por Foucault ocorre em sua aula de 30 de janeiro de $1974^{47}$.

Nessa aula, antes de abordar o corpo neurológico, ele cita o que considera como as três formas que a psiquiatria usa para abordar os pacientes psiquiátricos no século XIX: o interrogatório, a droga e a hipnose.

No entender de Foucault, é a partir da hipnose que o corpo do doente passa a participar da prática psiquiátrica. Ele menciona que o magnetismo, do tipo mesmerismo, é deixado de lado por volta dos anos 1830 na França, e que o magnetismo mais próximo de uma conceituação científica, caracterizado como "hipnotismo”, começa a ter espaço a partir da obra de Braid, de 1843, intitulada Neurhypnology, or the Rationale of Nervous Sleep. Com essa publicação, Braid torna conhecido o termo "hipnotismo". Ainda de acordo com Foucault, é a partir de Broca, em 1858-1859, que a hipnose ganha mais força, por ele operar um doente em estado hipnótico. Conforme Foucault, a partir da hipnose o psiquiatra passa a ter poder sobre o corpo do doente:

46 Sobre isto ver, por exemplo:

BAUDRILLARD, J. Esquecer Foucault. Editora Rocco, (1977) 1984.

FREITAS, F.F.P. A história da psiquiatria não contada por Foucault. História, Ciências, SaúdeManguinhos, vol. 11 (1): 75-91, jan-abr., 2004.

Conforme Freitas, a edição brasileira da História da Loucura de Foucault suprimiu os Posfácio da edição de 1972 francesa, com as críticas de Henri Gouthier e Jacques Derrida, tendo sido também suprimido na edição francesa de 1978. Freitas acha que Foucault cometeu equívocos em sua interpretação do nascimento da Psiquiatria.

47 FOUCAULT, M. O Poder Psiquiátrico, Martins Fontes, (2002), 2006, p. 345-374. 
“Logo, vocês vêem definir-se, ou antes, aparecer nessa hipnose, tal como ela é agora aceita, esse célebre corpo do doente que estava até então ausente da prática psiquiátrica. A hipnose é o que vai efetivamente possibilitar intervir no corpo, não simplesmente no nível disciplinar dos comportamentos manifestos, mas no nível dos músculos, dos nervos, das funções elementares. Por conseguinte, a hipnose é uma nova maneira, muito mais aperfeiçoada, muito mais extremada que o interrogatório, de o psiquiatra dominar efetivamente o corpo do doente, ou antes, é a primeira vez que o corpo do doente, em seu detalhe de certo modo funcional, vai enfim se encontrar ao alcance do psiquiatra"48.

No que diz respeito à técnica do interrogatório, Foucault diz que a percepção da doença pelo psiquiatra através dessa técnica, nesse período, só se dá através da linguagem.

Já o uso da droga dada ao doente pelo psiquiatra, permite uma percepção interna dos fenômenos da loucura, que Foucault chama de “apreensão interna” da loucura.

Ainda conforme Foucault, com a hipnose ocorre a apreensão do funcionamento do corpo do doente pelo psiquiatra, concomitantemente ao aparecimento do “corpo neurológico":

"Vocês estão vendo que temos aí os elementos a partir dos quais vão poder se constituir, ou melhor, os elementos que estão instaurados e que, bruscamente, nos anos 1860-1880, vão adquirir uma importância e uma intensidade extremas, quando, justamente, do próprio interior da medicina orgânica clássica, vai surgir uma nova definição, ou antes, uma nova realidade do corpo, isto é, quando se vai descobrir um corpo que não é simplesmente um corpo com órgãos e tecidos, mas um corpo com funções, desempenhos, comportamentos - em suma, quando se descobrir o corpo neurológico, e isso em torno de Duchenne de Boulogne, por volta de 1850-1860"49.

Assim, ele acentua uma diferenciação do corpo neurológico em relação ao corpo anatômico, na medida em que atribui ao primeiro uma dinâmica própria, em que estão presentes “funções, desempenhos e comportamentos”.

Foucault completa essa reflexão, dizendo que esse corpo neurológico vai “escapar” ao psiquiatra, pois este vai ficar com os métodos: o interrogatório, a droga e a hipnose. Ele considera que esses três elementos ainda mantêm o poder psiquiátrico no espaço asilar no transcorrer do século XX. Conforme Foucault, a droga e a hipnose

48 FOUCAULT, M. O Poder Psiquiátrico, p. 372.

49 Idem, p. 373.

35 
aproximam o corpo do paciente psiquiátrico do corpo estudado pela anatomia patológica, mas de modo diferente do método utilizado no exame neurológico.

Em sua aula de 6 de fevereiro de 1974, que faz parte da mesma compilação ${ }^{50}$, Foucault explica que o corpo neurológico é o corpo da "localização anatomopatológica”. Ele cita Charcot, que em 1879 diz que a constituição da neurologia é o "triunfo do espírito de localização"51.

“O que podemos entender por 'corpo neurológico’? É por aí que gostaria de começar hoje. Claro, o corpo neurológico ainda é, é sempre o corpo da localização anatomopatológica. Não há porque opor o corpo neurológico ao corpo anatomopatológico. $O$ segundo faz parte do primeiro, é, se assim podemos dizer, um derivado ou uma expansão dele. Aliás, a melhor prova disso é que Charcot, num de seus cursos, em 1879, dizia que a constituição, os progressos e, a seu ver, inclusive o perfazimento da neurologia, era o triunfo do "espírito de localização" 52 .

Devemos deixar claro que essa conceituação de Foucault a respeito de “corpo” não implica em confundir a idéia de sistema nervoso com a idéia de corpo neurológico, ou de corpo clínico com os sistemas clínicos. Esses conceitos de Foucault são fortemente arraigados ao desenvolvimento da semiologia de um lado e da anatomia patológica de outro. O elemento associado a estudos de fisiologia, que ele insere nesse processo, diz respeito à conceituação de "reflexo", a partir de experiências de Duchenne de Boulogne com estimulação elétrica de músculos.

Foucault assinala que a localização anatômica e a observação clínica da neurologia, ou seja, da clínica neurológica, não é a mesma da medicina geral:

“Mas creio que o que é importante é que os procedimentos para ajustar a localização
anatômica e a observação clínica não são em absoluto os mesmos quando se trata da
neurologia e quando se trata da medicina geral comum. E parece-me que a neurologia, a
clínica neurológica, implica uma colocação bem diferente do corpo no campo da prática
médica. Tenho a impressão de que o face a face do corpo-doente e do corpo-médico se faz de
acordo com uma disposição totalmente diferente na neurologia e na medicina em geral. E é a
instauração desse novo dispositivo que me parece ser o episódio importante, e é por isso que

50 FOUCAULT, M. O Poder Psiquiátrico. Martins Fontes, (2002) 2006, p. 306-419.

51 Devemos assinalar que esse raciocínio "de localização" em neurologia tornou-se consagrado, de modo que perdura até a atualidade como elemento importante e diferencial da neurologia, em relação a outras áreas do conhecimento médico. Desse modo, faz parte da linguagem neurológica cotidiana falar-se em "sinais localizatórios" para determinados sinais clínicos.

52 FOUCAULT, M. O Poder Psiquiátrico, p. 387.

36 
eu gostaria de procurar identificar o novo dispositivo que é instituído assim pela constituição de uma neuropatologia ou de uma medicina clínica neurológica”53.

Foucault considera que a formação da anatomia patológica, associada à clinica, situa-se entre Bichat ${ }^{54}$ e Laënnec ${ }^{55}$ (início do século XIX), e se trata de um processo que ele chama de "estímulo e efeito”.

Nesse processo de "estímulo-efeito", o que Foucault chama de "efeito" corresponde a algum fenômeno físico produzido pelo observador, fenômeno esse que não consta habitualmente do organismo, a não ser pela construção feita por esse observador quando da produção desse efeito, inserido em um determinado contexto de entendimento do órgão ou sistema pesquisado.

Desse modo, ao percutir o tórax ou ao pedir que o paciente diga "trinta e três”, o médico observa um “efeito” decorrente de um “estímulo” feito por ele. Dito de outra forma, pode-se dizer que ao percutir o tórax o médico provoca um efeito físico, efeito esse que, habitualmente, não faz parte do organismo. Ao pedir para dizer trinta e três, o médico palpa ou ausculta o efeito físico dessa solicitação e observa fenômenos colaterais a essa solicitação. Nas próprias palavras de Foucault:

“Quero dizer o seguinte: na anatomia patológica de Bichat-Laënnec, os sinais podem, é claro, ser imediatamente percebidos, ao primeiro olhar; também é possível obtê-los em conseqüência de um estímulo: percute-se, ouve-se, etc. Ou seja, no fundo é o sistema estímulo-efeito que é buscado na anatomia patológica clássica: percute-se o peito, ouve-se o barulho; pede-se para tossir e ouve-se a estridência da tosse; apalpa-se e vê-se se há calor. Logo: estímulo-efeito" ${ }^{56}$.

Diferentemente desse procedimento do tipo “estímulo-efeito” da clínica geral, conforme Foucault, na neurologia ocorre o fenômeno do tipo "estímulo e resposta”, ou seja, a um "estímulo” aplicado, observa-se uma "resposta” que seja própria do sistema nervoso:

53 FOUCAULT, M. O Poder Psiquiátrico, p. 387-388.

54 Marie François Xavier Bichat (1771-1802), depois de ter se iniciado na cirurgia em Lyon, no serviço de Marc-Antoine Petit (1762-1840) e de ter se tornado, em junho de 1794, aluno de Pierre Joseph Delsaut (1744-1795), um cirurgião do Hotel-Dieu, consagra-se à anatomia patológica em 1800, quando passa a estabelecer relações definidas entre as alterações dos tecidos e os sintomas clínicos.

FOUCAULT, M. O Poder Psiquiátrico. Martins Fontes Editora, (2003) 2006, p. 251.

55 René Théophile Laënnec (1781-1826) e Gaspard Laurent Bayle (1774-1816) procuraram fundir noções de clínica médica e de anatomia patológica. Laënnec aprimorou o método de auscultação e suas correlações com as patologias pulmonares.

FOUCAULT, M. O Poder Psiquiátrico. Martins Fontes Editora (2003) 2006, p. 251.

56 FOUCAULT, M. O poder Psiquiátrico, p. 390. 
“No caso do exame neurológico como está se constituindo no meado do século XIX, o essencial dos sinais, enfim o que faz um sinal ser um sinal, não é tanto o fato de que ele é [decifrado como um] efeito mais ou menos mecânico, como o barulho que segue a percussão na anatomia patológica clássica, mas de que um sinal é [decifrado] como resposta. A substituição do esquema estímulo-efeito pelo esquema estímulo-resposta, a instituição de toda uma bateria de estímulos-respostas é que é, a meu ver, capital”57.

Foucault refere, então, que da aplicação dessa bateria de estímulos-respostas podem ser citados diversos exemplos:

“No nível propriamente elementar, foi a descoberta fundadora da neuropatologia, a descoberta de Duchenne de Boulogne, quando, em suas pesquisas do que ele chamava de 'faradização localizada', conseguiu obter uma resposta muscular única, ou antes, a resposta de um músculo único a uma eletrização da superfície da pele umectando os dois electrodos; umedecendo a superfície da pele, ele conseguiu limitar o efeito da eletrização e obter uma resposta singular de um só músculo - foi a descoberta fundadora de tudo ${ }^{58}$.

Continua então Foucault, relatando que a partir daí ocorrem os estudos dos reflexos e dos comportamentos complexos, que implicam em uma "engrenagem de automatismos diversos ${ }^{59}$.

A seguir, Foucault cita duas ocorrências que ele considera importantes na elaboração desse sistema da observação neurológica, que são: a afasia ${ }^{60}$ conceituada por Broca e o andar dos tabéticos ${ }^{61}$ conceituado por Duchenne de Boulogne ${ }^{62}$. Quanto à marcha dos tabéticos, Foucault lembra que, no período abordado, ela está associada ao quadro denominado "paralisia geral” ${ }^{\text {, }}$. Ambos os quadros são fortemente associados à sífilis, nesse período ${ }^{64}$.

57 FOUCAULT, M. O poder Psiquiátrico, p. 390.

58Idem.

59 Ibidem.

60 Afasia corresponde a comprometimento da capacidade para compreensão ou expressão de linguagem verbal devido a lesão cerebral. O termo "afasia" foi proposto por Armand Trousseau em 1864, seguindo sugestão de um médico grego, que considerou o termo "afemia", criado por Broca, inapropriado, por significar "infame".

FINGER, S. Origins of Neuroscience, p. 379.

61 Tabes em latim significa "definhamento". Desde o século XIX esse nome é mais frequentemente citado como tabes dorsalis e diz respeito a um comprometimento da medula espinhal com alteração do andar, alteração essa que foi estudada por Duchenne. No transcorrer do século XIX esse quadro foi cada vez mais atribuído à sífilis.

62 Foucault situa essas ocorrências, bem como as experiências elétricas de Duchenne, entre os anos 18501870.

FOUCAULT, M. O Poder Psiquiátrico, p. 387.

63 A doença denominada "paralisia geral" ou ainda "paralisia geral progressiva" é uma entidade nosológica, cuja conceituação é principalmente atribuída a Antoine-Laurent-Jessé Bayle (1799-1858) que 38 
Ainda na comparação entre a observação clínica e a observação neurológica, Foucault considera que o sistema clínico de "Bichat-Laënnec" implica em uma codificação redutora e limitada a certos sinais de superfície, que só passa a ser detalhada pela anatomia patológica na necrópsia.

Diferentemente, conforme Foucault, na neurologia ocorre todo um detalhamento da superfície do indivíduo, no exame neurológico, com ênfase para cada mínimo aspecto, conforme exemplifica com observações feitas pelos assistentes de Charcot, a respeito da descrição de certas características da face de um paciente, descrição essa que Foucault chega a denominar de "impressionista”.

Foucault também inclui na estruturação do corpo neurológico a possibilidade de escalonar os fenômenos observados em neurologia, em um eixo evolutivo, que vai da motricidade reflexa à motricidade automática e à motricidade voluntária. Esse conceito aprimora-se gradativamente no transcorrer dos séculos XIX e $\mathrm{XX}^{65}$.

a formula a partir de estudos feitos desde sua tese, em 1822, até a década de 1850, sob muitos debates na Sociedade Médico-psicológica de Paris. Essa moléstia tem sido considerada como um modelo clínico, com o qual a mentalidade anatomo-clínica penetrou na psiquiatria, dando início a uma busca sistemática da lesão orgânica causal da loucura, de modo que a sala de necropsia se torna auxiliar do psiquiatra.

No século XIX, a causa dessa moléstia é gradativamente atribuída à sífilis.

HUERTAS, R. El siglo de da Clinica, p. 93-102.

$64 \mathrm{O}$ nome sífilis foi cunhado pelo médico italiano Giovanni Fracastoro (1478-1553) em seu poema Syphilis, sive morbus Gallicus, ou seja "Sífilis, a doença francesa”.

WEBSTER’S College Dictionary, Random House, New York, 1997.

Conforme Foucault, a grande estrutura que comanda a percepção da loucura encontra-se exatamente representada na análise dos sintomas psiquiátricos da sífilis nervosa. Ele cita o estudioso Henry Ey, que via na sífilis um protótipo que exerceu poder de atração irresistível sobre os psiquiatras. Foucault acha que isso se deve ao fato de que Bayle isolou, em psiquiatria, uma entidade (paralisia geral) que correspondia ao modelo médico, com alteração anatomo-patológica, sintomatologia específica e evolução definida.

FOUCAULT, M. O Poder Psiquiátrico, p. 425.

Em 1879, Alfred Fournier demonstra que a paralisia geral é uma complicação freqüente da sífilis. Mas esse achado leva a intensos debates nos anos seguintes na Sociedade Médico-Psicológica, em torno da causa da paralisia geral. A sífilis como etiologia definitiva da paralisia geral só é estabelecida em 1913, quando Noguchi e Moore detectam o Treponema pallidum no cérebro desses doentes.

FOUCAULT, M. O Poder Psiquiátrico, p. 375.

65 Essa escala evolutiva da motricidade, em sentido ascendente, com suas formas de motricidade reflexa, motricidade automática e motricidade voluntária, é atribuída a Hughlings Jackson (1835-1911), que desenvolve trabalhos a esse respeito nas décadas de 1880 e 1890, tendo sido influenciado por Darwin, Spencer e Charles Bell.

FINGER, S. Origins of Neuroscience. Oxford University Press, 1994, p. 271.

Essa conceituação evolutiva da motricidade permanence aceita em neurologia, na atualidade, e é parte importante do entendimento neurológico clínico de síndromes e níveis de comprometimento do sistema nervoso. 
Nessa “instauração” da neurologia, Foucault não faz considerações sobre os estudiosos alemães e ingleses como, por exemplo, Romberg ${ }^{66}$, ou Charles Bell ${ }^{67}$, que traçam seus caminhos científicos em torno de estudos sobre o sistema nervoso.

Para Foucault, além de sua diferenciação com a clínica, a neurologia também tem uma diferenciação com o campo da psiquiatria. Essa diferenciação ocorre na medida em que o psiquiatra quer ouvir informações verbais do doente no interrogatório, enquanto o neurologista “ouve” as respostas dadas "pelo próprio corpo do doente”.

Em relação ao psiquiatra, Foucault considera também que, durante o século XIX, “o corpo” do psiquiatra confunde-se com o próprio asilo. Desse modo, ele diz que: “O asilo é o corpo do psiquiatra, alongado, distendido, levado às dimensões de um estabelecimento, estendido a tal ponto que seu poder vai se exercer como se cada parte do asilo fosse uma parte do seu próprio corpo, comandada por seus próprios nervos”,68.

Concomitantemente, Foucault considera que, em pólo oposto a essa identificação do corpo do psiquiatra com o lugar asilar, estabelece-se outro corpo, o “corpo do cirurgião”, que se serve “das suas próprias mãos, do seu próprio corpo, para anular o mal”69.

Além dessa caracterização de corpos dos médicos psiquiatras e cirurgiões, Foucault também dispõe as diferentes noções de corpos dos pacientes. Ele situa o surgimento de um “corpo neurológico”, intermediário entre o corpo clínico e o corpo psiquiátrico, que passa a ser esse corpo que responde a estímulos, dentro de um contexto determinado de respostas e reações corporais. Em relação a essas respostas corporais, Foucault situa o aparecimento dos quadros histéricos “produzidos” por Charcot.

66 Moritz Heinrich Romberg (1795-1873) publica o primeiro livro texto sistematizado de neurologia intitulado Lehrbuch der Nervenkrankheiten des Menschen (Tratado das moléstias nervosas em humanos) entre 1840 e 1846 (traduzido para o inglês em 1853), quando diretor do Hospital Universitário de Berlim. Um sinal por ele descrito, que passa a ser conhecido como "sinal de Romberg" é considerado como um sinal importante na tabes dorsalis.

PEARCE, J. M. S. Romberg and his sign. European Neurology, 53: 210-213, 2005.

67 Charles Bell (1774-1842) é um médico escocês que em 1911 publica um folheto intitulado "Idea of a new Anatomy of the Brain”. Em 1824 republica seus achados. Em 1830 seus seis trabalhos são coletados sob o título The Nervous System of the Human Body. Alguns atribuem a ele o início de uma neurologia clínica.

PEARCE, J. M. S. Romberg and his sign. European Neurology, 53: 210-213, 2005.

FINGER, S. Origins of Neuroscience: A History of Explorations into Brain Function. Oxford University Press, 1994, p. 28-29.

68 FOUCAULT, M - O poder psiquiátrico, p. 227.

69 Idem, p. 235.

40 


\section{3. 2.3 - Rafael Huertas e o corpo social}

Um livro que também aborda os processos entre psiquiatria e as outras áreas, no século XIX, é El siglo de la clínica - para uma teoria de práctica psiquiátrica do historiador espanhol Rafael Huertas, de 2004. O autor é vice-presidente da Sociedade Espanhola de História da Medicina, diretor da revista Frenia e membro do Editorial Advisory Board of History of Psychiatry; parte importante de sua produção científica é voltada para a história da psiquiatria.

$\mathrm{Na}$ introdução, Huertas considera que a mente é uma das fronteiras mais disputadas da ciência atual, um território em que disciplinas diversas mantêm seus interesses, desde as mais clínicas, como a psiquiatria, a psicologia, a neurologia, até as mais experimentais, como as neurociências básicas, sem esquecer a filosofia, a pedagogia, a lingüística, a religião, a arte.

O autor refere que como ciência de baixa tecnologia, a psiquiatria é uma especialidade influenciável, cujo corpo teórico pode modificar-se, dependendo de considerações políticas, sociais ou econômicas. Além disso, continua Huertas, o objeto de conhecimento da psiquiatria é incerto e seus métodos subjetivos. Acrescenta que as diferenças epistemológicas entre escolas não se produz em nenhum campo científico como nas “disciplinas psi”: corpo e alma, cérebro e mente, matéria e pensamento, neurotransmissor e significante. O autor diz que as "histórias da psiquiatria" não se limitam a narrar as diferentes vertentes psiquiátricas, mas convertem-nas em veículos que legitimem as diferenças epistemológicas.

Huertas diz que o status científico da medicina mental é questionado, e refere que o estudioso Lanteri-Laura tem alegado que a psiquiatria não é uma ciência, porque os paradigmas psiquiátricos não se sustentam pela conceituação de Kuhn. O autor também cita German Berrios, que considera a psiquiatria como sendo um conjunto de linguagens desenvolvidas pela sociedade para descrever, explicar e manejar transtornos de conduta, que dependem de uma disfunção neurofisiológica ou psicológica.

O autor diz então que, apesar das diferenças, tanto Lanteri como Berrios, ambos clínicos e historiadores, indicam que a psiquiatria é, historicamente, um conhecimento predominantemente clínico, ilustrado por outros saberes e orientado para uma prática terapêutica. Acrescenta a preocupação de alguns estudiosos sobre o futuro 
da psiquiatria, se ela vai desaparecer ligada às neurociências, ou se vai ocorrer uma subdivisão em ramos; Huertas diz que o prêmio Nobel de Medicina de 2000, Kandel, sugere um novo marco conceitual para a psiquiatria, em que as neurociências passem a ser a base da investigação e da terapêutica psiquiátrica.

Refere o autor, então, que diversas vozes têm se pronunciado sobre a necessidade de construir um novo pensamento psiquiátrico, no qual a história desempenhe um papel fundamental na recuperação e redimensionamento de uma clínica e psicopatologia cada vez mais esquecidas.

O autor diz que, sem esquecer o trabalho de Michel Foucault, os estudos do âmbito psiquiátrico francês têm se desenvolvido por Georges Lanteri-Laura e Jean Garrabé, além de Paul Bercherrie. Na Escola de Cambridge, Huertas refere uma história conceitual da psiquiatria, com a revista History of Psychiatry, dirigida por German Berrios e codirigida por Roy Porter até o seu falecimento. No âmbito espanhol, o autor cita José Maria Alvarez com a obra A invenção das enfermidades mentais, onde há uma articulação entre a clínica e a história.

O autor diz que a história da psiquiatria pode cumprir um papel epistemológico de primeira ordem, ao explicar porque os profissionais de saúde têm determinada prática cotidiana e têm determinados discursos. Assim, ele diz ser favorável a uma colaboração entre o historiador profissional de psiquiatria e o psiquiatra com tarefas de historiador.

Assinala Huertas que o objetivo de seu ensaio é estudar os principais conteúdos do discurso psiquiátrico na prática clínico, e processado desde o nascimento do alienismo, na passagem dos séculos XVIII e XIX, até a descrição da esquizofrenia em 1911, a partir da qual, segundo Lanteri-Laura (citado por Huertas), inicia-se o paradigma das grandes estruturas psicopatológicas.

O livro se compõe de quatro capítulos e um epílogo.

O primeiro capítulo intitula-se A medicalização da loucura, com as subdivisões: Para um novo sistema: o nascimento da clínica; Entre a doutrina e a clínica: a nosografia de J. E. D. Esquirol; Uma nova semiologia: o distúrbio da sensação; Monomanias: o transgressor medicalizado.

O segundo capítulo chama-se A somatização da alma, com as subdivisões: Sobre a corporalidade; Sintoma e lesão; Degeneração e clínica psiquiátrica; O delírio crônico e seus desdobramentos. 
O terceiro capítulo intitula-se Contornando a ortodoxia alienista, com as subdivisões: Organicismo versus psicologismo, A dor moral, Nosografia $e$ antinosografia, A construção da histeria.

O quarto capítulo chama-se Dilemas terapêuticos, com as partes: $O$ tratamento moral, Do nihilismo terapêutico à higiene social, O non restraint, Curar a loucura, apesar de tudo.

Diversos comentários dessa obra serão utilizados em algumas seções deste trabalho. Aqui queremos assinalar o texto em que o autor fala sobre os estudos a respeito do corpo e sobre o corpo social, na parte Sobre a corporalidade, do segundo capítulo.

Huertas refere que, quando um historiador da ciência ou da medicina, aborda o problema do corpo humano, tradicionalmente se restringe às chamadas "ciências morfológicas”, o que inclui a anatomia, a histologia e embriologia. Ele acentua que, mesmo o estudo histórico do corpo doente tem sido conduzido de uma forma positivista.

No entanto, o autor diz que, nas últimas décadas do século $\mathrm{XX}$, essa história felizmente foi contaminada por outras correntes, como a história social, os estudos de gênero, e também por outras disciplinas como a antropologia, a filosofia, a psicanálise, etc. Ele atribui esses interesses a temores, no final do século $\mathrm{XX}$, relativos à sensação de perda do próprio corpo pela sociedade, ou das propriedades desse corpo. Após citar as abordagens feitas por Foucault a respeito do corpo, Huertas diz que há outras abordagens possíveis do corpo humano em cada momento histórico: abordagens simbólicas com paralelismos entre o corpo individual e o “corpo social”.

Após citar exemplos, Huertas comenta sobre a possibilidade de a concepção científica do corpo influenciar a maneira de entender o espaço urbano. Assim, ele diz que desde Harvey ${ }^{70}$ a cidade tem “pulso, respiração” e as pessoas trafegam por grandes “artérias e veias” dessa mesma cidade. Acrescenta o autor também que, desde Willis ${ }^{71}$, as cidades têm também “fibras e energias nervosas”.

70 William Harvey (1578-1657) demonstrou a circulação sangüínea em publicação datada de 1628. Ele foi influenciado por seus estudos em Pádua, com Fabricius de Aquapendente (1537-1619), que foi discípulo de Gabriello Fallopio (1523-1562) e este de Andreas Vesalius (1514-1564).

LYONS, A. S.; PETRUCELLI, R..J. Medicine, an Illustrated History. Abradale Press, 1987, p.432-433. 71 Thomas Willis (1621-1675) publicou em 1664 a obra Cerebri anatome, onde cunhou o termo "neurologia", entre outros termos.

FINGER, S. Origins of Neuroscience, 1994, p. 23-24.

43 
Assim como essas menções feitas por Huertas a respeito dessa influência da ciência sobre a visão do urbano, estudiosos que escrevem no fim do século XIX, como Durkheim e Gabriel Tarde também usam termos específicos que fazem parte da linguagem de estudos do sistema nervoso, para descrever e interpretar fenômenos sociais $^{72}$.

Pela extensão de nosso trabalho, não podemos aqui aprofundar essa questão, mesmo porque tratamos nesta seção do livro de Huertas. Mas podemos ao menos assinalar que Durkheim e Tarde, que são tidos mais como sociólogos, também entram em questões psicológicas, principalmente no tema da psicologia das massas.

I. 3. 3. - Historiografia sobre psiquiatria, psicologia e neurologia no Brasil e em São $\underline{\text { Paulo. }}$

Parte da historiografia da psiquiatria em São Paulo tem intersecção com a historiografia da neurologia e também com a psicologia ${ }^{73}$. No Brasil há uma historiografia da psiquiatria que tem pouca ou nenhuma abordagem sobre São Paulo.

\section{3. 3.1 - Psiquiatria}

A visão de Foucault sobre a loucura, a psiquiatria e a medicina fomentou uma interpretação conflituosa a respeito da convivência de disciplinas consideradas organicistas, com as consideradas não-organicistas. Assim como houve um estudo localizado em diferentes países, que se seguiram aos autores contestadores (Foucault, Laing, Goffman e Szasz), também ocorreu no Brasil a aplicação de tais trabalhos, mormente pela influência de Foucault. Há que se ressalvar que, enquanto nos países europeus e norte-americanos os anos 1960 e 1970 vivenciavam processos de contestação política em diversos contextos, o equivalente a isso para o Brasil foram atividades contrárias ou reflexivas a respeito do regime autoritário então vigente. Desse

\footnotetext{
${ }^{72}$ Algumas obras em que esses autores fazem uso de termos relativos ao sistema nervoso para um discurso sobre a sociedade são: TARDE, G. Monadologia e Sociologia. CosacNaify, (1895) 2007.

DURKHEIM, E. Da divisão do trabalho social. Martins Fontes, (1893) 2004.

DURKHEIM, E. As Regras do Método Sociológico. Martins Fontes, (1895) 2003.

73 Por exemplo, em vários capítulos do livro "História da Neurologia no Brasil” organizado por Rubens Reimão, 1999, alguns referidos neste trabalho. 
modo, a aplicação dos estudos de Foucault, nos anos que se seguiram a esse período, certamente colaborou no entendimento e decodificação de processos então em andamento.

Por certo esses trabalhos são de grande valor e apontam elementos importantes nos estudos realizados, no entanto, acreditamos que o ambiente do período a ser estudado por nossa pesquisa (1889-1936), tinha uma complexidade maior do que tem sido enfocado pelos referidos trabalhos.

Em termos de historiografia da psiquiatria no Brasil, a obra Danação da Norma - Medicina social e constituição da psiquiatria no Brasil, de Roberto Machado et al., de 1978, é emblemática. Ela faz detalhada descrição de aspectos históricos da medicina no Brasil e da psiquiatria no Rio de Janeiro, com citação dos primeiros escritos no Brasil sobre psiquiatria, chegando ao período de Teixeira Brandão e à lei de 1903.

Essa obra considera que a psiquiatria brasileira nasce dentro de uma visão de medicina social, que tem a sociedade como objeto e se impõe como controle social dos indivíduos e populações. Cita-se então que em 1830, na recém-criada Sociedade de Medicina e Cirurgia do Rio de Janeiro, é lançada a palavra de ordem: aos loucos o hospício $^{74}$. É referida como primeira tese da psiquiatria brasileira o trabalho de 1837 do médico Silva Peixoto, intitulado Considerações gerais sobre a alienação mental, na Faculdade de Medicina do Rio de Janeiro. São citadas outras teses sucessivas.

Machado et al. consideram que a consolidação da instituição psiquiátrica no Brasil está ligada a um conflito entre clericalismo e laicismo, resolvido a partir da República, com a saída das irmãs de caridade do Hospício Pedro II, por insistência de Teixeira Brandão, consolidando o poder médico sobre o asilo.

Nessa obra, não há menções sobre a psiquiatria em S. Paulo. Esse trabalho discute bastante a idéia de um projeto de medicalização da sociedade, ou seja, de um propósito político de poder dos médicos sobre a sociedade, em especial através da psiquiatria, discussão essa bastante forte no período em que esse livro é lançado.

A partir de nosso levantamento, devemos ressalvar que, apesar dos temas abordados por essa obra, ainda não há uma psiquiatria devidamente instituída, como área específica, no Brasil até 1883. Não há também médicos chamados de psiquiatras no período que vai até essa data.

74 MACHADO, R. et al. Danação da Norma: medicina social e constituição da psiquiatria no Brasil. Edições Graal Ltda., Rio de Janeiro, 1978, p. 376. 
A obra de Jurandir Freire Costa, de 1989, intitulada História da Psiquiatria no Brasil, embora com esse título, restringe-se praticamente à história da Liga Brasileira de Higiene Mental, fundada por Gustavo Riedel em 1923, entrando em discussões a respeito de eugenia e xenofobia. Não há menção a respeito de São Paulo.

De modo geral, os textos de história da psiquiatria em São Paulo estão presentes mais em publicações da própria área ${ }^{75}$.

As pesquisas em ciências humanas enfocam esse campo mais em estudos sobre as instituições, como, por exemplo, sobre o Hospital do Juqueri. Nesse sentido é emblemático o trabalho de Maria Clementina Pereira da Cunha, de 1986, intitulado " $O$ Espelho do mundo - Juquery, a História de um Asilo, que discute principalmente a questão do asilamento de pacientes psiquiátricos no Hospital do Juquery ${ }^{76}$.

Como obra própria do período de transição do governo militar para o democrático, acentua aspectos desse período, conforme diz a autora:

“A violência asilar e o uso direto da psiquiatria em práticas repressivas de governos totalitários - como atestam a psiquiatrização das dissidências no Leste europeu ou a presença de psiquiatras como assistentes "médicos" em sessões de tortura das ditaduras militares no Brasil, como em todo o Cone Sul - tem acendido o debate e fundamentado a posição dos críticos da psiquiatria e do asilo"77.

A autora centra-se na discussão do alienismo como estratégia vitoriosa no processo de "aburguesamento das sociedades de classes” e como “prática de exclusão social”. Refere que a República cria órgãos de disciplinarização, polícia médica e controle sanitário. A psiquiatria organicista é considerada como responsável pela criação do asilo, que promove a exclusão ${ }^{78}$.

\footnotetext{
75 Nesse sentido, ver em Psychatry on Line Brazil, bem como no periódico History of Psychiatry, artigos a respeito da História da Psiquiatria no Brasil e em São Paulo.

76 CUNHA, M.C.P. O Espelho do mundo: Juquery, a História de um Asilo. Paz e Terra, 1986.

77 Idem, p. 15.

78 Também em linha similar a esse trabalho, ver:

VASCONCELLOS, M.P.C. Doença mental acima de qualquer suspeita: Franco da Rocha e a prática psiquiátrica na cidade de S. Paulo, 1885-1923. Tese de doutorado, PUC-SP, 1992. 


\section{3. 3.2 - Psicologia}

A respeito de historiografia da psicologia no Brasil, podemos citar o psicólogo tcheco Josef Brozek (1913-2004), que é considerado, entre psicólogos, um promotor de estudos de história da psicologia, tendo se associado a psicólogos brasileiros estudiosos desse assunto, como Marina Massimi.

Assim, conforme Brozek e Massimi ${ }^{79}$, em Historiografia da Psicologia no Brasil, as últimas quatro décadas do século XX são “os anos dourados” da historiografia da psicologia, com o surgimento de grupos de trabalho e publicações de periódicos em diversos países. Conforme esses autores, a historiografia da psicologia no Brasil é recente; eles apontam como primeira publicação dessa natureza o livro do filósofo brasileiro Raimundo Farias, intitulado A base física do espírito, de 1912, que, segundo eles, tem um discurso pessimista sobre o futuro da psicologia no Brasil.

Esses autores citam diversos estudos de história da psicologia, detendo-se um pouco mais no trabalho de Lourenço Filho, que, em 1954, publica sobre a história da psicologia em compêndio sobre a história da ciência no Brasil. São abordadas as teses de médicos do século XIX, os psiquiatras do início do século XX, e assim por diante, com a citação de instituições e personagens.

Conforme está mencionado, Lourenço Filho ${ }^{80}$ refere-se mais à psicologia educacional, e à introdução do ensino da psicologia no ginásio e escolas normais a partir de 1890. Em sua obra também é citado o primeiro laboratório de psicologia aplicada à Educação no Brasil, o Pedagogium, instituído em 1890 no Rio de Janeiro. Menciona-se um seu similar, o Laboratório junto à Escola Normal de São Paulo, inaugurado em 1914. Relata-se também que em 1931 ocorre a instalação do Serviço de Psicologia Aplicada, que depois se torna o Laboratório de Psicologia Educacional do Instituto de Educação, em São Paulo.

79 BROZEK, J.; MASSIMI, M. Historiografia da Psicologia no Brasil. In: BROZEK, J.; MASSIMI, M., Historiografia da Psicologia Moderna. Edições Loyola, 1998, p. 209-221.

${ }^{80}$ Manoel Bergstrom Lourenço Filho (1897-1970), tem trajetória diversificada. Forma-se professor primário em Pirassununga, inicia o curso médico, mas larga no segundo ano, e passa a fazer Direito, que conclui em 1929. Mas, dedica-se à psicologia e à pedagogia. Implanta um laboratório de psicologia em Fortaleza. Sampaio Dória, seu professor na Faculdade de Direito, convida-lhe para sucedê-lo em 1925, no Laboratório de Psicologia Experimental da Escola Normal Caetano de Campos. Em 1927, participa da fundação da Sociedade Brasileira de Psicanálise, juntamente com Franco da Rocha, Durval Marcondes, Raul Briquet, Almeida Junior, Getúlio Moura Santos e outros.

BROZEK, J.; MASSIMI, M. Historiografia da Psicologia no Brasil. In Historiografia da Psicologia Moderna. Edições Loyola, 1998, p. 209-221. 
Segundo Massimi, Lourenço também destaca a presença de estrangeiros no Brasil, com atividades na área como Ugo Pizzoli, que instala o Laboratório de Psicologia Experimental em São Paulo em 1913; além das visitas de Henri Pieron, em 1927, Kohler em 1928, e Claparède em 1930.

Outras citações de Lourenço Filho vão além do período de nosso trabalho. No capítulo História da Psicologia no Brasil, do livro Historiografia da Psicologia Moderna, Brozek e Massimi relatam outros tantos estudiosos de história da psicologia no Brasil, mas que vão além dos interesses de nosso estudo.

Em História da Psicologia Brasileira - da época colonial até $1934^{81}$, da psicóloga Marina Massimi, são citadas aulas de psicologia dadas no âmbito da filosofia ensinada na Faculdade de Direito do Largo de S. Francisco, com pendores próximos do pensamento médico, ou do pensamento filosófico, ou ainda de cunho espiritual. Ela destaca a obra positivista do médico Pereira Barretto, como influência nesse ambiente. Também é citado o ensino de psicologia nas escolas religiosas e escolas normais, em contexto próximo da pedagogia.

Nas faculdades de Medicina, conforme a autora, são feitas teses sobre o tema “moléstias nervosas”. Sobre a psicologia médica, Massimi considera ter havido uma influência do materialismo francês, com o uso da psicologia pela medicina como poderoso instrumento de controle de indivíduos e populações.

No que diz respeito ao surgimento da psicologia científica, a autora destaca Pereira Barretto, que se forma na Bélgica em 1864, defende no Rio de Janeiro a tese Teorias das Gastralgias e das Nevroses em geral, em 1865, e lança, em 1874, sua obra As Três Filosofias, onde expõe a psicologia como parte da fisiologia.

Depois, Massimi cita o médico Henrique Roxo, como alguém que tenta associar psicologia, psiquiatria e neurologia. Refere também os médicos Teixeira Brandão e Austregésilo. Cita Maurício Medeiros ${ }^{82}$ (1885-1966) como talvez o primeiro brasileiro a estudar psicologia experimental no exterior com George Dumas.

81 MASSIMI, M. História da Psicologia Brasileira: da época colonial até 1934. E.P.U., 1990.

82 Mauricio de Medeiros estudou com Dumas na França após Manoel Bomfim. Medeiros organiza em 1907, o segundo laboratório de psicologia no Brasil, no Hospício Nacional. É referido que em 1906, Manoel Bomfim instalou no Pedagogium o primeiro laboratório de psicologia do país. (O nosso levantamento indica o ano de 1904).

GOMES, W. B. Avaliação psicológica no Brasil: Tests de Medeiros e Albuquerque. Aval. Psicol., v. 3, n.1, Porto Alegre, jun. 2004.

http://pepsic.bvs-psi.org.br/scielo Acessado em 10 de agosto de 2007. 48 
Massimi também relata a criação do Instituto Psycho-Physiologico pelo médico Domingos Jaguaribe (1843-1926), em São Paulo, no início do século XX, onde ele adota um tratamento por hipnotismo e sugestão contra o alcoolismo. Cita que Jaguaribe participa em 1900 do Congresso Internacional de Hipnotismo em Paris, entre outros congressos. Informa também que, em 1912, ele é presidente da Societé de Psychotherapie de Paris e professor da Escola de Psicologia de Paris, sendo então conhecido por estudiosos renomados; ele publica em 1913 a obra As Bases da Moral: Estudos de Psychologia Physiologica.

Massimi conclui com a citação dos primeiros cursos universitários de psicologia na Faculdade de Filosofia da Universidade de São Paulo em 1934.

A historiografia sobre a psicologia em São Paulo tem no livro História da Psicanálise - São Paulo: 1920-1969, da socióloga e psicanalista Carmen Lúcia Montechi Valladares de Oliveira, publicado em 2006, em São Paulo, um trabalho que faz ampla revisão e crítica da história da psicanálise e da psicologia em São Paulo. A autora parte do evento considerado como um marco inicial do surgimento público de Freud em São Paulo, o livro O Pansexualismo na Doutrina de Freud de Franco da Rocha, lançado em 1920, e Paulicéia Desvairada, de Mário de Andrade, escrito entre 1920 e 1922, onde Mário cita Freud.

A autora considera que, enquanto nos anos 1910 Freud é introduzido e divulgado no Rio de Janeiro pelos médicos, nos anos 1920 há um maior envolvimento dos artistas, em São Paulo, com a doutrina de Freud ${ }^{83}$. A autora também faz uma revisão crítica do papel de Durval Marcondes na história da psicologia em São Paulo, considerando que alguns fatos podem ter sido acentuados ou mesmo um tanto construídos, no sentido de elaborar uma determinada história da psicologia em São Paulo, bastante demarcada por Marcondes ${ }^{84}$.

\footnotetext{
${ }^{83}$ Em 1904, Franco da Rocha menciona Freud em seu livro Esboço de psychiatria forense.

Também nos periódicos médicos em São Paulo, no período antes do livro de Franco da Rocha de 1920, encontramos onze citações a partir de 1908/1909. Inclusive, um desse artigos é reprodução de uma publicação feita em jornal corrente, o que indica uma divulgação mais ampla do assunto. Isso não significa necessariamente conhecimento profundo ou adesão a essa doutrina, mas indica presença de alguma discussão sobre Freud no ambiente científico de São Paulo, em data anterior à que tem sido colocada como 1920.

NEVES, A.C. Freud antes de Freud em São Paulo. Revista Neurociências, 14 (3): 127-134, 2006.

84 OLIVEIRA, C.L.M.V. História da Psicanálise: São Paulo: 1920-1969. Editora Escuta - Fapesp, 2006. 49
} 
Em relação à discussão de “pioneirismos”, em capítulo do livro História da Psicologia no Século $X X^{85}$, o psicólogo Sagawa cita, em relação ao uso da psicanálise, Júlio Pires Porto-Carrero em 1924 no Rio de Janeiro, como quem primeiro utiliza a técnica psicanalítica, mas misturada a outras técnicas, enquanto refere que Marcondes, em 1925, usa apenas a psicanálise ${ }^{86}$.

Em livro sobre Durval Marcondes, Sagawa refere que Enjolras Vampré e Antonio Carlos Pacheco e Silva, sucessores de Franco da Rocha, são totalmente contrários à psicanálise no campo da psiquiatria ${ }^{87}$. Em relação a isso, reforça que o concurso para a cátedra de Psiquiatria da Faculdade de Medicina da Universidade de São Paulo, que ocorre em 1936, com Durval Marcondes e Pacheco e Silva como concorrentes, sela a vitória da psiquiatria organicista sobre a psicanálise.

Em relação à questão da rejeição da psicanálise por Pacheco e Silva, o psiquiatra Piccinini cita relato do médico Jorge W. F. Amaro, onde ele diz que, estando ele próprio em formação psicanalítica, consultou Pacheco e Silva sobre a possibilidade de organizar um Serviço de Psicoterapia no Instituto de Psiquiatria, utilizando a psicanálise, a psicoterapia de grupo e terapia comportamental. O médico relata que temia ver sua proposta recusada, em virtude do difundido boato de que Pacheco e Silva era contra a psicanálise. No entanto, sua proposta foi aceita, sendo que este alertou que era apenas contra psicoterapeutas que não conhecessem a psicopatologia psiquiátrica e que promoviam prejuízos aos pacientes devido a um "psicologismo" e a um furor interpretandis ${ }^{88}$.

85 SAGAWA, R.Y. História da Psicanálise no Brasil: importação ou descoberta? In: MASSIMI, M.; História da Psicologia no Brasil no século XX, E. P. U. , 2004, p. 35-56.

86 Não tem sido incluído com freqüência, entre os que estudam inicialmente a psicanálise, o estudioso baiano Arthur Ramos, que escreve em 1926 Augusto dos Anjos á luz da psychanalyse e nesse mesmo ano faz sua tese de doutoramento com o tema Primitivo e Loucura. Depois escreve diversos livros sobre esses temas.

RAMOS, A. Psychiatria e Psychanalyse. Editora Guanabara Koogan, Rio (publicado entre 1933 e 1936). Em 1935-1937 Ramos inaugura a cadeira de Psicologia Social na Universidade do Distrito Federal, ensinando aos alunos a distinção entre psicologia coletiva e psicologia social, incluindo aquela como subdivisão desta.

RAMOS, A. Prefácio. In: RODRIGUES, N. As collectividades Anormaes. Editado por Arthur Ramos, 1939.

Em nosso trabalho vemos que a utilização da psicanálise no Brasil ocorre mais através de um processo envolvendo diversos profissionais, do que através de um "pioneiro", inclusive com outros antes dos que são mais freqüentemente citados.

87 SAGAWA, R.Y. Durval Marcondes. Imago, 1999.

88 PICCININI, W.J. Antonio Carlos Pacheco e Silva (1898-1988). Psychiatry on line Brazil, julho de 2004. Em:< http://www.polbr.med.br/arquivo/wal0704.htm>. Acessado em 27 de maio de 2005. 


\section{3. 3.3 - Neurologia}

Os textos sobre história da neurologia em São Paulo têm sido feitos apenas pelos próprios profissionais da área. De modo geral, os textos assinalam a pessoa de Enjolras Vampré como tendo sido o “fundador da Escola Paulista de Neurologia”, após ter feito estágios em Salpêtrière, com os discípulos de Charcot, trazendo os fundamentos da "Escola Neurológica Francesa”. Os autores situam essa espécie de "fundação", no momento em que ele é nomeado para substituir o lugar de Franco da Rocha na cadeira de Psiquiatria e Moléstias Nervosas da Faculdade de Medicina e Cirurgia de São Paulo entre 1923 e 1925. É também frisado que em 1935-1936 ocorre o desdobramento dessas duas áreas como neurologia e psiquiatria ${ }^{89}$; sendo que há quem tenha se referido ao fato como um desdobramento entre neuriatria ${ }^{90}$ e psiquiatria.

\section{4. - Fontes e método}

Como fontes primárias são utilizados artigos científicos dos periódicos médicos paulistas. Além disso, livros e anais de congresso do período são utilizados para dialogar com os periódicos referidos.

Foram consultados os seguintes periódicos médicos de São Paulo:

- Revista Medica de São Paulo, de 1889.

- Revista Medica de São Paulo, de 1898 a 1914.

- Gazeta Clinica, de 1904 a 1936; não tivemos acesso aos exemplares do ano de 1903.

- Imprensa Medica, de 1904 a 1914.

- Annaes Paulistas de Medicina e Cirurgia, de 1913 a 1930.

- São Paulo Medico, de 1928 a 1936.

- Revista de Neurologia e Psychiatria de São Paulo, de 1934 a 1936.

89 LEITE NETO, A.M. A influência da Escola Neurológica Francesa na fundação da neurologia brasileira. In: REIMÃO, R., A História da Neurologia no Brasil, Lemos Editorial, 1999, p. 33.

ASSIS, J.L. A Escola Neurológica de São Paulo. In: REIMÃO, R., A História da Neurologia no Brasil, Lemos Editorial, 1999, p. 206.

90 O termo neuriatria passa a ser usado como alternativa ao nome neurologia entre 1916 e 1919. Neste ano, a publicação Archivos de Neurologia, Psychiatria e Medicina Legal passa a se chamar Archivos de Neuriatria e Psychiatria. Nessa época, reforçada pela divulgação da doutrina de Freud, a palavra psicologia passa a assinalar um determinado campo de estudo que parece distanciar-se um pouco da medicina. Como iatros é um prefixo relativo a "médico", a neurologia tornando-se neuriatria, se aproxima mais da maneira como vai se configurando a psiquiatria, tornando-se também uma área iatros. Nesse período há concomitantemente os termos: neurologia, neuriatria, neuropatologia e moléstias nervosas; o termo neuropatologia tem sentido mais abrangente. 
- Annaes da Faculdade de Medicina de São Paulo de 1926 e 1936.

- Arquivos de Assistência Geral a Psicopatas do Estado de São Paulo, de 1935 e 1936.

Desses periódicos são utilizados os artigos que se referem a temas relacionados com psiquiatria, neurologia, psicologia, ou ainda com distúrbios mentais ou com moléstias do sistema nervoso, ou com temas similares.

Além desse periódicos, também foram consultados:

- Annaes do Congresso Paulista de Medicina - 1916.

- Archivos Brasileiros de Psychiatria, Neurologia e Sciencias affins - 1905.

- Archivos Brasileiros de Neuriatria e Psychiatria - 1919-1936.

- O Progresso Medico - 1877.

O primeiro capítulo faz uma exploração geral de aspectos pertinentes à pesquisa, bem como a apresentação de personagens dos processos em questão. Cada capítulo seguinte corresponde a um dos períodos em que foi dividido o período geral do trabalho.

Quanto ao método, em sentido amplo, se estende desde o título do trabalho até o seu final. Visto de maneira mais convencional, podemos falar estritamente do método para analisar os artigos médicos paulistas do período enfocado, dialogando com outros textos contemporâneos aos citados, usando os referenciais citados a seguir.

Para análise do material de pesquisa utilizamos a conceituação de Michel Foucault sobre o corpo neurológico em O Poder Psiquiátrico, já referido.

Também fazemos uso da conceituação de paradigma em A Estrutura das Revoluções Científicas ${ }^{91}$, de Thomas Kuhn, no estudo dos processos em transformação na medicina do período estudado, mais particularmente nas áreas enfocadas.

$\mathrm{Na}$ abordagem dos processos de transformação de linguagem, condicionando a organização de áreas nomeadas como neuriatria, neurologia, psiquiatria, neuropatologia, psicologia, psicanálise, neuropsiquiatria, entre outras, bem como da linguagem científica dessas áreas, usamos os estudos sobre linguagem em Ciência em “O Caminho desde a Estrutura de Thomas Kuhn ${ }^{92}$.

Também utilizamos a obra do historiador Rafael Huertas, El siglo de la clínica - para una teoria de práctica psiquiátrica, onde esse autor aprofunda o debate não só

91 KUHN, T.S. A Estrutura das Revoluções Científicas . Perspectiva (1962, 1969), 2001. 92 KUHN, T.S. O Caminho desde A Estrutura. Editora Unesp, 2000. 
sobre psiquiatria, mas também sobre neurologia e psicologia no século XIX, de onde podemos tirar elementos para aprofundar a discussão dos temas em questão ${ }^{93}$.

Para uma análise de personagens, fazemos uso da conceituação de Bruno Latour a respeito da circulação de fatos científicos que dá vida às disciplinas científicas $^{94}$.

Bruno Latour considera que em história da ciência deve ser superada a dicotomia entre história externalista, baseada na política pura, e história internalista, baseada na ciência pura. Ele faz uma analogia dos estudos científicos com o sistema circulatório do organismo. Desse modo, se for seguida a "trilha da circulação dos fatos”, “pode-se reconstruir, vaso por vaso, o sistema circulatório completo da ciência” e começar a "examinar a farta vascularização que dá vida às disciplinas científicas”. Nesse discurso, ele chama de "translação” a uma mudança de vocabulário, onde termos políticos transformam-se em termos científicos, e vice-versa. Assim, subdivide o “sistema circulatório dos fatos científicos” em: mobilização do mundo, autonomização, alianças, representação pública, vínculos e nós.

“Mobilização do mundo” corresponde à “inserção dos não-humanos no discurso científico” - ou seja, a instrumentalização dos procedimentos científicos, desde a estatística até o contexto laboratorial. A “autonomização” diz respeito às organizações profissionais. "Alianças” equivalem a correlações em nível público ou privado. "Representação pública” diz respeito à comunicação com órgãos, como a imprensa. "Vínculos e nós” correspondem a ligações com outras instituições.

Quanto a alguns aspectos pertinentes à forma deste trabalho, de modo geral, adotamos o tempo verbal do presente correspondente ao momento em que os textos são escritos, exceto nas notas.

As palavras neurologia, psiquiatria e psicologia são escritas com maiúsculas quando se referem a nomes de cadeiras, disciplinas ou departamentos. Quando usadas no sentido genérico, são escritas com minúscula.

93 HUERTAS, R. El Siglo de la Clínica: para una teoria de la práctica psiquiátrica. Novalia Electronic Editions, Madrid, 2004.

${ }^{94}$ LATOUR, B. A Esperança de Pandora. Editora Edusc. (1999) 2001, p. 97-132.

53 
Capitulo 1 - Considerações gerais sobre as áreas enfocadas e personagens relacionadas às mesmas.

O estabelecimento de áreas científicas específicas, como neurologia, psiquiatria e psicologia, em São Paulo, no período abordado, é influenciado por um processo gradual de delimitação do que podemos chamar de “especialidade”, que no século XIX tem certa conotação de uma área diferenciada em relação à medicina em geral, mas ainda não corresponde exatamente ao que passa a ser caracterizado como especialidade durante o transcorrer do século XX, com o surgimento de associações formais de especialistas.

No Brasil, esse processo tem início com a reforma do ensino médico instituída por Leôncio de Carvalho, ministro do Império no gabinete de Sinimbu, por decreto promulgado em 19 de abril de 1879 (decreto n.7.247). Esse decreto promove a liberdade de ensino superior no Brasil e autoriza o funcionamento de cursos livres nas faculdades oficiais; é permitido o juramento conforme a religião de cada um; passa a ser exigida a habilitação de médicos estrangeiros; promove-se a abertura de cursos ao sexo feminino ${ }^{95}$.

Em 1881, o Barão Homem de Mello (tio do psiquiatra Homem de Mello, que será oportunamente citado), sanciona modificações no regulamento do curso médico (decreto 8.024) e assim a reforma faz sentir seus efeitos. São criadas, então, as cadeiras: Obstetrícia, Ginecologia, Oftalmologia, Moléstias Cutâneas e Sifilíticas, Histologia Teórica e Prática, Anatomia e Fisiologia Patológica, e a Cadeira de Psiquiatria e Moléstias Nervosas. Esta tem, como seu primeiro catedrático, Teixeira Brandão ${ }^{96}$.

O período de 1881 a 1889, segundo o médico Fernando de Magalhães, é o “melhor período” de toda a formação da Faculdade do Rio de Janeiro, em virtude da atuação de seu diretor, o cirurgião Vicente Cândido Figueira de Sabóia, o visconde de Sabóia $^{97}$. Essa entusiasmada menção a esse diretor, além de acentuar seu papel nesse processo, dá noção do clima de transformações presente na faculdade nesse período.

\footnotetext{
95 BENCHIMOL, J.L. Dos micróbios aos mosquitos: febre amarela e revolução pasteuriana no Brasil. Editora Fiocruz, Editora UFRJ, 1999, p. 30-31.

96 Antes de Teixeira Brandão se submeter a concurso e se tornar o catedrático da Cadeira de Psiquiatria e Moléstias Nervosas, em 1883, o médico generalista Nuno de Andrade, diretor do Hospício Pedro II, foi o primeiro responsável por essa cadeira logo de sua criação, em 1881.

COSTA, J. F. História da Psiquiatria no Brasil. Xenon Editora, 1989, p. 70.

97 BENCHIMOL, J.L. Dos micróbios aos mosquitos: febre amarela e revolução pasteuriana no Brasil. Editora Fiocruz, Editora UFRJ, 1999, p. 30-31. 
No Editorial da Revista Medica de São Paulo de 1889, que será abordado mais adiante em outra seção, há o uso específico do termo “especialistas”,"98, que indica a presença dessa conceituação no discurso médico desse período.

Quanto ao uso desse termo em sentido mais amplo, podemos nos remeter a uma explanação, a respeito de “especialização”, feita por Max Weber (1864-1920), um contemporâneo do período que estamos estudando. Ao proferir palestra a respeito de vocação científica, ele insere comentário sobre a especialização científica em seu discurso, considerando-a como inevitável, em virtude do estágio alcançado pela ciência:

"Creio que, em verdade, os senhores esperam que eu lhes fale de outro assunto, ou seja, da vocação científica propriamente dita. Em nossos dias, e referida à organização científica, essa vocação é determinada, antes de tudo, pelo fato de que a ciência atingiu um estágio de especialização que ela outrora não conhecia e no qual, ao que nos é dado julgar, se manterá para sempre. A afirmação tem sentido não apenas em relação às condições externas do trabalho científico, mas também em relação às disposições interiores do próprio cientista, pois jamais um indivíduo poderá ter a certeza de alcançar qualquer coisa de verdadeiramente valioso no domínio da ciência, sem possuir uma rigorosa especialização"99.

Assim, há nesse período uma tendência a serem cada vez mais valorizadas as, assim chamadas, especialidades científicas. No momento em que se instalam novas cadeiras na Faculdade do Rio de Janeiro, em 1881, elas passam gradativamente a se configurar cada vez mais como redutos de especialistas, que vão, aos poucos, estruturando uma linguagem própria ${ }^{100}$.

Nesse âmbito de instalação de cadeiras e especialidades, conforme dissemos, Teixeira Brandão é o primeiro catedrático em Psiquiatria e Moléstias Nervosas, sendo, portanto, criador de toda uma escola específica desses campos, que tem repercussões em São Paulo.

Neste capítulo, abordamos alguns elementos que são úteis no entendimento das áreas em questão, no período estudado.

98 Revista Medica de S. Paulo, 1889, p. 2.

99 Weber, M. Ciência e Política: duas vocações. Editora Cultrix, 1967, p. 24.

100 Devemos acentuar que, durante essa década de 1880, estudam na Faculdade do Rio de Janeiro alguns dos médicos que depois têm grande importância em São Paulo, como Arnaldo Vieira de Carvalho e Franco da Rocha. 
1. 1 - Caracterização das áreas em questão a partir de alguns trabalhos e personagens brasileiros

Nesta seção, abordamos conceituações das áreas em questão a partir de algumas obras, do período em estudo, que enfocam os temas debatidos, bem como de algumas personagens.

Uma primeira obra é um livro de Teixeira Brandão publicado em 1918. Embora seja dessa data, o autor insiste estar tratando dos conceitos que adota desde que começou a trabalhar com psiquiatria e moléstias nervosas. Ele é citado por si mesmo e por seus discípulos como o primeiro psiquiatra brasileiro, o que dá importância singular a seus conceitos. O fato de Teixeira Brandão ser o mestre de Franco da Rocha, que tem papel central em psiquiatria e moléstias nervosas em São Paulo, acentua mais o valor do estudo de sua obra para nosso trabalho.

Outras duas obras que abordamos aqui são: a tese de doutoramento de Franco da Rocha e seu livro de 1904 sobre Psiquiatria Forense. A distância entre ambas é de 13 anos, sendo a primeira de um formando em medicina e a segunda já após alguns anos de atividade com psiquiatria e moléstias nervosas, e já sendo conhecido por seu trabalho no Juquery. Ao abordarmos essas obras de Franco da Rocha, fazemos também menção ao psiquiatra Homem de Mello, por ser seu contemporâneo em S. Paulo, usualmente não muito lembrado.

Também outra obra que abordamos é o livro de Osório César, de 1929, intitulado A expressão artística nos alienados: contribuição para o estudo dos symbolos na arte. Devido ao contexto em que esse assunto se enquadra, esse trabalho de Cesar é abordado na penúltima seção do primeiro capítulo, em vez de acompanhar as primeiras seções referentes a personagens. 


\subsection{1 - Um achado: o livro de Teixeira Brandão}

Alguns elementos presentes no livro de Teixeira Brandão são úteis para o entendimento das áreas e de alguns termos a elas ligados no período estudado. Devo assinalar que não encontrei esse livro como referência bibliográfica feita por outro autor. Esse livro foi encontrado em levantamento sobre o assunto psiquiatria, feito para este trabalho, na Biblioteca da PUC-SP.

Assim, em 1918, Teixeira Brandão publica seu livro Elementos fundamentaes de psychiatria clinica e forense, como uma espécie de obra de final de carreira, para deixar assinalados alguns elementos que ele considera importantes, em certa confrontação com tendências do período em que foi escrito esse livro.

João Carlos Teixeira Brandão (1854-1921) forma-se em medicina no Rio de Janeiro em 1877. De 1878 a 1880 trabalha como médico em Barra Mansa. Após isso, por sugestão de João Vicente Torres Homem, professor de clínica médica, estuda psiquiatria na França, Alemanha e Itália. Em 1881, funda, juntamente com outros, a Policlínica Geral do Rio de Janeiro, onde é médico do Serviço de Moléstias do Sistema Nervoso. Em 1883, assume a direção da Casa de Saúde e Hospício de Alienados de S. Sebastião. Por determinação de Brandão, nesse local não há grades de ferro e camisas de força, que são, segundo ele, “meios violentos condenados pela psiquiatria moderna"101.

Ainda em 1883, Brandão obtem o primeiro lugar no concurso para lente da cadeira psiquiátrica e de moléstias nervosas da Faculdade de Medicina do Rio de Janeiro. Em 1884, passa a trabalhar no Hospício D. Pedro II e, em 1887, torna-se diretor dessa instituição. Nesse período, ele advoga pela adoção de “modernos” processos clínicos e funda colônias rurais a partir de $1889^{102}$.

Voltando ao livro de Brandão, inicialmente ele dá a entender que quer deixar demarcados seus próprios pontos de vista, pois, nesse período, outras doutrinas e teorias

${ }^{101}$ NOTABILIDADES, 1883, p. 1843. In: CASA DE OSWALDO CRUZ/FIOCRUZ, Dicionário Histórico e Biográfico das Ciências da Saúde no Brasil (1832-1930). Disponível em: $<$ http://www.dichistoriasaude.coc.fiocruz.br> Acessado em 6 de novembro de 2006.

102 CASA DE OSWALDO CRUZ/FIOCRUZ. Dicionário Histórico e Biográfico das Ciências da Saúde no Brasil (1832-1930). Em: <http://www.dichistoriasaude.coc.fiocruz.br> 
estão em voga. Deste modo, ele inicia o Prefácio: “Tendo chegado quasi ao termo da nossa carreira profissional, resolvemos publicar compendiadas as theorias e doutrinas que nos guiaram desde o começo do nosso curso de clinica psychiatrica”,103.

Em seguida, acentua ter sido ele o primeiro médico a trabalhar com psiquiatria no meio científico brasileiro, usando o reforço desse fato para deixar claro que as “questões metaphysicas” nunca guiaram seus estudos, e frisando que sempre se baseia na observação clínica e no que ele chama de “fenomenos vitaes”:

"Iniciador desses estudos, entre nós, jamais nos preoccupamos com as questões methaphysicas que as relações entre a alma e o corpo sobrelevam. Clinico antes de tudo, visando o doente, convencido de que o estado morbido não é mais do que o desvio ou desiquilibrio do estado physiologico, constituio sempre a nossa preoccupação dominante, o estudo dos phenomenos vitaes nas suas relações e concatenação, bem como a pesquisa das causas e do modo pelo qual se modificam ou se alteram essas relações, rompendo-se dessa arte a harmonia funccional do organismo" ${ }^{104}$.

Ele completa seu prefácio, frisando que não expõe apenas questões de natureza clínica, mas também outras que dizem respeito mais a aspectos sociais, demonstrando que ele, como cientista, não se restringe aos elementos técnicos de sua disciplina. Ao falar em “questões administrativas” e de direito, advoga para si a concretização da lei sobre os alienados de $1903^{105}$.

Atendo-nos, mais especificamente, às delimitações de campos científicos feitas por Teixeira Brandão, lemos a seguinte citação:

“A psychiatria, ramo da neuropathologia, tem por objecto o estudo da genese e evolução das affecções e das anomalias mentaes, congenitas ou adquiridas, das causas que as determinam e dos meios therapeuticos, hygienicos e moraes, adequados a cural-as ou a attenuar-lhe os effeitos"106.

Conforme podemos observar, o autor cita a psiquiatria como sendo uma subdivisão de um campo maior, que ele denomina como “neuropatologia”. Brandão centra os estudos da psiquiatria sobre o que ele denomina de "afecções e anomalias mentais”.

103 BRANDÃO, T. Elementos fundamentaes de Psychiatria clinica e forense. Livraria Editora Leite Ribeiro \& Maurillo, Rio de Janeiro, 1918, Prefácio, p. 4.

104 Idem, p.4.

105 Ver esse decreto nos Anexos.

106 BRANDÃO, T. Elementos fundamentaes de Psychiatria clinica e forense. Livraria Editora Leite Ribeiro \& Maurillo, Rio de Janeiro, 1918, Prefácio, p. 15. 
Em seguida, Brandão diferencia afecções “mentais” de afecções “nervosas”, mas ainda considerando que as perturbações "nervosas” devem “compreender e englobar” as mentais:

"Sendo, porém, todos os phenomenos mentaes manifestações do systema nervoso e delle dependendo, porque e como distinguirmos as affecções mentaes que, em rigor, significam perturbações da mente, das nervosas que abrangendo, genericamente, todas as modificações pathologicas, estaticas e dynamicas desse systema organico, necessariamente, as devem compreender e englobar? Como separar do estudo das affecções mentaes ou da psychiatria todos os estados pathologicos nos quaes, transitoriamente, ou por tempo dilatado taes phenomenos são observados"? ${ }^{107}$

Assim, Teixeira Brandão procura especificar o âmbito, ao qual entende dizer respeito à psiquiatria, voltando a fazer menção à metafísica e à divisão entre dualistas e monistas. Além disso, ele acrescenta um elemento diferencial ligado ao doente alienado, como sendo um doente especial, que fica submisso à intervenção da justiça pública, seja para "reprimir seus atos ou para preveni-los":

"Para os methaphysicos e os que ainda acceitam a doutrina dualista segundo a qual a funcção psychica não é uma forma de actividade organica, mas a manifestação de um elemento extranho e sobrenatural alheio as contingencias physico-chimicas, portanto não subordinadas as suas leis, a linha divisoria entre as afeç̧ões nervosas e mentaes é, perfeitamente comprehensivel e necessaria; para os monistas, porém, a razão deve ser outra. O habito de considerar o alienado como um doente especial, sujeito por força da propria afeç̧ão á intervenção da justiça publica, ora para reprimir-lhe os actos, ora para prevenil-os, não deixa de ter, para uns e outros, certa influencia, nessa distincção"108.

Ao prosseguir com sua explanação a respeito do campo que diz respeito à psiquiatria, aos poucos Teixeira Brandão lhe dá um caráter de “disciplina especial”, ou seja, considera que, apesar de estar classificada como um ramo da neuropatologia, a psiquiatria vai além dos limites da própria medicina, entrando em instâncias que ele chama de "individuais e sociais":

"Sem embargo de ser um ramo da pathologia nervosa, a psychiatria lida com factos tão distinctos dos que são communs á neuropathologia; de tantos conhecimentos extranhos ao dominio da medicina carece para a elucidação dos altos problemas individuaes e sociaes, cuja

107 Idem.

108 BRANDÃO, T. Elementos fundamentaes de Psychiatria clinica e forense. Livraria Editora Leite Ribeiro \& Maurillo, Rio de Janeiro, 1918, p.16. 
esteira luminosa ella traça as sciencias correlatas, que nos parece justificavel estudal-a como disciplina especial” ${ }^{109}$.

A seguir o autor refere-se a uma diferenciação de método, no que diz respeito à neuropatologia e à psiquiatria: “Força é confessar, além disso, que a psychiatria não póde subordinar-se ao methodo que a neuropathologia emprega no estudo dos phenomenos morbidos. Para esta o facto anatomico é essencial, para aquella a funcção"110.

Para reforçar essa diferenciação de métodos, o autor recorre a uma citação de Grasset, referente ao Congresso de Paris de 1900, onde se buscou favorecer uma aproximação entre neurologistas e psiquiatras, tendo havido um debate sobre essas diferenças metodológicas ${ }^{111}$ (Podemos notar que, enquanto no texto original em francês, usado nessa citação, utiliza-se a palavra "neurologie”, o autor não usa um termo equivalente em português como “neurologia”, mas sempre utiliza "neuropatologia”).

Acrescenta Teixeira Brandão que, enquanto na medicina geral e na neuropatologia de então, existem pontos fixos de referência para o observador, relativos a desvios do equilíbrio fisiológico, o mesmo não ocorre em psiquiatria, onde ele disse ser necessário considerarem-se condições sociais e culturais ligadas ao doente, como condicionantes para a interpretação do estado mórbido do mesmo:

“Em psychiatria, porém, o mesmo não se dá. E a razão é obvia: é que além de serem subjectivos os symptomas principaes não existindo um typo normal physico nem intelectual a referir-se o observador, a apreciação do caso morbido, ou suspeito tal, exige a indagação do grau de cultura, do meio em que vive o doente, e dos seus antecedentes, como elementos indispensaveis para o conhecimento do seu estado morbido mental, além da annotação dos symptomas apparentes"112.

Ainda outro aspecto encontrado nessa obra de Teixeira Brandão, de 1918, é uma referência a Freud, na qual ele cita que, para Freud e sua escola, a causa de toda atividade "normal e pathologica" é o "instinto de reprodução". Ele se refere à doutrina de Freud como "mera hypothese psychologica" e cita alguns aspectos gerais da

109 Idem.

110 Ibidem.

111 GRASSET, J.Rapport de la psychiatrie et de la neurologie. In: MARIE, A., Traité de psychologie et pathologie. V. I,p. 11, apud BRANDÃO, T., Elementos fundamentaes de Psychiatria clinica e forense, Livraria Editora Leite Ribeiro \& Maurillo, Rio de Janeiro, 1918, p. 17.

112 BRANDÃO, T.Elementos fundamentaes de Psychiatria clinica e forense. Livraria Editora Leite Ribeiro \& Maurillo, Rio de Janeiro, 1918, p.17.

60 
doutrina, entre eles a psicanálise. Podemos ver aqui uma citação de Teixeira Brandão relativa ao termo "psicologia”, ao mesmo tempo em que se refere à doutrina freudiana como "mera hipótese”113, talvez denotando uma certa carga de dúvida a respeito dessa hipótese.

Ainda podemos destacar uma crítica de Brandão a respeito das inovações no estudo psiquiátrico, que atribui mais aos estudiosos alemães ${ }^{114}$. Devemos notar que, em 1918, transcorre e termina a Primeira Guerra Mundial e a maioria dos médicos brasileiros colocou-se ativamente a favor dos franceses. Esses fatores talvez possam acrescentar alguns motivos a mais para a publicação de seu livro, além de sua rejeição a certas novidades:

“O amor excessivo da novidade e o snobismo favoravel a destruir as acquisições tradicionaes, podem sómente explicar o afan de tudo reformar, nomenclatura e doutrina, sem reflexão e criterio, estabelecendo a confusão e desordem na apreciação das cousas as mais simples e claras. De resto, a instabilidade de principios em que se baseia a escola allemã, verificada na serie infindavel de contradicções e rectificações, que se succedem nas varias edições de Kraepelin, seu principal representante, no momento actual, demonstra que não é impunemente que se despresam as tradições scientificas e as observações accumuladas por tantos clinicos eminentes que se dignificaram pelo labor, zelo e sacrificio, na tarefa ardua de conviverem com alienados, no intuito de minorar-lhes os soffrimentos e desvendar-lhes os segredos da afeç̧ão"115.

Teixeira Brandão considera que, em psiquiatria, deve-se estar atento às diversas alterações do doente. Nesse contexto, ele coloca o sistema nervoso em posição de regulador da nutrição do organismo:

"Em psychiatria, mais do que em outra especialidade medica, o clinico deve ter mais em attenção o doente do que a doença. $O$ estado geral do enfermo, as perturbações funccionaes $e$ organicas, postas em relevo pelo exame do conjuncto, devem ditar a medicação conveniente. Não se deve perder de vista jamais que o systema nervoso é o grande regulador da nutrição, e que, em toda a affecção mental, o metabolismo cellular é alterado. Primitivamente pelo

113 BRANDÃO, T. Elementos fundamentaes de Psychiatria clinica e forense. Livraria Editora Leite Ribeiro \& Maurillo, Rio de Janeiro, 1918, p.30.

114 Conforme o psiquiatra brasileiro Isaias Paim, os psiquiatras franceses preocuparam-se com a "sua pirotecnia nosográfica” no século XIX e perderam os vínculos com a realidade clínica, publicando, até hoje, "compêndios de Psiquiatria", sem uma observação pessoal e, segundo ele, tentam "conciliar o inconciliável”. PAIM, I. História da Psicopatologia. E.P.U., 1993, prefácio.

115 BRANDÃO, T. Elementos fundamentaes de Psychiatria clinica e forense. Livraria Editora Leite Ribeiro \& Maurillo, Rio de Janeiro, 1918, p.34.

61 
agente pathogenico que occasiona a affeç̧ão ou secundariamente por effeito da própria affecção o organismo do alienado apresenta-se sempre mais ou menos intoxicado”116.

Outro aspecto, nesse livro de Brandão, como já foi dito, é que ele procura esclarecer a legislação a respeito dos alienados, além de querer assinalar a sua própria atuação no estabelecimento desses aspectos legais. Cita que, em 1886, no Diario Official, ele já protestava contra o estado de coisas em torno do abandono dos alienados nas cadeias, tendo feito outros manifestos em anos seguintes. Prossegue, citando leis de outros países, e leis nacionais que passaram a ser feitas a partir da República. Frisou que renunciou ao cargo de Inspetor do Serviço de Alienados, no governo de Campos Salles, onde estava subordinado ao ministro Epitácio Pessoa, dizendo, em relação a esse ministro, que "nada poderíamos conseguir em prol dos alienados”.

Refere, então, ter sido eleito deputado ao Congresso Nacional, onde diz ter tido importante participação no decreto de 22 de dezembro de $1903^{117}$, a respeito dos alienados. Depois passa a criticar a atitude do governo em relação a esse decreto, promulgado 14 anos antes da publicação de seu livro, frisando que o governo não cumpre o que foi estabelecido pela lei, principalmente quanto à constituição de comissões, que em cada Estado possam fiscalizar essa lei. Brandão também se refere ao fato de alienados serem internados em estabelecimentos particulares, sem autorização legal e sem condições de serem tratados, atribuindo isso a uma fiscalização falha feita por “indagações e inqueritos ridiculos”, deixando os bens dos doentes sujeitos a “especulações de terceiros” na justiça. Ele diz que as leis poderiam ser suficientes para corrigir essas falhas, mas elas são burladas.

O fato de citar seu vínculo com o estabelecimento dessas leis, também pode ter sido uma forma de deixar marcado seu papel nesse processo, já que outros médicos também foram associados à promoção dessa legislação, como, por exemplo, Juliano Moreira (que será abordado mais adiante), que se tornou uma figura proeminente no cenário científico e médico nacional.

Teixeira Brandão também faz diversas citações detalhadas de legislação internacional, em torno de profilaxia e tratamento das doenças mentais. No capítulo que trata desse assunto, ele insiste na educação e na internação de insanos em hospitais,

116 BRANDÃO, T. Elementos fundamentaes de Psychiatria clinica e forense. Livraria Editora Leite Ribeiro \& Maurillo, Rio de Janeiro, 1918, p. 137.

117 Vide decreto nos anexos. 
apenas nas fases agudas. Diz que nunca empregou o uso das camisas de força. Insiste na necessidade de estabelecimentos específicos para insanos perigosos, ou criminosos. Ele também descreve vários casos, seus e de outros autores, incluindo os aspectos legais relacionados aos mesmos.

\subsection{2 - Claro Homem de Mello e Franco da Rocha: primeiros psiquiatras em São Paulo.}

Como é de sobejo repetido, o médico Franco da Rocha teve grande influência no estabelecimento das áreas de psiquiatria e moléstias nervosas em São Paulo. No entanto, em São Paulo ele foi precedido pelo psiquiatra Homem de Mello.

Claro Homem de Mello (1862-1925) nasceu em Pindamonhangaba, de família de políticos e nobres. Em 1883, matricula-se na Faculdade de Medicina do Rio de Janeiro. Durante seu curso serve como secretário de seu tio, o Barão Homem de Mello, ministro do Império. Interessado em psiquiatria, em 1886 é nomeado, pelo Barão de Sabóia, interno da Clinica Psiquiátrica do Hospício D. Pedro II. Em 1888 faz sua tese inaugural com o tema Paranoias. Esse estudo tem repercussão nacional e internacional, sendo elogiado pelo psiquiatra português Júlio de Mattos ${ }^{118}$.

Após formar-se em 1888, Homem de Mello passa a viver em São Paulo a partir de 1889, onde trabalha com psiquiatria e moléstias nervosas. Convidado pelo Barão de Jaguara, presidente da província de São Paulo, toma parte na comissão científica de combate à epidemia de febre amarela em Campinas. Por isso, recebe uma medalha de ouro dessa cidade. Em março de 1891, é nomeado por Américo Brasiliense, então presidente do Estado, para o lugar de médico do Hospício dos Alienados. Participa dos debates em torno da idéia de criação de um novo hospício, tendo escrito artigos a esse respeito na imprensa cotidiana. Em 1907, funda uma Casa de Saúde, moldada em congêneres de outros países. Nessa ocasião (segundo a fonte de referência), é a única desse tipo em São Paulo, atendendo pacientes de vários Estados que, até então, procuravam o Rio de Janeiro. Responde a perguntas publicadas na imprensa em geral, onde também debate sobre as bases científicas da medicina legal em relação aos

\footnotetext{
${ }^{118}$ GAZETA CLINICA. Necrologia. Dr. Claro Homem de Mello. 1925, p. 35. 
alienados. É também citado como cultor dos clássicos e conhecedor de História e Geografia $^{119}$.

De qualquer forma, embora Homem de Mello seja figura notada em certos círculos nesse período, a presença de Franco da Rocha no cenário médico científico em São Paulo acaba sendo acentuadamente marcante, se comparada a esse seu contemporâneo.

Francisco Franco da Rocha nasceu em Amparo, no Estado de São Paulo, em 23 de agosto de 1864. Citado, na referência que observamos, como "filho unico de um homem pobre, mas de familia antiga e conceituada daquela cidade, aprendeu as primeiras letras num colegio dali”. Por um tempo ajuda os pais na lavoura, com a finalidade de custear seus estudos em São Paulo, onde estuda no Colégio Morton, juntamente com Arnaldo Vieira de Carvalho, Vicente de Carvalho, Carlos de Campos e Paulo de Moraes Barros. Aos 17 anos, inicia os “preparatórios”, terminando-os no Rio de Janeiro em 1885, entrando, a seguir, no Curso Médico. Em dezembro de 1890, recebe o grau de doutor em Medicina. Durante o curso, interessa-se pelo campo psiquiátrico. É nomeado interno da Clinica de Moléstias Mentais da Faculdade do Rio de Janeiro e, no sexto ano, interno da Casa de Saúde do Dr. Eiras ${ }^{120}$.

Em virtude de sua intenção de trabalhar em São Paulo, recusa convites do Professor Teixeira Brandão para ficar no Rio, onde seria designado substituto na Faculdade. Recusa também oferta de Carlos Eiras para trabalhar na Casa de Saúde. Após chegar a São Paulo, começa a escrever no "Correio Paulistano" e no "Estado de S. Paulo”, onde propõe a organização do serviço público de assistência aos alienados, de acordo com os "modernos methodos" de tratamento psiquiátrico. No governo de Cerqueira César, é nomeado médico do Hospício de S. Paulo, quando começa seus trabalhos em torno da criação do Juquery ${ }^{121}$.

Para aprofundar-se no conhecimento de sua especialidade, Franco da Rocha estuda inglês e alemão, além do habitual francês, fazendo também citações de textos científicos no original em italiano e espanhol, em seus escritos. Isso o mantém sempre a par e passo com as novidades científicas, conforme se observa em seus artigos e livros. Escreve para os Archivos de Psychiatria de Buenos Ayres, a pedido de Ingenieros; para os Annales medico-psychiatriques de Paris, órgão da Sociedade Médica Psicológica, da

119 GAZETA CLINICA. Necrologia. Dr. Claro Homem de Mello. 1925, p. 35.

${ }^{120}$ GAZETA CLINICA. Necrologia, novembro de 1933, p. 302-303.

121 GAZETA CLINICA. Necrologia, novembro de 1933, p. 302-303.

64 
qual se torna membro. Escreve para o Algemeine Zeitschrift, de Berlim, e contribui para o Tratado Internacional de Psicopatologia, publicado antes da Primeira Guerra Mundial. Em 1918, é contratado para reger a Cadeira de Clínica Psiquiátrica e Moléstias Nervosas da Faculdade de Medicina de São Paulo, exercendo o cargo até 22 de outubro de 1923. Em 1927 funda a Sociedade Brasileira de Psicanálise juntamente com Durval Marcondes e outros. Escreve livro sobre a doutrina de Freud em 1919-1920, atualizando-o em 1930. Nos últimos anos de sua vida escreve estudos sobre ornitologia. Falece em $1933^{122}$.

Franco da Rocha deixa como sucessores: Enjolras Vampré, tido como o fundador da neurologia em São Paulo; Antonio Carlos Pacheco e Silva, mais conhecido como psiquiatra e como diretor do Juquery; Durval Marcondes, ligado ao campo da psicologia, tido como um dos pioneiros da psicanálise no Brasil. Podemos citar ainda, indiretamente, Osório César que tem grande parte de seu trabalho dedicado ao Juquery, embora sendo sido discípulo mais diretamente de Pacheco e Silva.

Observa-se, assim, de certa forma, em Franco da Rocha, uma espécie de síntese da origem das três áreas a serem estudadas em São Paulo.

\section{1. 3 - Algumas obras iniciais de Franco da Rocha.}

\section{1. 3. 1 - A tese inaugural de Franco da Rocha}

As teses inaugurais, no período abordado, são trabalhos realizados para a conclusão do curso médico. Embora feitas por estudantes, algumas chamam a atenção do ambiente científico, como, por exemplo, a já citada tese de Homem de Mello que foi elogiada pelo psiquiatra português Júlio de Mattos.

Esses trabalhos também podem fornecer dados referentes à ciência vigente no momento em que seu autor está se formando. Por outro lado, trata-se de um trabalho de alguém que ainda está em início de carreira (pois, embora ainda não diplomado, o indivíduo já trabalha como interno no serviço de algum professor) e, sendo assim, com pouca experiência. Além disso, as teses, de um modo geral, podem apontar determinados interesses científicos de seus autores, nesse momento. 
Diferentemente de seu mestre Teixeira Brandão, cuja tese inaugural diz respeito a cirurgia, Franco da Rocha já faz sua tese dentro da Cadeira de Clinica Psychiatrica, indicando seu interesse e persistência desde então, além de indicar também que há uma cadeira especifica para esse assunto, o que facilita também esse tipo de escolha.

Podemos notar, pelo conteúdo desse trabalho, que seu estudo também se enquadra no campo de moléstias nervosas, em virtude das argumentações e reflexões feitas estarem ligadas ao entendimento do cérebro, e do sistema nervoso como um todo, sendo que as manifestações motoras são os aspectos mais realçados.

A tese de Francisco Franco da Rocha data de 2 de maio de 1890, sendo referida como da Cadeira já citada, da Faculdade de Medicina do Rio de Janeiro, com o título Das perturbações dos movimentos nas molestias mentaes ${ }^{123}$.

Em sua introdução, Franco da Rocha diz não conhecer outro estudo semelhante ao seu, exceto o de Morselli, que, no entanto, deixou incompleta sua obra, porém tendo servido como referência para seu trabalho.

Ele inicia sua explanação, falando da fisiologia do movimento, a qual, conforme escreve, “depende dos sistemas organicos nervoso e muscular”124. Faz, então, um relato das pesquisas realizadas a respeito dos centros cerebrais "psycho-motores”125. Relata cinco teorias que, então, procuram explicar o funcionamento desses centros. Algumas são localizacionistas, ou localistas, ou seja, propõem centros de células cerebrais específicas para determinada funções, enquanto outras teorias não concordam com essa suposição ${ }^{126}$.

Franco da Rocha refere-se à distinção de movimento voluntário e involuntário, a fim de correlacionar certos movimentos a moléstias mentais. Ele acentua que é difícil distinguir, em relação aos movimentos voluntários e involuntários, onde começa um e acaba o outro, "tanto mais que é conhecida a transformação do movimento voluntario em movimento involuntario e vice-versa”127. Nesse ponto, refere-se a certa noção de "inconsciente»"128, ao comparar esses dois tipos de movimento, exemplificando com um

123 ROCHA, F.F. Das perturbações dos movimentos nas molestias mentaes. Tese de Doutoramento. Faculdade de Medicina do Rio de Janeiro, 1890.

124 Idem, p. 9.

125 Ibidem.

126 Idem, p. 9 a 15.

127 Idem, p. 16.

128 Conforme o sociólogo Cazeto, no século XIX a idéia do inconsciente não faz escândalo e é assunto da moda nas reuniões sociais européias dos anos 1870; citando outros estudiosos, esse autor refere que a 66 
indivíduo que, ao tocar piano, em parte de sua execução, não tem consciência de todos os seus movimentos.

Franco da Rocha termina o capítulo sobre "Fisiologia do Movimento", citando artigo de Glover, publicado nos Arch. de Neurologia ${ }^{129}$ (conforme grafado por Franco da Rocha), onde consta “o que ha de mais positivo sobre a topographia dos centros motores cerebraes", apontados "pela clinica, pela anatomia pathologica e pela physiologia” ${ }^{130}$. Assim, relata áreas cerebrais, correspondentes a diversas partes do corpo. Observe-se que ele usa uma publicação internacional, nomeada como sendo "de Neurologia”, para explicar estudos referentes ao campo psiquiátrico, embora não use essa palavra, nesse período, em outras situações.

Vemos que o próprio tema de Franco da Rocha acaba conduzindo a uma interligação entre moléstias nervosas e psiquiatria, na medida em que ele estuda “alterações de movimento”, ou seja, um aspecto descrito mais pelos estudos das doenças do sistema nervoso, associando a distúrbios psiquiátricos.

A seguir, o autor entra no aspecto da expressão das emoções. Segundo ele, esse assunto é não só de interesse científico, mas também artístico, pois os artistas também procuram entendê-lo (as emoções). Considera que o trabalho de Darwin ${ }^{131}$, sobre a expressão das emoções, condensa o de outros pesquisadores a respeito desse assunto.

Refere que, no corpo, principalmente a face pode expressar diversos estados psíquicos. Relata estudos do psiquiatra Feré (um discípulo de Charcot), o qual considera que cada representação mental corresponde a uma contração muscular equivalente, quase imperceptível, e que, em condições especiais, como no caso de uma pessoa hipnotizada, esta pode ter percepção suficiente de detalhes da face de alguém, a ponto

idéia de processos psíquicos inconscientes é mais acolhida no fim do século XIX, do que no início do século XX. Desse modo, antes de Freud, o inconsciente é um conceito em voga em ambientes filosóficos e psicológicos.

CAZETO, S. J. A constituição do inconsciente em práticas clínicas na França do século XIX. Editora Escuta Ltda. - Fapesp, 2001, p. 27 e p. 29.

129 Provavelmente “Archives de Neurologie” fundado por Charcot em 1880.

130 ROCHA, F. Tese de Doutoramento, p. 17.

131 Em 1871, Darwin escreve The Descent of Man and Selections in Relation to Sex e em 1872 escreve The Expression of the Emotions in Man and Animals. Em ambos os livros ele discorre a respeito das emoções e suas manifestações. Nesses trabalhos, refere-se elogiosamente a um trabalho de Charles Bell, de 1806, a respeito das emoções, e sobre o trabalho de Duchenne, também a esse respeito. Inclusive este pesquisador francês cede a Darwin algumas fotos de expressões faciais estudadas com uso de estímulos elétricos.

FINGER, S. Origins of Neuroscience: A history o explorations into brain function. Oxford University Press, 1994, p.268-271. 
de "ler o pensamento" ${ }^{132}$ na expressão facial observada. Conforme Feré, isso explica certos fenômenos tidos como extraordinários, mas que podem ser interpretados racionalmente por esse processo.

Franco da Rocha cita Darwin e Spencer, para se referir ao caminho das “forças nervosas”133, que têm suas transmissões pelas conexões das células nervosas, e que, um afluxo de força nervosa não dirigido por seu caminho habitual, sai por caminhos menos usados, exteriorizando-se, assim, por distúrbios de movimento.

Desse modo, Franco da Rocha considera que, quanto menos os músculos forem suscetíveis à vontade, mais eles podem estar propensos a receber influência das emoções, tais como o músculo cardíaco e a musculatura respiratória: “quando é muito intensa a emoção, os movimentos vão apparecendo inconscientemente”"134. A seguir, ele passa a citar exemplos, como o tremor, que pode estar presente em emoções de contrariedade, bem como as lágrimas. Baseado em Darwin, refere que há duas categorias de emoções: as excitantes e as deprimentes.

Depois, inicia a sua dissertação propriamente dita. Ele estuda os movimentos baseado em Morselli. Apresenta, em detalhes, uma subdivisão em grupos, por tipo de movimento, com alguns exemplos.

Um aspecto a ser destacado é que ele cita o estudioso E. Batault, o qual procura explicar a histeria por perturbações na célula nervosa cerebral, fazendo uso de teorias de Haeckel. Este considera como "ultimas particulas vivas de que se compõe a cellula", algo que ele chama de "plastidulos”. Assim, todos os processos biogenéticos da célula ocorrem devido a "movimentos ondulatorios, rithmicos dos plastidulos". Essa é a “theoria da perigenese dos plastidulos de Haeckel”, exposta em sua obra Psychologia cellular, de $1880^{135}$.

Essa é uma associação, feita por Haeckel, entre noções de psicologia associadas a uma hipótese de funcionamento celular. Entre essas duas teorias, Batault enquadra uma doença emblemática e enigmática desse período, a histeria.

Destacamos também que Franco da Rocha considera o estudo da fisionomia nos alienados como um verdadeiro “psychoscopio”. Nesse aspecto, citando Guislain, ele

132 ROCHA, F.F. Das perturbações dos movimentos nas molestias mentaes. Tese de Doutoramento. Faculdade de Medicina do Rio de Janeiro, 1890, p. 20.

133 Idem, p. 23.

134 Idem, p. 24.

${ }^{135}$ Idem, p. 57.

68 
escreve que o médico também é um artista, e que ambos têm interesse nos traços fisionômicos dos alienados.

Na parte intitulada “Therapeutica”, divide os quadros em excitantes e deprimentes e apresenta os medicamentos para ambas as situações. A contenção mecânica é outro tratamento citado, para os indivíduos muito furiosos. É feita menção à camisola (de força) como inconveniente, mas ele lembra que o sistema "no restraint" dos ingleses ainda não é, até então, adotado em todo o mundo (em rodapé Franco da Rocha cita, como curiosidade, o uso da cor azul como calmante e o vermelho alaranjado como estimulante ${ }^{136}$. Nos agitados também se aplicam banhos tépidos. Em alguns casos indica-se também o uso da medicação digitalis.

Nas situações de abatimento do organismo, são citados os “meios morais" e os “meios pharmaceuticos”, acrescentando a hidroterapia. Como meios morais são incluídos: passeios, trabalhos moderados e direcionados. A hidroterapia é considerada como tendo resultados surpreendentes. Franco da Rocha ressalva ter-se referido “á hydrotherapia dirigida scientificamente e não á hydrotherapia terror que empregava Leuret”. A eletroterapia é indicada em alguns $\operatorname{casos}^{137}$.

Pela tese de Franco da Rocha, observa-se que, nesse momento, há uma busca em entender os fenômenos psíquicos e os ligados ao sistema nervoso, dentro de uma única teoria. Além disso, concorrem diversas tendências e teorias em torno do entendimento de emoções, movimentos, e noções de fluxo nervoso. Noções de inconsciente estão presentes como forma de entender esses fatores. A influência de Darwin se faz notar ${ }^{138}$. Também, no item relativo ao tratamento, está presente uma restrição ao uso da camisa de força, bem como uma rejeição a certas formas de terapêutica denominadas de “terror”, o que denota certa sensibilidade e crítica quanto a determinados métodos.

136 ROCHA, F.F. Das perturbações dos movimentos nas molestias mentaes. Tese de Doutoramento. Faculdade de Medicina do Rio de Janeiro, 1890, p. 99.

137 Idem, p. 100.

138 As idéias de Darwin influenciaram Hughlings Jackson, que inseriu as noções de evolução no entendimento do sistema nervoso.

FINGER, S. - Origins of Neuroscience, 1994, p.268-272.

69 


\section{1. 3. 2. Uma obra de Franco da Rocha do início do século XX}

Em 1904, Franco da Rocha publica o livro Esboço de Psychiatria Forense, uma obra de quatrocentas e oitenta e uma páginas, na qual ele vai além do que o título do livro sugere, e expõe suas conceituações em geral sobre doenças mentais. Dessa obra de tal monta, observamos apenas alguns aspectos que mais interessam ao nosso trabalho, que são abordados neste item e em outras seções.

Na introdução, que ele chama de "Advertencia”"139, frisa que seu livro "não tem a pretensão de servir aos conhecedores da materia"140, devendo ser lido mais como “rudimentos de psychiatria”141, destinados a juristas e médicos que necessitem de algum aprofundamento no assunto. Além disso, ele acrescenta que o livro tem mais uma pretensão, que é a de "despertar em especialistas ${ }^{142}$ mais engenhosos a ideia de fazer obra completa e perfeita"143.

Em relação à loucura, ele diz que:

"Traçar a linha divisoria entre a razão e a loucura é tarefa inexequivel no estado actual das sciencias medicas. Com clareza inexcedivel já mostrou Maudsley que entre a razão e a loucura há uma zona de gradações tão subtis, que impedem a limitação justa - tal seria a definição - entre um e outro estado. (...) A palavra loucura tem significação muito limitada e não abrange hoje os casos em que a lei deve ter applicação.

Para o objectivo deste livro é de conveniencia procurar estabelecer a differença entre alienação mental e loucura. Basta lembrar que alienação mental é um termo mais geral, que abrange a loucura; podemos, portanto, empregar o termo alienação significando loucura, porém não o inverso.

Para nós, a alienação é uma perturbação ou anomalia, temporaria ou perpetua, das relações normaes preestabelecidas entre um individuo e o seu meio social, resultante sempre de um estado pathologico ou teratologico do cerebro. (...) É preciso notar a restricção do meio social, porque um acto que é loucura no Brazil pode não o ser na China”144.

De modo geral, nesse livro, Franco da Rocha direciona o entendimento das moléstias mentais para alterações do cérebro. No entanto, ao relativizar a loucura de

139 ROCHA, F. Esboço de Psychiatria Forense. Typographia Laemmert \& C., São Paulo, 1904, p.III.

140 Idem.

141 Ibidem.

142 Franco da Rocha utiliza com freqüência o termo "especialista” para referir-se aos psiquiatras.

143 ROCHA, F. Esboço de Psychiatria Forense. Typographia Laemmert \& C., São Paulo, 1904, p.III.

144 Idem, pp.1-3.

70 
acordo com seu contexto cultural, dizendo que isso pode variar entre diferentes grupos sociais, está inserindo outras variáveis que não só a estritamente médica.

Ao considerar a natureza cerebral da alienação, ele supõe as causas externas ao indivíduo como desencadeantes do distúrbio mental, mas sempre ocorrendo em um cérebro já predisposto a doenças.

Em outro trecho, acentua que “toda molestia mental é molestia cerebral”, considerando a consciência apenas como um “epiphenomeno”, "um aperfeiçoamento da funç̧ão cerebral”"145.

No capítulo intitulado “symptomatologia em geral”, Franco da Rocha dá idéia de seu entendimento das manifestações das doenças mentais. Ele divide os sintomas da loucura em “duas series de phenomenos”: alterações funcionais e alterações orgânicas.

As alterações funcionais, ele divide em dois grupos: alterações funcionais relativas à atividade e alterações funcionais especiais ou elementares.

As alterações funcionais relativas à atividade, ele divide em dois subgrupos: exageração ou excitação e diminuição ou depressão. As alterações funcionais especiais ou elementares, divide em: psíquicas e físicas.

Considera as alterações psíquicas como: alucinações e ilusões; perturbações da memória; concepções delirantes; perturbações afetivas; perturbações dos instintos; perturbações dos atos. Já as físicas são: alterações nervosas gerais; alterações da vida vegetativa.

Entre as alterações funcionais físicas, anteriormente citadas como "nervosas gerais” e “da vida vegetativa”, ele cita: insônia; perturbações da nutrição; alterações secretórias (que ele associa a falta de saliva ou a secura da pele); alterações aos exames de urina (que são referidas como ainda em pesquisa) e de sangue; lesões na pele; distúrbios no aparelho digestivo, no aparelho cardio-vascular, no aparelho respiratório.

Entre pesquisas sobre essas alterações funcionais físicas, Franco da Rocha cita estudo do pulso em alienados feito por Henrique Roxo em 1902, sem entrar em detalhes. Também relata estudo da temperatura em epilépticos, no Juquery, feito pelo médico D. Cavalheiro, onde não foi observada alteração importante, diferentemente de 
estudo internacional do estudioso Carlo Ceni, que descreve abaixamento da temperatura em epilépticos ${ }^{146}$.

As alterações orgânicas ${ }^{147}$, ou constitucionais, ele dispõe em dois tipos: o primeiro tipo corresponde a anomalias orgânicas de evolução e estigmas de degeneração - físicos ou psíquicos; o segundo tipo diz respeito a lesões de desorganização e ou lesões senis - físicas ou psíquicas.

De um modo geral, Franco da Rocha explica que os elementos constituintes da mente têm íntima relação de dependência entre si, de modo que, em determinada circunstância, mesmo havendo a predominância de uma alteração, por exemplo, do estado afetivo, pode haver comprometimento da associação de idéias, bem como dos atos. Assim, ele considera como artificial a subdivisão feita entre os sintomas, havendo apenas a acentuação do aspecto que mais se exacerba em cada quadro.

Quanto à descrição do exame físico no que concerne a sinais do sistema nervoso, ele relata o "exame do systema muscular”, descrevendo paralisias e alterações dos reflexos. Cita o "reflexo plantar”, mas não faz menção ao sinal de Babinski. Sobre os reflexos em dementes, aponta estudos feitos por Bettencourt Rodrigues.

Quanto ao comprometimento da sensibilidade, descreve diversas alterações e informa que há estudos em andamento sobre esses quadros e ainda não concluídos, sendo feitos por H. Head no London Hospital.

Em relação às anomalias constitucionais observáveis ao exame, ele diz que formam um vasto capítulo em psiquiatria, com estudos de Magnan, Lombroso e outros, onde são descritos os “estigmas dos degenerados”, tanto físicos quanto psíquicos. Ele enumera os estigmas físicos, referentes a várias alterações visíveis no corpo, além de tiques, convulsões da infância, chorea minor. Franco da Rocha frisa que: "para que o individuo seja um degenerado é preciso que tambem se verifique a presença de estigmas

\footnotetext{
${ }^{146}$ Observamos, por esta informação, que nesse período, no Juquery, são feitos trabalhos científicos que procuram seguir linhas internacionais, mas chegando a suas próprias conclusões, mesmo que discordantes das já consagradas.

147 Assinalamos que, para Franco da Rocha, em psiquiatria os termos "orgânico”, “físico”, "psíquico”, "funcional" não têm o mesmo sentido que por vezes procura-se usar em discursos a respeito de "organicismo", ou de "organicista". Para ele "alteração orgânica" diz respeito a alterações conhecidas, ou supostas da estrutura do sistema nervoso. Ele ainda reserva todo um campo de alterações funcionais, psíquicas ou físicas, para outras tantas manifestações estudadas pela psiquiatria. 
psychicos”, que ele descreve como obsessões e impulsões (onde cita fobias e manias específicas, bem como impulsões suicidas e homicidas) a partir de estudo de Magnan.

Além desse estudioso, outros que ele cita várias vezes nesse capítulo são: Ribot, Morselli, Kraft-Ebing, Pitres, Regis.

Esses estigmas, conforme sua citação de vários estudiosos, são correlacionados a noções de evolução ligadas ao desenvolvimento do indivíduo. A partir da noção de que a vida afetiva precede a função do conhecimento, Franco da Rocha, citando esses autores, considera esses estigmas como provenientes de distúrbios da emoção. Nesse contexto, ele valoriza a interferência de aspectos sexuais.

No capítulo em que discorre sobre causas da loucura, ele considera que, na maioria das vezes, há uma combinação entre causas cerebrais e extracerebrais.

As causas cerebrais ele subdivide em duas formas: predisposição, quando são “indeterminadas em relação aos elementos anatomicos”; degeneração, quando em grau mais avançado se revelam "por signaes mais evidentes"148.

As causas extra-cerebrais são assim designadas: intoxicações, infecções, moléstias da nutrição, traumatismo, afecções diversas no organismo, fases fisiológicas da vida.

Além desses dois tipos de causas, há outro grupo designado como "causas de ordem moral”, que são: “emoções fortes, contagio psychico, suggestão”149.

A seguir, Franco da Rocha passa a discorrer sobre esses diversos grupos de causas.

Em relação à intoxicação, frisa o alcoolismo como o fator mais importante, lembrando também outros menos freqüentes no Brasil, mas também presentes, como ópio, éter e cocaína, inclusive em São Paulo. O fumo também é citado como um tóxico relativamente fraco $^{150}$.

Quanto às infecções, ele considera que todas podem ser causa de alterações mentais, por dois mecanismos: por "effeito das toxinas" ou devido ao estado de “cachexia final” resultante da moléstia. Em relação a essas doenças, ele refere a febre

148 ROCHA, F. Esboço de Psychiatria Forense. Typographia Laemmert \& C., São Paulo, 1904, p. 21. 149 Idem.

150 Idem, p. 22.

73 
tifóide como de efeito mais desastroso sobre cérebros que não atingiram "grau normal de evolução"151.

Entre as infecções, o autor se detém mais detalhadamente sobre a sífilis, por ser causa freqüente de loucura, frisando haver um comprometimento devastador do organismo. Franco da Rocha discorda do que chama de "tendencia moderna" de atribuir-se a paralisia geral dos alienados à "infecção siphylítica”. Ele explica sua discordância por encontrar casos de "peri-encephalite chronica diffusa” (abordada mais adiante), em que não acha sífilis, segundo ele, mesmo com uma investigação acurada.

Além disso, também informa que a paralisia geral é rara em indivíduos de raça negra, enquanto que a sífilis é relativamente comum. Ele acha que há outros fatores, além da sífilis, que influenciam o aparecimento dessa moléstia, já que entre os negros da América do Norte a paralisia geral é mais freqüente do que nos negros do Brasil. Nas mulheres ele cita ser rara a paralisia geral (em brasileiras refere ter visto apenas um caso, e alguns em estrangeiras), enquanto que a sífilis é relativamente mais encontrável nesse sexo ${ }^{152}$.

Ainda como infecções que causem distúrbios mentais, Franco da Rocha menciona a tuberculose, a varíola, o “rheumatismo agudo”, a influenza, o “puerperio”, a febre amarela, a malária ${ }^{153}$.

Sobre as moléstias da nutrição que acarretam perturbações psíquicas, considera dois mecanismos: o depauperamento geral do organismo, ou a "auto-intoxicação". Neste caso, faz especial menção às moléstias da "glandula thyreoide” que acarretam “enfraquecimento especial do espirito”. Também cita a inanição, anemia e diabetes ${ }^{154}$.

O “artritismo” é referido por Franco da Rocha como sendo um estado orgânico favorável ao desenvolvimento de certas molestias mentais, como a paralisia geral, por exemplo. Ele considera que o artritismo favorece o aparecimento de moléstia no órgão mais sensível de cada indivíduo. Se o indivíduo tem o que Franco da Rocha chama de “cerebro cultivado”, ele entende que o artritismo favorece o aparecimento da paralisia cerebral $^{155}$.

O traumatismo de crânio é citado como causa de "demencia paralytica”. Em outros países, ele refere estudos em torno de "nevroses traumaticas” devidas a acidentes

151 ROCHA, F. Esboço de Psychiatria Forense. Typographia Laemmert \& C., São Paulo, 1904, p.22.

152 Idem, p. 23.

153 Idem, p. 24

154 Idem.

155 Idem, p. 24 e 25.

74 
de estradas de ferro. Aliado a isso, cita que, nesses outros países, a influência de fatores como "emoção e susto" foi exagerada por médicos que defendiam companhias em casos litigiosos com doentes ${ }^{156}$.

Sobre as "affecções nervosas" que se acompanham de "perturbações cerebraes”, o autor cita a “tabes”, que diz preceder ou combinar-se com a paralisia cerebral. Informa que, nas “polynevrites”, Korsakow descreveu uma forma de confusão mental que chamou de "psychose polynevritica"157.

Franco da Rocha também diz que a privação de um dos sentidos pode ser causa de idiotismo, mas alerta que a educação de surdos-mudos é belo exemplo de progresso científico e cita Laura Bridgmann, que perdeu visão e audição aos seis anos e foi educada pelo sentido do tato, de modo que aprendeu a ler e escrever ${ }^{158}$.

Cita, brevemente, que afecções do coração podem causar perturbações mentais.

Enfatiza que "dentre as afecções organicas, as que mais se relacionam com as molestias mentaes são, sem duvida, as do apparelho genital” e descreve algumas situações relativas a esses quadros. Cita também as psicoses pós-operatórias, às quais associa o shock como revelador de uma predisposição do indivíduo. Menciona também algumas moléstias que são "perturbadoras do estado de humor"159.

Refere as "phases physiologicas da vida individual”, ou seja, "a puberdade e a involução senil” como fatores especialmente associados a alterações mentais. Faz algum detalhamento dessas situações ${ }^{160}$.

Nas “causas de ordem moral”, Franco da Rocha cita emoções fortes e prolongadas, incluindo aí o traumatismo psíquico. Relata também situações circunstanciais como propícias ao aparecimento de loucura, tais como: condições de educação das crianças, revoluções, guerras civis, a luta pela vida. Nesta última situação refere o suicídio, o abuso do álcool, o excesso de trabalho físico e mental, o crime, a neurastenia. Todos estes quadros são considerados como acometendo o “cerebro anormal”, formando um grupo que ele diz ter sido bem delineado por Magnan, indo desde o “degenerado superior” até o “idiota”161.

156 ROCHA, F. Esboço de Psychiatria Forense. Typographia Laemmert \& C., São Paulo, 1904, p.25. 157 Idem, p. 25 e 26.

158 Idem, p. 26.

159 Idem, p. 26 e $27 . s$

160 Idem, p. 27-29.

161 Aqui Franco da Rocha faz uma nota para dizer que considera a lei de castração de degenerados inferiores feita nos Estados Unidos como de pouco valor, pois esses indivíduos, segundo ele, não tem capacidade de se reproduzir. 
Além disso, Franco da Rocha relata também o “contagio psychico” em que um indivíduo louco convence outro indivíduo predisposto a certos atos, podendo passar mesmo a ter um caráter epidêmico. Cita como exemplos o caso de Antonio Conselheiro e outro que chama de "epidemia religiosa espírita de Taubaté”.

Ele considera as aglomerações populares, que chama de "turba", como uma situação de transição entre o estado normal e a loucura, no fenômeno de contágio psíquico. Cita estudiosos, e também Shakespeare, como conhecedores desse tipo de manifestação, que diz ser influenciada principalmente pela "sugestão". Refere como exemplo as ocorrências de linchamentos nos Estados Unidos.

Franco da Rocha cita também o hipnotismo como provocador da histeria, evocando o testemunho de um discípulo de Charcot: Guinon.

Passando às causas inerentes à organização cerebral, relata a herança de tendências mórbidas do sistema nervoso e a degeneração psíquica. Ele frisa aqui não se tratar de doutrinas biológicas que tentam explicar a hereditariedade, como as de Darwin, Weissmann, ou Häeckel. Considera os males herdados como um fato incontestável. Cita Morel e Magnan como estudiosos importantes nesse assunto. Informa que, em 7 anos de estatísticas em São Paulo, observou 35\% de pacientes “francamente degenerados". Supõe que o número de predispostos talvez chegue a $80 \%$.

Franco da Rocha faz uma distinção entre predisposição e degeneração, explicando que, neste caso, há a presença de estigmas físicos e psíquicos. Refere que, nos degenerados, há uma ruptura da "harmonia funccional hierarchica” do cérebro. Para essa harmonia, ele diz que os lobos anteriores, sede das mais nobres funções psíquicas, se sobrepõem aos posteriores que correspondem aos instintos. Menciona a classificação dos degenerados de Magnan como a mais aceita, com os itens: idiota, imbecil, débil, degenerado superior. Neste item, Franco da Rocha cita estudiosos que apontam uma correlação algo paradoxal entre genialidade e “nevropathia”.

Sobre a influência da raça como fator etiológico na loucura, aponta que os dados são controversos e também dependentes de influências do meio. 


\section{2 - Linguagens, nomes, classificações}

Ao nos basearmos no discurso dos médicos e cientistas do período, para estudarmos o estabelecimento das disciplinas enfocadas, notamos a constante preocupação que eles têm com a linguagem e com a nomeação de diferentes fenômenos ou categorias, da maneira que consideram mais adequada, em cada circunstância. Desse modo, a utilização de palavras como psiquiatria, psicologia, psicanálise, psicoterapia ${ }^{162}$, psicopatologia, neurologia, neuropatologia, neuriatria, neuropsiquiatria, entre outras, remete à necessidade de abordagem específica do uso desses termos em determinados contextos, que delineiam conformidades ou diferenciações entre as palavras e seus atributos $^{163}$.

A palavra neurologia, embora criada por Willis no século XVII, tem para ele um sentido que difere do que vem a significar para os médicos do século $\mathrm{XX}^{164}$.

Também palavras como “moral”, ”degenerado”, “idiota”, etc. podem ter diferentes sentidos em diferentes contextos, podendo ter um sentido menos pejorativo em certas situações. Na medida em que esses termos circulam em diferentes ambientes,

162 Conforme Roudinesco, o termo "psicoterapia” foi criado em 1872 por Daniel Hack Tuke (18271895), neto de William Tuke (1732-1822) - este é considerado o fundador da psiquiatria inglesa.

ROUDINESCO, E. O Paciente, o Terapeuta e o Estado. Jorge Zahar Editor, 2005, p.35.

163 Conforme Foucault, até o século XVII os signos faziam parte das coisas e o discurso científico podia misturar observação, documento e fábula. A partir de então os signos tornam-se modos de representação, com uma distância aberta entre as palavras e as coisas, encontrando a história natural seu espaço nessa distância. A história natural passa a ser a nomeação do visível. No entanto, Foucault acha que ela não pode se constituir em biologia, porque no século XVIII "a vida não existe”, apenas existem "seres vivos". FOUCAULT, M. As palavras e as coisas. Martins Fontes, (1966,1981) 2002, p. 177-181, p. 222.

Paolo Rossi critica Foucault, dizendo que ele não relaciona a história natural a uma "filosofia da vida", mas a uma "teoria das palavras", negando assim uma comunicação de conceitos, ou passagem de métodos ou transferência de modelos; Rossi diz que Foucault se atem a identidades estruturais e a correspondências na representação. Rossi defende essa comunicação entre diferentes campos de investigação, entre sistemas de signos e estudos científicos.

ROSSI, P. A Ciência e a Filosofia dos Modernos: aspectos da Revolução Científica. Editora Unesp, (1989) 1992, p. 330-331.

Em "o Nascimento da Clinica” Foucault diz que a Clínica pede ao olhar tanto quanto a História Natural e que o sintoma transforma-se em signo; assim, Boissier de Sauvages sonhava ser o "Lineu das doenças" e a Medicina se submeteu, em parte, ao modelo naturalista (p. 95-116).

164 Feyerabend, citando Whorf, considera que "as línguas e os padrões de reação que envolvem não são meros instrumentos para descrever eventos (fatos, estados de coisas), mas que são também modeladores de eventos (fatos, estados de coisas), que sua gramática encerra uma cosmologia, uma visão abrangente de mundo, da sociedade e da situação do ser humano, que influencia o pensamento, o comportamento e a percepção".

FEYERABEND, P. Contra o método. Editora Unesp (1992) 2003, p. 227.

77 
além do âmbito científico, certas palavras têm reforçados seus sentidos estigmatizados e estigmatizantes $^{165}$.

Desse modo, embora este trabalho não tenha a linguagem como seu foco principal, é importante que tenhamos certa atenção a palavras e nomes utilizados no período, em virtude da importância da nomenclatura para a caracterização das áreas científicas estudadas ${ }^{166}$.

O uso específico da linguagem, na nomeação de moléstias, adquire especial atenção nas classificações, especialmente nas classificações de moléstias psiquiátricas. Assim, passamos a algumas considerações a respeito das classificações.

A partir do período do Renascimento, começam a aparecer certas nomeações de loucuras. Conforme Foucault, Paracelso (1493-1541) faz uma distinção entre formas de loucura, de acordo com suas causas, o que não é aceito como classificação dentro dos critérios do período clássico, onde se consideram as classificações baseadas em conhecimento a respeito das próprias moléstias através de suas manifestações clínicas.

Assim, Paracelso distingue tipos de loucura, conforme sua causa: os Lunatici, os Insani, os Vesani e os Melancholici. A doença dos Lunatici se deve à lua e suas variações. A moléstia dos Insani se deve à hereditariedade. Os Vesani são privados da razão devido ao abuso de bebidas ou alimentos. A moléstia dos Melancholici se deve a um vício de suas naturezas internas.

Alguns desses termos persistem na nomenclatura médica. Por exemplo, um termo do latim, como a palavra vesania (loucura), passa por esta nomeação de Paracelso, e depois origina a palavra “vesânia” em períodos seguintes. Esse termo passa a ser usado pelos psiquiatras brasileiros e paulistas como referente a certos quadros de perda da razão ${ }^{167}$.

165 Conforme Thomas Kuhn, embora novos paradigmas nasçam de antigos, os novos não usam os mesmos termos da mesma forma que o anterior, podendo haver o que ele chama de incomensurabilidade entre as teorias.

KUHN, T. A Estrutura das Revoluções Científicas. Editora Perspectiva, (1962,1970) 2001, p. 188-189.

166 Conforme Le Goff: "Um aspecto importante da análise histórica é o do vocabulário, da terminologia, da 'nomenclatura'”.

LE GOFF, J. Prefácio. In: BLOCH, M. Apologia da História: ou o Ofício de Historiador. Jorge Zahar Editor, 2002.

Em Apologia da História, Marc Bloch indica como o historiador deve conduzir sua análise com o auxílio de uma dupla linguagem, a da época estudada, o que lhe permite evitar o anacronismo, mas também a do aparato verbal e conceitual da disciplina histórica atual. Além disso, o próprio Bloch, nessa obra, recomenda cuidado com coincidências fortuitas entre palavras, evitando-se precipitações em conclusões derivadas da presença isolada de um mesmo termo em textos diferentes.

BLOCH, M. Apologia da História: ou o Ofício da Historiador. Jorge Zahar Editor, 2002, p. 120-121. 167 FOUCAULT, M. História da Loucura na Idade Clássica. Editora Perspectiva, 1987 (1972), p. 193. 78 
Ainda, conforme Foucault, em 1609, o estudioso Platero publica o que pode ser considerado como uma primeira classificação de distúrbios mentais, na medida em que se baseia em lesões das funções dos sentidos externos e internos (que correspondem a: imaginação, razão e memória). Esse autor considera quatro grupos de moléstias: mentis imbecillitas, mentis conservatio, mentis alienatio, mentis defatigatio ${ }^{168}$.

Na classificação de Platero, observamos que esse autor introduz o termo alienatio, o que pode ter dado depois os termos “alienado” e “alienação”169.

Outras classificações de doenças mentais se sucedem a essa de Platero. Ao mesmo tempo também são elaboradas classificações de moléstias em geral.

Conforme Foucault, o médico Sydenham (1624-1689) inicia o pensamento classificatório em medicina, de um modo geral. Entre os quadros por ele descritos constam histeria e hipocondria (esta é a denominação por ele dada à histeria masculina). Ainda no que diz respeito às classificações das moléstias em geral, Foucault acentua o papel da classificação intitulada Nosologie, de Sauvages (1761) e da classificação denominada Nosographie, de Pinel (1798), como obras bastante influentes sobre o pensamento médico classificatório ${ }^{170}$. Essas e algumas outras classificações gerais abrangem também moléstias mentais.

Os termos que compõem as classificações são criados de acordo com as conceituações médicas e as circunstâncias do momento em que são adotadas. Conforme Huertas, a cristalização definitiva da noção de "enfermidade nervosa” ocorre ao longo do século XVIII, principalmente por conta de autores ingleses e franceses. Esse autor cita como exemplo o estudioso inglês Fleming, que cria o termo "neuropatia”, quase um quarto de século antes de William Cullen propor o termo “nevrose”171.

O termo "nevrose” ${ }^{172}$, com suas variadas conceituações no transcorrer do tempo, tem importância especial na delimitação das áreas em questão, em nosso trabalho.

\footnotetext{
168 Idem, p. 193-194.

169 Embora Platero tenha lançado o termo alienatio, as palavras "alienado, alienação e alienista" são consagradas a partir de Pinel, que é considerado como o "primeiro alienista", mais apropriadamente do que "primeiro psiquiatra". O termo "psiquiatra" foi lançado na Alemanha em 1808, alguns anos depois de Pinel já estar atuando no alienismo, conforme já referido.

170 FOUCAULT, M. O nascimento da Clínica. Editora Forense Universitária, (1980) 2006, p. 2 e p. 22.

171 HUERTAS, R. El siglo de la Clinica: para una teoria de práctica psiquiátrica. Novalia Eletronic: Editions, 2004, p. 167.

172 Optamos aqui por usar a grafia antiga de "nevrose", conforme as publicações do período por nós abordado, deixando a forma "neurose" para nos referirmos ao uso dessa palavra em contexto posterior à 79
} 
A designação “nevrose” é proposta por William Cullen (1710-1790) em 1769, em sua obra Synopsis nosologiae methodicae, e depois em 1777, em seu First Lines of the Practice of Physick ${ }^{173}$. Esse autor utiliza a palavra "nevrose” para designar afecções “do sentido e do movimento"174, que não dependem de “pirexia”(febre) ${ }^{175}$ ou de lesão local dos órgãos, mas de um comprometimento geral do sistema nervoso ${ }^{176}$.

Em outras palavras, ao elaborar esse conceito, Cullen refere-se a qualquer doença própria do sistema nervoso, e, portanto, não originada em outra parte do organismo.

Conforme o período, alguns autores incluem entre as nevroses, os quadros de histeria e hipocondria formulados por Sydenham ${ }^{177}$. Outros estudiosos subdividem as nevroses em dois grupos: “nevroses maiores” (que incluem histeria e hipocondria) e “nevroses menores" (os outros quadros) ${ }^{178}$.

Cullen subdivide a nevrose ${ }^{179} \mathrm{em}$ : comata (condições similares a apoplexia e derrames), adynamiae (distúrbios similares às atuais alterações do sistema nervoso autônomo ${ }^{180}$ ), spasmi (quadros similares a convulsões) e vesaniae (deterioração intelectual) ${ }^{181}$.

Com o desenvolvimento da anatomia patológica, no século XIX, o conceito de nevrose vai passar a dizer respeito apenas aos quadros do sistema nervoso "sem comprometimento orgânico detectável”. Conforme Huertas, essa conceituação começa a se firmar a partir da obra de Pinel, concomitantemente ao aprimoramento dos estudos

influencia da doutrina freudiana, dentro de um entendimento mais próximo da psicologia e da psiquiatria, do que da neurologia.

173 HUERTAS, R. El Siglo de la Clinica: para una teoria de práctica psiquiátrica. Novalia Electronic Editions, 2004, p. 167-168.

174 Idem.

175 Ibidem.

176 Embora Huertas tenha usado "sistema nervoso", não obtivemos dados diretos do texto de Cullen para sabermos se ele já usava essa designação, que nos parece ter ganho consistência após Bichat, no início do século XIX.

177 De acordo com Willis, contemporâneo de Sydenham, a histeria não depende do útero e se deve a uma "ataxia dos espíritos animais", ou seja, do funcionamento do sistema nervoso.

178 HUERTAS, R. El Siglo de la Clinica: para una teoria de práctica psiquiátrica. Novalia Electronic Editions, 2004, p. 167.

179 Após as publicações onde registra o termo nevrose, Cullen publica, em 1782, uma classificação de doenças mentais mais simples do que a extensa classificação de Sauvages de 1767. Esta era tida como sendo de pouco cunho prático, por ser similar à classificação de Linneu para plantas e animais, sendo então considerada como de difícil aplicação.

PESSOTI, I. Os Nomes da Loucura. Editora 34, 1999, p.39-42.

$180 \mathrm{O}$ sistema nervoso autônomo diz respeito à parte do sistema nervoso que inerva as vísceras, bem como à musculatura denominada musculatura lisa (que se diferencia da musculatura denominada esquelética).

181 ALEXANDER, F.G.; SELESNIK, S.T. História da Psiquiatria. Ibrasa (1966) 1968, p. 157. 
patológicos. Ao longo desse mesmo século, esse grupo de moléstias (nevroses) caminha mais ao lado dos clínicos e dos médicos que aos poucos constituem a área de moléstias nervosas, enquanto os psiquiatras estudam mais o que eles chamam de "psicoses" (termo esse que, como já dissemos, foi criado na Alemanha em 1845) ${ }^{182}$.

Na França, conforme Huertas ${ }^{183}$, os primeiros alienistas, a partir de Pinel, rejeitam as classificações extensas (Huertas acentua que o termo "alienista" se estabeleceu a partir de Pinel, que adotou o termo "alienado", em vez de "louco" ou “insensato”).

Huertas refere que essa nomenclatura de Pinel está ligada a um processo de difusão da "ideologia”184 (conforme estabelecida por Destutt de Tracy em 1796), sendo que Cabanis (1757-1808) foi o encarregado de levar esse processo de divulgação da “ideologia” à medicina. Assim, Cabanis (em 1803) critica tanto Sauvages quanto Cullen, dizendo que suas classificações não têm cunho prático. Pinel também critica esses autores, e faz uma classificação simplificada (1809) de moléstias mentais, com os itens: mania (com ou sem delírio); melancolia; demência; idiotia ${ }^{185}$.

Huertas refere que, nessa circunstância, há uma “idéia unitária de alienação” como sendo uma patologia única, podendo ter certas variações. Huertas relata que o médico italiano Chiarugi, em 1793, também tem um conceito unitário da loucura, tendo sido, no entanto, criticado por Pinel, que, então, considera Chiarugi dogmático em seus conceitos e com pouco embasamento prático ${ }^{186}$.

Esquirol, entre 1816 e 1818, acrescenta os nomes "lipemania” (outro nome para melancolia) e “monomania” à classificação de Pinel ${ }^{187}$.

Conforme Huertas, em 1838 Esquirol consagra o uso do termo "moléstias mentais” (em vez de alienação) no nome de sua obra Des maladies mentales considerées sous les rapports médical, hygiénique, et médico-légal, aproximando as conceituações

182 HUERTAS, R. El Siglo de la Clinica: para una teoria de práctica psiquiátrica. Novalia Electronic Editions, 2004, p. 167.

183 HUERTA, R. El siglo de la Clinica: para uma teoria de práctica psiquiátrica. Novalia Electronic Editions, 2004, 30-33.

184 Conforme Huertas, citando Rosen e Staum, Destutt de Tracy (1754-1836) criou o termo "ideólogo", definindo a ideologia como a análise das idéias, como uma filosofia básica que se constitui como fundamento de qualquer conhecimento. Essa ideologia abrange: a ideologia propriamente dita, que analisa a origem das idéias; sua expressão através dos estudos gramaticais; e a lógica ou combinação dessas ditas idéias.

HUERTAS, R. El siglo de La Clinica, 2004, p. 30-31.

185 Idem.

Também em PESSOTI, I. Os Nomes da Loucura. Editora 34, 1999, p. 241-242.

186 HURTAS, R. El siglo de La Clinica, 2004, p. 34-35.

187 PESSOTI, I. Os Nomes da Loucura, 1999, p. 242.

81 
psiquiátricas das conceituações clínicas, pois em “moléstias mentais” ele passa a considerar também sintomas orgânicos, além dos sintomas psíquicos.

Huertas acha que psiquiatria e clínica caminham próximas no século XIX. Ele discorda do estudioso Lanteri-Laura, para quem a psiquiatria fica à margem da renovação das disciplinas médicas empreendida pela Escola de Paris, com Corvisart (1755-1821) e Laennec (1781-1826) entre outros (que fundam uma nova semiologia baseada no método anatomoclínico). Huertas acha que Pinel e Esquirol trabalharam com o raciocínio anatomoclínico ${ }^{188}$ e que esse raciocínio teve um papel importante na definição de certas sintomatologias psiquiátricas, como, por exemplo, a alucinação. No entanto, Huertas acentua que Pinel e Esquirol ainda mantêm uma forma de classificar as moléstias dentro de um formato algo similar á classificação de Linneu para plantas e animais, embora mais simplificada ${ }^{189}$.

Huertas cita alguns autores que encontram em Jean Pierre Falret (1794-1870), com sua obra de 1864, um elemento delimitante de um novo paradigma psiquiátrico, quando esse estudioso discorda de uma visão da loucura como enfermidade única e passa a uma visão pluralista das moléstias mentais. Nesse sentido, ele discorda do conceito de monomania, proposto por Esquirol, e abre a possibilidade de admitirem-se vários tipos de mania. Falret, em 1854, também caracteriza o que chama de "loucura circular”, ou seja, com alternâncias entre sintomatologia maníaca e lipomaníaca.

Em todo esse processo, Huertas acha que Falret está principalmente se colocando contra Guislain (1797-1860) e contra os autores alemães partidários da "Einheitpsychose” (psicose única). Assim, Falret elabora uma concepção pluralista das moléstias mentais e aproxima-se (mais do que Pinel e Esquirol) do raciocínio e da prática clínica $^{190}$.

Diversas classificações de moléstias psiquiátricas, e modificações das mesmas, ocorrem no transcorrer da segunda metade do século XIX, principalmente nas escolas francesa e alemã.

A partir do final do século XIX, aos poucos, a classificação do alemão Kraepelin se impõe por um longo período, não sem polêmicas. Os dados a seguir são obtidos de artigo da historiadora Hannah S. Decker sobre Kraepelin.

188 HUERTAS, R. - El siglo de la Clinica, 2004, p. 58-59.

189 Idem, p. 60-61.

190 Idem, p. 83-86.

82 
Emil Kraepelin (1856-1926) ${ }^{191}$ foi atraído, desde o colégio, por “questões psicológicas”. No curso médico tem contato com a psicologia experimental de Wilhelm Wundt (1832-1920), que o influencia bastante. Aos 27 anos (1883) aceita a oferta de um editor para escrever um manual de psiquiatria. Esse livro acaba se tornando seu tratado que é reeditado nos 26 anos seguintes até a oitava edição.

Quando da publicação da segunda (1887) e da terceira (1889) edições, ele relata ver-se forçado a considerar o transcurso das moléstias para classificá-las. Em sua quarta edição (1893), introduz o termo “demência precoce” como uma entidade diagnóstica. Na quinta edição (1896) considera estar dando um passo decisivo da passagem de uma classificação isoladamente sintomática, para uma classificação que ele chama de “clínica”, por incluir condições de origem, de transcurso e de término das moléstias.

Na sexta edição (1899) ele deixa clara a dicotomia entre as psicoses endógenas, separando a demência precoce de uma nova entidade que chama de psicose maníacodepressiva. Considera a causa da demência precoce como sendo uma autointoxicação, dirigida aos neurônios corticais, proveniente de um distúrbio do metabolismo. Já a psicose maníaco-depressiva ele atribui à degeneração. Seu livro evolui para edições com vários volumes, com a sétima edição em 1903 e 1904 e a oitava entre 1910 e 1915.

Nessas edições há um incremento em estudos a respeito da volição, ou vontade, algo que sempre perpassa sua obra. Alguns interpretam o aumento desse interesse devido à sua decepção com aspectos sociais e políticos da Alemanha nesse período, sendo ele um monarquista. Assim, ele atribui à “fraqueza de vontade” um papel importante no desencadeamento das moléstias psiquiátricas.

Kraepelin é figura polêmica, por alguns tido como de atitude distante de seus pacientes, em parte por ser de uma geração de psiquiatras que procuram dados objetivos, contrária à geração romântica anterior. Nascidos no mesmo ano, Kraepelin e Freud criticam-se mutuamente. Paradoxalmente, Kraepelin, tardiamente, acaba fazendo algumas afirmações semelhantes a conceitos psicoanalíticos.

Um contemporâneo de Kraepelin e Freud é Pierre Janet (1859-1947). Sua visão da histeria é intermediária entre a visão de Charcot, a visão de Bernheim, a de Babinski e a de Freud; no entanto ele faz restrições a cada uma delas. Acha que a histeria é muito ligada à emoção. Devemos lembrar que, por sua longevidade, Janet precede e sucede no

191 DECKER, H. S. The Psychiatric Works of Emil Kraepelin: a Many-Faceted Story of Modern Medicine. Journal of the History of the Neurosciences, 13 (n.3): 248-276, 2004. 
tempo a alguns desses estudiosos, tendo formulado algumas propostas similares às de Freud, um pouco antes deste.

Em sua obra de 1924, As nevroses ${ }^{192}$, após fazer um retrospecto sobre a nevrose, lembrando que esse termo foi cunhado por Cullen - e serviu para guardar as moléstias inexplicáveis, em variadas classificações -, Janet expõe que considera as nevroses como “alterações do desenvolvimento das funções”, levando em conta uma associação entre funções psicológicas e somáticas. Ele acha impossível uma concepção anátomo-fisiológica da histeria e tem um tom crítico sobre estudiosos, sendo alguns deles, neurologistas, que facilmente supõem determinados centros cerebrais relativos à histeria ou a certas funções psicológicas, sem que esses centros tenham sido devidamente determinados.

Quanto à classificação de moléstias mentais em São Paulo, no período abordado por nosso trabalho, a obra de Franco da Rocha, Esboço de Psychiatria Forense ${ }^{193}$, que já foi parcialmente abordada, pode ser ilustrativa.

Nessa obra de 1904, Franco da Rocha escreve um longo capítulo sobre essa classificação, expondo também detalhadamente suas próprias conceituações sobre moléstias mentais, deixando claros seus pontos de vista que, nesse momento, divergem, em parte, de seu mestre, Teixeira Brandão, bem como de outros estudiosos internacionais. Ele mantém uma posição crítica sobre classificações em psiquiatria, relativizando seus limites:

“Estabelecer uma classificação em psychiatria é traçar um methodo de estudo, sempre artificial emquanto este ramo da medicina não estiver assente em base solida e uniforme.

A noção physiologica da evolução cerebral, de que se serviram Magnan, Schüle e outros, é muito boa sob o ponto de vista geral, e permitte a divisão das moléstias mentaes em duas grandes classes, bem distinctas nos extremos. Mas nenhum criterio ha para marcar o fim da primeira classe e o começo da segunda”,194.

As duas classes a que ele se refere dizem respeito, respectivamente, a perturbações em cérebros que atingiram o "grau normal de evolução” no ponto extremo da primeira classe, e em cérebros "francamente degenerados" na segunda classe. Sobre essa subdivisão, Franco da Rocha questiona: “qual o critério para se julgar si o doente é

192 JANET, P. As nevroses. Livraria Garnier, Rio de Janeiro, 1924.

193 ROCHA, F. Esboço de Psychiatria Forense. Typographia Laemmert, S. Paulo, 1904.

194 ROCHA, F. Esboço de Psychiatria Forense. Typographia Laemmert, S. Paulo, 1904, p. 207. 
da primeira ou da segunda classe? A separação entre uma e outra é uma violencia que cria embaraços”

Em sua postura questionadora sobre a classificação, Franco da Rocha estabelece, a partir dessa publicação, certo distanciamento da classificação de Teixeira Brandão ${ }^{196}$ :

“A classificação que ora adoptamos é a mesma do professor Teixeira Brandão, com pequenas modificações, que não são essenciaes, mas que melhor se accommodam á noção pratica que nos veiu de quinze annos de observação.

Cada nova classificação que se estabelece é um embaraço opposto aos trabalhos de conjuncto, necessarios de tempos em tempos para se apurar o material colhido neste estudo ainda tão eriçado de dificuldades.

Por isso muito hesitamos antes de modificar a classificação do nosso mestre, classificação que nos serviu até o presente" ${ }^{\text {197. }}$.

Apesar de procurar ser modesto nessa afirmação, e respeitoso em relação a seu mestre, no transcorrer do texto Franco da Rocha deixa caracterizados seus próprios pontos de vista.

Franco da Rocha divide sua classificação em três seções mais amplas: duas classes e um grupo à parte. A primeira classe é dividida em três grupos. A segunda classe diz respeito a loucuras dos cérebros “francamente degenerados”. O grupo à parte é denominado “grupo demencial”, com o subtítulo “lesões cerebrais grosseiras”198. Ele acentua que, na maioria dos casos, há uma mescla de quadros, sendo menos comuns os quadros puros (com sintomatologia de apenas uma subdivisão da classificação).

A primeira classe é dividida em três grupos.

No primeiro grupo da primeira classe, Franco da Rocha situa as perturbações desenvolvidas em cérebros que atingiram ao "grau normal de evolução". Ele considera como caráter fundamental, nesses casos, uma “perturbação afetiva”, com casos curáveis e sem modificação estrutural no cérebro. Divide essas “psychoses” em dois tipos: “mania e lypemania ou melancolia”199.

195 Idem, p. 208.

196 Franco da Rocha utiliza a classificação de Teixeira Brandão desde o início da publicação de seus folhetos sobre dados estatísticos do Hospício de São Paulo e do Juquery a partir de 1895.

197 ROCHA, F. Esboço de Psychiatria Forense. Typographia Laemmert, S. Paulo, 1904, p. 208. 198 Idem, 209-211.

199 ROCHA, F. Esboço de Psychiatria Forense. Typographia Laemmert, S. Paulo, 1904, p. 209-211. 85 
No segundo grupo da primeira classe, ele inclui as perturbações agudas decorrentes de intoxicações de origens diversas, e também as perturbações graves da nutrição. As três condições desse grupo ele denomina de: “confusão mental allucinatoria”, “delírio agudo” e “estupidez vesanica”. Por sua vez, a “confusão mental allucinatoria” se subdivide em “intoxicação” (álcool, morfina, cocaína, éter, etc.) e “toxi-infecções” (puerpério, febre tifóide, influenza, varíola, etc.) ${ }^{200}$.

No terceiro grupo da primeira classe, Franco da Rocha inclui as formas que, conforme diz, estabelecem transição entre a primeira e a segunda classe. Ele considera que há o que chama de "grande predisposição lunatica", mas sem haver ainda o que chama de “degeneração”, esta caracterizada por sinais físicos e psíquicos desde a infância. Aqui ele inclui: "loucuras periódicas”, “catatonia” e "delírio systematico chronico progressivo (typo de Magnan)”. As “loucuras periódicas” são subdivididas em: “intermittente, circular, dupla forma e maníaca-depressiva”201.

Na segunda classe, que corresponde às "loucuras dos cerebros francamente degenerados”, estão incluídos: “paranoia; syndromas episodicos dos degenerados (obsessões e impulsões, idéias fixas); loucura moral; neurasthenia; hysteria; epilepsia; demencia paranoide; hebephrenia; imbecilidade; idiotia”202.

O grupo à parte, denominado "grupo demencial”, subtitulado como de "lesões cerebraes grosseiras”, ele diz separar dos outros por ter como característica uma demência mais ou menos acentuada, conseqüente a "lesões grosseiras do orgam psychico, diffusas ou em foco”. Franco da Rocha acentua que tais formas podem ser vistas em indivíduos “livres de taras hereditarias”. Aí ele inclui as intoxicações e infecções chronicas. São referidos: "Peri-encephalite chronica diffusa; alcoolismo chronico; syphilis cerebral; lesões em foco (traumatismos; tumores; hemorrhagias, pachymeningite, etc.); demencia senil e demencia secundaria”203.

Em seu livro, Franco da Rocha estende-se por duzentas e sessenta e cinco páginas, para detalhar explanações a respeito da classificação e de seus diversos itens. Sendo assim, evidentemente só podemos apontar alguns aspectos de todo esse texto.

Em diversos momentos, diferentemente de seus contemporâneos, Franco da Rocha admite a possibilidade de convivência de conceitos aparentemente antagônicos,

200 Idem.

201 Ibidem.

202 Ibidem.

203 ROCHA, F. Esboço de Psychiatria Forense. Typographia Laemmert, S. Paulo, 1904, p. 209-211. 86 
em geral provenientes de divergências entre a escola francesa e a alemã. Essas abordagens são aqui relatadas, na medida em que caminha a apresentação de seus conceitos.

A mania e a melancolia (lipomania) ele chama de "psycho-nevroses”, que são opostas em suas manifestações: uma apresenta "aceleração da associação de idéias” e “agitação motora” e a outra, “depressão dos sentimentos" e "entrave na associação de idéias”. Quando essas condições se apresentam isoladas, Franco da Rocha diz que ocorre cura na maioria dos casos. Quando são manifestações associadas a outras moléstias, a melhora da mania ou da melancolia passa a depender da melhora dos outros quadros. Também são apresentados diagnósticos diferenciais com outras condições.

Entre os quadros associados à melancolia, Franco da Rocha acentua as “nevroses”, podendo haver alterações sensitivas similares aos quadros que integram as nevroses (das quais ele cita a histeria, a epilepsia e a neurastenia). Ainda quanto à melancolia em condições não muito graves, Franco da Rocha refere que não chegam muito ao psiquiatra, pois são diagnosticados como "neurasthenia” por clínicos: um diagnóstico que, segundo ele, agrada os familiares do doente ${ }^{204}$.

Ao elaborar o segundo grupo da primeira classe, embasado em “intoxicações e infecções”, Franco da Rocha passa a dar ênfase a causas de alterações mentais provindas de fora do sistema nervoso, embora ainda faça menção a algum grau de predisposição desse sistema, que facilita o aparecimento da sintomatologia. Em relação às manifestações psiquiátricas, ele considera as intoxicações e infecções agudas como sendo menos graves do que as crônicas.

Sobre as intoxicações, Franco da Rocha escreve mais a respeito das conseqüências do uso agudo de bebidas alcoólicas em suas variadas manifestações. Entre esses quadros, usa o termo “epileptóide” para referir-se a indivíduos que, mediante pequena ingestão de bebida, apresentam exacerbadas alterações mentais e de comportamento. Outra intoxicação que ele relata, deve-se ao "abuso de morphina”, dizendo ser um problema bem conhecido em São Paulo, embora menos comum do que em outros países. Os casos por ele vistos se deveram ao uso da morfina como calmante, referindo-se a médicos imprudentes que entregam a seringa e o medicamento na mão de 
pacientes. Segundo Franco da Rocha, embora de diagnóstico difícil, esses casos podem ser esclarecidos mediante exame minucioso da pele, que, conforme diz, fica “completamente tatuada” pelas picadas ${ }^{205}$.

A respeito das infecções agudas, Franco da Rocha enfatiza mais os casos ligados à febre tifóide, podendo variar desde um "abatimento do nivel intellectual”, até uma "confusão mental allucinatoria”206.

Ele apresenta uma série de sinonímias para esta última condição. Também diz que esse quadro pode se apresentar em outras situações psiquiátricas, entre as quais inclui o que chama de "grandes nevroses", ou seja, histeria e epilepsia. Além do "estado cahotico das idéias”, o autor nota algumas alterações físicas, entre elas o "exaggero de reflexos”. Quanto à possibilidade de registro das falas dos doentes ele refere que: “É difficilimo conservar de memória os monólogos que se ouvem desse teor; para reproduzil-os seria preciso apanhal-os em phonographo... Os disparates são de tal ordem, que nenhum ponto de apoio encontra a memoria que os quizer conservar e reproduzir”.

Outra manifestação aguda, situada neste segundo grupo da primeira classe, é denominada por Franco da Rocha como “delírio agudo”, chamada por alguns autores de “expressão super-aguda da mania”, e que ele informa estarem os estudiosos de acordo que se trata de manifestação proveniente de “infecção gastro-intestinal”. Acrescenta que um dos primeiros trabalhos a esse respeito foi apresentado pelo médico Bettencourt Rodrigues no Congresso dos Alienistas de Paris em 1889. Ele também cita estudos de outros autores a esse respeito, e entre eles menciona Kraepelin.

Além dessa menção a Kraepelin, Franco da Rocha faz outras menções a esse estudioso, de modo que sua influência se faz sentir em seu trabalho, entre outros autores.

Ainda nesse segundo grupo da primeira classe (que, segundo Franco da Rocha, outros chamam de "psychoses asthenicas”), também se inclui a "estupidez vesanica”, que, conforme diz, provém de estados de esgotamento, ocorrendo o que ele chama de “paralysia ou estagnação do labor cerebral que forma o pensamento”, gerando uma situação que ele chama de "vácuo mental”, com diminuição dos reflexos "conjunctival, palpebral e plantar”. Franco da Rocha faz menção aqui à tensão arterial (aparentemente

205 ROCHA, F. Esboço de Psychiatria Forense. Typographia Laemmert, S. Paulo, 1904, p. 231-239. 206 Idem, p. 239-248. 
sua primeira menção a esse respeito) que diminui, o coração fica lento e a respiração fica lenta e superficial, as pupilas se dilatam, mas reagem normalmente. Ele considera necessário um diagnóstico diferencial com certos casos de melancolia, pois mais frequentemente encontra casos “de transição” entre esses dois diagnósticos ${ }^{207}$.

No terceiro grupo da primeira classe, o primeiro item diz respeito ao que Franco da Rocha chama de "loucuras periodicas", com duas formas gerais: "loucura intermittente" e "loucura de dupla forma". A intermitente pode ser de caráter melancólico ou de caráter maníaco. Já a de dupla forma apresenta uma alternância entre melancolia e mania ${ }^{208}$.

Nesse subgrupo, Franco da Rocha expõe diferenças entre as escolas francesa e alemã, e expõe suas próprias opiniões a respeito. Assim, informa que os estudiosos alemães consideram a mania (já citada) como sendo uma forma de loucura intermitente.

Ele diz que isso não está de acordo com o observado na prática, pois ele tem registrado pacientes seus curados de mania, há 13, 14 e 15 anos, que trabalham regularmente sem que tenham apresentado novo episódio. Assim, no diagnóstico de mania, ele diz preferir acompanhar os estudiosos franceses que consideram esse quadro como independente e curável. Ele deixa expresso que discorda de Kraepelin e outros nessa discussão.

Franco da Rocha prolonga o debate sobre as duas escolas e refere que o quadro designado como "loucura maniaca depressiva” para os alemães, corresponde, para os franceses, aos “delírios polymorphicos dos degenerados”, conforme Magnan. Nesse debate, ele acha que as observações clínicas e conceitos das duas escolas têm valor.

Diz que o nome "loucura maniaca depressiva” só foi aceito por ser escoltado pela autoridade de Kraepelin. No entanto, considera esse um “nome feliz” por delimitar melhor o quadro; já o “delirio polymorphico” dos franceses, segundo ele, é mais abrangente e inclui outras alterações.

Sobre a repetição desses episódios no mesmo paciente, Franco da Rocha refere que há situações no Hospício, em que se avisa a família do doente de que podem buscálo por estar melhor, mas eles só aparecem após um mês, e acabam encontrando o doente em início de nova fase da loucura.

207 ROCHA, F. Esboço de Psychiatria Forense. Typographia Laemmert, S. Paulo, 1904, p. 248-250. 208 Idem, p. 250-26 
No terceiro grupo também está presente um subgrupo intitulado “catatonia”, moléstia essa conceituada pelo alemão Kahlbaum. Aqui, novamente Franco da Rocha expõe divergências entre alemães e franceses. Outra vez se remete a Kraepelin, dizendo ser ele um alienista de “boa reputação actual”, e que dá força a esse diagnóstico. Refere que estudiosos franceses discordam e incluem esses casos entre os "delirios polymorphicos dos degenerados”.

Nesse debate, Franco da Rocha acha que ambos os lados têm razão e não vê mal em usar o nome catatonia para certas situações em que se aplica esse diagnóstico. Assim, ele descreve as diversas fases da catatonia. Diz que a rápida evolução desses casos para a demência pode implicar no que é chamado por Kraepelin de “demencia precoce”. No entanto, ele diz não saber se esse termo "precoce”, usado por esse autor, se refere à rapidez da entrada na demência, ou à idade do paciente. Ele diz que a demência precoce também se confunde com outros casos presentes na idade jovem.

Fechando esse item, ele refere ser mais fácil usar uma única palavra como “catatonia”, em vez da longa frase: “depressão melancholica dos degenerados, com phases de estupor e phases de excitação, acompanhadas de rigidez alternada com plasticidade muscular, com tendencia rapida a demencia”.

Ele acrescenta que o mal das nomenclaturas se deve ao fato delas serem aplicadas em diferentes países, a fenômenos diferentes. Assim, ele defende o uso do termo "catatonia”.

Ainda no terceiro grupo da primeira classe, Franco da Rocha inclui o polêmico quadro do “Delirio Systematizado Chronico Progressivo de Magnan”:

“Esta forma de loucura foi extrahida por Magnan da massa ainda confusa dos delírios de perseguição que Lasègue, também por sua vez, tinha separado das lypemanias, dando delles uma completa descripção, em que se acha esboçada a distincção mais tarde bem estabelecida por Magnan, isto é: - delírios progressivos, de evolução lenta, e - delirios subitaneos, que se apresentam bruscamente, sem o período de lento preparo dos primeiros”.

Franco da Rocha prossegue, discorrendo a respeito da divergência entre diferentes escolas.

Ele explica que os delírios lentos progressivos foram estudados por Magnan, de modo que elaborou o conceito de "delirio systematizado chronico", que a psiquiatria francesa aceitou como um tipo mórbido definido. Os delírios de instalação brusca foram 
chamados por Magnan de "delirios systematizados dos degenerados" e que, conforme Franco da Rocha, são encontrados no título "Paranoia”.

Ele acentua que, para os “tratadistas não franceses”, o delírio sistematizado crônico, ou "psychose systematizada progressiva”, é considerado apenas como uma variedade da paranóia. Franco da Rocha informa que os alemães, italianos e norteamericanos preferem essa conceituação. Ele acrescenta que, entre os ingleses, alguns usam o termo "paranoia", outros ainda conservam a "monomania” de Esquirol (abandonada, conforme Franco da Rocha) e é raro encontrar-se o conceito de Magnan.

Após chamar essas questões de "babel em psychiatria”, ele apresenta as quatro fases, ou períodos desse quadro: $1^{\circ}$ - de hesitação ou inquietação; $2^{\circ}$ - de perseguição; $3^{\circ}$ de grandeza; $4^{\circ}$ - de demência.

Embora aceitando esse quadro, a certa altura de sua explanação Franco da Rocha diz discordar de Magnan, quando este diz que essa moléstia acomete indivíduos predispostos, mas não degenerados. Assim, o psiquiatra paulista diz que:

“Não o seguimos em sua opinião, porque, em primeiro lugar, seria preciso determinar o que se deva entender por degeneração. A linha que separa os predispostos dos degenerados é vaga e arbitrária. O que para uns é degeneração, para outros pode não o ser. Basta isso para despertar logo a duvida”209.

Continuando a expressar seus questionamentos a respeito das formas de classificação, Franco da Rocha diz que:

“A clinica não se amolda a descripções eschematicas, a clichês. Os casos de transição entre uma e outra approximada forma de loucura, a differenciação de typos do mesmo grupo, devida á multiplicidade de factores, são um verdadeiro escolho para as classificações. Só ha um meio para separar os grupos de molestias: - appellar para as grandes linhas geraes”210.

A seguir, Franco da Rocha faz uma proposta inovadora e conciliadora das conceituações divergentes:

“Qual o inconveniente em incluir-se essa forma de delirio systematizado no título Paranoia, desde que se lhe dê a indicação do typo, denominando-a, por exemplo, Paranoia progressiva ou tardia, ou Paranoia completa, como já lhe chama Möebius? O próprio Krafft-Ebing, partidario da origem sempre degenerativa da paranoia, não a denomina Paranoia adquirida (erworbene)? ${ }^{211 \text {, }}$

209 ROCHA, F. Esboço de Psychiatria Forense. Typographia Laemmert, S. Paulo, 1904, p. 279. 210 ROCHA, F. Esboço de Psychiatria Forense. Typographia Laemmert, S. Paulo, 1904, p. 281. 211 Idem. 
Assim, ele completa que a discrepância dos autores, quanto ao quadro estar ou não associado à degeneração, confirma a existência do delírio systematizado progressivo ao lado da paranóia. Por outro lado, ele diz que os mesmos estudiosos que não aceitam as doutrinas de Magnan, descrevem a forma por ele apontada, embora envolta em outros tipos clínicos. Franco da Rocha supõe que, nas próprias estatísticas do Hospício, podem haver casos de delírio sistematizado progressivo que figurem dentro do item paranóia.

O primeiro item da segunda classe (que não é dividida em grupos), Franco da Rocha denomina “paranoia” 212 . Ele diz que a confusão é tal nesse capítulo da psiquiatria, que cada estudioso que usa esse termo está obrigado a explicar qual conceito tem do mesmo. Segundo ele: “não há forma de alteração mental mais própria para pôr em relevo a difficuldade de traçar a linha divisoria entre a sanidade e a insanidade do espirito"213.

Relata entender por paranóia: "todos os casos de anomalia mental que se destacam pela systematização de concepções delirantes ou delusorias (baseados ou não em alucinações), e com a conservação de memoria, da psycho-motilidade e da forma logica apparente do raciocinio"214.

Ele diz também que a paranóia é uma anomalia congênita dos sentimentos, repercutindo sobre a inteligência, ou seja, uma alteração no desenvolvimento cerebral, que ele considera como “uma forma superior de degeneração”, e que se manifesta desde a infância por algum “desvio" sempre perceptível. Ele explica que, da doutrina evolucionista foi tirada a noção de parada no desenvolvimento do indivíduo, com manifestação no caráter, de modo que há uma espécie de volta ao instinto de conservação na fase defensiva, que repercute sobre a inteligência. Ele reforça essa conceituação a partir de Nina Rodrigues que, segundo diz, abraça as idéias de Del Greco.

Conforme Franco da Rocha, a maioria dos paranóicos está fora dos hospícios e ocupam posição na sociedade. Já os que estão internados têm seus quadros confundidos com outros que também apresentam delírio.

212 Idem, p. 282-323.

213 Idem, p. 283.

214 Idem. 
Franco da Rocha critica o uso, pelo português Julio de Mattos, do termo alemão "verrückheit” para designar paranóia, dizendo tratar-se de um desnecessário germanismo. Considera "verdadeiro desastre” a noção de "paranoia aguda” introduzida por Westphal, porque, a partir daí, multiplicam-se as paranóias para os mais diversos estados mórbidos; acrescenta, em tom crítico que, para Ziehen, poucas são as alterações que não sejam paranóia.

Franco da Rocha diz que frequentemente há associação da paranóia com alguma deformidade de qualquer orgão importante, como o sexual, por exemplo, funcionando como "o eixo do delirio paranoico"215.

Após discorrer sobre variantes da paranóia e relatar exemplos clínicos, Franco da Rocha adverte que esse é o terreno mais perigoso da psiquiatria, pois há necessidade de ponderação e critério, para não dar por louco o gênio que rompe com seu meio intelectual para estabelecer um novo modo de pensar. Ele acentua que tais confusões nunca ocorreram em asilo de alienados dirigido por poderes públicos, mas sempre em casas particulares de saúde, ou em asilos governados por congregações religiosas.

Outro item da segunda classe Franco da Rocha denomina de "syndromas episodicos”. Informa ele que esses quadros, estudados por Magnan e seus discípulos, são constituídos por obsessões chamadas “phobias” e obsessões seguidas de impulsões. Considera as fobias freqüentes na "neurasthenia”, principalmente com um caráter hipocondríaco.

Em sua exposição sobre a obsessão, Franco da Rocha cita Freud (1904) (provavelmente a primeira, ou uma das primeiras citações escritas sobre Freud em São Paulo):

"A doutrina de Freud, que attribue a origem exclusiva da nevrose de angustia á deficiencia de satisfacção sexual, não se sustenta, por ser muito exclusivista. Os factos observados depõem contra essa opinião, embora contenha ella boa parte de verdade. Não se pode negar a grande influencia da vida sexual como momento etiologico na explosão de estados de obsessão. Os casos observados desde a infancia mostram, entretanto, que essa doutrina não se sustenta"216.

215 ROCHA, F. Esboço de Psychiatria Forense. Typographia Laemmert, S. Paulo, 1904, p. 291. 216 ROCHA, F. Esboço de Psychiatria Forense. Typographia Laemmert, S. Paulo, 1904, p. 329. 93 
Também na segunda classe, Franco da Rocha inclui a "neurasthenia", que explica ser um "estado morbido do systema nervoso que se caracteriza por extrema irritabilidade ou hyperestesia, com tendencia a rapida fadiga ou exhaurimento"217. Ele informa que, das variantes desse quadro, os que lhe interessam são "a cerebrasthenia e a psychastenia”, que se revelam precocemente por terrores noturnos, incontinência de urina, emotividade excessiva e outros sintomas. Além disso, cita também a neurastenia adquirida proveniente de traumatismos, sustos, emoções e esgotamentos.

Ele aponta que a sintomatologia da neurastenia, que mais importa na psiquiatria, é a que se manifesta em fobias, obsessões e depressão melancólica ou hipocondríaca. Aqui ele frisa que, exceto esses casos, a neurastenia pertence mais à alçada da “neuropathologia”. No entanto, não dá qualquer explicação para esta afirmação. Diz que esses indivíduos vagueiam por todos os médicos e mudam sempre de opinião sobre suas próprias moléstias. Acentua que, por vezes, é difícil distinguir a neurastenia da histeria.

A “loucura moral” é outro item da segunda classe. Franco da Rocha informa que foi descrita por Prichard, em 1835, como moral insanity. Trata-se de mais um quadro polêmico entre os estudiosos. Diz respeito a uma alteração de sentimentos éticos e afetivos. No entender dele, nunca cursa com inteligência brilhante, mas apenas mediana, em indivíduos sem "solidariedade moral na sociedade”.

Como, segundo ele, esse quadro depende de constituição orgânica defeituosa, pode cursar associado a epilepsia, histeria e imbecilidade. Explica também que o louco moral é acometido de "todas as paixões ruins": vaidade, espírito de vingança, crueldade, mentira, cólera, ódio. Lembrando um artigo de sua autoria, frisa que esses indivíduos são intoleráveis tanto na sociedade, como no hospício, ou na cadeia, o que os torna “desclassificados".

Ainda na segunda classe, Franco da Rocha inclui a “epilepsia”218. Refere que essa moléstia é tão comum e tão estudada em suas manifestações clínicas, que ele só vai aos pontos principais. No entanto, ele se estende por vinte e três páginas nesse tema.

217 Idem, p. 329-330.

218 ROCHA, F. Esboço de Psychiatria Forense. Typographia Laemmert, S. Paulo, 1904, p. 343-367. 
Em nota, ele faz menção a "noções recentes, que estabelecem a unidade anatomica e physiologica do neuronio”, e se reporta a Golgi, Cajal e outros e a uma publicação do americano Langdon, de 1896, que procura explicar “a epilepsia e a maior parte das nevroses convulsivas” por defeitos em partes mais delicadas do neurônio. Franco da Rocha acha que essa concepção pode ser extensiva à histeria, pois, segundo ele, pode ser compatível com os conceitos de Janet e Sollier sobre esses quadros. Ele acha que poderia ser feita uma concepção sintética que reunisse todas essas hipóteses e mais o esquema de Grasset para a "physiopathologia do psychismo", para o entendimento “dessas afecções de caracter misterioso”.

Ele considera então dois aspectos na epilepsia: os ataques epilépticos e a loucura ligada à epilepsia. Entre ambos, como transição, ele situa "os delírios passageiros, equivalentes epilepticos ou epilepsia psychica”, e o “estado crepuscular”.

Diz que o epileptico é um degenerado, mas lembra que "o talento e o genio não têm escapado a tal nevrose”. Cita exemplo de indivíduo que conhece, o qual tem qualidades morais e sociais que são a negação da degenerescência, de modo que ele enquadra um caso desse tipo como “epilepsia essencial”.

Franco da Rocha subdivide os ataques epilépticos em dois tipos: o "grande mal”, com acesso convulsivo, segundo ele, também chamado "gotta coral” ou "mal de gotta”, e o “pequeno mal” com “ausencia” ou “vertigem epileptica”.

Depois, informa detalhes sobre essas crises e suas variantes, comentando também a respeito de eventos delituosos associados a tais crises, particularmente citando que, em certa ocasião, teve a oportunidade de examinar um desses criminosos juntamente com o “illustre medico Dr. Bettencourt Rodrigues”219.

Ainda relata que, qualquer das formas de loucura dos degenerados (paranóia, loucura moral, síndromes episódicos, imbecilidade, idiotia), pode cursar com ataques epilépticos.

Entre os fenômenos precoces da infância na epilepsia, cita o terror noturno e as convulsões da infância. Ele chama de epilepsia tardia a que surge após os cinqüenta anos de idade.

Franco da Rocha assinala que os estudiosos Krafft-Ebing e Schüle consideram casos de crise convulsiva única como não sendo epilepsia, podendo estar ligada a certas

219 Franco da Rocha cita Bettencourt Rodrigues em seu livro, para reforçar e valorizar suas observações, o que pode dar idéia do prestigio desse médico nesse período. Por essas citações Rodrigues estuda sintomatologia mais própria de moléstias nervosas. 
eventualidades clínicas. Sobre esses casos, ele diz concordar com Kraepelin, que acrescenta outras sintomatologias a esses quadros, como, por exemplo, alteração do humor ${ }^{220}$.

O autor ainda relata que as formas de epilepsia encaixadas no quadro de “pequeno mal” são as mais complicadas para o diagnóstico. Assim, Franco da Rocha sugere que o profissional memorize as várias formas desse tipo de crise que ele deixa detalhadas em seu texto.

A epilepsia jacksoniana (descrita por Hughlings Jackson) também é apresentada. Ele considera de menos importância que a epilepsia essencial, por não haver alteração de consciência na crise jacksoniana (valorização essa principalmente sob o ponto de vista do médico legista, conforme ele assinala). Refere como etiologia desses casos: traumatismos, sífilis, tumores. Informa que o próprio Jackson chama esses quadros de epileptiformes.

Franco da Rocha chama a atenção para situações em que criminosos recebem o rótulo de epilépticos, e, desse modo, os advogados requerem um exame psiquiátrico. Nesses casos, ele considera a necessidade de provas “cabaes e positivas”, podendo ter que deixar o acusado em reclusão no hospital para um “estudo serio e conveniente”.

A "hysteria"221 também é um quadro que Franco da Rocha insere na segunda classe de moléstias mentais. Ele se refere a essa moléstia como "uma nevrose funccional”, com sintomatologia em dois aspectos: sintomas somáticos e sintomas contínuos.

Os sintomas somáticos, ele considera como tendo caráter paroxístico, incluindo: alterações de sensibilidade, alterações sensoriais, alterações motoras e secretórias, fenômenos vasomotores diversos. Assinala a conservação da consciência, o que a diferencia da epilepsia.

Os sintomas que ele chama de "continuos", diz serem de especial interesse, por se referirem ao estado mental do histérico, denotando o "caracter ou temperamento hysterico”. Além disso, como fenômeno paroxístico da esfera mental, refere os "estados crepusculares”, em analogia a condições semelhantes da epilepsia.

Ressalva que ambos os tipos de sintomas cursam em conjunto. 
Em relação aos ditames determinantes da caracterização desses quadros, afirma: “A neuropathologia tem na hysteria um dos seus maiores capítulos, em cuja construcção figura o nome de Charcot e a - Eschola de Salpetrière, por elle criada”222.

Franco da Rocha diz que considera a histeria como uma "manifestação degenerativa”. Mas, lembra haver indivíduos que tiveram completa “evolução mental”, porém com crises ou paroxismos convulsivos. Em quase todos os casos, considera a presença de estigmas físicos e psíquicos dos degenerados.

Informa que a histeria é bem mais freqüente nas mulheres do que nos homens, e que essa diferença é mais acentuada no Brasil do que na Europa.

Quanto às alterações somáticas da histeria, diz serem quase sempre dependentes de um fator psíquico e simularem quase todas as enfermidades, mas de forma grosseira e com incongruência sintomática. Assim, ele descreve uma série de alterações visuais, alucinações, eventualmente precedendo ataques convulsivos; também alterações de audição, olfato, paladar são relatadas. Assinala que é raro faltarem alterações da sesibilidade cutânea, sendo um dos sintomas capitais da histeria. Desse modo, a anestesia pode afetar até metade do corpo. Já a hiperestesia ocorre mais em zonas especificas do corpo. Franco da Rocha acentua que as zonas hiperestésicas foram chamadas por Charcot de "zonas hysterogenicas”, sendo que a compressão dessas zonas pode tanto ocasionar como suprimir os ataques. A perturbação dolorosa que mais incomoda é a “zona precordial”, similar a acessos de angina do peito.

Ele chama a atenção para um estigma histérico específico que corresponde às “manchas da melancolia”, que aparecem espontaneamente, mas que podem ser usadas pelos pacientes para se dizerem maltratados.

Os sintomas motores descritos na histeria são muito variados: convulsões clônicas, movimentos coreiformes, tiques, espasmos, contraturas e paralisias. Aqui, ele assinala que pode haver confusão com lesões cerebrais ou medulares. Frisa que isso se esclarece a partir da incoerência dos sintomas. Cita o exemplo da "astasia-abasia”, quando o individuo não consegue ficar de pé e nem andar, mas consegue executar todos os outros movimentos. Em seguida, enumera uma série de alterações motoras de natureza histérica e acentua que, por simularem diversas moléstias, esses quadros são um tesouro para curandeiros, charlatões e para a religião.

222 Idem, p. 368. 
Quanto aos sinais dos ataques histéricos, diz que os grandes ataques, de quatro fases completas, descritos por Charcot, são raríssimos em sua experiência em São Paulo, dizendo que só após quinze anos de trabalho viu um caso desses.

Relata então que, após as iniciais “auras sensitivo-sensoriaes” segue-se a primeira fase, com perda de sentidos e rigidez muscular; na segunda fase surgem convulsões e contorsões (chama essa fase de “clownismo”). Segundo ele, a terceira e a quarta fases se confundem, correspondendo respectivamente a atitudes plásticas e delírio das palavras. As alucinações que acompanham esses delírios, ele diz serem chamadas de "estado crepuscular hysterico”.

Neste ponto, Franco da Rocha faz breve menção ao fato de alguns duvidarem da existência do grande ataque, ou "hystero-epilepsia”, e considerarem como conseqüência da "educação que constantemente lhes era dada pelos medicos que os estudavam”. Ele considera que “incontestavelmente” esse é um modo exagerado de ver as coisas. Assim, ele deixa consignada sua opinião sobre isso, nesse momento ${ }^{223}$.

Explica os pequenos ataques histéricos como tendo apenas parte das fases citadas. Observa que há formas irregulares e de transição entre histeria e epilepsia. O diagnostico diferencial entre as duas nevroses, como diz, pode ser especialmente difícil se a histeria se apresentar apenas na fase epileptóide, correspondente à primeira fase da grande histeria.

Franco da Rocha diz que todas as formas de loucura podem conviver com a histeria. Assim, nota que psicoses e nevroses podem coexistir, sendo que a histeria mais comumente ocorre junto com a paranóia.

Ele informa que não se conhece o vinculo que une os fenômenos psíquicos aos somáticos da histeria. Também diz que os mestres da neuropatologia querem que essa nevrose passe a ser uma psicose (ou seja, mais próxima da psiquiatria do que das moléstias nervosas). Assim, ele diz que Janet considera a histeria uma psicose pertencente ao grupo das moléstias mentais por insuficiência cerebral, com um enfraquecimento para a faculdade de síntese psicológica.

Devido ao vínculo entre hipnotismo, histeria e medicina legal, Franco da Rocha considera oportuna uma melhor abordagem do hipnotismo. Ele sugere ao leitor

223 Nesse livro, em nenhum momento Franco da Rocha cita o nome de Babinski. Como ele é bastante atualizado e informado, esse silêncio (ao menos em 1904) é mais significativo, dando a entender que ele discorda das idéias de Babinski sobre a histeria, ao menos nesse momento. 
consultar o livro do professor da Faculdade de Direito de São Paulo, Dr. Alcântara Machado, “Ensaio medico-legal sobre o hipnotismo”.

Franco da Rocha diz que, sobre hipnotismo, a doutrina de Charcot, da Salpetrière, se opõe à de Bernheim de Nancy. Para o primeiro o hipnotismo é como uma nevrose, próxima da histeria, sendo poucas as pessoas hipnotizáveis, exceto os histéricos. Para o segundo o hipnotismo é semelhante ao sono normal, sendo dependente de sugestão. Dessa sugestão, diz Franco da Rocha, pode decorrer um crime.

Ele informa que a escola de Charcot não admite que possa haver submissão total do hipnotizado, de modo que esse indivíduo rejeita sugestões que se oponham a seus princípios. Bernheim pensa o contrário e acha que é possível o crime a partir da sugestão; ele reforça esse ponto de vista, citando experiências feitas em laboratório de psicologia experimental.

A seguir, Franco da Rocha descreve os três períodos de hipnotismo descritos por Charcot: estado letárgico, estado cataléptico, estado sonambúlico ou sonambulismo. Conforme Franco da Rocha, Liebeault, que é contrário a Charcot, descreve seis estados.

Franco da Rocha prefere seguir a classificação de George Guinon para o sonambulismo, em suas diversas manifestações, sendo que esses estados se ligam à histeria, exceto o primeiro que se liga à epilepsia. Tais estados são: automatismo comicial ambulatório, sonambulismo histérico, vigilambulismo histérico, sonambulismo hipnótico. Em seguida, ele dá exemplos de casos de sonambulismo associados a situações criminais. Aconselha o médico a não hipnotizar uma mulher, se ela não estiver em presença de outra pessoa, pois a doente pode denunciar imaginários atentados ao pudor.

O próximo item, da segunda classe de moléstias mentais, apresentado por Franco da Rocha, corresponde à “demencia paranoide”224. Ele já acentua, logo de início, que esse título foi criado por Kraepelin, e acrescenta que esse estudioso insere esse quadro, juntamente com “catatonia” e "hebephrenia” no grupo denominado "demencia precoce” de sua própria classificação.

Ao explicar essa alteração, Franco da Rocha adverte para a possibilidade de confundir esses casos com paralisia geral, já que em ambos pode haver sintomatologia

224 ROCHA, F. Esboço de Psychiatria Forense. Typographia Laemmert, S. Paulo, 1904, p. 397-402. 99 
de exaltação do estado afetivo, com delírios de grandeza e de perseguição e alucinações. Em seguida, são citados exemplos do hospício, melhorados pela terapia do trabalho.

A "hebephrenia"225 é outro quadro colocado por Franco da Rocha na segunda classe, e que explica como sendo próprio da puberdade, período esse que ele situa aproximadamente entre quatorze e vinte anos de idade. Considera esse quadro ligado a degeneração e às modificações sexuais desse período, manifestando-se por onanismo e alterações de comportamento, que evoluem para demência. Informa que tais casos são raros e cita exemplo do hospício.

Outro item que Franco da Rocha insere na segunda classe é “imbecilidade e idiotia”226. Quanto à idiotia, ele cita oito formas mencionadas por Bourneville, que correspondem a variadas e evidentes lesões cerebrais. Em geral apresentam importante limitação intelectual.

Já o imbecil é considerado um degenerado superior ao idiota, podendo ter algum grau de instrução. Franco da Rocha chama a atenção para esses indivíduos, pois podem se envolver em crimes, inclusive pela facilidade de serem dirigidos por outras pessoas.

Ele faz certa crítica à situação dos imbecis das classes abastadas, pois, embora com boa habilidade manual, essas famílias não aceitam que esses indivíduos trabalhem com essas habilidades, em virtude da classe à qual pertencem; assim, insistem em fazêlos desenvolver atividades que ficam sempre acima da capacidade que têm, e acabam saindo-se mal em tudo que fazem. Informa ele que há imbecis que necessitam de proteção legal, e sob o ponto de vista criminal podem ser semelhantes a meninos de 13 ou 14 anos.

Como dissemos, Franco da Rocha, além de dispor a sua classificação em primeira e segunda classe, elenca também um grupo à parte que intitula "grupo demencial”,227. Esse grupo se caracteriza por "grosseiras lesões materiaes do orgam psychico".

225 Idem, p. 402-409. 226 Idem, p. 409-417. 227 ROCHA, F. Esboço de Psychiatria Forense. Typographia Laemmert, S. Paulo, 1904, p. 417-471. 100 
Em primeiro lugar, ele descreve a "peri-encephalite chronica diffusa”, também chamada "paralysia geral dos alienados”, ou “demencia paralytica”. Caracteriza esse quadro por dois fatores: sintomas de enfraquecimento psíquico geral e progressivo; alterações progressivas motoras que podem chegar até a paralisia geral.

A esses dois elementos, ele informa que se juntam outros como: mania ou estado melancólico, ou alternância entre esses dois, ou um delírio paranóico. Na periencefalite, ele considera dois tipos de manifestação: forma delirante expansiva e forma apática.

A forma delirante expansiva se inicia com uma fase denominada por Franco da Rocha de "período medico-legal”, quando o doente apresenta superexcitação intelectual e se atira a toda espécie de negócios, faz palestras intermináveis, formula grandes projetos e seus atos denotam descuidos, esquecimentos e pouco caso para princípios morais. Informa o autor que, nesse período, o médico é chamado principalmente para resolver "um problema de insomnia".

Conforme Franco da Rocha, prosseguindo a confusão com grandes perdas de dinheiro, com a compra de títulos e coisas similares em centros industriais e comerciais, a família acaba por chamar o médico, considerando a possibilidade de tratar-se de loucura, embora havendo resistência a essa possibilidade.

Soma-se a esse corolário uma excitação sexual e uso de álcool que, muitas vezes, não correspondem ao usual do individuo. O quadro evolui para tremores faciais e alterações da linguagem. O autor cita então exemplos de projetos megalomaníacos, e impossíveis, de doentes do hospício.

Franco da Rocha acentua a importância da alteração dos reflexos pupilares para esse diagnóstico. Informa que depois surgem as alterações somáticas, tróficas e vasomotoras, sendo que a diversidade das sedes das lesões implica em variabilidade na apresentação de reflexos tendinosos. Ele diz que, conforme Bettencourt Rodrigues, o exagero dos reflexos tendinosos, juntamente com a abolição ou diminuição do reflexo plantar, são sinais importantes. Acrescenta que se somam fraqueza muscular, tremores, alterações de coordenação e de sensibilidade, juntamente com importante alteração da memória, do comportamento, com delírio de grandeza. A duração do quadro vai de seis meses (mais raramente) até cinco anos, terminando com a morte, após vários tipos de ataques epileptiformes ou apopletiformes. 
Diz o autor que, enquanto a forma delirante ocorre mais em indivíduos com maior atividade intelectual, a forma apática da periencefalite compromete aqueles com pouca atividade cerebral profissional. A forma apática tem essa manifestação em lugar da hiperexcitação, embora as respostas verbais do indivíduo mantenham certo caráter eufórico.

Ele nota que a paralisia geral é rara em mulheres, bem como em negros. Franco da Rocha insiste em que a luta pela vida seja causa importante da paralisia geral, já que entre negros norte-americanos, que têm posição social mais elevada do que os negros brasileiros, essa moléstia se faz mais presente, já que o trabalho cerebral é mais exigido.

Ele também acha que a sífilis, isoladamente, não basta para causar a moléstia, já que essa doença é relativamente comum entre os negros brasileiros, diferentemente da paralisia geral. Ele também refere ter observado casos na mesma família, o que contraria a “origem exogenica da paralysia progressiva”, e reforça essa posição citando outros autores.

Franco da Rocha dispõe um item dentro da paralisia geral, que intitula “cytodiagnostico na paralysia geral”, onde explica as alterações observadas no exame de líquido cefalorraquiano, também presentes na sífilis cerebral. Ele diz que esse procedimento é feito na França e na Alemanha, o que facilita o diagnostico diferencial com neurastenia ou psicastenia. Diz que, para sentir-se autorizado a afirmar a eficácia desse processo, solicitou ao médico Arthur Mendonça que examinasse o líquido cefalorraquiano de diversos casos de paralisia geral, o que veio a confirmar a mesma alteração observada em outros países. Em seguida, Franco da Rocha descreve o procedimento técnico para a realização de tal exame e ressalva que as alterações observadas, também podem estar presentes nas meningites e poliomielites.

No grupo demencial, Franco da Rocha inclui a "syphilis cerebral”,228 . Ele inicia dizendo que, "no período terciario da infecção syphilítica”, instala-se um estado de demencia progressiva, que pode se acelerar a partir de “ataques apoplecticos”, que vão deixando uma somação de sintomas: hemiplegia, crescente fraqueza muscular, piora gradual da memória, etc. Informa que essa demência não tem um quadro característico a ponto de ser exclusivo da demência sifilítica; como as lesões são variadas, não há também um quadro muito típico de sífilis cerebral. Acrescenta que o diagnóstico da 
moléstia sifilítica no restante do organismo, juntamente com alteração mental, podem conduzir ao diagnóstico. Embora um tratamento rigoroso possa levar à cura, diz que a recuperação plena da alteração psíquica não costuma ocorrer.

Franco da Rocha se refere à “opinião dos neuropathologistas” para distinguir a sífilis arterial, da sífilis das meninges, e apresenta as características que diferenciam essas duas condições.

O autor acentua que é comum haver uma soma das duas formas e que a cura só é possível nas fases iniciais, sendo a própria cura também um elemento diagnóstico. Ele completa esse item com o exemplo de um caso.

O quadro intitulado “demencia alcoolica” é incluído por Franco da Rocha no "grupo demencial” 229 . Ele informa que esses casos evoluem para atrofia cerebral irremediável e morte. Após dar um exemplo, cita um caso notável de resistência ao álcool em uma, segundo ele, célebre negra africana chamada Quezumba, que freqüentou durante vinte anos todas as prisões de São Paulo, tendo entrado em demência só após esse período.

Ainda no "grupo demencial”, Franco da Rocha insere os quadros denominados “afecções organicas senis” ${ }^{230}$. Ele associa esse quadro principalmente à “arterioesclerose” e considera que esta se desenvolve facilmente "nas actuaes condições da vida humana civilizada”. Ele adverte principalmente "os medicos ainda pouco praticos” para terem certo cuidado na avaliação desses casos, pois a eventual interdição legal de supostos dementes pode trazer surpresas. Nesse sentido, relata três casos que inicialmente pensou tratar-se de demência, mas que depois melhoraram, sendo, portanto, transitórios.

Outro quadro também da classificação de Franco da Rocha, no grupo das demências, intitula-se “demencia por lesões em foco"231. Informa que esses casos se devem a arteriosclerose, que também pode ser sifilítica ou alcoólica, com hemorragias, ou ainda dentro do quadro de "cerebro-esclerose lacunar progressiva”. Ele recomenda

229 Idem, p. 439-442.

230 Idem, p. 442-453.

231 ROCHA, F. Esboço de Psychiatria Forense. Typographia Laemmert, S. Paulo, 1904, p. 453-455. 103 
exame minucioso, pois esses casos podem cursar com afasia, o que pode ter valor médico legal.

O último quadro listado por Franco da Rocha no grupo demencial diz respeito à “demencia secundaria” ${ }^{232}$. Neste subgrupo ele insere os quadros de psicoses que evoluem para uma sintomatologia demencial. Acrescenta alguns exemplos.

Franco da Rocha termina seu item sobre demência, enfatizando o valor do trabalho aplicado a esses quadros:

“O habito do trabalho como que reeduca o individuo, dando-lhe uma certa sombra de consciencia do seu valor como creatura humana. $O$ trabalho em conjuncto desperta hábitos de convivencia e certas maneiras de proceder que disfarçam o aspecto selvagem e bruto do demente abandonado nas salas dos hospícios.

Eis ahi uma das grandes vantagens do systema de asylo-colonia, como temos em Juquery, onde procuramos diminuir o caput mortuum que faz tão má impressão nos asilos”233.

A seguir Franco da Rocha apresenta um capítulo intitulado "evolução das molestias mentaes”, onde expõe vários casos de melhora ou de cura observados no hospício, bem como casos de alternância de sintomatologia, e situações clínicas incuráveis.

Ao finalizar seu livro, Franco da Rocha insere a estatística colhida em dez anos no Hospício de São Paulo. Informa também reproduzir, no final, a lei de 1903 sobre assistência aos alienados, fazendo alguns senões:

“Tambem reproduzimos, sem commentar, a lei federal de Dezembro de 1903 sobre a assistencia aos alienados. Poderiamos analysar varios dos pontos (a nosso ver) defeituosos dessa lei; não o fazemos, no entanto, porque, em geral, a lei é boa, e dará bons resultados - si puder ser executada”234.

232 Idem, p. 455-458.

233 Idem, p. 458.

234 ROCHA, F. Esboço de Psychiatria Forense. Typographia Laemmert, S. Paulo, 1904, p. 471. 


\section{3 - Moléstias Nervosas e Neurologia}

Um fator não muito enfocado, nos estudos sobre a ciência do período em questão, é o campo de "moléstias nervosas”, que aos poucos deixa essa designação para chamar-se “neurologia”. Por vezes aparece nomeado como neuropatologia, embora este termo seja mais usado para nomear uma área ampla que engloba psiquiatria e moléstias nervosas.

As “moléstias nervosas”, no período abordado, situam-se além do campo das alterações mentais ou comportamentais isoladamente, e ficam nas entrelinhas entre as observações clínicas, psiquiátricas e psicológicas, em um “corpo neurológico” ainda em formação, no período por nós estudado.

Um dos elementos que marcam uma diferença entre "moléstias nervosas” e “neurologia” corresponde ao já citado grupo de moléstias denominado “nevroses”, que é um grupo estudado como anexo às moléstias nervosas.

Entre as nevroses, a histeria ganha especial destaque, principalmente a partir dos estudos do médico francês Jean Martin Charcot, no século XIX, que leva a conceituação desse quadro para as proximidades das doenças do sistema nervoso.

Até chegar a Charcot, o termo histeria atravessa diversos períodos históricos. A primeira conceituação de histeria remonta à Antigüidade, quando então é considerada a moléstia do "útero errante” (hyster, útero em grego).

Essa moléstia passa a ser redefinida por Sydenham (1624-1689) como um quadro que pode afetar tanto mulheres quanto homens, sendo que, para estes, ele usa o termo "hipocondria”, deixando, assim, de ligar o quadro ao útero ${ }^{235}$. Já Willis a considera como uma “ataxia dos espíritos animais”.

Conforme Huertas, ambos esses estudiosos deram um caráter especificamente “moderno” à histeria, em sua idéia fisiológica e classificatória ${ }^{236}$.

Ainda conforme Huertas, no século XIX, Paul Briquet (1796-1881) publica, em 1859, Tratado Clinico e Terapêutico da Histeria, onde discute o papel das emoções e da

235 Sydenham, tradicionalmente chamado de "Hipócrates inglês", deixa de lado o que chama de hipóteses filosóficas na medicina e reforça o valor da observação clínica e dos métodos empíricos. Em suas observações sobre histeria, considera que ela pode simular quase todas as moléstias, e atribui a histeria a causas emocionais e alterações dos "espíritos animais" (o que corresponde a uma conceituação de certos tipos de “vapores” ligados ao funcionamento da alma, em associação ao organismo).

ALEXANDER, F.G.; SELESNIK, S.T., p. 138-139.

236 HUERTAS, R. El Siglo de la Clinica. 2004, p. 166-194.

105 
frustração sexual nesses quadros. Em 1873, Lasègue publica "Sobre a anorexia histérica”, onde ele se atem aos sintomas digestivos da histeria, e considera haver uma espécie de "perversão intelectual” nesses quadros, com elementos psicológicos que podem dar lugar a somatizações ${ }^{237}$.

Embora tenha feito essas referências a Briquet e Lasègue, Huertas relata que, no século XIX, a histeria está principalmente ligada a um nome e um lugar: Jean-Martin Charcot (1825-1893) e o hospital parisiense de Salpêtrière. Ele informa que, a partir de 1870, Charcot faz uma revisão da histeria, aplicando os princípios da semiologia médica desenvolvida pela escola de Salpêtrière.

Desse modo, de acordo com Huertas, Charcot busca sinais objetivos que diferenciem a histeria das enfermidades orgânicas e das simulações, elaborando quadros clínicos típicos, com períodos e fases regulares. Como falta uma lesão anatômica correlata à histeria, ele recorre à possibilidade de haver uma alteração fugaz, dinâmica e apenas funcional.

Assim, Charcot delineia uma forma de caracterizar o quadro clínico da histeria, com determinadas alterações de sensibilidade, e alterações motoras, bem como situações de associação a epilepsia. Pelo estudo desses casos, usando o hipnotismo, Charcot considera o sintoma histérico como sendo uma auto-sugestão, sobrevinda de um traumatismo psíquico ${ }^{238}$.

Todos esses elementos constituem um verdadeiro paradigma em torno do quadro de histeria, que vai além dos muros da Salpêtrière e penetra na sociedade parisiense, a qual comparece a essa instituição para assistir às conferências do prof. Charcot, realizadas às terças-feiras, como uma forma de espetáculo. Esse paradigma penetra também nos mais diversos ambientes acadêmicos e condiciona a conduta diagnóstica e terapêutica dos quadros de histeria ${ }^{239}$.

A difusão das idéias de Charcot pode ser observada por suas próprias afirmações nas conferências das terças-feiras. Em uma delas ocorrida em 13 de dezembro de 1887, ele se defende de afirmações de um médico de New York, que o acusa de ser a causa de vários cirurgiões fazerem a retirada dos ovários, para curar

237 Idem.

238 Ibidem.

239 No período de efervescência em torno de Charcot, entre outubro de 1885 e fevereiro de 1886, Freud freqüenta Salpêtrière. Conceitos e práticas aprendidas com Charcot relacionadas à histeria influenciam os estudos posteriores de Freud.

FOUCAULT, M. O poder psiquiátrico, p. 436.

106 
histeria. Charcot diz ter se referido a histéricas ovarianas (que cessam o ataque por compressão dos ovários) por ter certeza desse fato, mas acrescenta que nunca se referiu aos ovários como causa da histeria. Ele diz ver senhoras voltarem da Alemanha e da Suíça sem seus ovários e, no entanto, continuarem com histeria ${ }^{240}$.

Em outra conferência, de 7 de fevereiro de 1988, refere-se ao inglês Gouwers (que ele, Charcot, considera como "um médico brilhante”) que não acredita em suas descrições. Diz que Gowers confunde crise epiléptica com crise histérica ${ }^{241}$.

Ainda conforme Huertas, ao fazer seus estudos, Charcot se coloca a serviço dos ideais republicanos, portanto no sentido contrário à Monarquia e à Igreja. Assim, ele caracteriza comportamentos religiosos como sendo comportamentos histéricos e usa de terminologia religiosa para designar determinados fenômenos histéricos (estigma, conversão, etc) ${ }^{242}$.

Com essa diversidade de fatores ligados à sua pessoa, Charcot é foco de atenção e polêmicas, mesmo fora do campo médico, sendo personagem fascinante e enigmática, atraindo até mesmo a atenção da literatura em geral ${ }^{243}$. Sua influência para além do campo médico se faz presente ${ }^{244}$, por exemplo, em escritores como Emile Zola, Guy de Maupassant e outros ${ }^{245}$.

Jean Martin Charcot (1825-1893) nasceu em Paris. Ele era uma criança com atenção para detalhes e com talento artístico para o desenho, de modo que isso influenciou seu método anatomoclínico, sua documentação científica e suas investigações ${ }^{246}$. Em 1853, forma-se na Faculdade de Medicina da Universidade de Paris, com tese inaugural sobre alterações articulares, alterações essas que ele continua

\footnotetext{
${ }^{240}$ CHARCOT, J. M. Grande Histeria. Contra Capa Livraria, 2003, p. 21.

${ }^{241}$ Idem, p. 45.

242 HUERTAS, R. El Siglo de la Clinica. 2004, p. 166-194.

243 GOETZ, C.G. Charcot in contemporary literature. J. Hist. Neurosci, 15 (1): 22-30, 2006.

244 Charcot atraiu a curiosidade científica do Imperador D. Pedro II, de quem se tornou médico e amigo. Charcot assinou o atestado de óbito de D. Pedro II em 1891.

TEIVE, H.A. et al. Charcot and Brazil. Arq. Neuropsiquiatr, 59 (2-A): 295-9, 2001.

245 KOEHLER, P. About medicine and the arts. Charcot and French literature at the fin-de-siècle. $J$. Hist. Neurosci. 10 (1): 27-40, 2001.

${ }^{246}$ Charcot designava-se a si próprio como um "visual”. Essa capacidade de olhar impressionou Freud que se referiu a isso, dizendo que sob esse olhar surgiam novos quadros clínicos. Charcot publicou, com seu discípulo Paul Richer, “Os demoníacos na arte” e “Os disformes e os doentes na arte”, onde trabalham com aspectos visuais nas doenças.

QUINET, A. Apresentação. In: CHARCOT, J. M., Grande Histeria. Contra Capa Livraria, 2003, p. 9-10. 107
} 
estudando posteriormente (o que o coloca também como um dos iniciadores da reumatologia) ${ }^{247}$.

Charcot aprofunda seu conhecimento em anatomia patológica e estuda as correlações anatomoclínicas. É nomeado professor de anatomia patológica em 1860 e, em 1862, torna-se diretor da Salpêtrière. Estudando e agrupando os pacientes por diferentes sintomatologias, ele delimita e caracteriza a esclerose múltipla de modo diferenciado da moléstia de Parkinson, nome este que ele cunha em homenagem a esse estudioso, que descreveu essa doença ${ }^{248}$.

Seu interesse pela patologia foi influenciado por seu mestre Pierre Rayer, médico pessoal do Imperador Napoleão III. Seu segundo mentor foi Duchenne de Boulogne (1806-1870), que desperta em Charcot o desejo de aprofundar seu conhecimento sobre sistema nervoso, especialmente no setor neuromuscular, o que propicia a descrição de outras alterações e moléstias (que posteriormente passam a ser designadas pelo seu nome isoladamente, ou associado a outro estudioso). Duchenne também influencia Charcot no uso da fotografia em seus estudos, pois o próprio Duchenne tem grande coleção de fotos de seus experimentos e observações clínicas. Em 1875, tendo se aprofundado a respeito do sistema nervoso, Charcot declara não considerar o cérebro como homogêneo, mas sim formado por várias regiões associadas especializadas em diferentes funções ${ }^{249}$.

Como já foi dito, Charcot é habitualmente considerado o primeiro catedrático em doenças do sistema nervoso ${ }^{250}$. Em 2 de janeiro de 1882, um decreto assinado pelo

GOETZ, C.G. Visual art in the neurologic career of Jean-Martin Charcot. Arch. Neurol., 48 (4): 421$5,1991$.

247TEIVE, H.A.G.; MUNHOZ, R.P.; BARBOSA, E.R. Little-known scientific contributions of J-M Charcot. Clinics, 62 (3), São Paulo, 2007.

LAGLER, R. The enduring mark left by Jean-Martin Charcot on rheumatology. Rev. Rhum. Engl. Ed. 64: 809-15, 1997.

TAN, S.Y.; SHIGAKI, D. Jean-Martin Charcot (1825-1893): pathologist who shaped modern neurology. Singapore Med, 48 (5): 383-384, 2007.

${ }^{248}$ Idem.

249 TAN, S.Y.; SHIGAKI, D. Jean-Martin Charcot (1825-1893): pathologist who shaped modern neurology. Singapore Med, 48 (5): 383-384, 2007.

${ }^{250}$ De modo similar ao "mito de fundação" da psiquiatria por Pinel, celebrado em pinturas, também há um quadro pintado por Pierre-André Brouillet em 1887, o qual retrata uma aula de Charcot cercado por seus grandes discípulos, na qual sua famosa paciente histérica, Blanche Wittman, apresenta uma crise, ou está hipnotizada. Esse é um momento em que, enquanto a ciência pasteuriana explica as doenças através dos microorganismos, concomitantemente Charcot explica e demonstra seu domínio sobre as doenças do sistema nervoso e em particular sobre a histeria, por meio do uso da hipnose. Babinski é o discípulo em destaque, atrás da paciente. Alguns psiquiatras estudiosos de história da psiquiatria, dos anos 1960, apontam um dos indivíduos retratados no quadro como sendo Freud (no livro de Alexander e Selesnik). 108 
presidente da República Francesa cria a Cadeira de Neurologia na Faculdade de Medicina de Paris, com o nome de "Clínica de Doenças do Sistema Nervoso". Dois anos antes disso, em 1880, Charcot funda o periódico Archives de Neurologie, colocando definitivamente a palavra neurologie, em francês, como própria do campo de estudos das moléstias nervosas.

Alguns estudiosos acham que há evidências documentais de que Charcot, intencionalmente, considerava a Cadeira de Doenças do Sistema Nervoso como uma prioridade em sua carreira.

Conforme esses estudos, em torno de 1880, convencido da importância de seu projeto, Charcot acumula argumentos a seu favor, incluindo dados de fontes francesas e alemãs, especialmente de seus colegas Westphal e Erb. Charcot sabe que não há precedentes similares ao seu projeto, nem mesmo em Berlim. Assim, ele prepara cuidadosamente uma apresentação manuscrita, apontando a necessidade da nova cadeira, baseada nos então recentes progressos teóricos e práticos. Ele descreve a psiquiatria como já tendo uma Cadeira na Faculdade, mas correspondendo, segundo ele, a uma pequena parte da "neuropatologia”, rejeitando a idéia de combinar as duas disciplinas. Embora o projeto tenha encontrado a oposição de vários colegas da Faculdade, ele tem suporte político a seu favor. O ato de criação da cadeira pelo governo surpreende a própria faculdade ${ }^{251}$.

Entre os discípulos de Charcot, um deles, Charles Bouchard, acaba se tornando seu opositor, mesmo após ter sido ajudado por seu mestre a se tornar professor de patologia geral. A hostilidade de Bouchard torna-se visível, quando ele nega a Babinski a nomeação de professor, apenas por este ser discípulo de Charcot ${ }^{252}$.

Babinski, por sua vez, é o discípulo de Charcot que modifica a conceituação de histeria estabelecida por Charcot.

Ainda antes de Babinski, quem primeiro questiona a visão de Charcot sobre histeria é Bernheim. Hippolyte Bernheim (1840-1919), professor da faculdade e presidente da Société Médicale de Nancy, faz criticas em suas publicações, às

No entanto, conforme nosso levantamento, o suposto Freud é, na verdade, Gilles de La Tourette (no site da Université Pierre et Marie Curie), um conhecido discípulo de Charcot.

251 SIGNORET, J.L. Creation of Charcot's chair. Rev. Neurol. (Paris), 138 (12): 887-92, 1982.

GELFAND, T. How Charcot got his chair. Hist. Sci. Méd. 28 (4): 307-12, 1994.

252 TAN, S.Y.; SHIGAKI, D. Jean-Martin Charcot (1825-1893): pathologist who shaped modern neurology. Singapore Med, 48 (5): 383-384, 2007. 
experiências de Charcot, desde os anos 1880. Bernheim considera todo o quadro descrito em Salpêtriére como induzido pelos médicos. Acha que o hipnotismo é apenas a ativação de uma propriedade normal do cérebro, por ele nomeada como sugestionabilidade, que é a aptidão para ser influenciado por uma idéia aceita e, assim, procurar atingir sua realização ${ }^{253}$.

Embora Bernheim tenha assinalado esse posicionamento, Babinski ${ }^{254}$ torna-se figura marcante na mudança do entendimento da histeria. Joseph François Félix Babinski (1857-1932) foi chefe da Clínica de Charcot, de 1885 a 1887. Após a morte deste, distancia-se de seus conceitos e, em 1901, em uma comunicação à Sociedade de Neurologia de Paris, propõe a substituição do termo "histeria” por “pitiatismo”, do grego peitho, “persuasão” e iatos, “curável”, considerando esse um quadro solucionável pela persuasão. Entre 1906 e 1909 ele desenvolve, na prática, sua concepção, de modo que os quadros histéricos gradativamente diminuem em quantidade, incluindo os que anteriormente eram tidos como clássicos ${ }^{255}$.

Mesmo com essas novas propostas, os conceitos deixados por Charcot continuam sendo influentes, tanto no campo da neurologia, quanto da psiquiatria. Inclusive a contribuição de Charcot para uma interface entre essas duas áreas tem sido revista, incluindo mesmo sua influência sobre a psicanálise ${ }^{256}$.

Tratando dessa convivência entre psiquiatria e neurologia, encontramos no já citado livro de Teixeira Brandão uma única utilização da palavra “neurologistas”, dizendo respeito a alguns aspectos do exame físico:

“A investigação do estado dos reflexos superficiaes e profundos assim como do tonus muscular offerecem tambem grande interesse. Da maneira de se comportarem uns e outros sob a acção de excitantes diversos decorrem para os alienistas e neurologistas seguras deduç̧ões clinicas. (...) $\mathrm{O}$ estudo detalhado, porém, de taes phenomenos mais interessa á propedeutica das afeç̧ões nervosas, em geral, do que á psychiatria”257.

253 FOUCAULT, M. O poder psiquiátrico. Martins Fontes, (2003) 2006, Notas, p. 434.

254 Foucault considera que Babinski foi quem primeiro promoveu uma "despsiquiatrização" do que havia sido construído por Charcot, diferindo esse processo da antipsiquiatria, pois ele acha que a despsiquiatrização mantem o poder do médico sobre o doente.

FOUCAULT, M. Microfísica do Poder. Editora Graal, 1979, p. 124.

255 Idem, p. 437.

256 WHITE, MB. Jean-Martin Charcot's contributions to the interface between neurology and psychiatry. Can. J. Neurol. Sci., 24 (3): 254-60, 1997.

257 Idem, p. 39. 
Aqui ele confirma a diferença entre o que chamamos de corpo neurológico e o âmbito da psiquiatria. Como sua formação também abrange a área de moléstias nervosas, chega a comentar alguns aspectos do exame neurológico, como o estudo dos reflexos.

Teixeira Brandão foi influenciado por seu mestre Torres Homem, a aprofundarse em psiquiatria e moléstias nervosas. Por sua vez, Torres Homem é o médico que escreve, pela primeira vez no Brasil, de forma sistemática, sobre o sistema nervoso. Embora seja de período anterior ao nosso trabalho, ele tem importância singular nos processos relativos a este estudo.

Torres Homem, em 1877, é quem primeiro publica no país uma série de aulas intituladas “molestias do systema nervoso”, aulas essas dadas a partir de julho de 1875, em suas Lições de Clinica Medica na Faculdade de Medicina do Rio de Janeiro ${ }^{258}$. Na leitura dessas aulas podemos constatar que ele tem uma linguagem científica bem articulada e atualizada com a ciência, fazendo citações de autores como Paul Broca e Claude Bernard, entre outros, citando a importância da fisiologia e da patologia, e fazendo uso de conhecimentos então recentes. Por essas aulas, pode-se ver a presença de uma linguagem e uma prática que seguem os padrões científicos do momento, refletindo-se no ensino e na atividade clínica de Torres Homem, expressas nos casos de comprometimento do sistema nervoso por ele relatados.

João Vicente Torres Homem, Barão de Torres Homem, nasceu no Rio de Janeiro em 1837. Ao ingressar no curso de medicina, este ainda é marcado por forte presença de cirurgiões (conforme a referência que consultamos) e sua prática é mais acentuada em atividades militares. A elite social também tem uma visão da medicina como uma "profissão manual”, portanto de caráter "pouco nobre”. Torres Homem é de família nobre, e filho de médico; essa profissão, para seu pai, se enquadra mais dentro da perspectiva de uma formação superior dada a um político e homem de elite, e não tanto para exercer plenamente a profissão na prática ${ }^{259}$.

Torres Homem (1837-1887) pertence a um período que se inicia com a fundação da Sociedade de Medicina do Rio de Janeiro em 1829 - a qual conduz a reforma do ensino médico em 1832 - e termina no início dos anos 1880, com

258 TORRES HOMEM. Moléstias do Systema Nervoso. (Publicado em várias lições que foram dadas a partir de 5 de julho de 1875). O Progresso Medico, 1877.

259 CORADINI, O.L. Grandes famílias e elite profissional na Medicina no Brasil. História, Ciências, Saúde - Manguinhos, III (3): 425-466, 1997. 
modificações substanciais da Academia Imperial de Medicina ${ }^{260}$. No período sucessivo, em 1882, deixa-se de celebrar a sessão magna na Academia, e em 1883 interrompe-se a rotina de reeleições, com a renúncia de seu presidente José Pereira do Rego, o Barão do Lavradio, que também chefia a Junta Central de Higiene Publica, de 1863 a 1881. Também em 1882 falece o último representante da geração que fundou a Sociedade de Medicina em 1929, Luiz Vicente de Simoni. Desse modo, a geração à qual pertence Torres Homem, que cultua o ecletismo e que, até certo ponto, resiste a algumas inovações do cenário científico internacional, cede lugar a outra geração, a qual considera a experimentação como base do progresso em Medicina ${ }^{261}$.

Torres Homem é influente professor de Clínica na Faculdade de Medicina do Rio de Janeiro e está sempre atento às inovações em neuropatologia. No entanto, não aceita as inovações científicas pasteurianas.

Formado em 1858, Torres Homem é diferente de seus contemporâneos, no sentido de que, embora oriundo da nobreza, tem grande interesse pela medicina no dia a dia. A pessoa que mais o influenciou nesse aspecto foi o professor de Clínica Médica, Manuel Valadão Pimentel, Barão de Petrópolis, de quem se tem poucos dados, mas que parece ter sido também um indivíduo bastante interessado na prática médica, de modo que passou esse interesse a um de seus discípulos. .

As principais atividades médicas de Torres Homem são voltadas para a Clínica e o ensino da medicina. Na Academia de Medicina luta contra os consultórios de farmácia. Participa de um concurso para o cargo de opositor (espécie de assistente) na Faculdade de Medicina, mas não é aprovado.

Em 1862, junto com outros, funda a Gazeta Médica do Rio de Janeiro. Em 1863, o imperador aprova sua nomeação para membro titular da Academia Imperial de Medicina, instituição essa que habitualmente conta com presença constante do Imperador, nesse período.

260 Em 1829 foi fundada a Sociedade de Medicina do Rio de Janeiro. Em 1935 essa sociedade passou a chamar-se Academia Imperial de Medicina. Em 1889 seu nome mudou para Academia Nacional de Medicina.

CASA DE OSWALDO CRUZ/FIOCRUZ. Dicionário Histórico-Biográfico das Ciências da Saúde no Brasil (1832-1930) Em: <http://www.dichistoriasaude.coc.fiocruz.br> Acessado em 3 de abril de 2006.

261 Entre estes, nessa década de 1880, estão presentes na Academia: Domingos Freire, João Batista Lacerda, José Maria Teixeira, e outros.

BENCHIMOL, J. L. Dos micróbios aos mosquitos: febre amarela e a revolução pasteuriana no Brasil. Editora Fiocruz, Editora UFRJ, 1999, p. 30-33. 
Em 1865, concorre à cadeira de Higiene e História da Medicina, mas não passa no concurso. Nesse mesmo ano, após outro concurso, assume o lugar do Barão de Petrópolis, na Clínica. Em 1874, juntamente com o Barão do Lavradio e com Souza Costa, é incumbido de elaborar projeto sanitário para a cidade. É relator de comissão para avaliar a pretensão de ensino da homeopatia na faculdade, sendo contrário a esse propósito.

Torres Homem tem como discípulos Francisco de Castro e Miguel Couto. Diferente de outros nesse período, não lega sua profissão a seus familiares, mas a seus discípulos. Também não fez como seu pai e outros, ou seja, nunca chega a viajar à Europa, para estudos médicos. Valoriza a observação clínica e a necropsia. Não aceita a doutrina pasteuriana.

Sua maior obra é Lições de Clinica Medica. É dito que “por alguns foi considerado o melhor médico que o Brasil já teve”. Certa ou não, essa afirmação dá uma idéia de sua presença no cenário médico. Morre em $1887^{262}$.

No que diz respeito a moléstias do sistema nervoso, nessa caracterização de doenças referentes a um determinado sistema do organismo, na linguagem de Torres Homem já existe um elemento que tende a configurar uma determinada disciplina científica, na medida em que ele trabalha com o conceito de "sistema", como sendo uma subdivisão orgânica, a qual encerra em si certas atribuições e coerências internas, que permitem isolar e elaborar características próprias de certas estruturas e funções.

O discurso de Torres Homem, a respeito do sistema nervoso, dá a entender que ele tem certo aprofundamento sobre o assunto. A recomendação que ele faz a Teixeira Brandão, para dedicar-se a estudos em psiquiatria e moléstias nervosas, pode-se dever à percepção de uma nova área que vem se configurando.

Além disso, o próprio Torres Homem observa diferenças entre o comprometimento físico e o comprometimento “moral ${ }^{263}$ ”, atentando para certa tendência, que ele chama de “organicista”,264, dos alienistas de seu tempo. Isso também

262 CORADINI, O.L. Grandes famílias e elite profissional na Medicina no Brasil. História, Ciências, Saúde - Manguinhos, III (3): 425-466, 1997.

263 A palavra "moral” não tinha o sentido de referir-se a aspectos ligados a conceitos de bem e mal, e sim um sentido similar ao termo "psíquico" ou "psicológico".

264 Em 1843 foi lançado o períódico “Annales médico-psychologiques”. Esse periódico tornou-se palco de debates permanentes entre partidários do organicismo e dos que se diziam dualistas. Em favor do organicismo havia, por exemplo, L. Rostan, autor de "Exposição dos princípios do organicismo, precedido de reflexões sobre a incredulidade em matéria de medicina” (1846). Entre os dualistas havia P.N. Gerdy, Frédéric Dubois d’Amiens, C. Michéa, Loius François E. Renaudin. 
nos chama a atenção para a citação da categoria específica de "alienista", citada pelo médico brasileiro, sendo que ainda não havia uma categoria médica, desse tipo, bem definida, no país:

"Lembrai-vos, senhores, do que se passa na loucura, e por maior que seja a confiança que depositeis nas doutrinas dos organicistas, não concordareis com elles por certo, attribuindo o delirio do infeliz louco a uma lesão material da camada cortical do cerebro. Um individuo sensato e muito intelligente recebe em seu moral um golpe violento que o dilacera cruelmente (...) O que se passou em seu cerebro, que deu logar a tão completa mudança na principal e mais importante de suas funcções? Ninguém o sabe, nem o saberá tão cedo, apezar das tendencias organicistas dos alienistas modernos" ${ }^{265}$.

Nesse discurso, Torres Homem cita "alienistas” com tendências “organicistas”, o que indica o uso desse termo para adjetivar determinada forma de considerar os fenômenos a serem estudados por esse campo. Também observamos o uso do termo “modernos"266, incorporado a seu vocabulário, para referir-se a essas novas tendências, o que imprime uma dinâmica a esse texto como sendo de alguém que está atento às novidades científicas.

Tendo seguido o conselho de Torres Homem, Teixeira Brandão aprimora-se como alienista e também no campo do sistema nervoso, mas ficando com a nomeação de ser versado em psiquiatria e moléstias nervosas, com maior ênfase na primeira.

Assim como ele, há um Franco da Rocha versado em “moléstias nervosas”, que não aparece como tal, embora publique vários trabalhos sobre moléstias do sistema nervoso. De modo similar, acontece com outros indivíduos que se identificam como psiquiatras, ou mesmo como alienistas.

Neste trabalho, queremos assinalar uma construção da neurologia, que ocorre junto à psiquiatria e à psicologia, no período estudado. Para ilustrar essa interligação, podemos lembrar, por exemplo, que o professor Austregésilo ${ }^{267}$, que é considerado como primeiro catedrático em Neurologia no Brasil - empossado em 1912 no Rio de

FOUCAULT, M. O Poder Psiquiátrico, p. 424.

265 TORRES HOMEM. Molestias do systema nervoso. O Progresso Medico, 1877, pp.260-261.

266 Conforme Le Goff (História e Memória), o uso do termo “moderno” nos séculos XIX e XX, pode ter o sentido de progresso, mas também o sentido de decadente, ou alguma coisa que seja questionável.

Para Torres Homem, o uso de "moderno", nesse texto, pode ter certo sentido de desaprovação por parte dele, na medida em que ele dá a entender que questiona a explicação organicista. Sua rejeição às idéias de Pasteur pode acompanhar posicionamento semelhante quanto ao moderno.

267 Dados biográficos da Academia Brasileira de Letras. 
Janeiro $^{268}$-, continua a debater temas psiquiátricos e psicológicos com empenho semelhante ao observado em assuntos neurológicos ${ }^{269}$. Sendo assim, ao mesmo tempo em que se instala a Cadeira de Doenças do Sistema Nervoso, as doutrinas e práticas das áreas enfocadas ainda são razoavelmente mescladas.

O professor Austregésilo, também comumente citado como A. Austregésilo, chama-se Antonio Austregésilo Rodrigues Lima. Em 1876, nasce em Recife, Pernambuco. Estuda no Colégio das Artes em Recife, onde conhece Tobias Barreto e participa de movimento literário e artístico. Aos 16 anos muda-se para o Rio de Janeiro para cursar Medicina.

Em seu curso sofre grande influência do clínico Francisco de Castro. Forma-se em 1899, com a tese Estudo Clinico do Delirio. Em 1901, é designado por Miguel Couto para ser diretor de laboratório. Em 1902, torna-se médico da Santa Casa. No governo Rodrigues Alves (1902-1906), integra a equipe do professor Juliano Moreira, que assume a Diretoria da Assistência aos Alienados.

Após várias tentativas, sem sucesso ${ }^{270}$, para ser admitido por concurso na vida acadêmica, é designado em 1909 pela Congregação da Faculdade, para ser professor substituto de Clínica Médica, Patologia Interna e Clínica Propedêutica. Em 1912, é designado por unanimidade, pela congregação da Faculdade de Medicina do Rio de Janeiro, como professor da recém fundada cátedra de Doenças do Sistema Nervoso.

Austregésilo freqüenta serviços de famosos estudiosos na França e nos Estados Unidos. Em 1928 traz desse país a idéia, que sugere ao médico José Ribeiro Portugal, de iniciar a neurocirurgia no Rio de Janeiro ${ }^{271}$.

Funda os Arquivos Brasileiros de Medicina e os Arquivos Brasileiros de Neurologia e Psiquiatria ${ }^{272}$. Em 1914, assume uma cadeira na Academia Brasileira de

268 GOMES, M.M. História da Neurologia no Rio de Janeiro. In: REIMÃO, R.(org), História da Neurologia no Brasil, Editora Lemos, 1999, p.174.

269 Como exemplo, podemos citar a obra de Austregésilo intitulada "Psicologia e Psicoterapia", publicada em 1951, por Irmãos Pongetti Editores, do Rio de Janeiro. No mesmo exemplar estão citadas obras de Austregésilo, algumas em francês, e uma série intitulada Clínica Neurológica, a partir de 1917. AUSTREGESILO, A. Psicologia e Psicoterapia. Irmãos Pongetti Editores, Rio de Janeiro, 1951. 270 Conforme o médico Marcos R. Gomes de Freitas, fatores que podem ter influenciado no insucesso inicial da carreira de Austregésilo podem ter sido: a origem humilde, sua cor (era mulato) e sua precária situação econômica e social. Freitas ainda referiu que Austregésilo, em sua infância, teve certas dificuldades em virtude de sua tartamudez e de apresentar certos tremores.

TEIVE, H.A.G. et al. Professor Antonio Austregésilo: o pioneiro da neurologia e do estudo dos distúrbios do movimento no Brasil. Arquivos de Neuro-Psiquiatria, 57 (n.3B), set, 1999.

271 Idem.

272 Austregésilo foi um divulgador de conhecimentos relativos a alterações mentais entre leitores leigos, e popularizou noções de histeria, neurastenia, debilidade nervosa, ou mesmo a noção de "nervosos", em 115 
Letras. É deputado federal por Pernambuco de 1922 a 1930. É membro de várias associações e academias de vários países. Morre em $1960^{273}$.

Austregésilo também publica em 1912, no periódico L'Encephale, um artigo a respeito de um sinal neurológico, sucedâneo do sinal de Babinski, denominado sinal de Austregésilo e Esponsel. Essa publicação indica que Austregésilo também trabalha em torno da elaboração do corpo neurológico, em torno da delimitação de seus mecanismos do tipo estímulo-resposta.

Ainda sobre fundações de disciplinas neurológicas, acrescentemos que, em 1914, na Bahia, Luiz Pinto Carvalho torna-se o primeiro catedrático de Neurologia nesse Estado, com a separação da cátedra de Psiquiatria e Moléstias Nervosas, em cátedras de Clínica Psiquiátrica e Clínica Neurológica ${ }^{274}$.

Vemos aí uma gradual delimitação desses campos científicos nas duas primeiras faculdades de Medicina do Brasil, com os termos "Moléstias Nervosas", ou "Doenças do Sistema Nervoso", ou "Neurologia”, aplicados como nomes para uma disciplina ou cadeira do curso médico.

Em relação à elaboração da neurologia como disciplina científica em São Paulo, pelas pesquisas foi possível verificar que, enquanto o termo "moléstias nervosas”, desde o início, acompanha Franco da Rocha e seus seguidores, o uso das palavras neurologia, “nevrologia”, ou neurologista, quando aparece em publicações paulistas, refere-se a médicos de outras localidades, como Bahia, Rio de Janeiro, ou de outro país. Podemos ver, por exemplo, no artigo de 1902, de Juliano Moreira, na Revista Medica de São Paulo, transcrito da Gazeta da Bahia, a identificação desse autor como "substituto de Psychiatria e Nevrologia na Faculdade da Bahia”275. Esse médico

relação a indivíduos acometidos desses quadros. No prefácio da edição de 1917 de "A Cura dos Nervosos", ele diz que "este livro é escrito para os doentes"; também refere que "com a vida moderna a debilidade nervosa se exalta, e os sintomas ansiosos dominam o cômputo das populações das cidades. Acha-se o nervosismo tão espalhado que podemos dizer que todo o mundo foi, é, será nervoso". O autor estimula o otimismo, a confiança, a coragem, etc. e a psicoterapia. Nesse livro, que teve várias edições, cita Freud, entre outros autores.

AUSTREGESILO, A. A Cura dos Nervosos. Livraria Jacintho Editora, 6ª edição, 1933.

273 Dados obtidos no site da Academia Brasileira de Letras.

http://www.academia.org.br em 23 de agosto de 2006 às 21:47 hs.

274 ANDRADE FILHO, A.S.; SANTANA JUNIOR, P.A. Ensino da Neurologia na Bahia: aspectos históricos. In: REIMÃO, R. (org.), História da Neurologia no Brasil, Editora Lemos, 1999, p.89.

275 MOREIRA, J. O asylo-colonia de alienados em Juquery (S.Paulo). Revista Medica de São Paulo, 1902, p.210. 
tem singular atuação na psiquiatria no Brasil, de modo que é tido por alguns como o fundador da especialidade no país - sendo mais conhecido do que o próprio Teixeira Brandão -, o que dá uma idéia do papel emblemático que tem para a Psiquiatria e mesmo para a Medicina.

Juliano Moreira nasceu em Salvador, Bahia, em 1873. Por vezes é designado como fundador da disciplina de Psiquiatria no Brasil, talvez por alguns traços fortes de sua biografia: mestiço (mulato), de família pobre, extremamente precoce, ingressa na Faculdade de Medicina da Bahia aos 13 anos, graduando-se aos 18 anos (1891), com a tese Syphilis maligna precoce. Cinco anos depois, torna-se professor substituto da seção de doenças nervosas e mentais. De 1895 a 1902, freqüenta cursos sobre doenças mentais e visita asilos nos países: Alemanha, Inglaterra, França, Itália e Escócia. De 1903 a 1930, dirige o Hospital de Alienados no Rio de Janeiro, onde recebe internos para o ensino da Psiquiatria, embora não seja professor no Rio. Uma referência que consultamos diz que ele "aglutinou ao seu redor médicos que viriam a ser de especialidades como neurologia, psiquiatria, clínica médica, patologia, pediatria, medicina legal”. Isso pode parecer um exagero, mas devemos frisar que ele também se tornou especialista em Dermatologia e Sifilografia. Um aspecto marcante em sua obra é uma explicita discordância quanto à atribuição da degeneração do povo brasileiro à mestiçagem, especialmente em relação a uma suposta “contribuição negativa” dos negros na miscigenação. Não questiona a teoria da degenerescência em si, mas as suas causas, que eram mais atribuídas à hereditariedade por outros estudiosos. Ele acha que a luta contra as degenerações nervosas e mentais, deve ser uma luta contra o alcoolismo, a sífilis, as verminoses, as condições sanitárias e educacionais ${ }^{276}$.

Juliano Moreira se alinha às então novas correntes psiquiátricas e de prática asilar. Divulga a obra de Kraepelin. Faz mudanças no Hospício Nacional de Alienados, onde instala laboratórios, acrescenta diversas especialidades, abole a camisa de força, retira grades das janelas; também cuida da formação de enfermeiros e de registros

276 A viúva de Juliano Moreira encaminhou a Gilberto Freyre artigo de 1905, que foi apresentado no Primeiro Congresso Afro-brasileiro em Recife, em 1934, em que Moreira aponta o álcool introduzido aos escravos como facilitador do processo de colonização e como elemento degenerativo. Em outro artigo de 1929, Moreira assinala pesquisas feitas por vários testes psicológicos que não mostraram diferenças entre as raças no Brasil; segundo ele, indivíduos de grupos étnicos considerados inferiores, quando nascidos e criados sob boas condições, têm desempenho melhor do que indivíduos de raças nórdicas, criados sob condições inadequadas.

ANTUNES, E. H. Raça de Gigantes: A Higiene Mental e a imigração no Brasil. In: Psiquiatria, Loucura e Arte. Edusp, 2002, p. 96. 
administrativos e estatísticos. Reforça a necessidade de aprovar a lei de assistência aos alienados de $1903^{277}$. Também estuda sifilografia, dermatologia, infectologia e anatomia patológica, além das doenças nervosas e mentais. Tem correspondências com Kraepelin. Conhece Freud, devido a dominar a língua alemã. É tido por alguns como o primeiro a mencionar Freud no país, em uma aula de 1899. Foi membro de diversas sociedades científicas internacionais e nacionais. Com outros, funda os Archivos Brasileiros de Psychiatria, Neurologia e Medicina Legal (1905) e a Sociedade Brasileira de Psychiatria, Neurologia e Medicina Legal (1907). Também tem a visão de que a medicina deve promover a sanitarização do país e também é a favor da higiene mental e da eugenia, sendo que, como já foi dito, não tem uma visão negativa da miscigenação; portanto a eugenia que defende não é a de cunho racista, porém mais voltada ao sanitarismo. Juliano Moreira falece em $1933^{278}$.

Ainda sobre o uso do termo neurologia, em 1905 funda-se no Rio de Janeiro a publicação Archivos Brasileiros de Psychiatria, Neurologia e Sciencias Affins, pelos médicos Juliano Moreira e Afranio Peixoto, identificados, no primeiro exemplar desse periódico, como alienistas do Hospital Nacional de Alienados. Em 1907, é fundada a Sociedade Brasileira de Neurologia, Psychiatria e Medicina Legal associada a essa publicação, também no Rio, com a mudança do nome do periódico para Archivos brasileiros de Psychiatria, Neurologia e Medicina Legal ${ }^{279}$.

Em 1919 essa publicação passa a ser chamada Archivos Brasileiros de Neuriatria e Psychiatria. Nessa ocasião, aparece a tendência de utilizar o termo “neuriatria”, para se referir a moléstias nervosas, em vez de neurologia, talvez para aproximá-la da psiquiatria e afastá-la da psicologia, já que o prefixo “iatros” refere-se à medicina. Isso também pode se traduzir por uma forma ainda incerta de denominar o campo neurológico, já que há termos concomitantes para nomear a mesma área.

Em relação ao uso desse novo termo, acrescente-se que, na Universidade Federal do Paraná, em 1920, foi criada a cátedra de Neuriatria, por Octavio da Silveira, cadeira essa que em 1923 deixa de existir como tal e passa a ser dividida em cátedra de

277 Essa lei consta na seção de Anexos.

278 ODA, A.M.G.R.; DALGALARRONDO, P. Juliano Moreira, um psiquiatra negro frente ao racismo científico. Revista Brasileira de Psiquiatria, 22 (4): 178-9, 2000.

279 ARCHIVOS BRASILEIROS DE NEURIATRIA E PSYCHIATRIA, edição especial de 50 aniversário, 1955. 
Neurologia e cátedra de Psiquiatria ${ }^{280}$, reforçando, nessa situação, um uso transitório do termo neuriatria, por pouco tempo, como abrangendo as duas áreas.

Em São Paulo, o uso da palavra neurologia, para se referir a essa área, em suas próprias instituições, demora mais tempo para ser adotado do que nos outros centros. Inicialmente é citada algumas vezes no transcorrer da primeira década do século XX, na Imprensa Médica, como oportunamente veremos. A partir da criação do periódico Annaes Paulistas de Medicina e Cirurgia em 1913, concomitantemente à criação da Faculdade de Medicina e Cirurgia de São Paulo, as palavras neurologia e neurologista passam a ser mais usadas, gradativamente, com mais freqüência, nas publicações paulistas, conforme veremos oportunamente.

Antes ainda de serem fundadas disciplinas de neurologia em São Paulo, um discípulo de Franco da Rocha, Enjolras Vampré, envolve-se gradativamente cada vez mais com as moléstias do sistema nervoso.

Em 1885 nasce Enjolras Vampré em Laranjeiras, Estado de Sergipe. Sua família muda-se para São Paulo em 1886. Faz estudos preparatórios no Ginásio de Ciências e Letras de São Paulo. Estuda na Faculdade de Medicina da Bahia, de 1903 a 1908. Durante o curso, torna-se interno da "Cadeira de Clinica Psychiatrica e Molestias Nervosas”, sob a chefia do professor Luiz Pinto de Carvalho. Em 1904 e 1905, auxilia no combate à peste bubônica na Bahia. Em 1907 e 1908, torna-se interno do Hospital de Isolamento, sendo designado chefe da comissão de saneamento dessa moléstia, na cidade de Alagoinhas. Ainda estudante, elege-se como presidente da Sociedade Beneficente Acadêmica. Logo após diplomado, torna-se sócio fundador da Sociedade Médica da Bahia. Em 1908, sua tese de doutoramento intitula-se “Considerações sobre as perturbações nervosas e mentaes na peste bubonica”. Escolhido como o melhor aluno de sua turma e, por suas notas, seu retrato é colocado no Panteon da Faculdade de Medicina da Bahia, tendo sido premiado com uma viagem à Europa, viagem essa realizada em 1911, quando já está no Juquery ${ }^{281}$.

Além dessa, faz outra viagem em 1925, por conta da Faculdade de Medicina de São Paulo. Nessas ocasiões, freqüenta os cursos de Babinski, Dejerine, Foix, Guillain,

280 SITIO, Disciplina de Neurologia da Universidade Federal do Paraná. Em: http://www.hc.ufpr.br/neurologia/Neuroinformacoes.htm Acessado em 23 de março de 2006 às 18:16 hs. 281 EDITORIAL. Revista de Neurologia e Psychiatria de São Paulo, abril-junho, vol.4 (n.2): 57-59, 1938. 
Bertrand; em Berlim freqüenta os serviços da Charité; também na Alemanha vai aos serviços de Daldorf, Wuhlgaiten, Herzberg e Brech $^{282}$.

Em 1909, Enjolras Vampré é nomeado médico interno do Juquery. Diferentemente de seu mestre Franco da Rocha, que é algo recluso e pouco freqüenta as reuniões da Sociedade de Medicina e Cirurgia, Vampré, desde o início de sua profissão, torna-se um membro assíduo dessa Sociedade, onde sempre tem destaque. Além disso, começa a escrever vários artigos científicos já a partir de 1910, inicialmente endereçados do próprio Juquery ${ }^{283}$.

Em 1911, torna-se inspetor sanitário na Capital e, em 1912, torna-se diretor da Seção de Neuropsychiatria do Instituto Paulista ${ }^{284}$, cargo que ocupa até o falecimento. Em 1910, ingressa na Sociedade de Medicina e Cirurgia de S. Paulo, na qual exerce todos os postos: primeiro secretário em 1914, bibliotecário em 1919, vice-presidente em 1920 e presidente em 1921. Em 1935, passa à categoria de sócio honorário. Em 1930, é um dos fundadores da Associação Paulista de Medicina, da qual torna-se presidente em 1935. Funda a seção de Neurologia e Psiquiatria dessa Associação, sendo seu primeiro presidente, em 1931. Também é membro da Sociedade de Neurologia e Psiquiatria do Rio de Janeiro, membro correspondente da Academia Nacional de Medicina de Buenos Aires, membro correspondente da Sociedade de Neurologia de Paris, membro honorário da Academia Nacional de Medicina. A partir de 1935, recebe o cargo de presidente honorário da Associação Médica do Instituto Penido Burnier de Campinas ${ }^{285}$.

Em 1925, é contratado para chefiar a Cadeira de Psiquiatria e Moléstias Nervosas da Faculdade de Medicina de S. Paulo. Terminado esse contrato em 1927, ele é renovado por tempo indeterminado. Em 1932, a Congregação da Faculdade envia, às instâncias competentes, um memorial propondo seu nome para a função definitiva da cátedra, independentemente de concurso. No entanto, Vampré solicita a abertura de inscrições para o concurso. Em fins de 1935, ele é aprovado no concurso da Cadeira de

\footnotetext{
282 Idem. 283 Ibidem.

284 Não temos dados sobre esse Instituto Paulista, se seria equivalente à Policlínica de São Paulo. Parece tratar-se de instituição privada, talvez equivalente ao Instituto fundado por Rubião Meira em 1909, que será mencionado oportunamente. Não temos dados para confirmar se essa designação de neuropsiquiatria foi dada posteriormente, ou se já era usada em 1912, conforme a referência.

285 EDITORIAL. Revista de Neurologia e Psychiatria de São Paulo, abril-junho, vol. 4 (n.2): 57-59, 1938. 
Neurologia, tendo na banca Antonio Austregésilo, Aloysio de Castro, Alfredo de Britto Filho, Delfino Ulhôa Pinheiro Cintra e Ovídio Pires de Campos ${ }^{286}$.

Vampré atende, em sua clínica particular, o número de aproximadamente 22 mil doentes. Contam-se entre seus assistentes: Adherbal Tolosa, Paulino Longo, Oswaldo Lange, Carlos Gama e Fernando de Oliveira Bastos. Em 1928 é paraninfo dos formandos. Em 13 de maio de 1938, enquanto dá aula de “malarioterapia das afecções neuroluéticas”, é acometido de acidente vascular cerebral e falece em 17 de maio ${ }^{287}$.

Um contemporâneo desses discípulos de Vampré, que segue trajetória paralela, e tem destaque na instalação da Neurologia em São Paulo, é Fausto Guerner (19031938). Os dados que temos a seu respeito constam de seu necrológio publicado na Revista de Neurologia e Psychiatria de S. Paulo. As informações que passamos é uma copilação das falas dos médicos Pacheco e Silva e Thomé Alvarenga em reunião da Seção de Neuropsiquiatria da Associação Paulista de Medicina ${ }^{288}$.

Consta que Gerner foi discípulo de Austregésilo (portanto, no Rio de Janeiro), e que, logo após se formar, partiu para a Europa. Lá estudou com H. Claude, Guillain, De Clérambault, Babinski e Bertrand. Pacheco e Silva refere que lhe encontrou na Salpêtrière em 1926. Após voltar ao Brasil, passou a trabalhar como alienista do Instituto Aché, além de assistente voluntário do Prof. Vampré e médico alienista do Hospital do Juquery. Pacheco e Silva diz que Guerner se empenhava na elaboração de trabalhos científicos.

Thomé de Alvarenga informa que ele se dividia entre o Hospital do Juquery, a chefia do Ambulatório de Higiene Mental, o serviço de Neurologia da Santa Casa, as sociedades médicas, as revistas especializadas, de que foi fundador (S. Paulo Medico) e colaborador, e a clínica particular. Alvarenga acrescenta que Guerner orientou as teses de doutoramento da Sylvio Ribeiro de Souza (1928), Mário Yahn (1933), Edmur da Costa Pimentel (1933) e Edmur de Aguiar Withaker (1933), três aprovadas com grande distinção e uma com distinção. Foi escolhido por Otávio de Carvalho para ser o catedrático de Neurologia da Escola Paulista de Medicina. Após a necrologia, estão relatadas todas as publicações de Fausto Guerner. Os temas dizem respeito a assuntos

286 Idem.

287 Ibidem.

${ }^{288}$ PROFESSOR FAUSTO GUERNER (1903-1938). Revista de Neurologia e Psychiatria de São Paulo, julho-setembro, 1938, p. 101-105. 
neurológicos propriamente ditos, temas de higiene mental, temas de psiquiatria. Há também na lista Conferência pelo Rádio e artigos de jornal; entre estes artigos, um é sobre Psicanálise (1930).

\section{4 - Psiquiatria e Psicologia}

No item correspondente à historiografia já foram aventadas linhas gerais a respeito da gradual caracterização desses campos. Pode ser de interesse que se ressalvem alguns aspectos mais próximos de nosso enfoque, a respeito de São Paulo e Brasil, e no período a ser abordado.

A psiquiatria em São Paulo estabelece-se bastante alicerçada no trabalho de Franco da Rocha. Esse trabalho abrange um período de 1892 até 1932, quando do último registro de uma palestra dada na Associação Paulista de Medicina. Esse período de 40 anos tem fases de maior intensidade, principalmente a partir do início do funcionamento do Juquery, em 1898, até sua aposentadoria em 1923.

Como veremos, por algumas vezes, Franco da Rocha faz referência ao excesso de trabalho que tem no Juquery, de modo que se sente impedido de poder dedicar-se melhor às atividades científicas. Essa sua queixa se atem tanto à impossibilidade de escrever mais, quanto também do fato de não poder contar com um laboratório no Hospício, que lhe propicie melhor investigação dos casos, bem como em relação à pesquisa. Essa lacuna, que perdura durante praticamente todo o tempo que fica no Juquery, só é preenchida com a chegada de Antonio Carlos Pacheco e Silva, que traz para trabalhar no laboratório do Juquery o estudioso de Salpêtrière, Konstantin Tretiakoff.

O feito de Antonio Carlos Pacheco e Silva, de trazer um estudioso de Salpêtrière logo de sua chegada, quando ele mesmo (Pacheco e Silva) ainda é jovem e no início de sua profissão, demonstra ser um indivíduo determinado em relação a seus objetivos.

Em 1919, Antonio Carlos Pacheco e Silva (1898-1988) ${ }^{289}$ forma-se na Faculdade de Medicina do Rio de Janeiro. Em 1920, estagia com o professor Pierre

\footnotetext{
${ }^{289}$ PICCININI, W. J. Antonio Carlos Pacheco e Silva. Psychiatry on line Brazil, (9) julho, 2004. http://www.polbr.med.br/arquivo/wal0704.htm 122
} 
Marie em Paris. Nesse mesmo ano, é contratado para organizar o Laboratório de Biologia e Anatomia Patológica do Hospício do Juquery. Em 1924, contrata o professor Constantin Tretiakoff, neuropatologista da Salpêtrière, de fama internacional, para o laboratório do Hospício. Também nesse ano edita Memórias do Hospício do Juquery. Participa da Sociedade de Medicina e Cirurgia de São Paulo e da Associação Paulista de Medicina. Em 1923, com a fundação da Liga Brasileira de Higiene Mental, no Rio de Janeiro por Gustavo Riedel, Pacheco e Silva é responsável pela sucursal de São Paulo, ocasião em que tem também associação com grupos ligados a idéias eugênicas. Apoia a Revolução Constitucionalista de 1932, e chega a ficar preso no Distrito Federal, nessa ocasião. Em 1933, dá a aula inaugural da Escola Paulista de Medicina e torna-se o primeiro catedrático de Psiquiatria. Em 1934 é deputado constituinte. Em 1936 vence concurso para a cátedra de Psiquiatria na Faculdade de Medicina da Universidade de São Paulo. É deputado constituinte em 1933-34 e 1946. Nos anos 1950 promove a criação do setor de Psiquiatria do Hospital das Clínicas que se torna um Instituto que passa a ter seu nome.

Como já apontado na historiografia, alguns estudiosos alegam que o encaminhamento da psicologia em São Paulo pode ter dependido em parte de certa aversão de Pacheco e Silva à psicanálise. A partir de nosso levantamento isso pode ser relativizado, haja vista, por exemplo, o fato de Osório César, seu discípulo, ser adepto da teoria psicanalítica e desenvolver seu trabalho no Juquery, quando Pacheco e Silva é diretor.

Embora o papel fundamental que a psicanálise desempenha na estruturação da psicologia como um campo próprio em São Paulo, é importante lembrar-se que a psicologia já vinha sendo trabalhada. Como já foi dito, antes da psicologia médica, a psicologia próxima da filosofia e da pedagogia é ensinada na Faculdade de Direito e em algumas instituições de ensino.

A psicologia médica, que em seu início confunde-se com a então chamada psicologia científica, fundada por Wundt na Alemanha entre as décadas de 1870 e 1880, tem na França nomes fortes como Pierre Janet e George Dumas. O médico Manoel Bomfim, que trabalha no Rio de Janeiro, é discípulo desses dois pesquisadores e consta em periódicos paulistas já em 1904, com publicações de sua própria autoria, bem como 
na citação de seu cargo como responsável pelo primeiro laboratório de psicologia no país.

Manoel Bomfim não é muito citado por décadas, talvez por ter sido opositor de fortes figuras no ambiente intelectual, como Silvio Romero. Bomfim é contrário ao uso das idéias evolucionistas para reforçar os conceitos racistas, entre outras idéias que não seguem alguns ditames científicos do período. Embora a presença de Bomfim nos periódicos paulistas seja discreta, consideramos importante ele ser mencionado neste trabalho pela singularidade de suas posições e também porque faz parte deste trabalho chamar a atenção para pessoas ou eventos pouco enfocados na historiografia das áreas estudadas.

Também há outros registros em torno de debates psicológicos nessas revistas, um tanto mesclados entre outras polêmicas, algumas vezes por autores que não têm uma marca tão fortemente associada à psicologia, e em outras vezes por nomes de peso como, por exemplo, George Dumas.

Manoel Bomfim, quando estuda com Janet e Dumas, aprende uma psicologia que busca suas explicações em alterações cerebrais.

De alguma forma, o médico Durval Marcondes acaba sendo um elo entre essa psicologia médica nos moldes de Bomfim e a psicologia que se constitui depois como um campo independente. Além disso, podemos frisar que, mesmo depois de a doutrina freudiana ter sido divulgada por Franco da Rocha, e principiada sua prática com Durval Marcondes, ainda assim, esses conceitos guardam noções advindas de alguns elementos que Freud recebeu de Charcot, como por exemplo, a idéia de traumatismo psíquico.

Durval Marcondes nasceu em São Paulo em $1899^{290}$. Ao ler o artigo Do delirio em geral de Franco da Rocha - publicado em 20/03/1919 no jornal O Estado de São Paulo, ano em que ele inicia o curso de medicina -, interessa-se por psiquiatria e psicanálise. Em 1922, publica poesia na revista Klaxon do Movimento Modernista. Em 1924, inicia a prática de psicanálise de forma autodidata. Em 1926, concorre a vaga de Literatura no Ginásio do Estado, com a tese $O$ symbolismo esthetico na literatura. Ensaio de uma orientação para a critica literaria baseada nos conhecimentos fornecidos pela Psychanalyse. Em 1927, funda a Sociedade Brasileira de Psicanálise e a Revista Brasileira de Psychanalyse, juntamente com outros. Em 1927, funda o serviço

290 SAGAWA, R.Y. Durval Marcondes. Imago, 1999. 
de Higiene Mental Escolar. Troca correspondências com Freud. Em 1937, torna-se Livre Docente da Clinica Psiquiátrica da FMUSP. Participa de grupos e movimentos de psicanálise e psicologia. Falece em 1981.

\section{5. - A questão dos limites entre as áreas}

Neurologia, psiquiatria e psicologia sempre tiveram e têm certos espaços de intersecção, nos quais não há nitidez na diferenciação entre essas áreas, constituindo espaços comuns.

Além disso, a junção ou separação dessas diferentes designações - em uma mesma área comum, ou em disciplinas com limites mais demarcados, constituindo verdadeiras especialidades -, além de serem determinadas pelas inovações científicas, também acompanham as transformações sociais, culturais e políticas nas diferentes circunstâncias em que estão envolvidas.

No entender de Foucault, entre os anos 1820 e 1880, ou seja, até o aparecimento da neurologia, com seu dispositivo clínico próprio, há as “doenças mentais” distintas das “verdadeiras doenças”, estas diagnosticadas pela clínica ${ }^{291}$.

Nesse período, ainda segundo Foucault, essas “verdadeiras doenças” correspondem apenas àquelas dignas de terem um diagnóstico diferencial, ou seja, têm características próprias que as diferiam de outras doenças. Já as “doenças mentais”, segundo ele, estão simplesmente presentes ou não, de modo que o indivíduo é simplesmente louco, ou não. Nesse sentido, as classificações psiquiátricas, nesse período, têm um valor relativo, pois, independemente de sua subdivisão, no seu todo, o que importa é essa diferença binária entre ser ou não ser louco ${ }^{292}$.

Em situação intermediária entre esses dois grupos, nesse período entre as décadas de 1820 e 1880, ainda conforme Foucault, estão as “nevroses”, que correspondem a doenças “intermediárias válidas”. Isso porque têm características próprias de doenças clínicas, com diagnóstico diferencial, mas sem substrato orgânico conhecido. 
Assim, ele aponta duas datas de início de dois processos em torno de debates a respeito do fundo orgânico das doenças mentais. Em 1820, começa o debate sobre as causas da loucura, com a defesa de tese de Étienne Georget, intitulada Dissertation sur les causes de la folie. A outra data corresponde a 1843, quando é lançado por Baillager, Cerise e Longer o periódico Annales médico-psychologiques, subtitulado como Jornal de anatomia, de fisiologia e de patologia do sistema nervoso destinado particularmente a recolher todos os documentos relativos à ciência das relações do físico e de moral, à patologia mental, à medicina legal dos alienados e à clínica das nevroses ${ }^{293}$.

Portanto, em 1843, na França, esses diferentes conceitos estão posicionados em torno do sistema nervoso. Nas décadas seguintes, Duchenne e Charcot, estabelecendo o corpo neurológico, estabelecem determinados vínculos entre esses termos.

$\mathrm{Na}$ linha de como Foucault entende a neurologia, considera que ela permite conhecer a "atitude intencional do indivíduo"294 sujeito no próprio interior de seu corpo" ${ }^{295}$, ou seja, no entender dele, a análise do comportamento encontra respostas no próprio corpo. Por outro lado, Foucault considera que, diferentemente da clínica, o neurologista necessita da cooperação, compreensão e vontade do doente para a obtenção das respostas do corpo ${ }^{296}$.

Foucault diz que, diferentemente de outros autores, não acha que, entre os anos 1820 e 1880, tenha havido uma oposição entre corpo e espírito, ou entre doenças orgânicas e doenças psíquicas. Ele considera que há, nesse período, uma dicotomia entre as “doenças válidas”297 (descritas pela anatomia patológica) e as que precisam de "uma prova de realidade”, entre as quais, estão as doenças mentais.

Há, entre esses dois grupos, um terceiro, que ele chama de "intermediário”, no qual ele inclui um “intermediário válido”, como a paralisia geral, e um “intermediário inválido” onde estão as nevroses, que abrangem as convulsões, a epilepsia, a histeria, a hipocondria. Assim, ele cita que, no primeiro número dos Annales médicopsychologiques, de 1843, os redatores dizem que é necessário ocupar-se da loucura,

293 Idem, p. 424.

294 Idem, p.393.

295 Ibidem.

296 Foucault considera que o fenômeno de o doente obedecer, cooperar e o corpo falar por ele, nesse processo do "corpo neurológico", acaba criando uma "cilada” da qual emerge a histeria, nos moldes de Charcot.

FOUCAULT, M. O Poder psiquiátrico. Martins Fontes, p.393.

297 FOUCAULT, M. - O Poder psiquiátrico. Martins Fontes, p. 398. 
enquanto que, das neuroses, é muito difícil, por serem distúrbios difíceis de entender, “proteiformes” 298 (um termo recorrente para a histeria), sendo, portanto, "banidos da observação”. Assim, Foucault escreve que:

“A emergência do corpo neurológico, ou melhor, desse sistema constituido pelo aparelho de captura clínica da neurologia e pelo corpo neurólogico que é seu correlato, vai possibilitar precisamente apagar a desqualificação, essa dupla desqualificação epistemológica e moral de que as neuroses eram objeto até por volta da década de 1870. Essa desqualificação vai poder ser apagada na medida em que vai se poder colocar finalmente essas doenças ditas “neuroses”, isto é, essas doenças dotadas de componentes sensitivos e motores, não exatamente no domínio das doenças neurológicas propriamente ditas, mas bem ao lado, não tanto por suas causas como essencialmente devido às suas formas”299.

Desse modo, Foucault acha que o diagnóstico diferencial pelo exame físico (que não pode ser aplicado à loucura) torna-se viável para diferenciar distúrbios neurológicos, com lesões anatômicas assinaláveis, das “nevroses”, de modo que estas foram incluídas no rol das “doenças sérias”300. Portanto, isso ocorre na medida em que esse grupo de moléstias passa a ser avaliado pelos critérios próprios para o diagnóstico neurológico.

Acompanhando essa reflexão, Foucault diz que Freud aproxima o papel de Charcot frente à histeria, de modo similar ao papel de Pinel em relação à loucura: Freud considera que, do mesmo modo que Pinel liberta os loucos das correntes, Charcot permite que os histéricos sejam reconhecidos como doentes ${ }^{301}$.

Ainda, conforme Foucault, Charcot descreve uma série de "estigmas" 302 orgânicos, encontráveis nos histéricos, e característicos para o diagnóstico, mesmo fora das crises, como: alterações de sensibilidade, distúrbios do campo visual, contratura circular em torno de uma articulação. Além disso, Charcot também insere a noção de traumatismo, ou trauma, como fator desencadeante da histeria.

Esses diversos elementos, no período de Charcot, mantêm as nevroses mais próximas das moléstias nervosas do que da psiquiatria.

298 Idem, p. 399.

299 Idem, p. 399-400.

300 Idem, p.400.

301 Foucault refere que houve condições favoráveis em Salpêtriére, para que a histeria reinasse no período de Charcot, em um campo comum de tentativa de tomada de controle entre médicos de um lado, e histéricos de outro.

FOUCAULT, M. O Poder psiquiátrico. Martins Fontes, p.400.

302 Idem, p. 402. 
Em 1893, ano em que Charcot morre e Kraepelin lança o conceito de demência precoce na quarta edição de seu tratado de psiquiatria, Breuer e Freud publicam seu primeiro artigo sobre histeria, intitulado "Sobre o mecanismo psíquico dos fenômenos

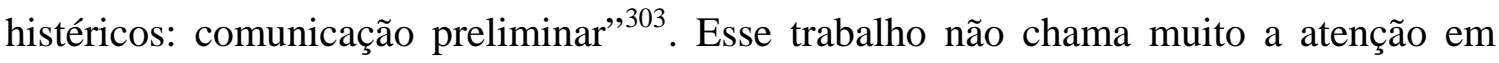
Viena e na Alemanha, mas recebe comunicação elogiosa de Janet na França, além de traduções para inglês e espanhol. Nesse artigo, os autores se remetem ao paradigma de Charcot para a histeria, sem questioná-lo e abordam a noção de trauma psíquico, bem como o uso da hipnose. Eles referem-se à histeria como neurose, psicose, neuropsicose. Há certa inovação nesse artigo, na acentuação dada aos mecanismos psíquicos em torno da idéia de catarse, recalcamento, alterações de consciência. Por outro lado, os próprios autores relatam hipóteses similares às suas, publicadas por outros estudiosos ${ }^{304}$.

Em outros trabalhos da década de 1890, Freud fica a meio caminho entre aceitar mecanismos químicos ou mecanismos psíquicos para as neuroses. Só em 1905, deixa de tentar correlacionar as vias de associação mental com os neurônios e tratos nervosos. No entanto, até o fim da vida ele acredita na possibilidade de se encontrar uma base física para os fenômenos mentais ${ }^{305}$.

Como dito anteriormente, em 1882 ocorre a instalação da cadeira de doenças do sistema nervoso, por Charcot, institucionalizando, na França, uma área específica, diferenciada das áreas de psiquiatria e psicologia.

No Brasil, há o processo inicial de institucionalização de algumas dessas áreas, como a instalação de uma única cadeira de Psiquiatria e Moléstias Nervosas, no Rio de Janeiro, em 1881. Em 1912, é estabelecida a já citada cadeira de Neurologia (ou de doenças do Sistema Nervoso), no Rio de Janeiro, e depois em outros Estados.

Em São Paulo essa institucionalização segue etapas diferentes, acompanhando, em parte, as trajetórias e atuações de instituições como o Hospício do Juquery, ou as Faculdades de Medicina, além de outros fatores.

O aparecimento da psicanálise é um elemento que acentua as articulações e diferenciações entre essas áreas, seja internacionalmente, como no Brasil, ou em São

\footnotetext{
${ }^{303}$ BREUER, J.; FREUD, S. Estudos sobre a Histeria. Obras Completas de Sigmund Freud, Imago Editora, (1895) 1995, p. 39-53.

${ }^{304}$ Esses estudiosos são Binet, Janet, Strumpell, Moebius, Delboeuf. BREUER, J.; FREUD, S., idem.

${ }^{305}$ STRACHEY, J. Comentários e notas. In: BREUER, J.; FREUD, S., Estudos sobre a Histeria. Editora Imago, 1995, p. 27. 
Paulo. Esse processo tem sido entendido, por vezes, como fortemente conflituoso entre as disciplinas em questão. Alguns estudos, que têm uma preferência "não organicista" pela interpretação dos fenômenos mentais, acentuam essa visão.

Um desses trabalhos é a tese Médicos, psicanalistas e loucos: uma contribuição à história da psicanálise no Brasil, de Carlos Ponte. Ele diz que a autora Jane Russo alerta para as tensões entre neurologistas e psiquiatras no início do século $\mathrm{XX}$, e considera o termo neuropsiquiatria como uma forma para escamotear uma disputa entre diferentes concepções de alienação mental e de sua prática equivalente. Assim, conforme Ponte, Russo acha que a psiquiatria corria risco de ser englobada e descaracterizada pela neurologia, alinhada com o que ela chama de novo modelo de cientificidade através da disssecção de cadáveres ${ }^{306}$. Assim, ainda conforme esse autor, Russo acha que a psicanálise permitiu à psiquiatria fazer frente ao organicismo neurológico ${ }^{307}$.

Nesse texto, podemos observar uma hipótese de que a psicanálise ${ }^{308}$ teria salvado a psiquiatria de ser absorvida pela neurologia.

Em contraste com essa posição, em um artigo dos psicólogos Baumaister e Hawkins (2004) ${ }^{309}$, os mesmos consideram que as teorias neuroquímicas surgidas a partir dos anos 1950 "salvaram a psiquiatria de ser englobada pela psicologia”, o que poderia ter ocorrido, em virtude de seu paradigma psicanalítico anterior ${ }^{310}$.

\footnotetext{
${ }^{306}$ A expressão referente a um "novo modelo científico" baseado na dissecação de cadáveres, talvez seja imprecisa, já que esse tipo modelo começa nos séculos XVI e XVII, não sendo, portanto, novidade no início do século XX.

307 PONTE, C. F. Médicos, psicanalistas e loucos: uma contribuição à história da psicanálise no Brasil. Tese de Mestrado, Escola Nacional de Saúde Pública/Fiocruz, 1999. Em: $<$ http://portalteses.icict.fiocruz.br/pdf/FIOCRUZ/1999/pontecfm/capa.pdf.>

Acessado em 23 de julho de 2005.

308 Considera Castel que a própria psicanálise tem seus dispositivos de poder, de "seita", e que não existe nenhuma história real da psicanálise enquanto movimento social.

CASTEL, R. O Psicanalismo. Edições Graal, 1978.

309 BAUMEISTER, A.A.; HAWKINS, M.F. The Serotonin Hypothesis of Schizophrenia: A Historical Case Study on the Heuristic Value of Theory in Clinical Neuroscience. Journal of the History of Neurosciences, 13 (n. 3): 277-291, 2004.

310 O psiquiatra Régis, no prefácio de seu livro, de 1903, Précis de Psychiatrie, cita que na primeira edição, de 1884, de seu Manual Prático de Medicina Mental, a psiquiatria é uma parte isolada das ciências médicas, vivendo das descobertas clínicas da primeira metade do séc. XIX. Na segunda edição, de 1892, ele assinala que houve só algumas mudanças. No entanto, após 1893, ele aponta grandes inovações, que chama de "um movimento", que muda completamente "cette spécialité médicale". Aponta como defeitos dos tratados de psiquiatria, o fato de estudarem apenas as grandes loucuras dos asilos de alienados e não tratarem das psicoses sintomáticas, que ele chama de "delírios dos hospitais", aos quais atribui causas infecciosas e por intoxicações. Assim, diz que seu livro procura inserir a psiquiatria nas grandes doutrinas da patologia geral personificadas pelo prof. Bouchard. Diz que escreve sobre uma psiquiatria "francesa" que possa se destacar da estrangeira.
} 
Essas duas considerações colocam a psiquiatria em um meio caminho entre a neurologia e a psicologia, estando a psicanálise de um lado e as teorias organicistas de outro. Para alguns, a psiquiatria persiste como disciplina devido à psicanálise, para outros ela se individualiza em virtude de explicações organicistas. Talvez a coexistência entre esses diferentes aspectos da psiquiatria, aparentemente um tanto contraditórios, seja uma característica da própria disciplina.

Em nosso trabalho, veremos que a convivência entre psicanálise e medicina foi mais complexa do que se possa supor à primeira vista.

Quanto ao termo neuropsiquiatria (ou seja, um termo que engloba ambos os campos), paradoxalmente passa a ser mais usado após o estabelecimento das diferentes cadeiras em separado na década de 1930, do que antes disso. No período anterior a essa década, o termo “neuropatologia” preenche mais freqüentemente esse campo amplo comum. Assim, convivência e divergência entre essas áreas compõem um quadro complexo, de modo que ambas as tendências podem ter colaborado para o aprimoramento dessas disciplinas ${ }^{311}$.

Como já foi dito, a psicologia no Brasil ${ }^{312}$, no período estudado, de um modo geral, tem um caminho entre a filosofia e a pedagogia - junto a cursos ligados à área de ciências humanas -, enquanto que a psicologia médica fica mais próxima da psicologia experimental.

Em 1934, junto à Faculdade de Filosofia, Letras e Ciências Humanas da Universidade de São Paulo, a psicologia passa a ter certa configuração que caminha para uma área com suas características próprias, em campo de conhecimento intermediário entre ciências humanas de um lado e psiquiatria e neurologia de outro ${ }^{313}$.

RÉGIS, E. Précis de Psychiatrie. Collection Testut. Octave Doin, Éditeur, Paris, 1906, p. I-VI.

Queremos assinalar que há em seu livro um capítulo sobre "psicopatias nas doenças do sistema nervoso". Isso indica, ao mesmo tempo, uma distinção e uma intersecção entre esses dois grupos de moléstias, bem como também usa o termo "psicopatia", quando, até então, usava-se apenas o termo "neuropatia" em sentido amplo.

311 Feyerabend, citando Latour, acentua que as controvérsias promovem um desenvolvimento da ciência. Diz que os filósofos da biologia já suspeitavam que não havia uma entidade chamada ciência, com princípios definidos, mas que a ciência compreenderia diversidade de abordagens, podendo haver mesmo tendências contrárias entre si no mesmo campo científico.

FEYERABEND, P. Contra o Método. Editora Unesp, (1992), 2003, p. 12-13.

312 Quanto a isso ver:

MASSIMI, M. História da Psicologia Brasileira: da época colonial até 1934. E.P.U. , 1990.

MASSIMI, M. (org.). História da Psicologia Brasileira no Brasil do século XX. E.P.U., 2004.

313 O autor Dwelshauvers diz que "a psicologia é por si mesma uma ciência e não um anexo a outras ciências", e que em seu livro não tratou de "fisiologia do sistema nervoso", diferentemente dos primeiros tratados, como os de Wundt, ou de Watson e Warren. Diz que estes colocavam a psicologia como dependente da fisiologia. Cita o Tratado de Psicologia Experimental de Froebes como exemplo de obra 130 
No nosso levantamento, constatamos que proximidade e distanciamento entre as diferentes áreas estão presentes no período estudado, tendo sido mais complexos do que fazem supor posições que simplesmente antagonizem ou harmonizem os diferentes campos focados.

\section{6. - Intersecção com outras áreas científicas e com outros setores.}

A consolidação das disciplinas em questão ocorre concomitantemente a processos em outras áreas científicas médicas e não médicas, de modo que há uma intersecção entre as diferentes transformações e configurações de novos paradigmas, havendo interferências mútuas entre as áreas.

O período estudado é um tempo de intensas transformações, no Brasil e no mundo, na configuração da medicina como um campo profissional, seja no que diz respeito às inovações científicas, seja em relação à sociedade em geral - interessa-nos mais a sociedade brasileira e a paulista - e ao âmbito político, compreendendo a elaboração de normatizações e inserções em diferentes contextos.

Podemos ver, por exemplo, o complexo ambiente e as intersecções entre áreas nesse período, através de Juliano Moreira, que, como já dissemos, sendo da área de psiquiatria e moléstias nervosas, tem forte oposição á idéia de que a miscigenação leva á degenerescência do povo brasileiro; ao mesmo tempo, é favorável à promoção da eugenia e da higiene mental, mas sem o sentido racista, e sim de promoção da saúde e da educação.

Além disso, conforme nosso levantamento, nesse período cursos de clínica médica abordam temas neurológicos, entremeados entre outros temas. Médicos de várias áreas escrevem sobre temas neurológicos, psicológicos e psiquiátricos.

Na virada dos séculos XIX e XX, há certa centralidade do cérebro e do sistema nervoso em relação ao entendimento do organismo, levando a uma generalidade no trato de alguns temas referentes a esse sistema. Essa centralidade pode se dever à teoria do

que não usa a fisiologia. Acha que conhecimento de fisiologia é indispensável à psicologia, mas, mesmo assim, decidiu não incluir um capítulo de fisiologia.

DWELSHAUVERS, G. Traité de Psychologie. Payot, Paris, 1928. 
neurônio e ao grande conhecimento do sistema nervoso, nesse momento, se comparado às noções a respeito de outros sistemas.

Além dessas interfaces com outros campos científicos e sociais, também há uma influência mútua entre psiquiatria, psicologia e o mundo das artes ${ }^{314}$, principalmente a partir da psicanálise e da doutrina de Freud, à qual os participantes da Semana de Arte Moderna de 1922 aderem enfaticamente ${ }^{315}$.

Um exemplo específico do encontro entre psiquiatria e as artes, que não é muito conhecido, diz respeito ao texto escrito por Franco da Rocha intitulado $A$ Psicologia do Boato, publicado no jornal O Estado de São Paulo, em 1920, estimulado pelo livro A Pulseira de Ferro de Amadeu Amaral, que foi usado em aulas de psiquiatria. Esse texto é publicado como prefácio desse mesmo livro de Amadeu Amaral $^{316}$, por Paulo Duarte, nos anos 1970, quando relança as obras desse escritor. Franco da Rocha usa a literatura em suas aulas, e considera esse livro interessante para servir de exemplo da psicologia do boato. Após correspondência com Amadeu Amaral, Franco da Rocha escreve esse texto, onde cita vários estudiosos de psicologia, entre eles Freud, Jung, Tarde, Sergi, Bergson.

314 Em outros países essa intersecção também ocorre. Em 1906 é defendida, em Paris, a tese “A Patologia Mental nas obras de Gustave Flaubert” de Philibert de Lastic, influenciada por trabalho anterior de Dumesnil sob semelhante título. O autor analisa tanto a obra quanto o próprio escritor à luz de estudiosos franceses, principalmente Janet, Ribot e Régís. Deste último autor, De Lastic faz alusão ao termo "cinematográficas" como forma de designar certas alucinações, onde se vê o uso de uma palavra, e seu referente, passando do campo artístico para o campo científico.

DE LASTIC, P. La pathologie Mentale dans les oevres de Gustave Flaubert. Thèse pour le Doctorat en Médecine. Librairie J. -B. Baillière et Fils, 1906.

Também, nesse período, a estreita convivência de Proust com os renomados neurologistas franceses, influencia sua obra "Em busca do tempo perdido".

BOGOUSSLAVSKY, J. Marcel’s Proust life long tour of the Parisian Neurological intelligentsia: From Brissaud and Dejerine to Solier and Babinski. European Neurology, 57: 129-136, 2007.

${ }^{315}$ OLIVEIRA, C.L.M.V. História da Psicanálise: São Paulo: 1920-1969. Editora Escuta, Fapesp, 2006. 316 Amadeu Amaral (1875-1929) é escritor paulista com atividade em jornalismo, literatura, com prosa e poesia, investigações de folclore e de lingüística. Um de seus livros mais conhecidos é “O dialeto caipira”. Faz parte do que se chama de caboclismo, que é uma das facetas da pregação patriótica surgida na segunda metade dos anos 1910. Juntamente com Julio de Mesquita Filho, Monteiro Lobato e outros intelectuais, estudantes e políticos, em 1915, participa da criação da Liga Nacionalista, que alimenta um sentimento nativista com a idéia de pesquisar fontes de regeneração da vida nacional na tradição, na história e na cultura popular rural, como antídoto ao cosmopolitismo exacerbado, "ao vício do homem urbano de copiar padrões culturais das nações decadentes”. Amaral é um tanto contrário aos sentimentalismos que, a seu ver, persistem no romantismo regionalista; assim ele "firmou-se no cenário paulista como um dos principais expoentes do novo espírito científico, oferecendo ao público uma obra pautada por análises etnológicas, histórico-lingüisticas e sociológicas”, mesmo em sua obra ficcional. Sua simpatia pelo caipira impregna seus textos, como certo lamento pela perda da tradição. Ele também participa do Instituto Histórico e Geográfico de S. Paulo e da Academia Paulista de Letras.

FERREIRA, A.C. A epopéia bandeirante: letrados, instituições, invenção histórica (1870-1940). Editora Unesp, 2001. 
Outra correlação entre psiquiatria e artes é a sugerida por alguns entre uma provável convivência entre Teixeira Brandão e Machado de Assis, que pode ter influenciado a elaboração da obra $O$ Alienista, pois o escritor pode ter conhecido os reclamos, a respeito das condições do Hospício do Rio de Janeiro, feitos pelo psiquiatra. Embora essa obra de Machado seja de 1882 e escrita no Rio de Janeiro, ou seja, fora dos limites do enfoque do nosso trabalho, ela tem conexões com nosso tema, pela própria convivência de Franco da Rocha com Teixeira Brandão. Ainda sobre O Alienista, há que se lembrar também da atitude de distância de Machado, em relação ao entusiasmo da “geração de 1870” pela ciência, em especial pela ciência darwinista e spenceriana e seus conceitos sociais de pendor racista ${ }^{317}$.

Alguns supõem que a figura do alienista Simão Bacamarte é inspirada em José da Cruz Jobim, um dos primeiros médicos do Hospício Pedro $\mathrm{II}^{318}$, também político e com posição tida como muito conservadora, tendo havido um episódio conflituoso entre ele e os estudantes de Direito da Faculdade de S. Francisco.

Essa figura também pode ter sido delineada de forma caricata, talvez pelo fato do escritor sofrer de epilepsia e, ilustrado como era, perceber-se “classificado" entre os demais insanos. $\mathrm{O}$ alienista desse conto, que acaba asilando toda uma cidade, tem sido usado como uma figura emblemática dos psiquiatras criadores de hospícios como “depósitos de loucos”.

No entanto, as interpretações feitas por diversos trabalhos, a respeito das instituições psiquiátricas, do período a ser abrangido neste estudo - ou seja, 1889 a 1936 - têm sido feitas através de imagens construídas em períodos após estes anos, ou até mesmo reforçadas pela imagem criada por Machado de Assis antes desse período.

No transcorrer da Primeira República, as instituições psiquiátricas têm configurações mais organizadas, se comparadas com o período monárquico, ou com o período posterior à época de nosso estudo. Ampliando, podemos dizer que o entendimento de psiquiatria, neurologia e psicologia, em seus diversos aspectos, no período 1889-1936, tem sido moldado em elementos anteriores e posteriores a esse próprio período ${ }^{319}$.

317 MISKOLCI, R. Machado de Assis, o outsider estabelecido. Sociologias, 15: 352-377, 2006.

318 PICCININI, W. J. Voando sobre a História da Psiquiatria. Psychiatry on Line Brazil, 2000. Disponível em:< http://priory.com/psych/wal0800.htm>. Acessado em 30 de março de 2005.

319 Para assinalar a diferença entre a situação dos pacientes psiquiátricos durante o período enfocado por nosso trabalho e após esse período, fazemos uma citação da psiquiatra Lygia Maria de França Pereira: 133 
Nesse sentido, de um melhor entendimento do Juquery nesses anos, bem como da interação entre esses campos e as artes, pode ser útil o enfoque da figura de Osório César e sua obra, em especial seu livro A expressão artística nos alienados: contribuição para o estudo dos symbolos na arte, de 1929.

\section{7 - Osório César e sua obra, interface entre psiquiatria e arte:}

um outro retrato do Juquery.

Osório Thaumaturgo César nasceu em 1895, em João Pessoa, Paraíba. Chega a São Paulo com 17 anos, onde estuda odontologia. Na ocasião, para se sustentar, dá aulas de violino. Começa a estudar medicina em 1918, no curso de medicina ministrado junto à Escola de Farmácia, na então chamada Universidade de São Paulo. Com a extinção desse curso, ele transfere-se para a Faculdade de Medicina da Praia Vermelha, no Rio, em 1920. Forma-se em 1925, aos trinta anos de idade, fixando-se na área de anatomia patológica. Antes disso, em 1923, já é interno no Hospital do Juquery. Nesse local, em 1925, é oficialmente contratado como médico, e assim permanece por quarenta anos ${ }^{320}$.

César lança, em 1919, o livro Doutrinas Biologicas (ainda quando estudante), dedicado ao argentino Ingegnieros e prefaciado por Ulysses Paranhos. Em 1922, lança os trabalhos A chimica da vida e Dois ensaios, sendo que, neste último, faz correlação entre reações de albuminas e funções psíquicas. Em 1927, em parceria com J. Penido Monteiro, escreve Contribuição ao Estudo do Simbolismo Mystico nos Alienados: um Caso de Demencia Precoce Paranoide num Antigo Escultor, obra que alguns indicam que talvez tenha sido traduzida para francês e alemão. Em 1929, lança a obra sobre a arte dos alienados. Nesse período freqüenta o meio intectual paulista e círculos interessados em psicanálise ${ }^{321}$.

\footnotetext{
"Marcado pela política assistencialista do Estado Novo - segundo a qual os doentes mentais perambulantes deveriam ser recolhidos aos hospitais psiquiátricos e ficava proibido manter quaisquer insanos em cadeias públicas - o Juquery passa a enfrentar o drama da superlotação crescente. Sua população internada quase duplica entre 1938 e 1939”. A autora acrescenta, em nota, que o complexo do Juquery teve, entre 1927 e 1938, 1840 internos; em 1939 o número passou para 3325 doentes.

PEREIRA, L.M.F. Os primeiros sessenta anos da terapêutica psiquiátrica no Estado de São Paulo. In: ANTUNES, E.H.; BARBOSA, L.H.S.; PEREIRA, L.M.F.,Psiquiatria, Loucura e Arte, Edusp, 2002, p. 43.

320 ANDRIOLO, A. A Psicologia da Arte no olhar de Osório César: leituras e escritos. Psicologia, Ciência e Profissão, 23 (4): 74-81, 2003.

321 Idem. 
Nos anos 1930, Cesar estuda em Paris, Alemanha, Itália e União Soviética, tendo participado de um Congresso de Psiquiatria sob a presidência de Pavlov. Na ocasião, é acompanhado por Tarsila do Amaral, então sua companheira. Cesar tem grande afinidade pelo marxismo, sendo que, em 1933, publica dois livros sobre o Estado Proletário, um ano após o retorno de sua viagem à União Soviética. Por isso, é preso pelo governo de Getúlio Vargas ${ }^{322}$.

Em 1933, participa da exposição organizada por Flávio de Carvalho, no Clube dos Artistas Modernos, chamada Semana dos Loucos e das Crianças, com a palestra intitulada Estudo Comparativo Entre a Arte de Vanguarda e a Arte dos Alienados. Organiza a I Exposição de Arte do Hospital do Juqueri, em 1948, no Museu de Arte de São Paulo, com obras dos doentes. A partir da criação da Seção de Pintura do Juqueri em 1949, essa seção e a Associação de Assistência aos Psicopatas de São Paulo promovem exposições na capital e no interior. Em 1950, apresenta sua coleção de obras em Paris, na Exposição de Arte Psicopatológica, do I Congresso Internacional de Psiquiatria; na ocasião apresenta o texto Contribuição ao Estudo da Arte entre os Alienados. Em 1952 é convidado, pela Maison National de Chareton, para ir a Paris estudar Psiquiatria Social, onde ministra a palestra Arte em Psicopatologia, na Sociedade Médico-Psicológica ${ }^{323}$.

Osório César promove reuniões em sua residência com músicos e pintores, quando, a partir da música, os pintores fazem certas produções. Desse ambiente participam: Walter Levy, Aldo Bonadei, Mário Zanini, Carlos Scliar, Gastão Worms, Durval Serra, entre outros. A música ouvida é principalmente de Beethoven, Prokoffief e Stravinsky. Osório César morre em $1986^{324}$.

Observa-se que Osório César concilia sua formação em anatomia patológica com sua adesão á psicanálise, além de seu conhecimento em arte, dando uma idéia de um ambiente complexo emn torno das áreas de psiquiatria, psicologia e neurologia no período abordado.

322 Ibidem.

324 ANDRIOLO, A. A Psicologia da Arte no olhar de Osório César: leituras e escritos. Psicologia, Ciência e Profissão, 23 (4): 74-81, 2003. 
A obra de Osório César A expressão artistica nos alienados: contribuição para o estudo dos symbolos na arte ${ }^{325}$, de 1929, é bastante ilustrativa de diversos aspectos em torno das áreas enfocadas, na década de 1920, em São Paulo.

O prefácio desse livro é escrito por Motta Filho, que se identifica como artista e estudioso.

Esse prefácio e o texto de Osório César transmitem um clima e um ambiente do hospício, um tanto diferente daquele que depois delineia o Juquery como uma espécie de casa de horrores. Podemos notar até mesmo pelos dados biográficos de Osório César que, mesmo em período posterior ao de nosso trabalho, ele mantém atividades artísticas com os pacientes do Hospital.

No prefácio, datado de 1927, Motta Filho cita um diálogo que teve com um dos internados, em uma de suas visitas ao Juquery, que lhe perguntou se estava chegando para ser internado e depois disse: "Me desculpe; aqui não se distingue o louco do homem são. E, entre os medicos, ha mais loucos de que entre os loucos”326.

Motta Filho diz ter ficado com uma “impressão desnorteante” dos insanos, vendo "um fundo commum com todos nós" nos pacientes e recorda-se da frase que dizia que “em cada um de nós há um louco adormecido”.

Após elogiar o trabalho de Osório César, Motta Filho cita que Machado de Assis, que tinha ataques epilépticos, vivia a despertar dentro de si o homem e o louco e criou a figura delirante de Quincas Borba e do Alienista onde ironicamente apagava a linha divisória entre anormalidade e a loucura.

A seguir, o autor do prefácio diz que:

“A arte nos alienados, como estuda carinhosamente Osório César, é a revelação maravilhosa de que a humanidade, em sua proteiforme manifestação, é sempre inexoravelmente a mesma. A arte é então a grande unificadora da espiritualidade humana. Ella parte da profundidade do inconsciente e, descarregando a angustia que enche o nosso peito de homem civilisado, de homem equilibrado, faz rebrotar em nós aquillo que fomos, aquillo que as conveniencias do momento recalcam - a crença, o primitivo, o selvagem. $O$ alienado, não possuindo o freio da normalidade, torna-se um ser á parte por isso mesmo, mas na arte, na arte que é a libertação para Goethe, que é a unica flôr para Schopenhauer - ele é tão humano, tão artista, como todos os homens, como todos os artistas”327.

325 CESAR, O. A expressão artística nos alienados: contribuição para o estudo dos symbolos na arte. Gráfica do Hospital do Juquery, São Paulo, 1929.

326 MOTTA FILHO, Prefacio. In: CESAR, O., A expressão artística nos alienados: contribuição para o estudo dos symbolos na arte. Gráfica do Hospital do Juquery, São Paulo, 1929, p. XVII.

327 Idem, p. XVIII. 
Em seguida, Motta Filho menciona grandes artistas como sendo também loucos, citando a atribuição de cada um inerente à loucura. Assim, menciona Dante, Homero, Milton, Cervantes, Camões, Dostoiewski, Balzac, Maupassant, além da geração de artistas do século XIX, segundo ele, tidos como loucos para a "psychologia morbida de Grasset”.

O autor do prefácio continua, dizendo que se quiséssemos “fazer psychologia fácil, popular, escandalosa, acabaríamos por affirmar que todo artista é um louco”328.

Por essa afirmação, percebe-se que há, então, nesse período, um determinado tipo de psicologia tida como popular, fácil e escandalosa. Portanto, não há apenas a psicologia dos estudiosos, dos cientistas, ou dos eruditos.

Em seguida, Motta Filho explana que "nem todo artista é louco, como nem todo louco é artista”329. O que ele considera haver é o que chama de fundo comum: “o espírito artístico que sempre se manifesta no homem”330. Assim, ele considera que esse espírito "nasce nas camadas profundas de seu inconsciente e transvasa para a vida como que avelludando a estrada daquelles que nasceram com o dom de não compreenderem a harmonia tranquilla da vida medíocre”331.

Observamos, assim, que Motta Filho faz menção ao inconsciente como depositário desse espírito artístico também compartilhado pelo louco. Além disso, sua referência é elogiosa a uma espécie de inadequação ao que chama de vida medíocre. Ele acentua de tal modo esse aspecto do louco, que compara os insanos a Michelangelo:

“Aquelle velho paranoico que faz no hospicio versos rythmados e bellos; aquelle pobre pintor mystico; aquelle pobre demente precoce catatonico que faz desenhos quasi como sente e pensa, - são todos elles possuidores daquella mesmíssima emoção, daquelle mesmíssimo sentimento que fez com que Miguel Angelo ferisse com o seu camartello os joelhos estylizados de seu formidavel Moyzés”332.

Após considerações sobre a dificuldade de conceituar a arte, Motta Filho relata que Osório César serve-se da psicanálise para estudar a expressão artística nos alienados. Assim, o autor do prefácio acrescenta que "Freud veio, com o seu methodo,

\section{Ibidem.}

329 Ibidem.

330 Idem, p. XVIII e XIX.

331 Idem, p. XIX.

332 CESAR, O. A expressão artística nos alienados: contribuição para o estudo dos symbolos na arte. Gráfica do Hospital do Juquery, São Paulo, 1929, p. 19. 
esclarecer uma serie de pontos escuros da Psychologia. Abriu o inconsciente fechado, de há muito, a sete chaves”333.

A seguir, Motta Filho acrescenta que: "Mas o grande medico austríaco não está bem conhecido entre nós. Espanta os rotineiros e é explorado pelos pedantes das novidades livrescas”334.

Essa afirmação dá idéia da polêmica em torno de Freud no período, de modo que, quando ele diz que Freud não é bem conhecido, ele provavelmente se refere à falta de conhecimento em profundidade da doutrina freudiana.

Ao falar do estudo de Osório César pela doutrina de Freud, Motta Filho tece elogios a ambos:

"Entretanto, por este trabalho de Osório César podemos, desde logo, avaliar a grandiosidade da conquista scientifica feita por Freud. No estudo das manifestações estheticas dos alienados, dirigido por um rigor custoso e paciente de um verdadeiro psychanalista que comprehendeu bem a theoria freudiana em todas as suas formas, - nós encontramos, evidenciando-se, como um resultado de analyse chimica, o factor inconsciente na vida affectiva e emocional da arte”335.

A seguir, Motta Filho continua tecendo elogios ao trabalho de Freud, por ter trazido o inconsciente para uma "realidade objectiva"336, deixando de ser apenas uma categoria filosófica. O autor do prefácio acentua que Freud fixou "a mechanica do espirito pelo estudo das nevroses e pela observação dos sonhos”.

Nessa explanação, observamos um indício de que, com Freud, as nevroses passaram definitivamente do território da neurologia para a psiquiatria e psicologia, na medida em que se passou a dizer que ele estabeleceu a mecânica, o funcionamento do espírito pelo estudo das nevroses.

Ao referir-se ao recalcamento cotidiano do inconsciente, que se superficializa nos sonhos e na arte, Motta Filho considera que “a arte é um sonho acordado”,337. Assim ele dispõe a arte em relação a esse foco de estudo freudiano correspondente ao sonho.

Ao encerrar o prefácio, Motta Filho novamente dá indícios da polêmica em torno da psicanálise:

\section{Ibidem.}

334 Ibidem.

335 MOTTA FILHO, Prefacio. In: CESAR, O., A expressão artística nos alienados: contribuição para o estudo dos symbolos na arte. Gráfica do Hospital do Juquery, São Paulo, 1929, p. XIX e XX.

336 Idem, p. XX.

337 CESAR, O. A expressão artística nos alienados: contribuição para o estudo dos symbolos na arte. Gráfica do Hospital do Juquery, São Paulo, 1929, p. 20. 
"Mas, em se tratando da psychanalise, estou certo de que Osorio Cesar vae enfrentar a hostilidade do scientificismo dominante. Levará 'bordoadas' como se diz na giria. E eu, que prasenteiramente o acompanho, faço votos para que dessa luta o seu nome ganhe a victoria que tanto merece a sua honesta cultura e o seu formoso talento"338.

Apesar dessas "bordoadas" citadas por Motta Filho, devemos lembrar que o próprio Osório César tem formação científica sólida em anatomia patológica, e devemos atentar também para que essa obra, que faz uso da psicanálise, foi realizada no Hospital do Juquery, com a anuência de seu diretor, costumeiramente tido como avesso a essa doutrina.

Na introdução a esse livro, a qual Osório César chama de Advertencia ${ }^{339}$, datada de Abril de 1929, ele refere ser essa obra decorrente do esforço de 6 anos de “trabalho estafante”. Diz, então, que desde quando começou como interno no Juquery, primitivos e a das crianças”. Ele diz ter tido essa idéia a partir de um livro alemão e um livro francês que tratam desse assunto.

No começo teve dificuldades, que atribuiu à "litteratura escassa entre nós, falta de Museu artistico no Hospital e principalmente carencia de solido conhecimento da matéria que iamos estudar”340. César refere que algumas dificuldades foram vencidas “graças á bondade e á ajuda de dois grandes amigos, a quem devemos a realização deste trabalho: - Dr. Antonio Carlos Pacheco e Silva, jovens cientista, director do Hospital do Juquery, e Dr. Alarico Silveira, erudito profundo, que tudo sabe e ensina”341.

Ele então refere que foi organizado o Museu com peças e trabalhos dos doentes do Juquery e foram procuradas revistas nacionais, estrangeiras, bem como foram comprados livros de outros países, principalmente da Alemanha, que versam sobre arte e loucura.

César explica a orientação de seu trabalho: quando se tratam de "artistas do Juquery”, é transcrita a história psiquiátrica do paciente e faz-se uma análise de sua obra. Em casos interessantes, principalmente em "casos de demencia precoce com desenhos symbolicos”342, refere ter aplicado “a psychanalyse de Freud, tal como o fez

\section{Idem.}

339 Idem, p. XXI.

340 Ibidem.

341 CESAR, O. A expressão artística nos alienados: contribuição para o estudo dos symbolos na arte. Gráfica do Hospital do Juquery, São Paulo, 1929, p. XXI.

342 Idem. 
na Allemanha Morgenthaler, no seu curioso livro Ein 'Geisteskranker als Künstler’ e como já fizemos nós em trabalhos anteriores, publicados em collaboração”343.

Ele dá, então, informação sobre essas suas outras publicações. Uma é de 1927, juntamente com J. Penido Monteiro, este como segundo autor, intitulada Contribuição ao estudo do symbolismo mystico nos alienados. Outra foi juntamente com Durval Marcondes, este como primeiro autor, intitulada Sobre dois casos de estereotypia graphica com symbolismo sexual, publicada em Memorias do Hospital do Juquery (números 3 e 4, conforme citado).

No fim de sua advertência, Osório César agradece ao prof. Roquette Pinto, diretor do Museu Nacional do Rio de Janeiro e a seu assistente Dr. Raimundo Lopes, pelo auxílio na consulta às coleções de peças dos índios do Brasil e dos negros ${ }^{344}$.

No primeiro capítulo intitulado A expressão artistica nos alienados, o autor dá algumas indicações, em um preâmbulo, a respeito do que vai tratar. Desse modo, referese a "falso conceito na apreciação da loucura”345, e também à “interpretação exacta da psychologia dos alienados” ${ }^{346}$. Assim, ele aponta que, quem não conhece um hospício, tem idéia errônea do que lá se passa:

“Quase toda gente pensa que um Hospicio é logar fechado onde passam a vida inteira os pobres doentes do espirito sem nada dizer, sem nada fazer, que não sejam cousas desassisadas.

Falar de um louco, dizia Esquirol, é, para o vulgo, falar de um homem que aprecia mal as suas relações com o mundo exterior, a sua posição e o seu estado; que se entrega aos actos mais desordenados, mais extravagantes, mais violentos, sem motivo, sem combinações previas, sem premeditação.

Este conceito, felizmente, não é de todo verdadeiro. Quem entrar n'um manicomio e procurar conversar attentamente com os doentes, ouvir com interesse as suas queixas, as suas curiosas historias, notará, certamente, que entre uma grande parte d'elles, o raciocínio é logico, a linguagem é correcta e a imaginação, por vezes, é exuberante»347.

Cesar passa então a citar um conceito de alienado (que cita como sendo do autor francês Voivonel, de 1927): “é um doente cujas perturbações do espirito são um obstaculo, transitorio ou permanente, á sua adaptação á sociedade na qual elle deve

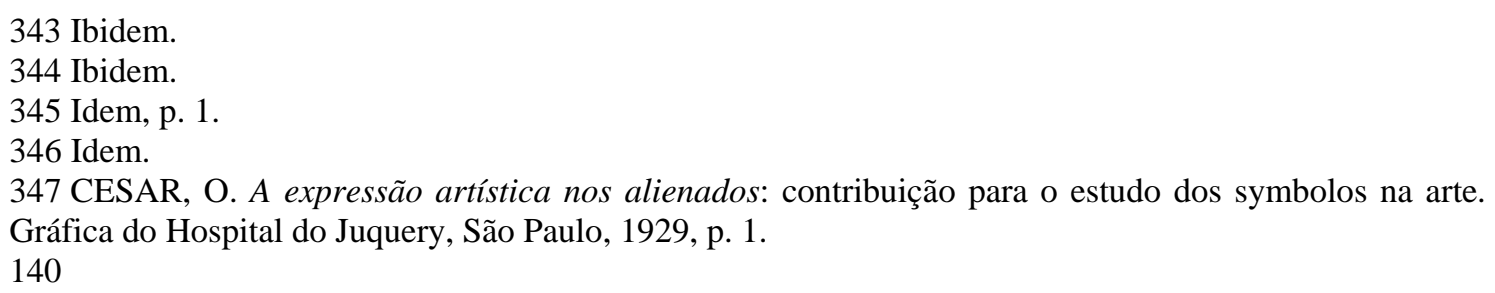


viver”348. Mas, nesse ponto o autor chama a atenção para o fato de que nem todo alienado é o que uma parte do povo julga ser:

“... um pobre ente humano desprovido de actividade psychica normal e que passa a vida inteira dizendo tolices sem poder se occupar em coisas uteis á communidade. Não, isto é uma falsa idéia. $O$ alienado, como a experiencia demonstra, é um doente que, submettido a um regimen moderado de trabalho, auxiliado com um tratamento carinhoso dos medicos, enfermeiros e ajudantes, é capaz de um esforço util e productivo”349.

A seguir, César cita o que considera como experiência de eficácia sobejamente conhecida, que diz respeito aos “Asylos Colonias”350, onde se usa o trabalho moderado, segundo ele, com ótimos resultados. Assim, relata texto de Franco da Rocha, de 1912, em favor dessa forma de tratamento. Depois, usando o nome de “ergotherapia”351, ele se refere a essa mesma atividade, vista por Pacheco e Silva na Europa e nos Estados Unidos.

Depois, o autor passa a se referir a poetas, desenhistas, escultores e outros artistas encontrados nos manicômios, e se diz admirado com concepções filosóficas, literárias ou plásticas surpreendentes.

Relata depois estudos feitos a esse respeito desde 1876, por diversos autores.

César coloca, então, um Quadro da Classificação das Artes nos Alienados ${ }^{352}$, baseado, segundo ele, em uma ordem cronológica, de acordo com a evolução das artes. Assim, delimita quatro grupos: arte do primitivo; arte primitiva; arte clássica; arte de vanguarda. Em seguida, faz uma série de considerações a respeito desses grupos, citando outros estudiosos e fazendo correlação com a arte das crianças (de outros autores e do Juquery) e de povos, assim chamados, primitivos (há no livro várias fotos de trabalhos de pacientes e dos “primitivos”), incluindo narrativas literárias e música, citando também exemplos de pacientes do Juquery ${ }^{353}$. Acrescenta o que chama de interpretação psicanalítica das obras, citando autores, como Freud, Jung e outros, chamado atenção para alguns símbolos sexuais.

348 Idem.

349 Idem, p. 1 e 2.

350 Idem, p. 2.

351 Idem, p. 2 e 3.

352 CESAR, O. A expressão artística nos alienados: contribuição para o estudo dos symbolos na arte. Gráfica do Hospital do Juquery, São Paulo, 1929, p. 6.

353 Em um desses exemplos, à página 25, o autor descreve itens do exame neurológico e do exame clínico, antes de passar ao exame mental. 
No capítulo dois, Osório César aborda mais de perto alguns artistas do manicômio, entre os tais um que ele considera como sendo um escultor cubista. Ao comentar a respeito da obra desse paciente, faz comparações com outras obras e referese aos estudos de Charcot e Richer sobre a arte como forma de registrar doenças e deformações (de 1889). O autor chama a atenção dos leitores para que não se assustem com o fato de ele ter classificado como beleza essa obra de arte. Frisa que a concepção de beleza tem mudado, em comparação com anos antes, e que a arte para ser genial precisa ser livre. Procura delinear como se forma a imagem na mente do artista. Compara a estética futurista com a estética da arte dos manicômios, frisando não querer com isso fazer objeção a essas artes, e considerando-as interessantes. Faz comentários sobre Picasso, sobre outros artistas e sobre outros estudiosos.

De modo geral, seu entendimento sobre o processo psicológico dessas formas de arte gira em torno de espontaneidade, de contatos com aspectos que ele chama de primitivos em relação a períodos de evolução da humanidade, e também bastante ligados a aspectos emocionais. $\mathrm{O}$ autor também entende o desenvolvimento artístico de cada indivíduo como sendo um retrospecto do desenvolvimento da humanidade, de modo que a arte das crianças é similar à arte dos primitivos.

Em seguida, passa a comentar alguns símbolos nas artes, fazendo várias comparações, referindo-se também aos “graffittis”,354 em murais, bem como a bonecas construídas pelas pacientes, comparando com bonecos indígenas.

Sobre a tatuagem, ele informa que há apenas cinco pacientes tatuados no Juquery, todos de nacionalidade síria. Cita que Lombroso considera todo homem tatuado como criminoso e que, para esse autor, a tatuagem na infância é um sinal precoce de criminalidade. Cesar acrescenta que, modernamente, esse ponto de vista passou a ser combatido. No entanto, ele mesmo nota que, entre os criminosos, há grande número de tatuados. Lembra o sentido iniciático da tatuagem para certas organizações criminosas, e que entre os primitivos representava uma forma de beleza.

A respeito da música, ele acha que é a forma de arte que mais se conserva equilibrada no cérebro do alienado. Discorda dos estudiosos que consideram os esquizofrênicos como não tendo sensibilidade musical; para reforçar sua opinião cita

354 CESAR, O. A expressão artística nos alienados: contribuição para o estudo dos symbolos na arte. Gráfica do Hospital do Juquery, São Paulo, 1929, p. 48. 
casos do Juquery. Nesse sentido, inclusive cita a “Charanga Hebephrenica”355, que é um grupo de 15 pacientes músicos regidos por um parafrênico, que fica horas e horas ensaiando "sem uma queixa" 356 . O autor frisa a capacidade de um doente compositor, que escreve corretamente suas composições.

Sobre a dança entre os doentes mentais, César refere que tem um ritmo primitivo, frequentemente acompanhada de canto. O autor cita Ribot ${ }^{357}$, que atribui à dança primitiva uma significação sexual, guerreira, ou religiosa.

No capítulo três, César discute a conceituação de demência precoce, dando a entender que esse é um debate em curso, no momento em que escreve o livro. Lembra que a demência precoce foi estudada inicialmente por Morel em 1858 e depois teve seu conhecimento “desenvolvido extraordinariamente" ${ }^{358}$ por Kraepelin. Acrescenta a concepção de 1911, do psiquiatra português Júlio de Mattos:

"É uma psychose constitucional caracterizada por uma desagregação das funç̧ões affectivomotoras e inttelectuaes, sobrevindo, em regra, na adolescencia ou na juventude e tendo por termo, para a qual caminha atravez de episodios allucinatorios e delirantes, uma irreparavel fallencia mental”359.

A seguir, César cita várias sinonímias dessa moléstia, entre elas a esquizofrenia. No transcorrer de seu texto, o autor usa ora demência precoce, ora esquizofrenia, citando alguns autores, dando a impressão de uma transição entre o uso desses termos. Lembra também que sintomas similares a esse quadro podem ser vistos também em moléstias sabidamente orgânicas. Assim, há um debate sobre a demência precoce, ou esquizofrenia, ser mais uma síndrome do que uma moléstia.

Depois, relata uma “autobiografia” ${ }^{360}$, de um paciente com esse quadro, do Hospital do Juquery, escrita em francês pelo próprio paciente, e com evidentes delírios de grandeza. Referindo-se ao mundo fantástico, de sonhos, desses pacientes, o autor

355 Idem, p. 53. Na pág. 55 chama de Charanga do Juquery.

356 Idem.

${ }^{357}$ Théodule Ribot (1839-1936), filósofo de formação, orientou-se para a psicologia com o projeto de fazer dela uma disciplina independente. Empenha-se em uma psicologia objetiva, apoiando-se na observação precisa dos fatos. Sente-se próximo da psicologia inglesa de Spencer e da psicologia alemã, além de remeter-se a Claude Bernard.

BRAUNSTEIN, J. F.; PEWZNER, E. História da Psicologia. Instituto Piaget, 2003.

358 Idem, p. 58.

Osório César, tal qual seus contemporâneos, refere-se a Kraepelin com palavras entusiásticas. No mesmo parágrafo, ele diz que Roxo considera essa "uma das mais belas concep̧̧ões” de Kraepelin, fazendo eco também a todo esse entusiasmo pelo estudioso alemão.

359 CESAR, O. A expressão artística nos alienados: contribuição para o estudo dos symbolos na arte. Gráfica do Hospital do Juquery, São Paulo, 1929, p. 58.

360 Idem, p. 62, 63. 
lembra o conceito de “autismo” ${ }^{361}$ do prof. Bleuler, que se aplica a essa situação. César cita Ribot, que considera uma alternância no indivíduo normal entre "autismo" e percepção do mundo exterior, sendo que, nesse caso, o indivíduo é capaz de distinguir entre vida imaginária e interior, e vida real e exterior. No alienado, desaparece a distinção entre os dois mundos. Como exemplos de situações em que isso ocorre, César cita a demência precoce, a parafrenia e a paralisia geral.

A seguir, cita alguns casos e a sua respectiva interpretação psicanalítica. Seu entendimento da arte produzida por pacientes acometidos desses processos é de que há “uma regressão atavica ás épocas pre-historicas da humanidade” ${ }^{362}$. Após apresentar alguns casos, César considera a arte futurista “positivamente uma arte eschizophrenica”; diz que os artistas futuristas não são alienados, mas têm temperamentos esquizofrênicos $^{363}$. Depois cita outros casos, analisando o conteúdo de símbolos sexuais em algumas situações.

No capítulo quatro, o autor refere-se às parafrenias, a poetas parafrênicos e poesia mística. O autor se ateve à conceituação de parafrenia de Kraepelin, considerando esse grupo bem definido e diferenciado da esquizofrenia. Na parafrenia não há modificação da personalidade, nem perda da afetividade e nem da iniciativa. Assim, conforme Cesar, Kraepelin admite quatro tipos de parafrenia: sistemática, expansiva, confabulatória e fantástica. A parafrenia sistemática se caracteriza por delírio de perseguição e delírio de grandeza mais tardiamente. A parafrenia expansiva têm delírio de grandeza com euforia e idéias eróticas. Na parafrenia confabulatória há baixo nível intelectual e delírio com ilusões de memória e alucinações. Na parafrenia fantástica, o indivíduo diz ter falado com animais ou com seres fantásticos, com alucinações e delírio de perseguição. Conforme César, a forma expansiva é mais rica em símbolos para o estudo psicanalítico. Nos hospícios os poetas parafrênicos são muito comuns. A seguir o autor apresenta alguns exemplos.

361 Idem, p. 63. Esse conceito de autismo, conforme citação de Osório César, consta do Tratado de Psiquiatria de Bleuler, de 1924, não correspondendo exatamente ao significado que autismo passa a ter posteriormente.

362 Idem, p. 66.

363 Aqui o autor cita a divisão que Bleuler faz dos indivíduos normais em "sintonistas" e "esquizoides", diferenciando um do outro pela faculdade, destes últimos, de perder contato com o meio. Idem, p. 74. 
No capítulo cinco ${ }^{364}$ o autor comenta como os antigos consideravam a inspiração poética, e os delírios como de origem ligada aos deuses. Acrescenta classificações de outros autores a respeito da arte nos alienados.

Assim, relata os delírios de origem celeste descritos por Platão. Acentua que os loucos e os gênios se confundem num mesmo furor, num mesmo delírio. Ele repete uma frase de Platão: “O poeta é cousa subtil, instavel e sagrada; elle jamais cantará sem a intervenção de um transporte divino, sem um doce furor”365. De Platão, também relata que este considerava o delírio mais como um bem do que um mal, principalmente quando enviado pelos deuses.

Conforme César, Aristóteles achava que, em acessos de congestão cerebral, diversas pessoas se tornavam poetas, profetas e sibilas. Ainda, de Aristóteles, cita a idéia de que filósofos, sábios e poetas eram "biliosos", ou seja, neuropatas, hipocondríacos, melancólicos ${ }^{366}$.

O autor também comenta que, na antiguidade, “o conceito de que os alienados possuíam uma sobrenatural intelligencia foi admitido como uma verdade irrefutavel”367. Cita Areteu da Capadócia, Molière, Shelley, Max Jacob, etc.

César apresenta a classificação de M. Pailhas para a arte dos alienados, que subdivide conforme os tipos de moléstia, em cinco subgrupos. Do autor Reja, apresenta uma classificação em três subgrupos, conforme o tipo de arte produzida.

A seguir são apresentados exemplos do Juquery e do estudioso Reja. Um dos poemas produzidos por um paciente desse estudioso foi comparado com o Poema Abulico de Mário de Andrade, que foi reproduzido por Osório César.

No capítulo seis, Osório César apresenta vários conceitos de paranóia.

De Lombroso, em relação à paranóia, lembra o termo mattoide, que esse autor usa para designar indivíduos comuns que apresentam semelhança com os gênios e que são uma transição entre estes, os loucos e os indivíduos normais. Assim também, refere que Maudsley nomeia esses indivíduos como "homens com temperamento vizinho da loucura”, que Morel, Legrand du Salle e Schüle chamam esses doentes de "nevrosicos

364 CESAR, O. A expressão artística nos alienados: contribuição para o estudo dos symbolos na arte. Gráfica do Hospital do Juquery, São Paulo, 1929, p. 100-117.

365 Idem, p. 100.

366 Idem, p. 101.

367 Idem, p. 101.

145 
hereditarios”, e diz que Régis prefere a designação "nevropatas” e que a maioria dos autores chama de "paranoicos”368.

Osório César expõe, então, o conceito de paranóia publicado por Roxo (segundo informa, publicado no Manual de Psychiatria de 1925):

“A paranoia que significa pensar errado, pensar de viez, diz o prof. Roxo, consiste em um delírio systematizado, bem encachado, logico, sem allucinações como elemento essencial e antes como verdadeira excepção, em que de uma idea falsa tira o individuo uma serie de conclusões razoaveis e em que ha, como vicio fundamental, primitiva e originaria autophilia, egocentria resultante, inadaptabilidade ao meio e reaç̧ão consequente conta este”369.

Assim, César acrescenta que a paranóia é pouco encontrada nos manicômios. Informa que essas pessoas desgraçam famílias, esbanjam fortunas, apresentam-se como vítimas de perseguições, discutem, argumentam, sofismam. Diz que eles se impõem às multidões: "Passam por santos, por super-homens. Adquirem devotos. Admiradores incondicionaes. São os casos de loucura collectiva"370.

Assim, o autor cita reformadores sociais e religiosos como indivíduos dotados de paranóia. Cita conceitos de Tanzi e Lugaro. Informa referências de Franco da Rocha aos estudos de Freud sobre paranóia.

A seguir, apresenta exemplos de pacientes do Juquery com quadro de paranóia. Um desses exemplos é um caso observado por Franco da Rocha e apresentado no Segundo Congresso de Psychiatria, Neurologia e Medicina Legal em São Paulo, em 1918. Outro exemplo é um curioso caso de paciente bastante ilustrado que faz uma série de comentários sobre a obra de Freud.

As diversas referências a Freud, feitas por esse doente, dão a entender que nesses anos os livros de Freud são lidos além do círculo de médicos e artistas.

Na conclusão de seu livro, Osório César insiste em que o louco é um individuo que merece o interesse da sociedade, pois, fora de seus episódios de loucura, é uma pessoa como outra qualquer. Salienta a produção artística desses indivíduos, que sempre se faz com representações emocionais, frutos de descargas acumuladas, "no subconsciente adormecidas pela censura”371.

368 CESAR, O. A expressão artística nos alienados - contribuição para o estudo dos symbolos na arte. Gráfica do Hospital do Juquery, São Paulo, 1929, p. 101.

369 Idem, p. 118.

370 Idem, p. 119.

371 CESAR, O. A expressão artística nos alienados: contribuição para o estudo dos symbolos na arte. Gráfica do Hospital do Juquery, São Paulo, 1929, p. 159. 
Em relação às classificações, Osório César se diz inimigo das mesmas. Informa que foi obrigado a formular uma classificação, para fazer o estudo comparativo entre a arte dos alienados, a arte do primitivo, a arte primitiva e a de vanguarda. Diz que a arte do primitivo não é arte, mas uma pré-arte.

Após tecer mais comentários sobre a arte dos alienados, o autor passa a explicar parte da doutrina freudiana, através de trechos do livro de Franco da Rocha ( $O$ pansexualismo na doutrina de Freud, 1920), principalmente a respeito de conceitos de inconsciente, pré-consciente e consciente. Diz que, nesse texto, Franco da Rocha relata que Freud prefere o termo pré-consciente, para determinada instância da dinâmica mental, ao termo subconsciente, para evitar a "linguagem commum da psicologia”372.

Esse comentário dá a entender que no início do século XX há uma espécie de psicologia que usa uma, assim chamada, linguagem comum, ou seja mais próxima de uma linguagem popular. Portanto, há a psicologia dos estudiosos e uma outra psicologia, que tem certa difusão entre as pessoas em geral. Assim, a psicologia tem mais esse elemento, que torna mais complexo o quadro das áreas em estudo nesse período: uma psicologia que, embora um tanto popular, tem uma linguagem de certa erudição, já que utiliza o termo “subconsciente”.

César acentua que a doutrina de Freud veio revolucionar a psicologia, e que principalmente pelos sonhos e pela simbologia freudiana, a psicanálise busca material para estudo. Acrescenta que, assim como os sonhos, a arte dos alienados se presta a um papel similar, através de símbolos, fazendo uso de processos mentais próprios dos antepassados da humanidade.

372 Idem, p. 163. 


\section{8 - A década de 1880 - período de transições}

O ano de 1889, início do período de nosso estudo, demarca o fim de uma década de transformações no âmbito internacional e no Brasil.

Na França, conforme já foi dito, em 1880 Charcot cria o periódico Archives de Neurologie e em 1882 torna-se o primeiro catedrático de uma disciplina de Neurologia.

Freud forma-se em 1881, em Viena, e fica em Paris, como discípulo de Charcot, desde fins de 1885 até o início de 1886.

Em 1885, é criada a Sociedade de Psicologia Fisiológica na França. Em 1889, ocorre em Paris o Primeiro Congresso Internacional de Psicologia.

Esse Congresso de Psicologia de Paris, de 1889, é gestado no transcorrer dessa década. Quem primeiro fala na necessidade de um congresso internacional de psicologia é Julian Ochorowicz (1850-1917), considerado fundador da psicologia polonesa. Em 1881, ele envia um artigo a Théodule Ribot, editor da Revue Philosophique de la France et de l'Étranger, intitulado Projeto de um Congresso Internacional de Psicologia. Nesse artigo, ele descreve o estado disperso da psicologia em 1881 e seus prévios 50 anos, incluindo 12 subdisciplinas, variando da psicofísica à psicologia da arte. Ele sugere como a psicologia deve caminhar para a unificação, através de troca de informações, observações e experimentos, incluindo entre essas atividades um congresso de psicologia. O rápido desenvolvimento dessa idéia, em 8 anos, deve-se à criação das sociedades de psicologia, sendo a primeira a Sociedade de Psicologia Fisiológica em Paris, em 1885. A criação dessa sociedade permite à psicologia ser reconhecida como fazendo parte do domínio científico. O Congresso trata mais de temas fisiológicos do que filosóficos ${ }^{373}$.

Nesse Congresso está presente Pierre Janet (que, mais tarde, alega que Freud retirou o termo “psicanálise” de seu termo “análise psicológica”). Concomitantemente a esse congresso, ocorre o Congresso Internacional de Hipnotismo Experimental, onde ambos, Janet e Freud, estão inscritos, embora Janet não compareça, porque está no próprio Congresso de Psicologia, de modo que eles não se encontram. Como já foi dito, Freud forma-se em 1881, trabalha em diversos hospitais de Viena até sua estada em

373 NICOLAS, S.; SODERLUND, H. The Project of na International Congress of Psychology by J. Ochorowicz (1881) - International Journal of Psychology, 40: 395-406, 2005. 
Paris, de outubro de 1885 a fevereiro de 1886. Janet foi convidado por Charcot a trabalhar em Salpêtrière em $1890^{374}$.

Portanto, essa foi uma década efervescente em Paris, em torno de psicologia, psiquiatria e neurologia. Pelo referido por Ochorowicz, a respeito de doze subdivisões da psicologia, constata-se intensa atividade em torno dessa área na França, no século XIX. Ao mesmo tempo, a área de doenças do sistema nervoso é uma disciplina apenas nascente, ainda se estruturando em torno do que temos chamado de corpo neurológico. A psiquiatria mantem-se entre as duas áreas, com o interrogatório, a hipnose, as drogas e os asilos.

Também nessa década de 1880, surgem laboratórios e obras de psicologia nos Estados Unidos, principalmente em torno de William James ${ }^{375}$.

Conforme já comentado, na Faculdade de Medicina do Rio de Janeiro, em 1881, são instaladas novas cadeiras como a de Psiquiatria e Moléstias Nervosas, sendo que, em 1883, Teixeira Brandão assume essa disciplina.

374 VIGUIER, R. Les rapports litigieux de Janet et de Freud. Disponível em: <http://pierrejanet.com/JSarticles/2004/rv04.doc>. Acessado em março de 2006..

375 FINGER, S. Origins of Neuroscience: a History of Explorations into Brain Function. Oxford University Press, 1994, p. 275-277.

JAMES, W. Coleção “Os Pensadores”. Editora Nova Cultural, 1989, Introdução. 
Capítulo 2 - $1^{\circ}$ Período - 1889-1898:

Do Império à República,

Da Ladeira do Tabatingüera para as margens do Juquery:

A Locomotiva Paulista chega aos insanos.

Para estudarmos neurologia, psiquiatria e psicologia no período pretendido, em São Paulo, devemos conhecer algumas condições em que surgem essas áreas, e quais as especificidades ligadas ao estabelecimento das mesmas na cidade e no Estado.

A passagem de Império à República no Brasil, demarcada em novembro de 1889, acompanha-se de uma série de processos que buscam demarcar diferenças de eficiência do novo regime em relação ao anterior. Conforme a historiadora Silva (2003) a educação e a saúde passam a servir como auxiliares na construção da modernização do país, a partir da República; aliada a isso, a autonomia recém-adquirida do Estado de São Paulo dá expressão aos interesses regionais e à realização desses objetivos republicanos ${ }^{376}$.

Ainda no Império, em editorial de 16 de maio de 1889, em sua edição de lançamento, a Revista Medica de S. Paulo ${ }^{377}$ assinala a necessidade “urgente” de uma revista científica que acompanhe o “desenvolvimento material” da província:

"A necessidade de uma revista scientifica, de ha muito reconhecida entre nós, torna-se cada vez mais urgente, attentas as circumstancias de progresso social que tem tido esta provincia. $O$ desenvolvimento material, o augmento de riqueza publica e particular, têm marchado em progressão por demais rapida; o nivel moral e intellectual conserva-se em quase no antigo grau de muitos annos passados. Póde-se applicar a verdade da lei physiologica, o desenvolvimento exagerado de um orgão e funcções, prejudicando outros. Contra essa ordem de couzas se levanta hoje a Revista Medica de S. Paulo"378.

A afirmação da necessidade, de equiparar o nível moral e intelectual de São Paulo a seu desenvolvimento econômico, diz respeito aqui, a um anseio mais específico da classe médica de São Paulo. A comparação feita com uma lei fisiológica, que aponta um desequilíbrio entre os órgãos do corpo humano em determinadas circunstâncias, está presente em reflexões de outros autores, em outros momentos, a respeito das condições

376 Silva, M.R.B. O mundo transformado em laboratório: ensino médico e produção de conhecimento em São Paulo de 1891 a 1933. Tese de Doutorado, Faculdade de História, FFLCH, USP, 2003, p. 16.

377 A Revista Medica de S. Paulo foi o primeiro periódico científico médico na província, como já anteriormente citado.

378 EDITORIAL. Revista Medica de S. Paulo, p. 1, 1889, 150 
do país. Essa aplicação do raciocínio biológico às condições sociais é feita por estudiosos que escrevem nesse período ${ }^{379}$.

Quando o autor escreve que "torna-se cada vez mais urgente”, ou ainda "em progressão por demais rápida”, deixa-nos diante de um fenômeno desse período, que diz respeito à "velocidade" presente em São Paulo nos mais diversos aspectos: no aparecimento de inovações sociais, nas construções da cidade, na expansão ferroviária e econômica na província, e assim por diante. Há a percepção de um descompasso entre algumas instâncias da sociedade em comparação a outras instâncias.

Em relação a este aspecto de “rápidas mudanças” desse período, queremos mencionar um texto de Anthony Giddens (1990), que reforça esse ponto como um diferencial importante entre as ordens sociais tradicionais e as instituições sociais modernas:

“Como deveríamos identificar as descontinuidades que separam as instituições sociais modernas das ordens sociais tradicionais? Diversas características estão envolvidas. Uma é o ritmo de mudança nítido que a era da modernidade põe em movimento. As civilizações tradicionais podem ter sido consideravelmente mais dinâmicas que outros sistemas prémodernos, mas a rapidez da mudança em condições de modernidade é extrema. Se isto é talvez mais óbvio no que toca à tecnologia, permeia também todas as outras esferas”380.

Assim, Guiddens acentua que esse ritmo de mudança, próprio da modernidade, embora seja mais óbvio na tecnologia, também está presente em outros âmbitos da sociedade.

No que diz respeito a esse e outros aspectos relativos à ciência nesse período, podemos acompanhar várias reflexões presentes na obra 1890-1914: No tempo das certezas, de Ângela Marques Costa e Lilia Moritz Schwarcz, referente a intervalo de tempo similar ao primeiro e ao segundo período de nosso trabalho:

"Estamos falando, portanto, de um momento em que uma certa burguesia industrial, orgulhosa de seu avanço, viu na ciência a possibilidade de expressão de seus mais altos desejos. Tal qual uma revolução industrial que não acaba mais, aqueles homens passavam a domar a natureza a partir de uma miríade de invenções sucessivas. Cada novo invento levava a uma cadeia de inovações, que por sua vez abria perspectivas e projeções inéditas. Dos inventos fundamentais aos mais surpreendentes, das grandes estruturas aos pequenos

\footnotetext{
${ }^{379}$ Por exemplo, os estudiosos Durkheim e Gabriel Tarde, já citados em nota. 380 GIDDENS, A. As conseqüências da Modernidade. Editora Unesp, (1990) 1991. p. 15. 151
} 
detalhes, uma cartografia de novidades cobria os olhos desses homens, estupefatos com suas máquinas maravilhosas”31.

Ainda sobre o papel da ciência nesse contexto de "tempo das certezas", as autoras referem que:

“As exposições universais passavam a demonstrar didaticamente o progresso e a imaginar o amanhã; os mapeamentos e inventos olhavam para os impasses do presente, mas de esguelha miravam o século seguinte; a "sciencia" impunha-se como forma de redimir incertezas. Sonhou-se muito na passagem do século XIX para o XX. Era esse o momento das realizações, da efetivação de projetos de controle das intempéries naturais. Ainda não pairava no ar o cheiro da guerra; a idéia do conflito parecia controlada pela fantasia do progresso, e os novos avanços técnicos traziam a confiança de um domínio absoluto sobre a natureza e os homens ${ }^{\text {’382. }}$.

Após falarem das ambigüidades do progresso, com seus problemas e riscos, as autoras relatam também condições do Brasil, que nos fazem lembrar elementos de “continuidade e ruptura” (continuidade e ruptura a que já nos referimos em relação a São Paulo):

"Não se passa impunemente pelo fato de ter sido a última nação a abolir o cativeiro, já que até maio de 1888 era possível garantir a posse de um homem por outro. Era difícil a convivência entre o projeto republicano - que, recém-inaugurado em novembro de 1889, vendia uma imagem de modernidade - $\mathbf{e}$ a lembrança recente do sistema escravocrata, que levava à conformação de uma sociedade patriarcal, marcada pelas relações de ordem pessoal, violenta e na qual vigorava um profundo preconceito em relação ao trabalho braçal”383.

Ambigüidades como essas também são percebidas pelos médicos de São Paulo, no Editorial da Revista Medica de S. Paulo, em 1889, fazendo críticas à "má organização política e social” e ao "sistema centralizador” (do Império), que limitam a produção científica brasileira, apesar do talento e ilustração do brasileiro:

“Não é que falte ao brazileiro talento, illustração ou aptidões scientificas para collaborar, no concerto da civilisação com outros povos. $O$ facto que assignalamos, depende quase exclusivamente da nossa má organisação politica e social, que por meio do systema centralisador e official, tudo esterilisa e mata, tornando quase impossivel a vida fora desse

381 COSTA, A.M.; SCHWARCZ, L.M. 1890-1914: No tempo das certezas. Companhia das Letras, 2000, p. 10.

382 Idem, p. 11.

383 Idem, p. 11-12.

152 
influxo malefico, que geralmente produz mais cogumellos sem valor e parasitas prejudiciais que organismos robustos e de valor incontestavel”384.

A queixa do “sistema centralizador oficial” está presente em outras referências, em relação a dificuldades para o trabalho científico. Essa referência negativa ao centralismo do Império mostra influências republicanas entre os médicos, que fazem parte da elite social da província.

Conforme Love (1979), mais de três quartos dos políticos paulistas no período por ele estudado (1889-1937) são bacharéis formados em direito ou medicina, sendo que 63\% deles foram diplomados pela Faculdade de Direito de São Paulo, num total de $70 \%$ de advogados ${ }^{385}$. Embora haja predominância destes, há também algum envolvimento dos médicos com a atividade política ${ }^{386}$.

Ainda no Editorial de 1889, a Revista Medica de São Paulo cita pesquisadores que "são obrigados a recorrerem a publicações e sociedades estrangeiras”387, para que seus trabalhos sejam conhecidos "no mundo scientifico”388, pelo fato de que não há periódicos suficientes no Brasil, justificando também, assim, a necessidade desta nova revista. Desse modo, o editorial cita nomes de alguns desses estudiosos brasileiros que publicam em outros países, sendo que a maior parte deles não é de São Paulo ${ }^{389}$.

Vemos que os editores dessa revista, ao mesmo tempo em que se remetem a seus vínculos com a província, também se referem a seus elos nacionais, principalmente com o Rio de Janeiro.

Para fazer jus à ciência médica brasileira, o editorial ainda cita os nomes de Mello Franco ${ }^{390}$ e Torres Homem, do Rio de Janeiro, como importantes no assunto da

384 EDITORIAL. Revista Medica de S. Paulo, pp. 1-2, 1889.

385 LOVE, J. A locomotiva: São Paulo na federação brasileira (1889-1937), Editora Paz e Terra, 1982.

386 Em 1889, os médicos que se queixam desse centralismo sofreram a influência de um período de transformações na Faculdade de Medicina do Rio de Janeiro. Conforme Benchimol, o decreto de 1879, de Leôncio de Carvalho, ministro do Império, que institui a liberdade de ensino superior no país "refletia o ideário liberal e cientificista de uma geração que se notabilizou por sua ilustração e pela autoria de outras reformas, inclusive da substituição da Monarquia pela República em 1889” .

BENCHIMOL, J.L. Dos micróbios aos mosquitos: febre amarela e a revolução pasteuriana no Brasil. Editora Fiocruz, Editora UFRJ, 1999, p. 30.

387 Revista Medica de S. Paulo, 1889, Editorial, p.2.

388 Idem.

389 Os são os nomes que foram citados: Domingos Freire, Barbosa Rodrigues, Silva Araújo, Azevedo Lima, Guedes de Mello, Hilário Gouvêa, Lacerda, Lutz, Clemente Ferreira.

390 Francisco de Mello Franco (1757-1822) nasceu em Minas Gerais e estudou Medicina em Portugal, após a reforma do ensino na Universidade de Coimbra em 1772. Além de ter escrito sobre as febres do Rio de Janeiro, que é ao que se refere na revista, ele escreveu, em 1794, a obra intitulada "Medicina Teológica”, que interessa mais de perto ao nosso tema, pois se trata de uma obra de cunho psicológico. 153 
“pyretologia”391 “"attentas as epochas em que cada um foi escripto”,392, como referências tradicionais a serem respeitadas.

Temos então, no primeiro exemplar da Revista Medica de São Paulo, menções a pessoas de diferentes gerações de médicos no Brasil, alguns com certa participação nas áreas enfocadas em nosso trabalho.

É nesse contexto de mudanças sociais e políticas, bem como científicas, que o nosso estudo se inicia. Nós vamos analisar esses processos, de maneira mais específica, na área médica em São Paulo, não esquecendo de suas correlações nacionais e internacionais.

\section{1 - Instituições médicas no período 1889-1898}

No já referido editorial da Revista Médica de S. Paulo de 1889, o autor queixase também da “falta absoluta de associações e orgãos scientificos" referentes à medicina, que ele atribui à própria classe médica brasileira (além de outras dificuldades que credita ao centralismo do governo):

“A classe medica brazileira soffre de um grave mal, que a torna fraca, não tendo o papel que deveria representar, nem a influencia a que tem direito na nossa sociedade: é a pouca fraternidade que existe entre seus membros, e o estado quase constante de agressão que predomina entre elles.

Esse modo de ser, filho de nosso meio social e político, ainda mais grave se torna pela falta absoluta de associações e orgãos scientificos onde se discutam as questões puramente profissionaes ou de valor especulativo para a medicina e seus ramos.

A iniciativa individual pouco pode, e quando tenta levar a effeito qualquer empreza que destrua esse vicio, vê-se completamente aniquilada”393.

O uso da expressão "falta absoluta” pode expressar mais um sentimento em relação a essas questões, do que uma ausência completa de associações, já que havia, por exemplo, a Academia Imperial de Medicina e a Sociedade de Medicina e Cirurgia

Mello Franco pertence a um período inicial da Medicina no Brasil, tendo chegado ao país em 1817 e falecido em 1822.

ABREU, J.L.N. A educação física e moral dos corpos: Francisco de Mello Franco e a medicina lusobrasileira em fins do século XVIII. Estudos Ibero-Americanos, PUCRS, v. XXXII, n. 2, p. 65-84, dezembro 2006. Acessado em 22 de setembro de 2007 às 21:23 hs.

391 EDITORIAL. Revista Medica de S. Paulo, Editorial, p. 2, 1889.

392 Idem.

393 Idem; p.1. 
do Rio de Janeiro, além de alguns periódicos. Certo grau de desunião entre os médicos, como podemos observar em nossas leituras, é um assunto que perpassa o período de nosso trabalho e que se acentua, episodicamente, em situações concretas.

A respeito dessa classe médica desunida comentada no editorial, podemos nos remeter à seguinte consideração de Pierre Bourdieu, a respeito da sociedade moderna:

"A cumplicidade e a familiaridade (congeniality), fundadas na comunidade de cultura, deitam suas raízes ao nível do inconsciente e conferem às elites tradicionais uma coesão e uma continuidade sociais de que são carentes as elites unidas apenas pelos vínculos do interesse profissional”394.

Essa pode ser uma forma de entender o tênue vínculo da classe médica paulista ainda em formação, talvez sem os vínculos culturais citados por Bourdieu.

Trata-se de uma classe de filhos da terra paulista (alguns não), os quais chegam trazendo influências de seus locais de formação. Assim, eles mantêm vínculos com outros centros, principalmente com a Faculdade de Medicina do Rio de Janeiro.

Ao chegarem a São Paulo, buscam, na figura de Pereira Barretto, alguém em que possam se alicerçar. Barretto, que estudou na Europa e de lá veio para o interior do Estado de São Paulo, depois se fixa na capital, sendo, no início da República, já um veterano entre seus pares.

Em um contraponto a esse certo grau de dispersão, desses novos médicos chegados ao Estado, o impulso federativo do início da República propicia alguma união entre os médicos, principalmente em torno das questões de saúde pública.

De qualquer forma, há várias situações de fragilidade das organizações de classe dos médicos ${ }^{395}$. Um exemplo é a própria Revista Medica de São Paulo que dura apenas em torno de um ano, quando fundada em maio de 1889.

Outro exemplo dessa fragilidade: na Revista Medica de 1889, há o registro do ato de fundação da Sociedade de Medicina e Cirurgia de São Paulo, ocorrido nesse

394 BOURDIEU, P. A Economia das trocas simbólicas. Editora Perspectiva. 2005, p.217.

395 Em âmbito nacional, também há altos e baixos nas organizações dos médicos, como, por exemplo, em 1901, quando publicou-se uma “Constituição da Ordem Medica Brazileira”, com 109 artigos e seus respectivos parágrafos, promulgada por um, assim chamado, Supremo Conselho dessa ordem, em 8 de maio de 1901, tendo como presidente o Senador Candido Barata Ribeiro. O fato é que essa organização não vingou.

BURGOS, C. A Ordem Medica Brasileira. Revista Medica de São Paulo, p. 235-237, 1901.

CONSTITUIÇÃO DA ORDEM MEDICA BRASILEIRA. Revista Medica de São Paulo, p. 245-253, 1901. 
mesmo ano, no dia 7 de setembro, em uma das salas da Academia de Direito ${ }^{396}$. Essa sociedade não foi adiante. Em 1895 é fundada novamente uma outra sociedade com o mesmo nome, que desta vez perdura.

Nesse ato de fundação da sociedade, Cesário Motta Filho diz entusiasticamente que a data de sete de setembro, que indica apenas a separação de Portugal, agora passa a marcar também “O inicio da emancipação pela sciencia”397.

Em outro discurso do mesmo evento, o médico Miranda Azevedo julga que, por falta de uma instituição como essa, os paulistas não têm distinção na medicina. Ele diz que, em outras áreas do saber, São Paulo teve Bartolomeu Gusmão, José Bonifácio, o botânico Correa de Mello, o orador Antonio Carlos, o poeta Álvares de Azevedo, o músico Carlos Gomes. Lembra que o médico “oculista” Álvares Machado tem talento excepcional como operador, mas só é conhecido como orador e político. Também acrescenta que uma das causas do pouco prestigio da classe médica “é a ausencia completa que há de espirito de fraternidade que tanto prejudica a boa harmonia de seus membros” ${ }^{\text {398 }}$. Considera que a Sociedade de Medicina pode contribuir "para destruir esse mal” ${ }^{399}$. Recorda a tentativa feita, sem sucesso, em 1878 para se fundar uma Sociedade Médica e fazer em São Paulo um primeiro Congresso Médico ${ }^{400}$.

Essas declarações formam um retrato do clima em torno de promoção de atividades científicas médicas, em fins do Império, vistas pelos olhos de médicos paulistas, desejosos de uma descentralização e melhor promoção dessas atividades.

Por outro lado, a determinação desses médicos paulistas no desencadeamento desses eventos demonstra que, ao mesmo tempo em que há dificuldades, eles também estão em processo de organização em torno de suas instituições.

No período de 1889 a 1898, sendo este o ano em que se inicia o funcionamento do Hospício do Juquery, ocorre o processo de consolidação do federalismo na República, com a passagem de presidentes militares ao primeiro presidente civil, Prudente de Moraes, em meados desse período (1894), e com a projeção econômica e

396 A importância desse evento pode ser avaliada pela presença do presidente da Província, Couto de Magalhães à reunião.

SOCIEDADES SCIENTIFICAS. Revista Medica de São Paulo, p. 141-142, 1889.

397 SOCIEDADES SCIENTIFICAS. Revista Medica de São Paulo, p. 143, 1889.

398 Idem.

399 Ibidem.

400 Em relação aos iniciadores da idéia do Congresso de 1878, Machado citou os nomes de: Caetano de Campos, Nogueira Cardozo, Cesário Motta e Gustavo Godoy. 156 
política do Estado de São Paulo, ao mesmo tempo em que instituições científicas paulistas são estabelecidas.

Logo no inicio do novo regime, em 1889, Prudente de Moraes, presidente do governo provisório do Estado de São Paulo, lança decretos, entre os quais vários que dizem respeito à saúde. Há regulamentação administrativa e de atendimento médico na Hospedaria dos Imigrantes. São tomadas medidas para conter a epidemia de febre amarela em Campinas. É feito contrato com o médico Arnaldo Vieira de Carvalho para dirigir o serviço de cultura e produção de vacina do Estado de São Paulo ${ }^{401}$.

Em 1891 é promulgada a constituição federal e as constituições estaduais. Também nesse ano o presidente do Estado de São Paulo, Jorge Tibiriçá, é afastado pelo governo federal, por ser próximo ao Partido Republicano Paulista e toma posse Américo Brasiliense, alinhado aos grupos federais. Em novembro desse mesmo ano, Deodoro da Fonseca tenta um golpe, dissolvendo o Congresso Nacional. Por haver resistências, Deodoro renuncia e Floriano Peixoto assume a presidência, o que acaba favorecendo os republicanos paulistas (a partir de 1894, com o paulista Prudente de Moraes, configurase a política da Primeira República, com o federalismo instalado) ${ }^{402}$.

Em 1892, é feito o primeiro regulamento sanitário estadual da República, no Estado de São Paulo. Subordinado à Secretaria Estadual dos Negócios do Interior, criase, nesse ano, o Serviço Sanitário, formado por um Conselho de Saúde Pública e uma Diretoria de Higiene, a qual é dividida em: Laboratório Farmacêutico, Laboratório de Análises Químicas, Instituto Vacinogênico e Laboratório de Bacteriologia. Em 1893 este Laboratório de Bacteriologia é transformado em Instituto Bacteriológico ${ }^{403}$.

Em 1895, funda-se uma nova Sociedade de Medicina e Cirurgia de São Paulo, sendo que, desta vez, como já referido, a instituição perdura.

Nesse mesmo ano, médicos paulistas tentam organizar, em São Paulo, o Quarto Congresso de Medicina e Cirurgia do Brasil (desde o $3^{\circ}$ Congresso, em 1890, na Bahia, S. Paulo está atrasado em dar continuidade aos congressos médicos brasileiros). Em 1897, os organizadores paulistas desistem de realizar esse Congresso, aparentemente por morosidade do Senado estadual em votar a subvenção ao evento. Esse é mais um exemplo da fragilidade das organizações médicas na ocasião.

401 Silva, 2003, p.17-18. 402 Telarolli Jr., p.70-71. 403 Silva, 2003, p. 32, 40. 157 
Em meio a todo esse contexto abordado, ocorrem processos que dão condições ao estabelecimento de uma nova instituição asilar especialmente destinada a doentes mentais, que vai ser o Hospício do Juquery.

Nesse período, Franco da Rocha é o indivíduo capaz de articular algumas condições favoráveis à instalação da ciência (relativa a doenças mentais e moléstias nervosas) em São Paulo, dentro dos objetivos da República.

\section{1. 1. - Assistência a Alienados em São Paulo antes do Juquery}

Alguns aspectos, que são anteriores ao período abrangido pelo trabalho, são de interesse para o entendimento do contexto de instalação dos hospícios no Brasil, e por isso são aqui comentados.

Para a análise da assistência a alienados em São Paulo, antes do Juquery, fazemos uso de dois textos. Um artigo de 1905, de Juliano Moreira, publicado em 1905 nos Archivos Brasileiros de Psychiatria, Neurologia e Sciencias affins, do Rio de Janeiro, sob o título Noticia sobre a evolução da assistencia a alienados no Brasil, sendo que suas informações sobre o Juquery foram passadas por Franco da Rocha ${ }^{404}$. O outro texto, de Pacheco e Silva, de 1936, é proveniente de seu concurso para Cátedra de Psiquiatria na Faculdade de Medicina da Universidade de São Paulo ${ }^{405}$.

No Rio de Janeiro, capital do Império, as ações voltadas para a construção de um Hospício se iniciam a partir de 1841, com um decreto do Imperador nesse sentido, após reclamos de médicos. Em 1852, esse Hospício inicia suas atividades.

Em 1848, cria-se em S. Paulo uma lei no sentido de criar um estabelecimento desse tipo, o que faz Pacheco e Silva afirmar que “coube a São Paulo a iniciativa, entre os Estados do Brasil, de dispensar assistência condigna aos psicopatas” ${ }^{406}$. Nessa

404 MOREIRA, J. Noticia sobre a evolução da assistencia a alienados no Brasil. Archivos Brasileiros de Psychiatria, Neurologia e Sciencias Affins, p.65-101, 1905.

Nesse artigo, após o histórico do Hospício Nacional, Moreira passa a falar dos hospícios dos outros Estados, lamentando não poder falar de todos que gostaria, por não ter obtido resposta de alguns. Sobre isso, diz que "bem sei que muitas vezes fica sem resposta um pedido de informações quando são más as que temos que dar. Esse mal entendido bairrismo é, porém, um dos meios de pactuar com as irregularidades publicas".

405 PACHECO e SILVA, A.C. A assistência a psicopatas no Estado de São Paulo: breve resenha dos trabalhos realizados durante o período de 1923 a 1937. Juqueri, São Paulo, Brasil, 1945, p.7-16.

406 PACHECO e SILVA, A.C. A assistência a psicopatas no Estado de São Paulo: breve resenha dos trabalhos realizados durante o período de 1923 a 1937. Juqueri, São Paulo, Brasil, 1945, p.7. 
afirmação, ao se restringir ao Estados, ele não inclui o Hospício Nacional, já que este é de alçada do Império, passando depois à alçada federal, não sendo, portanto, de alçada estadual.

Nessa lei de 1848, o artigo $5^{\circ}$, da lei n.12 de 18 de setembro, dispõe que o governo mande levantar a planta e orçamento de um Hospital de Alienados, com capacidade para recolher todos os alienados da província, e faz apresentação dessa planta e do orçamento à Assembléia Provincial. A lei acrescenta que:

“Emquanto a Assembleia não deliberar sobre este objecto, o Governo, despendendo até a quantia de 2:000\$000 (dois contos) empenhar-se-á em alliviar os males daquelles infelizes ou tratando com a Meza da Santa Casa de Misericordia para que sejam recolhidos ao Hospital de Caridade, ou empregando os meios que mais conducentes lhe parecer para tão justo fim"407.

Não se tem noticia de quem fez essa lei, assim dita "humanitária” por Moreira, no período do presidente da província Domiciano Leite Ribeiro. Franco da Rocha acredita que, apesar da existência da lei, nunca a Santa Casa chegou a asilar os alienados.

Em $1852^{408}$, sendo Presidente da província o padre Vicente Pires da Motta, por força de um regulamento de cinco de maio desse ano, é instalado o Hospício "numa casa da Rua de S. João, nas proximidades do Largo actualmente chamado da Republica, onde funcionou até 1864”. No texto de Pacheco e Silva lê-se “na Rua de S. João, nas proximidades da atual Rua Ipiranga"409.

No primeiro ano (1852) em que é aberto, o Hospício abriga nove doentes, dos quais alguns são criminosos. Refere Juliano Moreira que, alguém que entrou ali por esse tempo, contou depois a Franco da Rocha ter visto pendurado, ao lado da porta, um chicote do tipo "rabo de tatu”. Diz Moreira que não se sabe se era muito usado, mas pondera que, se o administrador leigo Thomé Alvarenga era, como se dizia, “um bom homem”, ele teria usado o instrumento “mais para intimidar do que para fustigar”, além

407 MOREIRA, J. Noticia sobre a evolução da assistencia a alienados no Brasil. Archivos Brasileiros de Psychiatria, Neurologia e Sciencias Affins, p. 85, 1905.

408 Conforme Paulo Fraletti, o Hospício de S. Paulo foi instalado em 14 de dezembro e o Hospício do Rio de Janeiro em 5 de dezembro, ambos em 1852.

PICCININI, W.J. História da psiquiatria: Franco da Rocha, vida e obra. Psychiatry on line, vol.8, n.4, 2003. Acessado em 26 de abril de 2005.

409 PACHECO E SILVA, A.C. A assistência a Psicopatas no Estado de São Paulo: breve resenha dos trabalhos realizados durante o período de 1923 a 1937. Oficinas Gráficas da Assistência a Psicopatas, Juqueri, S. Paulo, 1945, p. 7. 
do que, teria recebido "bons conselhos do clinico da cidade que fazia o serviço sanitario do Hospicio, a principio gratuitamente depois a 50\$000 mensaes”,410.

Essas considerações talvez expressem mais o que Franco da Rocha e Juliano Moreira pensam do uso da agressão aos alienados (pois essas informações foram passadas de Franco da Rocha a Juliano Moreira), do que a eventual realidade daqueles dias.

Refere Pacheco e Silva que “já nessa época eram admitidas duas categorias de doentes - pensionistas particulares e indigentes”. Acrescenta esse autor também que, como os escravos não eram considerados indigentes, os seus donos tinham que pagar as despesas do hospício. Assim, quando um escravo apresentava sinais de loucura, logo era libertado, conforme consta, segundo Pacheco e Silva, no Arquivo do Hospital do Juquery. Desse modo, muitos escravos conseguiram alforria ${ }^{411}$.

Refere também Pacheco e Silva que o clínico, que atendia aos doentes, não se ocupava da afecção mental dos alienados, tratando-lhes quando surgisse alguma doença, ou durante as epidemias da cidade ${ }^{412}$.

Segundo ambos os autores, o número de internados no Hospício da Rua São João cresceu de tal maneira, que em 1858 já não há mais acomodações. Desse modo, foi comprada a chácara da Ladeira do Tabatingüera, de propriedade do Padre Monte Carmello. Como o sobrado era pequeno, e o governo não tivesse verba para a reforma necessária, as obras só foram concluídas em 1864, quando ocorre a transferência dos pacientes da Rua São João ${ }^{413}$.

O primeiro administrador do novo Hospício foi Thomé de Alvarenga. Em 1868 foi substituído por seu filho Frederico de Alvarenga. Conforme Pacheco e Silva, o teor dos ofícios enviados por ambos aos governantes, pedindo providências e recursos, são provas da atenção deles ao hospício. Foi citado que Frederico de Alvarenga empregou dinheiro ganho em loteria para melhorar o estabelecimento, também conhecido como

410 MOREIRA, J. Noticia sobre a evolução da assistencia a alienados no Brasil. Archivos de Psychiatria, Neurologia e Sciencias Affins, p. 85, 1905.

411 PACHECO E SILVA, A.C. A assistência a Psicopatas no Estado de São Paulo: breve resenha dos trabalhos realizados durante o período de 1923 a 1937. Oficinas Gráficas da Assistência a Psicopatas, Juqueri, S. Paulo, 1945, p. 7.

412 Idem, p. 8.

413 MOREIRA, J. Noticia sobre a evolução da assistencia a alienados no Brasil. Archivos de Psychiatria, Neurologia e Sciencias Affins, p. 85, 1905.

PACHECO E SILVA, A.C. A assistência a Psicopatas no Estado de São Paulo: breve resenha dos trabalhos realizados durante o período de 1923 a 1937. Oficinas Gráficas da Assistência a Psicopatas, Juqueri, S. Paulo, 1945, p. 7. 
Hospício da Várzea do Carmo. Mais tarde, com os presidentes da província Nabuco de Araújo, Laurindo de Brito e João Teodoro, e com a ajuda do cônego Andrade, várias autorizações orçamentárias permitem a Frederico Alvarenga aumentar o edifício até o ponto em que se acha em 1903, quando é desativado ${ }^{414}$.

Em 1890, o médico Xavier de Mesquita, que trabalhou muitos anos no estabelecimento, retira-se por doença. Assim, já em tempos de República, são nomeados os médicos João César Rudge (sobre quem não obtivemos dados) e Claro Homem de Mello, este já sendo um psiquiatra ${ }^{415}$, portanto o primeiro psiquiatra a se instalar no Hospício e, até onde se sabe, na cidade, inclusive um pouco antes de Franco da Rocha, conforme já dito (Homem de Mello foi admitido em março de 1891) ${ }^{416}$.

Não há dados a respeito da saída de Homem de Mello do Hospício, mas não deve ter sido por diferenças com Franco da Rocha, pois o primeiro faz a defesa deste em um artigo de 1904, que será exposto no capítulo pertinente.

Conforme J. Moreira, desde 1891 está o Governo do Estado autorizado pelo poder legislativo a criar diversas colônias de alienados no interior, em diversos pontos afastados da Capital. Franco da Rocha, que chega a São Paulo em 1892, convence os poderes públicos de que não é conveniente tal autorização, pois considera necessário criar na capital ou perto, um "hospício central modelo”, construído segundo os ditames da “psiquiatria moderna” de então, em pavilhões isolados, anexando-se uma colônia para ser aplicado o sistema do tipo open-door ${ }^{417}$.

Ainda no mesmo artigo de 1905, refere J. Moreira que, em 1892, com o grande aumento da população no Estado de São Paulo pela vasta corrente imigratória, torna-se

414 PACHECO E SILVA, A.C. A assistência a Psicopatas no Estado de São Paulo: breve resenha dos trabalhos realizados durante o período de 1923 a 1937. Oficinas Gráficas da Assistência a Psicopatas, Juqueri, S. Paulo, 1945, p. 8 e 9.

MOREIRA, J. Noticia sobre a evolução de asistencia a alienados no Brasil, p.86.

415 Há que se ressalvar que Homem de Mello, bem como todos os seus contemporâneos intitulados psiquiatras ou alienistas, são assim designados conforme sua formação nesse período, antes de haver alguma sociedade de especialistas (a primeira foi fundada em 1907, no Rio de Janeiro, a Sociedade de Neurologia, Psiquiatria e Medicina Legal). De qualquer forma, a maioria desses psiquiatras faz sua tese inaugural sobre temas psiquiátricos, além de permanecerem algum tempo após se formarem em serviços de profissionais da área mais antigos. Assim como os serviços psiquiátricos de outros estados, o Juquery também se torna um centro formador de psiquiatras.

416 MOREIRA, J. Noticia sobre a evolução da assistencia a alienados no Brasil. Archivos de Psychiatria, Neurologia e Sciencias Affins, p. 86, 1905.

PACHECO E SILVA, A.C. A assistência a Psicopatas no Estado de São Paulo: breve resenha dos trabalhos realizados durante o período de 1923 a 1937. Oficinas Gráficas da Assistência a Psicopatas, Juqueri, S. Paulo, 1945, p. 8.

417 MOREIRA, J. Noticia sobre a evolução da assistencia a alienados no Brasil. Archivos de Psychiatria, Neurologia e Sciencias Affins, p. 86, 1905. 
insuficiente o velho edifício do hospício, para os pacientes de São Paulo. O então presidente do Estado, José Alves de Cerqueira César, decide reorganizar o serviço de Assistência aos Alienados e pede a orientação de Franco da Rocha. Em 1893, havendo no Hospício cerca de 350 doentes, e tendo-se a necessidade de mais um médico, é nomeado Franco da Rocha para ocupar esse cargo ${ }^{418}$.

Vemos assim que, antes da instalação do Juquery, há em São Paulo um processo de criação e adaptação de instituições destinadas a doentes mentais, conforme as condições sociais e políticas dos períodos correspondentes. Em 1852, é inaugurado um estabelecimento para esse fim, em São Paulo, praticamente de forma concomitante ao do Rio de Janeiro, embora a grande diferença dos imóveis em que esses hospícios são instalados.

Isso pode denotar que apesar das diferentes condições de organização médica entre Rio e São Paulo, além da diferença entre esses municípios, de alguma forma, ambas as sociedades viram a necessidade de dar início a um processo em torno de instituições dessa natureza.

O primeiro local do Hospício de São Paulo perdura até 1864, quando passa a funcionar o Hospício da rua Tabatingüera, em virtude do aumento do número de doentes mentais. Devemos notar que, até essa data, o município de São Paulo não chega ainda à sua fase de crescimento mais acentuado. No entanto, o primeiro estabelecimento não é mais suficiente para o número de pacientes.

Deve-se lembrar também que, como acentua Pacheco e Silva, o hospício tinha leitos públicos e privados. Além disso, conforme já referido, escravos tidos como loucos ganhavam a liberdade, em virtude dos custos com os quais seu propietário teria que arcar, pois os escravos só podiam ocupar leito particular. Por outro lado, devemos lembrar que, nessa época, a cidade era um burgo de estudantes de Direito influenciados por idéias aboliconistas (teriam estimulado o "enlouquecimento” dos escravos?). Não sabemos o quanto esses diversos fatores poderiam ter influenciado no aumento de doentes mentais, na cidade que ainda não havia crescido muito.

De 1864 a 1898, o Hospício da Várzea do Carmo é efetivo em sua função de abrigar os doentes psiquiátricos. No entanto, no início da República, as autoridades constatam a insuficiência de espaço, nesse estabelecimento, para abrigar a quantidade 
crescente de doentes mentais. Esse é um momento em que o crescimento de São Paulo se acelera, com muitos imigrantes.

Além disso, a República tem seu programa de fazer valer a ciência como importante fator de organização da sociedade. Assim, o Hospício, que antes contava apenas com um médico clínico visitador, após a instalação da República passa contar com médicos contratados para trabalharem no próprio hospício, havendo, entre eles, pelo menos um psiquiatra em 1891 (Homem de Mello) e depois Franco da Rocha, em 1893.

Em 1896, Franco da Rocha torna-se o primeiro diretor médico desse estabelecimento. Este é um fato que será novamente citado na seção a seguir.

\section{1. 2. - Construção do Juquery}

Para abordarmos a construção do Juquery dispomos de dois artigos de Juliano Moreira. Um artigo é de 1902, da Revista Medica de São Paulo, e foi reproduzido da Gazeta Medica da Bahia, intitulado O asylo-colonia de Alienados em Juquery $(\text { S.Paulo })^{419}$. O outro artigo é de 1905, dos Archivos de Psychiatria, Neurologia e Sciencias Affins e já foi anteriormente citado.

O autor relata sua visita ao Juquery (em 1902), onde foi inaugurado mais um pavilhão do “asylo-colonia”420. Ele tece louvores aos progressos sanitários do Estado de São Paulo, "que trata seus alienados com desvelo, tal como os povos cultos"421. J. Moreira considera que “pode-se aquilatar o grau de aperfeiçoamento moral de um povo

419 MOREIRA, J. O asylo-colonia de Alienados em Juquery (S.Paulo). Revista Medica de S.Paulo, p. 210-213, 1902.

No subtítulo desse artigo, Juliano Moreira é identificado como "Substituto de Psychiatria e Nevrologia na Faculdade da Bahia”. Essa é a primeira vez que em um periódico médico paulista aparece uma designação de "Nevrologia" (neurologia) referente a alguma instituição brasileira.

420 Em 1902, Franco da Rocha escreve artigo para a revista argentina "Archivos de criminologia” onde descreve “a organização e vantagens” do primeiro "asylo-colonia” (Juquery) fundado na América do Sul. Ele explica então que o "asylo-colonia” corresponde a colônias agrícolas para alienados. Ele descreve a primeira colônia como sendo dividida em duas partes: uma para criação de animais (incluindo vacas leiteiras) e outra para agricultura. Além disso, ele acrescenta haver carpintaria e sapataria, frisando que a maioria dos alienados se adapta mais ao trabalho agrícola. Ele acentua a prática "open door” na colônia como o mais notável avanço na moderna assistência ao alienado e diz que se tivesse que voltar ao hospício fechado, abandonaria o cargo de Diretor.

SÁ, E.N.C. Análise de uma organização pública complexa no setor saúde: o conjunto Juqueri no Estado de São Paulo. Tese de Doutorado. Faculdade de Saúde Pública da USP, 1983.

421 MOREIRA, J. O asylo-colonia de Alienados em Juquery (S.Paulo). Revista Medica de S.Paulo, p. 210, 1902. 
pelos cuidados que elle saiba dispensar aos que têm o infortunio de ensandecer”,422. A certa altura ele escreve que:

"Em obediencia á decisão do Congresso Internacional dos Alienistas reunido em Paris em 1889, o Dr. Franco da Rocha desde 1892 envidou esforços para que fosse fundado em S. Paulo um asylo-colonia e não colonias agricolas para alienados em pontos diversos e distantes do territorio do Estado. De facto aquelle Congresso tinha aconselhado como preferiveis os asylos medico-agricolas compostos de um asylo central, cercado de estabelecimentos agricolas sempre que as circumstancias o permitirem. Desde que não era absolutamente aproveitavel o velho hospicio então existente, desde que a circumstancia de não ter S. Paulo ainda uma Faculdade Medica, não impunha a necessidade da creação de uma clinica urbana, não vejo melhor alvitre que o aconselhado pelo Dr. Franco da Rocha”423.

Desse modo, Franco da Rocha, ao chegar a São Paulo em 1892, já tem intenções e propostas referentes à criação de uma instituição em moldes indicados pelo referido congresso.

Juliano Moreira cita então que, em 1894, o Secretário do Interior de São Paulo, Dr. Cesário Motta, relata em suas próprias palavras: “A casa em que estão recolhidos os loucos torna-se dia a dia mais insufficiente e impropria pelo accumulo de doentes”424. Depois, Cesário Motta envia ofício ao Secretário da Agricultura, com o fim de obter informações sobre o local mais apropriado à construção de um novo Asilo, conforme lei do Congresso Estadual, que já havia autorizado tal procedimento. Uma comissão, composta de dois engenheiros e Franco da Rocha, oscilou entre escolher um terreno na Mooca, no Juquery, ou no Alto de Santana. Foi decidido pelo terreno às margens do rio Juquery, tendo sido comprados 70 alqueires de terra, “próxima à estação desse nome, na Estrada de Ferro inglesa”425, pois apresenta as vantagens:

"Estar a 55 minutos da Capital, perto de uma estação de linha ferrea por onde passam cerca de 14 trens diarios, banhado pelo rio Juquery, cuja agua potavel e tem acerca de 2 leguas uma queda com força media de $\mathbf{1 0 0}$ cavallos para mover machinas. Além disto, ao Estado offerecia gratuitamente, um generoso particular, 10 alqueires de terra sendo facil a

\footnotetext{
422 Idem.

423 Ibidem.

424 MOREIRA, J. O asylo-colonia de Alienados em Juquery (S.Paulo). Revista Medica de S.Paulo, p. 210, 1902.

425 MOREIRA, J. Noticia sobre a evolução da assistencia a alienados no Brasil. Archivos de Psychiatria, Neurologia e Sciencias Affins, p. 87, 1905. 
acquisição dos terrenos circumvizinhos. Accrescendo a tudo isto a proximidade das Cayeiras, onde havia cal e pedra em abundancia para as obras ${ }^{\text {} 426}$.

Neste texto, refere Juliano Moreira que, em 1895, em seu Ensaio de Estatistica, Franco da Rocha descreve as péssimas condições em que se acham os alienados no velho edifício do antigo hospício. Ainda, conforme J. Moreira, foram os presidentes do Estado, José Alves de Cerqueira César (governou de 15.12.1891 a 23.8.1892) e Bernardino de Campos (governou de 23.08.1892 a 1.5.1896) ${ }^{427}$, que confiaram a Franco da Rocha a escolha do sistema de hospício a adotar. Por essa menção e pelas datas de gestão de ambos os governos, Cerqueira César já se mostrava interessado nas propostas de Franco da Rocha desde 1892. Admirado com essa oportunidade dada a um médico alienista, J. Moreira afirma:

"Pela primeira vez neste paiz deu-se inteiramente ao medico alienista o direito de dizer quaes principios devem orientar a construcção de um manicomio, e, o que é mais, deu-se-lhe a missão de ao lado do architecto pôr em pratica estes principios. E tão afortunada é aquella terra que poude dispor de um architecto intelligente, o Dr. Ramos de Azevedo, a quem o Dr. Franco da Rocha não poupa louvores pela alta competencia que poz em pratica para effectuar os preceitos salutares da hygiene hospitalar ao serviço dos manicomios”, ${ }^{\text {428. }}$.

A nosso ver, o fato de se ter dado a um médico alienista o direito de orientar essa construção, indica o reconhecimento desse especialista, por parte dos governantes, como um elemento importante no sentido de construir uma República sintonizada com a ciência.

Conforme Juliano Moreira, tendo o governo autorização, desde 1893, para despender até mil contos, o presidente Bernardino de Campos manda começar as obras em fins de 1895. Embora iniciada a construção, o acúmulo de doentes no velho hospício demanda resolução mais imediata. Assim, o governo compra, em 1895, uma chácara em Sorocaba, adaptando-a para 80 alienados, enquanto aguarda a construção do Juquery ${ }^{429}$.

Ainda, de acordo com Moreira, em março de 1896, falece o administrador do velho Hospício, Frederico de Alvarenga. Uma lei estadual transforma o lugar de

426 MOREIRA, J. O asylo-colonia de Alienados em Juquery (S.Paulo). Revista Medica de S.Paulo, p. 210, 1902.

427 LOVE, J. A Locomotiva: São Paulo na federação (1889-1937). Editora Paz e Terra, 1982, p. 397. 428 MOREIRA, J. O asylo-colonia de Alienados em Juquery (S.Paulo). Revista Medica de S.Paulo, p. 211, 1902.

429 MOREIRA, J. Noticia sobre a evolução da assistencia a alienados no Brasil. Archivos de Psychiatria, Neurologia e Sciencias Affins, p. 87, 1905. 
administrador em cargo de diretor, só podendo ser exercido por médico. Desse modo, Franco da Rocha é nomeado o primeiro diretor médico do hospício em São Paulo.

Em maio de 1896, Franco da Rocha vai a Sorocaba instalar a colônia provisória, que foi construída para aliviar a quantidade de internados no hospício. Deixa lá 80 alienados a cargo de um administrador, havendo uma visita clinica diária feita por um médico da localidade. O local é visitado por Franco da Rocha uma vez por mês ${ }^{430}$.

Refere Moreira que a colônia do Juquery foi concluída antes do hospício propriamente dito, e foi inaugurada em 18 de maio de 1898. O acúmulo de pacientes no velho hospício impôs a inauguração dessa colônia, mesmo antes de todo o complexo ${ }^{431}$.

Em seu artigo de 1902, após descrição de tudo que Juliano Moreira viu no asilo, ele refere a conexão do Juquery com o mundo, através da estrada de ferro, situando a moradia de Franco da Rocha a meio caminho dessa conexão:

“A distancia entre a estação da Estrada ingleza e as varias dependencias do Asylo-colonia é vencida por um pequeno ferro-carril de bitola estreita. Mais ou menos a meio trajecto entre a referida estação e o hospicio central está o elegante chalet morada do director»432.

Moreira sugere a Franco da Rocha elevar as condições do hospicio aos melhores da Alemanha e da América do Norte, aventando a possibilidade de anexar laboratórios à instituição. Além disso, considera o Juquery o melhor hospício do país:

“Terminada a construcção do hospicio, si o meu distincto collega Dr. Franco da Rocha annexar-lhe um laboratorio anatomo-pathologico, um pequeno bacteriologico e um biochimico, dando-lhe o respectivo pessoal idoneo, si ainda installar alli um gabinete de psychophysiologia, terá elevado o esplendido estabelecimento que soube fundar, á altura dos mais perfeitos da Allemanha e da America do Norte. Até hoje está muito acima dos tres toleraveis existentes em todo o vasto territorio nacional”433.

Juliano Moreira conclui, sugerindo aos outros Estados seguirem o exemplo de S. Paulo, no intuito de "servir bem a causa publica",434.

430 Idem.

431 MOREIRA, J. O asylo-colonia de Alienados em Juquery (S.Paulo). Revista Medica de S.Paulo, p. 211, 1902.

432 MOREIRA, J. O asylo-colonia de Alienados em Juquery (S.Paulo). Revista Medica de S.Paulo, p. 212, 1902.

433 Idem, p. 212.

434 Idem, p. 212-213.

166 


\section{2. - Revistas médicas no período 1889-1898}

Conforme já assinalamos, o primeiro periódico científico de São Paulo, relativo à Medicina, é a Revista Medica de São Paulo, com seu primeiro número em 16 de Maio de 1889. Os responsáveis por esse periódico são os médicos Augusto César Miranda de Azevedo, Francisco de Paula Souza Tibiriçá ${ }^{435}$. Ainda em seu editorial podemos ler:

“A idea que presidiu a sua creação, foi contribuirmos para a existencia de um jornal, no qual se debatessem questões scientificas, que são levadas a imprensa diaria, onde logo perdem o caracter que deverião offerecer, para assumirem as proporções de polemicas individuaes e agressivas"

Essa afirmação indica, em primeiro lugar, que há uma intenção de organizar, ordenar, e apropriar-se dos debates sobre as questões científicas que circulam na imprensa diária, para um espaço que seja da alçada da classe médica. Em segundo lugar, demonstra que os leitores dos jornais diários têm interesse por essas, assim chamadas, “questões científicas”, sendo, portanto, assuntos que permeiam a sociedade, além da esfera dos médicos.

Ainda, quanto aos objetivos da publicação, os editores referem que: “Occuparse-ha das questões geraes de medicina, chirurgia, hygiene publica, policia sanitaria e ethica medica, registrando estudos clinicos e experimentaes sobre todos os ramos de medicina, chirurgia e sciencias correlativas" ${ }^{\text {437. }}$.

Assim, nem nos objetivos, nem sobre os temas a serem abordados, constam assuntos psiquiátricos, neurológicos, ou psicológicos de maneira declarada. Esses assuntos são tratados dentro de questões gerais de medicina.

De modo semelhante a outras instituições médicas, com período de existência breve, a Revista Medica de São Paulo, iniciada em 1889, perdura apenas até 15 de fevereiro de $1890^{438}$.

Em 1898, é lançada outra publicação científica médica em São Paulo, que perdura até 1914, também chamada com o mesmo nome de Revista Medica de São Paulo, com o subtítulo Jornal practico de medicina, cirurgia e hygiene. Seus fundadores são os médicos Victor Godinho e Arthur Mendonça, inspetores do Serviço Sanitário ${ }^{439}$.

435 REVISTA MEDICA DE S. PAULO, 1889.

436 EDITORIAL, Revista Médica de São Paulo, p.3, 1889.

437 Idem, p. 3.

438 SILVA, M.R.B., 2003, p.105.

439 REVISTA MEDICA DE S. PAULO, 1898.

167 
Conforme a historiadora Silva (2003), o objetivo da Revista é "auxiliar o clínico e o higienista no combate às moléstias e epidemias que se espalhavam pelo Brasil”, baseando-se em dados estatísticos, de higiene e saúde pública, além de estudos de casos clínicos e artigos de algumas especialidades ${ }^{440}$.

A Revista aceita artigos com certa liberdade, pois acolhe algumas polêmicas entre médicos discordantes. São também publicados alguns artigos de engenheiros, concernentes a assuntos climáticos e sanitários. Em uma seção literária, por alguns anos, o escritor Coelho Netto publica crônicas intituladas “Cavacos”.

Ainda no período anterior a 1898, ocorre a publicação de folhetos por Franco da Rocha, intitulados “Estatistica e Apontamentos” concernentes ao Hospício de São Paulo, iniciados em 1894 ou 1895. Alguns desses folhetos são publicados na Revista Medica de São Paulo, a partir de 1898.

\section{3. - Temas e questões em debate (1889-1898)}

Os temas e questões em debate nesse período, inicialmente (1889) dizem respeito a assuntos provenientes de relatos internacionais, ou ainda de estudiosos do Rio de Janeiro. Em 1898, há artigos escritos em São Paulo, por Franco da Rocha, concomitantemente com outros artigos de outras regiões do país. Os debates giram em torno de classificação das moléstias psiquiátricas, bem como sobre o entendimento do sistema nervoso, mais especificamente a respeito da então recente doutrina do neurônio, além de moléstias como histeria e beribéri.

Nesse período de 1889 a 1898, são utilizadas como fonte a Revista Medica de São Paulo, publicada durante o ano de 1889 e Revista Medica de São Paulo publicada no transcorrer do ano de 1898. Essa Revista de 1898 publica ou reproduz alguns trabalhos realizados em anos anteriores a esse, além dos artigos do próprio ano de 1898. Portanto, não fizemos uma ampla cobertura desse período, na medida em que em boa parte da década de 1890 não há publicação de periódico científico médico em S. Paulo. 


\section{3. 1. - Os debates presentes na Revista Medica de S. Paulo em 1889}

No que diz respeito mais especificamente ao editorial da Revista Medica de São Paulo, de 1889, visando conceitos e debates, vemos que os editores sublinham os assuntos que estão em voga: patologia intertropical, estudo de febres, beribéri e estudos de botanistas.

Pode-se ver que, entre esses temas, nada chama a atenção em relação aos campos de psiquiatria, psicologia, ou moléstias nervosas, em primeiro plano, embora as febres e o beribéri possam acometer o sistema nervoso. Na verdade, o foco principal nesses casos, é a busca do esclarecimento da causa desses processos, dentro da conceituação pasteuriana.

Esse editorial também refere que: “A materia medica brazileira offerece um mundo novo e immenso para explorações, mas só agora começa a dirigir-se persistentemente para ahi a attenção de alguns especialistas nacionaes”441.

O uso da palavra “especialistas", neste texto, pode estar sendo influenciado pela já citada reforma do ensino na Faculdade do Rio de Janeiro de 1881, que criou uma diversidade de cadeiras.

Quanto a artigos sobre as áreas em questão, em 1889, a Revista Medica de São Paulo faz algumas publicações correlatas a esses assuntos. É publicado um artigo de autoria de Charcot, reproduzido de outros periódicos.

O artigo de autoria de Charcot é reproduzido dos Annaes de Orthopedia e Cirurgia Pratica (não sabemos de qual nacionalidade), que, por sua vez, traduziu do periódico francês Gazeta Hebdomadaria ${ }^{442}$. Nesse trabalho, intitulado "tratamento da tabes pela suspensão”, Charcot relata um novo método para tratamento da tabes ${ }^{443}$. O artigo é subtitulado como "uma lição do professor Charcot”, relativo a uma aula do mesmo, ou reverenciando a fala e a autoridade do mestre francês.

Essa terapêutica consiste em uma "suspensão mecânica” do paciente, buscando uma forma de estiramento da coluna e da medula pela própria força da gravidade. Esse artigo será comentado mais adiante.

441 EDITORIAL. Revista Medica de São Paulo, p.2, 1889.

442 CHARCOT, J. M. Tratamento da tabes pela suspensão. Revista Medica de S. Paulo, p. 23-27, 1889. 443 Tabes: quadro que se caracteriza por dores e alteração sensitiva nos membros inferiores e alteração de marcha. No tempo de Charcot, achava-se que tinha várias causas, mas havia uma tendência a considerar a sífilis como principal causa. Essa causa acabou sendo confirmada algum tempo após o achado do agente infeccioso causal da sífilis. 
Alguns assuntos inerentes às áreas de psiquiatria e neurologia (ou moléstias nervosas) estiveram presentes no Segundo Congresso Brasileiro de Medicina e Cirurgia de 1889, e são publicados na Revista Medica de S. Paulo ${ }^{444}$. Essas discussões serão enfocadas nos temas em debate correspondentes, no que diz respeito a histeria, hipnotismo, beribéri $^{445}$.

\section{3.2 - Classificações de doenças psiquiátricas e estatísticas. - (1889-1898)}

A classificação das doenças psiquiátricas é alvo de diversos estudos e debates durante o período abordado por nosso trabalho. As divergências, em torno de vários aspectos dessas classificações, refletem dúvidas e imprecisões dos próprios estudiosos do período. As mudanças gradativas dessas classificações acompanham o estabelecimento das áreas em questão.

Ao observarmos essas classificações, algumas vezes é difícil termos idéia exata de alguns termos ou diagnósticos utilizados pelos estudiosos de então, pois parece-nos haver certa repetição do mesmo conceito em várias subdivisões das classificações. Isso denota uma insistência dos estudiosos na busca de preciosismo no vocabulário, com a finalidade de encontrar a melhor definição possível para a moléstia observada, bem como para deixar assinalados marcos científicos de escolas, professores, ou tendências de preferência do autor da classificação.

Em março de 1898, na Revista Medica de São Paulo, é publicado um resumo do quinto folheto publicado por Franco da Rocha ${ }^{446}$, como "Estatísticas e Apontamentos sobre o Hospício de Alienados de São Paulo”447.

Como esse é o quinto folheto, entende-se que desde a primeira publicação desses folhetos em 1894 ou 1895, publicação essa intitulada “Ensaio de Estatística”,448,

444 SEGUNDO CONGRESSO MEDICO BRAZILEIRO. Revista Medica de S. Paulo, p. 145-166, 1889. 445 Além desses assuntos, também há breve menção à apresentação feita pelo médico Carlos Eiras a respeito da Paralisia Geral em Alienados, mas sem mais detalhes.

446 ROCHA, F. Hospício de Alienados. Revista Médica de São Paulo, anno I, n.2, p. 32, 1898.

447 Neste artigo, Franco da Rocha chama sua classificação de "psychiatrica". O título das classificações é variável. Régis, em sua obra de 1905, chama a classificação de "Classificação Metódica das Psicopatias”, incluindo aí um item de Psicopatias em Moléstias do Sistema Nervoso.

448 Essa data consta em página anexa ao livro "Esboço de Psychiatria Forense”(1904) em lista de publicações de Franco da Rocha. 
Franco da Rocha procura fazer um estudo metódico dos dados estatísticos referentes aos pacientes internados no Hospício, bem como comentários sobre certos assuntos.

Na publicação de 1898, esses assuntos são: a divergência de Franco da Rocha com um advogado sobre responsabilidade penal de um epiléptico; observações sobre estupidez vesânica; leis sobre alienados; observações sobre loucura na raça negra; epilepsia jacksoniana; paralisia geral ${ }^{449}$.

Franco da Rocha considera necessário um tempo de cinco anos para acumular dados suficientes para chegar a conclusões sobre os estudos estatísticos por ele realizados. Por isso, segundo ele, suas informações ainda não incluem dados como idade e estado civil dos pacientes.

Dos 246 pacientes que entraram no hospício durante o ano de 1897, informa-se que alguns não chegaram a ser classificados "porque não eram loucos e retiraram-se depois de algumas semanas de observação" ${ }^{450}$.

Sendo assim, nesse momento, há alguns indivíduos que adentram ao hospício e lá ficam por algum tempo, até chegar-se à conclusão de que não são loucos e, desse modo, têm alta.

O autor debate a imprecisão da classificação psiquiátrica ${ }^{451}$ e usa um exemplo da literatura universal, citando Sheakespeare, em seu inglês original, para referir-se a certa dificuldade em diferenciar o quadro de paranóia do quadro de delírio sistemático crônico. Ele frisa que, em virtude dessa confusão, os alemães preferem chamar todas essas alterações de paranóia.

Parte das dúvidas de classificação de Franco da Rocha reflete o debate a nível internacional sobre as classificações de doenças psiquiátricas, principalmente entre franceses e alemães, que já foi citado em outro capítulo.

Ao discursar sobre suas dúvidas na classificação, o autor faz uma citação do estudioso alemão Wernicke, de 1896 (da obra Grundiss Psychiatrie, conforme citado por Franco da Rocha), onde esse estudioso defende a idéia de “um estado paranóico"452, em

449 ROCHA, F. Hospício de Alienados. Revista Médica de São Paulo, anno I, n.2, p. 32, 1898. 450 ROCHA, F. Hospício de Alienados. Revista Médica de São Paulo, anno I, n.2, p. 33, 1898.

451 Em seu folheto de 1896, sobre "Estatísticas e Apontamentos", Franco da Rocha fala em "balbúrdia" em relação à classificação de moléstias mentais e diz adotar a classificação usada por Teixeira Brandão no Rio de Janeiro.

GIORDANO J, S. A persistência da higiene e a doença mental: contribuição à história das políticas de saúde mental no Estado de São Paulo. Tese de Mestrado em Medicina Preventiva, da Faculdade de Medicina da Universidade de São Paulo, 1989.

452 ROCHA, F. Hospício de Alienados. Revista Médica de São Paulo, anno I, n.2, p. 33, 1898. 
vez da doença paranóia ${ }^{453}$. Ele comenta essa conceituação de Wernicke, para ilustrar suas dificuldades e dúvidas em torno de como classificar.

A classificação que ele adota nesse artigo, se divide em duas Classes, sendo a Primeira Classe referente a indivíduos que "desenvolveram normalmente o cerebro" (conforme a própria terminologia por ele usada) e que posteriormente são comprometidos. A Segunda Classe corresponde a indivíduos com “desenvolvimento incompleto do cerebro ou à degeneração hereditaria”,454.

A Primeira Classe se divide em três grupos. O primeiro grupo corresponde a “psycho-nevroses”. O segundo grupo chama-se “cerebro-psychoses”. O terceiro grupo intitula-se “cerebropathias”.

As “psycho-nevroses”, conforme Franco da Rocha, desenvolvem-se sobre uma perturbação afetiva e são tidas como de origem vasomotora. As "psicho-nevroses” se dividem em: mania (com duas divisões: excitação maníaca e mania propriamente dita) e "lypemania” (com duas divisões: delirante e sem delírio).

As “cerebro-psycoses”, ainda conforme Franco da Rocha, apresentam grave comprometimento do "mechanismo psychico" e produzem "modificações estructuraes do cerebro”. Elas incluem: “mania grave (Tobsucht dos allemães)”; “delirio systematizado chronico de Magnan”(com seus quatro períodos: hesitação, perseguição grandeza, demência); loucuras periódicas (com três divisões: intermitente; de dupla forma; circular); loucuras consecutivas a "perturbações physicas extra-cerebraes”.

Nesta última subdivisão constam os itens: loucura por moléstias agudas ou por moléstias puerperais (ambas consideradas na classificação como formas de confusão mental); loucura por intoxicações diversas (apontadas na classificação como responsáveis por delírio agudo); estupidez vesanica; estupor alucinatório; demência (subdividida em: agitada, catatônica, apática).

As "cerebropathias", de acordo com o autor, correspondem a afecções resultantes de lesões cerebrais agudas, subagudas, ou crônicas, difusas ou em foco, com predominância de manifestações psíquicas. Ainda conforme o autor, a perturbação

453 Wernicke considera a paranóia um “estado” relacionado ao que ele e seus seguidores procuram caracterizar como "sintomas elementares", que são, para ele, sintomas básicos em psiquiatria, supostamente encontráveis em indivíduos de qualquer comunidade ou cultura, e que se manifestam em estados alterados, como uma espécie de superficialização de sintomas primitivos inibidos.

DOWBIGGIN, I. Back to the future: Valentin Magnan, French Psychiatry, and the classification of mental diseases, 1885-1925. Social History of Medicine, 9 (3): 383-408, 1996.

454 ROCHA, F. Hospício de Alienados. Revista Médica de São Paulo, anno I, n.2, p. 33-34, 1898. 
psíquica é secundária. Neste grupo há as subdivisões: meningoperiencefalite difusa; paquimeningite e hematoma; alcoolismo crônico; demência senil, ou por traumatismo, ou por lesões em foco; escleroses primárias ou consecutivas; sífilis cerebral.

A Segunda Classe, como já foi dito, corresponde a quadros associados a desenvolvimento incompleto do cérebro ou a degeneração hereditária. Essa classe tem várias subdivisões. A primeira subdivisão corresponde à paranóia (explicada na classificação como sendo delírio primordial sem base afetiva), subdividida em forma alucinatória e forma simples ${ }^{455}$. A segunda subdivisão corresponde a "loucuras coexistindo ou substituindo a histeria, epilepsia, hipocondria, ou idéias fixas (também chamada na classificação de paranoias abortadas de Westphal). A terceira subdivisão corresponde a loucura dos degenerados hereditários com os itens: loucura moral (lúcida ou impulsiva); idiotia; imbecilidade.

Após apresentar uma tabela a respeito dos casos observados, Franco da Rocha refere ter havido uma mortalidade no hospício de quase dez por cento, na qual ele inclui pacientes que "entraram num dia para morrer no outro, tal o estado de miseria em que são recebidos”456.

Nessa classificação psiquiátrica, Franco da Rocha situa a histeria, a epilepsia e a hipocondria, que eram quadros classificados habitualmente dentro do grupo das “nevroses”, apenas como condições “associadas à loucura ou sucedidas pela loucura”. Sendo assim, nessa classificação psiquiátrica, Franco da Rocha não cita o grupo das “nevroses” propriamente dito, talvez por este ser mais próximo de moléstias nervosas.

\section{3.3 - $\underline{\text { Histeria }}-(1889-1898)$}

O médico Thomaz de Aquino publica na Revista Medica de S. Paulo, em 1889, o artigo "Um caso de hysterismo simulando accesso da febre intermittente" ${ }^{457}$. Nesse artigo, o autor considera a febre como uma das inúmeras modalidades de manifestação da histeria, que ele acentua ser uma "nevrose”, dizendo ser a histeria o "protheu da medicina”.

455 ROCHA, F. Hospício de Alienados. Revista Médica de São Paulo, anno I, n.2, p. 33-34, 1898.

457 AQUINO, T. Um caso de hysterismo simulando accesso da febre intermittente. Revista Medica de São Paulo, p. 106-111, 1889. 
Antes de relatar o caso observado, ilustra previamente sua explanação com outro caso referente a uma criança que foi tratada por outro médico como impaludismo, e que apresentou “ataques” associados a febre. Ele considera que o distúrbio dessa criança correspondia a uma "nevrose convulsiva”, pois as crises cessaram após o uso de "nevrostenicos".

Quanto ao caso propriamente dito de seu artigo, trata-se de uma mulher de 19 anos de idade, que tem ataques há anos, e que foi vista por ele durante a gravidez, quando apresentou ataques associados a febre. Ele tentou aplicar tratamentos para impaludismo, mas não teve sucesso. As crises só melhoraram após o parto. Em outra gravidez a paciente apresentou sintomas que o autor interpretou como relacionados à histeria, tais como: cefaléia, espasmo do esôfago, temperamento nervoso. O autor instituiu bromureto de potássio e outros medicamentos, com o que houve melhora. Assim, considera esse quadro como sendo uma enfermidade de "origem puramente nervosa”. Ele insiste na hipótese de "febre hysterica”, embasado em conceito de Grasset denominado "nevrose vaso motrix intermittente".

Nesse mesmo ano, nesse periódico, um outro artigo sobre histeria aborda essa moléstia pelo tratamento por hipnotismo, em vez de medicação, pelo médico que, nesse momento é o mais entendido em hipnose no Rio de Janeiro e talvez no Brasil. Na sessão de oftalmologia do Segundo Congresso Brasileiro de Medicina e Cirurgia, de 1889, o médico Francisco Fajardo ${ }^{458}$ lê "uma extensa memoria sobre o tratamento das perturbações oculares na hysteria”,459.

\footnotetext{
458 Francisco Fajardo formou-se em 1888, com a tese intitulada "Hipnotismo". Foi considerado como o primeiro médico no Brasil a tratar desse tema. Uma versão ampliada desse trabalho foi impressa em 1896, com o título "Tratado de Hipnotismo". Esse livro e outros trabalhos promoveram a disseminação da hipnose entre os clínicos, entre eles Miguel Couto. Utilizando-se desses conceitos, Érico Coelho fez, juntamente com Fajardo, investigações sobre manifestações mediúnicas. Em 1892, Fajardo tornou-se assistente da cadeira de Clínica Propedêutica, que tinha Francisco de Castro como professor catedrático. Fajardo depois se tornou discípulo de Domingos Freire. No ano desse Congresso, em 1889, Domingos Freire estava no auge com seus conceitos microbianos, ao mesmo tempo em que também estavam acentuadas as controvérsias em torno do entendimento da febre amarela, além de outras moléstias infecciosas. Nesse contexto, a beribéri, doença com comprometimento de nervos periféricos e também do cérebro, estava contada entre as que estavam associadas a alguma forma de microorganismo e seria estudada também por Fajardo.

BENCHIMOL, J.L. Dos micróbios aos mosquitos, p. 303.

459 SEGUNDO CONGRESSO BRAZILEIRO DE MEDICINA E CIRURGIA. Revista Medica de São Paulo, p. 154, 1889. 
Ele relata caso de cura de uma “cegueira hysterica absoluta”460, por apenas uma sessão de sugestão hipnótica. Discute a hipótese de haver simulação nesses casos, acentuando que, nesse mesmo ano o termo simulação foi discutido e adotado no Congresso de Psicologia de Paris. Perguntado sobre como diferencia os casos de histeria dos casos de simulação, Fajardo diz se ater à "historia do doente, seus habitos, educação, herança, etc" ${ }^{\text {461 }}$, bem como em alguns meios próprios do exame. Ele acrescenta o exame de campo visual em um dos casos, que foi feito pelo oftalmologista Moura Brazil.

A Revista Medica de São Paulo publica, em 1898, um artigo enviado por $\mathrm{H}$. Villaça, médico da cidade de Juiz de Fora, Minas Gerais, datado pelo autor em 8 de fevereiro de 1898, intitulado "Gravidez Falsa"462.

O autor refere ser comum a todo médico encontrar mulher que pense estar grávida pelo tempo de um, dois ou três meses, com o útero vazio. No entanto, ele viu o caso de uma paciente que manteve esse estado por nove meses, chegando até mesmo ao "trabalho de parto perfeitamente simulado" ${ }^{463}$. Trata-se de paciente de 48 anos que foi vista pelo médico poucas vezes, mas que, em certo momento, começou a apresentar até mesmo alterações mamárias próprias da gravidez ${ }^{464}$.

O autor foi chamado para atender ao parto, enquanto ocorriam contrações, notando que o útero estava normal. Villaça observou que, para o parto normal, "faltava apenas” a saída do feto. Assim, ele conclui:

“Até onde pode chegar a imaginação de uma mulher hysterica. É um apparelho genital com accessorios, obedecendo cega e automaticamente ordens emanadas de um cerebro enfermo, claudicante! Procurar explicar a physiologia pathologica de semelhantes phenomenos é estabelecer outras tantas conjecturas, sem tirar siquer nenhuma conclusão racional”465.

O autor conjectura então que, como a paciente ficou grávida várias vezes, conhecia assim essa experiência, e que havia se tornado "amante de um rapaz” e, no entender dele, um filho seria a forma da paciente casar-se com esse rapaz. O autor considera que essa foi a “causa sugestiva” desse quadro.

\section{Idem.}

461 Idem, p. 155.

462 Essa condição é bastante conhecida em psiquiatria, obstetrícia, ginecologia e clínica geral com o nome de "pseudociese".

463 VILLAÇA, H. Gravidez Falsa. Revista Medica de São Paulo, anno I, n.3, p. 49, 1898.

464 Idem.

465 Idem, p. 51.

175 
Esses três artigos expressam alguns aspectos da histeria nesse período, com uma abrangência desse diagnóstico inclusive para casos de febre, com a noção de que a auto-sugestão é um fenômeno associado ao aparecimento desse quadro, com a suposição de haver algum mecanismo orgânico transitório do tipo vascular, e com o tratamento por hipnotismo. São aspectos associados ao paradigma de então para esse quadro.

Os artigos também denotam uma circulação do periódico por outros estados, e o interesse de médicos dos mesmos em enviar seus trabalhos para São Paulo.

\section{3.4 - Beribéri $^{466}-(1889-1898)$}

Neste período, o beribéri é uma moléstia considerada como uma forma de nevrite, ou seja, uma inflamação de nervos periféricos. Em virtude da forte presença do paradigma pasteuriano, os estudiosos procuram o germe que consideram como responsável por essa moléstia. Sendo essa a hipótese etiológica, há certa apreensão dos médicos em relação à possibilidade dessa doença desencadear uma epidemia.

Na Revista Medica de São Paulo, há registro do Segundo Congresso Brasileiro de Medicina e Cirurgia ${ }^{467}$, de 1889 , onde um dos assuntos é a discussão sobre "Natureza, causas e tratamento do beribéri" ${ }^{468}$. Uma das preocupações é de que essa moléstia possa, tal qual a febre amarela, tornar-se endêmica e epidêmica no Rio de Janeiro. O médico Vitorino Pereira relata estudos de Silva Lima e de Pacifico Pereira a esse respeito ${ }^{469}$.

O expositor refere-se ao fato de ser possível fazer o diagnóstico diferencial entre essa e outras moléstias apenas por dois sinais observados por Charcot: alterações do reflexo patelar e dos sinais elétricos ${ }^{40}$. Ele também contesta a prioridade da descoberta

466 Atualmente considera-se como causa do beribéri uma deficiência de vitamina B1 (tiamina). Seu quadro clínico apresenta comprometimento dos nervos periféricos e também pode comprometer o encéfalo, podendo haver alteração mental e de memória, além de manifestações de motricidade ocular, entre outras. Essa forma encefálica é chamada de síndrome de Wernicke, ou ainda de WernickeKorsakoff, sendo mais frequentemente observada em indivíduos alcoólatras, principalmente os mal nutridos. Recentemente há pesquisas em torno de um fungo presente no arroz poder facilitar essa moléstia, por meio de comprometimento do metabolismo da vitamina B1.

467 A Revista faz apenas uma narrativa sobre as atividades desse Congresso, mas não apresenta a própria fala dos participaantes do mesmo.

468 SEGUNDO CONGRESSO BRAZILEIRO DE MEDICINA E CIRURGIA. Revista Medica de São Paulo, p. 152, 1889.

469 Idem.

470 Ibidem. 
de Lacerda, que alega ser o germe da beribéri um bacilo, enquanto Silva Lima encontrou um micrococo, em acordo com estudos internacionais.

O médico Martins Costa, presente a essa discussão, não aceita que tenham sido diagnosticados como beribéri, alguns casos surgidos "na ultima quadra epidemica”. Ele acha que são "nevrites” de outras causas infecciosas.

Vemos assim, que, mesmo em se tratando de hipóteses diversas, a causa microbiana é tida como certa, o que demonstra a força do paradigma pasteuriano nesse período.

Nas divagações a respeito do diagnóstico correto da moléstia, são relatados, como únicos elementos que possam trazer alguma certeza, sinais clínicos e elétricos apontados por Charcot.

Nesse período de pleno domínio do mestre francês sobre o entendimento das doenças do sistema nervoso, suas indicações são seguidas de modo geral, inclusive no Brasil. Esses achados de Charcot compõem parte do que se estrutura como o "corpo neurológico” apontado por Foucault.

Na Revista Medica de São Paulo, em 1898, o médico Francisco Fajardo, do Rio de Janeiro, publica um artigo intitulado "Do hematozoario do beriberi e seu pigmento" ${ }^{471}$, no qual ele discorre a respeito de demonstração de preparados feita à Academia Nacional de Medicina em 28 de abril de 1898, apresentando um germe causador do beribéri.

Fajardo refere que, desde 1893, estuda a etiologia do beribéri. No entanto, ele diz que, depois de ter sido afastado do Laboratório Bacteriológico Federal, providenciou, a suas custas, um laboratório bacteriológico vindo de Lantenschläger, em Berlim ${ }^{472}$.

Inicialmente, no artigo, ele repete uma citação do estudioso Pfeiffer, de que o estudo dos protozoários está, nesse momento, em fase nebulosa semelhante à bacteriologia de 15 anos antes; de modo que ele pede o concurso de médicos, zoologistas e histiologistas para essas pesquisas, do mesmo modo que fizeram médicos e botânicos na bacteriologia ${ }^{473}$.

471 FAJARDO, F. Do hematozoario do beriberi e seu pigmento: demonstração de preparados feitos á Academia Nacional de Medicina em sessão de 28 de Abril de 1898. Revista Medica de São Paulo, anno I, n.5, p. 87, 1898.

472 Idem.

473 Ibidem. 
Fajardo cita então o que considera como "genial descoberta de Laveran” (descoberta do protozoário causador da malária), acrescentando a afirmação: “que o beriberi seja molestia infectuosa já não padece mais duvidas”. Assim, relata vários autores para reforçar sua hipótese, incluindo os que fazem comparação entre as moléstias beribéri e malária, procurando sugerir um protozoário como agente etiológico dessas doenças.

\section{3.5 - Doutrina do neurônio - (1889-1898)}

O espanhol Ramon y Cajal (1852-1934), baseado em estudos do italiano Golgi (1843-1926) a respeito de métodos e técnicas para a visualização do neurônio, aprimorou esses procedimentos. No entanto, Golgi considera a célula nervosa como apenas um elemento que faz parte de uma rede, ou retículo, e não tem autonomia. Já Ramon y Cajal estabelece uma doutrina em que essa célula tem autonomia, ficando interligada a outras.

Ele traduz seu trabalho do espanhol para o alemão, para torná-lo conhecido no meio científico. Assim, em 1889, apresenta seu material em Berlim aos cientistas Kölliker e Waldeyer. Esse trabalho causa tal impressão em Kölliker, que este aprende espanhol de forma autodidata, para ler o trabalho de Ramol y Cajal no original.

Após aceitar essa doutrina, em 1891 Waldeyer dá o nome de neurônio à célula encontrada e Kölliker, em 1896, dá o nome de “axônio” ao prolongamento do neurônio. Golgi não aceita a doutrina da autonomia do neurônio ${ }^{474}$.

Essa teoria de Cajal é divulgada no ambiente científico internacional, sendo aceita gradativamente, dando novos entendimentos do funcionamento do sistema nervoso e de suas moléstias, pelo trabalho feito também por outros pesquisadores ${ }^{475}$.

No transcorrer da última década do século XIX, essa doutrina de Ramon y Cajal, a respeito do neurônio, chega também aos estudiosos brasileiros, que sempre estão atentos às novidades científicas. Eles também fazem estudos e pesquisas embasados nesses novos conceitos.

474 FINGER, S. Origins of Neuroscience: a History of Explorations into Brain Function. Oxford University Press, 1994, p. 45-48.

475 Ramon y Cajal e seu opositor, Golgi, dividiram ambos o Prêmio Nobel em 1906.

FINGER, S. , p. 48. 
Assim, na Revista Medica de São Paulo, em 1898, os médicos do Rio de Janeiro, Francisco Fajardo e Miguel Couto, publicam um artigo intitulado "Caso de Polynevrite Palustre"476, onde referem-se a conceitos ligados à noção de neurônio.

Os autores comentam que até há pouco tempo não se aceitava a lesão isolada dos nervos periféricos, considerando-se sempre necessária uma lesão dos centros de crescimento dos neurônios. Depois, eles dizem que esse ponto de vista mudou, frisando que: "hoje a luta vai acesa entre peripheristas e centralistas" 477 , indicando uma disputa entre esses dois pontos de vista. Os autores dão a entender que eles são favoráveis ao entendimento periferista.

Em suas conclusões, eles usam a palavra “neurona”, para se referirem à célula nervosa periférica, objeto da discussão:

"Portanto, acompanhando as idéas modernas, adiantadas pelas recentes descobertas acerca da estructura nervosa, é forçoso concluir que só podia estar afectado, no caso presente a parte peripherica, do neurona motor peripherico. É a parte peripherica da unidade anatomica peripherica que, soffrendo o processo da intoxicação palustre, se exteriorizou por dados etiologicos, nosologicos e anatomicos, que pareceu justificada a inclusão do facto no activo das polynevrites palustres”, ${ }^{478}$.

A seguir, os autores citam vários casos registrados por estudiosos estrangeiros em datas recentes em relação ao artigo (entre esses Laveran, Raymond, e outros), para reforçarem sua hipótese.

Neste artigo, os autores usam o então recente conceito de neurônio, para darem seu entendimento sobre essa polêmica entre centralistas e periferistas, em torno do funcionamento e da forma de instalação das doenças do sistema nervoso periférico.

Em outro artigo de 1898, de Franco da Rocha, a respeito da Tese de Concurso de Miguel Couto, intitulada “Dos espasmos nas afecções dos centros nervosos”479, há também a questão da doutrina do neurônio.

Franco da Rocha comenta que Miguel Couto entra em terreno de muitas hipóteses, nas “altas e obscuras regiões dos centros nervosos” ${ }^{40}$. Ele acrescenta que esses

476 FAJARDO, F.; COUTO, M. Caso de Polynevrite Palustre. Revista Medica de S. Paulo, anno I, n.3, p. 42-44, 1898.

477 FAJARDO, F.; COUTO, M. Caso de Polynevrite Palustre. Revista Medica de S. Paulo, anno I, n.3, p. 42-44, 1898.

478 Idem, p. 44.

479 ROCHA, F. Dos espasmos nas afecções dos centros nervosos; These de Concurso do Dr. Miguel Couto. Revista Medica de São Paulo, p. 193-195, 1898.

480 Idem, p. 194.

179 
debates atingem mesmo a questão de nomenclatura, referindo-se especificamente à palavra neurônio:

"Controversias surgem a cada passo, mesmo em questões das mais simples, como a de nomenclatura. A palavra neuronio, por exemplo, com tanto successo lançada por Waldeyer, não é tão universalmente acceita, como faz crer uma nota da these do Dr. M. do Couto; um histologista se oppoz a ella ${ }^{481}$.

Em seguida, Franco da Rocha acrescenta um texto no original alemão de Kolliker, em publicação de 1896, para ilustrar esse debate, e comenta sobre o assunto principal do trabalho de Miguel Couto, dizendo que ele definiu o espasmo como uma contração muscular involuntária, tendo estudado esse fenômeno em várias moléstias.

Franco da Rocha acrescenta uma série de detalhes que fazem parte do estudo de Miguel Couto, incluindo 87 casos de comprometimento do encéfalo e 37 de comprometimento da medula espinhal. Das conclusões gerais elencadas, citamos que o autor conclui que a epilepsia jacksoniana é expressão clínica de uma lesão no córtex cerebral, com localização determinada e que os espasmos em geral se devem a uma esclerose do feixe piramidal.

Essas duas suposições caminham no sentido de retirar as moléstias relacionadas com esses espasmos (epilepsia, coréia e similares) do grupo das nevroses, na medida em que se formulam hipóteses de alterações definidas do sistema nervoso.

Também está presente o conceito de feixe piramidal ${ }^{482}$, ou sistema piramidal, como único território do cérebro responsável pela atividade motora, estando citado o "neurônio motor” como entidade fisiológica nesse contexto.

Franco da Rocha comenta a hipótese de Miguel Couto para a coréia, na qual este considera que essa moléstia irrita ou comprime o feixe piramidal, mas não o destrói. Franco da Rocha acrescenta a esse comentário a hipótese de Langdon, um estudioso americano, embasada nos estudos sobre o neurônio (estudos de Cajal, Golgi e de outros autores); nesse artigo de 1896, Langdon parte da teoria do neurônio para formular

481 Kolliker foi um dos entusiastas da teoria do neurônio de Ramon y Cajal. Pode ser que ele se opusesse ao nome neurônio. Ou ainda o histologista citado pode ser Golgi, que se opunha à teoria do neurônio como sendo uma célula com individualidade.

482 O nome "piramidal” para esses feixes de neurônios advém do fato de Thomas Willis ter nomeado uma estrutura, pela qual passam esses feixes, de "pirâmides" (ele considerava-as reservatórios de “espíritos animais”). A partir de estudos de Hughlings Jackson nos anos 1860 com certos tipos de crises epilépticas, aos poucos se estruturou o conceito do sistema piramidal como ligado á motricidade.

FINGER, S. Origins of Neuroscience, 1994, p. 24; 193-194. 180 
correlações mais complexas entre as estruturas do sistema nervoso, para tentar explicar o mecanismo da coréia ${ }^{483}$.

Franco da Rocha conclui com a recomendação da leitura da tese aos que se interessem pela "neuro-pathologia"484.

Os comentários de Franco da Rocha indicam que ele está inteirado dos debates nacionais e internacionais a respeito de estudos do sistema nervoso, embasados na teoria do neurônio.

\section{3. 6 - Moléstias nervosas - (1889-1898)}

Em 1898, na Revista Medica de S. Paulo, Franco da Rocha faz um resumo de três artigos de revistas internacionais recentes do mesmo ano. Os três comentários são reunidos na seção "Revista das revistas", sob o título "Molestias nervosas"

Um dos artigos é do Archiv für Psychiatrie a respeito de 8 casos de Coréia de Huntington, diferenciando-a da Coréia de Sydenham, considerando que a primeira é de natureza hereditária e a segunda de natureza infecciosa ${ }^{486}$.

Outro artigo é da Centralblatt für Nervenheilkunde und Psychiatrie, do professor Bechterew, que estudou os reflexos nos indivíduos tabéticos, relatando que as alterações desses reflexos são sintomas precoces nessa moléstia, bem como também a analgesia de certos nervos (à compressão) também são precoces nos quadros de tabes ${ }^{487}$.

A publicação dessas resenhas, sob o título de "moléstias nervosas”, indica o enquadramento de coréias e tabes nesse grupo de doenças. Além disso, os estudos sobre as duas formas de coréia indicam elementos de conhecimento sobre essas moléstias que tendem a retirá-las do grupo das nevroses, o qual, como já referido, é anexo às moléstias nervosas.

Ainda nesse contexto de moléstias nervosas estudadas por Franco da Rocha, em 1898 ele publica artigo referente a um comprometimento de medula espinhal observado no hospício.

483 Idem.

484 Idem.

485 ROCHA, F. Revista das Revistas: Molestias Nervosas. Revista Medica de S. Paulo, anno I, n.3, p. 74-75, 1898.

486 Idem.

487 Idem, p. 74-75.

181 
Trata-se de artigo sobre um caso de "paralisia espinhal ascendente aguda”,488, que ele atribuiu à vacina contra a varíola, a qual foi aplicada a um paciente do hospício. Mesmo com essa conseqüência, Franco da Rocha defende a prática da vacinação, argumentando que esses casos de efeitos indesejáveis são raros e que, o caso em questão se deve a um sistema nervoso frágil e vulnerável, para onde se dirigem as toxinas presentes na vacina.

Ele compara seu diagnóstico com casos semelhantes de outros autores, e refere não ter como confirmar com detalhes patológicos sobre o seu caso, afirmando que "nós não possuimos laboratorio anatomo-pathologico, por isso nada adeantamos”.

Nesta afirmação, Franco da Rocha indica a falta de algo que ele considera importante e que vai demorar a ter: um laboratório no Juquery.

\section{4 - Práticas e procedimentos (1889-1898)}

Este item diz respeito a práticas e procedimentos relativos a formas de exame clínico ou munido de aparelhos, ou métodos de laboratório para realização de diagnóstico; ou ainda práticas e procedimentos referentes a formas de terapêutica, relativas às áreas em questão, que aparecem registrados nas revistas desses anos.

No artigo de Charcot, “Tratamento da tabes pela suspensão”, já referido anteriormente, de 1889, na Revista Medica de S. Paulo, o professor diz que, quando há muitos remédios contra uma mesma moléstia, nenhum deles funciona. Ele supõe que, provavelmente, às vezes a própria natureza cura alguns casos atribuídos a certos medicamentos $^{489}$.

Charcot relata então que, na Salpêtriére, em 1867, empregou o nitrato de prata, preconizado por Wunderlich, para tratar casos de tabes, mas com pouco resultado. De modo semelhante, outros medicamentos, como mercúrio e iodureto de potássio, tiveram resultado nulo ${ }^{490}$.

A seguir, refere ter conhecido o tratamento por suspensão para tabes - uma suspensão mecânica do corpo do paciente -, por intermédio de um aluno russo, que lhe

488 ROCHA, F. Paralysia espinhal ascendente aguda. Revista Medica de São Paulo, anno I, n.3, p. 41-42, 1898.

489 CHARCOT, J. M. Tratamento da tabes pela suspensão. Revista Medica de S. Paulo, p. 24, 1889.

490 Idem. 
falou do tratamento feito por um médico de Odessa, Dr. Motchoukowsky. Charcot informa ter enviado seus assistentes à Rússia para conhecerem o tratamento. Cita um paciente do médico russo que tinha muitas dores, sinais e sintomas, sendo que, após 99 suspensões, “finalmente restabeleceram-se as funcções sexuaes com grande prazer para o interessado" ${ }^{491}$. Charcot disse reconhecer que "a suspensão apresentava como resultado capital a restauração das funcções sexuaes” ${ }^{492}$. Desse modo, conforme diz, Motchokowsky teve a idéia de tratar assim os “impotentes nevropathicos”. Então, ele acrescenta:

"Permitti-nos, senhores, uma digressão. Ha, como sabeis, em Paris e outros paizes, estabellecimentos onde se põem em pratica todos os esforços e os meios variados para que os impotentes, e sobretudo os velhos recobrem uma virilidade mais ou menos ficticia, capaz pelo menos de assegurar por certo tempo a satisfacção de desejos, mais ou menos naturaes. Pensamos se não seriam conhecidas as virtudes aphrodisiacas da suspensão, e, para nos assegurarmos deste facto, enviamos emissarios encarregados de colher informações”493.

Para reforçar a importância dessa terapêutica na restauração das funções sexuais, Charcot cita as atividades médicas de Paris e de vários países para restabelecer essa função, conforme o texto. Desse modo, vê-se que, antes de Freud, a medicina já tem uma atividade terapêutica voltada para a esfera sexual.

Também se observa, a partir da publicação desse artigo, que os médicos de São Paulo têm interesse nesse assunto, seja pelos diagnósticos, como pelo tratamento, bem como por Charcot, na medida em que esse trabalho foi escolhido para ser publicado na Revista Medica de S. Paulo.

Na Revista Medica de São Paulo, de 1889, é publicada uma resenha a respeito de outra publicação internacional, desta vez sobre um artigo publicado na Revue de l'hipnotisme.

Nessa resenha, o médico José Redondo, em 1889, trata de um artigo dessa referida revista, artigo esse denominado "Tratamento empírico do sonambulismo"494. Esse artigo se refere a um dicionário publicado em 1741, que relata “curas de

491 Idem, p. 25.

492 CHARCOT, J. M. Tratamento da tabes pela suspensão. Revista Medica de S. Paulo, p. 26, 1889. 493 Idem. 494 REDONDO, J. Tratamento empírico do somnambulismo. Revista Medica de S. Paulo, p. 120, 1889. 183 
sonambulismo natural” ${ }^{\text {495 }}$ por meio de chicotadas aplicadas no momento do fenômeno. Segundo Redondo, esse tratamento "não seria hoje mais aceito tão facilmente”496.

Por esse artigo observa-se a prática da hipnose em voga, nesse período, havendo até mesmo uma Revista de Hipnotismo. Além disso, a recusa a um tratamento considerado “um processo muito brutal”, indica uma determinada percepção crítica a esse tipo de conduta no final do século XIX. A partir do desenvolvimento da prática hipnótica, o estado do hipnotizado passou a ser considerado similar ao quadro de sonambulismo, o que retirou esta manifestação de entendimentos tidos como mais obscuros, inserindo-a no campo científico.

Nesses dois artigos internacionais relatados, observa-se a presença direta e indireta de Charcot: em seu relato pessoal propriamente dito e na disseminação da prática do hipnotismo. A influência de Charcot se faz sentir ainda por anos adiante, passando a diminuir, após Babinski e outros estudiosos trabalharem com outros paradigmas, principalmente no que diz respeito à histeria. Mas algumas noções propostas por Charcot se mantêm em um contexto mais amplo, seja em relação a alguns aspectos inerentes às áreas em questão, bem como em relação à clínica em geral ${ }^{497}$.

Já em outro artigo de 1898, de Franco da Rocha, pode-se observar certa contestação deste, a um paradigma científico de outro mestre francês, Trousseau. Esse artigo da Revista Medica de São Paulo intitula-se “Accidentes da Dentição”498.

Franco da Rocha relata casos de quatro crianças, irmãos, com alterações gengivais, sendo que duas morreram e duas se salvaram. Ele atribui a cura destas crianças à sua decisão de fazer incisão em suas gengivas. Franco da Rocha diz saber que

495 Idem.

496 Ibidem.

497 A influência de Charcot também se faz sentir em diversos outros fatores:

Charcot foi o responsável pela difusão do conceito de neurastenia, estabelecido anteriormente pelo médico americano Beard.

GOETZ, C.G. Poor Beard! Charcot's internationalization of neurasthenia, the "American disease". Neurology, 57 (3): 510-4, 2001.

Charcot influenciou o conceito freudiano de trauma psíquico.

LIBBRECHT, K.; QUACKELBEEN, J. On the early history of male hysteria and psychic trauma. Charcot's influence on Freudian thought. Hist. Behav. Sci., 31 (4): 370-84, 1995.

O nome de Charcot está ligado a aproximadamente vinte moléstias, incluindo sintomatologias e alterações anátomo-patológicas.

Em: <http://www.whonamedit.com>. Acessado em 20 de março de 2007.

498 ROCHA, F. Accidentes da dentição. Revista Medica de São Paulo, anno I, n. 6, p. 112-113, 1898. 184 
esse procedimento contraria a doutrina de Trousseau, a qual repele energicamente essa conduta.

No entanto, Franco da Rocha fez sua própria interpretação da situação. Ele argumenta com noções de fisiologia, segundo as quais “a susceptibilidade reflexa é exagerada nos systemas nervosos tenros, ainda em periodo de organização" ${ }^{\text {"499 }}$. Assim, ele acha que uma irritação periférica (a inflamação das gengivas) pode produzir “perturbação vaso-motora de caracter grave, devido aos phenomenos cerebraes por ella provocados" ${ }^{\text {500 }}$. Desse modo, ele considerou que removida a perturbação, “não se dará o edema cerebral" ${ }^{501}$.

Podemos observar, nesse momento, a relação suposta entre o sistema nervoso e o resto do organismo, no que diz respeito a um conceito de irritação do cérebro, associada a uma idéia de perturbação vaso-motora, provocando um comprometimento cerebral, que por sua vez, gera graves conseqüências no organismo. Esse raciocínio está ligado a uma idéia do cérebro como um órgão com certa centralidade em relação aos outros, não só em relação a manifestações neurológicas ou psíquicas, mas também em relação a outros mecanismos fisiológicos ${ }^{502}$.

Ainda quanto à terapêutica, em outro item dessa seção Revista das Revistas, de 1898, há uma referência a um artigo do periódico alemão “Neurologie Centralblat”, de fevereiro desse ano, a respeito do sucesso do uso da medicação adonis vernalis para epilepsia, medicamento esse fortemente recomendado por Bechterew ${ }^{503}$.

Outro item, da mesma seção, se refere a um artigo do periódico francês Journal des Praticiens, de 1898, que relata dois casos de sucesso do uso da sugestão como

499 Idem.

500 ROCHA, F. Accidentes da dentição. Revista Medica de São Paulo, anno I, n. 6, p. 112-113, 1898.

501 Idem.

502 A idéia do cérebro como um órgão central em relação a diversas funções do organismo também pode ser encontrada em uma resenha feita na seção "Revista das Revistas”, em 1898, na Revista Medica de São Paulo, a respeito de artigo de 1889 do autor E.S. London para a "Centralblat fur Pathologie" de 1889, artigo esse intitulado "Os hemispherios cerebraes e a immunidade". $\mathrm{O}$ autor relata pesquisa em que foram retirados os lobos cerebrais de pombos, ficando eles suscetíveis ao carbúnculo. O autor associa esse dado experimental ao fato de que indivíduos paralíticos eram mais suscetíveis à tuberculose. Conclui, assim, que a fagocitose (defesa celular) está sob dependência direta dos hemisférios cerebrais. Esse autor considera a fagocitose como sendo o mesmo fenômeno chamado de medicatrix naturae pelos antigos, ou seja, um processo de cura natural por conta do próprio organismo.

REVISTA DAS REVISTAS: os hemispherios cerebraes e a immunidade. Revista Medica de S. Paulo. Anno I, n. 6, p. 123, 1898.

503 REVISTA DAS REVISTAS: adonis vernalis na epilepsia. Revista Medica de S. Paulo, Anno I, n. 10, p. 219, 1898 
terapêutica. Em um desses casos, um camponês estava convencido de que ficaria cego. No outro caso, havia a presença de vômitos incoercíveis, devido ao indivíduo pensar ter comido carne de cachorro ${ }^{504}$.

Nesses dois relatos terapêuticos concomitantes, observam-se dois caminhos em voga para tratar esses quadros: o tratamento medicamentoso e o tratamento pela sugestão. Essas diferentes condutas foram aplicadas aos casos então enquadrados entre as "nevroses”, como a epilepsia e a histeria, que constam desses artigos.

\section{5 - Conclusões do período 1889-1898}

Para evitarmos ser repetitivos, vamos procurar restringir a replicação de comentários que acompanham os artigos, que estão situados nas diferentes seções como forma de tornar mais explicativa à descrição desses textos, e que já têm certo caráter de conclusão.

É necessário frisar, antes de tudo, o aparecimento e a gradual estabilidade dos periódicos médicos em São Paulo como palco vivo de debates, discussões, relatos de pesquisas, de opiniões, etc. que permitem uma visualização dos processos em torno das áreas enfocadas, bem como suas correlações com diversos fatores. No transcorrer dos diversos períodos abordados as revistas vão crescer em variedade e complexidade, trazendo toda uma dinâmica a respeito de nossos estudos, inclusive na própria fala das personagens.

No primeiro período correspondente a dez anos, chama-nos a atenção a diferença entre o início e o fim desse intervalo. Essa diferença se expressa pelo aparecimento marcante de Franco da Rocha no cenário médico de São Paulo. Devemos acentuar aqui a chegada dessa personagem a São Paulo como um divisor de águas, não só em termos de cuidados aos doentes psiquiátricos, como também em uma forma de construir a ciência médica em São Paulo, inserida no contexto republicano, bem como em uma geração de médicos que se instala na cidade com desempenho e objetivos

504 REVISTA DAS REVISTAS: a suggestão na therapeutica. Revista Medica de S. Paulo, Anno I, n.10, p. 219-220, 1898. 
singulares; nos anos 1890, elabora-se na cidade o que pode ser chamado de uma “escola médica de São Paulo”, entre altos e baixos das organizações entre os médicos.

Com dois anos de formado, Franco da Rocha chega a São Paulo com forte determinação, de modo que logo se projeta na imprensa local, defendendo seus objetivos. Em pouco tempo, adquire todo o apoio do Estado para seu projeto, além de orientar a execução desse projeto.

Queremos assinalar a velocidade com que esse processo se instala, coordenado por um médico praticamente recém-formado.

Além disso, sua publicação de um artigo em revista médica alemã, nessa mesma década, bem como também de folhetos periódicos com dados estatísticos do hospício, indicam uma determinada linha de elaboração de uma ciência médica, ou mesmo psiquiátrica, própria de Franco da Rocha, antes ainda de haver o periódico médico paulista de 1898.

Demarcando seu caráter próprio, ele é também um questionador de alguns conceitos estabelecidos, na medida em que lança dúvidas sobre o valor e a forma das classificações psiquiátricas, ou ainda na maneira de seguir suas próprias reflexões, em confronto com afirmações paradigmáticas de antigos estudiosos. De modo similar, questiona também determinações legais a respeito dos alienados.

Ainda um fato a assinalar sobre Franco da Rocha, é sua constante atualização em relação aos novos temas científicos em voga na Europa e Estados Unidos, sem defasagem no tempo em relação às novas informações. Consideramos que esse é também um fator que vai configurar a "escola de Franco da Rocha”, que se constrói com certa independência de outros centros psiquiátricos brasileiros.

O corpo neurológico é bastante marcado pelos paradigmas de Charcot nesses anos, tanto em relação aos quadros de histeria, como em relação a outras moléstias. A interpretação, dos dados obtidos pelo sistema estímulo-resposta, incorpora um novo paradigma de entendimento do sistema nervoso, através da doutrina ou teoria do neurônio.

Foucault diz que no século XIX, o corpo do psiquiatra se confunde com o hospício; em Franco da Rocha, isso tem seu equivalente. Sendo assim, ao envolver-se com o Juquery desde os primeiros momentos de sua criação, ele elabora e constrói seu próprio corpo, enquanto profissional de psiquiatria e moléstias nervosas. 
Pela conceituação de Latour sobre a circulação dos fatos científicos, em relação ao item mobilização do mundo, Franco da Rocha faz uso de dados estatísticos, na construção do processo científico com que se envolve. Em termos de representação pública, escreve em jornais cotidianos e periódicos científicos, inclusive internacionais. Quanto a alianças, vínculos e nós, seu trabalho científico se faz estreitamente ligado à República. No fator de autonomização, Franco da Rocha não tem envolvimento muito próximo com as associações médicas do período, de modo que este não é um ponto forte em seu envolvimento com o processo de sua área de atuação.

Esses e outros estudos fazem com que, na virada do século, o sistema nervoso seja um dos mais estudados no organismo, de modo que assume uma singular centralidade em relação aos outros sistemas, sendo atribuído a ele até mesmo o controle das defesas do corpo. Em um tempo em que os microorganismos e as epidemias são a principal atração da ciência médica, como elementos que vêm de fora do organismo, o sistema nervoso é o melhor representante do próprio interior do corpo. Sua expressão semiológica se estabelece na gradual configuração do corpo neurológico. 
Capítulo 3 - 2º Período: 1899-1912.

Do Juquery à Faculdade de Medicina.

Neste período ocorre o estabelecimento definitivo do Juquery como instituição plena em relação aos cuidados com pacientes psiquiátricos. Concomitantemente ocorre um gradual processo de amadurecimento das condições para a criação de uma faculdade de medicina em São Paulo.

O agente causal microbiano da sífilis é desvendado, bem como se estabelece o exame para seu diagnóstico, além de seu tratamento, o que influencia fortemente o entendimento dessa moléstia em relação a seus quadros psiquiátricos e neurológicos.

O conceito de histeria é modificado por Babinski, que, com um novo paradigma sobre essa moléstia, reduz em muito a presença desses casos em hospitais e asilos. Outros estudos de Babinski em andamento vão determinar os contornos do corpo neurológico.

\section{1 - Instituições médicas (1899-1912)}

\subsection{1 -Hospício da Capital e Hospício do Juquery (1899-1912)}

Em 1900, a Revista Medica de S. Paulo publica uma parte de “Apontamentos e Estatística” ${ }^{505}$, de Franco da Rocha, referente ao registro de casos em 1899.

Entram 259 doentes durante esse ano, com uma média de 590 doentes em tratamento, sendo 420 na capital e 170 na colônia do Juquery.

Nesse ano são registradas 89 mortes. Saem curados, 79; não curados, 15; melhorados: 10 .

$\mathrm{Na}$ estatística de formas de loucura, a única em que são contados mais estrangeiros do que brasileiros corresponde à "lypemania”, com 32 casos para estrangeiros e 23 para brasileiros. Nas outras formas, há predomínio de brasileiros. Na distribuição por raças, há grande predomínio em geral para acometidos da raça branca. Conforme a informação da tabela, "pardos" e "pretos” são acometidos em quantidade bem menor. Apenas na forma “loucuras periódicas” há a igualdade de 3 casos contados em cada raça.

505 ROCHA, F. APONTAMENTOS E ESTATISTICA. Revista Medica de S. Paulo, anno III, n. 5,, p.8994, 1900. 
Os números dos que saem melhorados, curados e não curados podem indicar certa dinâmica no fluxo de pacientes da sociedade para o hospício e vice-versa, ou seja, a entrada dos doentes psiquiátricos no hospício não ocorre de forma definitiva e irreversível.

Talvez o número de doentes distribuídos entre brancos, pardos, pretos e estrangeiros, com predominância de brancos na maioria dos grupos, guarde certa proporção com a distribuição da população. No entanto, essa hipótese demanda outras análises para além de nosso trabalho.

Em 1901, no artigo “Apontamentos e Estatistica”, Franco da Rocha publica dados referentes a $1900^{506}$. Nesse ano, 170 pacientes são internados na colônia do Juquery, tendo havido apenas um óbito, de paciente que já chegou em más condições ao estabelecimento, comforme o texto. Assim, ele considera como não tendo havido praticamente nenhum óbito, nesse ano, na colônia. No Hospicio da cidade de São Paulo são contadas 129 entradas; 55 mortes. Saem curados, 48; melhorados, 9; um paciente sai sem ser curado.

Em 1902, Franco da Rocha publica, na Revista Medica de São Paulo, o artigo "Hospicio de Alienados de S. Paulo - Secção de Juquery, Colonia Agricola e Hospicio da Cidade» ${ }^{507}$. Dando a entender que está muito atarefado com as três seções, ele se desculpa pela demora em publicar os dados do hospício como tem feito anualmente (vemos, assim, que Franco da Rocha e seus locais de trabalho entram na velocidade e ritmo da acelerada cidade de São Paulo):

“O Asylo de alienados de Juquery, seç̧ão propria de tratamento, embora ainda incompleto, foi inaugurado em 6 de maio de 1901 com 240 doentes homens.

O serviço administrativo dos asylos de alienados de São Paulo, tal como está, esparso em 3 secções, e um só director para todas ellas, torna o logar que actualmente occupo muitissimo penoso, obrigado, como sou, a superintender em todas as seç̧ões. É esta a razão da tardança no apparecimento destas notas que annualmente publico.

Não tenho com estas notas outra pretensão mais que fornecer informações aos que tiverem mais tempo disponivel e, mais provectos, possam se utilizar dellas para estudos geraes”508.

506 ROCHA, F. Apontamentos e Estatística. Revista Medica de S. Paulo, p. 80, 1901.

507 ROCHA, F. Hospicio de Alienados; Secção de Juquery, Colônia Agrícola e Hospicio da Cidade. Revista Medica de S. Paulo, p. 75-76, 1902.

508 Idem, p. 75. 
Em seguida, o autor passa aos relatos estatísticos e às tabelas de dados por diagnósticos. Em 1901 há 186 doentes novos, sendo 81 mulheres e 105 homens. Saem curados, 45; melhorados, 15; não curados, 9. Faleceram 53 pacientes. $\mathrm{O}$ total de doentes em tratamento nesse ano é de 818. A mortalidade corresponde a 6,5\%. O autor considera o número de altas por cura como “insignificante” por ser de 5,5\%.

Em 1903 fecha-se o Hospício da Capital, sendo que no Juquery há o Hospício e a colônia.

Em 1905, Franco da Rocha publica a estatística referente aos anos de 1903 e $1904^{509}$. A distribuição de casos pelos diferentes grupos de diagnósticos segue a classificação que está discutida em outra seção deste capítulo. É feita uma subdivisão por sexo, raça e nacionalidade (brasileiro ou estrangeiro). De modo geral, há uma predominância entre os doentes de homens brancos brasileiros, em relação aos outros subgrupos.

Em 1906 Franco da Rocha viaja para a Europa e para os Estados Unidos ${ }^{510}$.

A partir de 1906, as estatísticas do Juquery deixam de aparecer na Revista Medica de São Paulo (ressalve-se que não foi publicada estatística no ano de 1899, referente a 1898).

Em 1908, Franco da Rocha inicia, nos arredores do Juquery, a prática de assistência familiar aos insanos, relatada mais adiante na seção correspondente a “práticas e procedimentos”.

Em 1909, quando da inauguração de um curso de diagnóstico clínico, Rubião Meira comenta a respeito do Juquery como um local de ensino:

"No Hospital do Juquery existe, senhores, outra escola no nosso Estado. Alli o dr. Franco da Rocha, psychiatra insigne que faz honra ao Brasil e é conhecido em toda a immensa vastidão do nosso paiz pelos seus acurados trabalhos a que preside a mais bem orientada observação, constitue o centro da psychiatria paulista, a verdadeira escola onde se pode bem estudar os desvios do espirito, as molestias que atacando a intelligencia retiram do convivio social os individuos affectados. A opinião do dr. F. da Rocha, vós todos sabeis, em materia de alienação mental, nas conferencias medicas como nas questões medico-legais, é acatada, entre nós, com o mesmo recato e impõe a mesma consideração que a de Kraepelin, de Juliano Moreira, de Charles Feré, de Chaslin, Ballet, Raymond e outros da envergadura scientifica desses emeritos professores" ${ }^{\text {,11 }}$.

\footnotetext{
${ }^{509}$ ROCHA, F. Estatística Psychiatrica. Revista Medica de S. Paulo, p. 204-207, 1905.

${ }^{510}$ NOTICIAS. Revista Medica de S. Paulo, p. 170, 1906.

511 Idem, p. 81. 
Em publicação de 1912, intitulada "Hospício e Colônias do Juquery”, Franco da Rocha apresenta as subdivisões da assistência aos pacientes psiquiátricos:

- um asilo fechado, de tratamento;

- colônias agrícolas anexas ao asilo, onde o “open door” é completo;

- assistência familiar dentro do perímetro do estabelecimento;

- assistência familiar fora dos terrenos do asilo, na vila de Juquery.

Conforme o médico Barradas Barata, autor da referência consultada para esses dados, nesse momento, em 1912, esse método de abordagem de pacientes psiquiátricos é modelo para o Brasil e para o mundo ${ }^{512}$.

\subsection{2 - Faculdade de Medicina e instituições similares (1899-1912)}

A leitura da Revista Medica de São Paulo mostra que, em 1900, há o registro de uma movimentação dos médicos paulistas no intuito de fundar uma escola de medicina, que começa a ser organizada, mas não chega a se concretizar.

O médico Queiroz Mattoso faz uma proposta à Sociedade de Medicina e Cirurgia de São Paulo, na sessão de $1^{\circ}$ de setembro de 1900, a respeito da criação de uma “Escola Medico-Cirurgica n’esta Capital” ${ }^{\text {"13 }}$. O texto da Revista refere-se a certo clamor da sociedade pela criação da Faculdade, lembrando lei, comissões, a imprensa e o povo. É frisado que, após a idéia da Faculdade de Medicina, em 1891, já apareceram: a “Escola Polytechnica”, o “Gymnasio do Estado" e a "Escola Livre de Pharmacia”. Assim, o editorial reforça o que considera como fatores que assinalam a importância da medicina:

\footnotetext{
“Basta passar-se em ligeira revista a decisiva importancia da Medicina sobre as questões da jurisprudencia, sobre os delicados problemas de psychologia, ou sobre as magnas questões de pedagogia e de sociologia, para immediatamente nos capacitarmos da franca e decidida acceitação que deverá merecer a idea da organização de uma Faculdade de Medicina em S. Paulo"514.
}

\footnotetext{
512 BARRADAS BARATA, A. Hospital Psiquiátrico: contribuição para o seu planejamento. Tese de Doutoramento apresentada ao Departamento de Prática de Saúde Pública da Faculdade de Saúde Pública da Universidade de São Paulo, 1972.

513 EDITORIAL: Faculdade de Medicina de São Paulo. Revista Medica de São Paulo, anno III, n. 9 p. 209, 1901.

514 Ibidem. 
Ainda nesse editorial da revista, há o relato da reunião da Sociedade de Medicina e Cirurgia ocorrida em 14 de setembro de $1900^{515}$, onde o médico Arnaldo Vieira de Carvalho apresenta as cadeiras dessa Faculdade, e seus respectivos professores. Entre as 33 cadeiras listadas, há a Cadeira de Clinica Psiquiátrica designada a Franco da Rocha, separada da Cadeira de Moléstias Nervosas, que está direcionada a Bettencourt Rodrigues.

São formadas comissões para organizar os estatutos, para angariar donativos e subvenções. Arnaldo Vieira de Carvalho é aclamado presidente interino, Luiz Pereira Barretto é aclamado presidente honorário da nova Escola. Arnaldo Vieira de Carvalho pede às comissões que apressem os seus estudos, a fim de ser instalada a escola com a possivel brevidade. No entanto, a faculdade não chega a se concretizar.

Nesse momento, observa-se que os médicos estão se movimentando em torno da criação de uma faculdade em São Paulo, mas algum fator impede de obterem êxito. Não temos elementos para saber o que ocorre, mas, de qualquer forma, ainda significa alguma instabilidade nas organizações da classe médica.

Em relação à psiquiatria e moléstias nervosas relatadas nessa proposta de faculdade, podemos notar que, em 1900, há uma posição de separar ambas as áreas em duas cadeiras em São Paulo, o que pode significar uma tentativa de acompanhar o que já havia sido feito na França por Charcot, em relação a uma cadeira específica de moléstias do sistema nervoso.

O médico português Bettencourt Rodrigues, proposto para essa cadeira, é citado várias vezes por Franco da Rocha em seu livro Esboço de Psychiatria Forense, como alguém que pesquisa e se aprofunda em aspectos do exame neurológico e que lhe acompanha em algumas avaliações de pacientes feitas por solicitação jurídica.

Na Revista Medica de S. Paulo, em 1909, publica-se um artigo denominado “Instituto Clínico"516. Nesse texto, informa-se a criação, no dia 15 de fevereiro, de um curso de diagnóstico clínico, pelos médicos Rubião Meira e Ulysses Paranhos. Rubião Meira faz uma conferência intitulada "O ensino livre da Medicina”. Entre os que

515 EDITORIAL: Faculdade de Medicina de São Paulo. Revista Medica de São Paulo, anno III, n. 9 p. 210, 1901. 516 INSTITUTO CLINICO. Revista Médica de S. Paulo, anno XII, n. 3, p. 76-83, 1909. 193 
assistem a essa conferência, está listado o médico Enjolras Vampré, de modo que o seu nome aparece, provavelmente, pela primeira vez nas revistas paulistas.

Em seu discurso, Rubião Meira considera inaugurado o "ensino médico livre na nossa florescente capital, que, para ter attingido ao apogeo de sua civilização, só lhe faltava a instituição que hoje aqui se levanta" ${ }^{517}$.

Essa sua afirmação e a seguinte são cheias de ufanismo paulista, nesse período em que a cidade é um canteiro de obras. Em relação a seu curso também há certo exagero, já que diz ser essa a instituição que falta para a capital atingir o apogeu da civilização.

Meira acrescenta que, apesar disso, ainda fica faltando o ensino médico oficial. Ele acentua que, em São Paulo, “somos realmente, dentro da vastidão immensa do paiz, uma população livre e independente, com vida sua, propria, autonoma”518. Assim, ele institui o "ensino livre e independente, á semelhança do que se passa em innumeras localidades do mundo" 519 .

Para reforçar essa iniciativa, cita grandes nomes da ciência, que não fizeram parte dos quadros de faculdades de medicina, como Pasteur, Claude Bernard, Huchard, Babinski, Laveran, bem como outros cientistas e professores em outros países, além da França. Especificamente sobre Babinski, ele diz:

“O grande nevropathologista, tido como professor official, tão intenso é o renome que o cerca e tão vasta a illustração do seu espirito, e que no hospital da Pitié, entre a multidão de medicos e estudantes de medicina, prelecciona sobre as affeç̧ões nervosas, estudando de modo original as perturbações da sensibilidade na hysteria, o estado mental dos hystericos, a symptomatologia e a pathogenia das nevrites, demonstrando em seu curso pratico, mais frequentado que as aulas da Faculdade, o valor da docencia livre, que é a suprema ambição de nosso ensino" ${ }^{\text {520. }}$.

Refere-se também a contra-exemplos de professores de faculdades que, segundo ele, trouxeram maleficios à humanidade, citando os nomes de Broussais, Dieulafoy e Koch, explicando os motivos dessa sua opinião.

Prosseguindo, ele faz menção à qualidade dos cirurgiões de São Paulo, encabeçados por Arnaldo de Carvalho. Cita os higienistas liderados por Adolpho Lutz e

517 INSTITUTO CLINICO. Revista Médica de S. Paulo, anno XII, n. 3, p. 77, 1909.

518 Idem.

519 Idem, p. 78

520 Idem. 
Artur Mendonça. Fala de Vital Brasil, que tem reconhecimento no exterior. Em relação à psiquiatria, sua fala sobre o Juquery já foi exposta em outro item.

Meira acrescenta o valor dos exames hematológicos e outros exames de laboratório a serem ensinados, além de frisar o ensino minucioso da semiologia nervosa, entre as outras semiologias.

Aqui se observa uma tentativa de ensino médico talvez um pouco mais formal do que aquele que já ocorre em São Paulo, ainda antes de haver alguma Faculdade.

Além disso, há um momento do discurso em que Meira relata já haver tentado, por duas vezes, ser professor da Faculdade do Rio de Janeiro, por concurso, sem ter conseguido. Isso demonstra também que há, nesse período, uma demanda de indivíduos em condições de ensinar medicina, porém sem ter como fazê-lo oficialmente em São Paulo, embora ocorra ensino em enfermarias e reuniões científicas.

Em 1910, na Gazeta Clinica, na seção "Noticiário”, publica-se um artigo intitulado "Faculdade de Medicina de São Paulo"521. A Congregação da Escola de Pharmacia de S. Paulo, em abril de 1910, delibera convidar vários clínicos para serem professores do curso médico que se inicia ${ }^{522}$.

Segundo o periódico, o professor Amâncio de Carvalho, diretor dessa Escola, nesse ano, convida Rubião Meira para ser professor da cadeira de Clínica Propedêutica. Meira recusa esse convite, com carta publicada na Gazeta Clinica. Entre outras razões, ele refere que os médicos formados por tal escola só podem clinicar em S. Paulo, já que essa escola não pode ser reconhecida pelo Código de Ensino da República. Além disso, ele acha que os farmacêuticos não podem dar aulas para os médicos. Meira cita a faculdade do Rio Grande do Sul como bom exemplo de ensino médico.

521 NOTICIARIO. Gazeta Clinica, p. 59-60, 1910.

${ }^{522}$ Conforme o historiador André Mota, em 19 de novembro de 1911 foi criada a Universidade de São Paulo, uma instituição privada (não deve ser confundida com a fundada em 1934), da qual fez parte esse Curso de Medicina. O autor do projeto dessa instituição foi o médico Eduardo Augusto Guimarães, positivista e político que fez campanha pelo ensino privado no país. Os cursos dessa Universidade eram: medicina, direito, belas artes, comércio, engenharia, odontologia e farmácia. O diretor do curso médico foi o médico Antonio Carini, havendo a importante participação de Ulysses Paranhos. Essa instituição foi combatida pela maioria dos médicos da Sociedade de Medicina e Cirurgia de São Paulo, que queriam um curso mantido pelo Estado e não queriam farmacêuticos ensinando médicos. Supõe-se também uma disputa entre grupos de médicos nessas divisões.

MOTA, A. Tropeços da Medicina Bandeirante: Medicina Paulista entre 1892-1920. Edusp, 2005, p. 171181. 
Em 1911 é publicado na Revista Medica de S. Paulo o artigo "Reforma do Ensino Medico - Decreto n. 8.661 - de 5 de abril de 1911”, por Rivadavia da Cunha Corrêa $^{523}$.

Nesse ano é lançado um novo Regulamento das Faculdades de Medicina, de influência positivista, elaborado por Rivadavia da Cunha Correa, que causa grandes polêmicas, devido a propor novas formas de organização dos cursos médicos, que não são bem recebidas por eles.

Especificamente no decreto, no artigo 6, entre as matérias do curso de “sciencias medicas e cirúrgicas”, consta o item “Clinica psychiatrica e de moléstias nervosas”. No artigo 11, o curso de “Clinica psychiatrica e moléstias nervosas” está listado em último lugar, no sexto ano do curso médico.

Em 1912, na Revista Medica de S. Paulo, são publicados vários artigos sob o título "A reforma do ensino e a autonomia das faculdades", de autoria do médico A. Pacifico Pereira ${ }^{524}$. Esses artigos procuram divulgar as noções da Lei Rivadavia anteriormente citada.

Este e alguns outros artigos dispõem sobre a chamada "lei organica do Ensino Superior e do Fundamental da Republica”, dando novos regulamentos às Faculdades de Medicina, de Direito, à Escola Politécnica e ao Colégio D. Pedro II. O ministro, autor da reforma, diz que têm em vista "uma suave e natural passagem da vigente officialização do ensino para sua completa desofficialização, corollario fundamental do principio da liberdade profissional consagrado na Constituição da Republica"525.

Ainda, segundo essa informação, esse regulamento "liberta a consciencia academica da oppressão dos mestres, arreda destes a tutela governamental, em cujo passivo se inscrevem todas as culpas da situação periclitante a que chegaram as instituições de ensino, acredito dar um passo a frente com a actual organização"526.

O artigo passa a narrar o histórico de diversas reformas no regulamento do ensino, culminando com a então recente proposta de desoficialização, embasada no Positivismo. Também é feita uma tentativa de aprofundar o conhecimento do que ocorre no ensino médico na França e na Alemanha, entre outros países, procurando

523 CORREA, R.C. Reforma do Ensino Medico; decreto n. 8661, de 5 de abril de 1911. Revista Medica de S. Paulo, p. 150-158, 1911.

524 PEREIRA, A.P. A reforma do ensino e a autonomia das faculdades. Revista Medica de S. Paulo, p. 27-39; 46-55; 71-80; 84-90; 160-168, 1912.

525 Idem.

526 Ibidem.

196 
comparações, sendo que se refere ter a França um sistema centralizador, enquanto a Alemanha tem um sistema mais autônomo.

Um aspecto polêmico é a conseqüente abolição dos privilégios de diplomas escolásticos ou acadêmicos de profissionais das artes liberais, como médicos, engenheiros, advogados, juristas, tornando as profissões livres da necessidade de títulos ou diplomas, levando ao que chamam de "liberdade profissional".

Em relação à organização da faculdade, há um estímulo à chamada "livre docencia”, à imagem das faculdades alemãs, com professores que dão aula nos cursos, mas recebem de maneira diversa daqueles que têm vínculo direto com o Estado, ou a Faculdade.

Outro artigo de 1912, sobre o mesmo assunto, do médico Pacífico Pereira, é subtitulado “A seriação das materias do curso medico"527. Nesta parte, dessa sucessão de artigos sobre a reforma do ensino e a autonomia das faculdades, é descrita a seriação das disciplinas nos anos respectivos do curso médico. No sexto ano, vem citada por último a disciplina de “clinica psychiatrica e de molestias nervosas”.

No mesmo ano, dando continuidade a esse assunto, o médico Pacifico Pereira, publica o tema “A instrucção pratica”528. Neste artigo, o autor refere que, em 1877, após conhecer universidades alemãs e austríacas, pediu ao governo brasileiro uma reforma do ensino médico, que pudesse prover as faculdades de laboratórios e material técnico para o estudo prático. Depois, ele narra, sucessivamente, as transformações legais no Brasil para promover uma melhora do ensino prático de medicina e a construção de laboratórios na Faculdade do Rio de Janeiro e da Bahia.

Ainda em 1912, é publicada uma continuação desse tema, do mesmo autor, subtitulado como "A clinica psychiatrica”529.

O autor refere que, na Faculdade de Medicina da Bahia, o ensino da clínica psiquiátrica é o que luta com maiores dificuldades para sua organização prática, "por falta de um serviço regular de assistencia a alienados de cujos estabelecimentos possa

527 PEREIRA, A.P. A Reforma do Ensino e a Autonomia das Faculdades - continuação. Revista Medica de S. Paulo, p. 244-249, 1912.

528 PEREIRA, A.P. A Reforma do Ensino e a Autonomia das Faculdades. Revista Medica de S. Paulo, p. 285-193, 1912.

529 PEREIRA, A.P. A Reforma do ensino e a autonomia das faculdades. Revista Medica de S. Paulo, p. 368-376, 1912. 
elle utilisar-se" ${ }^{530}$. Nesse sentido, cita o papel importante das Santas Casas como local que cuida dos insanos, de modo geral, mesmo na ausência de um asilo adequado.

Após relatar exemplos de outros países, o autor evoca palavras de Nina Rodrigues: “A disciplina psychiatrica, reputada até não ha muito tempo uma das especialidades mais particularisadas, forçou os limites restrictos impostos á sua acção, e impõe-se hoje como uma clinica geral, cujo conhecimento deve ser exigido de todos os medicos clinicos" ${ }^{» 31}$.

Após essa citação, ele comenta a responsabilidade dos clínicos como conselheiros de família, como em situação quando "combalida a integridade mental de um dos seus membros”, o médico seja capaz de dar "a proposta e medidas medicas ou juridicas promptas e seguras”532.

Além disso, reforça a "efficacia da intervenção medica precoce na cura das molestias mentaes, concorrendo para alliviar o Estado do onus pesadissimo da assistencia aos cronicos incuraveis”533. Também se refere ao “papel capital que hoje toca á psychiatria nas relações constantes dos medicos com a administração publica e a distribuição da justiça" ${ }^{534}$. O autor completa seu artigo com propostas pertinentes a solicitações já feitas à direção da Faculdade da Bahia em 1905.

As considerações de Pereira sobre o ensino de psiquiatria e moléstias nervosas não é o ponto principal de polêmica sobre a nova lei. O autor chega a citar Nina Rodrigues (que tinha diferenças com a tendência positivista em relação à profissão médica), para frisar que o conhecimento psiquiátrico não seria mais de alçada do especialista, mas do clínico geral. Por outro lado, a grande discussão sobre a lei Rivadavia, dizia respeito à forma de aceitar a profisionalização, mesmo sem diploma.

Dois anos após a iniciativa de um curso médico pela Escola de Pharmacia, são tomadas medidas definitivas para a instalação da Faculdade de Medicina de São Paulo, que inicia suas atividades no ano seguinte.

530 PEREIRA, A.P. A Reforma do ensino e a autonomia das faculdades. Revista Medica de S. Paulo, p. 368-376, 1912.

531 Idem.

532 Ibidem.

533 Ibidem.

534 Ibidem.

198 
Desse modo, em 1912, na Revista Medica de S. Paulo, na seção “Noticias”, é publicado um informe intitulado "Escola de Medicina em S. Paulo"535. Nesta notícia é relatado o Projeto apresentado à Câmara dos Deputados em 17 de outubro, para a criação de uma Escola de Medicina e Cirurgia em São Paulo, remetendo-se à lei n.19 de 12 de Novembro de 1891, a qual já previa a criação de um curso de Medicina ${ }^{536}$. Na lista de disciplinas está colocada, em último lugar, no sexto ano, a disciplina de "Clinica Psychiatrica e Molestias Nervosas”537.

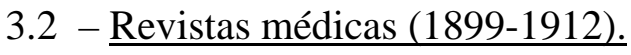

Em 1903 é lançado em São Paulo o periódico Gazeta Clínica, que perdura por décadas. Essa publicação aceita artigos com ampla variedade e liberdade a seus autores, servindo inclusive como espaço de discussões e debates os mais diversos, eventualmente chegando ao pitoresco. Não tivemos acesso ao primeiro exemplar e seu editorial. Vários editores se sucedem nesse periódico, como Xavier da Silveira, Rubião Meira e outros.

De 1904 a 1914 circula também em São Paulo o períodico Imprensa Medica. Ele é subtitulado como "Jornal pratico de Medicina, Cirurgia, Hygiene e Therapeutica”, e notifica ser publicado nos dias 10 e 25 de cada mês. Consta como seu diretor o médico B. Vieira de Mello.

$\mathrm{Na}$ “Comissão de Redacção” estão os seguintes médicos e suas respectivas atribuições: A. Vieira de Carvalho, diretor clínico do Hospital da Misericórdia; Franco da Rocha, diretor do Hospício de Alienados; Sylvio Maya, diretor da Maternidade; C. Espinheira, diretor do Hospício de Isolamento; L. Pereira Barreto, professor honorário

535 NOTICIAS: Escola de Medicina de S. Paulo. Revista Medica de S. Paulo, anno XV, n. 12, p. 434436, 1912.

${ }^{536} \mathrm{O}$ historiador André Mota, citando Elza Nadai, afirma que a Faculdade de Medicina não foi fundada logo após o decreto de 1891, porque os interesses políticos estavam voltados para os outros cursos, como engenharia, destinados ao progresso de São Paulo, e já havia instituições médicas na cidade; também embasado na mesma autora, afirma que a faculdade de 1912 saiu rapidamente do papel por interesses políticos eleitorais.

MOTA, A. Tropeços da Medicina Bandeirante: Medicina Paulista entre 1892-1920. Edusp, 2005, p. 181183.

537 NOTICIAS: Escola de Medicina de S. Paulo. Revista Medica de S. Paulo, anno XV, n. 12, p. 434436, 1912. 
da Escola Polytechnica; Amâncio Carvalho; professor de Medicina Pública; W. L. Strain, diretor do Hospital Samaritano; F. Pignatari, diretor do Hospital Oftálmico; Clemente Ferreira, presidente da Liga Paulista contra a Tuberculose; Paulo Bourroul, inspetor sanitário do Estado de S. Paulo.

Constam como "Redactores correspondentes” os médicos: Alfredo de Britto, diretor da Faculdade e professor de Clinica Propedêutica da Bahia; Nina Rodrigues, professor de Medicina Legal da Bahia; Anísio Carvalho, professor de Clinica Médica da Bahia; Nuno Andrade, professor de Clinica Medica do Rio de Janeiro; Augusto Vianna, professor de Bacteriologia da Bahia; Pacheco Mendes, professor de Clinica Cirúrgica da Bahia; Chapot Prevost, professor de histologia do Rio de Janeiro; Pedro Carrascosa, professor substituto, da Bahia ${ }^{538}$.

Seu primeiro exemplar, de 10 de julho de 1904, consta como ano XII, número 1. Em seu editorial intitulado "Nosso Programma”, Vieira de Mello dá a entender o motivo dessa numeração. Ele explica que, em 1881, no Rio de Janeiro, foi fundada a revista União Medica, por Julio de Moura, Moncorvo, Silva Araujo e Moura Brasil, “pleiteando a causa dos médicos e mostrando-lhes o dever de intervirem na solução de questões vitaes de instrucção publica, reforma do codigo penal, immigração, etc.”. O autor informa que, em 1882, a gerência do periódico foi confiada ao ainda "sextoannista” do curso de medicina ${ }^{539}$, Vieira de Mello, que no ano seguinte assumiu a posição de redator-gerente. Em 1891, o periódico foi suspenso pelo motivo de Vieira de Mello sair do país.

Em 1904, Vieira de Mello reinicia a revista, segundo ele com o intuito de fazer uma publicação prática, onde o clínico encontre "sem esforço a summa dos trabalhos scientificos realizados no pais e no exterior”. Justifica a necessidade do periódico ser quinzenal pela rapidez com que os trabalhos científicos se sucedem.

Vieira de Mello informa ter demorado a retomar a publicação, em virtude de sua nova instalação passar a ser em São Paulo. Assim se expressa o editor, a respeito da nova sede paulista do periódico:

538 Nota-se que a revista se coloca como tendo uma interligação com outros centros médicos científicos. 539 É notável que Vieira de Mello, ainda aluno, já assuma a editoriação de uma publicação. Nesse período, por esse e outros dados, alguns alunos, ou recém-formados, logo se envolvem com atividades profissionais de destaque. Algumas teses inaugurais, que são trabalhos de conclusão de curso, adquirem certo destaque, como, por exemplo, a já citada tese de Homem de Mello. 
“Fazendo acompanhar o nome de cada redactor de um titulo clinico ou scientifico, é nosso intuito patentear o nucleo importante de estudos que possue S. Paulo, no tocante á medicina, collocando a classe medica paulista em condições de poder competir com a de paizes estrangeiros os mais adeantados.

De facto, possue S. Paulo, alem do Hospital de Misericórdia, vasto repositório de casos clínicos de alto interesse, confiado á competencia profisional do Dr. Arnaldo Vieira de Carvalho auxiliado por um grupo de illustres e estudiosos clínicos, a Maternidade, o Hospício de Alienados, o Hospital Ophtalmico e o Hospital de Isolamento, sob a respectiva direcção clinica dos Drs. Sylvio Maia, Franco da Rocha, W. L. Strain, Francisco Pignatari e Candido Espinheira, nomes vantajosamente conhecidos do nosso meio pelas suas aptidões scientificas e profissionaes" ${ }^{540}$.

A seguir, ele cita os nomes dos outros membros da comissão de redação e elogia os colaboradores da Bahia e do Rio de Janeiro.

Vieira de Mello conclui, enumerando as seções da revista: trabalhos originais, revista das publicações científicas, revista dos hospitais, formulário terapêutico, indicador bibliográfico, variedades e notícias.

Embora este trabalho esteja circunscrito a São Paulo, alguns eventos ocorridos em outros locais são de interesse para o estudo em questão, quando associados às áreas enfocadas, podendo também permitir uma melhor compreensão dos diversos elementos em jogo.

Desse modo, a publicação do Rio de Janeiro, Archivos Brasileiros de Psychiatria, Neurologia e Sciencias Affins, lançada em 1905, inicia uma nova fase de revista médica (em relação a publicações mais especializadas) nos campos estudados, sendo então já focada em áreas médicas mais específicas. Neste caso, além de observarmos o termo "Psychiatria” no título, que é uma palavra já consagrada no meio médico e científico, vemos também, de maneira clara, a adoção do termo “Neurologia”, como se referindo a um campo de conhecimento equivalente ao então utilizado como “Moléstias Nervosas”. O acréscimo de “Sciencias Affins” pode talvez indicar a percepção dos fundadores do periódico, de que eles estão diante de um campo de estudo que tem intersecção com outras áreas além das nomeadas.

540 MELLO, V. Editorial. Imprensa Medica, p.2, 1904.

Com essas afirmações, Vieira de Mello dá a entender que São Paulo é um importante centro da ciência médica, no momento em que se inicia a revista. 
Essa publicação, fundada por Juliano Moreira e Afrânio Peixoto ${ }^{541}$ (caracterizados na publicação como “alienistas”) no ano de 1905, em 1907 passa a se chamar Archivos Brasileiros de Psiquiatria, Neurologia e Medicina Legal, na medida em que acompanha a fundação da "Sociedade Brasileira de Neurologia, Psiquiatria e Medicina Legal”, a qual ocorre também em 1907.

Em 1919, há nova mudança do título desse periódico, passando a ter o nome de Archivos Brasileiros de Neuriatria e Psychiatria.

Entre os colaboradores elencados no primeiro exemplar, de 1905, de Archivos Brasileiros de Neurologia, Psychiatria e Sciencias Affins constam, de São Paulo, os médicos Bittencourt Rodrigues e Franco da Rocha. Nesse primeiro exemplar são publicados artigos dos autores: Juliano Moreira, Afrânio Peixoto, Fernandes Figueira, Kraepelin (traduzido por Austregésilo), J. Chardinal.

\section{3 - Temas e questões em debate (1899-1912).}

\section{3.1 - Classificações das doenças - (1899 - 1912)}

Em 1899, na Revista Medica de São Paulo, Franco da Rocha analisa a tese inaugural de Álvaro Fernandes a respeito da "loucura moral” (moral insanity) ${ }^{542}$. Ele acentua a convicção de Fernandes, que com ousadia (no entender de Franco da Rocha) enfrentou os mestres, para mostrar o seu modo de pensar. Refere que o doutorando considera a loucura moral como uma entidade mórbida distinta, e não apenas como uma síndrome, condição esta que pode ocorrer em diversas formas de moléstia mental. Assim, Fernandes dispõe a loucura moral como associada a atos voluntários premeditados, em indivíduos com “perversão dos instinctos sociaes”.

Enquanto comenta a tese de Fernandes, Franco da Rocha acrescenta suas próprias idéias sobre o assunto.

541 Afrânio Peixoto (1876-1947) foi médico, político, romancista, ensaista, crítico literário. Formou-se na Faculdade de Medicina da Bahia em 1897, com a tese “Epilepsia e Crime”. Foi professor de Medicina Legal na Faculdade do Rio de Janeiro, entre outros cargos relativos à sua profissão. Foi membro da Academia Brasileira de Letras.

Em:<http://www.academia.org.br> Acessado em 8 de abril de 2007.

542 ROCHA. F. Moral Insanity; These inaugural do Dr. Alvaro Fernandes. Revista Medica de São Paulo, p. 204-207, 1899.

Nos artigos em que Franco da Rocha analisa teses, frequentemente acaba mais expondo suas idéias, do que trata das teses. 
Franco da Rocha considera que a loucura moral implica em inteligência intacta, ou mesmo brilhante, ao lado de perversão dos sentimentos éticos, com ausência de emoção acompanhando essas situações. Como exemplo de indivíduos que ele considera como comprometidos por esse quadro, cita nomes conhecidos como Bacon, Bocage, Benvenuto Cellini.

Refere ainda Franco da Rocha que o reconhecimento desse quadro por Hack Tuke está de acordo com a lei de evolução e dissolução mental, estabelecida por H. Spencer, tendo sido o termo “moral insanity” determinado por Prichard. Reporta-se também a uma citação de Bleuler, de 1893, de que esses indivíduos não são habitualmente considerados como loucos e sim como criminosos.

No entanto, Franco da Rocha frisa que esse distúrbio se deve a "uma evolução viciada do cerebro”. A isso ele acrescenta: “Mas, como limitar nitidamente a loucura moral? Onde acaba o politico egoista, desassisado e pernicioso? Onde começa o louco $?^{543,}$

Citando outros autores, ele acentua as dificuldades do psiquiatra para estabelecer esse diagnóstico, pois a única maneira de declarar um indivíduo como louco moral é pelo mal que ele fizer à sociedade. No entanto, nesse ponto, ele diz:

"Mas qual o tribunal para julgar a perniciosidade de taes individuos? Eis o nó da questão. Elles são jornalistas, advogados, medicos, litteratos; em todas as profissões ha um grupo enorme de desclassificados, agora ha pouco mencionados por Le Bon, na Psychologie du Socialisme, como o terreno proprio para a germinação das ideias socialistas”, ${ }^{244}$.

Franco da Rocha frisa que a sociedade não pode se livrar desses casos. Assim, encerra, dizendo que: “Conhecemos individuos cujo procedimento não tem outra explicação senão a ausencia de senso moral. Não temos a necessidade de dar aqui o resumo desses casos; é mesmo perigoso entrar muito neste assumpto"545.

Em 1900, na Revista Medica de S. Paulo, Franco da Rocha volta a abordar a loucura moral inserida no contexto de "Política e Loucura". Este é o título da tese de

543 ROCHA, F. Moral Insanity; These inaugural do Dr. Alvaro Fernandes. Revista Medica de São Paulo, p. 206, 1899. 
formatura do médico Domiciano Maia, comentada nesse artigo $^{546}$. Franco da Rocha diz estar entrando "por esse assunto escabroso" estudado por Maia. Assim ele (Franco da Rocha) acentua que a Psiquiatria tem o que estudar, "não só na politica, mas também nas artes e na sciencia” ${ }^{547}$, frisando que nesse terreno já entrara Lombroso com seus discípulos.

Franco da Rocha refere que esses doentes se apresentam de dois modos ao estudo: os que enlouquecem após um choque moral e aqueles cujas idéias políticas já são sintomas de "má conformação congenita do cerebro"548.

Após comentar exemplos da tese de Maia, Franco da Rocha diz que:

“Onde a degeneração é bem pronunciada o individuo, em imminencia de loucura, só espera um motivo qualquer, um movimento social subito, por exemplo, para entrar em delirio, cujo conteudo é de preferencia esse facto social, embora nada tenha que ver com ele directamente. Destes vi em S. Paulo mais de um durante a revolta de 6 de Setembro"549.

Ainda sobre certos indivíduos com a possibilidade de apresentarem loucura moral, consideramos ilustrativo o texto a seguir, onde Franco da Rocha comenta que:

"Desde a infancia mostram na casa paterna as pestes que vão ser na sociedade. Vadios, insubordinados, inconsistentes, incapazes de esforço aturado a não ser para o mal, expulsos de collegios, não tomam profissão alguma a não ser por pouco tempo; em relação ao vicio são como limalhas de ferro para o iman e, cousa singular, um grande numero delles termina a carreira desenfreada assentando praça; outros d'ahi saem para continuar ainda a serie interminavel de desatinos. Neste typo esboçado acima está o louco moral mais comum. Não é este porem o typo unico do grupo; comporta elle muitas variedades, como, por exemplo, o querelante, o inventor e descobridor de cousas inuteis, sendo de notar (circumstancia interessante) que a estes ultimos a direcção dos balões, bem como o motu-continuo, têm dado que fazer á bola. Cabem nesta especie todos os typos de paranoia simples”550.

Franco da Rocha acrescenta que, tanto em política como em religião, há sempre indivíduos que a toda pressa, apaixonadamente, querem "mudar a ordem das cousas estabelecidas, talvez em busca de um estado social em que se acommodem melhor” ${ }^{\text {} 51 .}$

546 ROCHA, F. Política e Loucura; these de formatura do Dr. Domiciano Maia. Revista Medica de S. Paulo, p. 79, 1900.

547 Idem.

548 Ibidem.

549 Ibidem. Não temos informação sobre essa revolta de 6 de setembro.

550 Ibidem.

551 Ibidem. 
Assim, acrescenta que: "são creaturas inqualificaveis; no hospicio não podem estar, na sociedade são praga”. Ele diz que alguns têm servido à prática de boas idéias. Mas ele pergunta se, sem o barulho deles, essas idéias não teriam funcionado melhor. Cita a tese de Maia, quando este diz que os paranóicos perigosos vivem conosco e não nos asilos, tendo a forma atraente de um patriotismo exagerado.

Vê-se que a interpretação científica de certos fenômenos sociais, nesse período, está submetida a uma visão que os considera como passíveis de entendimento dentro de uma explicação patológica. Nessas condições são incluídos indivíduos de diversas camadas sociais e tendências, aparentemente fazendo parte mais de uma camada social letrada, pelos exemplos citados.

É curiosa a citação de Franco da Rocha a respeito dos "inventores de coisas inúteis” ou dos que estão preocupados com a “direcção dos balões”, nesse ano de 1900. É inevitável lembrarmos de Santos Dumont. Recordamos também a abordagem das autoras Costa e Schwarcz, na obra “1890-1914 - no tempo das certezas”, a respeito desse período profícuo em uma espécie de mania de invenções.

Referem essas autoras que, entre 1870 e 1910, deram entrada mais de nove mil pedidos de privilégios industriais nos órgãos públicos competentes, reforçados por uma lei de 1882, que solicitava detalhes dos inventos. Ainda de acordo com as autoras, nesse ano de 1900, especificamente sobre o assunto de balões, o conhecido José do Patrocínio, que estava sendo perseguido politicamente e com o seu jornal indo à falência, resolveu recorrer à ciência e inventou um balão dirigível que, segundo ele, seria a maior conquista do século. No entanto, seu balão não subiu e tornou-se motivo de chacota ${ }^{552}$.

A leitura isolada do artigo de Franco da Rocha pode causar estranhamento por essas citações. Mas, as informações de Costa e Schwarcz, podem inserir esse dado no contexto em torno de certo tipo de ciência no Brasil, na virada dos séculos XIX para XX, com várias pessoas envolvidas com projetos de invenções.

Algumas dessas pessoas poderiam ter sido interpretadas como patológicas, pela ciência psiquiátrica, como no caso de Franco da Rocha (não sabemos se em relação a José do Patrocínio, ou a outros), ao referir-se sobre os inventores de balões.

552 COSTA, A.M.; SCHWARCZ, L M. 1890-1914: no tempo das certezas. Companhia das Letras, 2000, p. $130-133$. 
Em 1900, a Revista Medica de S. Paulo publica uma parte de “Apontamentos e Estatística”553, de Franco da Rocha, referente ao registro de casos durante o ano de 1899. Os dados estatísticos já foram expostos em outra seção.

A classificação das moléstias continua sendo dividida entre dois grandes grupos: as moléstias desenvolvidas em cérebros que atingiram o "grau normal de evolução" 554 e as “constitucionais devidas ao desenvolvimento incompleto do cerebro" ${ }^{\text {555 }}$. Foram listadas as subdivisões respectivas dos dois grupos, similares aos anos anteriores.

Em 1901 na Revista Medica de São Paulo, Franco da Rocha analisa o trabalho do psiquiatra argentino José Ingenieros, intitulado em espanhol "Dos páginas de psiquiatria criminal”, ou seja "Duas páginas de psiquiatria criminal”556.

Ao apresentar esse trabalho, Franco da Rocha discute questões do momento, referentes ao entendimento sobre o alienado delinqüente. Acrescenta que o autor apresenta bases para um estudo mais rigoroso e científico desses casos. Afirma que, até então, esses indivíduos não haviam sido submetidos a um exame criterioso para que fossem classificados no quadro dos delinqüentes, principalmente nas situações de causas orgânicas (causas hereditárias ou adquiridas).

Ele relata a crítica de Ingegnieros às novas escolas penais, como a de Ferri, que reune todos os loucos em um mesmo grupo.

Franco da Rocha acrescenta que os alienistas conhecem loucos perigosos e não perigosos. Assim ele se expressa sobre a opinião de Ingegnieros: "Na opinião do auctor (e creio que na de todos os que estudam) o tempo se encarregará de firmar a noção de temibilidade do delinquente, varrendo aos poucos as innocentes incongruencias ao livre arbitrio que por tanto tempo deram pasto aos fabricantes de psychologia metaphysica” ${ }^{\text {557. }}$.

Desse modo, ele reproduz a classificação de Ingegnieros que, resumidamente, acha que todo indivíduo arrastado ao crime por uma anomalia psíquica é um degenerado,

553 ROCHA, F. Apontamentos e Estatística. Revista Medica de S. Paulo, anno III, n. 5, p.89-94, 1900.

554 Idem.

555 Ibidem.

556 ROCHA, F. Bibliografia: Dos páginas de psiquiatria criminal; por José Ingegnieros, Buenos Ayres. Revista Medica de São Paulo, p. 19, 1901.

557 ROCHA, F. Bibliografia: Dos páginas de psiquiatria criminal; por José Ingegnieros, Buenos Ayres. Revista Medica de São Paulo, p. 19, 1901. 
sendo essa degeneração hereditária ou adquirida, com anomalia na esfera moral, ou na esfera intelectual, ou na esfera volitiva.

Franco da Rocha acentua que essa classificação não foi feita em torno das causas do delito, mas pelos "fatores organicos do delinquente que se associam aos cosmicos e sociaes”. Acentua também que não há tipos absolutos, mas uma associação destes em um mesmo indivíduo, pois afirma que "não ha enfermidades psychicas, mas sim enfermos psychicos”,558.

A respeito dos meios eliminadores do problema dos delinqüentes, Franco da Rocha afirma que Ingegnieros “com certeza” não é partidário das idéias de P. Naecke (1899), que propôs a castração como meio mais seguro e menos dispendioso de impedir a propagação dos degenerados ${ }^{559}$.

Em seus “Apontamentos e Estatística” de 1901, publicados na Revista Medica de S. Paulo, em sua edição de 15 de março desse ano, Franco da Rocha chama a seção “Apontamentos” de “Causas da Loucura” 560. Diz ter escolhido “assumpto escabrosissimo, ante o qual vacillamos um pouco, reflectindo que onze annos de pratica não são tempo ainda sufficiente para um estudo de tal monta",561.

Ele alerta para o fato de que, como são só apontamentos, não divide o estudo em seções didáticas. Desse modo, subdivide o texto de forma um tanto aleatória. Fazemos aqui um acompanhamento do artigo na seqüência em que está disposto.

558 Idem.

559 Em seu livro "Esboço de Psychiatria Forense" de 1904, Franco da Rocha diz considerar de pouco valor a lei da castração votada em Michigan, pois, segundo ele, os "degenerados inferiores" não têm capacidade de reprodução.

ROCHA, F. Esboço de Psychiatria Forense, p. 31.

O sociólogo Antunes acha que, neste artigo, Franco da Rocha deu a entender que concordava com a castração dos loucos perigosos, por ter feito uma comparação com a castração de animais.

ANTUNES, J.L.F. Medicina, Leis e Moral: Pensamento médico e comportamento no Brasil (1870-1930), 1995, p. 100.

560 ROCHA, F. Apontamentos e Estatística; Apontamentos: Causas de Loucura. Revista Medica de São Paulo, p. 73-80, 1901

Como já vimos, em seu livro de 1904, "Esboço de Psychiatria Forense", Franco da Rocha reserva um capítulo à "Etiologia Geral", onde aborda as causas da loucura. Divide as causas em extra-cerebrais e cerebrais e diz que na maioria das vezes há uma associação entre esses dois fatores. Ele realça com mais ênfase (do que neste artigo de 1901) diversos fatores causais extra-cerebrais. Em seu livro, o que ele chama de causa cerebral diz respeito a dois fatores: a herança de tendências mórbidas do sistema nervoso e a degeneração.

ROCHA, F. Esboço de Psychiatria Forense, p. 21-51.

561 ROCHA, F. Apontamentos e Estatística; Apontamentos: Causas de Loucura. Revista Medica de São Paulo, p. 73, 1901. 
Franco da Rocha inicia, dizendo que, na maioria das vezes, a loucura tem várias causas concomitantes, sendo possível, na maioria dos casos, “distinguir o que é essencial do que é occasional”.

A seguir, tece considerações sobre o fator hereditário ser a principal causa de loucura “entre nós”, conforme sua conceituação nesse momento.

Diz ser difícil verificar informações, sobre hereditariedade, com a família do doente, dizendo: “A acreditar-se nestas informações, cada família, em S. Paulo, só tem tido um doente do systema nervoso: - aquelle de que se trata na ocasião"562.

No entanto, afirma que “felizmente, S. Paulo não é muito grande”563 e que só há um hospício, de modo que não é difícil obter informações sobre um doente (assim, passa a idéia de que considera São Paulo uma cidade passível de controle, ao menos em termos de cuidados psiquiátricos).

No caso da sífilis, afirma que o recurso do exame físico é útil, e descreve vários sinais clínicos sugestivos da moléstia.

Nos casos ligados ao álcool, cita duas situações. Uma em que o uso do álcool é ocasional, e apenas permite que se manifeste um quadro que provém de um degenerado. A outra situação se refere ao álcool como causa única do distúrbio psiquiátrico.

$\mathrm{Na}$ primeira situação, do degenerado que se manifesta ao ingerir álcool ocasionalmente, ele diz haver confusão na classificação desse caso, de modo que, nas estatísticas, pode ser contado como alcoolismo, ou ainda como intoxicação aguda, e não como um degenerado.

Dizendo que falta uma boa classificação para as moléstias psiquiátricas e que faltam informações no Hospicio, Franco da Rocha acrescenta como exemplo de embaraços na classificação, casos com manifestações mistas.

Nos casos ligados ao álcool como causa única, ele diz que o quadro é mais claro, com “rebaixamento do nivel intellectual”, embotamento das “faculdades moraes” e “o individuo perde quase que de todo o que se chama caracter”. Ainda refere o enfraquecimento da memória e a perturbação de diversos órgãos.

Ele diz que esses casos são raros no hospício, porque, para o povo, esses indivíduos não têm o que se caracteriza como loucura, a não ser em eventuais delírios,

562 ROCHA, F. Apontamentos e Estatística; Apontamentos: Causas de Loucura. Revista Medica de São Paulo, p. 73, 1901.

563 Idem. 
ou quando vistos por quem os conhecia bem antes. Assim, ele cita uma paciente do hospício que, por 20 anos, percorreu todos os postos policiais de São Paulo, antes de chegar ao estado de demência. Cita também um caso referido na revista Lancet, em 1900, de indivíduo que foi preso 400 vezes, antes de ser considerado incapaz e recolhido ao asilo de alienados.

Franco da Rocha considera o alcoolismo também como causa exclusiva de loucura, em São Paulo, menos freqüente do que na Europa, onde, segundo ele, há motivos para isso, os quais diz não existirem em São Paulo.

Ele aponta a degeneração como causa mais freqüente de loucura em S. Paulo, do que o alcoolismo. Assim, relata que, em seis anos, houve 506 casos de loucura dos degenerados no hospício e 105 devidos a alcoolismo. Ele acha que esse número de degenerados ainda está subestimado, pois outros casos como "estupor, lypemania, confusão mental, loucura puerperal e, sobretudo, loucura periodica”564 provavelmente são também de degenerados.

Entre os degenerados, cita haver grande contingente de estrangeiros. Franco da Rocha acha que a razão não é obscura:

"Entre os immigrantes abundam os desequilibrados, sonhadores de riquezas, que imaginam, com os olhos na America, um infinito de prosperidade e fortuna. Aqui chegados, vendo em pouco tempo desfeitas as suas illusões, esbarrando com a dura realidade da lucta pela vida, longe da terra onde nasceram, opprimidos pela saudade, recorrendo ao alcool como consolo, lá vão, caminho do Hospicio, augmentar os detrictos da sociedade recolhidos áquella casa”,565.

A seguir, o autor se concentra mais demoradamente em um grupo, que ele denomina como os “desclassificados” da sociedade. Ele usa esse termo para designar “typos especiaes que não cabem nem na sociedade nem no Hospicio. Na sociedade são loucos, no Hospicio não o são”566. Assim ele comenta sobre esse grupo:

“No Hospicio, sob regimen severo e regularidade de vida, mantém-se em bom estado mental, apparente. São um tormento continuo para os chefes de serviço; pedem a sua liberdade com insistencia terrivel, com apparencia de logica e não deliram. Saem para a rua, a sociedade não os quer. São o tormento dos conhecidos e vivem em lucta constante com a policia”567.

564 ROCHA, F. Apontamentos e Estatística; Apontamentos: Causas de Loucura. Revista Medica de São Paulo, p. 73, 1901.

565 Idem, p. 74.

566 Idem, p. 74-75.

567 ROCHA, F. Apontamentos e Estatística; Apontamentos: Causas de Loucura. Revista Medica de São Paulo, p. 75, 1901. 
Desse modo, ele descreve o que considera como o histórico de vida desses indivíduos. Pela sua descrição, dá a impressão de ter visto diversos desses casos em seus onze anos de profissão. Também, por essa descrição, vê-se que os “desclassificados” pertencem a uma classe social mais favorecida:

“No collegio ou na eschola é um insubordinado, ás vezes expulso por intoleravel, incorrigivel. Si consegue fazer os preparatorios, o que é raro, fica nos primeiros degraus do curso superior, arranjando logo uma incompatibilidade qualquer. Vai para a Escola Militar; lá continua o mesmo homem; torna-se notavel pela sua inferioridade moral, é desligado e vai para um batalhão, de onde arranja sahida com a protecção que, donde quer que venha, muitas vezes elle a tem. Com alguns conhecimentos obtidos, principalmente de outiva, acontece muitas vezes que de soldado se torne jornalista. Começa agora uma nova serie de actos desregrados, nos quaes apparece sempre o caracter desequilibrado, indo terminar afinal no Hospicio",568.

Refere ainda que, estando dentro do hospício, esse individuo volta ao "estado mental que lhe era normal”, em virtude da regularidade da vida. Desse modo, insiste: “Ahi temos o desclassificado: no Hospicio todos acham que elle deve sahir; na sociedade todos acham que elle deve estar no Hospicio"569.

Ele frisa que esse tipo descrito não é um padrão único desses casos, havendo variações dependentes de fatores influenciadores da carreira desses indivíduos, presentes em classes sociais mais elevadas: "a fortuna, o meio, a educação, o grau de intelligencia, etc.”.

Franco da Rocha refere-se à capacidade de Shakespeare em retratar esses indivíduos postados diante de discursos de Brutus e Marco Antonio. Ele comenta que: “a psychologia das massas populares não pode ser analysada sem o estudo deste elemento capital”. Acentua que esses indivíduos podem ser inteligentes, mas com desordem de caráter.

Nesse aspecto, refere ter-se admirado a respeito do estudioso Gustave Le Bon: “Admira-nos que G. Le Bon, que é naturalmente tido por psychologo, desconheça o estudo de Sergi - Le Degenerazioni Umane - e censure os psychologos de profissão por

568 ROCHA, F. Apontamentos e Estatística; Apontamentos: Causas de Loucura. Revista Medica de São Paulo, p. 73, 1901.

569 Idem. 
não darem ao caracter a importancia que elle merece”570 (referindo-se à obra de Le Bon “Lois Psychologiques de l’Evoluction des Peuples”, de 1894.) ${ }^{571}$.

Em sua vivência em São Paulo, como psiquiatra, Franco da Rocha dá a entender que considera esses indivíduos desclassificados como comuns na cidade:

“Extendemo-nos um pouco mais sobre estes individuos porque elles ahi estão pela rua, por toda a parte. Agite-se um pouco a sociedade por qualquer motivo, e elles surgirão logo. São candidatos constantes ao Hospicio. Muitos motivos futeis são dados pelos interessados como a verdadeira causa da molestia, ao apresentarem no Hospicio seus doentes. As vezes é por causa de uma namorada"572!

Franco da Rocha acha que as causas hereditárias predominam em relação à loucura. Considera que alguns desses casos podem ser devidos a um pai que se embriague às vezes e que, nesse estado, tenha fecundado o óvulo de onde veio o doente.

Também acha possível que influências nocivas atuem no sistema nervoso central desde o primeiro dia de gestação. Assim, acha um tanto arbitrária a diferença entre herança neuropática e degeneração psíquica, pois não há linha divisória precisa entre predisposição e degeneração. Como exemplo, cita a paranóia, dizendo que uns consideram como degeneração e outros não.

Há uma subdivisão desse artigo, em que Franco da Rocha comenta sobre a sífilis como causa de moléstias psiquiátricas. Essa parte do artigo será analisada em outra seção deste trabalho.

Em outra subdivisão são referidas causas menos comuns de loucura. O traumatismo é considerado causa rara e Franco da Rocha cita o exemplo de um soldado que ficou com demência paralítica após uma queda sobre a cabeça, além de outros dois casos similares.

570 ROCHA, F. Apontamentos e Estatística; Apontamentos: Causas de Loucura. Revista Medica de São Paulo, p. 75, 1901.

571 O médico Gustave Le Bon (1841-1931) é um dos estudiosos que propaga as noções de psicologia de massas. Ele tem opinião bastante própria a respeito da psicologia. Em sua obra de 1911, "As Opiniões e as Crenças", refere que todos os métodos, que configuraram os estudos da psicologia, são insuficientes para o estudo que vai descrever, citando-os um a um. Cita inclusive o "método das localizações cerebrais", dizendo que estas estão quase inteiramente abandonadas, inclusive "os centros da linguagem e da escrita". Desse modo, ele discorre sobre sua própria maneira de entender as opiniões e as crenças, fazendo uso de poucas referências a outros estudiosos.

LE BON, G. As opiniões e as crenças. Companhia Brasil Editora, S. Paulo, (1911) 1956.

572 ROCHA, F. Apontamentos e Estatística; Apontamentos: Causas de Loucura. Revista Medica de São Paulo, p. 75, 1901. 
Ele diz que as psicoses pós-operatórias são muito comuns na literatura científica, mas raríssimas entre nós, citando um caso que ele atribuiu ao terror que se apossou de uma doente antes da operação. Refere também casos devidos ao uso do clorofórmio e do éter.

Além dessas causas, Franco da Rocha comenta que, embora muitas vezes sejam informados casos de loucura supostamente devidos à suspensão da menstruação, ele discorda dessa hipótese, pois, conforme diz, os que assim pensam, não levam em consideração a possibilidade de haver uma predisposição neuropática, além da anemia, que frequentemente está presente nesses casos. Cita pesquisa de Näcke, de 1896, que concorda com sua impressão.

Essa opinião de Franco da Rocha acompanha a tendência em diminuir a atribuição dos distúrbios mentais, na mulher, ao útero. O gradativo entendimento dos hormônios vai permitir uma melhor associação entre alterações de humor e menstruação. A observação que foi feita, sobre a possibilidade de uma predisposição nevropática associada a uma anemia, já indica outro entendimento, que não atribui quadros psiquiátricos a alterações uterinas, mas a outros fatores presentes no organismo.

Na Revista Medica de São Paulo, em 1902, na seção “Bibliographia”, Franco da Rocha publica seus comentários a respeito de tese inaugural de Mario Leal, aprovado com distinção no Rio de Janeiro em 1901. O título do trabalho é "Um caso de demencia precoce da puberdade" ${ }^{\text {573. }}$.

Refere Franco da Rocha que o autor faz considerações fisiológicas relativas à puberdade, apoiando-se em autoridades sobre o assunto. Como se trata de caso raro, ele considera desculpável que Leal tenha estudado apenas um caso.

Franco da Rocha refere que: "poucos são partidarios da creação de Kahlbaum ${ }^{574}$, o primeiro que quis dar á demencia precoce na puberdade, foros de entidade morbida definida sob o nome de hebephrenia" ${ }^{\text {575. }}$.

573 ROCHA, F. Um caso de demencia precoce da puberdade (these inaugural do Dr. Mario Leal approvado com distincção - 1901 - Rio de Janeiro). Revista Medica de S. Paulo, p. 213-214, 1902.

574 Karl Kahlbaum (1828-1899), psiquiatra alemão, acreditava que todos os sintomas poderiam ser organizados em grupos e tomou como modelo os sintomas da paralisia geral. Introduziu os termos: “complexo de sintoma”, "ciclotimia”, "catatonia” e "hebefrenia”.

ALEXANDER; SELESNIK. História da Psiquiatria, p. 220.

575 ROCHA, F. Um caso de demencia precoce da puberdade (these inaugural do Dr. Mario Leal approvado com distincção - 1901 - Rio de Janeiro). Revista Medica de S. Paulo, p. 213, 1902. 
Franco da Rocha considera não haver dúvidas de que a puberdade é uma época de importantes transformações fisiológicas, pois entra em funcionamento um órgão que “até então existia virtualmente”, referindo-se aos órgãos sexuais, quando há então "uma transformação psychica profunda”. Comentando sobre a conexão da sexualidade com a vida psychica, ele diz que: "Nos centros superiores não entra o influxo do novo orgão sem oscillações e motivos de extraordinario alcance para a vida psychica” ${ }^{\text {„576. }}$.

Ele recorda, então, os termos habituais de “loucura da juventude”, ou ainda “rabugice e egoismo de velho”, em relação a épocas da vida de grandes transformações fisiológicas. Considera que os normais e equilibrados não ultrapassam certos limites dessas loucuras da juventude, enquanto que os anormais são “tarados por má herança”, e esse desequilíbrio se revela na ocasião propícia da puberdade.

Assim, acha que a verdadeira causa das moléstias mentais, entre os 13 e os 21 anos, é a degeneração cerebral por herança, ou por acidente nas primeiras épocas da vida. Ele não concorda com o autor da tese em discussão, o qual cita a puberdade em si como causa do distúrbio. Franco da Rocha prefere dizer que "a puberdade é um momento etiologico de psychoses

No que diz respeito a novas conceituações em torno da demência precoce na puberdade, observa-se que esse período da vida passa a ser visualizado e delimitado pela psiquiatria, como tendo características próprias. O fato de Franco da Rocha não achar que a própria puberdade possa causar doenças, mas apenas propiciar condições para que elas apareçam, assinalando as transformações sexuais como próprias do período, marca mais ainda essa fase como diferenciada entre a infância e a idade adulta.

Em 1905, na Revista Medica de S. Paulo, Franco da Rocha publica "Estatística Psychiatrica” ${ }^{578}$, correspondendo aos anos 1903 e 1904, com o título geral em ambas de “Movimento do Hospicio de Alienados de Juquery”.

Entre esses dois anos ocorre uma modificação da classificação, sendo que em 1904 a nova classificação é baseada no livro escrito por Franco da Rocha intitulado Esboços de Psychiatria Forense ${ }^{579}$, já comentado em outro capítulo.

576 Idem.

577 Ibidem.

578 ROCHA, F. Movimento do Hospicio de Alienados do Juquery; Estatistica Psychiatrica. Revista Medica de S. Paulo, anno VIII, n. 5, p. 204-207, 1905.

579 ROCHA, F. Movimento do Hospicio de Alienados do Juquery; Estatistica Psychiatrica. Revista Medica de S. Paulo, anno VIII, n. 5, p. 206, 1905. 
Essa classificação já foi abordada no capítulo correspondente à apresentação do livro. Com o uso da mesma para a estatística do Juquery apresentada na revista, Franco da Rocha torna essa classificação conhecida aos leitores desse periódico.

Como assinala em seu livro, ele criou uma classificação própria, diferenciada daquela feita por Teixeira Brandão; esta, até 1903, é utilizada para as publicações sobre o Juquery. Assim, a partir de 1904, Franco da Rocha demarca, de forma mais acentuada, características próprias de seu entendimento das moléstias psiquiátricas.

Em 1903, há a divisão geral em duas classes. A $1^{\text {a }}$ Classe, sem título, diz respeito a moléstias adquiridas e com 3 grupos: "Psycho-Nevroses", “CerebroPsychoses”; “Cerebropathias”"

O grupo “cerebro-psychoses”, em 1904, passa a se chamar “perturbações agudas consecutivas a intoxicações de origens diversas e actuando sobre um cerebro invalido; perturbações graves da nutrição" 581 .

Em 1904, o título do grupo “cerebropathias” deixa de ser usado, constando apenas os quadros: loucuras periódicas, subdivididas em intermitente e maníaca depressiva; catatonia; delírio sistematizado de Magnan ${ }^{582}$.

Na mudança acima ocorrida, em 1904, Franco da Rocha passa a dar mais destaque a causas externas ao cérebro, como intoxicações e perturbações da nutrição, que originam moléstias cerebrais, com manifestações psiquiátricas ${ }^{583}$.

A 2a classe, em 1903 é intitulada: "Molestias constitucionaes devidas ao desenvolvimento incompleto do cerebro ou á degeneração hereditaria”584. Nessa classe estão incluídas: "paranoia; loucura coexistindo ou substituindo á hysteria, ou epilepsia, ou hypocondria; hebephrenia ou demencia precoce; loucura dos degenerados, delirios polymorphos; imbecilidade; idiotia"585.

Em 1904, essa $2^{\text {a }}$ classe passa a se chamar: "loucuras dos cerebros francamente degenerados”, compreendendo os seguintes quadros: “paranoia, loucura moral, hysteria, epilepsia, hypochondria, demencia paranoide, hebephrenia, imbecilidade, idiotia”,586.

580 Idem, p. 204.

581 Idem, p. 206.

582 Idem.

583 Ibidem.

584 Idem, p. 204.

585 Idem.

586 ROCHA, F. Movimento do Hospicio de Alienados do Juquery; Estatistica Psychiatrica. Revista Medica de S. Paulo, anno VIII, n. 5, p. 206, 1905. 
Em 1904 é criado um terceiro grupo à parte (que antes era listado de outra forma), chamado "lesões cerebraes grosseiras”, compreendendo: "peri-encephalite chronica diffusa; alcoolismo cronico; syphilis cerebral; lesões em foco (hemorrhagia); demencia senil; demencia secundaria”,587.

Observamos que Franco da Rocha insere, na segunda classe do primeiro grupo, algumas nevroses, que em suas classificações anteriores apenas eram referidas em situações de loucura desencadeada por esses quadros. Assim, parte do quadro de nevroses, que ficava mais próximo de moléstias nervosas, nessa classificação, está dentro das moléstias psiquiátricas.

Podemos ver que Franco da Rocha publica, no ano 1905, as estatísticas de 1903 e 1904, diferentemente do que vinha fazendo regularmente, a cada ano, além de não ter acrescentado seus “Apontamentos”, com comentários. Em ano anterior ele já havia dado a entender que estava com muito trabalho, o que dificultava sua publicação dos dados. Esse excessivo trabalho e o fato de ter publicado um livro em 1904, podem ter sido fatores que dificultaram sua rotina em publicação das estatísticas.

Em meados da primeira década do século XX, é publicado um trabalho a respeito de suicídio na cidade de São Paulo. A incidência dessa ocorrência leva a esse estudo, sendo esse fenômeno mais um elemento de aproximação da cidade do contexto das metrópoles modernas.

Assim, em 1906 são publicados na Revista Medica de S. Paulo resultados referentes ao trabalho do médico Alcântara Machado, um “folheto” de 63 páginas, intitulado "Suicídios na capital de S. Paulo" ${ }^{588}$. O trabalho foi feito com levantamento minucioso pelo autor junto a setores como imprensa, polícia, hospitais, cartórios. O autor foi citado como o primeiro a estudar esse assunto em S. Paulo. Machado refere como causas de suicídio em S. Paulo: alienação mental, com 19\%; dificuldades financeiras com 15\%; “amores” com 14\%; alcoolismo, 12\%; criminosos, com 10\%; outras causas, 9\%; desgostos domésticos, com 7\%; sofrimentos físicos, com 5,9\%; perda de parentes, $3 \%$.

\footnotetext{
587 Idem. 588 NOTICIAS: Suicídios na capital de S. Paulo; pelo Dr. Alcantara Machado. Revista Medica de S. Paulo, p.374-375, 1906. 
Nos anos 1906, 1907, 1908 não encontramos artigos referentes a “classificações de moléstias” nas áreas em questão.

Desse modo, fazemos aqui algumas considerações sobre alguns registros feitos nas revistas, nesses anos, que podem trazer alguns elementos para se pensar sobre a ausência de artigos, nessas duas revistas, referentes a classificações.

O editorial inicial de 1906 da Revista Medica de São Paulo procura explicar porque em 1905 houve menos artigos publicados de modo geral, relatando que nesse ano não houve muitos assuntos de interesse da classe médica e da Sociedade de Medicina e Cirurgia, além de haverem mais periódicos médicos na cidade (Gazeta Clinica e Imprensa Medica). Essa situação pode ter perdurado no decorrer de 1906.

Esse editorial também avisa que a revista passou a ser propriedade de apenas um dos editorialistas, o médico Vitor Godinho, o que pode ter mudado os interesses a respeito de temas a serem publicados ${ }^{589}$.

Em 1906 a Revista Medica de S. Paulo informa também que Franco da Rocha partiu em viagem por Europa e Estados Unidos, o que pode explicar sua ausência em publicações.

Em 1906 morre Nina Rodrigues, que era um dos que polemizavam a respeito de classificações e nomeações de moléstias.

Em 1905 é encontrado o micróbio causador da sífilis. Isso atrai a atenção de profissionais e pesquisadores para um aprofundamento nesse assunto.

Talvez esses diversos fatos somados possam ter feito com que não tenha sido publicado, nesses anos, algum artigo sobre classificação de moléstias.

No ano de 1907 há apenas um artigo de Franco da Rocha e não versa sobre esse tema.

No ano de 1908, podemos ter algum indício do que ocorria com as publicações médicas em São Paulo através de artigos satíricos denominados "Palestrinhas”, que começam a sair na Gazeta Clinica nesse ano, assinados por certo "Dr. Epaminondas Victorio”, colocando, entre parênteses, “formado nos Estados Unidos” e que diz escrever de Itaporanga ${ }^{590}$.

Ironizando os médicos de São Paulo, ele diz que a Escola de Medicina de São Paulo ainda não foi fundada apenas devido à falta de harmonia e coesão da classe

589 Nesse exemplar da Revista o tipografista registrou o ano de 1905 em vez de 1906. Seria um ato falho em relação à mudança de direção do periódico?

${ }^{590}$ PALESTRINHAS. Gazeta Clinica, p. 107-109, 1908.

216 
medica paulista, "porque todos seriam directores, vice-directores, professores, fiscaes do governo, indicados, sem direito a duvidas e discussões, pelo proprio sentimento e supremo juizo individual da soberana competencia”.

Do mesmo modo, ele lembra da fundação da Academia de Letras em São Paulo, quando qualquer um se proclamava com “indubitaveis capacidades” para fazer parte da mesma. Em seguida, comenta sempre ter ouvido dos paulistas se chamarem "os americanos do Brasil”, querendo exprimir "espírito emprehendedor, o carater arrojado, a coragem para grandes lances e commettimentos, a sede insaciavel de progresso dos homens desta porção do Brasil”.

Lamentando, ele acaba por concluir que "estamos degenerados”. Acentua que São Paulo está “sem Imprensa que o defina”. Assim, prossegue:

“Qual é o jornal, que, entre nós, se occupa com o estudo serio dos magnos problemas sociaes, lançando com frequencia artigos de redacção que diffundam idéas uteis, que orientem a opinião publica, que algo edifiquem na sociedade? O Estado de São Paulo é o que tem melhores correspondentes, e é o mais noticioso e com seç̧ão telegraphica mais copiosa; a Gazeta é quem lança melhores artigos de fundo, quando alguma questão se levanta. Os demais... valha-nos Nossa Senhora da Bocca-aberta!... Nenhum, absolutamente nenhum, apresenta hoje uma redacção forte, inteiriça, de notável competencia, com verdadeira organização jornalistica. Da imprensa scientifica... é melhor silenciar-se!... Três são as revistas medicas que se publicam entre nós (e só destas quero eu falar, porque das outras me não dôo) e é triste lembrar que o Dr. Victor Godinho, proprietario e redactor de uma dellas, para animar a collaboradores, já inseriu em letra de forma - "que recebia como pagamento de seus assignantes em debito quaesquer artigos ou estudos, originaes ou em traducção, com prometimento de lhes continuar a remessa da Revista"!

A seguir ele diz que, mesmo assim, Godinho não conseguiu o seu intento. Elogia Godinho pelo seu livro médico que já está na sua segunda edição, o que, segundo ele, é coisa rara para livro médico no Brasil, e espera que Godinho e seus colegas talvez descubram o germe da "terrivel molestia da indiferença e da inactividade que por São Paulo vae se alastrando epidemica ou já endemicamente”.

Em 1909, a Gazeta Clinica publica um artigo escrito pelo médico Jayme Gonçalves ${ }^{591}$, em dezembro de 1908, intitulado "Idéias fixas e obsessões" "592. Gonçalves relata os diversos tipos de fobia que podem acometer os neurastênicos. A seguir, relata

591 Não conseguimos informações sobre este autor.

592 GONÇALVES, J. Idéias fixas e obsessões. Gazeta Clinica, p. 44-46, 1909.

217 
diversos tipos de manias (a maior parte, manias por medicamentos) classificadas entre as obsessões como: dipsomania, cocainomania, morfinomania, cloralmania, antipirinomania e outras que ele associa ao progresso da farmácia química.

Desse modo, Gonçalves acentua que essas novas manias fazem com que os pacientes passem a andar por toda parte com esses medicamentos e façam o possível para obtê-lo e estocá-lo. Refere que "todos os pacientes reconhecem o mal que praticam, mas o desejo é mais forte do que a vontade" ${ }^{593}$. No item de impulsos obsessivos ele inclui a piromania e a cleptomania, entre outros.

A certa altura, Gonçalves se refere a Breuer, Freud e Janet, o que parece ser uma primeira referência a Freud em uma revista médica paulista, após a citação de Freud no livro de 1904 de Franco da Rocha.

Portanto, o autor cita que Breuer, Freud e Janet descreveram "as idéias fixas subconscientes" ${ }^{594}$. Conforme o autor, eles consideram que "estas idéias que podem ter consequencias graves só se manifestam durante ataques hystericos, os sonhos, os acessos somnambulicos. Ellas ficam fora da consciencia no estado normal”595.

A seguir ele cita diversos autores, que classificam as idéias fixas como paranóias e degenerações, como, por exemplo, o professor Teixeira Brandão. Entre os diversos tratamentos, o autor acha importante a cura pela sugestão ${ }^{596}$.

Até este artigo (1909), as revistas registram deferências dos estudiosos a Teixeira Brandão. Ao entrar a década seguinte, outros personagens passam a ser referência, o que também pode ter estimulado o professor a escrever seu livro em 1918.

Em 1910, na Revista Medica de S. Paulo, Enjolras Vampré publica o artigo "Um caso de psychose comicial post-convulsiva”, sendo o autor identificado como médico do Juquery ${ }^{597}$. Vampré relata um caso, do hospício, de epilepsia, que se seguiu de quadro psicótico, inicialmente tido como psicose maníaco-depressiva, mas que depois apresentou variáveis que afastaram essa possibilidade, caminhando o diagnóstico mais para um quadro demencial.

593 GONÇALVES, J. Idéias fixas e obsessões. Gazeta Clinica, p. 44-46, 1909. 594 Idem. 595 Ibidem. 596 Ibidem. 597 VAMPRÉ, E. Um caso de psychose comicial post-convulsiva. Revista Medica de S. Paulo, p. 21-23, 1910. 
No desfecho do artigo, o autor comenta a dificuldade com que lutam os médicos do hospício para estabelecer um diagnóstico, pois os casos são recebidos de outros médicos apenas com o registro de que sofrem das faculdades mentais, sem mais dados. O autor cita Franco da Rocha, em sua publicação Estatística do Hospício de Alienados, de 1896, que já assinalava esse tipo de dificuldade em relação a casos encaminhados por outros médicos ao hospício.

Observamos que Vampré queixa-se da falta de dados, a respeito dos doentes encaminhados por médicos “não especialistas”, que, supostamente, não são munidos dos mesmos critérios do pensamento psiquiátrico, ou do conhecimento do que temos chamado de corpo neurológico, por não haverem quaisquer registros acerca de avaliações referentes a esses campos, por parte dos generalistas. Esse dado pode também sinalizar uma acentuação da distância entre especialistas e generalistas.

Outro artigo de Vampré desse mesmo ano dá idéia de que os conceitos estão mudando e novas idéias estão ganhando espaço.

Em 1910, Enjolras Vampré publica artigo na Revista Medica de S. Paulo, intitulado "Epilepsia psychica com syndroma de Stockes-Adams"

Esse artigo trata do relato de um paciente de 22 anos, internado no Juquery, que desde a infância apresentava epilepsia e que depois passou a ter um quadro psiquiátrico, quadro esse que determinou sua internação. Durante a internação teve quadros de tontura e palidez, com redução de batimentos cardíacos.

Vampré considera que o problema cardíaco e a epilepsia talvez tenham a mesma origem, mas frisa que não pode ser um caso da (conforme ele escreve) “antigamente” chamada “epilepsia cardíaca”, pois essa passou a ser uma patologia “descreditada pela sciencia”,599.

Embora sem mais dados no próprio artigo, que possam esclarecer detalhes, vemos uma mudança no entendimento da epilepsia, pela própria forma com que Vampré se refere a uma forma de epilepsia desacreditada pela ciência. A epilepsia, que é considerada uma nevrose, por ser mal compreendida, está, aos poucos, sendo melhor

598 VAMPRÉ, E. Epilepsia psychica com syndroma de Stocke-Adams. Revista Medica de S. Paulo, p. 184-186, 1910.

599 Idem. 
delimitada. Também um melhor entendimento do vínculo entre os diferentes órgãos do corpo, permite reduzir a noção de centralidade do cérebro em relação ao organismo. Entenda-se que no caso relatado por Vampré ele conclui tratar-se de paciente com dois quadros: um problema cerebral (a epilepsia) e um problema cardíaco (Stocke-Adams).

Em 1912, é publicado na Revista Medica de S. Paulo o artigo intitulado “Falsos neurasthenicos”, por Henrique Roxo ${ }^{600}$.

Neste artigo o autor enfatiza a diferença entre o reconhecimento dessa moléstia pelos especialistas "em neurologia e psychiatria”, de forma mais aprimorada do que os “medicos não especialistas”.

Desse modo, Roxo ${ }^{601}$ afirma que: "Frequente é a quem se especializa em neurologia e psychiatria, receber a exame doentes que trazem o diagnostico de neurasthenia firmado por medicos não especialistas nos quaes a diagnose tem de ser contestada. A falta de habito de ver nevropathas justifica plenamente o erro"602.

Observa-se, então, uma afirmação mais categórica da diferenciação das especialidades neurologia e psiquiatria, em relação às outras áreas médicas, sendo que, até então, não havia sido feita uma menção dessa forma.

Por outro lado, vemos também uma declaração de que se trata de um quadro comum tanto á psiquiatria quanto à neurologia, embora essas áreas já sejam um tanto separadas em diferentes cadeiras no Rio de Janeiro (local de Roxo), pois nesse mesmo ano de 1912, cria-se, na Faculdade do Rio de Janeiro, a Cadeira de Neurologia.

Ele diz que a neurastenia é mais rara do que se pensa. O que há mais freqüentemente é "a psychastenia, exgottamento nervoso originario, que torna o individuo ludibrio constante das obsessões, phobias e idéias fixas. Neste caso já ha a predisposição originaria a se exgottar por qualquer esforço, minimo que faça”603.

Desse modo, o autor refere que as emoções repetidas esgotam o sistema nervoso mais depressa que qualquer outra causa, e que a soma de longo esforço

600 ROXO, H. Falsos neurasthenicos. Revista Medica de S. Paulo, p. 386-393, 1912.

${ }^{601}$ Obtivemos poucos dados biográficos de Henrique Roxo. Só encontramos uma pequena biografia na Enciclopédia Larousse Cultural (vol.21, p. 5147), onde consta que Henrique de Brito Belfort Roxo nasceu no Rio de Janeiro em 1877 e morreu na mesma cidade em 1969. Em 1921 tornou-se catedrático da Clínica Psiquiátrica da Faculdade de Medicina do Rio de Janeiro; foi diretor do Instituto de Neuropatologia. Outros dados referidos são os mesmos que aparecem no transcorrer deste trabalho, dizendo respeito a publicações. Chama a atenção uma publicação de 1899 intitulada "Sífilis Cerebral", já que ainda era estudante de medicina. Sua tese inaugural de 1901 será comentada oportunamente. 602 ROXO, H. Falsos neurasthenicos. Revista Medica de S. Paulo, p. 386-393, 1912. 603 ROXO, H. Falsos neurasthenicos. Revista Medica de S. Paulo, p. 386-393, 1912. 220 
intelectual com pensamentos aflitivos, somados a alguma "degeneração neurica”, ou “tara nevrophatica”, resulta em neurastenia. Roxo cita Dejerine, para explicar a neurastenia como soma de esforço intelectual e inquietação.

Roxo também se refere à neurastenia como "molestia de Beard" e cita outros diversos epônimos. Remetendo-se a uma discussão havida na Sociedade de Neurologia de Paris em 1909 e 1910, e citando diversas opiniões, Roxo diz que o debate ficou entre dois grandes grupos: “ou a emoção é essencial na neurasthenia ou secundaria”604.

Tentando fazer uma demarcação dos sintomas principais, Roxo cita a sintomatologia apontada por Charcot: cefaléia, astenia neuromuscular, raquialgia, dispepsia por atonia gastro-intestinal, insônia e estado mental depressivo.

Em seguida, Roxo lista uma série de diagnósticos diferenciais, que necessitam tratamento específico, não devendo ser confundidos com neurastenia.

Ele acha que a chamada psicastenia, considerada por Janet, trata-se apenas de um tipo ou grau da neurastenia, com uma predisposição nos “que já nascem com uma resistencia nervosa minima”, 605 . Ele também se refere a Bernheim, que, em publicação de 1910, relata que a psicoterapia não pode vencer a neurastenia, por esta ser de origem orgânica.

\section{3. 1. 1. - Classificações: Paranóia (1899-1912)}

Entre as designações e diagnósticos de moléstias psiquiátricas, a paranóia é dos quadros que mais se prestam a polêmicas que circulam em torno das classificações e conceituações psiquiátricas, nesse período. Os periódicos médicos paulistas publicam artigos que registram esses debates.

Em 1904, na Revista Medica de São Paulo, o professor Nina Rodrigues apresenta um longo artigo, publicado em duas partes, intitulado "Atavismo Psychico e Paranoia”606 . Esse formato e extensão da publicação indicam a importância do tema e do autor, para a Revista Medica.

604 Idem. 605 Ibidem. 606 RODRIGUES, N. Atavismo Psychico e Paranoia. Revista Médica de S. Paulo, p. 102-109, 131-138, 1904. 
Nesse trabalho, Rodrigues discute as classificações relacionadas a vários conceitos de paranóia. Ele precede seu artigo propriamente dito, com palavras de Ribot $^{607}$, do livro Les maladies de la personnalité, de 1897, onde esse autor afirma que a personalidade constitui algo complexo e com perturbações multiformes, de modo que a interpretação da mesma só é possível com demorada observação.

Rodrigues acha que: "uma boa analyse psychologica de certas anomalias mentaes deve auxiliar poderosamente a resolução do problema psychologico do homem criminoso"608.

Nina Rodrigues segue a escola alemã e considera incluídos no grupo das paranóias o delírio crônico sistemático de Magnan dos franceses, e outras formas de delírio.

Ele relata que a doutrina antropológica da paranóia foi feita pela escola italiana, a partir dos autores Tanzi e Riva, sucessores da escola de Lombroso. Assim, a "teoria atávica de Tanzi e Riva” supõe que a paranóia possa ser uma espécie de regressão do doente a um estado primitivo, selvagem, anterior na evolução humana. Rodrigues discorda desse ponto de vista e considera a paranóia mais como uma desorganização mental, ou desagregação mental degenerativa.

Rodrigues acha que pode haver uma localização cerebral para o delírio, mas que ainda não foi encontrada. Ele diz que, conforme Ribot e Sergi, pode ser usada “a teoria evolutiva aplicada à psicologia” ${ }^{609}$ para entender a paranóia e, assim, pode-se pensar numa espécie de “mutilação mental” ${ }^{610}$, deixando o indivíduo estacionado em

607 O filósofo Theodule Ribot (1839-1916) é considerado por muitos como "pai da psicologia” na França. Ele influenciou o distanciamento da psicologia em relação à filosofia, aproximando-a das ciências naturais. Nessa transição ele encontrou opositores entre os psicólogos metafísicos antigos e entre os partidários da linha científica. Em 1870, Ribot lançou sua obra "La Psychologie Anglaise Contemporaine”, onde combateu os pontos de vista de Comte com as idéias de outros positivistas como Stuart Mill e Spencer.

GUILLIN, V. Théodule Ribot's ambiguous positivism: philosophical and epistemological strategies in the founding of French scientific psychology. J Hist Behav Sci. 2004 Spring;40(2):165-81.

Em 1888, Ribot iniciou aulas de psicologia no College de France. Esse fato é tido como um início oficial do ensino de psicologia, no nível universitário, na França.

NICOLAS, S.; CHARVILLAT, A. Introducing psychology as an academic discipline in France: Théodule Ribot and the Collège de France (1888-1901). J Hist Behav Sci., Spring;37(2):143-64, 2001. 608 Nesse mesmo artigo, Rodrigues reforça essa afirmação com seus estudos sobre a criminalidade nos negros e a paranoia na raça negra, citando sua publicação "La paranoia chez les nègres" nos "Archives d'Anthropologie Criminelle".

609 RODRIGUES, N. - Atavismo Psychico e Paranoia. Revista Médica de S. Paulo, p. 102-109, 131138, 1904.

610 Idem. 
determinado nível psíquico mais primitivo, mas sem haver uma regressão da maneira como pensam Tanzi e Riva.

Após várias citações e reflexões, Rodrigues discorda de outros autores e concorda com o estudioso Greco, para quem a paranóia não tem apenas envolvimento intelectual, mas também envolvimento emocional.

Vemos aqui, além de forte influência do paradigma da teoria da evolução, também uma busca de elementos que possam ser universais, tanto em psicologia, quanto nas alterações mentais, elementos esses situados em uma ancestralidade comum a toda humanidade, que tenha uma expressão psíquica e comportamental similar. O conceito de paranóia, que é um ponto de discordância entre diversas escolas do período, estabelece uma intersecção entre psiquiatria, psicologia, antropologia, etnologia, chamando a atenção dos estudiosos para o entendimento do raciocínio lógico nesses quadros, associado à emocionalidade.

Em 1905, na Gazeta Clinica, é publicada uma aula dada em 30 de junho de 1905, na Faculdade do Rio de Janeiro, por Henrique Roxo, designado como "lente substituto interino de Clinica Psychiatrica e de Molestias Nervosas”. Está registrado que a aula foi “estenographada pelo Interno de Clinica Francisco Maciel. O título da aula é "Psychose systemathizada progressiva",

O autor informa que o conjunto sintomático da "psicose sistematizada progressiva” é reconhecido pelos diversos autores. Eles discordam, no entanto, no que diz respeito a considerá-la uma entidade autônoma, ou apenas uma forma de paranóia. O autor cita que o prof. Teixeira Brandão aceita esse quadro como um tipo clínico a parte, do delírio crônico de Magnan, ao qual prefere chamar de "psicose sistematizada progressiva”. Relata que os autores alemães encabeçados por Kraepelin a englobam na paranóia $^{612}$.

Depois o autor faz um histórico desse quadro, lembrando as divergências a respeito dessa moléstia. Assim, afirma que Magnan ${ }^{613}$ refundiu as reflexões, de vários

611 ROXO, H. Psychose systematisada progressiva; aula dada em 30 de junho de 1905. Gazeta Clinica, p. 331-340, 1905.

612 Idem.

613 No livro de 1904, "Esboço de Psychiatria Forense", Franco da Rocha refere a classificação de degenerados de Magnan como a mais aceitável entre as que se referem a degeneração.

ROCHA, F. Esboço de Psychiatria Forense, p. 42.

Essa classificação de Magnan, de 1895, tem dois grandes grupos: psicoses simples e estados degenerativos. Nas psicoses simples estão: mania, melancolia, delírio crônico com evolução sistemática e 223 
estudiosos, no "delirio cronico", subdividido em quatro períodos: de hesitação ou ruminação intelectual, o de perseguição, o de grandeza e o de demência. Roxo acrescenta que os autores ainda divergem sobre a fase de demência.

Em 1905 é publicada, na Gazeta Clinica, outra aula do prof. Henrique Roxo, na qual ele continua trazendo elementos de debates sobre os diagnósticos em psiquiatria. Essa aula foi dada em 25 de agosto na Faculdade do Rio de Janeiro, sendo que o prof. Roxo é identificado como "professor interino da Clinica Psychiatrica e Molestias Nervosas” (foi registrado que a aula foi “estenographada pelo interno Mario Pinheiro”). O título da aula é “Paranoia”614.

O autor refere que veio da Alemanha o termo paranóia com Krafft-Ebing e principalmente Kraepelin. Ele diz que, há muitos anos, o prof. Teixeira Brandão já assinalara os caracteres da paranóia, de uma forma que muito se aproximava do alemão. Conforme Roxo, com “clareza e precisão” Teixeira Brandão expusera o conceito, com limites mais vastos do que os de Kraepelin, pois (ainda de acordo com Roxo) este deixa para o grupo das demências precoces alguns casos de paranóia ${ }^{615}$.

Diferenciando a paranoia de outros quadros, Roxo refere que na melancolia o individuo se sente culpado de tudo, enquanto que, na paranóia, o meio é culpado de tudo; a paranóia sempre é crônica, assim, um suposto diagnóstico de paranóia aguda corresponde, na verdade, a um quadro de confusão mental ${ }^{616}$.

Nesses dois artigos, Roxo demonstra uma atitude de reverência a Teixeira Brandão como seu mestre, de modo que, além de seguir seus conceitos, considera que o prof. Brandão formulou melhor o quadro de paranóia do que Kraepelin.

Esse é um momento (1905) em que Roxo ainda comporta-se nas aulas como bastante ligado a Teixeira Brandão. Já Franco da Rocha, desde 1904, dá início a sua própria maneira de entender as moléstias psiquiátricas, com uma classificação própria diferenciada da de seu mestre.

\footnotetext{
loucuras intermitentes. Nos estados degenerativos há: estado mental primordial constante; síndromes episódicas (obsessão, impulsão, inibição); delírio de perseguição; estados delirantes. HUERTAS, R. El siglo de la clinica, p. 117-118.

614 ROXO, H. Paranóia; aula dada em 25 de agosto de 1905. Gazeta Clinica, p. 398-406, 1905. 615 Idem. 616 Ibidem. 
Em 1910, Franco da Rocha publica artigo que denota a aceitação de novos paradigmas em psiquiatria. Assim, na Revista Medica de S. Paulo, ele publica um artigo intitulado “Que é um paranoico?”, artigo esse que foi publicado no jornal Estado de S. Paulo, em 1 de outubro de $1910^{617}$.

Nesse texto, Franco da Rocha explica a conceituação da paranóia, fundamentado principalmente em Kraepelin. Ele refere que esse termo foi usado em diversas situações, em diversos países, mas que o conceito de Kraepelin é o mais aceito. Nos casos de paranóia “costumam-se desenvolver lentamente systemas duradouros e inabalaveis de idéias delusorias ao lado de perfeita conservação da clareza e da ordem no pensar, no querer e no agir”618.

O autor cita D. Quixote como um bom exemplo de paranóia, sendo que, tal como ele, pessoas na sociedade desenvolvem viva impressão de perseguição pelas mais diferentes organizações e indivíduos. Assim, ele diz que, para o paranóico "não ha autoridade que esteja isenta de ser considerada como um dos perseguidores. (...) Todos os representantes da autoridade publica são os inimigos naturaes do paranoico antisocial”619.

Franco da Rocha acrescenta que há paranóicos em harmonia com a sociedade, que costumam se dedicar à pintura, à música e às artes. Porém, ele diz que esses casos são raros e que os casos de transição, entre a paranóia e a loucura moral, correspondem a indivíduos mentirosos, intrigantes e caluniadores.

Um desses, conforme Franco da Rocha, propôs, em um artigo de jornal, incendiar o hospício de São Paulo, “como medida de salvação publica, porque, dizia elle, aquella casa só servia para vinganças politicas”.

Sobre isso, o autor comenta: "Essa é a noção que todos elles têm de direito, justiça e bem publico; só enxergam a propria pessoa e os interesses proprios”620.

Em meio à sua explanação, Franco da Rocha volta ao tema da loucura moral, citando esse mesmo caso.

Esse tipo de proposta, vinda de um jornal, pode reforçar o que ele já disse em outro artigo, onde considera como destino dos loucos morais “a profissão de jornalista”.

617 ROCHA, F. Que é um paranoico? Revista Medica de S. Paulo, p. 364-367, 1910.

618 Idem.

619 Ibidem.

620 Ibidem. 
Esse fato pode denotar também certa indisposição de Franco da Rocha com alguns jornalistas que talvez sejam críticos de seu trabalho.

Observa-se também que, entre 1904 e 1910, Franco da Rocha passa a aceitar as idéias de Kraepelin a respeito de paranóia, já que em sua classificação de 1904, ele já considerava alguma modificação em relação à classificação de Teixeira Brandão, mas ainda incluía em sua classificação elementos das classificações francesas, ao mesmo tempo em que havia alguns itens da classificação de Kraepelin.

Além disso, também se nota o interesse e esclarecimento da classe letrada por esse assunto, já que o artigo foi publicado em jornal cotidiano.

A trajetória da conceituação e classificação da paranóia, nesse período, expressa o gradual predomínio da escola de Kraepelin sobre as outras doutrinas psiquiátricas, principalmente no quesito classificação de moléstias. Além disso, observa-se que, até certo momento, esse diagnóstico tem uma função algo análoga à das nevroses, ou seja, de abrigar psicoses de difícil caracterização, ou que não se enquadram em outros grupos. A partir de Kraepelin, simplifica-se esse conceito.

\section{3.2 - Nevroses $-(1899-1912)$}

A grande variedade de nevroses, neste período, indica uma forma de entender diversas manifestações do organismo como sendo provenientes ou ligadas ao sistema nervoso. Assim, apresentamos aqui, em sete subseções, nove quadros que são considerados como formas de nevroses.

\section{3. 2. 1. - Nevroses: Histeria e neurastenia (1899-1912)}

Neste período, textos sobre histeria continuam aparecendo nas revistas, pois as idéias e práticas instituídas por Charcot a respeito dessa moléstia se mantêm presentes. Aos poucos, notícias sobre a conceituação de Babinski sobre histeria vão ganhando espaço. 
Em 1901, na Revista Medica de São Paulo, Franco da Rocha publica artigo intitulado "Mutismo Hysterico no Homem”621, no qual descreve caso de indivíduo de 30 anos, do sexo masculino, acometido de mudez, de instalação súbita ${ }^{622}$.

O autor refere, então, ter lembrado dos estudos de Charcot, e assim, passou a examinar a sensibilidade do paciente, encontrando algumas alterações concordes com a orientação de Charcot sobre histeria. Ainda seguindo o mestre francês, relata: "Lembreime de fazer a pressão do testículo, o que provocou violenta dor e a palavra voltou-lhe imediata e perfeitamente. Não havia a menor duvida: era um caso de mutismo hysterico no homem”623.

Refere o autor que esse paciente também apresentava dificuldade para caminhar e ficar em pé, embora com força muscular preservada. O paciente voltou, dias depois, com o mesmo problema.

Estando o médico Alberto Seabra em visita ao consultório de Franco da Rocha, este sugeriu a Seabra que hipnotizasse o paciente. Isso foi feito e Franco da Rocha refere que: “depois do somno e salutar suggestão, retirou-se o doente em optimas condicções para não mais voltar, o que faz suppor que ainda continua bem”624. O autor diz ter visto outro caso similar no Hospicio de Alienados.

Em 1901, Franco da Rocha pauta sua visão de histeria pelos ditames de Charcot, inclusive observando as alterações sensitivas indicadas pelo professor, a compressão do testículo, bem como o uso da hipnose. Sua solicitação a Alberto Seabra, para usar essa terapêutica, denota que ele, Franco da Rocha, não domina essa técnica.

621 Em 1890, mesmo ano em que Franco da Rocha apresenta sua tese, o farmacêutico Eduardo Jansen Vieira de Mello apresenta tese para obter grau de doutor em Medicina à Faculdade da Bahia, com o título “Hysteria no Homem”. Ele refere estar "exuberantemente provada” a existência desse quadro no homem, desde observações de Landouzy e do livro de Briquet de 1859. Cita outros autores que permitiram a esse quadro ocupar "posto brilhante" entre as nevroses, destacando Charcot. Enfatiza a mesma teoria de Batault (também foi citada por Franco da Rocha em sua tese), assinalando que Batault baseou-se na perigênese dos plastídulos de Haeckel. Cita palavras de Batault, que compara o ser humano a uma grande república celular, onde a célula nervosa é o elemento mais nobre, o trabalhador intelectual dessa república. Por isso, essas são as células mais delicadas e vibrações anômalas dos plastídulos podem causar histeria. A partir de Haeckel, o autor atribui a causa da histeria à hereditariedade, ou pela adaptação do organismo a diversas doenças como: tuberculose, intoxicações, moléstias infecciosas, traumatismos.

MELLO, J. V. Hysteria no homem. Tese para obter o grau de doutor em Medicina. Faculdade de Medicina da Bahia, 1890.

622 ROCHA, F. Mutismo Hysterico no Homem. Revista Medica de São Paulo, p. 240, 1901.

623 Idem.

624 ROCHA, F. Mutismo Hysterico no Homem. Revista Medica de São Paulo, p. 240, 1901. 
Conforme já dissemos, a nosso ver, ao seguir as orientações de Charcot para o diagnóstico de histeria, Franco da Rocha inevitavelmente chega ao diagnóstico desse quadro, haja vista que os procedimentos indicados pelo estudioso francês conduzem a toda uma forma de reflexão e obtenção de sinais clínicos, dentro de um consistente paradigma.

O médico Antonio Austregésilo é autor bastante presente nos periódicos paulistas. Em 1901, faz suas primeiras publicações na Revista Medica de S. Paulo sobre assuntos médicos em geral.

Em 1902, publica seu primeiro artigo em São Paulo, sobre assuntos em torno de quadros mentais. O artigo intitula-se “Sobre um caso de simulação hysterica” ${ }^{625}$. Ele relata o caso de uma paciente de 14 anos, que apresentou lesões cutâneas, tendo consultado "notavel especialista”626, o qual diagnosticou hemorragias cutâneas, às quais associou a suspensão da menstruação.

Tendo visto o caso, Austregésilo desconfiou do formato das manchas, e acabou por descobrir que elas eram produzidas por queimaduras feitas com ácido fênico, pela própria paciente. Considerou, então, como sendo um “caso de simulação ou ardil hysterico" ${ }^{\circ 27}$.

Em 1904, na Revista Medica de S. Paulo, a médica Judith Santos, do Rio de Janeiro, publica, em duas partes, um artigo intitulado "Gravidez Hysterica”,628.

É notória a singularidade dessa publicação feita por uma mulher ${ }^{629}$, nesse período, entre as outras publicações feitas por homens. Conforme se depreende do texto, Judith Santos é médica mais voltada para a área obstétrica, sendo que, conforme sua menção no artigo, é filha do Professor Silva Santos, provavelmente também mais voltado para a mesma área, de quem ela relata dois casos de gravidez histérica,

625 AUSTREGESILO, A. Sobre uma simulação hysterica. Revista Medica de S. Paulo, p. 21-22, 1902. 626 Idem.

627 ROCHA, F. Mutismo Hysterico no Homem. Revista Medica de São Paulo, p. 240, 1901. 628 SANTOS, J. Gravidez Hysterica. Revista Medica de S. Paulo, p. 305-307, 379-384, 1904. 629 Quanto á presença feminina no ambiente científico, em 1906, é publicado, na Revista Medica de S. Paulo (p.201-205), discurso do médico Victor Godinho, intitulado "A mulher nas Escolas Superiores", pronunciado em sessão solene da Escola de Pharmacia, em 10 de maio. Há premiação da farmacêutica Leonor de Aguiar, com prêmio provindo de doação de Emílio Ribas a essa escola. Godinho se refere às mulheres que se destacaram na História, cita as primeiras mulheres médicas. Diz que falta pouco para as mulheres estarem em pé de igualdade com os homens e que as mulheres intelectuais promoverão a emancipação feminina. 
acrescentados a outros três casos observados por ela mesma. Ela inicia seu texto, situando esses casos em um misto de influências de sugestão e de fatores orgânicos:

"São mais communs do que se pensa os casos de gravidez falsa, autosuggestiva ou phantastica em mulheres, de ordinario hystericas, impressionaveis ou que têm grande desejo ou receio de ter filhos. Para que entretanto essas manifestações tenham logar, parece, senão indispensavel, muito frequente a existencia de uma lesão somatica do apparelho genital”30 ${ }^{\text {. }}$

Na medida em que apresenta os cinco casos observados, a autora delineia suas hipóteses para explicar os fenômenos observados. Em geral, ela aponta antecedentes familiares, dentro do que chama de "tara nevropathica”, ou "tara neuro-arthritica”, com variados casos, em algumas famílias, de histeria, entre outras ocorrências.

Santos acentua a importante influência da sugestão, tanto na indução da moléstia, quanto em seu processo de cura. Considera importante o papel do músculo diafragma na configuração do abdome indicativo de gravidez, no que ela chama de "tumor gravidico". Assinala a necessidade de haver algum comprometimento somático na esfera genital, para que se instalem os “syndromas hystero-neurasthenicos”.

Consultando a literatura, para o entendimento do que observou, a autora refere que, antigamente, esse tipo de alteração era atribuido a uma simulação intencional; depois surgiu o conceito de uma simulação “inconsciente”, com um ponto de partida nos ovários. No entanto, a autora contesta essa associação aos ovários, na medida em que lembra casos de “tumores phantasticos” em indivíduos do sexo masculino, como, por exemplo, um caso dessa natureza que acometera um médico.

Judith Santos cita o estudioso Lawson Taits, que considerava os fenômenos nervosos, ligados à falsa gravidez, associados a uma forma da mulher acometida “chamar a atenção” de outras pessoas por meio dessa sintomatologia.

A autora refere-se também ao "Tratado das molestias das mulheres” de Robert Barnes, o qual considera uma associação entre os órgãos abdominais e o sistema nervoso. Assim, ela refere que Barnes atribuía essa falsa gravidez a uma soma de imaginação, força mental e força emocional.

A autora também assinala que esse estado, também chamado de "falsa gravidez”, foi nomeado pelo estudioso Mason Goode como “pseudocyesia”.

Após citar esses estudiosos, Judith Santos atualiza a compreensão desses quadros, estando inteirada da teoria do neurônio, citando inclusive a autonomia neuronal. 
Comenta "estudos modernos" das funções dos centros nervosos, contrapondo-se a autores mais antigos:

“Dado, porém, o tempo já um pouco recuado, em que ambos escreveram, comprehende-se que hoje em dia, com os conhecimentos que nos ministram os factos da psycho-pathologia experimental relativos aos effeitos do hypnotismo e da suggestão, assim como os estudos modernos das funcções dos centros nervosos, sobretudo no que respeita ás localizações e á autonomia neuronial, á categorização dos reflexos e dos respectivos centros sensitivo-motores, etc., já se pode doutrinar muito mais intelligivelmente sobre os extranhos casos até então mui vaga embora corretamente analysados"

Esse discurso de Judith Santos dá a entender que ela nota uma diferença entre uma conceituação anterior e outra mais recente, inteirando-se de um novo paradigma. Chama a nossa atenção que essa autora faz uma síntese dos elementos que deram forte consistência ao que temos chamado de "corpo neurológico", fazendo alusão a alguns fatores que são citados por Foucault, que os considera formadores dessa conceituação, dentro do que ele chama de mecanismo estímulo-resposta.

Outros fatores por ela citados, como hipnotismo e sugestão fazem parte dos elementos utilizados por Charcot para elaborar o diagnóstico de histeria.

Após citar o prefácio de Charles Richet para o livro de Maxwell, de 1904, Les phenomènes psychiques, a autora insere todo esse debate no que ela chama de "teoria geral da sugestão”, com suas duas ordens de efeitos, mentais e somáticos, “capazes de evoluir, no mais variado sentido, conforme a natureza de cada organismo e sua situação psycho-physiologica" ${ }^{632}$. Falando de passagem sobre o "tratamento sugestivo", ela lembra as teses de Francisco Fajardo e de Ulysses Paranhos a esse respeito.

Assim, a autora apresenta uma conciliação entre conceituações mais próximas de noções da teoria da sugestão, de uma linha menos organicista, e as conceituações propriamente cerebrais, comumente mais associadas a posturas mais organicistas.

Em 1904, o Dr. Cursino Moura, de Taubaté, publica, na Revista Medica de S. Paulo, artigo intitulado “Anorexia hysterica”,633. Para fazer esse diagnóstico o autor se reporta aos estudiosos Lasègue, Gall, Charcot e Ductil.

631 SANTOS, J. Gravidez Hysterica. Revista Medica de S. Paulo, p. 384, 1904. 632 SANTOS, J. Gravidez Hysterica. Revista Medica de S. Paulo, p. 305, 1904. 633 MOURA, C. Anorexia hysterica. Revista Medica de S.Paulo, p. 513-515, 1904. 230 
Moura considera o caso observado como incomum, já que a anorexia histérica foi descrita em pacientes jovens, e a paciente em questão tinha quarenta anos. Assim, considera esse um caso de "hysteria senil",634.

Reforça seu diagnóstico com o fato de a família da paciente ter tido casos de moléstias mentais e nevroses. Moura relata vários sintomas, que ele denomina como “estigmas histéricos”.

Com essas considerações o autor indica seguir os parâmetros de Charcot para o diagnóstico de histeria. Inclusive cita a descrição de Charcot para a anorexia histérica, dizendo que este chegou a ver quatro casos de morte por esse quadro. O autor considera ter observado exatamente o mesmo quadro traçado por Charcot.

Em 1904 é publicado artigo que mantém a conceituação da histeria, mas supõe a possibilidade desse quadro ser melhorado por terapêutica medicamentosa. Assim, o médico Xavier da Silveira escreve artigo, na Gazeta Clinica, a respeito do uso do valerionato de zinco na histeria ${ }^{635}$. Ele diz que “a nevrose hysterica não se dobra á acção de medicamentos”636. Refere que, apesar do progresso da medicina em todos os seus ramos, nada se conseguiu para curar a histeria, e nas outras afecções nervosas hereditárias. Desse modo, acha que tratamentos como isolamento, hipnotismo, sugestão, hidroterapia, pouco conseguem. Em seguida, relata o caso de uma paciente de 19 anos, que ele considera ter sido curada pelo valerionato de zinco.

Em 1905, na Revista Medica de S. Paulo, é publicado, no Boletim da Sociedade de Medicina e Cirurgia de S. Paulo, o artigo "Estudo de um caso de Amblyopia hystero-traumatica com scotoma scintilante”, pelo médico Bueno de Miranda $^{637}$.

Bueno de Miranda descreve um caso com alterações visuais ligadas a um trauma de crânio, e algumas outras alterações, que ele explica como histeria, a partir de estudos prévios de Charcot e seus discípulos. Para tratamento, o paciente usou capacete

634 Idem.

635 SILVEIRA, X. Notas de Clinica: do resultado do emprego do valerionato de zinco em um caso de hysteria. Gazeta Clínica, p. 103, 1904.

636 Idem.

637 MIRANDA, B. Estudo de um caso de Amplyopia hystero-traumatica com scotoma scintillante. Revista Medica de S. Paulo, p. 269-274, 1905. 
de gelo durante 20 dias, além de ioduretos, bromuretos, “duchas electricas, pontas de fogo na espinha, etc"638.

Como havia lesão cerebral e também histeria, o autor aconselhou continuar com ioduretos, bromureto e a eletricidade. O autor acha que talvez pudesse ter sido feita uma trepanação na área occipital correspondente ao trauma, embora fazendo a ressalva de que os centros visuais cerebrais ainda não estão cientificamente bem determinados.

Em 1905, na Revista Medica de S. Paulo, é publicado o artigo "Dores nas costas” pelo médico Julio Cardozo ${ }^{639}$. Entre as diversas situações de dores nas costas, Cardozo diz que essas dores são freqüentes nas histéricas, às quais recomenda tratar com hidroterapia. Nos casos de neurastenia, consistindo em "nevrose de angustia, imsonia intensa, depressão physica e psychica” ${ }^{640}$, exige-se uma “medicação energica”. Desse modo, ele utiliza medicamentos injetados no local da dor, associado a ducha tépida, ou corrente galvânica “após aplicação de pontas de fogo”641.

Observa-se a citação da neurastenia e histeria no mesmo artigo, em situação similar relacionada à dor. $\mathrm{O}$ autor não se detem em explicar os supostos mecanismos desses casos.

Em 1905 é publicado artigo sobre um tema que atrai a atenção da escola de Charcot, que é a astasia-abasia ${ }^{642}$, como uma suposta forma de histeria. Esse artigo é de autoria do médico Henrique Duque Estrada, com o título "Sobre um caso de astasiaabasia trepidante"; o médico foi identificado como "ex-assistente de Clinica Propedeutica da Faculdade do Rio de Janeiro"643.

O autor refere que, desde que Charcot chamou a atenção para esses casos de astasia-abasia, sua própria casuística passou a aumentar. Cita observações publicadas por autores brasileiros. Refere que, em geral, essas publicações robustecem a vinculação de tais quadros à histeria.

638 Idem.

639 CARDOZO, J. Dores nas costas. Revista Medica de S. Paulo, p. 406-410, 1905.

640 Idem, p. 408.

641 CARDOZO, J. Dores nas costas. Revista Medica de S. Paulo, p. 408, 1905.

642 Em neurologia, astasia significa "impossibilidade de ficar em pé” e abasia "impossibilidade de caminhar”.

643 ESTRADA, H. D. Sobre um caso de astasia-abasia trepidante. Gazeta Clinica, p. 137-146, 1905. 
Em contraposição, refere-se também ao estudioso Wald, que ligou um caso desse tipo a traumatismo cerebral. Estrada pondera que, no caso por ele visto, pode ter havido um "histero-traumatismo", ou seja, uma soma dos dois fatores.

Estrada cita opiniões de vários autores que se dividem entre explicações orgânicas, ou psíquicas e ainda uma mistura entre ambas, eventualmente incluindo a interferência do "subconsciente” na origem do quadro.

No caso por ele observado, descreve a ausência de vários sinais clínicos; anexa ao artigo uma figura com a distribuição das alterações sensitivas, bem como alterações no exame de nervos cranianos. $\mathrm{O}$ autor conclui como sendo um caso associado à histeria masculina.

Em 1907, Franco da Rocha publica, na Revista Medica de S. Paulo, um artigo a respeito do trabalho do psiquiatra argentino J. Ingenieros, da Universidade de Buenos Aires, intitulado “A linguagem musical e suas perturbações hystericas”644.

Franco da Rocha inicia este artigo, frisando que o autor do trabalho é pessoa renomada nos círculos psiquiátricos do velho mundo. Ele considera Ingenieros um “insigne psychologista”645.

Reportando-se ao texto de Ingenieros, Franco da Rocha nota que, "segundo a psychologia biologica a voz humana é um gesto” ${ }^{646}$ e que a música nasce de inflexões que os sentimentos imprimem à voz humana.

Ressalta que o autor, pelo estudo psicofisiológico da emoção musical, chega a conclusões sobre as formas e a evolução da inteligência musical. Assim, cita cinco grupos: idiotas musicais, imbecis musicais, inteligentes musicais, talentos musicais e gênios musicais.

Desse modo, Franco da Rocha diz que um indivíduo pode ser um inteligente musical, e um imbecil para outras coisas, e vice-versa. Em seguida, Ingenieros passa ao estudo das “amusias”647, que se junta ao estudo das “afasias”, como perda da capacidade de perceber ou emitir música. Nesse estudo das perturbações da linguagem musical, são

644 ROCHA, F. A linguagem musical e suas perturbações hystericas; pelo Prof. J. Ingenieros da Universidade de Buenos Ayres. Revista Medica de S. Paulo, p.453, 1907.

645 Idem.

646 Ibidem.

647 Ibidem.

233 
citadas as “dismusias histéricas”"648. Conforme Franco da Rocha, essas reflexões de Ingegnieros, sobre histeria, se baseiam na conceituação de Sollier e de Janet.

Em 1908, um artigo de Rubião Meira registra uma importante mudança de rumo na conceituação de histeria. Esse médico envia, da cidade de Paris à Gazeta Clinica, um relato a respeito de sua visita à clínica de Babinski ${ }^{649}$. Comentando a respeito da grande experiência de Babinski com histeria, ele informa várias mudanças na maneira de abordar essa moléstia:

“Ao doente ele convence rapida e extraordinariamente e já tenho visto hypnotisar de modo instantaneo hystericas (...) é um analysta primoroso e profundo; ele cava o symptoma até as suas ultimas raizes, procurando tirar delle todos os ensinamentos possiveis, de modo a lhe dar o diagnostico que procura fazer (...) elle esmiuça os signaes que aprehende, e não raro, nessa perquirição cuidadosa que faz, descobre um signal novo, forma uma concepção original, levanta uma theoria moderna que, não obstante o clamor contrario que se levanta, se firma e se avantaja sobre as demais que imperam. Haja vista o que está fazendo com a hysteria, de que elle está retirando, como stygma permanente e caracteristico que até agora o era para todos os pathologistas, a anesthesia, com sua conhecida maneira de ser. Elle tem demonstrado (...) que a anesthesia hysterica não é mais do que producto da suggestão da parte do medico ou simulação do lado do doente (...). Esta é a questão do momento aqui, no mundo medico de Paris (...). Inda ultimamente novo signal descobriu elle para caracterizar a hemiplegia organica - o signal de provação - e que ahi já devem conhecer por nota que o nosso distincto collega Celestino Bourroul enviou para a 'Imprensa Medica'. Pois esse signal elle o procura sempre e eu o tenho visto apresentar-se na mais nitida manifestação. É de esperar que a propedeutica nervosa cada dia mais se enriqueça com novos elementos de diagnostico, uma vez que ella tem, como fino analysta e tenaz indagador, um homem da envergadura de Babinski que hoje aqui domina estes estudos”650.

O sinal de Babinski, da propedêutica neurológica, foi descrito em $1896^{651}$. Portanto, doze anos antes deste relato de Rubião Meira. A forma como Meira descreve sua visita a Babinski, dá a entender que ele está presenciando uma importante novidade. O artigo de Bourroul, citado por Meira, é de 1906 e será comentado em outra seção.

648 ROCHA, F. A linguagem musical e suas perturbações hystericas; pelo Prof. J. Ingenieros da Universidade de Buenos Ayres. Revista Medica de S. Paulo, p.453, 1907.

649 MEIRA, R. Uma lição de Babinski. Gazeta Clinica, p. 59-61, 1908.

650 Idem.

651 BABINSKI, J. Sur le réflexe cutané plantaire dans certaines affections organiques du systeme nerveux central. C. R. Soc. Biol. (Paris) 3: 207-298,1896 apud TOLOSA, A.; CANELAS, H; Propedêutica Neurológica, H. Editora Sarvier, 1975, p. 49. 
Nesse artigo, Bourroul esclarece que não se trata do sinal de Babinski e dá mais explicações sobre essas manobras propedêuticas, que facilitam o diagnóstico de “hemiplegias orgânicas”652, conforme ele diz, diferenciando de casos histéricos ${ }^{653}$.

Meira está diante de um novo paradigma, ao observar a possibilidade de diagnóstico diferencial entre quadro orgânico e não orgânico, diante do estabelecimento de sinais obtidos pelo que temos chamado de "sistema estímulo-resposta”, que melhor delimita o “corpo neurológico”.

Também em 1908, é feita publicação de comentário sobre as idéias de Bernheim na Gazeta Clínica. Assim, na seção "Das Revistas”, há um texto intitulado “A hysteria segundo o professor Bernheim”654. Esta é uma resenha acerca de um artigo, do qual não foi citada a referência, a respeito do Prof. Bernheim, da escola de Nancy, que tinha uma interpretação algo diferente da de Charcot a respeito da histeria, conforme já foi dito:

“A concepção de hysteria, tal como Charcot e os seus discipulos a haviam formulado, já hoje não é admittida por toda gente, e de differentes lados se estão propondo uma idéia e uma definição novas. Á frente d'estas ultimas figuram as que o Professor Bernheim, de Nancy, que já tem publicado tantos trabalhos interessantes acerca d'esta questão acaba de dar ultimamente e que vamos fazer conhecer em breve exposição"

A seguir, vem a explanação de que Bernheim acha que só existem as crises histéricas, não havendo uma entidade mórbida real fora das crises. Acrescenta o autor da resenha: “por conseguinte, todos nós devemos ser mais ou menos hystericos, pelo

652 Em 1915, Babinski publica um "estudo clínico sobre os reflexos de defesa”, o que indica que ele continuou estudando esse aspecto do exame neurológico, depois de ter conceituado o reflexo em 1896 e depois de ter redefinido a histeria.

BABINSKI, J. Réflexes de défense: étude clinique. Rev. Neurol. (Paris), 29: 145-154, 1915. apud TOLOSA, A.; CANELAS, H.;Propedêutica Neurológica, H. Editora Sarvier, 1975, p. 49.

653 O sinal de Babinski já havia sido citado em 1905, nos "Archivos de Psychiatria, Neurologia e Sciencias Affins", em tese do Rio de Janeiro.

BIBLIOGRAPHIA. Resenha: BARROS, A. Contribuição ao estudo clinico dos reflexos cutâneos; these, Rio de Janeiro, 1905. Archivos Brasileiros de Psychiatria, Neurologia e Sciencias affins, anno I, n. 1, p. 132, 1905.

O sinal de Babinski também é citado em aula de Henrique Roxo de 1905, que será abordada oportunamente.

654 DAS REVISTAS. Resenha: A hysteria segundo o professor Bernheim. Gazeta Clinica, p. 47-48, 1908.

655 Idem. 
menos, aos olhos de um observador um pouco prevenido, como é forçosamente todo o psychiatra" ${ }^{656}$.

Em seguida, é dito que a primeira crise ocorre após uma emoção forte e que vai se reproduzir, se a pessoa for “hysterisavel”, por auto-sugestão. O prof. Bernheim também acha que não existem os então considerados estigmas anestésicos, álgicos, ou de alteração de campo visual. Ele diz que eles aparecem nas pessoas histerizáveis, em virtude de uma sugestão médica inconsciente.

O autor da resenha considera a histerabilidade um ponto fraco da escola de Nancy, achando a escola de Salpêtriére mais avançada, por incluir um substrato do metabolismo nervoso como base para a histeria, correlacionado fatores químicos e biológicos com esses quadros.

Em 1908, na Revista Medica de S. Paulo, publica-se o artigo "Dos Estados Mentaes nas Grandes Nevroses”657, de Henrique Roxo, referente a comunicação feita ao Sexto Congresso Brasileiro de Medicina e Cirurgia; o autor é identificado como “Assistente de Clinica Psychiatrica e Molestias Nervosas da Faculdade do Rio de Janeiro, ex-professor interino da referida clinica”.

Nesta explanação, Henrique Roxo considera como "grandes nevroses" a histeria, a epilepsia, a coréia e a neurastenia. Refere que pouco se tem escrito sobre o estado mental desses quadros, fora das situações de alienação evidente. Ele diz que a expressão "grandes nevroses” para essas entidades se deve mais a um respeito à tradição do que por atenção aos fatos, já que cada vez mais se verifica o papel do cérebro nesses quadros, de modo que o autor acha que devem ser vistas como neuropsicoses.

Roxo acentua que nem todos os estudiosos englobam a neurastenia entre as nevroses em geral. Informa que Kraepelin insere a neurastenia nas "psychoses por exgottamento”. Já o prof. Marcio Nery coloca esse quadro nas nevroses em geral, quando se trata de neurastenia hereditária. Roxo é desta ultima opinião e considera a neurastenia como tendo intimas conexões com a histeria, a epilepsia e a coréia.

O autor acha que o histérico vive em "dissipação constante de força neurica”, tendo uma atividade sempre dispersiva. Refere que há falta de vontade para refrear as

656 DAS REVISTAS. Resenha: A hysteria segundo o professor Bernheim. Gazeta Clinica, p. 47-48, 1908.

657 ROXO, H. Dos Estados Mentaes nas Grandes Nevroses. Revista Medica de S. Paulo, p.327-332, 1908. 
ações bruscas. Ele considera que as histéricas são bem inteligentes, mas essa inteligência lhes prejudica. Ele cita diversos autores, para confirmar que as pessoas histéricas são: egoístas; orgulhosas; sem compreensão dos deveres sociais; engendram mentiras; simulam; são instáveis; querem chamar a atenção; fazem insinuações perversas; são muito sugestionáveis; julgam-se atacadas por muitas doenças; encenam suicídio, mas não o praticam.

Diz o autor que antes se acreditava que houvesse "erotismo psychico constante" nas histéricas, e que elas se preocupavam sempre “com a realização de praticas sexuaes”. Daí aconselhava-se o casamento. "Puro engano”, diz Roxo. Contra essa idéia, ele cita Briquet, que verificou farta presença de histéricas entre as prostitutas de Paris, bem como Legrand Du Saulle, que considerava as histéricas dotadas de pouca sensualidade.

Roxo diz que esse quadro se deve também às histéricas viverem uma vida de devaneios e diz que "Brennen e Freud, de Viena, frisam bem a circumstancia de ser condição essencial da hysteria a existencia de estados hypnoides”658.

O autor diz que, como "a vontade” é insuficiente para melhorar esses quadros, ele acha que o hipnotismo pode ter valor terapêutico.

Quanto ao estado mental dos neurastênicos, diz Roxo que são os doentes que mais freqüentam os consultórios médicos, de modo que seu estado mental é de angústia constante, e vivem todo o tempo preocupados com seu estado de saúde. O autor cita Charcot, que notava os neurastênicos sempre carregando um caderninho, onde escreviam os menores incidentes.

Acrescenta Roxo que essas pessoas estão sempre desanimadas, sofrem o “delírio da duvida”, sem conseguir tomar decisões. São irritadiços, com emotividade exagerada, preocupam-se com as funções sexuais e podem apresentar impotência psíquica.

O autor diferencia histeria e neurastenia, dizendo que, na histeria, é relativamente comum que qualquer tratamento seja aceito pela sugestionabilidade do paciente, enquanto que, na neurastenia, isso não ocorre. Nesse sentido, enquanto ele indica o hipnotismo para a histeria, para a neurastenia considera a persuasão o mais indicado.

658 Esse é um dos primeiros artigos que cita Freud em periódico científico de S. Paulo, sendo, nesse caso, escrito por um autor do Rio de Janeiro. 
Em 1909, é publicado na Revista Medica de S. Paulo, pelo médico Cláudio de Souza, o artigo "Paresia diaphragmatica"659. O autor relata o caso de uma paciente de 19 anos, "filha de um paralytico geral e de mãe impressionavel”,660, que apresentou quadro de dificuldade respiratória. Num primeiro momento, foi pensado tratar-se de paralisia diafragmática pelo fato da paciente ser filha de "um paralytico geral”661.

No entanto, foi percebido que, quando a paciente se distraia com o exame, o diafragma esboçava movimento. Pelo fato da paciente referir incomodo com um "collete moderno”, além de haver áreas inespecíficas de alteração de sensibilidade (conforme o entendimento de Charcot sobre esses quadros), o autor concluiu pela hipótese de histeria. Refere ter curado a paciente com três sessões de hipnose.

Em 1909, na Imprensa Médica, publica-se artigo na seção “Neuropathologia”, com o título "Novas concepções sobre a hysteria”662, de autoria de A. Austregésilo, identificado como "alienista do Hospicio Nacional” (em nota, consta que o texto foi escrito em 1908).

O autor inicia, dizendo que, de alguns anos para a data de seu artigo, ocorrem modificações nas concepções clínicas e psicológicas “da grande nevrose”.

Assim, ele diz que a partir da leitura do livro de Briquet, dos trabalhos de Charcot e seus discípulos, especialmente de Janet, além de outros clássicos em neuropatologia, “acostumou-se a julgar a hysteria uma afecção do grupo das nevroses, bem delimitada, bem caracterisada, fazendo jus a um logar distincto na psychiatria ou na neuropathologia”, 663 .

Ele acrescenta que ela foi designada como "a grande nevrose, grande simuladora, proteo da neuropathologia” ${ }^{664}$, e foi diagnosticada com facilidade em clinicas civis e hospitais de alienados, principalmente em mulheres. Assim, conforme Austregésilo, qualquer caso de afecção nervosa de difícil diagnóstico passou a ser rotulada de histeria nas mulheres e neurastenia nos homens.

659 SOUZA, C. Paresia diaphragmatica. Revista Medica de S. Paulo, p. 181-182, 1909. 660 Idem. 661 Ibidem. 662 AUSTREGESILO, A. Neuropathologia: Novas concepções sobre a hysteria. Imprensa Medica, p. 814, 1909.

${ }^{663}$ Idem, p. 8.

664 Idem. 
Conforme o autor, a todo esse exagero só poderia surgir alguma reação e ela veio por intermédio de Nissl, Dubois, Babinski, Bernheim, tendo ocorrido apoio no Congresso de Alienistas e Neurologistas de Língua Francesa, em 1907.

Austregésilo acentua que, entre todos os autores contrários ao conceito então vigente de histeria, coube a Babinski o mérito de ter abalado radicalmente as idéias até então correntes na Europa, expondo sua teoria à Sociedade de Neuropatologia de Paris, em 7 de novembro de 1901.

Assim, ele informa que, para Babinski a histeria é um estado psíquico que torna o individuo capaz de se autosugestionar facilmente. Esse estado se manifesta por perturbações primitivas e secundárias. As primitivas podem ser reproduzidas por sugestão hipnótica e desaparecem com a persuasão. As secundárias estão subordinadas às primitivas.

Austregésilo diferencia sugestão de persuasão. Assim diz que quem sugestiona impõe uma idéia, absurda ou não, e a sugestão é o método de força hipnótica que torna o individuo um autômato do sugestionador. Já quem usa a persuasão, conforme o autor, mostra a razão de ser, demonstra as fontes da verdade do mal e insinua no espírito do doente o método da cura.

Prosssegue o autor, dizendo que Babinski sugeriu o nome pitiatismo (sugestão) para a histeria, por ser essa a forma de curá-la. Nesse ponto, Austregésilo diferencia a neurastenia, que, segundo ele pode melhorar pela persuasão, mas ainda necessita de repouso, alimentação, isolamento, etc. para sua cura.

Assim, diz Austregésilo, a histeria, ou pitiatismo, mostra-se como uma doença mental e só os fenômenos histéricos podem ser reproduzíveis pela sugestão hipnótica. Portanto, há aí também, uma diferenciação, por exemplo, de quadros de fobia, que, segundo ele, não podem ser curados apenas pelos métodos persuasivos.

O autor enumera, então, várias situações antes tidas como ligadas à histeria e descritas por estudiosos renomados, que perderam esse caráter, a partir da conceituação de Babiski. Desse modo, ele exclui da histeria fenômenos tróficos e vaso-motores. Austregésilo diz que esse é um fato insólito, pois era habitual acreditar-se nessa associação.

Além disso, o autor cita diversas situações como: alterações de pele, hemorragias, seio histérico, perturbações dos esfíncteres, alterações gástricas, respiratórias, febre histérica, etc. Sobre essas condições, ele diz: “tudo coisa antiga”. 
Por outro lado, informa que ainda pertencem ao pitiatismo: ataques, paralisias, contraturas, tremores, anestesias, perturbações sensoriais, hiperestesias, dores, afasia, gagueira, mutismo, amnésia, delírios, soluço, tosse, anorexias, dispepsias, etc.

Austregésilo acentua que a histeria não está bem constituída na neuropatologia, pois no congresso de 1907, diversas concepções foram aventadas e são a seguir colocadas.

Para Schneyder, que concorda com Bernheim, a histeria não é uma doença e sim uma manifestação de fraquezas inerentes à mentalidade humana, manifestações essas que podem surgir juntamente com as mais diversas moléstias. Ele acha que a histeria corresponde a um modo anormal de reagir às exigências da vida, com uma tendência à volta a um estado mental infantil.

Para Croq, Babinski e Dubois, a histeria é uma perturbação psico-nevrotica e, conforme Austregésilo, essa tendência ganha adesão dia a dia.

Nissl fez um balanço dos casos de histeria nos hospitais de alienados e encontrou raros casos, pois muitos que tinham esse diagnóstico eram relativos a situações tais como várias formas de demência, ou de intoxicação.

Claude situa a histeria dentro de uma grande diátese do estado constitucional do sistema nervoso, que ele prefere chamar de "nervosismo", caracterizado como uma falta de regularização nos processos reflexos elementares psíquicos ou orgânicos. A isso Austregésilo acrescenta a "falta de synthese mental” dos histéricos, conforme Janet e o psiquismo inferior, que segundo Grasset domina a personalidade do histérico.

Austregésilo acentua que os clínicos estão entrando em acordo e considerando a histeria não como uma doença à parte, mas como um estado mórbido pertencente à diátese do "nervosismo". Segundo ele, o nervosismo foi abandonado pelos autores modernos e depois resurgido pelos contemporâneos.

Assim, afirma que a histeria apresenta-se como uma psico-nevrose, ou como estados psico-nevroticos, que se desenvolvem em um terreno comum a todas as psiconevroses: o nervosismo. Informa também que Zbinden dá três características para o nervosismo: sugestionabilidade, irritabilidade, cansaço precoce.

Desse modo, Austregésilo resume, dizendo que o nervosismo se caracteriza pelo máximo de reação nervosa ao mínimo de excitação, sendo então uma diátese do dinamismo nervoso anormal. Assim, nesse terreno se desenvolvem os fenômenos histéricos, neurastênicos, hipocondríacos, obssessões, etc. 
O autor frisa que, para certos estudiosos como Nissl e Bernheim, a histeria não é nem mesmo uma nevrose ou uma doença, restringindo-se a uma crise de nervos que pode acometer qualquer pessoa, e propõem substituir o termo histeria por "crise de nervos”.

Nesse aspecto, Bernheim discorda de Babinski. Por outro lado, ambos concordam que não existem os estigmas histéricos.

Conforme Austregésilo, Bernheim discorda de que as histéricas sejam mentirosas, simuladoras, pérfidas, eróticas, intrigantes. Segundo ele, essa é a histérica do romance e não a da clínica.

Assim, diz que a tendência dos autores franceses é desmembrar, restringir ou negar a entidade mórbida identificada como histeria.

Austregésilo informa que os autores alemães também têm se preocupado com essa questão. No Congresso Internacional de Psiquiatria, Neuropatologia e Psicologia de Amsterdam, em 1907, o prof. Aschaffenburg foi o relator sobre "As novas teorias da histeria”, tendo referido, de passagem e sem comentários, sobre as doutrinas de Charcot, Janet e Moebius, desenvolvendo mais a teoria sexual da histeria de Freud.

Austregésilo diz considerar a teoria de Freud absurda, lembrando que Sollier considerava que na histeria há mais frieza sexual do que erotismo.

O autor acrescenta que um dos discípulos de Freud, Sadger, diz que, atrás de cada sintoma da histeria, oculta-se um forte desejo sexual, e que a falta de sua execução imediata excita mais o doente. Diz Austregésilo que o próprio Freud crê que o quadro clinico da histeria é conseqüência do grau de sexualidade das doentes. Ele, Austregésilo, considera essa apenas como mais uma teoria.

Finalizando suas considerações, Austregésilo lembra que Charcot já dizia que a mentalidade está sempre afetada na histeria. Ele reforça que a teoria da origem psíquica dos fenômenos histéricos está em voga, e considera que as idéias de Babinski sobre o pitiatismo serão vitoriosas sobre as outras.

Observa-se que entre os congressos franceses de 1901 e 1907, as idéias de Babinski ainda não foram totalmente aceitas, mas, concomitantemente, surgem também outros entendimentos da histeria, direcionados a desfazer as conceituações estabelecidas por Charcot. Austregésilo declara-se favorável à conceituação de Babinski. 
Em 1909, na seção “Neurologia” da Imprensa Medica, publica-se o artigo intitulado "Hysteria e syndromo hysteroide” 665 de autoria de A. Austregésilo, constando como “Memoria apresentada ao IV Congresso Medico Latino Americano”.

Assim inicia o autor: “A questão da hysteria está em via de ser resolvida. De Babinski começou a reacção contra a superabundância symptomatica da hysteria”.

Austregésilo pretende distinguir a sindrome histérica ou pitiática da falsa histeria ou histeria sintomática presente nas afecções mentais e nervosas. Assim, ele propõe o termo "Syndromo hysteroide" para o segundo quadro.

Para explicar sua proposta, o autor refere-se a seu próprio artigo anterior em que explica as idéias de Babinski. Assim, ele reforça que a histeria é oriunda da autosugestão e curável pela persuasão. Ele insiste em que os estigmas histéricos são sempre produto da sugestão médica inconsciente, conforme vários estudiosos que cita. Esses estigmas são: hemi-anestesia sensitiva, estreitamento do campo visual, abolição do reflexo faríngeo, zonas histerogenas, etc.

O autor refere então que, antes de Schneyder apresentar relatório no Congresso a esse respeito, ele próprio (Austregésilo) já havia observado sintomatologia histeroide em caso de demência precoce.

Ele passa então a apresentar casos vistos por ele, por Roxo, por Fajardo e por Babinski, inicialmente diagnosticados como histeria, que depois evoluíram e passaram a se apresentar como demência precoce. Acrescentou outros casos observados por estudiosos franceses e brasileiros, incluindo casos de tumor cerebral, sífilis, etc, que inicialmente foram diagnosticados como histeria, e que ele considera que deveriam então ser chamados de síndrome histeróide.

Ele rebate a eventual hipótese de associação entre a histeria e essa outra patologia, já que o quadro similar à histeria não é curável pela persuasão e recomenda a que os clínicos deixem de achar que qualquer pessoa com temperamento estranho seja considerada histérica, pois “positivamente não devemos estar mais neste tempo”.

Em 1910, é publicado na Revista Medica de S. Paulo o artigo "Hysteria masculina - hystero-traumatismo”, relacionado à apresentação feita à Sociedade de 
Medicina e Cirurgia de S. Paulo, em 3 de outubro de 1910, por Enjolras Vampré, identificado como médico do Juquery ${ }^{666}$.

Este artigo relata o caso de um paciente italiano, de 48 anos, internado no Juquery, que já estivera internado em manicômio de Roma. O paciente apresentou quadros pouco convincentes de convulsões, além de uma alteração motora e sensitiva sem correlação anatômica, que o próprio doente associou a um tiro que havia levado.

O autor fez o diagnóstico de histero-traumatismo baseando-se na conceituação de Grasset ${ }^{667}$. Por esse conceito, um indivíduo com determinados fenômenos nervosos, na vigência de algum traumatismo, passa a associar os dois quadros, podendo surgir, desse modo, alguma nova sintomatologia sem correlação anatômica. O autor também concluiu que o doente não era um morfinomano, devido à maneira como pedia seus analgésicos. Desse modo, Vampré acha que se trata de um histérico, assinalando que a histeria masculina é rara no Juquery, não tendo sido vista desde cinco anos antes da apresentação deste caso.

Observa-se nesses artigos, além da mudança de paradigma sobre a histeria a partir de Babinski, e dos informes a São Paulo diretamente de Paris, outras idéias também sobre esse quadro, incluindo a de Austregésilo.

\section{3. 2. 2. - Nevroses: Moléstia de Parkinson (1899-1912)}

Em 1900 é feito o provável primeiro relato registrado de doença de Parkinson em São Paulo. Assim, na Revista Medica de São Paulo, o médico Dias Martins publica um artigo intitulado "Molestia de Parkinson”668.

Ele relata o caso de um lavrador de 70 anos que, cinco anos antes, iniciou um quadro, que se instalou gradualmente, com alteração de força muscular e sensibilidade

666 VAMPRÉ, E. Hysteria masculina, hystero-traumatismo; observação apresentada à Sociedade de Medicina e Cirurgia na sessão ordinária de 3 de outubro de 1910. Revista Medica de S. Paulo, p. 76-79, 1911.

667 Joseph Grasset (1849-1918) foi professor em Montpellier. não chegou a ser tão famoso quanto Charcot, mas há sinais clínicos com seu nome. Foi professor de terapêutica, de clínica médica e de patologia geral. No entanto, estudou e escreveu também sobre psiquiatria, neurologia, filosofia e fenômenos paranormais. Em 1876 escreveu sobre a localização das moléstias cerebrais e em 1878 escreveu obra intitulada "Moléstias do Sistema Nervoso", ambos os livros aproximadamente concomitantes aos escritos de Charcot sobre o sistema nervoso.

Em: <http://www.whonamedit.com> Acessado em 27 de junho de 2006.

668 MARTINS, D. Moléstia de Parkinson. Revista Medica de S. Paulo, p. 248-252, 1900. 
do lado direito do corpo, somando-se também tremor e rigidez, bem como dificuldade de marcha.

Dias Martins fez o diagnóstico de moléstia de Parkinson, embora considere que haja também outros sinais favoráveis a outras doenças do sistema nervoso. Para reforçar sua hipótese, o autor relata dois casos descritos por Charcot e um caso descrito por Brissaud, semelhantes ao caso visto por ele, com mais alterações do que as que apenas caracterizam a moléstia de Parkinson.

Martins dá bastante ênfase ao que ele chama de "sofrimentos morais" que “abalaram o systema nervoso" do paciente, como uma das causas da doença. Nesse aspecto, ele diz que o paciente passou por conflitos domésticos com a mulher e com os filhos, o que lhe levou a fazer uso de bebida alcoólica. Martins soma esses dois fatores ao processo que ele chama de "evolução senil”, a qual explica como decorrente de “processo thrombotico, lento e gradual”.

Em seu relato pormenorizado, observamos que Martins não usa o termo “nevrose” em seu texto, e sim “afecções nervosas”, ao discorrer, de passagem, a respeito de outros diagnósticos possíveis para o caso em questão.

Em 1910, é publicado na Gazeta Clinica o artigo "Molestia de Parkinson Conferencia realizada na $3^{\text {a }}$. Enfermaria da Santa Casa de S. Paulo” - pelo estudante de medicina Eduardo Monteiro ${ }^{669}$.

O autor faz a descrição de um caso clínico sugestivo de moléstia de Parkinson e, em seguida, passa a relatar os antecedentes científicos históricos de descrição da doença. Ele também cita que, como a moléstia apresenta uma incidência maior nos Estados Unidos e Inglaterra do que em outros países, pode haver uma associação com o "enorme desenvolvimento industrial e consequente frequencia de dezastres emocionantes” ${ }^{670}$. Assim, ele diz que "as emoções são a causa mais deparada. Das suas modalidades destacam-se, pela sua maior frequencia, os terrores e os desgostos;

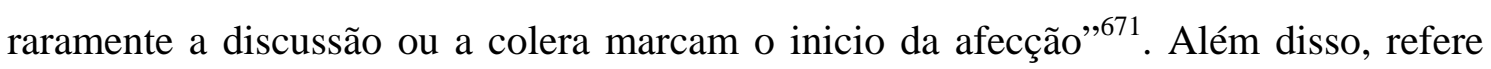

669 MONTEIRO, E. Molestia de Parkinson; conferencia realizada na $3^{\text {a }}$. Enfermaria da Santa Casa de S. Paulo. Gazeta Clinica, p. 50-58, 1910. 
que: “A fadiga costuma acompanhar de perto as emoções. Numa observação de Krafft o tremor e a rigidez estabeleceram-se por um membro fatigado pela profissão”672.

O autor também descreve os diversos achados anatomo-patológicos em diversas partes do sistema nervoso e dos músculos, mas sem características que possam esclarecer o mecanismo da moléstia.

Pode-se ver, pelo relato que essas considerações sobre a causa da doença de Parkinson, trazem uma visão de conseqüências negativas decorrentes do progresso, principalmente em Estados Unidos e Inglaterra. Ao descrever um caso de S. Paulo, e ao fazer essas correlações, o autor também pode estar apontando para alguma similaridade entre a sociedade desses países e de S. Paulo, no que diz respeito a problemas decorrentes do progresso. Observa-se também que, pela dificuldade em demonstrar um substrato anatômico para a moléstia de Parkinson, alguns autores tendem a classificar a doença entre as “nevrozes”. Sobre isso, assim se expressa o autor:

“Sabido como é, que o antigo grupo das nevrozes é aquelle das molestias sine materia, como se pode admitir que uma afeção sem lezão material tenha uma marcha irrefreavel e irremediavelmente fatal? Mas nenhum medico esclarecido do nosso seculo admite a existencia de molestias sine materia. $\mathrm{O}$ termo nevrozes tende a dezaparecer da linguagem medica, pois a sua existencia atual só se compreende para intitular as molestias cujas alterações os processos de laboratorio do nosso tempo ainda não conseguiram revelar" ${ }^{\mathbf{6 7 3}}$.

Assim, o autor pode estar expressando conceituações correntes em 1910, em torno da classificação de moléstias dentro do grupo das "nevrozes", que tende a desaparecer e vir a ser substituído por designações correlatas às alterações químicas associadas a essas moléstias, na medida em que esses fatores químicos sejam descobertos:

“Assim é que o tetano e a eclampsia não mais são registrados sob a rubrica de nevrozes; e as esperanças do momento cientifico são as de tirar a epilepsia desse quadro obscuro. $O$ prof. Dubois prognostica que as dezignações chimicas das nevrozes serão, um dia, substituidas por outras, mas anatomo-patologicas. Comtudo existem molestias nas quais as perturbações devem ser reportadas á ideação. Mas quem nos diz que mesmo nestas não existam alterações estatico-dinamicas? É pois tendencia dos neuropatologistas modernos considerarem como nevrozes propriamente ditas molestias nas quais o elemento psiquico goza um papel preponderante e constante"674.

672 MONTEIRO, E. Molestia de Parkinson; conferencia realizada na $3^{a}$. Enfermaria da Santa Casa de S. Paulo. Gazeta Clinica, p. 50-58, 1910.

673 Idem, p. 52.

674 MONTEIRO, E. Molestia de Parkinson; conferencia realizada na 3 ${ }^{\text {a }}$. Enfermaria da Santa Casa de S. Paulo. Gazeta Clinica, p. 52, 1910. 
Por essa afirmação percebe-se uma tendência, nesse momento, de passar a caracterizar o grupo das nevroses mais por suas características psíquicas, o que tende a deixar fora desse grupo os quadros com predominância de alterações somáticas.

No entanto, ainda usando conceituações do prof. Dubois, o autor acha que a moléstia de Parkinson ainda deve estar entre as nevroses, por ter alterações ignoradas. O autor relata proposta desse professor para os quadros psíquicos, de modo que ele sugere o nome de "psicoses”, com duas divisões: “psiconevroses” para os casos compatíveis com a vida em sociedade e "vezanias” para os casos graves que necessitem internação.

Essas propostas indicam modificações da classificação do grupo das nevroses e suas moléstias, nesse momento em que se modificam noções sobre o corpo neurológico, também definindo melhor o grupo das alterações psíquicas, de modo que há novas sugestões que possam englobar estas moléstias.

Em 1912, na Imprensa Medica, na seção “Neuropathologia”, publica-se o artigo "Sobre alguns signaes da paralysia agitante” ${ }^{675}$, pelo prof. Aloysio de Castro, artigo esse referente a comunicação feita à Academia Nacional de Medicina.

O autor observou onze casos de paralisia agitante, em várias clínicas e hospitais do Rio de Janeiro, também acompanhados por outros profissionais. Ele procurou abordar aspectos da sintomatologia, de conhecimento recente ou ainda em debate.

Um primeiro aspecto abordado é um dos ombros mais caído que o outro e a cabeça levemente pendida para um lado, presentes nesses quadros. Ele observou essas caracteristicas já no primeiro caso examinado e relata que, um pouco depois, encontrou publicação do estudioso americano Tilney, que chama a atenção para essas alterações. Nota o autor que, apesar do volumoso estudo de Richer e Meige sobre o mal de Parkinson, eles não atentaram a esses aspectos.

Castro acentua que em todos os onze casos por ele observados, notou ambas as alterações, de modo que diz confirmar as observações de Tilney. Ele reforça seu achado, citando que em algumas figuras do livro de Dejerine notou o desvio da cabeça. O autor acha que essas alterações se devem à predominância da rigidez muscular em um dos lados.

675 CASTRO, A. Neuropathologia: Sobre alguns signaes da paralysia agitante. (comunicação feita à Academia Nacional de Medicina). Imprensa Medica, p. 225-229, 1912.

Paralisia agitante é o nome que o próprio Parkinson havia dado inicialmente à moléstia. 
Outro debate diz respeito ao tremor da cabeça nessa molestia. Informa Castro que, guiada por Charcot, a escola francesa estabeleceu que o tremor do mal de Parkinson não compromete a cabeça, podendo ser apenas um movimento comunicado de outra parte do corpo, de modo que esse dado poderia ser distintivo do chamado tremor senil.

No entanto, o estudioso Mendel é discordante dessa opinião e acha que esse tremor é freqüente nos casos de paralisia agitante. Castro concorda com essa afirmação, pois observou esse tremor em oito dos onze casos. Outro debate é a contagem de oscilações desse tremor. Nos casos por ele vistos, o autor achou 2 a 4 oscilações por segundo, ou seja, um dado intermediário entre os outros autores.

Outra questão é a hipotética alteração de reflexos na paralisia agitante. Informa o autor que a maioria dos autores acha que o reflexo patelar não sofre alteração. Nos casos por ele vistos, esse reflexo estava aumentado, exceto em um caso em que não foi possível a pesquisa pelo edema presente.

Quanto ao reflexo aquileano, informa Castro que autores de peso têm relatado sua ausência no mal de Parkinson. Quanto a isto, ele diz que ainda está em debate se o reflexo aquileano se torna ausente em idosos normais, o que poderia dificultar a interpretação deste dado em casos de paralisia agitante.

\section{3. 2. 3. - Nevroses: Coréia (1899-1912)}

Em 1902, na Revista Medica de S. Paulo, é publicada a tradução feita por A. Austregésilo, do Rio de Janeiro, de um artigo do periódico Deutsche Medicinische Wochenschrift, de 23 de janeiro de 1902, do professor W. Westphal, da Clinica Psiquiátrica da Universidade de Greiswald, intitulado "Sobre a Choréa Chronica Progressiva”. O autor relata dois casos de "Coréia Crônica Progressiva” (Coréia de Huntington) com evolução para quadro demencial, acentuando as diferenças com a chamada "Coréia Minor" (Coréia de Sydenham), havendo quadro mental do tipo demencial no primeiro diagnóstico e delírio agudo alucinatório na Coréia Minor ${ }^{676}$.

O assunto em si, tratado no artigo, dá idéia de estudos que tornavam as formas de coréia mais entendidas clinicamente. Embora as coréias figurem entre as nevroses, nesse período, por não terem substrato anatomo-patológico definido, nesse artigo

676 WESTPHAL, A. (tradução de A. Austregésilo) Sobre a Coréia Chronica Progressiva. Revista Medica de São Paulo, p. 87-88, 1902. 
procura-se entender essas moléstias dentro de conceituações clínicas patológicas vigentes.

Em 1903, na Revista Medica de S. Paulo, Austregesilo publica artigo intitulado “Choréa degenerativa (ou de Huntington)”,"677. O autor se baseia em variada bibliografia. Ele refere que, embora haja várias publicações a respeito da coréia, esse era um quadro ainda não conhecido de todo, havendo ainda coisas por melhor definir, incluindo a diferenciação entre as diversas formas de coréia, bem como o nome mais adequado para cada uma dessas formas. Também foi citada a associação de certas formas de coréia com algumas moléstias, como associação da Coréia de Huntington com hereditariedade, ou ainda com epilepsia, enquanto que a coréia vulgar se associa à histeria. $\mathrm{O}$ autor acrescenta exemplos, com descrições clínicas detalhadas.

Nota-se nesse artigo a associação de uma das formas da coréia com a histeria. Esse dado tende a manter ainda a coréia próxima da histeria, no grupo das nevroses.

Em 1908, na Revista Medica de S. Paulo, foi publicado o artigo "Dos Estados Mentaes nas Grandes Nevroses”678, por Henrique Roxo. Esse artigo já foi parcialmente comentado no item das Nevroses correspondente a histeria e neurastenia.

O autor comenta sobre o estado mental nas grandes nevroses: histeria, epilepsia, coréia, neurastenia.

Em relação ao estado mental nos casos de coréia, Roxo refere que se assinala por uma instabilidade notável, cansam-se depressa e têm memória falha; são irritáveis, com uma depressão que lhes abate a fisionomia.

\section{3. 2. 4. - Nevroses cardíacas (1899-1912)}

Em 1903, na Revista Medica de S. Paulo, o médico Dias Martins publica artigo intitulado "Nevroses nas cardiopathias”"

O autor relata que em certas predisposições nervosas, herdadas ou adquiridas, o que ele chama de "cerebro cardiaco" pode provocar nevroses. Ele coloca, como principal

677 AUSTREgeSILO, A. Choréa degenerativa (ou de Huntington). Revista Medica de S.Paulo, p. 456463, 1903.

678 ROXO, H. Dos Estados Mentaes nas Grandes Nevroses. Revista Medica de S. Paulo, p. 327-332, 1908.

679 MARTINS, D. Nevroses nas cardiopatias. Revista Medica de São Paulo, p. 171-173, 1903.

248 
evidência dessa correlação, a melhora do quadro cerebral, após o uso de digitalis no tratamento da cardiopatia:

"É em taes cardiacos, que sobrevem nevroses, que sobrevem a hysteria (Potain, Lemoine), epilepsia (Giraudeau) 'provocadas ou despertas pela lesão cardiaca, habitualmente uma lesão valvular, sobretudo mitral (Merklen). E a relação destas nevroses, com as lesões valvulares, é demonstrada por sua melhora progressiva, sob a influencia da digitalis (Lemoine)"

O autor informa, então, o caso específico de um paciente de 50 anos, com sintomas respiratórios, cardíacos e de figado, que piorava “com os excessos da mesa e do fumo” ${ }^{681}$. A seguir, ele acrescenta a existência de uma "tara nevropatha, um abalo nervoso profundo" ${ }^{682}$, que ele associa ao fato de o paciente saber que "o ser mais caro a seu coração sofria de molestia grave"683:

Após algumas medidas terapêuticas sem sucesso, o autor finalmente acreditou chegar a uma solução pelo uso da digitalis, de modo que o doente voltou à alegria, ao desejo do trabalho e aos sentimentos afetivos.

Em 1905, na Imprensa Medica, é publicada resenha da tese inaugural de Álvaro Augusto de Souza Reis, do Rio de Janeiro, intitulada “Nevroses cardiacas"684. Conforme a resenha, o autor comenta causas morais e alterações de diversas partes do organismo que podem perturbar a inervação cardíaca. A seguir, ele aborda correlações entre a inervação cardíaca e a inervação de outros órgãos. O texto informa que o autor entende por nevrose cardíaca as perturbações funcionais do coração em conseqüência de desequilíbrio de sua inervação. Também o autor classifica as nevroses cardíacas em: psíquicas ou emotivas; reflexas e sintomáticas.

\section{3. 2. 5. - Nevroses: epilepsias (1899-1912)}

Em 1908, na Revista Medica de S. Paulo, foi publicado artigo intitulado "Dos Estados Metaes nas Grandes Nevroses”, por Henrique Roxo. Esse artigo já foi parcialmente abordado em outras seções.

680 MARTINS, D. Nevroses nas cardiopatias. Revista Medica de São Paulo, p. 172, 1903.

681 Idem.

682 Ibidem.

683 Ibidem.

684 BIBLIOGRAPHIA: Nevroses cardíacas; these inaugural do Dr. Álvaro Augusto de Souza Reis. Rio de Janeiro, Typ. Moraes, 1905. Imprensa Medica, p. 216, 1905. 
O autor estuda os estados mentais nas grandes nevroses: histeria, epilepsia, coréia, neurastenia.

Em relação aos epilépticos, Roxo refere que eles têm um aspecto sombrio que permite o seu reconhecimento. O autor cita Teixeira Brandão e Franco da Rocha, entre outros, para confirmar sua observação, de que esses indivíduos têm olhar triste, sombrio e profundo. Considera também que são pouco sociáveis e egoístas, irritáveis e guardam rancor por longo tempo. Diferem dos histéricos por não andarem solicitando a atenção dos outros.

Conforme o autor, Feré acha que há epilépticos com tenacidade e resolução, como Cesar e Napoleão. No entanto, lembra o autor que Afrânio Peixoto e outros estudiosos consideram que sempre há uma piora progressiva do quadro, tal como se comportou Napoleão em Waterloo, onde se mostrou pouco persistente.

Roxo ainda acrescenta que os epilépticos têm tendência para as práticas religiosas, porém sendo mais sinceras do que as das histéricas. Se premeditam vingança, fazem-na com ferocidade incrível, e se golpeiam o adversário fazem-no com número de golpes extraordinário, por um ato brusco.

Em 1909, é publicado na Revista Medica de S. Paulo, artigo apresentado no VI Congresso Brasileiro de Medicina e Cirurgia ocorrido em São Paulo em 1907, com o título “A epilepsia essencial e seu tratamento (conclusões)”, do médico Rezende Puech $^{685}$. O autor referiu oito conclusões a partir de ampla revisão feita sobre o tema epilepsia (não tivemos acesso ao artigo anterior).

Resumidamente, nessas conclusões o autor discorda da tendência que chama de moderna, de reduzir ao máximo os casos de epilepsia essencial e aumentar os casos de epilepsia sintomática ou de pseudo-epilepsia. O que ele chama de pseudo-epilepsia corresponde a ataques associados a epilepsia traumática e a epilepsia jacksoniana. Esta ele não considera como verdadeiro ataque. Ele só atribui o ataque verdadeiro à epilepsia essencial, ou idiopática.

Ele considera também que as epilepsias sintomáticas, com seus tipos epilepsia cardíaca, gástrica, gastro-intestinal, pueril, testicular, nefrética, uterina, artrítica, herpética, tuberculosa, sifilitica, cancerosa, anêmica, tóxica, saturnina, palúdica, gripal,

685 PUECH, R. A epilepsia essencial e seu tratamento (conclusões). Revista Medica de S. Paulo, p. 235236, 1909. 
etc., etc, não são epilepsias simtomáticas. Puech considera que esses casos, ou são epilepsia essencial, ou pertencem a algum fenômeno convulsivo não epiléptico.

Puech também acha que na epilepsia essencial não há uma lesão cerebral, mas apenas uma alteração do seu funcionamento. Assim, ele considera que a epilepsia é uma diátese do sistema nervoso central, com uma predisposição inerente a certo estado das células dos centros nervosos. Assim, ele acha que o alcoolista que se torna epiléptico, já tem uma predisposição a isso.

Quanto ao tratamento o autor acha que deve ser feito o tratamento sintomático com bromuretos, principalmente o bromureto de potássio, e o tratamento etiológico, visando corrigir, de maneira específica, desordens vaso-motoras, gastro-intestinais, dietéticas, etc. Além disso, recomenda uma profilaxia individual, evitando intoxicações. Ele termina dizendo que a epilepsia é incurável, mas pode ser atenuada.

Em 1912, é publicada, na Imprensa Medica, na seção “Revistas e Analyses”, resenha sobre o artigo "O epileptoidismo e os epileptoides" ${ }^{686}$, de autoria de Sante de Sanctis, do periódico “Rivista Ospedaliera”, de fevereiro de 1912.

Conforme o texto, o autor usa o termo "epiletoidismo", ao se referir ao “caracter epileptico”, próprio dos indivíduos “epileptoides”, que são aqueles que, sem apresentar acessos, têm esse dito caráter. Cita-se que eventualmente o epileptoide tornase epiléptico.

É descrita a sintomatologia do epileptoidismo: grande mobilidade do humor, agressividade, hiperexcitabilidade nervosa, reações explosivas sem motivo, refratariedade a trabalho continuo e regular, e não melhora pela "bromuração".

Conforme o texto, reforçam o diagnóstico: convulsões infantis; sintomas de tetania; herança epiléptica, alcoólica ou sifilítica; traumas de crânio na infância; incontinência urinária na segunda infância ou na mocidade; terrores noturnos; perturbações do sono.

Cita-se que a etiologia provável pode se dever a: processos inflamatórios no período fetal ou na primeira infância, traumatismos no período de crescimento, disposições hereditárias ou congênitas; alcoolismo dos pais, que também podem levar à dipsomania e tendências criminais.

686 REVISTAS E ANALYSES: SANCTIS, S.; O epileptoidismo e os epileptoides; Rivista Ospedalera, fevereiro de 1912. Imprensa Medica, p. 239, 1912. 


\section{3. 2. 6. - Nevroses gastro-intestinais (1899-1912)}

Em 1905, na Imprensa Medica, é publicado artigo intitulado "Diagnostico e tratamento das nevroses gastro-intestinaes”687, por V. de Mello.

O autor se refere a caso por ele observado de paciente com distúrbio gastrointestinal, que tinha alteração de reflexos. Assim, usou “medicação antinervosa”, que trouxe bons resultados. Desse modo, passa a informar sobre estudo do médico J. Boas de Berlim, a esse respeito. Refere que esse autor estudou os distúrbios do trato gastro-intestinal de natureza nervosa e propôs uma nova classificação para esses quadros. Em vez de subdividir em nevroses motoras, sensitivas, secretoras e mistas, esse autor propõe subdividir em nevroses monossintomáticas e polissintomáticas. Descreve esses quadros em relação a sintomas do estômago e dos intestinos.

O autor associa esses quadros a situações ou de depressão ou de excitação. Considera que pode haver comprometimento de reflexos e de sensibilidade, conforme os pontos alterados que podem ocorrer em casos de histeria.

Ele refere que o tratamento desses casos não tem regra fixa, pois, nessas situações, não são os medicamentos que curam e sim o médico. Também são recomendados: repouso, regime alimentar, mudança de meio, hidroterapia, eletroterapia, massagem, ginástica e medicamentos como bromureto, derivados do ópio e preparações da valeriana.

Em 1910, na Imprensa Medica, na seção “Revistas e Analyses”, é publicada resenha de trabalho intitulado “As afecções do systema digestivo em neuropathologia”688, pelo Dr. H. Zbinden, publicado em Paris, em 1909.

O texto comenta que o autor mostra a grande influência do sistema nervoso nas moléstias gastrointestinais, através das leis de Pavlov. Conforme o texto, essa lei se baseia em pesquisa feita por Pavlov, onde verificou a presença do que chamou de “secreção psíquica” em cães com refeições fictícias. Se os nervos pneumogástricos dos cães são cortados, não há mais a "secreção psychica”. O texto comenta que a secreção do “suco psíquico” pode ser inibida por uma causa psíquica como medo, ou irritação.

687 MELLO, V. Diagnostico e tratamento das nevroses gastro-intestinaes. Imprensa Medica, p. 385-387, 1905.

688 REVISTAS E ANALYSES: ZBINDEN, H.; As afecções do systema digestivo em neuropathologia. Paris, 1909, Masson \& C.a. Imprensa Medica, p. 295-297, 1910. 


\section{3. 2. 7. - Nevroses: asma; nevroses reflexas nasais (1899-1912)}

Em 1905, na Imprensa Medica, é publicada uma resenha sobre as conclusões comunicadas em memória do Prof. Soca sobre Asma ${ }^{689}$. A primeira conclusão é que a asma é uma "nevrose bulbar", efeito de uma predisposição hereditária que pode despertar “influencias diversas”. A seguir, as outras conclusões se referem a variações nas manifestações da moléstia, bem como seu desencadeamento por associação com as mais diversas doenças em várias partes do corpo.

Em 1908, na Revista Medica de São Paulo, é publicado artigo intitulado “Da rhinologia nas fronteiras das nevroses” ${ }^{690}$, pelo médico Francisco Eiras, sendo esse trabalho correspondente a uma "Memoria apresentada ao Sexto Congresso Brasileiro de Medicina e Cirurgia”.

O autor diz entrar em assunto que se alastra pela medicina em geral e que é um dos capítulos mais controversos de sua especialidade. Ele diz que não pretende ruir por terra "os edifícios magestosos da pathogenia neurologica”, mas registrar o que considera como observação diária na clínica, que são os reflexos nasais patológicos localizados ou à distância.

Ele se estende então na citação de diversos autores favoráveis à existência de “nevrose reflexa nasal” e alguns autores contrários. A seguir apresenta dez casos por ele observados, com diversas formas de nevroses, que foram curados, segundo diz, por algum tipo de intervenção nas estruturas nasais.

Depois, Eiras debate longamente a respeito dos diversos mecanismos que podem explicar essas nevroses, argumentando com diversos conhecimentos anatômicos relacionado a trajetos de nervos e correlações com regiões cerebrais. Apresenta um quadro complexo de autoria do estudioso Ménier, com subdivisões das nevroses produzidas por lesões ou desordens funcionais do nariz. Cita outros tantos autores e suas idéias, entre eles Potiquet, que "protesta vehementemente contra a introdução do nariz na pathologia interna” e não crê na relação entre a asma e o nariz, insistindo em que a asma é uma “nevrose bulbar”. A isso, Eiras responde com a citação do estudioso Lichtwitz, que em 1889 "tinha uma opinião muito mais consentanea com a theoria atual, 
perfeitamente estabelecida pela veracidade dos factos", admitindo duas categorias de "afecções nevropathicas”: as nevroses de origem nasal e faríngea, e as que se acompanham de afecções catarrais das mucosas.

Ele continua citando outros tantos trabalhos: de experimentos com animais, ou clínicos, ou ainda a respeito dos mecanismos associados à sensação de prazer, etc. A certa altura ele diz que: “A neurasthenia, a figura symbolica da nevrose, segundo os neurologistas modernos é uma entidade psychica: ahi temos, pois, como, em certos casos, afecções nasaes são passiveis de engendrar a nevrose! ${ }^{691 \text {, }}$

O autor sauda os progressos da otorrinolaringologia que com suas luzes pode esclarecer “o obscurantismo dos reflexos polymorphos das nevroses”. Reclama de não haver no curso médico o ensino dessa disciplina. Enfatiza a necessidade de conhecimento das nevroses reflexas nasais, lembrando que para isso ocorrer deve estar presente uma prerdisposição nevropática.

Ao concluir, o autor diz que os referidos reflexos podem engendrar as seguintes manifestações inerentes às nevroses: crises epileptiformes, histéricas, neurastênicas, coreicas, sensoriais, vasomotoras, hipocondríacas, alucinatórias, basedowiformes, vertiginosas, asmáticas, nevrálgicas, cardíacas, espasmódicas, etc. Ele diz ser indispensável o exame do nariz nas manifestações nevrósicas, bem como a instituição da terapêutica nasal.

\section{3. 3. - Sífilis do sistema nervoso. (1899-1912)}

Em seu artigo sobre Causas da Loucura, em 1901, na Revista Medica de São Paulo, Franco da Rocha refere que:

“A syphilis é, por si só, sufficiente para produzir a loucura, quer por lesões em foco na propria substancia cerebral, quer por lesões diffusas do apparelho vascular. A forma de loucura que mais se observa como consequencia da syphilis é a demencia, o abaixamento de nivel de todas as faculdades superiores, acompanhada de symptomas somaticos de lesões cerebraes e medullares. Tem se observado casos de demencia paralytica e esclerose em placas disseminadas; tivemos a bem pouco um doente syphilitico com todos os signaes da demencia e esclerose lateral amyotrophica, isto é, paralysia, atrophia muscular, um estado espasmodico bem pronunciado e reflexos exaggerados" ${ }^{692}$.

691 EIRAS, F. Da rhinologia nas fronteiras das nevroses. Revista Medica de S. Paulo p. 60, 1908. 692 ROCHA, F. Apontamentos e Estatística: Causas de Loucura. Revista Medica de São Paulo, p. 76, 1901. 
Nesse relato, o autor associa a sífilis a quadros de várias doenças. No entanto, não pensa o mesmo sobre a moléstia chamada “paralisia geral”:

“Ultimamente, com especialidade na Allemanha, está se firmando a idea de que a syphilis é a causa da paralysia geral. Como esta molestia é muito mais frequente nos paizes em que é mais renhida a lucta pela existencia, diz Krafft-Ebing que concorrem para o augmento desta enfermidade a civilização e syphilização" ${ }^{693}$.

No entanto, no entender de Franco da Rocha, a paralisia geral pode se dever também a outras causas, como alcoolismo, traumatismo, tendência hereditária, e "principalmente um cerebro fatigado na lucta pela vida" ${ }^{694}$, que ele considera mais intensa em países “mais civilizados” ${ }^{\text {”695 }}$. Reforça essa opinião, dizendo que: “Nos Estados Unidos, onde os negros já se acham muito mais civilizados que entre nós e luctam mais com o cerebro, a molestia já é mais frequente”696.

Devemos observar que, quando Franco da Rocha escreve em 1901, ainda não se conhece o agente causal da sífilis.

Em 1901, na Revista Medica de São Paulo, é publicado um resumo de artigo publicado por Frenkel, no periódico com nome abreviado como Arch. de Méd. et de Chir. Spec.”697 (abreviação que consta no próprio artigo), de março de 1901, com o título "Diagnostico Precoz da Ataxia ${ }^{698}$ Locomotora” ${ }^{699}$. Não há menção do nome do comentador brasileiro. Refere-se que o diagnóstico precoce desse quadro era difícil, pois no início parece ter pouco a ver com qualquer perturbação do sistema nervoso. O comentador chega a citar, mais especificamente o especialista "neurologista", provavelmente por estar fazendo uma tradução, já que no Brasil, e especificamente em São Paulo, não se encontra ainda o uso dessa palavra: “O auctor diz mesmo não haver

693 ROCHA, F. Apontamentos e Estatística: Causas de Loucura. Revista Medica de São Paulo, p. 77, 1901.

694 Idem.

695 Ibidem

696 ROCHA, F. Apontamentos e Estatística: Causas de Loucura. Revista Medica de São Paulo, p. 77, 1901.

697 REVISTA MEDICA DE S. PAULO. Diagnostico Precoz da Ataxia Motora, p. 270, 1901.

$698 \mathrm{O}$ termo ataxia diz respeito a certos distúrbios motores, principalmente em relação à marcha, relativos a atividades motoras inatas.

699 ROCHA, F. Apontamentos e Estatística: Causas de Loucura. Revista Medica de São Paulo, p. 77, 1901. 
um unico neurologista, incluindo os de maior fama, que em tabes dorsalis não tenha feito algum erro diagnostico"700.

A seguir o comentador lembra o conselho do prof. Wagner de Leipzig, o qual resume: em caso de doença interna crônica, deve ser lembrada a tuberculose; se for moléstia aguda, deve ser aventada a febre tifóide; quando a moléstia não puder ser incluida em entidade mórbida nervosa definida, deve então ser pensada a hipótese de tabes dorsalis.

Depois, são relatados sintomas que podem fazer parte do início desse quadro, lembrando que “90\% dos tabeticos tiveram syphilis" 701 . Foram citados, então, os sintomas precoces: dores fulgurantes, perturbações oculares, perda de certos reflexos, alterações sensitivas, crises gástricas e intestinais ${ }^{702}$.

Em 1902, na Revista Medica de S. Paulo, o médico Carlos Mauro, de Ribeirão Preto, publica um artigo denominado "Um caso de syphilis cerebral”703.

Ele comenta que a sífilis do sistema nervoso é mais freqüente do que se pensa.

Mauro refere que, além das formas chamadas de para-sifilíticas, que correspondem à paralisia geral e à tabes, as formas puramente cerebrais e espinhais são numerosas.

O autor aventa suposições de que o grande acometimento do sistema nervoso, nesses casos, talvez se deva ao fato de que esse sistema foi o último no desenvolvimento filogenético, e ainda está em via de diferenciação, sendo assim supostamente mais vulnerável. Outras hipóteses de Mauro para o quadro indicam que a moléstia depende do esgotamento na luta pela existência, ou ainda se deve a intoxicações ou autointoxicações.

A seguir o autor relata o caso de paciente de 32 anos, que passou a desenvolver alterações neurológicas, as quais regrediram com o tratamento de mercúrio e iodo, o que o levou a concluir pelo diagnóstico de sífilis.

Mauro passa então a discutir o raciocínio diagnóstico, fazendo considerações na tentativa de localizar a lesão no cérebro, ponderando as diferenças entre estudiosos que consideram a existência de centros cerebrais para funções específicas, enquanto outros,

700 ROCHA, F. Apontamentos e Estatística: Causas de Loucura. Revista Medica de São Paulo, p. 77, 1901.

703 MAURO, C. Um caso de syphilis cerebral. Revista Medica de São Paulo, p. 426-430, 1902. 256 
como Bianchi, não pensam assim: "não há centros absolutos, circunscritos, mas somente centros de maior intensidade funcional”704. O autor detem-se nesse debate por haverem sintomas e sinais localizatórios no paciente.

Pela rápida melhora com o tratamento, o autor considera tratar-se mais de arterite sifilítica do que de goma sifilítica.

Em 1905, Franco da Rocha publica na Revista Medica de S. Paulo suas considerações a respeito da tese inaugural do médico Antonio C. Penafiel, defendida no Rio de Janeiro, no mesmo ano, intitulada “Contribuição ao Estudo da Paralysia Geral dos alienados no Brazil»705.

Franco da Rocha elogia o trabalho, por considerá-lo único no país. Ele acentua que vem observando, por anos, que a paralisia geral pode ser a forma mais comum de loucura em médicos, engenheiros, advogados, jornalistas. Concorda com Penafiel, que se apoia em Bianchi, dizendo que a causa dessa moléstia é a luta pela existência, os desejos, a ambição, a febre do trabalho, "a dor das decepções, a orgia compensadora das sensações agradaveis” ${ }^{\text {706 }}$.

Franco da Rocha dá grande valor a elementos relacionados com a vida urbana agitada, como causa principal da paralisia geral, sendo que, como no outro artigo, ele acha que a sífilis pode ter algum papel nesse quadro, mas não sendo o fator mais importante.

A persistência de Franco da Rocha, em sua opinião sobre a causa da paralisia geral, pode estar embasada em sua experiência com os casos que observa na sociedade paulistana, já um tanto moderna, ou um tanto cosmopolita, com diversas profissões, com “a febre do trabalho", por ele citada, entre outros fatores da sociedade moderna.

Um registro feito pela Revista Medica de São Paulo indica que os médicos paulistas estão sendo informados de novidades científicas na Europa que vão interferir na prática de todos eles.

Assim, em 15 de junho de 1905, a Revista Medica de S. Paulo publica artigo de Ulysses Paranhos, artigo esse enviado de Paris e datado em 17 de março de 1905 . O

704 MAURO, C. Um caso de syphilis cerebral. Revista Medica de São Paulo, p. 426-430, 1902.

705 ROCHA, F. Contribuição ao Estudo da Paralysia Geral dos alienados no Brazil (these inaugural Rio de Janeiro, 1905). Revista Medica de S. Paulo, p. 99-100, 1905.

706 ROCHA, F. Contribuição ao Estudo da Paralysia Geral dos alienados no Brazil - (these inaugural Rio de Janeiro, 1905). Revista Medica de S. Paulo, p. 99-100, 1905. 
título é "O novo microbio da syphilis”707. O autor relata que, no dia anterior a seu escrito, foi apresentado na Academia de Medicina, por Metchinikoff, o micróbio causador da sífilis. Informa Paranhos que esse agente foi encontrado por Schaudinn, chefe da repartição sanitária de Berlim, em colaboração com seu assistente Hoffmann. Esse micróbio já tinha sido encontrado por Bordet e Gengow, discípulos de Pasteur, mas que, por uma série de dificuldades na pesquisa, eles desistiram da tarefa de melhor determinar esse agente.

Schaudinn encontrou esse germe em 26 casos, tendo enviado fotografias do micróbio e técnicas para Metchinikoff e Roux, para repetição e confirmação. Paranhos explica que esse micróbio é um “spirillo”; refere ele também que, desde 1830, já eram conhecidos "spirillos” (em forma espiral) em feridas purulentas, ou seja, mesmo antes do período microbiano de Pasteur. Shaudinn e Hoffmann apresentaram duas variedades de spirillos: o spirillo vulgar (spirochete refringens), que se encontra difundido, e o spirillo pallido (spirochete pallida), difícil de isolar e distinguir, encontrado na sífilis.

Paranhos refere ter, ele próprio, examinado o spirillo, tendo relatado sua descrição do germe. Acrescenta detalhes sobre como outros aspectos da pesquisa vieram a confirmar os dados obtidos, o que estimulou diversos laboratórios a prosseguirem seus trabalhos em torno desse assunto.

Em 1905, é publicada, na Gazeta Clinica, uma aula do Prof. Francisco de Castro $^{708}$, da Faculdade do Rio de Janeiro, constando ter sido essa aula redigida por Rubião Meira. O título da aula foi: "Caracteres do cancro syphilitico. Syphilis cerebral”709.

Nessa aula o professor inicialmente detalha o comprometimento cutâneo inicial na sífilis, chamado de cancro duro, também chamado de “syphiloma primario”, com suas particularidades e seus diagnósticos diferenciais com outras moléstias. Depois,

707 PARANHOS, U. O novo microbio da syphilis. Revista Medica de S. Paulo, p. 233-234, 1905.

708 Francisco de Castro (1857-1901) era um clínico que também dava aulas de moléstias do sistema nervoso, conforme visto em outros artigos. Rubião Meira publicou essa aula sobre sífilis quatro anos após a morte de Francisco de Castro. Este foi um discípulo de Torres Homem, o primeiro conhecedor de doenças do sistema nervoso entre os brasileiros. Castro também é considerado por alguns como "o fundador da Propedêutica no Brasil”, tendo escrito um “Tratado de Clínica Propedêutica”, que foi muito valorizado no meio acadêmico médico. Ele pode ter influenciado a segurança e o interesse de Meira por temas do sistema nervoso.

Dicionário Histórico-Biográfico das Ciências da Saúde no Brasil (1832-1930). Casa de Oswaldo Cruz, Fiocruz. <http://www.dichistoriasaude.coc.fiocruz.br> Acessado em 21 de agosto de 2007.

709 CASTRO, F. Caracteres do cancro syphilitico. Syphilis cerebral. Gazeta Clinica, p. 391-398, 1905. 258 
explica o período secundário da sífilis, que também é chamado de "virulento", ou “inflamatório” onde o professor descreve gânglios comprometidos pelo corpo, dores ósseas e forte possibilidade de contágio.

Após esse período que, conforme Castro, dura entre seis semanas e três meses, vem o período terciário, que dura entre onze meses e três anos. Nesse período, o professor refere haver uma lesão específica da sífilis, a “gomma”, que, conforme diz, representa já um comprometimento de todo o organismo.

A seguir, Francisco de Castro cita a sífilis cerebral, que, segundo ele, pode se revelar no período secundário ou terciário. Ele descreve, então, sete formas da sífilis cerebral: cefalálgica, epiléptica, paralítica, mental, afásica, apoplética, neurastênica.

Conforme o professor, o diagnóstico se faz pela história clínica e pelo exame do paciente, bem como pela resposta da moléstia à medicação intensiva pelo mercúrio e pelo iodureto de potássio.

Um ano após a demonstração do agente causal microbiano da sífilis, os periódicos paulistas já registram pesquisas a esse respeito feitas no Brasil.

Assim, em 1906, é publicado na Revista Medica de S. Paulo o artigo "Do treponema pallidum”, ${ }^{710}$ sendo referido como "um trabalho do Instituto Manguinhos”, pelo médico Raul de Almeida Magalhães. O trabalho é subtitulado com o detalhamento: "Morphologia e estructura, movimentos e cyclo-evolutivo do Treponema pallidum. Technica para a sua pesquiza, Methodos de coloração. Verificações positivas”.

Neste artigo o autor atualiza os mais diversos aspectos sobre o agente causal da sífilis, que foi identificado poucos anos antes, por Schaudinn e Hoffmann.

Com a descoberta do Treponema pallidum em 1905, passaram a se intensificar os estudos para encontrar uma cura para a sífilis. Assim, após ser inicialmente divulgado um novo medicamento em fins de 1909, durante o ano de 1910 essa divulgação ganha entusiasticamente as publicações brasileiras como uma grande conquista da ciência sobre as doenças.

Desse modo, em 1910 são publicados vários artigos na Revista Medica de São Paulo a respeito do medicamento destinado a combater a sífilis, o Arsenobenzol, ou

710 MAGALHÃES, R.A. Do treponema pallidum. Revista Medica de S. Paulo, anno IX, n. 15, p. 370373, 1906. 
“606”, anunciado em novembro de 1909, pelo pesquisador alemão Erlich e seu assistente $\mathrm{Hata}^{711}$.

Nesse mesmo ano também há um artigo informativo na Gazeta Clinica, intitulado “A Reaç̧ão de Wassermann”, informando que a reação, descoberta por este pesquisador em 1906, para diagnosticar sífilis, foi divulgada na Alemanha em 1907 e 1908 e no resto da Europa e do mundo em 1909 e 1910. Foi citado que em 1909 foi feita uma publicação brasileira sobre essa reação, desenvolvida no Instituto Oswaldo Cruz, por Arthur Moses ${ }^{712}$.

Essas três descobertas sobre a sífilis, ou seja, seu agente causal, bem como a reação para detectá-lo e o seu tratamento, são recebidas com entusiasmo pela comunidade científica.

Um ano após essa divulgação, já se observa a publicação de resultados do uso desse novo medicamento.

Assim, em 1911, na Revista Medica de S. Paulo é publicado o artigo "Um complicado caso clinico - communicação apresentada á Sociedade de Medicina e Cirurgia de S.Paulo na sessão ordinária de $1^{\circ}$ de Março de 1910”, por Enjolras Vampré $^{713}$.

Neste artigo o autor relata o caso de um paciente com antecedente de epilepsia, com “completa decadencia intellectual” "714, com comprometimento de memória, de capacidade de fazer cálculos e com delírio de grandeza. Além disso, apresentava tremores, alteração na fala, na escrita, na força muscular. Também apresentava lesões ósseas. A conclusão do caso foi que essas alterações se deviam à sífilis. A tentativa de usar o medicamento “606”, o Salvarsan, não obteve resultado neste caso, nem em outros quatro doentes com paralisia geral do Juquery.

711 GOUVEIA, H. O “606”: o novo especifico contra a syphilis. Revista Medica de S. Paulo, p. 384-395, 1910.

RAO, C. O “606”: o novo especifico contra a syphilis; sobre as technicas para a preparação das injecções. Revista Medica de S. Paulo, p. 404-406, 1910.

M.B. A descoberta de Ehrlich: novo e poderoso anti-syphilitico. Gazeta Clinica, p. 86-87, 1910.

712 GAZETA CLINICA. A Reacção de Wassermann, 1910, p. 81.

713 VAMPRÉ, E. Um complicado caso clinico; communicação apresentada à Sociedade de Medicina e Cirurgia de S. Paulo na sessão ordinária de 1 de março de 1910. Revista Medica de S. Paulo, p. 141-145, 1910.

714 Idem. 
Nesses pacientes descritos não foi observada a esperada cura. Essa experiência negativa de Vampré não foi fato isolado. Esse medicamento valeu-se mais de grande divulgação, do que de ampla eficiência.

Em 1911, na Imprensa Medica, na seção “Neuropathologia”, é publicado artigo intitulado "Paralysia Geral Juvenil”"715, de autoria de Bueno de Andrade e Zacheu Esmeraldo, “internos da Clinica Psychiatrica e de Moléstias Nervosas da Faculdade do Rio de Janeiro”.

Os autores iniciam dizendo que nas clinicas de doenças mentais é relativamente rara a "paralysia geral juvenil” e que decidiram fazer a publicação de um caso que observaram em maio de 1911, no Pavilhão de Observações, no Rio de Janeiro.

Trata-se de paciente de 16 anos, cujo relato foi passado por sua irmã aos observadores, em virtude das limitações de contato do mesmo. Os observadores incialmente pensavam tratar-se de um caso de "idiotia”, até obterem a informação de que o doente soubera ler e escrever. Outro dado familiar obtido foi um antecedente paterno sugestivo de sífilis. Ao exame, o paciente apresentava decadência mental, alteração de fala e de marcha. Além do exame geral, os autores descreveram em separado o exame de reflexos e de sensibilidade.

Diante desse quadro, os observadores relatam que seu mestre, prof. Henrique Roxo fez o diagnostico de paralisia geral e indicou o exame de líquido cefalorraquiano que apresentou reação de Wassermann positiva e franca linfocitose.

Os autores lembram que a confusão entre os diagnósticos citados é comum e reforçam seu achado com dados do Tratado de Psiquiatria de Kraepelin, onde ele diz que antes de se ter a possibilidade de examinar o líquido cefalorraquiano, o erro no diagnóstico era mais freqüente.

Eles referem que o prof. Juliano Moreira também concordou com o mesmo diagnóstico, embora tenha também aventado a possibilidade de mielite aguda disseminada que poderia ter acometido o doente e seu irmão, pois este tinha comprometimento da marcha. No entanto, os autores lembram que a evolução do quadro deu-se mais de acordo com a paralisia geral, incluindo o estado demencial profundo.

715 ANDRADE, B.; ESMERALDO, Z. Neuropathologia: Paralysia Geral Juvenil. Imprensa Medica, p.246-250, 1911. 
Os autores informam que o primeiro caso de paralisia geral juvenil foi descrito em 1877 por Clouston. No Brasil, até 1907, só dois casos haviam sido diagnosticados: um por Teixeira Brandão e outro por Juliano Moreira, este em 1902, que foi publicado no Journal of Mental Sciences. Em 11 de dezembro de 1910, dois outros casos foram apresentados por Ernani Lopes e Braule Pinto à Sociedade de Psychiatria, Neurologia e Medicina Legal, além de outro caso de Ulysses Vianna, anotado em rodapé pelos autores, de modo que eles dizem ser este o sexto caso estudado no Brasil.

Quanto á etiologia, eles consideram a sífilis hereditária como provável causa.

Em artigo sobre o salvarsan, Franco da Rocha mantém sua postura de certa desconfiança das novidades medicamentosas. Assim, em 1912, ele publica, na Revista Medica de S. Paulo, o artigo “O 'Salvarsan’ na Paralysia Geral”,716.

Em relação a esse medicamento, ele afirma: "logo no começo causou grande entusiasmo e esperança, como soe acontecer sempre que aparece uma nova, barulhenta medicação" 717 .

Depois, relata alguns casos de paralisia geral, nos quais foi aplicado o salvarsan. Considera que no único caso em que se viu melhora, esta foi independente do medicamento. Ele conclui que, as esperanças surgidas com o entusiasmo do "606”, já esfriaram bastante e, segundo ele, com razão, no que diz respeito aos quadros de paralisia geral.

\section{3. 4. - Beribéri. (1899-1912)}

Em 1900, o médico Fajardo publica artigo na Revista Medica de S. Paulo, referindo ter encontrado o hematozoário do beribéri no cérebro, inclusive publicando uma estampa do suposto protozoário ${ }^{718}$. Referindo-se a seu artigo anterior de 1898, ele relembra suas conclusões, nas quais declarou ter demonstrado a existência do hematozoário, similar ao da malária, presente tanto no sangue, como nos órgãos e que esse micróbio fabricava um pigmento.

Em seguida, o autor refere ter encontrado o hematozoário do beribéri e seu pigmento no cérebro de dois casos submetidos à autopsia; situação essa em que ele

716 ROCHA, F. O Salvarsan na Paralysia Geral. Revista Medica de S. Paulo, p. 21-23, 1912. 
considera ser mais fácil ainda estabelecer o diagnóstico. Para reforçar sua hipótese, ele cita os pesquisadores que encontraram o agente da malária no cérebro, como Laveran (1898), Mannaberg (1899), Leyden (1899).

Fajardo acrescenta que, em 1897, juntamente com o prof. Miguel Couto, apresentou, à Academia Nacional de Medicina, um caso de paciente comatoso, com diagnóstico de beribéri estabelecido em vida, confirmado por autópsia, na qual refere terem notado “os factos apontados por Marinesco no cerebro”"719.

Ele considera que, em relação ao hematozoário do beribéri, até então nada foi demonstrado, valorizando, assim, o seu próprio achado. Fajardo pensava que sua descoberta poderia ser reforçada pelo fato de que mesmo o estudioso Yamagiwa (1899) não encontrou nada semelhante em suas próprias pesquisas.

Fajardo responde a certas dúvidas sobre suas hipóteses, dizendo ter se certificado de que os pacientes por ele autopsiados não tiveram malária. Após relatar as alterações observadas no cérebro, lembra que as alterações cerebrais no beribéri foram bem estudadas no Brasil pelo professor Erico Coelho (1886) “e o são neste instante pelo doutorando Rocha Lima”,720.

O autor diz estar convencido de que as alterações da beribéri no cérebro são análogas às da malária, e para reforçar essa hipótese cita as alterações mentais que acompanham as “polynevrites” estudadas por Korsakoff e Soukhanoff (1897).

A seguir, o autor faz uma citação, em alemão, de Koch (1899) a respeito do progresso no estudo dos protozoários, que ele próprio considera poder aplicar ao agente causal do beribéri.

A obstinação de Fajardo, por um protozoário como agente do beribéri, indica a força do paradigma microbiano nesse momento, de modo que Fajardo está convencido de que encontrou esse agente causal. Tal como seu mestre Domingos Freire, em sua obstinação pela procura do agente causal da febre amarela, também Fajardo é persistente em relação au suposto micróbio do beribéri.

Em 1903, Franco da Rocha publica, na Revista Medica de São Paulo, um artigo intitulado "Notas sobre o beri-beri”721.

719 FAJARDO, F. O hematozoario do beribéri no cérebro. Revista Medica de S. Paulo, p. 17-18, 1900. 720 Idem.

721 ROCHA, F. Notas sobre o beribéri. Revista Medica de S. Paulo, p. 85-88, 1903. 263 
Essa moléstia acometeu vários doentes do Juquery. Ele informa que pensou inicialmente tratar-se talvez de outra doença, nevrite tóxica, e mandou examinar a alimentação e vasilhames de cozinha. Pediu análise química de um tubo de borracha da cozinha, baseado na epidemia de nevrites arsenicais de Manchester, em 1901; a análise nada revelou. Refere que um exame clínico cuidadoso levou à hipótese de beribéri, após o aparecimento de seis casos.

A seguir, diz que são adequadas todas as condições higiênicas e climáticas do Hospício, mostrando-se um tanto inconformado com o aparecimento da doença.

Relata também que apelou para o Instituto Bacteriológico do Estado e recebeu a visita de Adolpho Lutz, que considerou o arroz como causa da moléstia. Franco da Rocha discorda, pois, segundo ele, o mesmo arroz é consumido na colônia e no Hospício da Capital, sem causar problemas.

Passa então a citar pesquisadores que defendem a hipótese de um germe causador da doença e outros que defendem a hipótese de deficiência alimentar. Discorda desta última hipótese e acha que a solução a respeito da causa da moléstia virá da bacteriologia. Lamenta não ter laboratório no hospício, que teria ajudado a aprofundar esse estudo.

De qualquer modo, decidiu suprimir o arroz em um determinado setor e em outro cuidou do suprimento de água. Conforme diz, seguindo a literatura, a sangria é o que deu melhor resultado como tratamento.

Como observação que considera curiosa, cita que alguns empregados apresentaram sintomas da doença, mas sem grandes alterações ao exame físico; eles saíram para a Capital ou para Santos e passaram a não sentir mais nada. Franco da Rocha considera esses empregados como "nevropatas sugestionados” pelos sintomas que observaram. Referiu que dois meses após ter substituído a água dos doentes, não ocorreu mais nenhum caso de beribéri.

Em 1904, o médico Ulysses Paranhos publica na Revista Medica de S. Paulo um artigo intitulado "Notas sobre o tratamento do beri-beri"722.

Nesse trabalho, Paranhos diz que pouco se avançou nos últimos vinte anos, além de saber-se que “o beri-beri é uma nevrite multipla infectuosa”723. O autor refere

722 PARANHOS, U. Notas sobre o tratamento do beribéri. Revista Medica de S. Paulo, p. 138-144, 1904. 
então que, no Sanatório de Itaparica, onde há dezenas de doentes, ele conseguiu metodizar um roteiro clinico, abolindo remédios considerados inúteis e adotando outros medicamentos, “estudados e descobertos hodiernamente”. Ele adotou a subdivisão criada por Silva Lima, dividindo as formas clínicas em: “a atrophica ou paralytica, a edematosa ou hydropica e a mixta"724.

$\mathrm{Na}$ forma atrófica ou paralítica, ele refere que o tratamento se limita a fricções estimulantes, uso de "strychnina” e arsênico mineral; como último recurso recomenda ao paciente que faça uma viagem. Ele informa então a nova "therapeutica physica", que colocou a "droga chimica” em "plano inferior”, o que, segundo ele, modificou notavelmente “o modo curativo" do beribéri. Assim, ele cita: “a electricidade, a hydrotherapia e a massagem”. Em segundo plano cita “o arsenico organico ou arrehnal, a marapuama e os glycero-phosphatos" ${ }^{\text {725 }}$.

Sobre o arsênico orgânico, refere ter sido estudado por Armand Gautier. O marapuama diz pertencer à flora brasileira. Sobre os glicero-fosfatos, o autor acha que são os remédios por excelência nos casos de depressão nervosa.

$\mathrm{Na}$ forma edematosa, refere que são indicados os diuréticos "theobromina e o regimen lacteo”, além de purgativos. No caso de haver edema pulmonar, recomenda cafeina, ventosas e inalação de oxigênio. Nas formas mistas propõe uma mescla das possibilidades já recomendadas.

O autor termina seu relato, entrando em detalhes sobre o Sanatório da Ilha de Itaparica, na Bahia, como sendo um excelente local para o tratamento do beribéri.

\section{3. 5. - Doutrina do neurônio.(1899-1912)}

Em seu artigo de 1901, “Apontamentos e Estatística”, da Revista Medica de São Paulo, Franco da Rocha reproduz um trecho de artigo do Lancet de 1900, de F.W.Mott, intitulado The degeneration of the neurone ${ }^{726}$. Franco da Rocha considera esse trabalho como a noção mais exata que se pode ter, nesse momento, da influência da herança nas moléstias mentais. Assim, conforme Franco da Rocha, Mott refere que:

723 Idem, p. 138.

724 Idem, p.139.

725 Ibidem.

726 ROCHA, F. Apontamentos e Estatística. Revista Medica de S. Paulo, anno IV, n. 5, p. 73-80, 1901. 265 
“o que é herdado é a tendencia à molestia nervosa, mais do que a doença propriamente dita, frequentemente chamada tendencia (tara) neuropatica ou neuropsicopatica. O neuropata pode ser considerado como possuindo em algum local, de seu sistema nervoso, comunidades, grupos e sistemas de neuronios, com durabilidade defeituosa ou com baixo potencial herdado, tornando-se suscetiveis à depressão funcional e que, sob a influencia de fatores como condições toxicas do sangue, ou stress indevido, conduz a degeneração prematura. Para explicar morfologicamente a tendencia neuropatica herdada, supõe-se que há um defeito inerente ao plasma germinativo, que diz respeito à formação dos neuronios"727.

Vemos que Franco da Rocha estabelece aí uma ligação estreita entre lesão neuronal e doença psiquiátrica ou doença neurológica, embasado na literatura científica.

Ele afirma que um caso psiquiátrico, sem explicação causal, pode se dever a um indivíduo que tenha se embriagado algumas vezes e que, em uma dessas ocasiões, tenha fecundado o óvulo de onde veio o doente.

Em 1907, na Revista Medica de S. Paulo, é publicado, no Boletim da Sociedade de Medicina e Cirurgia de S. Paulo, um estudo sobre o sistema nervoso realizado em laboratório. Esse artigo tem o título “desenvolvimento das neurofibrillas”, de autoria do médico Eduardo Marques, identificado como assistente do Instituto Pasteur ${ }^{728}$.

Marques informa que seu trabalho diz respeito à sua tese inaugural, no Instituto de Manguinhos, sob a direção do "eminente mestre sr. Dr. Oswaldo Cruz". O autor refere que as estruturas denominadas “neurofibrilas” já eram conhecidas desde 1844, com Remak, e 1868, com Max Schultze. Conforme Marques, no momento em que desenvolveu sua própria tese sobre esse assunto, o estudo dessas estruturas celulares atraia especial atenção de diversos estudiosos como Cajal e outros.

Como a embriogênese das neurofibrilas é um aspecto menos conhecido sobre essas estruturas, o autor decidiu fazer sua tese sobre esse tema. Marques informa usar o método de Ramon y Cajal para evidenciar as neurofibrilas, por considerar a melhor técnica. O autor diz que os únicos trabalhos, até então feitos sobre a embriogênese das neurofibrilas, haviam sido feitos por Cajal, além de outros autores. Marques cita Ramon y Cajal em vários momentos de seu trabalho.

727 ROCHA, F. Apontamentos e Estatística. Revista Medica de S. Paulo, anno IV, n. 5, p. 73-80, 1901. 728 MARQUES, E. Desenvolvimento das neurofibrillas. Revista Medica de S. Paulo, p. 497-504, 1907. 266 
Este trabalho foi feito um ano após Ramon y Cajal e Golgi receberem o prêmio Nobel e durante o período de consagração de Oswaldo Cruz, com esse seu discípulo trabalhando com técnicas recentes de pesquisa das estruturas neuronais.

Em 1908 foi publicado na Revista Medica de S. Paulo, artigo intitulado "Inhibição sob o ponto de vista medico-legal: theoria e descripção synthetica dos neuronios” ${ }^{729}$, de autoria do médico Ponciano Cabral, identificado como "Medico legista de Campinas”.

O autor refere que, há mais de um ano, conserva os escritos que agora resolve publicar. Conforme diz, trata-se de uma síntese da teoria dos neurônios, na qual refere ter sido obrigado a penetrar, para melhor explicar alguns fatos em relação à medicina forense.

Cabral informa que foram criadas, "no fim do seculo passado", duas importantes teorias que, segundo ele, abalaram profundamente os conhecimentos clássicos até esse tempo adquiridos. Assim, relata que, com embasamento na fisiologia experimental e na anatomia patológica, descobriu-se que a parte nervosa do individuo é constituída de unidades independentes, unidades essas que têm ação definida e, sistematizadas ou em grupos, revelam o modo especial da função nervosa.

O autor afirma que, entre as diversas denominações propostas, o termo “neuronio" dado a essas unidades elementares teve êxito completo. Ele diz então que aprendeu do professor Silva Santos, do Rio de Janeiro, de sua tradução da monografia alemã do professor Hoche, que essa nova denominação foi estabelecida por Waldeyer em 1891, condensando, daí em diante, a teoria dos neurônios.

Além disso, informa Cabral que, a partir da clínica e da fisiologia, observa-se que a atividade especial de um nervo pode determinar uma suspensão do funcionamento de certo órgão; a essa função, foi proposto por Brown-Sequard o termo "inibição". Conforme o autor, esse fisiologista ampliou o uso desse termo para circunstâncias similares em que ocorra um fenômeno inibitório de alguma atividade relacionada ao sistema nervoso.

A seguir, Cabral explica a divisão do sistema nervoso, descreve o neurônio e seus componentes, explicando as várias designações desses componentes, de acordo

729 CABRAL, P. Inhibição sob o ponto de vista medico-legal; theoria e descripção synthetica dos neurônios. Revista Medica de S. Paulo, p. 503-508, 1908. 
com a preferência de cada um dos diferentes pesquisadores, incluindo estudiosos brasileiros. Assim, ele diz que o médico Silva Lobo, do Rio de Janeiro, verificou em seus estudos, certas peculiaridades do neurônio antes assinaladas por Cajal. Continuando, o autor descreve as relações dos neurônios entre si, bem como a fisiologia dos neurônios em suas diversas funções, distribuídos em centros: transmissores, reflexos, psíquicos, vaso-motores. Explica também os prolongamentos e tipos de neurônios.

Em 1909, continua a publicação de artigos de Ponciano Cabral, sob o mesmo título de "Inhibição sob o ponto de vista medico-legal - theoria e descripção synthetica dos neuronios

Nos artigos que se seguem ele descreve a sistematização dos neurônios periféricos, subdivididos como nervos raquianos, cranianos e o "grande sympathico". Ele detalha cada uma dessas subdivisões, e no item sobre o grande simpático, aborda o já dito caráter de inibição da função neuronal.

Em seguida, explica a sistematização dos neurônios da medula, onde relata, entre outros, neurônios relacionados ao cerebelo, bem como neurônios piramidais, que qualifica como condutores das “incitações” motoras voluntárias.

Depois aborda a sistematização dos neurônios encefálicos, sendo que, no que diz respeito a funções, assinala apenas que o cérebro recolhe todas as impressões conscientes da periferia, e dele partem todas as incitações motoras voluntárias, sendo também a sede das faculdades intelectuais. Assinala ainda que a assimetria, entre hemisférios cerebrais, é tanto maior quanto mais desenvolvida a capacidade intelectual do individuo. Destaca a circunvolução frontal ascendente, ou pré-rolandica, como maior zona sensitivo-motora do cérebro, sede dos centros nervosos.

Cabral aborda as vias neuronais sensitivas, cerebelares e motoras. Relata que são mais estudados os centros corticais da motilidade geral. Descreve as circunvoluções frontais como o “districto motor da actividade consciente”; relata que essa zona motora, também é uma zona excitável e epileptogenica. Na, assim chamada, camada piramidal do córtex, ele descreve os corpos celulares dos neurônios motores, e repete o dado de que esses neurônios formam a via piramidal, responsável pela motricidade voluntária.

730 CABRAL, P. Inhibição sob o ponto de vista medico-legal; theoria e descripção synthetica dos neuronios. Revista Medica de S. Paulo, pp. 14-19; 45-49; 89-93; 182-187, 1909. 
Quanto às vias cerebelares, o autor diz que são chamadas de vias motoras secundárias, que segundo alguns estudiosos (por ele citados), têm por função coordenar os movimentos.

Cabral ainda refere centros corticais relacionados aos órgãos dos sentidos e cita ainda uma “zona latente”, sobre a qual se aguarda esclarecimento da fisiologia.

Por estes longos artigos de Ponciano Cabral, pode-se constatar que a teoria do neurônio, e as doutrinas científicas embasadas nesse conceito, já tem vários detalhamentos e desdobramentos. Podemos assinalar que, no término de seu texto, o autor ressalta que "cada vez mais parece consolidar-se esta bella theoria que ha mais de dez annos lucta contra poderosos inimigos"731.

Após comentar que ainda há pontos pouco precisos nessa teoria, Cabral acrescenta que:

“ella nos trouxe a mais completa simplicidade no estudo do systema nervoso; e tão simples, tão facil se nos mostra, que o autor destas linhas, apenas por uma leitura de conhecimento passageiro, conseguiu em horas de lazer, tratar deste assumpto, outrora somente permittido aos grandes mestres" ${ }^{732}$.

O espaço dado pela Revista, a esses vários artigos sobre o mesmo tema, indica interesse dos editores em destacar esse assunto. O autor, da área de medicina legal, destaca a importância e objetividade da teoria no entendimento do sistema nervoso.

731 CABRAL, P. Inhibição sob o ponto de vista medico-legal; theoria e descripção synthetica dos neuronios. Revista Medica de S. Paulo, pp. 14-19; 45-49; 89-93; 182-187, 1909. 732 Idem. 


\section{3. 6. - Diagnóstico Diferencial (1899-1912) ${ }^{733}$.}

Franco da Rocha publica em 1899, na Revista Medica de São Paulo, um artigo intitulado "Um caso interessante de syringomielia"734.

Ele explica que é necessária essa publicação pelo fato desse caso ter levado a uma série de diagnósticos desencontrados não só em São Paulo como no Rio de Janeiro.

Relata, então, o caso de um paciente de 42 anos, com antecedentes de moléstias nervosas na família (principalmente quadros convulsivos). Aos 16 anos começaram os primeiros sintomas, com alterações dos dedos das mãos, que foram interpretadas nessa ocasião como de natureza óssea.

Depois de dois anos, o doente passou a apresentar fraqueza no braço direito, nevralgias e alterações de sensibilidade. Ele foi diversas vezes examinado no Rio de Janeiro e em São Paulo, tendo recebido os diagnósticos de: sífilis cerebral, impaludismo, polinevrite, esclerose lateral, histeria.

Franco da Rocha descarta cada uma dessas hipóteses, achando como mais difícil de afastar, a hipótese de histeria. Baseado na literatura científica, ele fez o diagnóstico de siringomielia $^{735}$.

Em um artigo posterior, no mesmo ano, na mesma revista ${ }^{736}$, Franco da Rocha responde a perguntas feitas pelo Dr. Mathias Valladão, que questiona a hipótese de siringomielia, formulada para esse caso.

Inicialmente, Franco da Rocha se defende a respeito do emprego da palavra “acromegalia”, que usou para se referir às alterações dos dedos do paciente. Franco da Rocha lembra a seu colega que "ha doentes, não ha molestias”737, contextualizando, assim, o uso que fez dessa palavra.

\footnotetext{
${ }^{733}$ Conforme Foucault o diagnóstico diferencial no século XIX é apanágio da medicina embasada na anatomia patológica, sendo que a psiquiatria, nesse período, procura se aproximar desse tipo de reflexão através de quadros como a paralisia geral. Já a neurologia tem no sistema estímulo-resposta e nos sinais localizatórios, outros elementos para exercitar o diagnóstico diferencial.

FOUCAULT, M. O Poder Psiquiátrico. Martins Fontes, 2006, p. 321-322;345-348;396-397.

734 ROCHA, F. Um caso interessante de syringomielia. Revista Medica de S. Paulo, anno II, n. 10, p. 279-281, 1899.

Siringomielia: comprometimento da região central da medula espinhal, que mais freqüentemente se manifesta por alterações motoras e sensitivas de cintura escapular.

735 Franco da Rocha cita, como reforço de sua hipótese, os autores: Oppenheim (1898), Strumpell (1897), Crocq (1899), Hirsch (1897), Luntz (1898), Marinesco, Bernhardt (1894), Schlesinger (1894), Schwarz (1898). Sobre a dificuldade de distinção com a histeria, ele cita um estudo de Erb (1893).

736 ROCHA, F. Um caso interessante de syringomielia. Revista Medica de S. Paulo, p.355-359, 1899.

737 Idem.

270
} 
Para esclarecer outros pontos duvidosos, sobre a evolução esperada dos sintomas, sobre alterações de sensibilidade, e outras questões, Franco da Rocha recorre a diversos autores ${ }^{738}$.

Como Valladão insiste na hipótese de histeria, Franco da Rocha, após elogiar seu colega (durante todo o artigo), diz:

“deixemos a panacéa da hysteria para quem não tem preparo e competencia, que lança tudo para essa valla commum, evitando o trabalho e estudo. O meu illustrado colega, com quem estou discutindo com prazer, porque discuto com quem sabe, não está nem estará nunca nesse numero. Si o meu collega fosse desse numero, declaro-lhe, com toda a sinceridade, que não me teria dado ao trabalho de responder-lhe, perdendo numa noite tres horas de bom somno"739.

Em artigo de 1900, na mesma Revista, Mathias Valladão publica seus argumentos contrários à hipótese de Franco da Rocha, utilizando alguns dos autores citados por este, porém conduzindo o seu raciocínio para o diagnóstico de histeria, pelo fato de considerar os achados clínicos inconsistentes com a siringomielia ${ }^{740}$.

Valladão também se refere a Franco da Rocha com diversos elogios. Termina seu texto afirmando que não imita seu colega, dizendo que "perdeu horas de sono", mas que teve "momentos ganhos” no debate com o colega "competente e talentoso".

No mês seguinte, na mesma revista, Franco da Rocha volta ao assunto ${ }^{741}$. Ele recorre a 297 observações de siringomielia feitas por Stephan Dimitroff, que por sua vez também incorporou o trabalho de Wladimir Roth de Moscou, e também o trabalho de Max Laehr, de 1896.

Citando outros trabalhos, que ele considera contraditórios em termos de fisiologia, Franco da Rocha diz querer se ater à clínica. Assim, ele parte para citações do tratado de Charcot, Bouchard e Brissaud. Cita também Neuhsud e Gowers (1898; 1899).

Chegando a uma conclusão conciliadora, ele procura reforçar sua hipótese de siringomielia, ressalvando que a histeria é o diagnóstico diferencial mais sério a ser levado em consideração, e ressalvando também que os dois quadros podem cursar no mesmo doente.

738 Esses autores são: Oppenheim, Schlesinger, Luntz, Raymond, Charcot, Bernhardt, Brissaud, Colman, Schlesinger, Strumpell, Sappey, Muller, Klumpke, Flower, Starr, Wernicke.

739 ROCHA, F. Um caso interessante de syringomielia. Revista Medica de São Paulo, p. 355-359, 1899. 740 VALLADÃO, M. Um caso interessante de syringomielia. Revista Medica de São Paulo, anno III, n. 1, p. 3-7, 1900.

741 ROCHA, F. Um caso interessante de syringomielia. Revista Medica de S. Paulo, anno III, n.2, p. 1822, 1900. 
Em 1903, publica-se na Revista Medica de São Paulo, na seção correspondente ao Boletim da Sociedade de Medicina e Cirurgia de S. Paulo, um relato do médico Ulysses Paranhos, intitulado "Um caso de pseudomeningite de natureza verminosa"742.

O Dr. Paranhos refere-se a um estado mórbido chamado por Bouchat, em 1866, de “pseudomeningite” e por Dupré, de “meningismo”, em analogia às falsas peritonites nomeadas como "peritonismo”, por Gluber.

Ambos concordam (Bouchat e Dupré) que, embora os sinais clínicos sejam de meningite, o exame do líquido cefalorraquiano é normal. No entanto, consideram tratarse de comprometimento de natureza orgânica e não como quadro associado à histeria. Assim informa Paranhos sobre essas hipóteses:

“Dupré, contrariando a opinião de Gilles de La Tourette que achava ser o meningismo uma entidade nosologica subsidiaria da hysteria, demonstrou, perante o Congresso de Medicina Interna de Lyão de 1890, que varias são as causas do syndroma, muito afastadas do dominio da nevrose.

Assim attribuem-se os accidentes de meningismo a origens reflexas, helminthiases, constipação de ventre e dentição laboriosa; a elementos infectuosos, pneumonia lobar, exanthemas, grippe, malaria e typho; a influencias toxicas, alcool, atropina, santonina e a auto-toxihemias, evoluindo em terreno predisposto e enxertado de estygmas nevropathas.

(...) Vomitos, delirio, febre, modificação do pulso, constipação de ventre, retenção de urinas, rigidez de nuca, estrabismo convergente, desigualdade pupilar, illustram a symptomatologia de ambas as affecções" ${ }^{\text {743 }}$.

Em seguida, o autor relata o caso de um menino de 5 anos, que foi acometido de quadro interpretado como "meningismo". Ao informar os antecedentes familiares do paciente, Paranhos frisa: “O pae de A.V. foi em tempo ethylista e a sua mãe era uma hysterica declarada. Esta tara nervosa já se tinha reflectido no producto da concepção por convulsões repetidas no seu primeiro anno de vida”, ${ }^{744}$.

Depois, o autor esclarece ter diagnosticado "verminose”, nessa criança. Ainda, conforme Paranhos, essa verminose foi tratada com sucesso, sendo que, conforme sua concepção, isso fez desaparecer o “meningismo”.

742 PARANHOS, U. Um caso de Pseudomeningite de natureza verminosa. Boletim da Sociedade de Medicina e Cirurgia. Revista Medica de S. Paulo, p. 261-263, 1903.

743 Idem, p. 262.

744 PARANHOS, U. Um caso de Pseudomeningite de natureza verminosa. Boletim da Sociedade de Medicina e Cirurgia. Revista Medica de S. Paulo, p. 263, 1903. 
Em outra seção da Sociedade de Medicina e Cirurgia ${ }^{745}$, no mesmo ano de 1903, Ulysses Paranhos toma a palavra para defender-se de um ataque, de Rubião Meira, a seu artigo sobre meningismo associado à verminose. Paranhos lança mão de vários autores, para corroborar sua hipótese, aceitando algumas correções de Meira quanto à apresentação do artigo.

A seguir, Rubião Meira ${ }^{746}$ toma a palavra para atacar, de maneira veemente, as argumentações de Paranhos, concentrando seu discurso mais na forma de argumentação deste, do que propriamente nas citações de literatura que foram mencionadas para defender a hipótese de meningismo.

Observamos nesse conflito de conceitos, que Ulysses Paranhos está sendo combatido por estar contrariando o paradigma de Charcot e seu discípulo Gilles de La Tourette para esses quadros. Paranhos dá uma explicação que se enquadra dentro do campo fisiopatológico, contemplando fatores que ampliam o entendimento de reações do sistema nervoso a certos quadros sistêmicos ou de outros órgãos. No entanto, suas argumentações e citações pouco valem, diante de conceitos firmados em Salpêtrière e fortemente defendidos por Meira.

Em 1905, na Gazeta Clinica, Rubião Meira publica um artigo, na seção "Medicina Pratica”, intitulado "Elementos de diagnostico do coma"747.

O autor considera que, tanto o médico de hospital como o da clinica civil, pode ter que intervir em pacientes em "estado comatoso”, situação em que é importante determinar sua causa.

Meira acentua a dificuldade do diagnóstico, atribuindo-a principalmente à falta de uma anamnese nessa situação. Lembrando sua própria tese inaugural, que versou sobre esse assunto, assinala a importância desse estudo.

Ele relata diversos tipos de coma, que variam conforme a velocidade de instalação, sendo abrupto o do tipo apoplético e de instalação gradual o coma relacioado com intoxicações ou infecções.

745 PARANHOS, U. Meningismo e Meningite; resposta ao Dr. Rubião Meira. Boletim da Sociedade de Medicina e Cirurgia de S. Paulo. Revista Medica de São Paulo, p. 309-313, 1903.

746 MEIRA, R. Meningite e meningismo; resposta ao Dr. Ulysses Paranhos. Boletim da Sociedade de Medicina e Cirurgia de S. Paulo. Revista Medica de S. Paulo, p. 313-316, 1903.

747 MEIRA, R. Elementos de diagnostico do coma. Gazeta Clinica, 89-97, 1905.

273 
A seguir, o autor dá sua descrição clínica dos casos de coma, fazendo diferenciações conforme as causas: hemorragia ventricular, hemorragia meníngea, uremia, alcoolismo, saturnismo, uso de ópio, meningite, esclerose em placas, embolia, trombose. Descreve sinais neurológicos, também de acordo com a gravidade do quadro, além de sinais gerais mais centrados em temperatura, respiração e pulso.

Meira informa, então, que o principal objetivo de seu estudo é o diagnóstico diferencial entre as causas de coma. Ele subdivide em três grupos de diagnóstico, conforme as causas: afecções meningoencefálicas; nevroses; toxicoses endógenas ou exógenas.

No primeiro grupo situa: hemorragia cerebral, meningites, trombose e embolia. Considera o modo de início do quadro como diferencial entre eles. Em sua descrição do coma por hemorragia cerebral, que qualifica como o “coma clássico”, assinala dados como sinais neurológicos e temperatura alterada ${ }^{748}$.

A sífilis está listada nesse grupo das afecções meningoencefálicas.

$\mathrm{Na}$ meningite como causa do coma, enfatiza a "meningite cerebro-espinhal epidemica”, havendo lugar também para a citação de outra das grandes doenças do período (além da sífilis, já citada) que é a tuberculose, causando também meningite.

Nos casos de embolia, o autor atenta para determinados sinais neurológicos localizatórios mais comuns, bem como sua associação a doenças cardíacas, lembrando ainda o nome de Charcot para certos elementos de diagnóstico diferencial. No primeiro grupo, cita também trombose, meningites, tumores.

No segundo grupo, referente às "nevroses”, cita o “coma epiléptico” após as convulsões. Lembra também o coma histérico, dentro da visão de Charcot:

“O coma hysterico substitue o somno hysterico e tem como caracteres principaes a existencia de batimentos convulsivos das palpebras, de movimentos gyratorios dos olhos, de zonas hysterogenas. Comprimidas essas o coma desapparece ou se transforma em classico ataque de hysteria"749. $^{\text {. }}$

No terceiro grupo de causas de coma, correspondente às toxicoses, são citados, como mais comuns, na intoxicação exógena, o coma alcoólico; na intoxicação endógena, o coma urêmico e o diabético. As infecções são consideradas como responsáveis por uma toxicose endo-exógena. O autor descreve as alterações dos diversos quadros,

748 Não há menção de pressão arterial. Anos depois, esse dado vai ampliar também para o âmbito sistêmico o olhar direcionado aos casos de coma.

749 MEIRA, R. Elementos de diagnostico do coma. Gazeta Clinica, 89-97, 1905. 
acentuando o uso do oftalmoscópio para o diagnóstico de hemorragia cerebral e tumores, fazendo, assim, um diagnóstico diferencial com as outras causas de coma.

O médico carioca Henrique Roxo, tido como psiquiatra, também faz incursões e leciona a respeito de moléstias do sistema nervoso. Desse modo, em 1905, na Gazeta Clínica, é publicada sua aula, dada em 27 de setembro, na Faculdade do Rio de Janeiro, com o título "Sclerose em placas de forma cerebellosa”. O autor é identificado como “lente substituto interino da Clinica de Molestias Mentaes e Nervosas”, sendo que a aula foi “stenographada pelo interno de Clinica, Francisco Maciel”750.

Roxo apresenta um caso inicialmente diagnosticado como esclerose em placas.

Em sua descrição do exame neurológico, refere ter pesquisado o reflexo de Babinski, o que indica esse sinal como conhecido e pesquisado na prática entre os médicos brasileiros, nesse momento. Roxo refere ter tido dificuldade na pesquisa desse reflexo, pelo espessamento da pele do pé do paciente em questão. Também informa ter pesquisado e notado a ausência de sinais, tais como: sinal de Romberg; sinal de ArgyllRobertson; de Westphal, etc. Ele descreve alterações cerebelares detectadas em seu exame.

Como o paciente referiu, posteriormente, um antecedente de sífilis, Roxo passou a questionar a hipótese inicial de esclerose em placas.

Em 1906, é publicado na Imprensa Medica, na seção “Consultas Medicas”, o artigo "Meios de diagnosticar hemiplegias incompletas ou ligeiras" 751 , pelo médico Celestino Bourroul. Esse é um de vários artigos que esse autor envia da França.

O autor refere que nem sempre é fácil verificar-se a existência de hemiplegia incompleta ou ligeira, em doentes que procuram o médico tempos depois do quadro, ou em situações nas quais “a zona rolandica ${ }^{752}$ ou perirrolandica, ou os feixes motores são acometidos por congestão, anemia ou espasmo” de forma muito rápida.

Como no exame de marcha, e de outros movimentos, não se encontram alterações, Bourroul relata três manobras que podem ser úteis nessas situações. A primeira manobra, chamada "Manobra de Babinski” (o autor acentua que esse sinal não

750 ROXO, H. Sclerose em placas de forma cerebellosa. Gazeta Clinica, p. 485-491, 1905.

751 BOURROUL, C. Consultas medicas: Meios de diagnosticar as hemiplegias incompletas ou ligeiras. Imprensa Medica, p. 122-123, 1906.

${ }^{752}$ Zona rolandica: Região do cérebro, localizada no lobo frontal, também chamada giro pré-central, que o autor associa à motricidade. 
deve ser confundido com o sinal do grande artelho de Babinski), na qual o doente, inicialmente deitado, deve sentar-se com os braços cruzados à frente do tronco; o membro lesado vai erguer-se um pouco da cama pela paralisia dos músculos estabilizadores. A segunda manobra diz respeito à elevação simples do membro lesado, com o doente deitado. A terceira, chamada "Manobra de Pierre-Marie”, é feita com o paciente sentado, fazendo uma flexão da coxa contra a força do observador.

Informa Bourroul que o prof. Grasset aplica largamente esses recursos em seu serviço clínico.

Em 1907, é publicado por Celestino Bourroul, na seção “Notas Clínicas” da Imprensa Medica, o artigo intitulado "Diagnostico de tumor cerebral”,

O autor refere que Babinski, em uma aula na Pitié, chama a atenção para uma síndrome que difere da síndrome clássica em casos de tumores cerebrais, mas que também corresponde a essa etiologia. Assim, ele ensina que uma hemiplegia antiga, acompanhada de reflexos não aumentados e perturbações mentais, pode dizer respeito a tumor cerebral.

Bourroul informa que, nas hemiplegias antigas, por amolecimento, hemorragia, ou lacunose cerebrais, a regra é que os reflexos tendinosos estejam aumentados em virtude da degenerescência do feixe piramidal, a partir da segunda ou terceira semana de quadro. Já nos tumores cerebrais, os reflexos se mantêm normais, por haver uma compressão, mas não uma destruição da via piramidal.

Em seguida, o autor apresenta dois casos por ele observados, que confirmam esses ensinamentos de Babinski.

Em 1907, Celestino Bourroul publica duas notas clínicas a respeito de elementos para o diagnóstico de certas condições ${ }^{754}$. A primeira nota intitula-se "Syphilis cerebral e reflexo pupillar luminoso (notas de uma lição de Babinski na Pitié)”.

O autor informa que o sinal de Argyll Robertson, ou seja, a abolição do reflexo pupilar à luz, com a conservação do reflexo de acomodação, é de grande importância para o diagnóstico de sífilis cerebral, como já foi demonstrado por Babinski e Charpentier.

753 BOURROUL, C. Notas Clinicas: Diagnostico de tumor cerebral. Imprensa Medica, p. 237-238, 1907.

754 BOURROUL, C. Notas Clínicas. Imprensa Medica, p. 273-274, 1907.

276 
Bourroul passa a descrever a técnica desse exame e insiste em que a alteração observada não é banal, como alguns querem inferir, tentando atribuir esse sinal também à histeria e à neurastenia. Ele acrescenta que Babisnki observou esse sinal em todos os casos com linfocitose raquidiana ${ }^{755}$, exceto em dois casos.

Diz o autor que o sinal também tem valor, por permitir o diagnóstico da sífilis do sistema nervoso em fase precoce, podendo ser instituído tratamento antes de chegar a fase de paralisia geral progressiva, ou de tabes. Ele acrescenta o relato de um caso visto por Babinski. Trata-se de caso de suposta histérica, que apresentava o sinal de Argyll Robertson, de modo que Babinski instituiu o tratamento mercurial. Esse tratamento foi suspenso por outro médico, que preferiu a hipótese de histeria. Com o tempo, a doente desenvolveu o quadro pleno de tabes.

A segunda nota intitula-se “Tabes e Reflexo do tendão de Aquiles”. Nesta nota, o autor recomenda sempre estudar o reflexo do tendão de Aquiles, nas suspeitas de tabes, pois esse reflexo pode estar ausente antes ainda do reflexo patelar, o que pode antecipar o diagnóstico.

Em 1908, é publicado na Imprensa Medica, artigo na seção “Medicina Pratica”, intitulado "Diagnostico entre o tabes e a polynevrite alcoólica - pelo professor Babinski (lição feita na Pitié)”756. Pelas características do artigo, o provável autor é Celestino Bourroul, embora na revista isso não esteja assinalado.

O texto inicia, dando características clínicas do paciente, cujo quadro serve de exemplo para a explanação de Babinski. O doente tem perturbações mentais e da marcha; sente dores nos membros; mantém os reflexos rotulianos e tem abolidos os reflexos aquileanos; não há alteração de sensibilidade; há enfraquecimento muscular; a marcha é do tipo steppage ${ }^{757}$; há dor à compressão dos músculos.

O autor diz que o primeiro diagnóstico que se impõe é o de "tabes associado à meningo-encephalite diffusa”, segundo ele uma associação muito comum, pois muitas vezes os tabéticos acabam desenvolvendo paralisia geral ${ }^{758}$. Ele frisa que o doente tem, desses quadros, as dores, a abolição dos reflexos tendinosos e as perturbações psíquicas.

\footnotetext{
${ }^{755}$ Linfocitose raquidiana: nesse período, é o termo para designar aumento da quantidade de células no exame de líquido cefalorraquiano.

756 MEDICINA PRATICA. Diagnostico entre o tabes e a polynevrite alcoólica; pelo professor Babinski (lição feita na Pitié). Imprensa Medica, p. 242-243, 1908.

757 Marcha em steppage também é conhecida como marcha do "pé caido”.

${ }^{758}$ A associação definitiva entre sífilis, tabes e paralisia geral ocorre apenas em 1913. 
No entanto, acentua que a alteração da marcha difere da tabes: nesta conserva-se a força e a contratilidade elétrica, ao contrario do caso em questão. Também é observado que na tabes há diminuição da sensibilidade à pressão dos músculos, ao contrário do que ocorre no doente visto.

Cita-se que o prof. Babinski exclui a hipótese da tabes por haver atrofia muscular e hiperestesia dos músculos.

Quanto às alterações psíquicas, o doente não tem nem comprometimento da palavra, nem a amnésia retrógrada dos paralíticos gerais.

Assim, Babinski conclui pela hipótese da "polynevrite alcoolica”, que se caracteriza pelas dores, atrofia muscular, steppage, hiperestesia muscular e perturbações intelectuais com perda da memória recente. Além disso, estão ausentes perturbações esfincterianas, e não há estreitamento periférico do campo visual, que são vistos na tabes.

Informa também o texto que Babinski se apóia na hipótese, então vigente, de independência entre si das diferentes formas de sensibilidade. Desse modo, diz que nos tabéticos há comprometimento isolado da sensibilidade profunda, diferentemente do caso em questão.

Em 1908, é publicada na Revista Medica de S. Paulo resenha sobre o trabalho de R. Russel, intitulada “Sobre as indicações operatorias nos tumores intra-cranianos”.

Esse texto aborda mais a questão dos diagnósticos diferenciais entre tumor cerebral e outras condições do que propriamente do tratamento cirúrgico. Conforme o texto o autor reclama de que tem sido feito pouco progresso nessa área, devido às operações serem tardias e mal selecionadas.

Ainda a resenha informa que Russel acha que a dúvida de intervir em caso passível de ser histeria, não tem razão de ser, porque, segundo ele, os sintomas de uma moléstia orgânica não se confundem com os de uma síndrome funcional. A seguir, são relatadas diversas alterações orgânicas que não estão presentes em histeria, entre elas as alterações de reflexos, incluindo-se o reflexo de Babinski.

O texto informa aspectos do diagnóstico diferencial entre a histeria e a epilepsia, frisando, entre outros aspectos, que a epilepsia jacksoniana pode ser manifestação de um tumor cerebral. Diferencia-se a paralisia progressiva de um tumor frontal, pelo fato do segundo acompanhar-se de cefaléias e vômitos e ter hemiplegia e afasia duradouras. Depois são citados alguns aspectos de diagnóstico diferencial com outras moléstias. 
Em 1910, na Revista Medica de S. Paulo, Henrique Roxo publica artigo intitulado "Diagnostico precoce dos tumores do lobo frontal"759. Este longo artigo, com muitas citações, explicita uma correlação entre o lobo frontal e alterações do comportamento e das funções cognitivas. Essas noções trazem um novo entendimento de alterações comportamentais causadas por lesões cerebrais.

O autor diz que, por vezes, pode haver confusão desses quadros com histeria. Aqui está uma expressão definida de diferenciação entre histeria e lesão orgânica do sistema nervoso. Roxo não nega a existência da histeria, mas, pelo aprimoramento da semiologia neurológica, pelo melhor conhecimento do cérebro, a histeria está, aos poucos, sendo mais delimitada como um quadro não orgânico.

\section{3. 7. - Localização e centros cerebrais (1899-1912).}

Em 1901, na seção “Notas de Clinica Cirurgica”, da Revista Medica de São Paulo, o médico Coriolano Burgos, da cidade de Amparo, publica o artigo "Fractura do craneo. Aphasia e Hemiplegia. Trepanação. Cura”760.

Burgos relata o caso de um individuo que sofreu ferimento na cabeça, do lado esquerdo, e apresentou-se comatoso, “com a perna e braço direito paralysados” ${ }^{761}$ e alteração da fala. O autor informa o procedimento cirúrgico a que submeteu o paciente, com melhora e cura do quadro clínico, dizendo que, na medida em que foi restituída a sua “integridade mental”, o doente “entrava na posse do seu $e u$, por algum tempo perdido"762.

Ao discutir seus achados, Burgos considera que, de acordo com a doutrina corrente sobre as localizações cerebrais, "temos aqui um caso de perfeito accordo com os trabalhos de Ferrier e Hitzig e principalmente comprovados por Charcot, em relação á sede dos centros motores do cortex cerebral”763.

759 ROXO, H. Diagnostico precoce dos tumores de lobo frontal. Revista Medica de S. Paulo, p. 186-198, 1910.

760 BURGOS, C. Notas de Clinica Cirúrgica: Fractura de craneo; Aphasia e hemiplegia; Trepanação; Cura. Revista Medica de S. Paulo, anno IV, n. 24, p. 439-441, 1901.

761 Idem, p. 439.

762 BURGOS, C. Notas de Clinica Cirúrgica: Fractura de craneo; Aphasia e hemiplegia; Trepanação; Cura. Revista Medica de S. Paulo, anno IV, n. 24, p. 440, 1901.

763 Idem. 
A seguir, ele detalha as correlações entre as lesões por ele observadas e esses conhecimentos. Sendo seu texto datado de dezembro de 1901, ele refere uma apresentação ocorrida em 22 de outubro desse ano, na Academia de Medicina de Paris, quando, segundo diz, “o professor Dieulafoy pretendeu dar um golpe profundo na doutrina das localisações cerebraes”764, apresentando um caso de sífilis cerebral, que à autopsia tinha lesões diferentes das esperadas pela correlação clínica.

Burgos considera esse um provável caso de exceção. Além disso, ele acha que a própria descrição do professor Dieulafoy levou também a uma hipótese de várias lesões cerebrais menos perceptíveis, que poderiam ser responsáveis por variados sintomas, contrariando as conclusões do professor.

Desse modo, Burgos conclui que "pequenos fatos isolados" não podem desmerecer "principios já adquiridos e aceitos por todos em relação às localizações cerebraes $^{765, \text {, }}$

Vemos por esse artigo que procedimentos neurocirúrgicos ocorrem numa cidade do interior paulista, nesse momento. Além disso, o responsável por esse relato está atualizado em relação aos debates correntes, na medida em que cita publicação bastante recente e próxima de seu próprio relato.

Observa-se também, que assuntos relativos ao sistema nervoso são debatidos também por médicos de outras áreas, além do campo da psiquiatria, moléstias nervosas e psicologia, que não se limitam à descrição dos casos observados, mas também entram nos debates e polêmicas em curso.

Uma dessas polêmicas é referida pelo autor, dizendo respeito a haver ou não áreas cerebrais específicas para determinadas funções. Burgos mantem-se alinhado com o paradigma vigente a respeito da localização e função de áreas cerebrais, embasado nos estudiosos Ferrier, Hitzig e, segundo ele, comprovados por Charcot.

A proximidade no tempo entre os debates científicos na Europa, bem como a prontidão de Burgos em praticar e observar em seu próprio paciente - no interior de São Paulo - uma correlação com esses debates, indicam toda uma dinâmica presente na ciência paulista desse período, em torno dos estudos em questão.

764 BURGOS, C. Notas de Clinica Cirúrgica: Fractura de craneo; Aphasia e hemiplegia; Trepanação; Cura. Revista Medica de S. Paulo, anno IV, n. 24, p. 441, 1901.

765 BURGOS, C. Notas de Clinica Cirúrgica: Fractura de craneo; Aphasia e hemiplegia; Trepanação; Cura. Revista Medica de S. Paulo, anno IV, n. 24, p. 439-441, 1901. 
Em 1904, na Gazeta Clínica, Rubião Meira publica uma aula do prof. Francisco de Castro, do Rio de Janeiro (registrada em anos anteriores, pois Castro faleceu em 1901), anotada pelo próprio Meira. O título da aula é "Estudo Clinico da Hemiplegia”766. Nessa aula foi explicada a localização de diferentes áreas cerebrais em relação a variadas manifestações de hemiplegia, comparando as variações desse quadro em relação à localização da lesão, seja em sistema nervoso periférico, ou em sistema nervoso central.

Em 1906, na seção “Neuropathologia”, da Imprensa Médica, o médico Celestino Bourroul publica o artigo "Monoplegia segmentar sensitivo-motora e jacksonismo psycho-motor por trauma cerebral (notas de uma lição do Professor Grasset, de Montpellier)" ${ }^{\text {767. }}$.

O autor apresenta inicialmente um caso dentro do que ele chama de uma “concepção nova” formulada pelo prof. Grasset, sendo esse o segundo caso descrito por esse professor e o sexto caso na literatura médica. Trata-se de um caso de trauma de crânio, com presença de lesão purulenta, no qual há indicação de cirurgia. Mas, conforme Bourroul, os médicos ainda não tiveram a autorização do patrão do doente, porque o caso envolve indenizações de trabalho, havendo "má vontade grande contra os médicos e cirurgiões”, pois, se não houver cura, serão acusados de terem piorado o mal.

O autor informa que o caso em questão se manifesta por crises de idéias fixas, associada a queda, seguida de "perda do conhecimento” e crise jacksoniana da perna direita (Bourroul diz que a concepção de epilepsia jacksoniana se ampliou, havendo também uma forma de crise psíquica, também presente nesse doente). Além disso, foi notada alteração motora e sensitiva no pé direito.

A hipótese de histeria foi afastada pela falta de estigmas e sintomas ${ }^{768}$.

A partir desses dados, o autor localiza a lesão a $2,5 \mathrm{~cm}$ adiante do sulco de Rolando ${ }^{769}$ e a 2 cm para fora da linha mediana. O autor procura associar essa

766 CASTRO, F. Estudo clinico da hemiplegia; (licção professada na Faculdade de Medicina do Rio de Janeiro pelo Prof. Francisco de Castro e redigida pelo Dr. Rubião Meira). Gazeta Clinica, p.372-380, 1904.

767 BOURROUL, C. Monoplegia segmentar sensitivo-motora e jacksonismo psycho-motor por trauma cerebral (notas de uma lição do professor Grasset, de Montpellier). Imprensa Medica, p. 77-79, 1906.

768 Cronologicamente, esse é o primeiro artigo que Bourroul envia da França, em 1906. Ao falar em estigmas da histeria vistos por Grasset, ele ainda se baseia no paradigma de Charcot. Os outros artigos de Bourroul vão inserir as inovações de Babinski, que, aos poucos, vão sendo incorporadas por outros professores. Em 1908, Rubião Meira, em Paris, constata o sucesso das inovações de Babinski.

${ }^{769} \mathrm{O}$ sulco de Rolando também chamado de sulco central, separa o lobo frontal do lobo parietal na face lateral do hemisfério cerebral. 
localização e os sintomas apresentados a uma concepção de Grasset de que as áreas periféricas musculares, correspondentes às áreas corticais motoras, são as regiões articulares. Assim, Grasset considera que esses “nervos articulo-motores” formam junto com o segmento sensitivo, um aparelho sensitivo-motor geral. Acrescenta o autor que os sintomas psíquicos se devem a acometimento do lobo pré-frontal tido como provável sede do psiquismo. Também são descritas as áreas relativas aos outros sintomas.

Em 1906, na Revista Medica de S. Paulo, publica-se um debate, que saiu nos periódicos La Semaine Médicale de 23 de maio de 1906, e em La Presse Médicale de 11 de julho de 1906, entre os neurologistas franceses Pierre Marie e Dejerine, debate esse intitulado “A aphasia e a terceira circumvolução frontal esquerda”770.

Os dois conhecidos neurologistas entraram em debate sobre as lesões cerebrais equivalentes aos quadros de afasia. Pierre Marie, a partir de diversas observações, discorda do modelo convencional de explicação da lesão cerebral nos casos de afasia, considerando que as chamadas áreas de Broca e de Wernicke não são relacionadas com as funções de linguagem a elas atribuídas.

Dejerine argumenta contrariamente, dizendo que Pierre Marie quer retroceder mais de oitenta anos na ciência, antes dos primeiros registros de associação de lesão cerebral com afasia.

Esse debate é recorrente na medicina, tendo acentuações em certos períodos do século XIX e do século XX, acompanhando as discussões entre localistas e não localistas, em termos de entendimento das áreas cerebrais e suas funções.

Em 1906, publicam-se na Revista Medica de S. Paulo, diversos artigos, sob o título "Fractura de craneo e morte mediata, no ponto de vista Medico-Legal”, pelo médico Ponciano Cabral, identificado como “medico legista de Campinas"771. Em diversos e longos artigos, Cabral detalha elementos que implicam em um grande conhecimento do crânio e do cérebro, com citação de casos e de diversos autores, denotando a importância do estudo do sistema nervoso para a medicina legal.

\footnotetext{
${ }^{770}$ REVISTA MEDICA DE S. PAULO. A aphasia e a terceira circunvolução frontal esquerda, p.472-473, 1906.

771 CABRAL, P. Fractura de craneo e morte mediata, no ponto de vista Medico-Legal. Revista Medica de S. Paulo, p. 381-387; 402-408; 421-426, 1906. 
A presença desses artigos também demonstra a importância da medicina legal e do estudo descrito, nesse período, pelo espaço ocupado na revista com vários artigos sobre o mesmo assunto.

\section{3.8 - Manifestações psíquicas e neurológicas de doenças sistêmicas (1899-1912).}

Em 1906, na Imprensa Medica, V. de Mello publica artigo denominado "Os syndromas suprarenaes”772.

O autor refere que até há "bem pouco tempo", a doença das glândulas suprarrenais se limitava á moléstia de Addison, caracterizada pela coloração bronzeada da pele e pela terminação fatal. O autor passa a informar, então, que estudos fisiológicos esclareceram que a suprarrenal tem outras funções, entre elas a de secretar uma substância hipertensiva que foi denominada adrenalina.

A seguir ele relata que o médico Leon Bernard publicou na Presse Médicale, em dezembro de 1905, um estudo geral sobre o conhecimento a respeito das alterações da glândula suprarrenal. Entre as várias manifestações de aumento das funções dessa glândula, o autor relata alterações relativas ao sistema nervoso, como quadro de cefaléia, vertigem, distúrbios visuais, afasia, encefalopatia convulsiva, hemiplegia. Nos casos de diminuição da função, refere: depressão profunda, cefaléia, delírio, agitação, convulsões, coma.

Em 1908, na Imprensa Medica, na seção “Pathologia mental”, é publicada resenha sobre palestra intitulada "Secreções internas e psychoses", proferida por Laignel-Lavastine, referido como “medico dos hospitaes de Paris”.

O texto inicia, dizendo que esse estudioso apresentou em congresso de alienistas e neurologistas franceses, um estudo sobre perturbações psíquicas que dependam de alterações das secreções internas. Assim, ele aborda patologias das glândulas de secreção interna: tireóide, paratireóides, hipófise, suprarrenais, ovários e testículos. Também apresenta suas várias manifestações: mixedema, síndrome de Basedow, tetania, eclampsia, acromegalia, gigantismo, síndrome de Addison, insuficiência ovariana, etc. Acrescenta os meios de pesquisar esses quadros.

772 MELLO, V. Os syndromas suprarenaes. Imprensa Medica, p. 14-15, 1906. 
Assim, são expostas as conclusões do autor: a coincidência freqüente de perturbações psíquicas nas síndromes glandulares é um fato; toda perturbação psíquica pressupõe uma predisposição cerebral ao agente mórbido. O autor frisa a associação entre esses elementos, para se contrapor a estudiosos que consideram apenas haver coincidência entre esses fatos.

O estudioso francês considera que, se a perturbação glandular ocorrer na infância, vai condicionar alterações psíquicas devido a desenvolvimento inadequado, havendo anomalias de estrutura. No adulto, o palestrante considera a ação hormonal de maneira variável, no que diz respeito ao estado mental. Ele supõe que as pesquisas podem vir a correlacionar certas expressões psicológicas de comportamento com determinados comprometimentos de glândulas. Nos casos de alterações psíquicas acentuadas, o expositor fala em psicose tóxica e intoxicação cerebral.

O palestrante conclui, reclamando da falta de atenção dos estudiosos competentes para a influência das perturbações glandulares nas síndromes psíquicas, pois, de outro modo, muitos doentes poderiam ser beneficiados pela investigação de tais alterações.

Em 1908, na Revista Medica de S. Paulo, é publicado o artigo “Influencia das molestias intercorrentes sobre certas psychoses”773, pelo médico Vargas A. Cavalheiro do Hospício do Juquery.

O autor refere que os alienados estão sujeitos a moléstias das diversas partes do organismo, em virtude de sua falta de higiene, de seu contato com portadores de diversas doenças, por alterações nutricionais e pelas "auto-intoxicações e infecções”. Entre as infecções, o autor informa não ter encontrado impaludismo no Hospício do Juquery.

Segundo Cavalheiro, todos que freqüentam institutos de alienados notam que uma moléstia intercorrente modifica o curso de uma moléstia mental. Assim, são observados casos de agitação que, no curso de uma doença intercorrrente, apresentam uma acalmia notável, inclusive com melhores condições de conversa e entendimento, com a melhora das faculdades de atenção e observação. Tem sido mesmo cogitada a possibilidade de aplicar algum método que faça uso do mecanismo de moléstias

773 CAVALHEIRO, V.A. Influencia das molestias intercorrentes sobre certas psychoses. Revista Medica de S. Paulo, p. 404-408, 1908. 
intercorrentes, para a melhora de condições psíquicas desses pacientes, mas isso ainda está em debate ${ }^{774}$.

A seguir, o autor relata vários casos do Hospício do Juquery, que obtiveram melhora, após serem acometidos por moléstias intercorrentes, inclusive passando a desenvolver atividades de trabalho no hospício. A persistência da melhora psiquiátrica teve duração variável.

Uma hipótese do autor, para explicar esses casos, é a ação direta ou indireta da própria infecção sobre os centros de atividade psicomotora.

Cavalheiro cita alguns estudiosos que correlacionam as alterações da loucura a modificações circulatórias. Assim ele diz que:

“Para certos psychologos seria possível explicar as modificações emocionaes pela acção da innervação motora vascular. G. Dumas descreve typos de alegria e de tristeza, dependentes da variação da tensão arterial, da circulação peripherica, da impulsão cardíaca, em diversos doentes de paralysia geral, mania, melancolia, etc. E suas observações com Klipel são a esse respeito quase concludentes, tendo elles observado por meio de thermometros aperfeiçoados, que coincidiam tais variações emocionaes com modificações da circulação e da temperatura da pelle"775.

O autor também se refere às estreitas relações que unem os centros nervosos ao resto do organismo, com influência mútua entre esses dois setores. Cavalheiro diz que a atenuação dos sintomas de excitação pode se dever à ação dos germes ou de seus produtos, de modo que as toxinas atuem diretamente sobre a célula nervosa (conforme o autor, esta é a idéia de Franco da Rocha), ou mesmo agindo sobre a inervação vasomotora, determinando alterações circulatórias.

Em seguida, o autor relata outros trabalhos, inclusive experimentais, sobre a ação de toxinas no sistema nervoso.

Em 1909, na Imprensa Medica, é publicada resenha sobre a tese inaugural de Enjolras Vampré, intitulada "Perturbações nervosas e mentaes da peste bubonica"776, cuja defesa está registrada como tendo ocorrido em 1908.

\footnotetext{
${ }^{774} \mathrm{O}$ método da malarioterapia, em casos de paralisia geral, baseia-se em mecanismo similar a esse. 775 CAVALHEIRO, V.A. Influencia das molestias intercorrentes sobre certas psychoses. Revista Medica de S. Paulo, p. 407, 1908.

776 BIBLIOGRAPHIA. Perturbações nervosas e mentaes da peste bubonica; tese do Dr. Enjolras Vampré apresentada a Faculdade de Medicina da Bahia, 1908. Imprensa Medica, p. 63, 1909. 
O texto apresenta um apanhado da tese, que vem também abordada em outro artigo a seguir.

No fim da resenha, consta que Vampré fez o internato em clinica psiquiátrica e moléstias nervosas, e que acaba de ser nomeado medico do Hospício do Juquery, de modo que "encontrará neste importante centro de aprendizagem vasto campo para prosseguir nos seus estudos tão bem iniciados, podendo tornar-se mais tarde um especialista nesse arduo e difficil ramo das sciencias medicas”.

Em 1910, Vampré publica dois artigos sobre o assunto de sua tese inaugural, que diz respeito a certas alterações presentes em indivíduos acometidos de peste bubônica.

Um desses artigos tem o título “A Tachypnéa na peste bubonica”777. Estando já no Juquery, Enjolras Vampré escreve esse texto embasado em sua própria experiência, por quase dois anos, “á cabeceira dos enfermos do Hospital de Isolamento de Peste em Mont-Serrat na Bahia”778. Nessa ocasião, ele observou que a taquipnéia (respiração rápida e curta) estava entre as alterações mais impressionantes nos casos de peste bubônica. Ele localizou a lesão responsável por essa sintomatologia no bulbo raquiano, em sua função de controle respiratório, estabelecendo o prognóstico de morte por asfixia. Ele cita vários autores e trabalhos, entre os quais sua própria tese de doutoramento, intitulada "Perturbações nervosas e mentaes da Peste Bubonica" 779. Relata opiniões divergentes de autores, que localizam em diferentes órgãos o que seria o principal responsável pela morte nos casos de peste, e que para ele, e alguns outros, corresponde ao bulbo raquiano e sua correlata sintomatologia respiratória.

Em seguida, Vampré cita a regra que elaborou para considerar o prognóstico desses casos, baseada na observação da evolução da freqüência respiratória, de modo que, se essa freqüência chegar a 36 movimentos por minuto, após 48 horas de quadro, o prognóstico de morte tem a probabilidade de 90\%. Para suas conclusões, ele observou 267 casos, juntando alguns dados de outros autores; assim, criou uma espécie de aforismo sobre a peste, dizendo que "o mal está no bubão e o perigo na respiração"780.

777 VAMPRÉ, E. A Tachypnéa na peste bubonica. Revista Medica de S. Paulo, p. 141-143, 1910.

778 Idem.

779 Ibidem.

780 Ibidem. 
O outro artigo de Vampré, também publicado em 1910, intitula-se "Perturbações mentaes da peste bubonica"781.

Ao relatar as manifestações mentais da peste bubônica, Vampré lembra recomendações do Congresso de Alienistas e Neurologistas franceses, de 1901, onde foi emitida uma nota em favor de uma sala especial nos hospitais para quadros de agitação e delírio, antes de serem destinados a hospícios, devido à possibilidade desses casos serem decorrentes de moléstias sistêmicas, as quais não necessitem de tratamento em hospício.

Em 1910, Enjolras Vampré, na Revista Medica de S. Paulo, publica o artigo "Interessante caso de um syndroma endocrinico genital”" ${ }^{, 72}$. Este artigo descreve um distúrbio comportamental associado a alterações hormonais, que, conforme o autor, melhorou com o uso de medicação hormonal.

Em 1911, o médico Antonio Austregésilo publica três artigos, na Revista Médica de São Paulo, sobre manifestações psiquiátricas desencadeadas por causas sistêmicas.

O primeiro desses artigos intitula-se “As dezordens mentaes na Ancilostomíase”783. O autor refere que, desde Esquirol, foram feitas associações entre alterações mentais e verminoses. Austregésilo acha que esses quadros podem ocorrer em indivíduos que já tenham previamente "psychismo alterado" ${ }^{784}$. Assim, considera a degeneração como causa predisponente, e o ancilostoma como causa determinante dessas manifestações. Em geral, ele acha que os quadros mentais melhoram com o tratamento da ancilostomíase.

O segundo artigo intitula-se "Psicoses infectuosas especialmente nas doenças tropicaes - (trabalhos clinicos)”785. Austregésilo acha que as perturbações psíquicas e nervosas só têm duas fontes etiológicas: a destruição e a intoxicação. Ele põe mais

781 VAMPRÉ, E. Perturbações mentaes da peste bubonica. Revista Medica de S. Paulo, p. 243-249, 1910.

782 VAMPRÉ, E. Interessante caso de um syndroma endocrinico genital. Revista Medica de S. Paulo, p. 10-11, 1910.

783 AUSTREgESILO, A. As desordens mentaes na ancilostomíase. Revista Medica de S. Paulo, p. 108111, 1911. 784 Idem.

785 AUSTREGESILO, A. Psicoses infetuosas especialmente nas doenças tropicaes (trabalhos clínicos). Revista Medica de S. Paulo, p. 202-214, 1911. 
ênfase na segunda em relação à origem de distúrbios mentais. Assim, acha que as intoxicações exógenas ou endógenas podem explicar a origem de muitos quadros psiquiátricos. Desse modo, cita alterações mentais nos casos de febre tifóide, varíola, gripe, reumatismo articular agudo, pneumococcias, colibacilose, septicemia, erisipela, caxumba, blenorragia, raiva, tuberculose, sífilis, malária, febre amarela, peste, cólera, lepra, beribéri, ancilostomíase, cisticercose.

O terceiro artigo intitula-se "Sindromes pluriglandulares endocrinicas trabalhos clinicos”786. Austregésilo faz longas digressões sobre moléstias hormonais que têm manifestação psíquica ou neurológica.

\section{3. 9. - Concepções e mecanismos de moléstias do sistema nervoso (1899-1912)}

Em 1903, é publicado o artigo "Embolia Cerebral”787, do médico Cursino Moura, de Taubaté, na Revista Medica de S.Paulo, a respeito de uma paciente de 38 anos, alcoólatra e que fazia tratamento para "hypoemia intertropical”.

O autor relata a evolução do caso observado e questiona a possibilidade de o alcoolismo facilitar a presença do ankylostoma duodenale no intestino da paciente, em analogia com outra conhecida associação entre alcoolismo e tuberculose.

O autor descreve o quadro clinico inicial como um ataque apoplético brusco, que o faz considerar como embolia cerebral esquerda, com "hemiplegia completa à direita, perda de conhecimento, estertores tracheaes, deglutição impossivel, etc.”788. Depois, deixa claro ter observado também a presença de afasia e de comprometimento visual.

Moura informa que adotou tratamento com medicação injetável e por via oral. Após três meses e meio, encontrou a doente relativamente curada, com algumas seqüelas.

O autor considera simples a sua descrição do quadro clínico, e sem originalidade. Ele deu valor a sua observação no suposto vínculo entre alcoolismo e “hypohemia intertropical”, tendo, no entender dele, levado a embolia cerebral.

786 AUSTREGESILO, A. Síndromes pluriglandulares endocrínicas; trabalhos clínicos. Revista Medica de S. Paulo, p. 243-252, 1911.

787 MOURA, C. Embolia cerebral. Revista Medica de S. Paulo, anno VI, n. 5, p. 89-91, 1903.

788 Idem, p. 90. 
A partir de 1905, o periódico paulista Imprensa Médica inicia a publicação de uma seção intitulada "Neuropathologia”. Nota-se que nesse mesmo ano também se inicia uma seção intitulada “Clinica Psychiatrica” ${ }^{789}$, denotando uma diferenciação de abordagens nos campos de ambas as seções.

Assim, em janeiro desse mesmo ano, é publicado, na seção “Neuropathologia”, o artigo "Contribuição ao estudo da poliencephalite superior»"790, pelo médico Francisco Pignatari.

O autor relata o caso de uma paciente italiana, de 36 anos, que foi atendida no Hospital Ophtalmico, por quadro de dor de cabeça súbita e alteração da visão. Pignatari descreve minuciosamente o exame dos músculos do pescoço e da cabeça, bem como dos movimentos oculares, e inclui também o exame de fundo de olho por oftalmoscópio. O autor passa então a debater o achado no exame de fundo de olho, dizendo que antigamente esse dado seria "pathognomonico" para tumores cerebrais. Ele passa a relatar, então, sua própria experiência na Alemanha, em 1894, com o professor Bergmann, onde observou cirurgias cerebrais de tumores, que levaram a melhora das alterações oftálmicas.

Em seguida, Pignatary relata estudos desde 1846, que gradativamente descreveram a localização dos nervos cranianos oculares no tronco cerebral. Como no caso observado há alterações desses nervos, o autor concluiu pelo diagnóstico de “poliencefalite superior”, ou seja, comprometimento de vários nervos cranianos.

Ele inferiu a possibilidade de tratar-se de sífilis e instituiu tratamento por iodureto de mercúrio, com o qual a paciente melhorou. Refere que tanto as poliomielites como as poliencefalites são causadas por intoxicações e infecções, destacando-se a sífilis.

Embora cite o questionamento que é feito à associação entre lesão de papila óptica e tumor cerebral, ele acha que seu caso continuou seguindo essa regra, por deverse a provável presença de goma sifilítica, com ação similar a um tumor.

789 Na primeira publicação da seção “Molestias psychiatricas” da Imprensa Medica, de maio de 1905, é publicado um texto do livro de Franco da Rocha, "Esboço de psychiatria forense", referente à "evolução das molestias mentaes”.

790 PIGNATARI, F. Neuropathologia: contribuição ao estudo da poliencephalite superior. Imprensa Medica, ano XIII, n. 1, p. 1-5, 1905. 
Em 1905, na seção “Neuropathologia” da Imprensa Medica, é publicada resenha de artigo da França intitulado "O tabes infantil”791, dos autores Hirtz e Lemaire.

$\mathrm{O}$ texto informa que o tabes manifesta-se mais frequentemente entre 30 e 50 anos, e que raramente pode ser infantil, ou juvenil, tendo sido confundido por muito tempo com a moléstia de Friedreich ou ataxia familial hereditaria.

Assim, autores reuniram os sinais característicos da moléstia: perturbações pupilares (sinal de Argyll); alterações dos reflexos tendinosos (abolição do reflexo patelar ou do reflexo de Aquiles); presença do sinal de Romberg. $\mathrm{O}$ autor lembra que esses sinais pertencem à sífilis do sistema nervoso e só constam na tabes porque esta é quase sempre de origem sifilítica.

Informa-se que os autores conseguiram copilar 47 casos e que alguns “neurologistas” se recusam a considerá-los verdadeiros, por terem se manifestado em crianças e “adolescentes”. Acentua-se que a sífilis dos adultos é adquirida, enquanto que a das crianças é hereditária ou adquirida no inicio da vida.

Em 1906, é publicado, na Imprensa Medica, artigo na seção "Neuropathologia”, intitulado "Claudicação intermittente dos centros nervosos (notas e considerações sobre uma lição de Grasset e sobre o trabalho de Dejerine 'Claudicação intermittente da medula espinhal’), ${ }^{\text {,792 }}$, por Celestino Bourroul.

O autor relata que a claudicação intermitente foi vista primeiramente no cavalo e depois foi descrita no homem por Charcot em 1858.

A partir do estudo da arteriosclerose por Huchard, Bourroul afirma que a claudicação intermitente enquadra-se, de um modo geral, nesse processo. Com a arteriosclerose considerada como moléstia sistêmica, o quadro de claudicação pode ocorrer em qualquer órgão.

Bourroul passa descrever a claudicação intermitente da medula espinhal, onde são observados episódios de dificuldade da marcha, podendo evoluir para paralisia, com aumento de reflexos e evolução para "paraplegia espasmodica”. São então relatados três casos observados por Dejerine, com as descrições de aumento dos reflexos, e em um dos casos a presença do reflexo de Babinski.

791 NEUROPATHOLOGIA. Resenha sobre: HIRTZ, E.; LEMAIRE, H., O tabes infantil juvenil, da Presse Medicale, maio de 1905. Imprensa Medica, p. 271-273, 1905.

792 BOURROUL, C. Neuropathologia: Claudicação intermittente dos centros nervosos (notas e considerações sobre uma lição de Grasset e sobre o trabalho de Dejerine 'Claudicação intermittente da medulla espinhal). Imprensa Medica, p. 193-203, 1906. 
Nesses casos, informa o autor que são usados medicamentos mercuriais, mesmo que não haja indícios outros de sífilis.

Bourroul acrescenta um caso que foi a ele apresentado por Grasset, antes ainda de publicação de Déjerine na Révue de Neurologie, sobre o mesmo assunto.

Quanto à claudicação bulbar, informa Bourroul que Grasset considera como própria da vertigem dos arteriosclerosos.

Em relação à claudicação cerebral, diz o autor que é freqüente pelo fato de a arterite e a arteriosclerose cerebral serem comuns, devido à enorme ocorrência da sífilis e pelas condições de vida nocivas a que modernamente se submete o homem. Assim, aparecem de forma intermitente, monoplegias, hemiplegias, formigamentos, disestesias, afasias.

O autor associa a essas causas o que é considerado como "tara nevropathica", que segundo ele, dia a dia se avoluma, pelo uso do álcool, pela propagação da sífilis e estes conjugados à herança, gerando assim grande quantidade de degenerados.

$\mathrm{Na}$ claudicação vaso-motora, simpática ou reflexa, além das hipóteses circulatórias, Bourroul comenta também supostos mecanismos reflexos entre o sistema nervoso e o resto do organismo, mutuamente.

Ele termina o artigo, reforçando a terapêutica mercurial para sífilis, no tratamento desses casos, apoiando-se em Grasset e Déjerine.

Em 1906, na Imprensa Medica, a seção "Neuropathologia” passa a chamar-se "Neurologia”, sendo publicado artigo intitulado "Do cerebro senil - no ponto de vista symptomatico e therapeutico" ${ }^{, 793}$ por Celestino Bourroul.

O autor inicia, lembrando que antes a velhice não era considerada doença, correspondendo ao aforismo senectus non est morbus. No entanto, conforme o autor, com o impulso que a medicina deu à noção de "angio-sclerose”, o aforismo sofreu inversão total e passou a ser senectus est morbus. Assim, ele diz que o termo "velhice" deve ser substituído por "senilidade" (o autor acrescenta em nota que o começo da velhice é fixado pela maioria dos autores em sessenta anos). Bourroul acrescenta a noção de Peter, “a esclerose arterial é a ferrugem da vida”, e a de Cazalis, “o homem tem a idade de suas arterias".

793 BOURROUL, C. Neurologia: Do cerebro senil no ponto de vista symptomatico e therapeutico. Imprensa Medica, p. 410-414, 1906. 
O autor acrescenta, à esclerose arterial, a esclerose das vísceras, e insere ambas em um processo devido a intoxicações endógenas e exógenas ocorridas no decurso da existência. Lembra estudo de Léri, que indaga o papel das várias formas de esclerose e da degenerescência celular, questionando quais desses aspectos são inicialmente responsáveis pelo processo que conduz à senilidade. Em relação a fatores tóxicos e o sistema nervoso (ainda a partir de Léri), o autor lembra que, enquanto as células do organismo em geral reagem de várias formas aos estímulos recebidos, eventualmente mesmo com proliferação dessas células, as células do sistema nervoso nem se multiplicam e nem se renovam no curso da existência, de modo que respondem a elementos tóxicos apenas com modificações em seu interior.

Bourroul lembra também a frase de Bouchard em relação ao sangue, “não só no estado normal, como no estado pathologico é um receptaculo e laboratorio de venenos”, de modo que os vasos são os primeiros a receberem as conseqüências de toxinas na circulação.

O autor volta a Léri, apresentando sua classificação das alterações vasculares em dois grupos: lesões em foco e lesões difusas.

Após descrever os diversos tipos de lesão em foco, o autor comenta que as lesões difusas são consideradas como não dependentes das lesões vasculares e decorrem de intoxicação direta das células nervosas.

Quanto à parte clínica desse estudo, o autor informa que Léri desdobra em dois grupos: os sinais que fazem parte da neurologia e os sinais que fazem parte da psiquiatria.

A seguir, Bourroul comenta sobre a "arterio-esclerose cerebral”. Ele frisa que esse quadro acompanha-se de sinais de esclerose também em outros órgãos. Relata que, no início do quadro, pode haver neurastenia, que Régis considera suspeita de ter origem esclerosa, se surgir em idosos; assim também pensa Grasset sobre nevroses aparecidas nesses indivíduos.

Além disso, informa que podem ser observadas afasia ou disartria transitórias; paresias passageiras; discretos ataques apopletiformes ou epileptiformes; cefaléia noturna; zumbido nos ouvidos; sonolência ou insônia; mudança de humor; cansaço físico e intelectual rápido, etc. 
O autor relata que formas de arteriosclerose "localizada grave", descritas por Binswanger e por Alzheimer, são anatomicamente caracterizadas por focos múltiplos muito pequenos de desintegração simples, evoluindo para quadro de demência.

Esse mesmo assunto tem uma continuação, em artigo publicado em 1907, na seção “Neurologia”, da Imprensa Medica, com o mesmo título e autor.

Assim, Celestino Bourroul adentra ao item "hemiplegias" 794 , relativo à arteriosclerose. Ele se remete a um trabalho de Pierre Marie, realizado em Bicêtre, e publicado em 1901 na Revue de Médecine, onde, a partir de autopsias, esse estudioso considera que, nos idosos, esse processo não se deve nem à hemorragia e nem ao amolecimento (isquemia), mas ao que ele chama de "processo lacunar".

A partir daí, informa o autor que os discípulos de Pierre Marie (Ferrand, Catola, Léri) se utilizam do conceito “lacunar”. Esses estudiosos frisam, então, que o idoso não resiste nem à grande hemorragia, nem ao grande amolecimento cerebral, não havendo tempo de sobrevida para serem observadas as contraturas que surgem mais tarde, decorrentes do comprometimento do feixe piramidal.

Desse modo, Bourroul acentua o valor dessas contraturas para facilitar a suposição de uma hemiplegia antiga. Essa situação, em idosos, ele diz conduzir ao diagnóstico do processo denominado "lacunar".

Ele acentua que a hemiplegia lacunar pode ser menos notada ou passar despercebida, pela falta de sinais mais evidentes; são hemiplegias incompletas, que podem ser transitórias. No entanto, lembra o autor que certas alterações sutis podem ser percebidas a um exame mais detalhado, como, por exemplo, alguma dificuldade em abotoar o paletó, ou uma disartria, ou discreta assimetria facial. Nesses casos as hemiplegias são mais acentuadas no membro inferior, diferentemente da hemiplegia do adulto não idoso, onde a predominância é no membro superior.

A marcha do paciente com estado lacunar pode ser a pequenos passos. Grasset nota que essa marcha se deve mais a uma perturbação locomotora automática e inconsciente, do que uma perturbação da motricidade voluntária. Por outro lado, o exame isolado da força muscular dos membros inferiores mostra-se preservada.

Quanto ao estudo dos reflexos nos quadros lacunares, Bourroul considera importante. No que ele chama de tríade piramidal - aumento de reflexos, trepidação

794 BOURROUL, C. Neurologia: Do cerebro senil sob o ponto de vista symptomatico e therapeutico: hemiplegias. Imprensa Medica, p. 1-5, 1907. 
epileptoide e contratura - só o primeiro item é observado. Acentua o autor como muito importante para confirmar o quadro piramidal, o sinal de Babinski, freqüentemente presente.

Além disso, acrescenta o autor que é também descrito o "riso e choro espasmodicos”, conforme Brissaud, que os associa a lesões dos núcleos cinzentos centrais.

Ainda em 1907, Celestino Bourroul continua suas explanações na seção “Neurologia”, dentro do estudo do cérebro senil ${ }^{795}$.

O autor inicia com o quadro chamado "syndroma paralysia pseudo-bulbar" e informa que esse quadro foi muito bem estudado por Brissaud, Halipré e Comte (discípulo de Déjerine). Esse quadro diz respeito a fenômenos paralíticos nos órgãos da deglutição, mastigação e fonação, por lesões no córtex cerebral em área correspondente aos territórios lesados, ou nas fibras de projeção que dela partem. Acentua-se que a bilateralidade das lesões é necessária para haver a moléstia, por causa da ação bilateral da maioria dos centros corticais. Assim, supõe-se que esse quadro se estabeleça após vários ataques. O autor acrescenta outros detalhes a respeito da síndrome que não são aqui relatados.

Outro quadro por ele abordado é a “syndroma da paralisia geral progressiva”. Embora com esse título, o autor se refere inicialmente a uma "pseudo-paralisia geral progressiva”, dizendo que, segundo Grasset, tem causa de natureza “cerebro-scleroselacunar”.

Informa o autor que esses quadros têm evolução mais lenta e benigna e com demência atenuada, se comparados com a “verdadeira” paralisia geral.

Bourroul acentua que a paralisia geral progressiva foi definida por Fournier como um "syndroma parasyphilitico”, que aparece quinze anos após o quadro de sífilis. Assim, geralmente se instala em tempo menor do que o referente aos quadros de pseudoparalisia geral progressiva, associada ao estado lacunar.

O quadro seguinte, abordado pelo autor, diz respeito às "paraplegias". Conforme Bourroul, as paraplegias da idade senil, associadas a causas lacunares, não são muito acentuadas e se devem mais a uma dificuldade da marcha, podendo situar-se dentro do que Pierre Marie chama de astasia-abasia. O autor lembra diferenciações com

795 BOURROUL, C. Neurologia: Do cerebro senil no ponto de vista synptomatico e therapeutico. Imprensa Medica, p. 17-22, 1907. 
outros quadros, inclusive aqueles devidos à inatividade muscular. Nesse sentido, recomenda não se deixar o doente apenas na cama, mas submetê-lo à ginástica passiva e ativa.

Outro quadro é a “epilepsia senil”. O autor informa que esses quadros se devem a "lesões materiais" do cérebro, em oposição à epilepsia essencial, que se inicia na infância. Como causas principais são citadas a sífilis e a arteriosclerose. Além disso, são citadas também as causas: epilepsia senil de Alzheimer; e outras lesões vasculares; fatores tóxicos.

Ainda em 1907, Celestino Bourroul continua com sua explanação sobre o cérebro senil $^{796}$. Ele passa então ao que chama de "Parte psychiatrica”.

Comenta o estado mental dos senis. Segundo ele, Léri considera que, a partir dos 75 a 80 anos, todos os velhos apresentam algum grau de deficiência mental. O autor descreve então uma série de características, que aparecem no estado mental, ou no comportamento dos idosos.

A seguir, refere-se ao tema "arterio-esclerose” nos senis. Nestes quadros, o autor relata serem observados: cansaço mental, cefaléias e vertigens, e sinais somáticos.

Outro assunto diz respeito a "Psychoses" na senilidade. O autor aponta uma predominância de melancolia simples ou ansiosa e confusão mental, podendo estar associada a intoxicações exógenas ou endógenas.

Finalmente, ainda em 1907, Celestino Bourroul publica a última parte de sua série de artigos sobre o cérebro senil, apresentando o item “Tratamento"797.

O autor considera quase todo o tratamento dessa condição como sendo do tipo "hygienico", ou preventivo. No tratamento relativo à parte vascular, o autor recomenda dieta alimentar, com regime lácteo e alimentação leve à noite. Álcool e fumo são proibidos.

Quanto ao tratamento do ictus, o autor se refere à conduta dos "naturistas”, que deixam o organismo por conta das forças naturais, e a dos “intervencionistas" que supostamente se dirigem às lesões peri ou parafocais, ou seja, para evitar o que é citado como “a congestão peripherica e de vizinhança” à lesão. Na prática são usados:

796 BOURROUL, C. Neurologia: Do cerebro senil no ponto de vista symptomatico e therapeutico. Imprensa Medica, p. 33-37, 1907.

797 BOURROUL, C. Neurologia: Do cerebro senil no ponto de vista symptomatico e therapeutico. Imprensa Medica, p. 69-74, 1907. 
purgativos, lavagens purgativas diuréticas, sanguessugas nas mastóides, escalda-pés, medidas que conservem o calor nas pernas, capacete de gelo.

Em 1908, na Revista Medica de S. Paulo, foi publicado o artigo intitulado “Charles Richet e a Physiologia”798, por Ulysses Paranhos.

O autor relata os diversos trabalhos de Richet, que têm grande peso na ciência. Em relação ao sistema nervoso cita o livro publicado em 1882, intitulado "Physiologia dos Musculos e dos Nervos”, no qual o autor destaca um melhor entendimento da atividade elétrica nos músculos e nos nervos.

Prossegue Paranhos, dizendo que: “Nos domínios da neurologia, uma das melhores memorias publicadas sobre as circumvoluções cerebraes é, sem duvida, a apresentada á Faculdade de Medicina de Paris, pelo Dr. Richet, para o seu concurso de professor”.

A seguir, o autor relata experimento realizado por Richet sobre o funcionamento cerebral, confirmado por outros estudiosos. Paranhos enfatiza também os estudos de Richet sobre anafilaxia e saúda seu "Diccionario de Physiologia” como obra de incomparável valor.

Em 1910, na Imprensa Medica, na seção “Neurologia”, é publicado artigo intitulado "Perturbações da cenesthesia na demencia precoce"799, de Henrique Roxo, correspondente a um comunicado feito à Sociedade de Psychiatria, Neurologia e Medicina Legal.

O autor refere que a demência precoce deriva de um processo de autointoxicação, em que a insuficiência das glândulas sexuais representa papel predominante.

O autor informa que no inicio do quadro há cefaléia com dor ocular. Além disso, pode ser relatada sensação de “caldo que escorre pelas tripas” e de modo similar há outras descrições fantásticas para qualquer percepção visceral, e assim outras perturbações de cenestesia, com alucinações psico-motoras. A seguir, Roxo relata um caso observado com essas alterações.

798 PARANHOS, U. Charles Richet e a Physiologia. Revista Medica de S. Paulo, p. 479-481, 1908. 799 ROXO, H. Neurologia: Perturbações da Cenesthesia na demencia precoce (comunicação à Sociedade de Psychiatria, Neurologia e Medicina Legal). Imprensa Medica, p. 113-117, 1910. 
Em 1911, na Gazeta Clinica, é publicado o artigo "Sobre um caso de Esclerose Lateral Amyotrophica - Molestia de Charcot”, referente à apresentação feita à Sociedade de Medicina e Cirurgia de S. Paulo em 15 de março de 1911, por Rubião Meira e Celestino Bourroul ${ }^{800}$.

Os autores relatam o caso de um paciente de 28 anos, com antecedente de sífilis aos 20 anos, e que desenvolveu esclerose lateral amiotrófica a partir de "um susto"801. Após apresentarem detalhes do exame físico, os autores terminam dizendo que, o fato de desencadeamento “pelo susto” pode ser favorável á hipótese de que a moléstia seja de natureza congênita. Eles consideram a sífilis como tendo um papel secundário nesse caso, ou apenas preparando o terreno para a esclerose lateral amiotrófica se assentar.

\section{3. 10. - Concepções sobre a relação entre cérebro e mente (1899-1912)}

Em 1904, na seção “Clinica Psychiatrica e Moléstias Nervosas”, é publicada a aula do médico Henrique Roxo, identificado como “lente substituto interino" na Faculdade de Medicina do Rio de Janeiro. O título dessa aula é “Actos Psychicos”802.

Henrique Roxo dá essa aula em substituição ao professor Márcio Nery. Roxo refere ter acompanhado por sete anos, como estudante e como médico, as preleções dos professores Teixeira Brandão e Márcio Nery, e diz ter lido livros da especialidade.

Ele ressalva que, por ser uma especialidade dada no último ano do curso médico, ela fica relegada a um segundo plano, em virtude da necessidade da feitura de tese pelos alunos, o que acaba exigindo mais do professor.

Sobre sua cadeira, ele diz: "Na cadeira de clinica psychiatrica e de molestias nervosas estudam-se as perturbações que se dão para o lado do systema nervoso, quer central, quer peripherico”.

Ele dá a entender que histeria e epilepsia são vistas como tendo mais manifestações psíquicas do que físicas, embora enquadradas em moléstias nervosas: “A hysteria e a epilepsia que são commumente tidas como molestias nervosas, essencialmente taes, apresentam manifestações psychicas que são preponderantes”.

800 MEIRA, R.; BOURROUL, C. Sobre um caso de Esclerose Lateral Amyotrophica: Molestia de Charcot. Gazeta Clinica, p. 37-38, 1911.

801 Idem, p. 37.

802 ROXO, H. Actos psychicos ( $1^{\mathrm{a}}$ aula dada pelo Dr. Henrique Roxo - lente substituto interino). Gazeta Clinica, p. 493-501, 1904. 
Assim, ele cita essas duas nevroses como sendo moléstias nervosas, ao mesmo tempo em que reconhece que os sintomas psíquicos superam os físicos. Roxo acrescenta que: “este facto foi n'esta cadeira admiravelmente explicado pelo Professor Dr. Teixeira Brandão, o sabio creador da psychiatria brasileira”. Assim, ele faz jus a seu mestre e dá a entender que há uma escola de Teixeira Brandão.

Em seguida, o autor explica que os atos psíquicos constituem o fundamento da psiquiatria: "Sentir, pensar e querer - tal é em synthese o que fórma um acto psychico. É indispensavel que conheçais o modo porque um individuo sente, pensa e age, para que possais bem aquilatar do que se passa no alienado"803.

Então o autor descreve suas noções do trajeto entre neurônios de um determinado estímulo, terminando por formar o que ele chama de "arco psychico":

“A excitação é levada da peripheria até o centro, é sentida, dá-se a sensação que é percebida no cerebro, e contra a qual se dá a reaç̧ão que é constituida pela aç̧ão motora. (...) A vontade é o acto psychico que representa a tendencia ao movimento, depois de haver sido percebida uma dada sensação. E a noção do facto psychico vem a ser a consciencia. Esta deve ser definida como o foi pelo sabio mestre Dr. Brandão, 'a noção intima do facto psychico que o acompanha e succede sempre a elle’. Sendo funç̧ão do acto psychico, effeito da sensação, deve estar sempre em relação com esta. Eis o motivo porque, diz o Professor Brandão, se não póde admittir uma consciencia unica, e sim deve se considerar estados de consciencia”.

Depois, Roxo considera que, pelo conceito de estados de consciência, o individuo varia, e não é o mesmo em diferentes fases da vida. Disse que: “A influencia do meio é poderosíssima, mas a indole do individuo o ampara e amortece sua acção”. Ele relativiza a moral: "a moral não é a mesma em todos os povos: os actos, certas phrases, que em certos meios são tidos como incorretos, passam n’outros como muito naturaes”.

O autor explica a personalidade como "síntese das sensações”, que pode ser alterada por algo que deturpe as sensações e desmembra-se no fim da vida quando se estabelece a demência, que ele chama de segunda infância. A seguir, explica outros conceitos psiquiátricos, sempre fazendo menção ao professor Teixeira Brandão.

Roxo diz ser desnecessário o conceito de alma para o entendimento da mente, colocando tudo na dependência de excitação e reação e diz que o cérebro é uma víscera como outra qualquer, que secreta o pensamento, do mesmo modo que o fígado secreta a 
bílis. Assim, ele diz que a alma contraria as leis da fisiologia e que essa é uma concepção desnecessária.

Em seguida, Roxo recomenda aos alunos que forem trabalhar no interior, que levem essas noções para que possam fazer alguma coisa, até que chegue "o especialista mais competente”. Assim, enumera uma série de medidas a serem tomadas em situações como agitação, mania, depressão, melancolia, torpor cerebral, confusão mental. Essas medidas vão desde banhos e compressas a "excitantes da circulação cerebral”, ou “desinfectantes que desembaracem o cerebro da toxhemia”.

Antes de terminar, ele lembra de um dever muito importante do médico, no que ele chamou de “questões médico-legais”, e que se trata de desaconselhar uniões conjugais que possam levar a transmissões hereditárias de doenças, considerando esse um dever do médico.

Em 1910, na Gazeta Clinica, publica-se artigo do médico A. Villas Boas, intitulado “A Physio-pathologia da vontade” ${ }^{804}$. Neste artigo, Villas Boas articula conceitos psicológicos, biológicos e neurológicos. O autor refere que o estudo das funções cerebrais tem aspectos de ordem “psicobiológica”, sendo desnecessárias explicações metafísicas pelo sistema da “introinspecção". Assim, ele diz que o fenômeno da vontade foi submetido ao rigor da investigação científica, de modo que ela provém da propriedade geral dos seres vivos de reagir ao meio e reproduzir fenômenos sob diversas causas.

Assim, juntando concepções de Ribot e Leibuts, diz que a vontade é uma propriedade instável, que ocorre por volições variáveis, e que volição é a tendência pra ir onde se acha que está o bem e fugir de onde se acha que está o mal.

O autor diferencia o conceito de "vontade”, do conceito de "livre arbítrio", deixando este para considerações metafísicas, que atribuem a ação dos animais a razões existentes por si próprio, independente dos fenômenos exteriores. Ele considera o livre arbítrio uma ilusão.

Villas Boas diz que o fenômeno biológico resulta do equilíbrio entre dois fatores: o organismo e o meio. Nesse sentido, diz que o indivíduo em biologia é o “indivíduo série”, onde fatores sucessivos se influenciam e resultam no ato voluntário.

804 VILLAS BOAS, A. A Physio-pathologia da vontade. Gazeta Clinica, p. 73-75, 1910. 299 
O autor diz que o reflexo é o tipo básico de toda ação nervosa. Assim, o movimento voluntário é todo movimento reflexo cuja execução é precedida de sua imagem consciente. Ele acentua que essa é a doutrina aceita pelos estudiosos contemporâneos.

Villas Boas divide as idéias em três grupos, conforme sua tendência em se transformarem em atos, podendo ser forte, moderada, ou fraca. A primeira situação ele dispõe similarmente às idéias fixas. A última associa a idéias abstratas. A moderada em situação intermediária entre essas.

Após a explicação de intrincado mecanismo do sistema nervoso associado á vontade, o autor acentua que dessa complicada operação cerebral se destaca a propriedade de inibição das células nervosas, condição necessária para os atos voluntários e refletidos.

Ele relata as condições que provocam comprometimento da capacidade de vontade, quando, então, cita Freud: "Freud comprehende as obsessões e phobias como uma nevrose anciosa de origem sexual, e devida a tensão genetica provocada pela abstinencia ou por excitações genesicas frustras”.

Desse modo, em 1910, o autor Villas Boas faz complexas associações entre elementos biológicos, neurológicos e psicológicos, inclusive citando Freud.

\section{3. 11. - Concepções em moléstias psiquiátricas (1899-1912).}

Em 1899, na Revista Medica de São Paulo, Franco da Rocha faz uma breve análise do artigo de Nina Rodrigues publicado nos Annales medico-psychologiques de 1898, com o título Èpidémie de folie religiose au Brésil, a respeito dos acontecimentos de Canudos. Para Franco da Rocha, ocorreu uma junção entre Antonio Conselheiro - um louco, com delírio coerente, na fase de “messianismo”805 - e o jagunço, um indivíduo com “mentalidade atrasada”, fetichista em religião e monarquista em política. Ele acha que Antonio Conselheiro, inimigo da maçonaria, identifica a República com esta sua inimiga, pela instauração do casamento civil, da secularização dos cemitérios, da separação da Igreja e Estado, etc.

805 ROCHA, F. Épidemie de folie religiose au Brésil par le Dr. Nina Rodrigues; extrait des Annales medico-psychologiques, (1898). Revista Medica de S. Paulo, p. 237, 1899. 
Franco da Rocha acrescenta que:

“o raciocinio curto do jagunço, que faz com que elle seja monarchista, se nos afigura tanto mais natural quanto esse raciocinio é encontrado na melhor sociedade, proferido por gente de gravata limpa, como se costuma dizer. Não é grande o numero dos que comprehendem entre nós a forma superior de governo que possuimos” ${ }^{806}$.

Esse assunto abordado por Nina Rodrigues volta à Revista Medica de São Paulo em 1901, em resenha na seção "Bibliographia” sobre esse trabalho do mesmo professor, a respeito da chamada “epidemia religiosa de Canudos”807. Nessa resenha, cita-se que, nos estudos mais importantes de "psychologia das turbas" Le Bon, o papel da loucura foi deixado em segundo plano. Assim, o objeto do professor Rodrigues é contestar essa visão e apresentar a importância da loucura nesse fenômeno.

Desse modo, conforme a resenha, o autor considera característica da turba a formação de uma “individualidade psychica” diferente da que é própria de cada pessoa. Assim, prevalece um caráter impulsivo, quando atiçada essa turba por um chefe que produz a “fusão da massa de pessoas”. É feita uma distinção dos grupos: um é descrito como dentro de uma "psychologia social” em situação tida como normal; outra situação é a da "psychologia collectiva”, que diz respeito às turbas ${ }^{809}$.

No estado de turba, segundo o texto, o autor acha que desaparece "o dominio da personalidade consciente". Portanto, considera que há um “contagio mental por suggestão collectiva”, em situação em que existam causas remotas associadas a uma causa momentânea, em geral algum determinado fator emocionante; nesse contexto, ainda pela resenha, Rodrigues pensa que o cabeça da turba é quase sempre um "louco latente", também chamado "semi-louco" ou mesmo "nevropatha",810.

O médico João Pondé, da Bahia, publica em 1901, na Revista Medica de São Paulo, artigo intitulado “Um caso de Gastrorrhagia nervosa em um arthritico"811.

806 ROCHA, F. Épidemie de folie religiose au Brésil par le Dr. Nina Rodrigues; extrait des Annales medico-psychologiques, (1898). Revista Medica de S. Paulo, p. 237-238, 1899.

807 BIBLIOGRAPHIA. Resenha: RODRIGUES, N.; La Folie des Foules: contribuition a l'etude des folies epidemiques au Brésil . Revista Medica de S. Paulo, p. 453-454, 1899.

808 Idem.

809 Ibidem.

810 Ibidem.

811 PONDÉ, J. Um caso de gastrorrhagia nervosa em um arthritico. Revista Medica de S. Paulo, p. 107109, 1901. 
O autor apresenta o caso de uma paciente que ele acompanhou, de 15 anos de idade, segundo diz, francamente histérica, com crises convulsivas, hemorragias, nevralgias, dores em coluna vertebral e articulações dos pés, que resistiam a analgésicos, sendo que seus parentes tinham reumatismo gotoso.

O autor considera que a gota é a doença artrítica que tem mais relação com as neuropatias. Assim, ele acha que um acesso de gota pode ser substituído por uma alteração mental, que por sua vez, pode ceder a um ataque gotoso.

Pondé estende esses vínculos entre moléstias, associando nevralgias, moléstias da pele, cefaléia, artritismo, epilepsia, histeria e loucura, dentro do campo da neuropatologia e da hereditariedade. Refere a asma como uma nevrose, que se alterna com fenômenos de artritismo.

Em seguida, cita trabalho do professor Lancereux, apresentado na Academia de Medicina de Paris no ano anterior (1900), sobre hemorragias neuropáticas do aparelho digestivo. Esse autor associa esse quadro a outros, em que ocorre uma suposta alteração circulatória associada a quadro neuropático. A seguir, o autor relata caso de paciente de 50 anos, que situou dentro dessas características de hemorragia neuropática, pois não se enquadrava em outros tipos de hemorragia ${ }^{812}$.

Em 1904, na Gazeta Clínica, na seção “Clinica Psychiatrica”, é publicado o artigo do médico Manoel Bomfim, identificado como "Director do Laboratorio de Psychologia Experimental do Pedagogium”; o título do artigo é "Das alucinações auditivas dos 'perseguidos'”,813.

Nesse artigo o autor discorre sobre o “delírio chronico systematico"814, também chamado de "paranoia” 815 pelos autores alemães e italianos. Nesses casos, segundo Bomfim, a inteligência está subordinada ao sentimento, sem quebra da lógica do pensamento. Ele informa que, no início do quadro, essa moléstia se apresenta como um exagero do egoísmo, de um amor-próprio e, em geral, após os 35 anos, aparece o delírio.

Ele relata, então, alguns casos dessa moléstia, que viu em Paris.

812 PONDÉ, J. Um caso de gastrorrhagia nervosa em um arthritico. Revista Medica de S. Paulo, p. 107109, 1901. 813 BOMFIM, M. Clinica Psychiatrica: Das alucinações auditivas dos perseguidos. Gazeta Clinica, p. 149-154, 1904.

814 Idem.

815 Ibidem. 
Em 1904, Franco da Rocha publica na seção "Bibliographia” 816 da Revista Medica de São Paulo, um artigo a respeito da obra intitulada Simulacion de la loucura, de 1903, de autoria do psiquiatra J. Ingegnieros, de Buenos Aires. Franco da Rocha considera que esse livro esgota o assunto “simulação”.

Reportando-se ao texto de Ingegnieros, Franco da Rocha lembra que o conceito de simulação, na esfera biológica, foi empregado por Darwin, referindo-se a um meio na "luta pela vida", compreendendo o mimetismo e a homocromia. Conforme Franco da Rocha, o autor argentino também se refere à simulação dentro da idéia de luta pela vida entre seres humanos.

Em seguida, Franco da Rocha reproduz textualmente, em francês, uma condensação sintética do trabalho de Ingegnieros, acentuando que esse livro deve ser lido por todo homem de ciência que se dedique à psiquiatria ou à medicina legal, dando a entender que é partidário das idéias do psiquiatra argentino.

Nesse resumo, Ingegnieros refere que simulação e dissimulação estão presentes na sociedade humana, na luta pela vida. Esse autor observa que, "para a multidão anonima”, “saber viver é saber simular”.

Ingegnieros considera que a psicologia dos simuladores é complexa. Ele acha que, embora todo ser humano simule em algum grau, no simulador propriamente dito esse traço é marcadamente notório. Cita os fatores congênitos e os adquiridos como determinantes desses quadros.

Ingegnieros considera existir a simulação da loucura pelos sãos, na luta pela vida, e a “sobressimulação”(sursimulation) nos próprios alienados. Além disso, acha que os alienados com noção de sua loucura “dissimulam” (dissimulation), ou seja, disfarçam sua loucura.

Além disso, conforme o autor argentino, há também a simulação dos delinqüentes contra o meio jurídico-penal. Ele acha que, como meio de descobrir a simulação, jamais devem ser empregados meios coercitivos e tóxicos. Considera a observação em uma clínica psiquiátrica como melhor forma de diagnosticar esses casos.

Comenta ainda que as leis da simulação no mundo biológico (mimetismo) seriam observáveis na simulação da loucura pelos criminosos. Pensa que existe um

816 ROCHA, F. Bibliographia: Simulacion de la loucura, pelo Dr. J. Ingegnieros (Buenos-Ayres, 1903). Revista Medica de S. Paulo, anno VII, n. 1, p.8-11, 1904. 
estreito paralelismo entre as transformações do meio jurídico e a evolução da loucura. Assim ele associa biologia, evolução, loucura, simulação e leis.

Portanto, Ingegnieros faz correlações entre diversos campos e insere a simulação entre os supostos normais e a dissimulação (e sobressimulação) entre os doentes mentais. Assim, ele situa o fenômeno simulação/dissimulação em uma espécie de palco comum do teatro social da vida, onde loucos e sãos compartilham uma forma de expressão que, simulando e dissimulando, aproxima esses dois grupos de indivíduos; ou seja, os supostos normais simulam doença, e os doentes, dissimulando, parecem normais.

Em 1909, é publicado na Imprensa Medica, na seção “Psychiatria”, artigo intitulado "Da prophylaxia da loucura”817, de autoria de Alcides Codeceira, artigo esse extraído da Revista de Medicina de Pernambuco, que foi reproduzido em duas partes.

O autor refere que a noção de etiologia é o preâmbulo indispensável ao estudo da profilaxia das diversas moléstias. Assim, ele passa a relatar as causas das moléstias mentais. Divide-as em dois grupos: causas predisponentes e causas ocasionais. Ele evoca Krafft-Ebing para dizer que não há linha de demarcação entre esses dois tipos em casos concretos.

Informa o autor que as causas predisponentes podem ser gerais, ou individuais. Entre as gerais constam: a civilização, as raças, os acontecimentos políticos, as revoluções, as idéias religiosas, as superstições. Entre as individuais há: a herança, a idade, o clima, as fases lunares, a temperatura, o estado civil, a profissão, a educação.

Continuando, ele explica que as causas ocasionais podem ser psíquicas, fisiológicas ou patológicas. As psíquicas são: surmenage ${ }^{818}$, emoções, paixões, pesares, imitação, contágio, prisão. As fisiológicas são: puberdade, menstruação, prenhez, parto, lactação, idade crítica. As patológicas são: intoxicações, infecções, moléstias do sistema nervoso, afecções viscerais, diáteses variadas, moléstias cirúrgicas, operações, afecções dos órgãos dos sentidos.

$\mathrm{O}$ autor pretende esmiuçar as causas que tem visto mais frequentemente no manicômio da Tamarineira. Cita primeiramente as idéias religiosas e superstições que, segundo ele, dividem o hospício com os casos de alcoolismo e com os casos de sífilis.

817 CODECEIRA, A. Psychiatria: Da prophylaxia da loucura. Imprensa Medica, p. 296-301 e 344-346, 1909.

${ }^{818}$ Surmenage é similar a estafa, desgaste.

304 
Depois passa à herança, que considera a causa mais importante, por transmitir as predisposições psicopáticas. Ele diz que em psiquiatria, segundo Régis, a herança pode ser: vesânica (das loucuras); cerebral (das doenças cerebrais); nevropática (das nevroses); infectuosa (heredo-sifilis); tóxica (heredo-alcoolismo).

A seguir, discorre sobre a prisão como causa de alienação mental, segundo ele um fato inconteste. Assim, cita dados estatísticos de outros países e do manicômio da Tamarineira, onde conclui que dois terços dos internados vieram da Casa de Detenção. Ele supõe que a tara hereditária dos presos se alia a outros fatores facilitadores da loucura.

Em seguida, aborda a sífilis, que, segundo ele, tem posição saliente entre as causas de psicoses e é a segunda causa no manicômio em que trabalha. Assim, divide os quadros ligados à sífilis em: psicoses da sífilis precoce; psicoses da sífilis tardia; psicoses parassifilíticas (da tabes e da paralisia geral).

A seguir, o autor discorre sobre o alcoolismo, que refere ser a primeira causa de loucura no manicômio da Tamarineira. Ele considera esse um verdadeiro flagelo da sociedade em geral, independente de classe social e raça, conforme suas observações.

Assim, partindo para a idéia de profilaxia, o autor considera necessário centrarse em: alcoolismo, sífilis, prisão, herança, idéias religiosas e misticismo.

O autor cita que leis proibitivas do uso do álcool, em estudo ou aplicação em outros países, seriam temerárias no Brasil, já que o povo está por demais enraizado nesse vício, e também porque existe, segundo o autor, uma oposição a toda medida coercitiva, venha ou não para o bem da coletividade. Assim, as disposições contra o álcool só podem ser aplicadas em casos agudos e públicos. Um melhor controle sobre os estabelecimentos de vendas de bebida também é difícil, pois, conforme o autor, o povo tem oposição sistemática ao cumprimento de disposições legais. Ele cita como exemplo a Suécia e a Noruega, onde diminuiu razoavelmente o alcoolismo, em virtude de regras, e também porque estabelecimentos de venda de bebidas devem promover a fundação de ligas anti-alcoólicas. Assim, conforme esse exemplo, Codeceira acha que pode ser feito algo através das ligas anti-alcoólicas e por criação de colônias para o tratamento de alcoólatras.

Quanto à profilaxia da sífilis, o autor diz que é difícil e que uma forma de abordar esse problema pode ser dispor o tratamento com facilidade aos doentes, como forma de divulgar cuidados a respeito desse mal. Codoceira refere que as tentativas de 
regulamentação da prostituição em alguns lugares, para prevenir a sífilis, parece não ter resultados animadores.

Sobre a profilaxia nas prisões, o autor recomenda a presença de um psiquiatra nas casas de detenção, o banimento da prisão celular e confiar a direção dos presídios a homens de reputado valor científico.

Sobre o item religião e superstição, ele considera necessário libertar a massa popular dos excessos da pratica religiosa que toca as raias do fanatismo e, conforme diz, evitar práticas de feitiçaria e espiritismo.

A respeito da causa hereditária, recomenda que os tarados sejam vigiados desde a infância, com boa alimentação e boa educação e com orientação em outras fases da vida. Quanto á procriação, acha que os casamentos consangüíneos só devem ser evitados se algum dos cônjuges apresentar alguma tara, enquanto que acha bom evitar casar muito jovem ou muito velho, ou sendo portador de moléstia que venha a trazer conseqüências para a descendência.

Em 1910, na Revista Medica de S. Paulo, Enjolras Vampré publica o artigo “Um caso de paranoia”, ${ }^{819}$. Este artigo relata o caso de um soldado, que foi encaminhado ao Hospício pela Força Pública, e que não sabia o motivo de ter sido para lá mandado, pois se dizia perseguido, insistindo que devia sua reclusão "aos civilistas de São Paulo”, pois ele se dizia "hermista e acha que todos os militares devem moralizar sua farda". Além disso, ele também se considerava um profeta e curador, guiado por uma força magnética. Vampré relata que o paciente tinha conduta “corretissima” no hospício, o que lhe fez questionar se certa sensação que o doente tinha, da ação exercida por uma suposta força magnética, não seria ser talvez uma forma de alucinação. Enfim, Vampré acabou concluindo que se tratava de um caso de paranóia.

Em 1910 é publicado na Imprensa Medica, na seção "Psychopatias”, artigo intitulado "Psychoses alcoolicas” ${ }^{\text {(20 }}$, pelo prof. Marcio Nery, constando que se trata de "Memoria apresentada ao IV Congresso Medico Latino Americano”.

O autor frisa que usa o termo "psychose alcoolica” para se referir às alterações duráveis, que são determinadas "sobre o espírito”, pela intoxicação por bebidas

819 VAMPRÉ, E. Um caso de Paranoia. Revista Medica de S. Paulo, p. 103-104, 1910.

820 NERY, M. Psychopathias: Psychoses alcoolicas - (memória apresentada ao IV Congresso Medico Latino Americano), Imprensa Medica, p. 1-6 e 17-23, 1910. 
alcoólicas. Assim, ele deixa de lado os casos de embriaguez aguda. Nery informa que usa o termo "delírio alcoolico" apenas para as manifestações de delirium tremens.

Ele diz que o termo "psychose” é usado de maneira variada pelos autores, lembrando que os filósofos alemães lhe dão um significado no singular (Psychose) como “estado da alma em suas manifestações normaes”, oposta à que o termo tem quando usado no plural (Psychosen) como "condições anormaes da mentalidade”.

No entanto, informa Nery que o termo "psychose”, no singular, assumiu outro sentido nas línguas latinas, significando também afecção ou moléstia mental. De qualquer modo, para o alcoolismo, ele acha que a designação “psychose” é mais apropriada do que “delírio”.

Em seguida, o autor comenta que, em tempos remotos, o ser humano já fazia uso de bebidas alcoólicas, e cita bebidas utilizadas pelos indígenas. Ele acha que esse antigo uso criou uma necessidade orgânica por essa intoxicação, de modo que se tornou uma necessidade hereditária.

Nery informa que Magnus Huss, de Estocolmo, em torno de 1849-1851, começou os estudos de alcoolismo crônico. Desde então os trabalhos são inúmeros.

Ele informa que o alcoolismo crônico predomina entre 25 e 45 anos. Diz que Magnan não considera que o álcool isoladamente seja epileptizante, mas pode ser, quando associado a outras substâncias como absinto, aniz, etc.

O autor acha que a intoxicação dos centros nervosos pelo álcool pode mascarar outros quadros concomitantes, de modo que a moléstia principal pode passar despercebida. Supõe também que, outras vezes, o álcool põe em evidência certas alterações que estavam latentes, como, por exemplo, em caso de paranóia. Informa que alguns alcoólatras submetidos a cirurgias, após o procedimento, apresentaram delírios que se prolongaram por anos.

Outra possibilidade, conforme Nery, corresponde ao que se chama moléstia de Korsakoff, onde há polinevrites e desordens mentais. Quanto ao quadro de delirium tremens, o autor cita vários estudos e discussões em torno de seu entendimento. O autor acrescenta, então, que o uso crônico do álcool acaba levando à demência, de modo que, nesta situação, aparecem outras alterações no organismo por conta dessa substância, entre elas os quadros vasculares e a arteriosclerose. Ele frisa que, em grau extremo, o alcoolismo crônico pode levar a um quadro semelhante à paralisia geral progressiva. 
Em suas considerações, o autor faz citações dos estudiosos Magnan, Legrain, Lancereaux, Jouffroy, Serveux, Wildermuth, Lasègue, Kraepelin e outros, incorporando noções tanto de autores franceses como de alemães.

Em 1910, na Imprensa Médica, na seção "Psychiatria”, é publicado o artigo “Significação semiologica das alucinações” ${ }^{821}$, da autoria de Alcides Codoceira, professor da Escola de Pharmacia de Pernambuco.

O autor refere que, a partir de discussão ocorrida na Sociedade MedicoPsychologica de Paris, em 1885, a respeito das alucinações, manteve-se o dilema, se os alucinados são sempre loucos, ou se essa pode ser uma condição normal do ser humano.

O autor expõe como as opiniões se dividem entre os estudiosos. Alguns discordam de atribuir a loucura a indivíduos tidos como gênios da humanidade, e consideram a alucinação como fisiológica. Os que assim pensam, citam como exemplo dessa hipótese, as alucinações do homem simples do campo, em relação às suas próprias crenças.

Frisa o autor que esse modo de pensar pode suprimir a linha de demarcação entre coisas distintas, como saúde e moléstia, delírio e razão, sonho e vigília.

Por outro lado, o autor cita exemplos de estudiosos que observaram casos de alucinação mais claramente associados a doenças mentais definidas.

No fim do período 1899-1912, Franco da Rocha retoma um assunto que já tinha sido tema de trabalho anteriormente, publicado na Alemanha. Assim, ele estudou novamente a loucura nos negros. Desse modo, em 1911, é publicado, em francês, na Revista Medica de S. Paulo, o artigo Contribuition a l'etude de la folie dans la race noire de Franco da Rocha ${ }^{822}$.

O autor inicia, dizendo que, doze anos antes, já tinha publicado artigo sobre manifestações psicopáticas na raça negra, na revista "Allgemeine Zeitschrift für Psychiatrie (Berlin, 1898)”. Neessa pesquisa, contou com 89 doentes. Neste outro trabalho de 1911, contou com 285 pacientes da raça negra.

821 CODOCEIRA, A. Psychiatria: Significação semiológica das hallucinações. Imprensa Medica, p. 230235, 1910.

822 ROCHA, F. Contribuition a l'etude de la folie dans la race noire. Revista Medica de S. Paulo, p. 458$462,1911$. 
O autor considera que os negros do Brasil receberam um "ligeiro verniz de cristianismo sobre o solido fetichismo de seus ancestrais" ${ }^{\text {823 }}$. Ainda conforme o autor, “embora a escravidão já tenha terminado ha 22 anos” "824, os seus efeitos ainda persistem sobre a mentalidade da raça negra, com condições inferiores de mentalidade em relação à raça branca, considerado apenas em média, “deixando de lado as exceções”.

Franco da Rocha diz que não se trata aqui de saber se o negro deve ser igual ou não ao branco, sob a influência da cultura e da evolução. Nesse sentido, ele lembra que essa é uma questão que apaixona "os Americanos do Norte”, citando um então recente “libelo contra o negro”, no livro The Color Line de W. Smith, em acordo com idéias do naturalista T. Huxley.

Franco da Rocha considera que essa discussão está longe do terreno da psiquiatria. Assim, ele faz algumas ponderações, dizendo ter encontrado raros casos de “demencia paralitica” entre os negros, enquanto que o alcoolismo e a sífilis são comuns nesse grupo. O autor também refere que há, entre os negros, maior ocorrência de dementes no sexo feminino, enquanto que, nos brancos, ocorrem mais no sexo masculino. Ele associa isso à menor exposição da mulher branca às adversidades.

Ao comentar sobre o alcoolismo, ele diz que, após a libertação, os negros se entregaram mais facilmente à bebida alcoólica, sendo esse um fator que compromete “raças inferiores ou superiores”. Ilustrando esse aspecto, o autor diz que o nosso indígena, “que pertence a uma raça inferior”, tem amor imoderado pelas bebidas fermentadas, do mesmo modo que o alemão pela cerveja e o escocês pelo whisky. Ele acha que o alcoolismo pode explicar a alta taxa de epilepsia entre os negros.

\section{3. 12. - Concepções psicológicas e noções sobre o sistema nervoso (1899-1912).}

Na sessão solene de recebimento do cargo de presidente da Sociedade de Medicina e Cirurgia de São Paulo, em $1899^{825}$, o médico Guilherme Ellis refere que a fraqueza e a doença do brasileiro se devem a uma má educação e que os estrangeiros não têm mais inteligência do que nós, frisando que a massa encefálica é a mesma, mas que eles a empregam melhor.

823 Idem.

824 Ibidem.

${ }^{825}$ ELLIS, G. Boletim da Sociedade de Medicina e Cirurgia de São Paulo; Discurso proferido pelo Dr. Guilherme Ellis na sessão de posse de 7 de março. Revista Medica de São Paulo, p. 92-93, 1899. 309 
Ellis diz que essa fraqueza já começa em tenra idade, e exemplifica com o caso de uma criança que ele conheceu saudável e que depois estava fraca, em virtude de a mãe ter passado, precocemente, a dar leite de vaca para a criança, para que os pais pudessem sair em atividades sociais. Ellis acentuou como causa, a ocorrência de desmame precoce, atribuído a preocupações vaidosas da mãe, acima dos “commandos da natureza”. Ele refere que o leite natural protege a criança de doenças.

Diz também que não é pelo número de horas diante de um livro, como uma espécie de castigo, que a criança vai aprender. Cita outros países, onde um dia escolar com atividades físicas e artísticas confere boa disposição de espírito e saúde. Acrescenta que, nos Estados Unidos, as doações de pessoas ricas deixaram de ir para os hospitais e passaram a ir para escolas e universidades, pois "quem tem uma educação, raramente precisará de um leito de hospital”826.

Ao tempo em que Ellis frisa o valor da educação como mais importante do que conformar-se ao atavismo, no ano seguinte, Pereira Barretto acentua a necessidade do raciocínio lógico para bem conduzir a reflexão científica. Além disso, procura integrar a doutrina neuronal com a filosofia e a psicologia.

Assim, em 1900, em um Boletim da Sociedade de Medicina e Cirurgia de São Paulo, publicado na Revista Medica, foi registrada a palestra do médico Luiz Pereira Barretto, sob o título de "Epidemiologia” e com o subtítulo “A logica como instrumento de pesquiza no estudo da epidemiologia”,827.

Pereira Barretto faz conjecturas, entre a filosofia e a biologia, sobre a forma de raciocínio lógico em ciência, extrapolando suas reflexões para as possibilidades de explicação dos distúrbios mentais. A partir de Aristóteles, lembra que tudo que está no intelecto entra pelos sentidos, de modo que o mundo externo é o regulador da razão positiva, de modo que, segundo ele, o excesso de subjetividade é a causa mais comum de alienação mental. Mas ele ressalva que a objetividade excessiva pode formar o imbecil.

Depois o autor faz considerações a respeito dos mecanismos cerebrais associados às funções mentais, no sentido de gerar o pensamento lógico, dizendo que os neurônios, da substância cinzenta de certa região do cérebro, trabalham as sensações e as

826 ELLIS, G. Boletim da Sociedade de Medicina e Cirurgia de São Paulo; Discurso proferido pelo Dr. Guilherme Ellis na sessão de posse de 7 de março. Revista Medica de São Paulo, p. 92-93, 1899.

${ }^{827}$ BARRETTO, L.P. Epidemiologia: A lógica como instrumento de pesquiza em epidemiologia. Boletim da Sociedade de Medicina e Cirurgia de S. Paulo. Revista Medica de São Paulo, p. 197-203, 1900. 
transformam em idéias. Em seguida, ele diz que em uma região superior ocorre a transformação das idéias em concepções abstratas.

A seguir, cita o beneficio da capacidade de abstração e também o risco de escapar ao mundo externo e "ser lançado sem governo nos mais extravagantes desvarios”. Sendo assim, o autor explana como entende poder-se conduzir bem o nosso espírito, principalmente através do estudo e da ciência, através de severa disciplina, acentuando que a matemática e as ciências naturais são indispensáveis à arte de observar.

Pereira Barretto então passa a associar a química e a física ao método da observação e ao método da experimentação; em biologia, acrescenta o método da comparação. Desse modo, ele considera que a lógica científica inclui esses três métodos: observação, experimentação e comparação.

A partir daí, ele sugere aplicar essas noções ao estudo das epidemias. Relata que Simond utilizou um modelo de lógica científica, para descobrir o processo que levaria ao aparecimento da peste bubônica. Pereira Barretto acha que o mesmo raciocínio deve ser usado para descobrir a causa da febre amarela. Ele acha que falta à classe médica de S. Paulo um pouco desse severo espírito de lógica científica, completando com sua opinião de que não acredita que o suposto "bacilo icteroide”, causador da febre amarela, possa ser transmitido pelo ar, mas acha que é transmitido pela água, tendo como provável aliado o pernilongo.

No início do século $\mathrm{XX}$, ganha espaço o processo educativo aplicado a pacientes com alterações mentais de nascença.

Desse modo, em 1902, na Revista Medica de São Paulo, é publicado, em duas partes, o artigo do médico Carlos Fernandes Eiras, intitulado "Da educação e tratamento medico pedagogico dos idiotas” ${ }^{828}$. O autor refere ter-se baseado em trabalhos estrangeiros, principalmente de Bourneville, o então diretor de Bicêtre. Acerca de seu próprio trabalho, ressalta Eiras que representa um grito de socorro em favor dos deserdados da sorte, abandonados física, moral e intelectualmente, que desde a infância são vítimas da natureza, considerados como idiotas. Ele se refere então à superação de dificuldades para educar os idiotas. Chama essa educação de tratamento médicopedagógico e refere que na Europa e nos Estados Unidos já existe esse trabalho.

\footnotetext{
${ }^{828}$ EIRAS, C. F. Da educação e tratamento medico pedagogico dos idiotas. Revista Medica de São Paulo, , p. , 1902. 
Eiras considera que, sem educação, eles acabam se tornando perversos, ou criminosos, levando o Estado a despender dez vezes mais com polícia e justiça, do que gastaria com a educação dos mesmos.

O autor refere que, quem primeiro empregou a educação nesses casos, foi o médico Itard, diretor do Instituto de Surdos-Mudos de Paris, ao educar um menino de 11 ou 12 anos encontrado em estado inteiramente selvagem, no início do século XIX. Depois, ainda conforme o autor, veio um período com as obras de Pinel, Esquirol, Belhome, Ferrus, Voisin, Delasiauve. Porém, ele acentua o papel de Seguin, discípulo de Itard e de Esquirol, que criou o método de tratamento médico-pedagógico da idiotia, com seu primeiro trabalho de 1838. Assim, Eiras se refere a esse estudioso: “Conduzir a creança, como que pela mão da educação do systema muscular á do systema nervoso, especialmente a dos sentidos, e desta ás noções, das noções ás idéas, das idéas á moralidade, tal foi o fim que procurou Seguin attingir”.

Segundo Fernald, citado por Bourneville, esse método foi confirmado pelas “experiencias modernas e pelas pesquizas psychophysiologicas”. Carlos Eiras refere-se então a outros estudiosos de outros países, culminando com Bourneville em Bicêtre, que iniciou seus trabalhos em 1878.

O autor passa então a explicar o funcionamento do cérebro, fazendo uma comparação com uma nação de estados confederados, fazendo assim uma analogia do órgão mais nobre, “que contem as faculdades superiores”, com a recente República.

Em seguida, Eiras explica as funções de cada região do cérebro, falando de áreas com neurônios, que tornam conscientes, sob forma de imagens mnemônicas, certas impressões sensitivas. Cita também outras regiões e fibras de associação, de modo que sintetiza tudo nas funções de: sensação, pensamento e ação. Diz que o comprometimento de neurônios de diversas áreas pode levar à idiotia.

Carlos Eiras fala, então, da importância da educação e do método médicopedagógico que teve a oportunidade de conhecer em Paris, com Magnan. Descreve os métodos de Seguin e Bourneville para educar a marcha, os pés, as mãos, a fala dos pacientes, podendo complementar com ginástica, dança, canto, música e jogos; eventualmente com o ensino primário e com habilidades profissionais. 
Em 1902, Souza Brito profere palestra no Centro de Sciencias, Lettras e Artes de Campinas, com o título “O Magnetismo animal e suas manifestações” ${ }^{829}$. Essa palestra foi publicada em três partes na Revista Medica de São Paulo.

O autor faz longa exposição com detalhes históricos. Ele refere que fatos da antiguidade, pertencentes ao ocultismo e às primeiras fases da história da Medicina, eram determinados pela sugestão, conforme as interpretações científicas e experimentações vigentes no período de sua palestra.

Passa, então, pelo mesmerismo e depois pelos estudos a respeito desse fenômeno, bem como por outros tantos estudos do século XIX sobre hipnotismo, chegando às escolas de Salpêtrière e de Nancy. Após discorrer sobre a capacidade da sugestão na sociedade, o autor considera que a hipnose, ou a terapêutica sugestiva, só deve ser usada por médico e nunca de forma recreativa, pois: “a suggestão annula a personalidade consciente, torna o individuo automato da vontade alheia para acções as mais extravagantes e criminosas ${ }^{830}$,

Em 1903, na seção “Bibliographia”, Franco da Rocha publica comentários sobre a tese inaugural do médico Ribeiro Gonçalves defendida na Bahia em 1902, intitulada “Menores delinquentes"831.

Franco da Rocha assinala inicialmente um capítulo intitulado "Psychologia da infancia”, a respeito de uma psicologia que ele considera científica, superando uma outra que ele remete ao "terreno das curiosidades philosophicas":

“Precede á Etiologia do Crime um capitulo bem traçado da Psychologia da infancia, onde o auctor defende a boa doutrina, embora dura e offensiva ao sentimentalismo piegas dos que estudam a psychologia não á luz da observação rigorosa dos factos, mas com preconceitos que a sciencia já relegou para o terreno das curiosidades philosophicas”832.

Em seguida, ele explica que o autor é favorável a uma interpretação de que o egoismo precede o altruismo, havendo na criança as mesmas tendências consideradas prejudiciais presentes no adulto, que são moduladas, conforme diz, pela educação e pela hereditariedade, citando Spencer para reforçar sua opinião.

\footnotetext{
${ }^{829}$ BRITO, S. O Magnetismo animal e suas manifestações. Revista Medica de S. Paulo, 1902, p. 302. 830 Idem. 831 ROCHA, F. Menores delinquentes (These inaugural do Dr. Ribeiro Gonçalves - Bahia, 1902). Revista Medica de S. Paulo, p. 77-79, 1903. 832 Idem. 
Franco da Rocha detalha o que pode formar um menor criminoso, citando fatores hereditários e influências do meio, como o alcoolismo, as nevroses, as psicoses, tendências ao crime, moléstias constitucionais dos ascendentes. Ele acha que quando esses indivíduos têm posição privilegiada na sociedade, podem ficar menos propensos a praticar crimes, embora continuem "perversos"; quanto aos menos favorecidos socialmente, o autor diz que não têm a mesma sorte.

Ele aponta os institutos correcionais como medida aliviadora do problema, “como o que acaba de se crear em São Paulo”833, mas ressalvando que alguns indivíduos, mesmo assim, “não tomam o bom caminho”. Além de felicitar o autor da tese, Franco da Rocha conclui, dizendo que “em São Paulo já temos o prazer de dizer que se comprehendeu esse assumpto devidamente» ${ }^{\text {} 834}$.

Em 1904, na Revista Medica de São Paulo, na seção “Bibliographia” foi publicada uma nota intitulada "O facto psychico", a respeito de uma publicação de Manoel Bomfim: “O objecto da Psychologia. Introducção a um curso de psychologia, pelo Dr. M. Bomfim, Professor da Escola Normal do Rio de Janeiro. Folheto de 27 paginas contendo uma erudita lição de psychologia”,835.

Essa é uma primeira nota, a aparecer nas publicações médicas paulistas, que faz uma menção direta a uma atividade de psicologia feita no Brasil, de maneira formal, relativa a um médico brasileiro estudioso de psicologia.

A Gazeta Clinica, em 1908, transcreve um artigo do Jornal do Commercio, acerca de uma palestra do professor Dumas, da Sorbonne, intitulada "Psychologia dos moribundos"836.

O professor faz duas indagações: “como se comporta o eu em presença da idéia da morte e o que a morte faz do eu, ou como o dissolve”837. Desse modo, ele passa a uma série de relatos de vivência de proximidade da morte, em que os indivíduos referiram ter visto passar toda sua vida de maneira rápida. O professor cita outros psicólogos, que

833 ROCHA, F. Menores delinquentes (These inaugural do Dr. Ribeiro Gonçalves - Bahia, 1902). Revista Medica de S. Paulo, p. 77-79, 1903.

834 Ibidem.

835 BIBLIOGRAPHIA. BOMFIM, M.; O objeto da Psychologia. Revista Medica de S. Paulo, p. 517, 1904.

836 DUMAS, G. Psychologia dos Moribundos. Gazeta Clinica, p. 108-110, 1908.

837 Idem. 
questionam o valor dessas narrativas, dizendo que essas lembranças são apenas cenas recapituladas, e que estão associadas ao que o Prof. Egger chama de "eu vivo”, que corresponde a uma “ idéia presente e colorida da vida que levou o eu”,838.

Dumas concorda com Ferré, o qual considera que todas essas experiências se devem a "phenomenos de exaltação cerebral, provocados por um começo de asphyxia”839. Ele também considera que pode haver uma excitação afetiva e intelectual, em virtude da proximidade da morte, que, associada à formação religiosa do individuo, provoca toda uma gama de manifestações.

Em 1908, foi publicada resenha, na Revista Medica de S. Paulo, referente a trabalho do Dr. Cleye Shaw, publicado na revista Lancet, em maio de 1908. Esse artigo intitula-se “A psychologia feminina" ${ }^{840}$.

O texto comenta que foi feito estudo minucioso procurando avaliar semelhanças e diferenças entre a psicologia dos dois sexos. Conclui-se que as semelhanças são absolutas e manifestas, enquanto as diferenças são acidentais e quase fortuitas. Foi estudada a emotividade, a afetividade, a memória, a vontade, o caráter, a percepção, o raciocínio, a atenção, a ideação. O texto comenta então que o Dr. Shaw concedeu á mulher “o direito ao voto”.

Conclui-se, dizendo que o Dr. Shaw acha que, a despeito das conquistas políticas, materiais e sociais, as mulheres não devem renunciar à feminilidade.

Em 1910, foi publicado um artigo na Revista Medica de S. Paulo intitulado “A cafeina”, de autoria do médico Mathias Valladão ${ }^{841}$.

Valladão refere-se aos estudos mais recentes a respeito da cafeína e suas propriedades estimulantes de “melhoramento apreciável dos processos psíquicos”, ${ }^{\text {, }}$, se comparado a outros agentes químicos. Ele reforça que “os modernos estudos de psychometria permittem demonstrar de uma maneira positiva esta acção da cafeína sobre as funcções cerebraes" ${ }^{\text {843 }}$.

838 DUMAS, G. Psychologia dos Moribundos. Gazeta Clinica, p. 108-110, 1908. 839 Idem. 840 VARIEDADES. A psychologia feminina. Revista Medica de S. Paulo, p. 497, 1908. 841 VALLADÃO, M. A cafeina. Revista Medica de S. Paulo, p. 224-228, 1910. 
No detalhamento dessa psicometria, o autor cita um conceito denominado “equação pessoal”, que diz respeito ao “intervallo de tempo, variável com os differentes cerebros, entre o momento da excitação de um nervo sensorial e a respectiva notação do phenomeno" ${ }^{\text {844 }}$. Nesse sentido, ele fala em medida da velocidade do pensamento, da duração de uma operação intelectual. Assim, ele se refere a um aparelho denominado “neurobiometro”, que utiliza respostas a um estímulo visual. Da mesma forma, ele se refere a medidas de percepção, discernimento, volição, associação de idéias. Segundo o autor, só a cafeína produz aceleração acentuada e persistente “dos actos psychicos”. Assim, ele diz que o café "foi sempre tido como a bebida intellectual por excellencia”845. O autor reforça a idéia de que o café é o mais indicado para esse efeito estimulante, por ser também rico em substâncias minerais, de modo que Valladão considera útil para “reerguer um systema nervoso deprimido",846.

\section{3.13 - Modernidade, sociedade, cérebro e mente (1899-1912)}

Em 1905, é publicada na Imprensa Medica resenha intitulada “A neurasthenia do operario e do proletario" ${ }^{847}$. Assim inicia esse texto:

“Até certo tempo a neurasthenia foi considerada apanagio das classes abastadas, não se cogitando da possibilidade de manifestar-se no operario e no proletario. Recentemente, porém, Ella tem sido observada em operarios e proletarios, conforme se deprehende de trabalhos publicados por Leubuscher e Bibrowicz, na Allemanha, e Iscovesco, na França”.

O texto prossegue, informando que os estudiosos alemães observaram 1.564 operários neurastênicos tratados no sanatório de Bulitz, tendo sido incapacitados para o trabalho. Esses autores acham que há um gradual aumento desses casos e atribui sua causa “a uma desproporção entre o trabalho produzido pelo operario e o lucro respectivo, bem como o meio em que elle vive e as suas aspirações”. Além disso, cita-se que Leubruscher e Bibrowicz acrescentam:

“a indifferença do operario pelo trabalho que é forçado pelas suas condições sociaes, o esgotamento physico consequente, as noites mal passadas em reuniões, conferencias ou em estudos para completar sua educação, provocam um verdadeiro esgotamento intellectual,

844 VALLADÃO, M. A cafeina. Revista Medica de S. Paulo, p. 224-228, 1910.

845 Idem.

846 Ibidem.

847 MOVIMENTO MEDICO. A neurasthenia do operario e do proletario. Imprensa Medica, p. 273-274, 1905. 
quando não excessiva tensão de espírito, dois factores de importancia capital na pathogenia da neurasthenia”848.

Conforme o texto, há diferença entre a neurastenia dos abastados e do proletário. Nestes, observa-se maior secura da pele e da boca, além de que seu estado mental tende mais para uma indiferença em relação ao que se passa a seu redor.

Cita-se que Iscovesco considera essa forma de neurastenia correspondente ao último período da moléstia, ou ainda que pode se dever a atrofias de glândulas do organismo. È também comentado que talvez a neurastenia das classes operárias possam explicar alguns casos de suicídio.

Em 1905, na Revista Medica de S. Paulo, na secção Revista das Revistas, é publicada uma resenha sobre a tese defendida da Escola de Lyon pelo médico E. Blanchet intitulada "O papel therapeutico do automovel”,849.

Nesse trabalho, o Dr. Blanchet considera o automobilismo indicado para doentes de tuberculose, asma, "nevropathas", neurastênicos, gotosos, diabéticos e reumatismo. Ele considera esse sport um "vigoroso excitante”.

No ano seguinte há outra publicação sobre esse tema. Em 1906, é publicado na Revista Medica de S. Paulo o artigo intitulado “O automobilismo sob o ponto de vista da hygiene e do tratamento das molestias”, traduzido do periódico Societé de therapeutique, datado de 10 de outubro de 1906, de autoria do médico Paul Le Gendre $^{850}$.

O autor refere que o higienista e o médico devem se preocupar com os automóveis, assim como se preocuparam antes com a bicicleta, haja vista certas particularidades que apresentavam, bem como a transformação nos hábitos que eles causaram (inclusive o autor cita ter-se pronunciado a respeito da influência da bicicleta na saúde em congressos de 1893 e 1894). De modo semelhante, ele passa a detalhar as variáveis observadas no que chama de “automobilismo”, como a velocidade, a trepidação, “a ducha de ar”, o resfriamento, a poeira, a imobilidade prolongada, “o estado psychico do conductor e dos outros viajantes”851.

\footnotetext{
848 Idem, p. 274.

${ }^{849}$ REVISTA DAS REVISTAS. BLANCHET, E.; O papel therapeutico do automóvel. Revista Medica de São Paulo, p. 267, 1905.

850 LE GENDRE, P. O automobilismo sob o ponto de vista da hygiene e do tratamento das molestias. Revista Medica de S. Paulo, p. 505-508, 1906.

851 Idem. 
$\mathrm{O}$ autor enumera os mais diversos efeitos do automobilismo, benéficos ou prejudiciais, nas diferentes partes do organismo. Considera indicado aos “neurasthenicos e os psychasthenicos”. Pela necessidade de concentração para o desempenho dessa atividade, ele também é indicado aos homens preocupados com negócios ou com a saúde:

É em parte por este motivo que bom numero de medicos têm depressa adquirido o gosto e muitas vezes a paixão por esse meio de locomoção, que os subtrahe nos intervallos das visitas á obsessão da clientela. Podemos, pois, logicamente aconselhar o automobilismo aos que têm necessidade do olvido e de repouso do espirito. Há, porem uma categoria de (...) 'cerebraes' , que são incapazes de usar com moderação de tudo que lhes pode proporcionar uma variedade de distraç̧ão (...) se constituem um perigo publico quando (...) fazem 120 k.»"852.

O autor acha desaconselhável a “epilépticos, alcoolistas e absinthistas". “Quanto aos transportados passivamente, conforme seu estado nevropathico (...) podem encontrar distracções ou uma espécie de inhibição do pensamento ou um estimulante vantajoso, e satisfazer a essa necessidade cada vez mais crescente nos contemporâneos, de movimentação incessante e rápida”853.

Em 1907, é publicado na Revista Medica de S. Paulo um longo artigo intitulado "O medico na sociedade do futuro", pelo médico Saul de Avilez, sendo esse texto apresentado no Sexto Congresso Brazileiro de Medicina e Cirurgia ${ }^{854}$.

O autor inicia, com receio pelo futuro da profissão médica, dizendo que se está em um século de individualismo exacerbado. Ele faz comentários sobre a sociedade, a política e a ética. Critica os médicos que fazem espetáculo na imprensa, com coisas ainda não esclarecidas pela ciência:

"Por isso o publico se interessa pelas theorias medicas, pelos methodos therapeuticos, pela competencia dos profissionaes com o mesmo esnobismo com que acompanha os novos perfumes e os novos figurinos. São como artigos de moda, novidades da estação: o medico, o microbio e o remedio; e o povo se diverte fazendo disso um sport”855.

Depois ele ataca a crise econômica que avassala todas as classes trabalhadoras, “espoliadas pelo capitalismo" e se refere a aspectos decorrentes das descobertas

852 LE GENDRE, P. O automobilismo sob o ponto de vista da hygiene e do tratamento das molestias. Revista Medica de S. Paulo, p. 505-508, 1906.

853 Idem.

854 AVILEZ, S. O medico na sociedade do futuro. Revista Medica de S. Paulo, 318-329, 1907.

855 Idem, p. 322. 
científicas, que criam necessidades artificiais no homem moderno, aumentando o desespero dos que não podem satisfazê-las:

“Todas as sciencias progrediram e a humanidade recebeu o beneficio das conquistas scientificas (...) As invenções materiaes, porém, se multiplicando, a proporção que dos laboratorios vêm a luz novas descobertas, criam no homem moderno uma variedade crescente de necessidades artificiaes, que augmentam o desespero dos que não as podem satisfazer e a avidez dos insaciaveis, levando ao extremo a desordem social”856.

Desse modo, ele acentua a discrepância entre a riqueza material e a consciência, havendo a inquietude da vida moderna, com conflitos entre raças e classes, dizendo que a classe literária tornou-se um proletariado intelectual.

Coloca-se contra os que querem acabar com o segredo profissional em medicina, levados por teorias hodiernas, que alegam prejuízos à sociedade. Adverte para o fato de os médicos estarem deixando algumas áreas de sua profissão livres para outros interessados:

"Inadvertidamente os medicos vão alienando de si certos encargos que outros profissionaes vão incluindo entre os seus misteres e que individuos, mesmo sem profissão, aproveitam para exploral-os, annunciando-se especialistas. Ora, o medico deve rehaver essas especialidades (...) É assim que a medicina esthetica, a massagem, a electrotherapia, a radiographia, a hydrotherapia, as analyses chimicas de diagnostico, etc. constituem hoje negocios comerciaes ou expedientes do charlatanismo" ${ }^{\text {"857. }}$.

A seguir, o autor refere-se ao grande desenvolvimento das "sciencias medicas" na segunda metade do século XIX, que modificou a prática da medicina e adentra a um comentário sobre as especializações:

“Ás especialisações scientificas vão correspondendo também especialidades da clinica. A proporção que os estudos e as indagações se aprofundam, se concentram a cada orgam, a cada grupo de enfermidades, a cada sexo, a cada periodo da vida e a cada molestia, o especialismo clinico, vae correlativamente subdividindo-se, restringindo-se, extremando-se. A especialisação parece a condição mesma do progresso da sciencia” ${ }^{\text {"858 }}$.

Nessa linha, o Avilez refere que a higiene, a profilaxia, a terapêutica e os “conhecimentos modernos de pathogenia” produzem uma crise profissional na medicina. Mas, ele acentua que, na medida em que se restringe a medicina curativa, amplia-se os domínios da medicina preventiva, de modo que, segundo o autor, a arte de curar o individuo, completa-se na ciência de defender a sociedade.

856 AVILEZ, S. O medico na sociedade do futuro. Revista Medica de S. Paulo, p. 323, 1907. 857 AVILEZ, S. O medico na sociedade do futuro. Revista Medica de S. Paulo, p. 325, 1907. 858 Idem, p. 326. 
Com um tom um tanto crítico ao "especialismo", o autor acha que no futuro o médico será pago para manter a saúde, em vez de curar doenças. Assim também diz que o “médico das famílias”, afastado pelo especialismo, voltará a ser o confidente e conselheiro da família.

A seguir, o autor faz longos comentários sobre a importância do "médico escolar” e todas as suas atribuições, incluindo orientações sobre exercícios físicos, liberdade, recreio, divertimentos ao ar livre e repouso. Inclui o cuidado com os que tiverem deficiência mental. $\mathrm{O}$ autor lamenta o que ele chama de "a moléstia do estado social”:

“Na hora actual da civilisação, não é só o corpo que precisa ser curado e preservado, o que está doente é o espirito e é a consciencia. Dir-se-ia que a molestia é o estado social, tal é o aspecto da vida contemporanea, de febre, de nervosismo, de miseria, e corrupção em que a humanidade se intoxica, se esgota, degenera e sucumbe. São as selvagerias morbidas do arrivismo, em que a ambição se hypertrophia, o egoismo se ankilosa e precipitam o homem de cabeça para baixo, no mar morto dos abusos. São os vicios, os excessos que se apoderam do homem, logo ao primeiro alvorecer da mocidade e dão-lhe cedo um desgosto profundo, uma sensação perfida da existencia: a visão do vacuo, onde nada ha digno de uma aspiração digna ou dão-lhe a ansia de devorar o maximo da vida no minimo de tempo" ${ }^{\$ 89}$.

Ele cita então uma série de moléstias, dizendo que esses males são de origem social, que não basta isolar a vítima do convívio de outras pessoas:

"São a tuberculose, a syphilis, o alcoolismo, as toxicopathias, a crapula, as psychoses sociaes, as affecções nervosas e cerebraes, molestias da miseria e da luxuria, que degradam o homem, sacrificam os descendentes e compromettem a raça. Mas os flagellos humanos são de origem social e para combatel-os com efficacia não basta isolar a victima, excluil-a do convivio. Nem é justo montar contra ella a perseguição dos sãos. São as condições da existencia que devem ser melhoradas ${ }^{860}$.

Nesse mesmo ano, o mesmo autor publica outro artigo, correlacionando distúrbios do sono às atividades da vida moderna.

Desse modo, em 1907, o médico Saul de Avilez publica na Revista Medica de S. Paulo um artigo intitulado "A insomnia e seu tratamento" ${ }^{861}$. De modo semelhante ao seu outro artigo, o autor transmite sua percepção do ambiente contemporâneo de então, em relação ao assunto abordado. Refere-se à insônia como um elemento ligado aos

859 AVILEZ, S. O medico na sociedade do futuro. Revista Medica de S. Paulo, 318-329, 1907. 860 Idem, p. 329.

861 AVILEZ, S. A Insomnia e seu tratamento. Revista Medica de S. Paulo, p. 521-528, 1907. 320 
novos tempos urbanos e modernos da cidade, citando entre suas causas: leitura à noite, “divertimentos impressionantes”, teatros, bailes, vida sedentária, "longos trabalhos á noite”862. Como tratamento, além de medicamentos, ele diz que:

"São igualmente meios poderosos contra insomnias rebeldes: a massagem, a electricidade em forma de effluvios estaticos, a radiotherapia, a canotagem, a gymnastica, a patinação, o automobilismo e outras formas de physioterapia; a mudança de clima, as viagens, a sugestão hypnotica, a persuasão em vigilia e outros processos psychotherapicos”863.

Em 1909, é publicado, na Gazeta Clinica, um artigo de autoria do médico Ascanio Villas Boas, intitulado "O nervosismo",864. O autor refere que cada época tem suas “formas de nervosidade" conforme o modo de pensar e agir "da civilização correspondente". Ele diz que o homem, além de ser um produto biológico da hereditariedade, também é “uma cellula do organismo social”. Desse modo, Villas Boas dá exemplos de moléstias de tempos passados, que eram "expressões morbidas de um estado affectivo e intelectual inherente a determinado periodo"865.

Sobre as alterações mentais próprias do tempo em que ele escreve, Villas Boas refere que:

No nosso tempo de industrialismo e de positivismo scientifico (...) as formas de nervosidade se manifestam muito claramente, denunciando o espirito, o modo de sentir, a mentalidade do tempo actual. São os estados neurasthenicos que as caracterisam. A forte concorrencia em todos os ramos de actividade, a intensidade da vida cerebral para afrontal-a, a rapidez das communicações e da transmissão do pensamento, a falta de crenças solidas para base da conducta, ligadas a predisposição mais ou menos poderosa, influem essencialmente na creação do desequilibrio mental. Em um notavel trabalho, a Degeneração, Max Nordau estuda os desequilibrados da arte contemporanea, imprimindo nas suas apreciações os exageros de ideias preconcebidas" ${ }^{866}$.

O autor também relata como Charcot diferenciava a neurastenia de estados hereditários: nestes predominam as fobias, as obsessões e as impulsões. Depois ele cita Deschamps e seu trabalho “Astenias Gerais”, onde este aplica a idéia de energia ao sistema nervoso. Assim, há astenia por esgotamento, ou de causa hereditária, ou por inibição, ou por intoxicação ${ }^{867}$.

862 AVILEZ, S. A Insomnia e seu tratamento. Revista Medica de S. Paulo, p. 521-528, 1907.

863 Idem, p. 523.

864 VILLAS-BOAS, A. O nervosismo. Gazeta Clinica, p. 30-33, 1909.

865 Idem.

866 Ibidem.

867 Ibidem. 
Villas Boas cita Leopold Saquer, que enumera as causas do "nervosismo atual” como sendo: a - a educação nas escolas, onde os pais obrigam os filhos a estudos para os quais não têm aptidão; b- “na puberdade”, “o goso mal reprimido dos sentidos”, bebidas alcoólicas e a sífilis; c- a falta de prazer no trabalho.

O autor refere que, no meio urbano, com a máquina substituindo o trabalho humano, o trabalho monótono leva à tristeza e ao alcoolismo, diferentemente do trabalho no campo. Assim, ele cita profissões que trabalham "por horas ou minutos” como jornalistas, guardas postais, guarda livros; ou ainda os que forçam o sistema nervoso na mira do sucesso, como: compositores de música, atores dramáticos, oficiais do exército, médicos, operadores.

$\mathrm{Na}$ neurastenia “confirmada”, ele indica os tratamentos: psicoterapia, climatoterapia, hidroterapia $^{868}$.

Em 1909, o médico Coriolano Burgos publica na Revista Medica de S. Paulo, o artigo intitulado "A nevrose do crime",869.

Burgos considera que existe na sociedade uma espécie de culto à violência, associado à exposição dos crimes os mais diversos. Acha que não só a hereditariedade gera o criminoso, mas também a ação do meio. Assim, diz que: “no campo vasto da humanidade é impossível traçar-se o ponto divisorio exacto onde termina a razão e começa a loucura”. Adiante, ele prossegue:

“Assim, nos dominios da loucura, que, por ser, na phrase feliz de um psychiatra, a noite da razão, não nos apercebemos muitas vezes das pequenas desordens mentaes que a precedem, $e$ que, no seio da familia ou da sociedade, são capituladas de simples devaneios, caprichos ou cousa que o valha (...) Se, como figuramos, é impossivel a determinação exacta dos limites da razão, é claro que, entre os dois extremos deve existir uma zona, provavelmente maior do que as duas reunidas. (...) é dessa zona, não desejada talvez, que vieram os maiores vultos da humanidade (...) não admira que de cerebros tempestuosos provenham idéias claras, as mais das vezes aproveitadas por outrem, ${ }^{\mathbf{8 7 0}}$.

Em seguida, após conjecturas acerca dos limites entre a doença mental e a perversidade, com a acentuação da inteligência do perverso, o autor faz certa comparação entre a guerra e o crime, dizendo que um general que vence com um plano "machiavelico” é um herói, e que o bandido bem sucedido recebe honraria de seus

868 VILLAS-BOAS, A. O nervosismo. Gazeta Clinica, p. 30-33, 1909.

869 BURGOS, C. A nevrose do crime. Revista Medica de S. Paulo, p. 122-125, 1909.

870 Idem. 
comparsas, mas eventualmente são "admirados por toda gente”. Ele diz que ambos habitam a zona intermediária que Cullere chamou de "fronteiras da loucura". Acrescenta que a guerra é um mal, com o intuito de evitar um mal maior, onde a civilização deixa de ser uma barreira às “extravasações humanas”, de modo que “apuram-se cada vez mais as machinas de destruição".

Passando a falar da divulgação e estímulo à criminalidade, o autor cita o cinema como um possível fator de influência, naqueles que têm tendências criminosas:

\footnotetext{
“Mas, pelo amor de Deus, não é a propria civilisação que mais concorre para a vulgarisação desses meios? Não somos nós mesmos co-responsaveis, quando, commodamente assentados, assistimos ao desdobrar methodico de um film cinematographico, onde o publico vê e aprende as cousas mais terriveis, assiste, em photographia movel, aos roubos e assassinatos mais pavorosos, com que se pretende explorar sua sensibilidade. No meio dos espectadores, quantas inclinações morbidas, quanto pendor latente para o mal, não recebe pela retina a excitação sinistra, a faisca diabolica que mais tarde vae atear $\mathrm{o}$ incendio naquelles cujo coefficiente da razão é nullo ou quase nullo?”
}

O autor ressalva a utilidade do cinema nas universidades para demonstrações práticas. Discorda de que se condene a imprensa por divulgar grandes crimes, "actuando como agente de propaganda”, pois considera esse um excelente meio repressor, pelo criminoso temer a divulgação do escândalo.

Às possíveis causas da criminalidade, como falta de instrução, vícios e o cinema, o autor acrescentou a "frouxidão criminosa da justiça” e a benignidade dos tribunais. No entanto, ele acha a pena de morte uma degradação das leis francesas e prefere castigos corporais de acordo com a gravidade do delito, conforme se faz na Inglaterra, onde cita o desaparecimento dos "hoolegins (gatunos que infestavam as ruas de Londres)”, por temerem um determinado chicote.

Avilez acha que talvez sua própria época venha a ser conhecida como a mais cheia de crimes, pois o bandido tem a perspectiva de ir para uma penitenciária luxuosa e confortável. Ele acha incrível que quem dominou inimigos da ordem de febre amarela, se veja de mãos atadas diante da epidemia social da "nevrose do crime".

Ele conclui, dizendo que se a febre amarela exprimia nosso atraso, o crime e o desfalque atestam nossa corrupção. Diz então que o patronato, a política e o suborno devem desaparecer de vez. 
3. 3.14 - Medicina e Direito: debates sobre alienismo. (1899-1912)

Na Revista Medica de São Paulo, em 1899, é publicado um longo debate a respeito de uma paciente recolhida ao Hospício de Alienados da Capital, debate esse que ganhou o espaço público com notícias a seu respeito na imprensa corrente.

Em primeiro lugar no artigo está o "Parecer Medico-Legal sobre o estado mental de Antonietta Cornazzani”, constando entre parênteses: “resposta aos quesitos formulados pela justiça”,871.

O parecer foi assinado em 3 de maio de 1898, pelos médicos Homem de Mello e Amâncio de Carvalho, nomeados judicialmente para responderem aos quesitos formulados a respeito do estado mental de Antonietta Cornazzani, menor recolhida ao Hospício de Alienados da Capital, onde, dizia-se, fora violada. O relatório informa dados gerais da paciente, com antecedentes psiquiátricos na família, dizendo que ela foi à escola, tinha uma profissão e entrou em “estado de excitação maníaca”.

Em seguida, os autores fazem uma descrição detalhada do exame do estado mental da paciente em questão e, embora registrem algumas alterações psíquicas, eles acham possível acreditar nas informações da mesma a respeito de ter sido violada. Para reforçar essa conclusão, eles se valeram de considerações de diversos estudiosos, como Cullere, Ziehen, Chaslin, e o Congresso de Medicina Mental de La Rochelle de 1894.

No artigo que estamos descrevendo, após o "Parecer Medico-Legal”, é publicado um resumo das considerações do advogado do réu desse suposto crime, considerações essas registradas no “Correio Paulistano”, em 22 de Dezembro de 1898.

Nessa declaração, o advogado acha que o exame médico foi feito em pouco tempo, apena 9 dias, quando tinham, os médicos, 25 dias para fazê-lo. Acha também o advogado que em um único exame apenas, não se pode avaliar o estado de alienação de uma pessoa. Considera ele um absurdo os médicos dizerem que a vítima tem excitação, mas não tem delírios e movimentos impulsivos, pois ele acha que estes dois quadros são conseqüências da excitação. Insiste o advogado em que todos os criminalistas dizem não se poder acreditar em alienados, e que a lei não lhes dá direito de prestar juramento.

871 PARECER MEDICO-LEGAL sobre o Estado Mental de Antonietta Cornazzani (resposta aos quesitos formulados pela justiça) - nomeados judicialmente os Drs. Amancio de Carvalho e C. Homem de Mello. Revista Medica de São Paulo, p. 102-107, 1899. 
No artigo que estamos relatando, após o resumo das considerações do advogado, consta um breve texto de Homem de Mello, de 31 de Dezembro de 1898, onde ele informa ter solicitado por escrito o parecer dos professores Teixeira Brandão, Souza Lima, Márcio Nery, Nina Rodrigues e Carlos Eiras, pedindo licença para tornar públicas as suas respostas.

A seguir, estão publicadas, nesse mesmo artigo, as respostas dos professores solicitados, que, por meio de diversas argumentações, concordaram com as conclusões dos médicos que assinam o "Parecer Medico-Legal”.

Com esses pareceres, Homem de Mello dá a discussão por encerrada, repetindo citações dos médicos Brazilio Machado e João Monteiro para o jornal “Estado de São Paulo”, a respeito dos advogados que “entram por searas que não conhecem” ${ }^{872}$, ao tecerem comentários sobre assuntos médicos.

Esse debate indica haver uma disputa pública na cidade de São Paulo, entre os psiquiatras e os advogados, a respeito de quesitos que envolvem aspectos legais em torno dos alienados. Conforme os comentários dos psiquiatras, esse tipo de disputa não é um caso isolado, parecendo serem debates razoavelmente comuns ${ }^{873}$.

O médico Deolindo Galvão publica na Revista Medica de São Paulo, em 1900, um artigo intitulado "Um exame de sanidade mental”"874, endereçado de Brotas, datado de 24 de abril de 1900. O autor relata ter sido nomeado pelo magistrado da comarca de Jaú, juntamente com o Dr. E. de Oliveira Pinto, para emitir parecer sobre o estado mental de determinada pessoa, da qual interessados requeriam “curatella”. Galvão acentua sua titulação: "Sabendo-me dedicado ao estudo da especialidade-psychiatria - e molestias

872 PARECER MEDICO-LEGAL sobre o Estado Mental de Antonietta Cornazzani (resposta aos quesitos formulados pela justiça) - nomeados judicialmente os Drs. Amancio de Carvalho e C. Homem de Mello. Revista Medica de São Paulo, p. 102-107, 1899.

873 No entanto, advogados e médicos estão unidos em diversas organizações de cunho literário, cultural, ou científico, em São Paulo, com maior número de profissionais e acadêmicos do Largo de S. Francisco. Uma dessas instituições é o Almanach Litterario de São Paulo (1876-1885). Outra é o Instituto Histórico e Geográfico de São Paulo, fundado em 1894, e sua revista, fundada no ano seguinte. Também a Academia Paulista de Letras, é um local de convivência e desencontros entre esses profissionais. Essa instituição, fundada primeiramente em 1907, pelo médico carioca Joaquim José de Carvalho, durou poucos meses, por disputas internas em torno das cadeiras. Em 1909 é refundada, sofrendo críticas pela imprensa de acadêmicos de Direito, tendo sido chamada ironicamente, por um jornal santista, de “Academia Paulista de Medicina”, em virtude da profissão de seu fundador .

FERREIRA, A.C. A epopéia bandeirante: letrados, instituições, invenção histórica (1870-1940). Editora Unesp, 2001.

874 GALVÃO, D. Um Exame de Sanidade Mental. Revista Medica de São Paulo, p. 121-123, 1900. 
nervosas, a cuja cadeira de professor concorri na Faculdade de Medicina da Bahia, merecendo neste certamen scientifico unanime approvação de meus mestres”875.

Galvão informa que demorou a apresentar relatório de sua observação, em virtude de sobrecarga de trabalho clínico, ao mesmo tempo em que o advogado insistia para que seu parecer fosse emitido. A seguir, Galvão publica sua avaliação do doente em duas partes. Na primeira parte, descreve como chegou ao diagnostico de paranóia, fazendo a citação de vários autores, dizendo-se feliz por ter seu diagnóstico confirmado por "especialista notavel da capital de S. Paulo".

Na segunda parte, cita sua impressão do paciente obtida tempos depois, quando constatou já tratar-se de demência total, a qual privava o doente das responsabilidades da sua vida juridica e social. Completa o autor, dizendo que escreveu esse parecer em 1899, na cidade de Jaú, e que “a argucia de um advogado” levou a achar que seu trabalho só valia “os proventos do regimento de custas”, sendo que esse mesmo advogado cobrava caro de seu cliente.

No mês seguinte a esse artigo, Franco da Rocha envia carta à Redação da Revista Medica de São Paulo, por ter sido muito perguntado por seus colegas, se o paciente em questão esteve no Hospicio e se tinha sido avaliado por algum médico de lá.

Em relação a isso, assim explica Franco da Rocha:

"Não conheço o doente, objecto do trabalho, nem sei se esteve no Hospicio; garanto, entretanto, que o diagnostico, tal como se acha lá exposto, não podia absolutamente ter sido subscripto por qualquer dos medicos deste estabelecimento. A classificação que adoptamos não permitte confusão do delírio chronico systematizado de Magnan com a paranoia"876.

Além do conflito entre o médico e o advogado, e o esclarecimento da classificação do Hospício, percebe-se, por esse artigo, e pela resposta de Franco da Rocha, a circulação das informações provenientes da Revista Medica e o interesse pela mesma entre os leitores, bem como o prestígio de Franco da Rocha em São Paulo nesse período, a ponto de publicar carta esclarecedora de comentários em relação a sua pessoa e ao hospício, a respeito do caso relatado. Também se observa não haver unanimidade entre os médicos a respeito desses temas abordados.

875 GALVÃO, D. Um Exame de Sanidade Mental. Revista Medica de São Paulo, p. 121-123, 1900. 876 ROCHA, F. Um exame de sanidade mental. Revista Medica de São Paulo, p. 154, 1900. 
Em 1901, Franco da Rocha escreve, na Revista Medica de São Paulo, um artigo sobre a publicação de Nina Rodrigues intitulada "O Alienado no Direito Civil Brasileiro" ${ }^{877}$.

Franco da Rocha elogia o trabalho gigantesco de Clóvis Bevilaqua com o Código Civil, mas considera muita coisa para um só homem, e acha que há falhas no código. Assim, justifica o valor do trabalho de Nina Rodrigues, para trazer retoques que, segundo ele, carecem ao Projeto Bevilacqua. Informa que Rodrigues analisou a parte do projeto referente aos alienados, e se atem a alguns pontos principais, recomendando a leitura do livro todo aos interessados.

Um dos aspectos, a que Franco da Rocha chama a atenção, é a "interdicção completa para loucos de todo o genero" ${ }^{\text {,78 }}$, em relação a direitos e posse sobre bens. Essa situação, segundo ele, põe o “medico perito” em embaraços. Assim, Franco da Rocha acha que há necessidade de verificação de cada caso, pois existem situações em que o paciente está "no gozo de suas faculdades" e apenas por um "ligeiro abaixamento intellectual” já pode sofrer sérios prejuízos.

Desse modo, ele acha que pode ser seguido o exemplo do Código Francês, onde há a instituição de um Conselho de Família e um Conselho Judiciário para avaliar cada caso.

Outro assunto, que Franco da Rocha ressalta, diz respeito às Casas de Saúde para alienados. Ele se atem mais especificamente ao fato de que essas instituições funcionam "sem a mínima fiscalização por parte dos Governos”.

Franco da Rocha acentua que, além de Nina Rodrigues, ele mesmo, três anos antes, em sua publicação de “Apontamentos e Estatística”, chamou a atenção para esse fato.

Em 1909, Franco da Rocha publica na seção “Medicina Publica” da Imprensa Medica, o artigo intitulado “A velha e a nova escola penal”.

O autor diz que muito se impressiona pela incongruência entre o codigo penal em vigor e a crescente preponderância que as idéias da escola penal positiva vem tomando no destino de alguns réus.

877 ROCHA, F. O alienado no direito civil brasileiro; pelo Dr. Nina Rodrigues. Revista Medica de S. Paulo, p. 327-329, 1901.

878 ROCHA, F. O alienado no direito civil brasileiro; pelo Dr. Nina Rodrigues. Revista Medica de S. Paulo, p. 328, 1901. 
Ele se diz de acordo com essa nova escola, que declara serem todos os criminosos entes anormais. Essa mentalidade anormal, que, segundo diz, constitui o “fator antropológico da criminalidade”, se manifesta quando o ambiente social e o ambiente físico favorecem as tendências anti-sociais de origem orgânica do indivíduo. A partir desse principio científico, diz ele que as penas não são castigos ou represálias contra os atos previstos como crimes, mas medidas de segurança da sociedade para se proteger dos indivíduos criminosos, evitando a repetição de atos dessa natureza. Outro aspecto reforçado por Franco da Rocha é que a pena deve ser graduada de acordo com a temibilidade do delinqüente e não de acordo com o ato criminoso, como estabelece o código.

Ele acha que a lei determina, “com hesitação”, se o individuo isento de culpabilidade por afecção mental seja entregue à família, ou recolhido em hospitais de alienados.

Conforme diz, começa aí um suplicio do qual não suspeitam, nem legisladores e nem juízes. Ele exemplifica com o caso de um epiléptico que se torna "um louco varrido”, em conseqüência de ingerir goles de álcool, e comete um crime. Conforme determina a lei, ele é enviado ao hospício, onde logo volta á vida regular.

Segundo Franco da Rocha, na escola penal positiva, a moléstia não seria um atenuante, mas um agravante, ou seja, sua “irresponsabilidade criminal” não o eximiria da "responsabilidade social". Assim, acha que esse individuo deveria permanecer detido, e exemplifica com a lei inglesa, que toma essas medidas em casos similares. Mas no entanto, em nosso meio, segundo ele, há confusão e desordem própria de “fases de transição na evolução organica, individual, ou social”.

Franco da Rocha diz que, nas condições atuais, como esses criminosos ficam por conta do diretor do hospício, cumprem a pena juntos, "o réu e o director do hospício”. Assim, ele conta que a família do paciente vem constantemente chorar à porta do hospício e mostrar as crianças na miséria e fome, porque lhes falta o chefe de família. Desse modo, segundo diz, o médico assume o papel de carrasco.

Como esse caso,, diz Franco da Rocha que muitos outros vêm diariamente ao diretor. Desse modo, ele pergunta: "Em que estado, no emtanto, ficará a consciencia do medico que tiver feito tão arriscada declaração? Só um ignorante poderá ficar tranquilo”. 
Ele acrescenta que, frequentemente, os advogados recorrem à "privação dos sentidos” do réu, como meio de inocentá-lo. Desse modo, conforme Franco da Rocha, ficou um conceito falso da doutrina positiva no público “meio letrado”, que diz: "Essa tal doutrina de Lombroso considera todos os criminosos como loucos. É boa! O individuo commette um crime e ainda deve ser muito bem tratado num hospital! Não faltava mais nada!”

Ele então diz que a doutrina positiva é caluniada pois propõe o contrário do que é difundido a seu respeito. Frisa que pacientes com casos graves de criminalidade devem ser removidos da sociedade, mas devem ser bem tratados, e devem trabalhar. Já os corrigíveis devem receber pena mínima.

Em 1910, na Revista Medica de S. Paulo, Enjolras Vampré publica artigo a respeito da obra do médico Carlos Penafiel, artigo esse intitulado "Responsabilidade criminal dos epilepticos (notas e observações medico-legais por Carlos Penafiel)”; Enjolras Vampré está identificado como “do Juquery”.

Vampré comenta essa obra de Penafiel, ex-catedrático da Faculdade de Medicina de Porto Alegre e médico legista da Polícia Judiciária. Conforme Vampré: “já vamos lentamente abandonando o verdadeiro marasmo scientifico em que nos achavamos, nos libertando da exclusiva orientação estrangeira”. Desse modo, ele se refere a trabalhos práticos nacionais, que vão constituir "as bases de nossas futuras doutrinas clinicas”.

Após citar alguns casos do livro, Vampré cita palavras de Franco da Rocha, no texto "A velha e a nova escola penal”:

"Dirão que é crueldade sequestrar por muito tempo uma creatura que não tem culpa de ser doente. Doentia, diremos nós, é uma sensibilidade vesga, que não julga crueldade o soffrimento por que passou a victima desse doente; que não se lembra das victimas futuras possiveis, si esse enfermo tiver o gozo da liberdade".

Sobre polêmicas em certos diagnósticos Vampré diz que: “quando o fato que se encontra está em oposição à teoria reinante, é preciso acceitar o facto e abandonar a theoria, mesmo quando esta, sustentada por nomes celebres, é geralmente adoptada”. 
Em 1910, na Revista Medica de São Paulo, Franco da Rocha faz uma apreciação da tese, do médico Arlindo Carvalho Pinto, apresentada na Faculdade de Medicina do Rio de Janeiro, intitulada “Capacidade civil dos aphasicos”879.

Como o autor é bacharel em Direito, o comentador considera esse assunto bastante oportuno. Em seu comentário, Franco da Rocha assinala que a doutrina clássica da afasia, de Bouillaud e Broca, está sendo abalada por Pierre Marie, considerado um “iconoclasta da aphasia classica” ${ }^{880}$. De qualquer modo, a questão da tese diz respeito á Medicina Legal e o autor refere ser necessário diferenciar afasia de anartria ${ }^{881}$, pois, segundo Franco da Rocha, na afasia há deficiência mental. Assim ele recomenda a solicitação de um perito para avaliar casos de implicação legal.

Em 1911, na Revista Medica de S. Paulo, é publicado artigo intitulado “Os alienados perigosos e o codigo penal”, de autoria de Franco da Rocha ${ }^{882}$. Esse artigo é subtitulado como “A propósito de appelação-crime n.5580, julgada em 7 de desembro de 1911 pelo Tribunal de Justiça”.

Neste artigo, Franco da Rocha se refere ao que ele considera como "deficiencia e anachronismo do Codigo Penal, quanto aos alienados delinquentes”883. Ele reforça: “Note-se bem que não digo 'loucos', mas sim 'alienados””884. Ele informa que vem debatendo bastante esse assunto em artigos nos jornais "Estado” e “Gazeta Juridica”. Diz que, embora os juízes sejam muito capazes, ficam sujeitos à lei, que, segundo ele, precisa ser modificada pelo legislativo. Considera que há diferença entre “imputabilidade” e "responsabilidade social”, ou seja, certos alienados criminosos, embora não sejam imputáveis, por oferecerem risco à sociedade, devem ficar recolhidos em local apropriado, que não seja o hospício.

Em relação à origem do problema, ele diz: "No fundo da questão, a causa unica do mal, o nucleo perturbador, é a doutrina que orientou o codigo - o livre arbitrio - essa

879 ROCHA, F. Bibliographia: Capacidade civil dos aphasicos. Revista Medica de S. Paulo, p. 240, 1910. 880 Idem.

${ }^{881}$ Anartria: alteração da fala por dificuldade motora nas estruturas que articulam a fala, diferentemenete da afasia, que diz respeito a comprometimento da elaboração da linguagem no próprio cérebro. 882 ROCHA. F. Os alienados perigosos e o codigo penal. Revista Medica de S. Paulo, p. 437-440, 1911. 883 Idem. 884 Ibidem. 
velharia já anniquilada pela sciencia. Emquanto esse mytho não for de todo varrido do Codigo, a balburdia continuará como até hoje»885.

Particularizando sua explicação, ele diz que, se o criminoso pedir habeas corpus, o Tribunal solicitará novo exame de peritos, que poderá dizer que não se trata de alienado e, assim, o suposto criminoso poderá ficar livre e voltar a causar problemas.

Ele cita a Inglaterra como sendo um país que já solucionou essa questão. Como exemplo de casos desse tipo, ele refere os casos de "embriaguez maniaca" ou "furiosa", em que o indivíduo em crise torna-se muito agressivo. Em termos de entendimento do que ocorre, Franco da Rocha explica ser fato conhecido que as últimas aquisições do desenvolvimento psíquico são as “mais elevadas, mais nobres”, mas também "as mais instaveis, mais frageis”, sendo, portanto, as primeiras a desaparecerem quando houver uma ação nociva sobre “o orgam psychico”. Assim, ele diz que a ação deletéria do álcool se faz sentir sobre os sentimentos éticos e sobre a vontade, de modo que o indivíduo volta às fases inferiores da evolução humana.

\section{3.15 - Afirmação de São Paulo. (1899-1912)}

Além do relato feito em seguida, sobre polêmica feita por Franco da Rocha a respeito de trabalho de Henrique Roxo, outros registros, que podem ser interpretados como sendo também indícios de afirmação de São Paulo, estão presentes no transcorrer de nosso trabalho, em diversos itens ${ }^{886}$.

\footnotetext{
885 Ibidem.

886 Há, na Revista Medica de S.Paulo, em 1900, uma carta do "Brazil Medico", endereçada à Revista dizendo: "Fundada por um pugillo de medicos estudiosos e dedicados ás causas da profissão, a interessante Revista caminha dessassombrada, demonstrando a pujança d'aquillo que nos temos habituado a chamar 'a Escola de S. Paulo'. Sem possuir uma Faculdade de Medicina, existe todavia na capital paulista mais do que isso, porque ahi foi constituído um verdadeiro centro de sciencia, um foco de luz, um seminario de obreiros dedicados. A Revista é e deve ser considerada a representante genuína dessa aggremiação de medicos, cujos esteios principaes estão collocados no Instituto bacteriologico de S. Paulo, nos hospitaes e na Directoria de Hygiene do Estado”.

CARTA DO BRAZIL MEDICO. Revista Medica de S. Paulo, p. 83-84, 1900. 
Em 1901, na seção “Bibliographia”, da Revista Medica de São Paulo, Franco da Rocha publica um artigo sobre um trabalho do médico Henrique Roxo intitulado “Causas de Alienação Mental no Brasil”887.

Franco da Rocha refere já ter elogiado Roxo por ocasião de sua “tese inaugural” de $1900^{888}$.

Ele considera de valor o trabalho de Roxo sobre "causas de alienação mental”, onde o autor fez uma estatística dos doentes do Hospicio do Rio de Janeiro nos últimos seis anos. Franco da Rocha reforça esse valor, dizendo: “A psychiatria no Brasil é uma especialidade atrazadissima, de modo que a publicação desses dados é sempre mais uma pedra para o alicerce do futuro edificio" ${ }^{\sharp 89}$.

A seguir, Franco da Rocha passa a fazer uma crítica sobre o título do trabalho Causas da alienação mental no Brazil - que considera mal escolhido, pois "o conteudo não corresponde ao rotulo”, conforme suas palavras. Ele acha que deveria ter sido simplesmente "Causas de alienação mental”, pois, a seu ver, não poderia extender ao Brasil inteiro, uma estatística que diz respeito somente ao Rio de Janeiro. Assim, ele comenta:

"Como poderia o auctor fazer uma synthese da etiologia da loucura no Brazil? Que nos conste não existe no nosso paiz publicação alguma de estatistica com dados scientificos, sinão as que pacientemente publicamos nós desde 1895, relativas somente a São Paulo. Com referencia ao Hospicio do Rio de Janeiro apparece agora, pela primeira vez, a estatistica só etiologica, justamente a parte boa do seu opusculo em questão. Dos outros Estados nada sabemos. Na Bahia mesmo, onde ha uma Faculdade de Medicina, só agora que o serviço se acha em mãos de Juliano Moreira, um medico de talento, illustração e actividade, podemos esperar alguma cousa. Antes disso, só conhecemos estudos de psychiatria na Bahia pela possante mentalidade de Nina Rodrigues, e mais um ou outro estudante isolado»"890.

Franco da Rocha questiona se esse título teria sido conseqüência de uma "lei geral”, que Roxo disse ter estabelecido.

887 ROCHA, F. Causas de Alienação Mental no Brasil; pelo Dr. Henrique Roxo. Revista Medica de São Paulo, p. 155-157, 1901.

${ }^{888} \mathrm{O}$ comentário sobre a tese de Roxo está na seção seguinte.

889 ROCHA, F. Causas de Alienação Mental no Brasil; pelo Dr. Henrique Roxo. Revista Medica de São Paulo, p. 155, 1901.

890 ROCHA, F. Causas de Alienação Mental no Brasil; pelo Dr. Henrique Roxo. Revista Medica de São Paulo, p. 155-157, 1901. 
Conforme Franco da Rocha, essa lei diz que "a alienação mental deriva sempre de uma perturbação nutritiva de qualquer das celulas cerebraes”891.

Ele comenta que, se essa lei justificasse o título, então deveria ter sido "causas de alienação mental no mundo”, pois, conforme diz, ninguém ainda formulou essa lei porque isso seria por demais banal, e seria repetir uma noção básica elementar de psiquiatria moderna, que está presente “da primeira á ultima pagina de qualquer tratado moderno de psychiatria”.

Outro defeito, que Franco da Rocha aponta no trabalho, é a falta de citação de autores brasileiros, permitindo, segundo ele, as seguintes conclusões:

“1 Brazil é o Rio de Janeiro; $2^{\circ}$ só o Dr. Roxo tem estudado alguma cousa de psychiatria no Brazil.

Tratou da grippe e não disse uma palavra sobre as observações de Marcio Nery no Brazil Medico. Tocou na questão de febre amarela e nada disse sobre os escriptos daquelle distincto professor e de Carlos Eiras.

Encontra o algarismo elevadissimo dos estados degenerativos, chama a attenção para o facto, mas nem uma palavra sobre o trabalho estatistico de um outro que, em São Paulo, encontrou o mesmo facto" ${ }^{892}$.

A seguir, ele critica afirmações que considera incorretas em relação a algumas doenças e a certas citações. Ele então conclui de forma severa seus comentários:

"Não nos increpe o auctor de termos publicado trabalhos incompletos, insignificantes e que por isso não temos direito de criticar o seu. Si assim pensar cahirá em erro. Os pequenos trabalhos que temos publicado trazem sempre uma especie de prefacio, em que se declara não serem elles mais que simples apontamentos, notas despretenciosas, apanhadas atalhadamente nos logares de uma administração pezadissima, como é a de dois hospicios em S. Paulo.

O seu não tem essa desculpa; apresenta-se rigido, impavido, com ar fidalgo de um trabalho exhaustivo sobre o assumpto, trazendo os seus inicios desde os 'primordios da humanidade'. Já fizemos justiça a uma parte do seu trabalho, ficamos quites”893.

Esse texto de Franco da Rocha não ficou sem resposta.

Em publicação posterior, na Revista Medica de São Paulo, no mesmo ano de 1901, na seção "Notas Bibliographicas", a editoria da revista refere ter recebido de

891 Idem.

892 ROCHA, F. Causas de Alienação Mental no Brasil; pelo Dr. Henrique Roxo. Revista Medica de São Paulo, p.157, 1901.

893 Idem. 
Franco da Rocha uma carta de Henrique Roxo, subscrita em oito de junho desse ano, que passaram então a publicar ${ }^{894}$.

Nessa carta, Roxo insiste em que envia sua carta com o objetivo de: “evitar que permaneça formulado a meu respeito conceito tão injusto qual o que foi emittido pelo eminente Director do Hospicio de S. Paulo” ${ }^{\text {„85 }}$.

Desse modo, ele inicialmente refere-se, respeitosamente, a Marcio Nery e Carlos Eiras, dizendo que suas citações, das moléstias estudadas pelos dois médicos, foram muito breves, não significando desrespeito o fato de não tê-los citado.

Sobre as publicações de Franco da Rocha, Roxo diz que não as conhecia e só passou a tomar conhecimento por meio de um amigo, quando seu próprio livro já estava publicado. Ele atribui isso à “limitada expansão que entre nós têm trabalhos d'essa natureza, os quaes, em geral, não se encontram nas bibliothecas que representam o nosso repositorio comum”,

A seguir, ele refere que tributa elevada consideração a Franco da Rocha e seus trabalhos científicos, e como Diretor do Hospicio.

Defende-se das outras críticas, dando a entender que o título dado ao trabalho foi o mais adequado entre as alternativas que tinha. Nas outras questões, refere que não houve erro, mas que quis ser conciso. Encerra, solicitando a possibilidade de ter publicada essa sua defesa na Revista Medica de São Paulo.

Em 1904 foi publicado na Revista Medica de São Paulo artigo intitulado "Perturbações mentaes dos negros no Brazil - do Dr. H. Roxo, assistente de Clinica Psychiatrica”; de autoria de Homem de Mello ${ }^{897}$.

Ele se refere ao trabalho do Dr. H. Roxo, que foi "lido perante um Congresso scientifico em terra extrangeira” ${ }^{898}$. H. de Mello critica a generalização para todo o Brasil, de um trabalho que foi feito apenas no Rio de Janeiro.

894 NOTAS BIBLIOGRAPHICAS. Carta de Henrique Roxo enviada pelo Dr. Franco da Rocha. Revista Medica de S. Paulo, p. 193-194, 1901.

895 Idem, p. 193.

896 Idem.

897 MELLO, H. Perturbações mentaes dos negros no Brazil; do Dr. H. Roxo, Assistente de Clinica Psychiatrica. Revista Medica de S. Paulo, p. 410-411, 1904.

898 Idem, p. 410. 
Diz também que, embora a raça abordada no trabalho seja a mesma, as variações de clima, meio social e educação podem provocar diferentes perturbações, de modo que “certamente irão influir no resultado estatistico" ${ }^{899}$.

Assim, ele discorda da metodologia adotada, bem como também considera que as variadas condições do meio podem interferir nas condições mentais do indivíduo negro, de maneira que ele (Homem de Mello) não dá tanto valor ao atavismo.

Homem de Mello também critica a menção de “inovação" no trabalho de H. Roxo:

“O auctor dá a entender claramente que é seu o unico trabalho escripto no Brazil sobre a loucura dos negros: 'os livros silenciavam sobre o assumpto'. O Dr. Franco da Rocha, entretanto, escreveu em 1896 um longo artigo sobre a loucura dos negros em S. Paulo. Essa memoria vertida para o allemão foi publicada em 1897 no Allgemeine Zeitschrift $f$. Psychiatrie, de Berlim. Na Chronica dos Annaes Medico-Psychologicos de 1898, honrosas referencias lhe foram feitas pelo Dr. Ritti. Outros jornais fizeram referencias a esse estudo, $e$ o Dr. Nina Rodrigues, que também tem estudos de subido valor sobre a raça negra, menciona esse artigo por varias vezes, o que mostra que não se trata de trabalho desconhecido"

A seguir, H. de Mello critica os resultados numéricos de Roxo. Diz que Franco da Rocha, como outros pesquisadores, encontrou o quadro denominado "mania” como alteração mais comum entre os negros, diferentemente de Roxo, que achou o quadro de “demencia”, como o mais freqüente nessa raça.

H. de Mello considera que Roxo errou, ao citar esses casos apenas pela sua evolução final e não pelas suas causas. Além disso, repetindo palavras de Roxo, discorda de sua opinião a respeito do cérebro dos negros:

“Entretanto o Dr. H. Roxo diz: 'Os casos de mania são relativamente raros nos individuos de raça preta... São dados que derivam das estatisticas que confeccionamos com o exame das observações. É uma manifestação dos cerebros de evolução normal. Era natural, portanto, que nos typos da raça inferior fosse ella escassa, "901.

Nesse ponto, Homem de Mello questiona o entendimento de Roxo a respeito do cérebro dos negros:

899 MELLO, H. Perturbações mentaes dos negros no Brazil; do Dr. H. Roxo, Assistente de Clinica Psychiatrica. Revista Medica de S. Paulo, p. 410, 1904.

900 Idem, p.410-411.

901 Idem, p. 411.

335 
“Mas, então o cerebro do negro não tem evolução normal? É justamente por essa causa que a mania se encontra frequentemente no negro (...) E, entre nós, ninguém contestará que o negro, em virtude da escravidão, teve as suas faculdades intellectuaes e moraes nos limites da imbecilidade (...) $\mathrm{O}$ alcoolismo chronico que conduz á demencia não é muito commum no negro em virtude de sua resistencia cerebral, indo de preferencia subjugal-o pelas lesões dos nervos periphericos, do figado e do coração",902.

Em 1906 é publicada na Revista Médica de São Paulo, uma aula dada no Rio de Janeiro pelo professor Roxo (aula dada em 1905), com a presença de Franco da Rocha registrada no artigo. Essa aula intitula-se "Hemorragia Cerebral”"903. Assim H. Belford Roxo inicia sua fala:

"A clinica psychiatrica e de molestias nervosas rejubila-se hoje com a presença do Exmo. Sr. Dr. Franco da Rocha, eminente Director do Hospício de Juquery, em S. Paulo. Ella sente-se orgulhosa com a presença d'aquelle que tem sido um dos mais laboriosos obreiros em prol da especialidade. Tem sido elle um dos que mais têm cooperado em favor dos pobres doentes que geralmente em sua inconsciencia lhe não podem significar o reconhecimento pelo muito que se tem esforçado em lhes melhorar a sorte. Dedicando-se á especialidade, havendo fundado o excellente Asylo de Juquery, vai elle demonstrando que nos podemos ufanar de ter uma concepção da psychiatria exclusivamente brazileira. Acompanhando os passos do Eminente Professor Dr. Teixeira Brandão, publicou elle um trabalho que já vos elogiei e que representa um dos melhores manuaes da especialidade. E muitos outros trabalhos tem escripto constantemente, honrando o Estado de S. Paulo, de que é filho, e o nosso caro Brazil, a patria commum. Apresentadas as saudações e expresso o agradecimento pela presença de tão preclaro collega, passo a tractar de um caso que pertence á neuropatologia e que é de diagnostico bem difficil, embora de apparente simplicidade”.

Em relação ao artigo em si, o autor aborda um caso especifico sugestivo de hemorragia cerebral, sobre o qual ele faz hipóteses e discussões.

Em 1905, foi publicado na seção "Movimento Medico” da Imprensa Medica, um artigo informativo, intitulado "O microbio da syphilis em S. Paulo”904 . Embora o artigo não trate diretamente de sífilis do sistema nervoso, nós fazemos aqui menção a este trabalho, pois certas pesquisas sobre essa moléstia, nesse período, são de impacto para medicina em geral, incluindo psiquiatria e neurologia.

902 Idem.

903 ROXO, H.B. Hemorrhagia cerebral; $13^{\mathrm{a}}$ aula dada em 26 de julho de 1905. Revista Medica de S. Paulo, p. 390-393, 1906.

904 MOVIMENTO MEDICO. O microbio da syphilis isolado em S. Paulo. Imprensa Medica, p. 294295, 1905. 
O texto inicia, informando que "está na ordem do dia” o achado de Schaudinn e Hoffmann a respeito do micróbio da sífilis, de modo que têm sido muitas as publicações a esse respeito. Deixa-se claro que não se deseja aprofundar esse assunto, mas que o objetivo desse informe é notificar que “em S. Paulo já se conseguiu isolar o microbio da syphilis descripto pelos autores acima apontados”.

O texto acentua que esse resultado se deve ao trabalho do Dr. Affonso Splendore, do Instituto Bacteriológico de S. Paulo, que, no entanto, por ser excessivamente acautelado e modesto, recusa-se a divulgá-lo sob seu nome.

Os responsáveis por esta divulgação, dizem que vencendo os escrúpulos respeitáveis, conseguiram a observação do caso, que passam a relatar. Assim, é feita a descrição do processo técnico realizado, dizendo que o Dr. Splendore continua em suas pesquisas e só pretende escrever sobre o assunto após reunir dados que lhe dêem certeza de seus achados.

Nesse mesmo ano (1905), na Imprensa Medica, Vieira de Mello publica informe sobre o fato de o Dr. Adolpho Lutz, diretor do Instituto Bacteriológico, ter observado microscopicamente o micróbio da sífilis em mais um caso, confirmando, segundo ele, que o material reativo empregado pelo Dr. Splendore tem boas condições para a pesquisa $^{905}$.

\section{4. - Práticas e procedimentos (1899-1912)}

\section{4. 1. - Psicologia experimental, psicoterapia e similares (1899-1912).}

Em 1901, na Revista Medica de São Paulo, Franco da Rocha publica comentários a respeito da tese do médico Henrique Belfort Roxo, de 1900, feita no Rio de Janeiro, sob o título "Duração dos actos psychicos elementares nos alienados”"906 . O comentador considera esse trabalho como um passo importante da Psiquiatria na Faculdade do Rio de Janeiro, por ser a primeira vez que um estudante se dedica ao estudo do que ele chamou de "psycho-physica”, em uma tese inaugural.

905 MELLO, V. O microbio da syphilis. Imprensa Medica, p. 317, 1905.

906 ROCHA, F. Bibliographia: Duração dos actos psychicos elementares nos alienados; these do Dr. Belfort Roxo; Rio de Janeiro, 1900. Revista Medica de São Paulo, p. 104-105, 1901. 
Franco da Rocha acha esse estudo bastante difícil, lembrando que o único autor que inclui o tempo de reação como sintoma foi Bevan Lewis, no livro Textbook of Mental Diseases de 1899. O psiquiatra paulista considera que o tempo de reação pode se tornar fator de importante ajuda no diagnóstico psiquiátrico, embora esses estudos ainda não tenham penetrado na clínica psiquiátrica, pois, conforme diz, Kraepelin, que tem um laboratório de psicologia, não aplica esse estudo. No entanto, Franco da Rocha acha que o progresso dos estudos de laboratório pode trazer o aperfeiçoamento dessa prática.

Na Revista Medica de S. Paulo, em 1901, Franco da Rocha faz menção à sua própria tese inaugural feita onze anos antes, intitulada "Perturbações do movimento nas molestias mentaes”, ao fazer uma análise da tese inaugural de J. A. Costa Pinto, defendida em 1900, na Bahia, intitulada “A Graphologia em Medicina Legal”907.

Franco da Rocha reproduz dois parágrafos de sua própria tese, onde diz que qualquer documento escrito pode ter valor diagnóstico, ressalvando que há exageros como do estudioso Schark. Em seguida faz um comentário: “Este Schack é um curioso; sua obra é por demais empírica e charlatanesca, não tem um ponto de vista philosophico e scientifico como as do abbade Michon e Crepieux Jamin. Entretanto é um livro curioso e interessante"

Ele refere que "na semiologia das afecções nervosas e mentaes” a grafologia já entrou decididamente e fornece indicações preciosas, "tanto em psychiatria como em medicina legal”. Ele acha que a escrita dos alienados e dos criminosos merece a mesma atenção que “os estygmas physicos”.

No entanto, ele considera de importância capital evitar “o ridiculo do charlatanismo”909 em relação à grafologia, conforme também acentua o autor da tese analisada.

Além disso, Franco da Rocha relata que os trabalhos da escola de Lombroso, para determinar o tipo físico de criminosos, têm fracassado e que o tipo físico só tem valor como um sinal subsidiário.

907 ROCHA, F. Bibliographia: A Graphologia em Medicina Legal; these inaugural do Dr. J. A. Costa Pinto; Bahia, 1900. Revista Medica de São Paulo, p. 56-57, 1901.

908 Idem, p. 56.

909 Idem. 
Para reforçar a importância da grafologia, Franco da Rocha faz relato que considera uma prova brilhante:

“A importancia da Graphologia já está provada de um modo brilhante na questão que ha pouco agitou todo o mundo - o processo Dreyfuss. Ahi Crépieux Jamin e Gurrin mostraram o valor dessa sciencia tão prejudicada pelo ridiculo que os charlatães têm irradiado de suas personalidades sobre ella" ${ }^{910}$.

Podemos acompanhar aqui a atualização do autor com os acontecimentos do período, pois o capitão Dreyfuss só vai ser reabilitado em 1905, e só em 1907 Crépieux Jamin vai escrever sobre o processo, enquanto que este artigo é de 1901.

Procurando ser mais claro sobre o que acha da grafologia, Franco da Rocha diz considerar a escrita “a materialização do caracter”. Ele insiste em que tem mais valor do que as expressões fisionômicas, embora, conforme cita, estas tivessem atraído estudiosos como Charles Bell, Darwin, Wundt, Gratiolet, Duchenne e outros.

Em sua experiência, revela ter notado "correspondencia exacta entre o caracter e a escripta”. No entanto, acrescenta: "mas o receio de ser arrancado da minha obscuridade para ser ridicularisado por tentativa de originalidade robuscada, me tem feito guardar as observações para o meu uso"911.

Em 1905, na Imprensa Medica, foi publicado por Vieira de Mello, na seção intitulada "Movimento Medico", artigo intitulado “A espermatorrhéa e sua therapeutica: reeducação psychica e tratamento somatico" $"$ "12.

O autor refere-se a certa "psychotherapia” intitulada "reeducação" instituída pelo Dr. P. E. Levy, aqui neste artigo direcionada mais especificamente à espermatorréia.

Enfatizando a importância da "psychotherapia” o autor refere que: “Já se foi o tempo em que a psychotherapia era considerada isoladamente, sem laços com o conjunto da therapeutica: o organismo é um e a therapeutica deve ser e não pode deixar de ser uma"913.

910 Idem.

911 Idem, p. 57.

912 MELLO, V. A espermatorrhéa e sua therapeutica: reeducação psychica e tratamento somatico. Imprensa Medica, p. 213-215, 1905.

913 Idem, p. 214.

339 
O autor acha que vários medicamentos tiveram sucesso, conforme a época, apenas devido à “acção inconsciente exercida sobre o elemento psychico", devido à confiança do doente na medicação. Diz que o Dr. Levy tem ponto de vista monista, ou unicista, e, assim, considera fatores psíquicos conjugados a fatores físicos. Desse modo, são recomendadas algumas medidas gerais aos pacientes, incluindo psicoterapia em sessões de reeducação, nas quais o médico dá várias orientações ao paciente até que ele mesmo complete a obra do médico com a "autotherapia psychica”.

Em, 1908 foi publicada na Revista Medica de São Paulo uma resenha sobre estudo do médico Doummond, publicado no British Medical Journal, a respeito da neurastenia ${ }^{914}$.

Conforme o texto, o autor considera a neurastenia uma perturbação psíquica, pois os sintomas físicos dos neurastênicos não têm substrato anátomo-patológico. Recomenda então verificar a história psíquica do paciente, tanto pessoal como familiar.

Informa-se que o autor considera de grande importância a personalidade psíquica do médico para o bom sucesso do tratamento, e faz questão de dizer que não se trata de hipnotismo, nem de sugestão, mas sim da relação comum entre o médico e o paciente. Frisa-se que o sucesso no tratamento consiste em corrigir e dominar o defeito mental do doente, não se devendo fazer uso de medicamentos, e que se deve animar o doente a pensar melhor do próprio eu e fazer esforços para superar seus incômodos.

O texto informa ainda que às vezes recomenda-se o isolamento do doente, para afastar-se de circunstâncias do ambiente. Citam-se outras terapêuticas, como o “tratamento de Weir Mitchell”, que acrescenta outras medidas ao isolamento. Também se informa que Dejerine considera como tratamento, a persuasão, e que ele não admite a sugestão, como usavam Charcot e outros, porque "não esclarece a intelligencia do doente e não exerce uma educação racional das faculdades volitivas, mas ao contrario" ${ }^{915}$.

Em 1908, na Revista Medica de São Paulo, na seção "Variedades”, foi publicada resenha sobre artigo intitulado “O hypnotismo e os criminosos”,916, de autoria

914 REVISTA MEDICA DE S. PAULO. Sobre a origem psychica da neurasthenia e da sua importância therapeutica. Revista Medica de S. Paulo, p. 300-301, 1908.

915 Idem, p. 301.

916 VARIEDADES. O hypnotismo e os criminosos. Imprensa Medica, p. 302, 1908. 340 
do Dr. Münsterberg, professor de Psicologia na Universidade de Harvard, publicado no Annals of Psychological Science.

O texto informa que, nesse trabalho, é questionado se durante a ação hipnótica é possível obter confissões que possam prevenir muitos crimes, ou ainda se é lícito ter o direito de incutir idéias morais recorrendo ao hipnotismo. O autor não chega a responder a questão, mas se propõe a estudar o que pode fazer “o psychologo moderno” para prevenir e suprimir o crime.

Em 1912, é publicada, na Imprensa Medica, resenha sobre o livro "Psychotherapia" ${ }^{917}$, de autoria do médico André Thomas, chefe de laboratório na Clínica de Moléstias do Sistema Nervoso da Faculdade de Medicina de Paris, com introdução do professor Dejerine.

Conforme o texto, o autor visa "o lado pratico da cura das molestias nervosas pela psychotherapia”, distinguindo os casos em que esse método merece ser aplicado. Ainda de acordo com a resenha, apesar da psicoterapia ter existido em todos os tempos e todos os meios sociais, ela só pode ser aplicada metódica e eficazmente por quem conheça a patologia humana por completo. Assim, afirma-se no texto que só o médico que for capaz de distinguir "as psychonevroses das moléstias orgânicas do systema nervoso”, pode ser um psicoterapeuta.

Lê-se também na resenha que, depois de haver estudado a sugestão, o hipnotismo, a autossugestão, o autor expõe os processos de "persuasão”, dito aqui como “verdadeiro methodo psychotherapico”, além de insistir sobre métodos adjuvantes, em especial o isolamento.

Consta também que o tratamento da histeria e da neurastenia ocupa a maior parte do livro, além do tratamento das “obsessões dos ticos, a educação das creanças anormaes e a reeducação dos enfermos atacados de certas lesões organicas”.

917 BIBLIOGRAPHIA. Psychotherapia; pelo Dr. André Thomas. Imprensa Medica, p. 238-239, 1912. 


\section{4. 2. - Laboratório Clínico (1899-1912)}

Em 1902, na Revista Medica de S. Paulo, publica-se um artigo da Gazeta Medica da Bahia, de autoria de Juliano Moreira, intitulado “Da necessidade da fundação de laboratorios nos hospitaes” ${ }^{918}$. Nesse artigo, o autor escreve que laboratórios em hospitais poderiam colaborar muito com a "nevrologia”, entre outras áreas citadas. Ele diz que, inclusive nas faculdades, há falta de materiais de laboratório, embora haja mais professores do que nas escolas estrangeiras.

Para reforçar sua afirmação, Moreira faz uma reflexão a respeito das modificações que a Medicina experimentou nas últimas décadas do século dezenove, através dos trabalhos publicados nesse período. Informa ele que nas sétima e oitava décadas desse século, foram maiores as contribuições ao estudo do "diagnostico physico”, com auscultação e percussão, em comparação com os resultados das necrópsias. Moreira diz também que se desenvolveu o termômetro, bem como o "ainda imperfeito microscopio”, e em raros casos o "esphygmographo”. Continuando, o autor informa que as pesquisas anatomopatológicas se espalharam pelo mundo e na Bahia floresceu o grupo que estudou filariose, ancilostomíase, ainhum, etc.

Diz Moreira que, na nona década do século XIX, surgiram os estudos físicoquimicos e os estudos do metabolismo se aprimoraram. O autor também detalha uma série de conhecimentos obtidos em outros países, nesse campo, que ainda não foram aplicados no Brasil; também cita que se desenvolveu a bacteriologia.

O autor informa que percorreu o Brasil, e só em S. Paulo encontrou um laboratório clínico ao lado de uma enfermaria (ele não especifica que local é esse). Moreira lamenta que os hospitais sejam tão relutantes em aceitar laboratórios, e não entenderem sua necessidade. Ele considera um crime o ensino médico ficar restrito à clinica, sem laboratório, e cobra dos jovens que exijam que lhes seja fornecida a “sciencia verdadeira”. Desse modo, ele sugere a instalação de um instituto anátomopatológico, um laboratório bacteriológico e um laboratório de química clínica, nos hospitais.

918 MOREIRA, J. Da necessidade da fundação de Laboratórios nos hospitaes (extraído da Gazeta Medica da Bahia). Revista Medica de S. Paulo, p. 258-262, 1902. 


\section{4. 3. Práticas nos hospícios e outros estabelecimentos (1899-1912)}

Em 1900, Franco da Rocha procura responder, em “Apontamentos e Estatística”, a questionamentos que estão sendo feitos a respeito dos métodos de tratamento, que utilizam o trabalho nos hospícios. Na Revista Médica de S. Paulo é reproduzida a parte relacionada com essas explicações, além de alguns dados estatísticos. Na sessão intitulada “A questão do trabalho nos hospícios” que:

"Levantou-se uma duvida. De onde quer que tenha vindo precisa ela de esclarecimento. $O$ ponto de vista, perfeitamente scientifico e moderno, que serviu de guia á nova instituição creada pelo governo de S. Paulo, póde não ser devidamente conhecido e dar assim logar a interpretação desfavoravel. $O$ intuito destes artigos é resolver as seguintes questões:

$1^{\circ}$ - É de utilidade o trabalho para os alienados?

$2^{\circ}$ - Qual o meio pratico de aproveitar semelhante trabalho? ${ }^{220 ",}$

Assim, ele passa a responder à primeira pergunta, subtitulando o seu texto com essa mesma pergunta. Cita aquele que ele considera ser talvez a mais proeminente figura da psiquiatria inglesa, Hac Tuke, de um texto do Dictionary of Psychological Medicine. Conforme Franco da Rocha, Tuke diz que:

“A occupação, lei universal da natureza para a saude, tanto do corpo como do espirito, é especialmente benefica para o louco, visto que substitue as idéas morbidas por novos e salutares pensamentos, revive o habito familiar de actividade diaria, restaura a estima da propria personalidade, mostrando ao paciente que é elle util para alguma coisa, ao mesmo tempo que the promove a saude geral do corpo. A occupação fora de casa é sem duvida a melhor, e os trabalhos de agricultura e jardim são meios inestimaveis de tratamento. Todas as especies de officinas são uteis, tanto para amadores como para os artistas”21.

Depois, Franco da Rocha cita Edward O’ Neill, médico superintendente do Asilo de Limerick, na Irlanda, que fez um discurso perante a Medico-Psychological Association, em 1896, registrado no The Journal of Mental Science de 1896, onde disse que: “o exercicio e a occupação systematica para os loucos constituem o assumpto que mais me tem interessado desde que comecei a estudar psychologia, acreditando que essa é a chave de aboboda do tractamento moderno da loucura"922.

\footnotetext{
${ }^{919}$ ROCHA, F. Apontamentos e Estatística. Revista Medica de S. Paulo, p. 89-90, 1900. 920 Idem, p. 89.

921 Idem, p. 90.

922 Idem. 
A seguir, cita Clouston, medico chefe do Royal Edinburgh Asylum Morningside, que escreveu um artigo para Mental Diseases de 1896, no qual relata a segunda-feira como o dia de mais tumulto no asilo, por seguir-se a um dia sem trabalho.

De modo similar, Franco da Rocha refere que outras instituições inglesas também aplicam o trabalho como terapêutica. Ele, então relata uma citação do médico alemão Kohlhaas, da revista Allgemeine Zeitschrift fur Psychiatrie de 1898, onde referiu sua admiração pelo sossego dos asilos ingleses, devido ao tratamento pelo trabalho.

Depois, Franco da Rocha cita o alemão Schule, autor de um tratado de moléstias mentais, que recomenda o trabalho em casos de melancolia ou de mania. Em relação à fraqueza psíquica, acentuada por Franco da Rocha como muito comum no Juquery, esse autor alemão recomenda trabalho no campo. Franco da Rocha cita também Otto Snell, medico do asilo de Hildesheim, que também recomenda a agricultura, conforme registrado em Grundzüge der Irrenpflege de 1897. Kraepelin também é citado, o qual referiu progresso no tratamento com as colônias e o trabalho no campo.

Sobre experiências registradas nessa aplicação, Franco da Rocha menciona o autor alemão Koppe, cuja experiência vem sendo imitada em vários centros. O estudioso Ziehen é citado como exemplo de aplicação desse tratamento em demência. Finalmente, ele fecha o relato de autores sobre esse quesito, com Kovalevsky, que aponta inclusive benefícios físicos dessa terapêutica, benefícios esses que acabam, segundo ele, por melhorar também os aspectos mentais.

Assim, Franco da Rocha conclui que o trabalho físico, no tratamento das moléstias nervosas e mentais, é útil: “ $1^{0}$ - sob o ponto de vista physiologico, como todo o movimento; $2^{\circ}$ - sob o ponto de vista hygienico, como meio de desenvolvimento; $3^{\circ}$ como meio moralisador; $4^{\circ}$ - como meio pedagogico; $5^{\circ}$ - como meio de equilibrar as funcções do cerebro",923.

Em seguida, ao comentar citação de Kovalevsky presente em "Hygiene e Tratamento das molestias mentaes e nervosas”, de 1890, Franco da Rocha diz que prefere aplicar o trabalho ao ar livre, como a jardinagem e os trabalhos de agricultura, “porque são executados em plena liberdade, em plena natureza, no ar puro”. Em segundo lugar, ele elege os trabalhos de cozinha e lavanderia e por ultimo de oficinas, porque estes colocam os doentes em condições menos favoráveis. 
Assim, após relatar outras experiências internacionais, ele diz que:

"Basta o que ficou dito para constituir solido alicerce sobre o qual assenta a instituição creada pelo governo de S. Paulo. Pobre do Director do Hospicio, se não tivesse esta muralha de granito para o defender. Se não tivesse dito na Europa tudo o que acima foi transcripto, a prata da casa de nada serviria",924.

A seguir, Franco da Rocha relata exemplos de sucesso do próprio Juquery, como um doente, que após 15 anos de separação da família, voltou a visitar os parentes em bom estado mental e hoje é pessoa que vive por si e está empregada no hospício.

Depois relata outro caso que chegou a descrever em artigo, para o Brazil Medico, em 1896, a respeito de doente que quando parava o trabalho, cessava a saude mental, ocorrendo o contrário quando voltava ao trabalho.

Assim, ele diz que muitos melhoraram, inclusive passando a ser empregados no hospício. Em dado momento de sua escrita, ele diz: “Agora mesmo, enquanto escrevemos estas linhas (coincidencia interessante), bate á porta do Hospicio, em busca de trabalho uma mulher que aqui entrou ha um anno, com delirio de perseguição, e que recuperou a saude no labor continuo de sol a sol”925.

A seguir, Franco da Rocha refere que essa paciente foi empregada e saiu do Hospicio em dezembro de 1898, com dinheiro e saúde mental. Volta agora, em busca de emprego, continuando com boa saúde mental. Relata ainda outro caso, de um italiano que foi tratado com o trabalho e que guarda na Caixa Econômica, a seu conselho, o produto de seu trabalho, para que algum dia volte à sua pátria.

Depois Franco da Rocha passa a responder à pergunta: “Qual o meio practico de aproveitar o trabalho dos loucos?”. Ele refere que a resposta pode ser deduzida das demonstrações anteriores:

“A maior parte dos nossos doentes provém da classe dos trabalhadores da agricultura, habilitados ao serviço rude de 10 e 12 horas por dia. Que fazer? Transformal-os aqui em alfaiates, sapateiros, typographos? Qual a melhor occupação para esses doentes, segundo a opinião dos mestres já citados? Não ha discordancia: é o trabalho da agricultura, por ser o que menos exige exforço intellectual. Portanto, ao leitor intelligente nada mais precisamos dizer. A orientação que domina no Hospicio de S. Paulo é completamente scientifica. E basta”,926.

924 Idem, p. 92. 925 Idem. 926 Idem, p. 93. 
Em 1903, Franco da Rocha publica na Revista Medica de S. Paulo seu trabalho anual intitulado “Estatistica e Apontamentos”, referente ao ano de $1902^{927}$.

Nesse texto, ele refere que está aplicando, há mais de um ano, o tratamento de “Clinotherapia”, que relata ser recomendado por europeus e por Juliano Moreira. Tratase de repouso no leito, com os doentes vigiados “por empregados” durante todo o dia. Ele escolheu os doentes agitados e turbulentos, tanto para afastá-los das enfermarias, como para testar o método. Uma primeira observação indicou que o método é custoso, pela excessiva despesa com enfermeiros. Ele considera como um bom método nos casos de psicoses agudas. Nos outros casos, o benefício se restringe à tranqüilidade nas enfermarias.

Nos casos de paralisia geral, tem utilidade por prevenir quedas, e suas conseqüentes contusões e ferimentos. Outra vantagem referida: “podem ser dispensados quartos caros acolchoados para os doentes de formas agudas"928. À noite, são dados medicamentos hipnóticos e os doentes dormem nos quartos isolados.

Outro assunto abordado por Franco da Rocha nessa publicação é o prognóstico em Psiquiatria, referindo que, nessa especialidade, é mais incerto do que em outras. Nesse sentido, exemplifica com três doentes que tiveram alta em 1902. Um ficou internado por quatorze anos, outro onze anos, e outro nove anos. Há também um caso de alta após 20 anos, que ele refere não ter citado por não conhecer o início do caso, que tinha sido anterior ao período em que ele passou a trabalhar no hospício.

O primeiro desses casos é de um "paranoico com delirio ambicioso"929, que tinha acessos de raiva e agressividade. Após sua mudança para o Juquery, com o sistema de liberdade adotado, o paciente apresentou atenuação suficiente para seu quadro, de modo que pode ter alta, e está há um ano com a família, “muito alegre, trabalhando, sem ter tido collisão alguma com seu meio social”930.

Os outros dois casos, de nove e de onze anos de internação, tinham intervalos de calma curtos e períodos longos de excitação; antes de receberem alta, passaram por mais de um ano trabalhando “em bom estado mental”" ${ }^{31}$. No momento do relato, ambos já

927 ROCHA, F. Hospicio de S. Paulo, Estatística e Apontamentos. Revista Medica de S. Paulo, p. 463466, 1903.

928 Idem.

929 Ibidem.

930 Ibidem.

931 Ibidem. 
estão, há dois anos, sem sintomas e trabalhando. A paciente que ficou por vinte anos passou a estar com a família, sem ter precisado voltar ao hospicio.

Há ainda um outro caso, de uma mulher que se retirou do hospício há quatro anos, onde estivera por quinze anos. Seu tratamento foi o trabalho manual com a lavagem de roupa; passou a trabalhar tão bem, que foi empregada no próprio hospício, com o que ganhou algum dinheiro e se retirou.

Assim, Franco da Rocha acentua que o trabalho é de importância capital para os alienados. Ele diz que o sistema de colônia agrícola já reduziu despesas para o Estado. Considera que, no futuro poderão ser deixados doentes para trabalharem em casas de famílias que os sustentem.

Nesse mesmo ano, foi reproduzido, em periódico médico paulista, artigo do Jornal do Commercio, que faz revisão do período de governo de Rodrigues Alves, de 1902 a 1906, a respeito de medidas referentes à saúde, das quais destacamos apenas uma parte.

Desse modo, no final do ano de 1906, a Revista Médica de São Paulo publica artigo do Jornal do Commercio a respeito do governo do Dr. Rodrigues Alves, de 1902 a 1906. Assinala o trabalho de Oswaldo Cruz no saneamento do Rio de Janeiro, a modernização do Instituto de Manguinhos, além de outras medidas higiênicas.

Também destaca a necessidade de reformar por completo a Assistência aos Alienados da Capital da República, “após rigorosa syndicancia”. Nesse sentido, foi chamado a dirigir o Hospício Nacional “o Professor Juliano Moreira, da Faculdade da Bahia”(em 1903). Ele apresentou um plano de reforma que incluí nova lei de assistência aos alienados, bem como meios considerados mais eficazes de cuidar e tratar os insanos. Daí resultou o decreto 1132, de 22 de Dezembro de 1903, reorganizando a Assistência aos Alienados. Essa lei "Ihes salvaguarda as pessoas e os bens; ella realizou a antiga aspiração de beneficiar o insano com a protecção legal e de garantir aos suspeitos de o serem”. Assim, foi feita uma reforma para transformar o hospicio num "hospital modelo". Desse modo, “foram banidos todos os processos obsoletos de contenção: a camisa de força, a casa forte, os vexames de toda sorte foram substituidos pelo opendoor, pela klinotherapia, pela balneação prolongada, dando resultados magnificos”. 
Para atender à superpopulação do hospício, o governo solicitou ao Congresso a criação de uma "Colonia”, que ainda aguarda resolução.

Em 1905, na Revista Medica de S. Paulo, na seção "Noticias”, foi publicada matéria intitulada "Instituto Psycho-Physiologico" ${ }^{932}$. O texto parte de uma conceituação de que a terapêutica deixou de usar métodos considerados complicados e sofridos para o paciente, como sangria e substâncias químicas, para utilizar métodos mais confortáveis e naturais, como os assim chamados métodos físicos, principalmente no terreno do sistema nervoso:

“A medicina, dia a dia, tende a simplificar os processos de tratamento. Acabou-se a epocha das tisanas nauseantes, dos apózemas complicados e da sangria desastrada e este tempo, onde o ficar doente era começar um martyrio de operações complexas, succedeu uma therapeutica suave, commoda e até confortavel.

A droga chimica diminuiu seu circulo de generalização, o produto biologico appareceu com seu contingente benefico e os agentes naturaes ganharam foros de cidade, desde a hydrotherapia, com sua gamma variada, até a massagem salutar e estimuladora.

O repouso, a luz, o calor, a agua, a electricidade têm hoje valiosas applicações no mister clinico, curando doentes, desanimados as vezes com os remedios pharmaceuticos e desesperançados de rehaver a saude preciosa.

A therapeutica physica, actualmente, é indispensavel ao exercicio da medicina; sem ella certas affecções, sobretudo da esphera nervosa, ficariam sem elementos capazes de suster ou modificar sua evolução"

O texto informa que a cidade de S. Paulo deixa de ter uma "grande lacuna”, com a criação do novo "Instituto Psycho-Pshysiologico", podendo contar com mais métodos de cura:

“A capital de São Paulo, cidade possuindo cerca de trezentos mil habitantes, tinha a grande lacuna de não contar com um estabelecimento completo, onde os agentes naturaes fossem empregados na arte de curar. Felizmente, desde o dia $1^{\circ}$ de outubro, tivemos o prazer de ver removido este inconveniente. O Dr. Domingos Jaguaribe inaugurou, no seu bello parque, situado a rua Veridiana, um Instituto Psycho-Physiologico que, pela sua excellente disposição e riqueza materil faz honra a nossa Paulicéa" ${ }^{334}$.

932 NOTICIAS. Instituto Psycho-Physiologico. Revista Medica de S. Paulo, p. 414-415, 1905. 
Segundo o texto, nos três pavilhões que compõem o Instituto, distribuem-se as atividades de: massagem, ginástica, hidroterapia, aparelhos para mecanoterapia, cabines para banhos, utensílios para ginástica, salão de duchas, eletroterapia, fototerapia, consultórios médicos, inalações medicamentosas, sala de curativos cirúrgicos e ginecológicos, “aposento reservado para suggestões hypnoticas”, terraço para banho de sol, tanque de natação.

Em 1905, é publicada em São Paulo uma aula do Prof. Henrique Roxo, na Gazeta Clinica, na seção “Clinica Psychiatrica”. O professor é identificado como “lente interino da Clinica Psychiatrica e de Molestias Nervosas” da Faculdade do Rio de Janeiro. O título da aula é "Klinotherapia"935.

O autor discorre a respeito dessa terapêutica, que consiste no tratamento pelo repouso no leito. Ele faz um discurso contra o uso da camisa de força, apoiando-se no papel da Magnan contra esse método.

Assim, Roxo insere a clinoterapia, a hidroterapia e a eletroterapia no mesmo rol de medidas terapêuticas, particularizando para a clinoterapia a possibilidade de “convencer ao alienado de que elle é um doente como outro qualquer”. O autor refere ainda a clinoterapia como um tratamento moderno, que causou uma "profunda revolução no regimen dos alienados”, tendo acarretado, inclusive, a “educação dos enfermeiros".

A seguir, Roxo passa a um relato histórico sobre a clinoterapia, assinalando que em 1838, o seu criador como método cientifíco, Ellis, a indicava em casos de “irrigação muito abundante do cerebro”. Roxo cita depois outros estudiosos que usaram o método. Ele nota que, na França, o sistema não é muito aceito devido à falta de enfermeiros.

Após referir alguns outros países e estudiosos que empregaram o método, o autor passa a relatar seu emprego no Brasil, queixando-se da falta de atenção de governantes passados em relação ao Hospício e elogiando a situação então vigente, em que o governo concedeu verbas avultadas à instituição, triplicando o número de empregados.

935 ROXO, H. Klinotherapia. Gazeta Clinica, p. 411-423, 1905. 
Em 1909, na Revista Medica de S. Paulo, é publicado o artigo “Assistencia familiar aos insanos em S. Paulo - relatorio apresentado ao Quarto Congresso Medico Latino-Americano”, de autoria de Franco da Rocha ${ }^{936}$.

Franco da Rocha relata, no Estado de São Paulo, a assistência domiciliar, cuja tentativa já está sendo feita há um ano. Ele adotou o sistema que chegou a observar na Escócia pessoalmente, com diferenças adequadas a São Paulo. Nesse sentido, ele expressa sua visão das diferenças entre a Escócia e São Paulo (embora ele se refira "a este país”):

"A lucta pela existencia é mais facil aqui, onde a população pobre pode viver sem necessidade de submetter-se a todo e qualquer recurso de que possa haurir auxilios para sua subsistencia. Na população rural, condensada e pobre daquelle paiz, as cousas se passam de outro modo: um auxilio de sete shillings por semana, á troca de tolerar um demente em casa, não pode ser desprezado, como poderá se dar aqui, neste paiz immenso e rico, onde ninguém morre de fome e muito menos de frio" 937 .

A seguir, o autor refere que se preferiu escolher uma região de população pobre, com lavradores proprietários nacionais, pois os imigrantes não se fixam na terra. Assim, adotaram o município de Juquery a $18 \mathrm{~km}$ do asylo-colonia. Desse modo, no dia 14 de abril de 1908, foram transferidos alguns insanos. A partir daí passaram a ser acompanhados pelos médicos do Asylo-colonia. Chegaram a ser 25 pensionistas até a data do artigo.

Franco da Rocha considera, inclusive, haver uma animação por parte dos outros lavradores, bem como uma satisfação dos pacientes. Ele salienta que desfalcou o asilo central de indivíduos que eram importantes trabalhadores desse local, mas considerou o sacrifício necessário, sendo escolhidos sempre os indivíduos mais tranqüilos. Diferentemente da Escócia, o asilo manteve uma ligação administrativa com esses pacientes. Os lavradores assinam um compromisso pelo qual declaram que darão alimento aos pensionistas, igual ao de sua própria mesa, e que não irão obrigá-los ao serviço, mas vão aceitar o que eles quiserem prestar; além disso, comunicarão os casos de doenças ao diretor do Asilo. Ainda não foram enviadas mulheres para esse sistema, pois na Escócia há o registro de uma gravidez a cada três anos, associada a esse método.

936 ROCHA, F. Assistencia familiar aos insanos em S. Paulo; relatorio apresentado ao Quarto Congresso Medico Latino-Americano. Revista Medica de S. Paulo, p. 341-342, 1909.

Esse trabalho também foi reproduzido na Imprensa Medica, em 1909.

937 Idem. 
O autor conclui com o reconhecimento da boa vontade do governo do Estado em colaborar com essa forma de assistência.

Em 1910, na Revista Medica de S. Paulo, é publicado o artigo "Hospício de Juquery”, de autoria de Enjolras Vampré (identificado como sendo médico do Juquery) ${ }^{938}$.

Vampré diz que, em 1852, o Hospício, com 9 doentes, tinha um chicote de rabo de tatu pendurado à ombreira da porta e que, 58 anos depois, tem um asilo de tratamento com 8 pavilhões, possuindo conforto para abrigar 400 homens e 320 mulheres, duas colônias agrícolas com 386 doentes crônicos, e assistência familiar com 32 doentes. Assim, segundo ele, o contraste, entre os dois momentos, é completo.

No entanto, faltam dois elementos para completar a obra: um pavilhão para moléstias intercorrentes e outro para alienados criminosos. Para reforçar essa idéia, o autor cita a lei de 1903, do Brasil, e o Congresso Penitenciário de 1895, na França, e o Congresso de Alienistas e Neurologistas da França de 1896, em que foram mencionados os “asylos de segurança”.

Em 1912, Vampré publica na Revista Medica de S. Paulo o artigo "Necessidade da hospitalização precoce dos alienados em S.Paulo"939.

Vampré diz que, apesar de todo o adiantamento que há no Estado de São Paulo, em termos de cuidados aos alienados, através do Hospício do Juquery e do trabalho de Franco da Rocha, ainda existe um demérito em relação a essa questão, que é a lentidão com que os alienados chegam ao seu lugar adequado para tratamento, ficando em prisões e cadeias, às vezes por meses, aguardando serem conduzidos ao Juquery.

Segundo o autor, os alienados passam por uma espécie de recapitulação das fases de desenvolvimento no tratamento das moléstias mentais, dizendo acerca do paciente: “é encarcerado, punido, preso entre grades e em fortes camisolas de força, como nos tempos anteriores a Pinel e Esquirol”" tem tanto mais probabilidade de cura, quanto mais cedo for iniciado o tratamento"941.

938 VAMPRÉ, E. Hospicio de Juquery. Revista Medica de S. Paulo, p. 10-11, 1910.

939 VAMPRÉ, E. Necessidade da hospitalização precoce dos alienados em S. Paulo. Revista Medica de S. Paulo, p. 81-84, 1912.

940 Idem.

941 Ibidem. 
Conforme Vampré, em outros países os alienados são levados de ambulância diretamente para o hospital, sem necessidade de passar pelo posto policial. O artigo encerra, solicitando à Sociedade de Medicina e Cirurgia que demande esforços para acabar com a colocação de alienados em prisões.

Em 1912, na Revista Medica de S. Paulo, Enjolras Vampré publica o artigo “Assistencia aos alienados em Berlim”. O artigo foi escrito em Berlim em junho de 1911, subtitulado como "Primeira parte do relatório apresentado ao Exmo. Snr. Dr. Director da Faculdade da Bahia”942.

Vampré, em sua viagem pela Europa, enviou este relatório ao Diretor da Faculdade da Bahia, dando uma série de informações sobre a situação do cuidado aos alienados.

Ele relata que, em Berlim, há cinco grandes asilos, sendo ainda insuficientes, devido ao grande crescimento da cidade após a guerra de 1870. Informa também que a Assistência aos alienados na Alemanha sofreu completa transformação há 40 anos, em virtude do progresso em psiquiatria em vários países, e também devido ao impulso dado ao estudo das moléstias do cérebro, nas vinte clínicas psiquiátricas alemãs.

O autor, então, refere que, na Alemanha, fundaram-se ou iniciaram-se: 1clínicas psiquiátricas autônomas (pequenos hospitais de tratamento); 2 - vastas colônias agrícolas (tratamento em liberdade); 3- pavilhões de vigilância contínua (tratamento para agitados); 4 - abandono completo de todos os meios de contenção; 5 generalização do tratamento pela clinoterapia; 6 - reação contra o isolamento celular; 7 - criação de colônias para epilépticos, delinqüentes, bebedores habituais, nervosos; 8 assistência familiar aos alienados.

Vampré também faz uma descrição cronológica do desenvolvimento da psiquiatria na Alemanha, atribuindo a Langermann, em 1805, a fundação do primeiro estabelecimento para tratar indivíduos com perturbações mentais. Reil foi o iniciador dos asilos-colonia. No entanto, foi a partir de Griesinger, em 1845, com seu tratado de moléstias mentais, que a psiquiatria se modificou grandemente. Diz o autor que, segundo Wernicke, Griesinger foi o fundador da psiquiatria moderna, tendo fundado diversos asilos.

942 VAMPRÉ, E. Assistencia aos alienados de Berlim. Revista Medica de S. Paulo, p. 125-141, 1912. 352 
O autor louva a rapidez com que os alienados são recebidos nas instituições a eles destinadas, e volta a lamentar a demora com que isso acontece em São Paulo, onde há um centro avançado de psiquiatria no Juquery. Em relação ao ensino da psiquiatria, Vampré diz que na Alemanha é mais abrangente do que no Brasil, queixando-se de alguns médicos no Brasil, que nada sabem sobre psiquiatria e nunca entraram num hospício.

\section{4. 4. - Tratamentos medicamentosos (1899-1912)}

Em 1900, na Revista Medica de S. Paulo, Franco da Rocha publica artigo intitulado "Tratamento da Coréia"

Dizendo não ser rara a coréia em S. Paulo, ele se refere a um artigo do professor Bechterew, a respeito do tratamento da Coréia, publicado em 1900 na revista “Centralblatt für Nervenheilkunde und Psychiatrie”.

Conforme diz, Bechterew se refere à recente proposta de um autor para tratar a coréia com altas doses de arsênico, os quais se apóiam também em estudos antigos, acrescentando que esse tratamento tem complicações perigosas. Informa Franco da Rocha que o professor pergunta sobre o "imperativo cathegorico do non nocere” em terapêutica e acrescenta que o estudioso alemão acha que há uma “sofreguidão” pela busca de tratamento específico para as moléstias.

Em acordo com Bechterew, Franco da Rocha diz que, em casos de coréia, ele próprio também utilisa doses menores de arsênico, isoladamente ou associado a bromuretos e antipirina. Nos casos graves, de complicação com reumatismo e endocardite reumática, o professor alemão recomenda salicilato de sódio, bom ar, banhos mornos.

A seguir, Franco da Rocha apresenta caso de paciente de 16 anos, em que ele aplicou a conduta inglesa de altas doses e viu alguns sintomas de intoxicação, referindo que “por felicidade não tive motivos de um serio aborrecimento", pois o doente sarou, tanto da doença quanto dos sintomas secundários ao tratamento. Assim, a lembrança desse caso e do conselho de Bechterew fazem com que ele aconselhe a conduta desse professor.

943 ROCHA, F. Tratamento da Coréia. Revista Medica de São Paulo, ano III, n. 10, p. 237-238, 1900. 353 
Em outro item do mesmo artigo de 1900, Franco da Rocha refere-se com certa ironia a um novo medicamento hipnótico chamado Dormiol, dizendo que “já estamos habituados a esta especie de nomenclatura em que o fabricante attribue ao seu remedio propriedades que só podem ser demonstradas na pratica”.

Assim, ele diz que esse remédio não é tão novo, tendo aparecido primeiramente em 1898, mas sem ter grande aceitação. Sobre o uso desse medicamento no hospicio, ele acentua que é preciso ter cautela antes de iniciar qualquer tratamento, pela variedade de condições presentes nos doentes. Acrescenta que, muitas vezes, o recolhimento no hospício já é um calmante.

Em 1904, na Imprensa Medica, no item “Indicador Bibliographico”, no subtítulo “Molestias do systema nervoso”, foi publicada resenha intitulada "Tratamento da epilepsia chronica com paroxismos e do estado de mal epileptico"944, de J. Vires de Montpellier (Gazette dês Hôpitaux, fev.1904).

Conforme o texto, esse tratamento é subdividido em fases em relação ao ataque epiléptico.

Antes do ataque, se são convulsões generalizadas, usa-se "tratamento prophylactico”, para evitar o efeito de “causas de irritação reflexas, luminosas, sonoras, etc., a autointoxicação, a fadiga e o uso de bebidas alcoolicas”.

Se são crises parciais, recorre-se à “medicação perturbadora”, representada por "vesicatorios, cauterisações, ligadura do membro originario da aura”. Se for crise considerada como “visceral”, indica-se ingestão de água, sal ou pão, ou ainda a compressão das artérias carótidas.

Durante o ataque, recomendam-se cuidados gerais para reduzir os efeitos de quedas e sufocações.

Após o ataque recomenda-se a correção de luxações e fraturas e dar “estimulantes diffusivos” como chá e café.

Fora do ataque, dá-se "medicação antispasmodica”, como belladona, isolada ou associada ao bromureto; também a valeriana em clisteres; ou musgo em clisteres, ou sais de zinco, considerados como poderosos contra a epilepsia. Há também uma fórmula com borato de sódio.

944 INDICADOR BIBLIOGRAPHICO. Molestias do systema nervoso: Tratamento da epilepsia chronica com paroxysmos e do estado de mal epileptico, J. Vires, de Montpellier (Gazette des Hôpiteux, Fev. 1904). Imprensa Medica, p. 87-88, 1904. 
Os bromuretos são considerados como exercendo ação sobre o "neurona motor cortical, diminuindo sua excitabilidade”. Cita-se que Charcot dava preferência aos bromuretos de potássio, de sódio e de amônia divididos em duas vezes no dia. Recomenda-se o método de Charcot de aumento gradual de medicação.

No estado de mal epiléptico, considera-se necessário cessar imediatamente as crises, com o uso de inalação de clorofórmio, de nitrito de amilo, de injeções de morfina e clisteres de cloral.

Em 1904, na Imprensa Medica, é publicada resenha sobre o artigo “Emprego do borax no tratamento da epilepsia” ${ }^{945}$, por F. Hoppe. O autor relata que, em algumas situações, o uso de bromureto é insuficiente para controlar crises epilépticas, principalmente em casos com comprometimento em outros órgãos. Em alguns desses casos, o autor considera que os boratos, antes usados no tratamento da epilepsia, podem ser bons adjuvantes no tratamento com bromuretos.

Em 1904, na Imprensa Medica, é publicada resenha sobre o trabalho “Tratamento das gastro-nevroses organopathicas"946, por Hayem. O autor acha que as crises gástricas devem ser consideradas como manifestações dos centros nervosos da vida orgânica ou vegetativa, e não como ligados aos centros psychicos. Assim, ele considera que a terapêutica deve visar "o estado gastrico”. Conforme o caso, o autor recomenda tratamento cirúrgico, ou supressão de álcool, ou repouso, ou medidas alimentares. A "neurasthenia dos adolescentes e dos adultos acompanhada de dyspepsia” é tida como podendo se beneficiar da "cura de altitude”.

Em 1905, na Revista Medica de S. Paulo, publica-se resenha sobre artigo do Archives Generales de Medicine, de maio de 1905, referente ao "Tratamento dea epilepsia pelo methodo de Bechterew”, dos autores Marcel Briand e G. Halberstadt ${ }^{947}$.

Informa-se que, em 1894, Bechterew, por experiências e observações, criou um método de tratamento da epilepsia associando adonis vernalis ao bromureto. Ele partiu

945 INDICADOR BIBLIOGRAPHICO. Molestias do systema nervoso: Emprego do bórax no tratamento da epilepsia, F. Hoppe (Berlin Klin. Woch., 4 de junho de 1904). Imprensa Medica, p. 137-138, 1904. 946 INDICADOR BIBLIOGRAPHICO. Moléstias do systema nervoso: Tratamento das gastro-nevroses organophaticas, por Hayem. Imprensa Medica, p. 235-236, 1904.

947 REVISTA MEDICA DE S. PAULO. Resenha: Briand, M.; Halberstadt, G.; Tratamento da epilepsia pelo methodo de Bechterew, p. 291, 1905. 
do princípio de que existe uma hiperemia encefálica associada aos acessos epilépticos, incluindo aí a constatação feita por Magnan, de alterações sugestivas ao exame de fundo de olho.

Em vez do uso de digitálicos, ele prefere adonis vernalis, por regularizar os batimentos cardíacos, promover vasoconstrição e diurese, com eliminação de toxinas. Os autores, em 1899, empregaram esse método e consideraram ter havido sucesso, corroborado por outros autores relatados no artigo.

Na Gazeta Clinica, em 1905, é publicada a aula “Tratamento da epilepsia”, dada pelo Dr. Henrique Roxo, identificado como "lente substituto interino de Clinica Psychiatrica e de Moléstias Nervosas”, da faculdade de Medicina do Rio de Janeiro ${ }^{948}$.

Ele refere ter experimentado quase todas as medicações para epilepsia, afirmando que, na maioria das vezes, elas tiveram valor negativo. O autor passa então a elogiar os brometos, principalmente o brometo de potássio, sendo atestada sua eficácia por todos os tratadistas modernos, sendo que ele emprega em associação com outros medicamentos. Cita autores como Charcot, Legrand du Saulle e Voisin, que diziam que o brometo deve ser “o pão do epiléptico”.

O autor reconhece as vantagens do tratamento brometado. No entanto, refere que, em 1903, conheceu o tratamento do professor Urbano Alessi, de Pisa, nas páginas da "Riforma Medica” de 22 de abril de 1903, onde foi registrada uma fórmula que, segundo ele, pode corrigir ou evitar alterações sistêmicas, as quais podem favorecer a ocorrência de crises epilépticas. Assim, ele recomenda associar essa fórmula ao brometo.

Em 1905, Na Gazeta Clinica, na seção “Notas therapeuticas”, publica-se o artigo “A medicação phosphorica na Psychastenia”, texto esse retirado do periódico registrado como Pr.Med. de 1904 (sem menção a autor) ${ }^{949}$.

O texto indica o papel preponderante dos elementos fosforados no substrato químico dos processos mentais. Reforça isso com A. Gautier, que observou essa perda dos fosfatos, tanto maior quanto mais ativa a vida intelectual do indivíduo. Apela também ao trabalho de Mairet, o qual constatou que nas crises nervosas agudas, “do

948 ROXO, H. Tratamento da epilepsia. Gazeta Clinica, p. 129-137, 1905.

949 NOTAS THERAPEUTICAS. A medicação phosphorica na psychasthenia. Gazeta Clinica, p. 125, 1905. 
delírio, da mania, lipemania, epilepsia, etc.”950, ocorre aumento na proporção da uréia e ácido fosfórico na urina. Desse modo, conforme o artigo, concluiu Martinet que a administração de preparados de fósforo se impõe em todos os casos de evidente ou provável "gasto nervoso"951.

Em 1910 é destacado, em vários artigos da Revista Médica de São Paulo, o início do uso do medicamento chamado de “606”, ou Salvarsan, criado pelo prof. Ehrlich, da Alemanha, como sendo uma grande esperança contra a sífilis. Esse assunto já foi citado anteriormente em outro item.

\section{4. 5. - Tratamento cirúrgico (1899-1912)}

Em 1901, na Revista Medica de São Paulo, há dois artigos de procedimentos cirúrgicos envolvendo o sistema nervoso. Um caso já foi relatado em outro item, a respeito do trabalho do médico Coriolano Burgos de Amparo em cirurgia craniana.

Outro relato foi feito pelo médico Dias Martins, da cidade de Rio Claro, a respeito de caso de meningocele, comprometendo criança de 42 dias de idade ${ }^{952}$. Após expor os estudos de diversos autores a respeito desse quadro, o autor relata o comprometimento dessa criança, fazendo, em seguida, a descrição da cirurgia realizada, tendo sido referida a cura e alta após oito dias da operação.

Em 1907 é publicada, na Revista Medica de S. Paulo, uma resenha sobre o artigo "Estado actual da cirurgia do cerebro" "953, pelo Prof. Allen Starr. Nesse artigo são descritas, de forma sucinta, as aplicações da cirurgia do cérebro em casos de: abscessos cerebrais, tumores cerebrais, hemorragia cerebral, epilepsia e cerebroplégicos. O autor desaconselha o tratamento cirúrgico em casos de imbecilidade-idiotia.

950 Idem.

951 Ibidem.

952 MARTINS, D. Um caso de meningocele. Revista Medica de S. Paulo, p. 202-204, 1901.

953 REVISTA DAS REVISTAS. STARR, A.; Estado actual da cirurgia do cérebro; J.A.M.A., n.12, 1907. Revista Medica de S. Paulo, p. 293, 1907. 


\section{4. 6. - Assistência a alienados delinqüentes (1899-1912)}

Em 1903, na seção “Bibliographia”, da Revista Medica de S. Paulo, Franco da Rocha publica suas considerações sobre a tese inaugural do médico Francisco Pondé, ocorrida na Bahia, em 1902, aprovada com distinção, intitulada “Assistencia publica aos alienados delinquentes no Brazil”954.

Foi oportuno a Franco da Rocha poder comentar esse trabalho, pois veio de encontro a um assunto que é foco de seu interesse, o "alienado delinqüente”, fazendo menção de aconselhar o governo a esse respeito, lembrando a criação de hospícios para criminosos alienados, em outros países. Ressalta ele que, antes de Pondé, o médico A. Regnard, na França tratou desse assunto em relatório apresentado ao Conselho Superior de Assistência Pública (conforme os Annales Medico-psychologiques em 1901, citados por Franco da Rocha).

Ele acentua essa questão, com queixas a respeito de ocorrências no Hospicio do Juquery, em especial em relação a quatro criminosos que, segundo ele, são calmos e raciocinam bem, mas que procuram meios de fuga com grande argúcia. Franco da Rocha diz que o hospício não é cadeia e que esses indivíduos trazem um constante sobressalto. Ele considera o tratamento inútil nesses casos, classificando esses indivíduos como “degenerados”. Acrescenta que alguns alienados criminosos não perturbam o hospicio e lá podem ficar. Franco da Rocha acha que o governo deveria fazer um anexo à cadeia, como meio de transição para um sistema melhor.

Ele considera também que esses indivíduos criminosos podem ser acobertados pelo diagnostico psiquiátrico, o qual pode levá-los à liberdade, propiciando a possibilidade de cometerem novos crimes, ou ainda, transformando o hospício em cadeia. Assim, ele acha que é difícil atingir o objetivo do hospício que é dar aos doentes uma vida comum em sociedade.

954 ROCHA, F. Assistencia publica aos alienados delinquentes no Brazil (these inaugural do Dr. Francisco Pondé, Bahia, 1902) (approvada com distincção). Revista Medica de S. Paulo, p. 135-136, 1903. 


\section{4. 7. - Exame e tratamento por coleta de líquido cefalorraquiano (1899-1912)}

Em 1905, na Imprensa Medica, é publicado por Vieira de Mello, um artigo intitulado "A meningite cerebro-espinhal epidemica e o meningococo"955.

O autor comenta que as autoridades sanitárias de Nova York tornaram obrigatórias, para os casos de meningite cérebro-espinhal, todas as medidas impostas às moléstias epidêmicas e contagiosas durante a epidemia que por lá grassou, com 910 óbitos de janeiro a abril de 1905.

Mello informa que o prof. Chauffard, a propósito de um caso com esse quadro, fez uma explanação atualizando dados sobre a moléstia. Quanto à sintomatologia clínica, foi explicado que os quadros mais graves são os que comprometem também alguma das partes do sistema nervoso além das meninges.

Foi dito que o melhor elemento para o diagnóstico desse quadro é a punção lombar e o exame do líquido cefalorraquiano, demonstrando o meningococo. Além disso, Mello explica que a punção lombar também é um bom tratamento para o sintoma de cefaléia, além de suprimir “toxinas”.

Em 1906, publica-se na Revista Medica de S. Paulo, o artigo "Meningite cerebro-espinhal epidemica" ${ }^{956}$, de autoria do professor alemão Adolpho Baginsky (sobre o tradutor do artigo, constam apenas as letras T.B.). O autor fez um artigo detalhado e minucioso sobre a meningite, com dados históricos, com muitas citações de autores e trabalhos, inclusive sob o ponto de vista epidemiológico, registrando o conhecimento do agente microbiano causal desde 1887.

Baginski faz uma descrição do quadro clínico, com comprometimento dos diversos sistemas, incluindo o sistema nervoso, com alterações de natureza física e mental, citando o reflexo de Babinski e outros reflexos como fenômenos, segundo ele, muito notados nesses casos. Cita o exame do líquido cefalorraquiano como fator fundamental para o diagnóstico de meningite.

955 MELLO, V. Movimento medico; A meningite cerebro-espinhal epidemica e o meningococo. Imprensa Medica, p. 236-239, 1905.

956 BAGINSKY, A. Meningite cérebro-espinhal epidemica. Revista Medica de S. Paulo, p. 136-143, 1906. 
Em 1906, é publicada na Revista Medica de S. Paulo, na seção "Revista das revistas”, a resenha intitulada “Tratamento da meningite epidêmica - pelo Dr. Carlos da França” ${ }^{957}$. Esse pesquisador português observou em uma epidemia, em seu país, que a meningite epidêmica podia ser tratada pela "puncção lombar pelo methodo de Quincke”, pelo fato de tal procedimento diminuir a pressão do líquido cefalorraquiano, e, assim, retirar bactérias do organismo e eliminar toxinas, aliando a isso a injeção de uma solução antisséptica no canal raquiano.

Em 1910, na Revista Medica de S. Paulo é publicado o editorial “Tratamento da epilepsia pela introdução do bromureto de potássio no liquido cephalo-rachiano”958.

No editorial de 31 de janeiro de 1910, registra-se que Franco da Rocha, Oliveira Fausto e Enjolras Vampré estão fazendo uma tentativa de tratamento de casos graves de epilepsia com a injeção de bromureto de potássio no líquido cefalorraquiano. Um paciente, que tinha dez crises por mês, ficou dezesete dias sem crise, o que foi considerado surpreendente. Antes desse procedimento, a retirada de líquido cefalorraquiano (para diminuir a pressão intracraniana) não havia surtido efeito nos casos em que foi adotada.

\section{5. - Conclusões do período 1899-1912}

Nestas conclusões, vale a mesma observação feita na conclusão do capítulo anterior, em relação a evitar repetições de comentários.

Neste período um novo paradigma sobre a histeria vem substituir a conceituação de Charcot. Ao modificar e reduzir essa conceituação, Babinski lança novas delimitações sobre o corpo neurológico. Fazendo a eliminação dos estigmas, ele restringe a sintomatologia da histeria ao terreno mental. Ao responsabilizar o médico como indutor da sintomatologia histérica, ele lança um novo olhar sobre o relacionamento entre médico e paciente.

957 REVISTA DAS REVISTAS. FRANÇA, C.; Tratamento da meningite epidêmica; Deutsche Med. Wochens., 1905, n. 20. Revista Medica de S. Paulo, p. 143, 1906.

958 EDITORIAL. Tratamento da epilepsia pela introdução do bromureto de potássio no liquido cephalorraquiano. Revista Medica de S. Paulo, p. 21, 1910. 
A partir do estabelecimento, em 1896, do sinal que adquire seu nome, Babinski gradativamente acrescenta novos fatores ao sistema estímulo-resposta, redesenhando os contornos do corpo neurológico.

Esse novo paradigma chega a São Paulo, por meio de médicos que vão a Paris. Primeiramente Celestino Bourroul, pela Imprensa Médica, em 1906, comunica os novos sinais estudados por Babinski; no entanto, sua informação tem poucos adjetivos e limita-se ao aspecto técnico. A leitura de seu artigo não permite a percepção dos leitores para grandes novidades.

Por outro lado, em 1908, Rubião Meira, fazendo menção a esse artigo de Bourroul, envia uma correspondência a São Paulo cheia de adjetivos e empolgações, sem assinalar tanto a questão técnica. Ambas as comunicações expressam uma singularidade da construção da neurologia em questão em São Paulo.

O artigo de Bourroul se insere em uma sucessão de comunicações por ele enviadas da França para a Imprensa Médica: um periódico que em sua fundação, explicita a sua própria passagem, como instituição, do Rio de Janeiro para São Paulo.

Já o texto de Meira é uma forte expressão de uma mudança de paradigma em relação à histeria.

Ambos os artigos significam uma comunicação direta das novidades científicas européias com os médicos de São Paulo. É interessante que Franco da Rocha, que sempre está atualizado, silencia sobre Babinski. Aparentemente, ele parece continuar um seguidor de Charcot. Sua posterior adesão à doutrina freudiana pode reforçar essa possibilidade, já que Freud remete-se a Charcot por várias vezes.

As outras formas de nevrose passam a acumular pesquisas e conceituações no sentido de dar-lhes características próprias, de modo que caminhem para saírem desse grupo. O próprio conceito de nevrose passa a ser questionado, considerando-se esse grupo apenas como o que reúne as moléstias que ainda não tiveram esclarecido o seu processo fisiopatológico. Esse discurso, de modo geral, considera que esse esclarecimento deve vir de estudos anátomo-patológicos ou químicos.

No entanto, achamos surpreendente que o início dessa mudança de rumo é dado pela conceituação de Babinski a respeito da histeria, que passa a atribuir parte importante do mecanismo formador desse quadro à sugestão, ou seja, a um fenômeno que ocorre no âmbito dos processos psíquicos. 
Embora Foucault chame toda essa abordagem de Babinski, em relação à histeria, de despsiquiatrização (pois não acha que seja exatamente um tipo de antipsiquiatria), consideramos que, limitando a histeria ao contexto psíquico, Babinski está colaborando na passagem desse quadro, do campo das moléstias nervosas para o campo da psiquiatria.

No que diz respeito ao entendimento do sistema nervoso, ao mesmo tempo em que se aprimora a teoria do neurônio, outros achados, como a descoberta dos hormônios e do sistema imunológico, colaboram para uma diminuição da centralização do sistema nervoso em relação ao organismo, centralização essa que é mais acentuada na virada do século.

Quanto ao paradigma microbiano em relação ao sistema nervoso, o desaparecimento de artigos sobre o micróbio responsável pelo beribéri, após a morte de Fajardo, indica que essa era uma busca que passou a ser apenas desse pesquisador, em meados da década de 1910. O processo de solução das epidemias de febre amarela, e a descoberta do agente causal da sífilis, dirigem, então, o olhar perscrutador de micróbios para outros objetivos.

A descoberta do microorganismo responsável pela sífilis desencadeia todo um movimento de atenção e renovação de conceitos em torno desse quadro, bem como de processos associados ao mesmo. Os médicos de São Paulo são informados do novo germe diretamente de Paris, por Ulysses Paranhos.

Em nosso levantamento observamos um dado que não temos visto em trabalhos a esse respeito. Referimos-nos à menção feita na Imprensa Médica em 1905, ao trabalho do médico Affonso Splendore do Instituto Bacteriológico de São Paulo, no sentido de isolar e identificar o germe causado, da sífilis, ou seja, no mesmo ano em que foi apresentado em Paris. Ao menos nos registros das revistas paulistas, esse registro antecede aqueles referentes ao Instituto Manguinhos. É notória também a maneira singular de como esse trabalho de Splendore foi informado nessa publicação, de maneira indireta, por seus colaboradores, em virtude desse pesquisador ser muito cuidadoso na exposição de seus dados, e não considerar ainda como o momento adequado para publicar suas pesquisas sobre o Treponema pallidum.

Assim como esse dado, há uma série de outros que, somados, formam um quadro dessa escola de São Paulo mencionada no Brazil Medico em 1900. Em relação 
ás áreas enfocadas por nosso trabalho, no período de 1899-1912, o Juquery é o principal local que tem esse papel com características próprias de São Paulo. Na própria capital, há também o Instituto Psicofisiológico de Domingos Jaguaribe e a Casa de Saúde de Homem de Mello, mas não temos como avaliar o peso desses estabelecimentos na configuração de instituições ou práticas com aspectos mais fortemente paulistas.

O Hospício do Juquery também tem práticas psiquiátricas próprias de alguém ousado para o período. Ao dizer que se não fosse aplicado o sistema open door ele deixaria o cargo de diretor, Franco da Rocha expressa determinação em seus objetivos.

Consideramos também importante assinalar a instalação do tratamento domiciliar em casas próximas do hospício, com acolhimento do alienado por famílias e acompanhamento pelos médicos do Hospício como um método bastante inovador na abordagem desses pacientes; aplicação essa divulgada e elogiada como a primeira na América do Sul. Aliás, o próprio Juquery como um todo é divulgado pelo próprio Franco da Rocha em revistas argentinas no início do século XX.

Esse tratamento domiciliar é praticamente ignorado nos trabalhos sobre o Juquery que temos visto, ou não é dada a devida ênfase à sua inovação.

Um procedimento prático que se destaca nesse período é a coleta e exame de líquido cefalorraquiano. Um aspecto é a própria retirada do líquido como forma de tratamento, e outro aspecto é o exame de suas alterações como meio de obtenção de dados importantes para o diagnóstico no cotidiano. Assim, o laboratório biológico e químico se agrega à elaboração semiológica do corpo neurológico, como elemento que confirma mais as hipóteses etiológicas do que as localizatórias.

O nome "Psychopatias", de uma seção da Imprensa Médica, denota um enquadramento das doenças psíquicas em um determinado grupo. Anteriormente, “neuropatia” era um termo suficiente para dizer respeito, de modo genérico, a certas condições relacionadas a quadros psiquiátricos ou a moléstias nervosas. A configuração da histeria como um quadro restrito ao campo psíquico, fora do campo orgânico, após Babinski, dá margem à aceitação de moléstias exclusivas dessa área.

Para entendermos como é marcante o aparecimento dessa conceituação, vemos, em 1909, em artigo sobre as novas idéias a respeito da histeria, na Imprensa Medica, a perplexidade de Austregésilo, falando também por seus pares, diante do novo 
paradigma que determina não mais haver alteração vasomotora responsável pela histeria. A abertura a esse novo âmbito do psíquico pode ter propiciado uma aceitação das idéias de Freud. Assim, talvez Babinski tenha facilitado a aceitação de Freud.

Apesar dessa novidade do grupo de moléstias psíquicas nesse momento, a psicologia é mencionada antes disso. Trata-se mais frequentemente da psicologia médica, ou ainda como um uso genérico do termo psicologia aplicado aos discursos. De qualquer forma, sendo psicologia, trata da mente e do comportamento, independente da sua adjetivação. A diferença entre as psicologias, diz respeito mais a como entender o seu mecanismo intrínseco, mas o seu objeto de estudo é o mesmo. Há também diferenças de métodos na abordagem desse mesmo objeto.

Em período posterior, a área da psicologia vai adquirir características que vão ampliar seus contornos e criar gradativamente um campo com identidade própria. No entanto, quando os artigos deste período falam em George Dumas, tratam de um psicólogo; quando tratam de Manuel Bomfim, também falam de um psicólogo. Ocorre que ambos são médicos. Já Ribot, que também é tido como psicólogo, sendo muito bem aceito pelos médicos, tem sua formação em filosofia.

No que diz respeito à convivência dos psiquiatras com os advogados, nesse período em São Paulo, é frequentemente conflituosa, em parte porque a cidade, até há pouco tempo, era um burgo de estudantes de direito; mas também porque há uma questão mais ampla que diz respeito a interfaces com a medicina legal, ou ainda em relação às idéias positivistas na recente República.

No que diz respeito aos personagens desse período vistos a partir da conceituação de Latour, Franco da Rocha continua tendo como seu ponto fraco o pouco envolvimento com as associações de médicos. Nos outros fatores, ele mantém seus vínculos com a República e continua publicando em jornais e periódicos. Sua apresentação de dados estatísticos dos hospícios acompanha a elaboração de uma classificação de moléstias psiquiátricas com sua própria marca; no entanto, neste item, que Latour chama de mobilização do mundo, Franco da Rocha lamenta a falta de laboratório no Juquery, que, segundo ele poderia tornar seu trabalho mais científico.

Sob a mesma forma de análise, diferentemente de seu mestre, Enjolras Vampré envolve-se desde o início de sua carreira com as associações médicas; além disso, publica continuamente nos periódicos médicos nos últimos anos do período 1899-1912. 
Capítulo 4 - Terceiro Período - 1913-1932:

Da Faculdade para a diversidade: de um tempo de certezas ao fim da era federativa; a complexidade do corpo neurológico.

Este terceiro período abrange desde o início da Faculdade de Medicina e Cirurgia de São Paulo em 1913, até o ano de 1932, um ano marcante para São Paulo, em virtude da Revolução Constitucionalista.

\section{1 - Instituições e personagens (1913-1932)}

\subsection{1 - Faculdades de Medicina (1913-1932)}

A instituição mais marcante, neste período, é a Faculdade de Medicina e Cirurgia de São Paulo, cujo início de atividades demarca o próprio começo desta fase.

A Faculdade é instituida por decreto em fins de 1912 (que se remeteu a decreto anterior de 1891) e dá início a suas atividades em 1913. Devemos ressalvar que, embora a Faculdade tenha iniciado suas atividades nesse ano, somente em 1918 passam a ocorrer, efetivamente, as aulas de psiquiatria e moléstias nervosas.

Em 1915, publica-se, na Gazeta Clinica, um artigo intitulado "Os nossos mestres”, por alguém que assina pelo pseudônimo de "Radamés"959. O autor diz que são publicados palpites, nos jornais correntes, sobre a escolha de lentes para a Faculdade de Medicina e Cirurgia de S. Paulo. Assim, ele faz uma lista de três partes de indicações: certas, prováveis e possíveis. Entre as prováveis está elencada a cadeira de Moléstias Nervosas com o nome de Enjolras Vampré.

Pode-se acrescentar que, logo anteriormente a esse texto, na Gazeta Clinica, há um informe intitulado "Palpites”,960, dizendo circularem notícias de que, em fevereiro de 1916, o governo do Estado vai completar a congregação da Faculdade de Medicina, sendo que, entre as 15 especialidades citadas, há a “Clinica Psychiatrica”.

Constata-se assim que em 1915, já se associa Enjolras Vampré à área de moléstias nervosas, embora isso tenha se concretizado em definitivo somente vinte anos 
depois, já que, em lista emitida em 1917, Franco da Rocha figura como responsável por uma única cadeira de Psiquiatria e Moléstias Nervosas.

Ao tempo em que correm essas listas, nota-se que também há um interesse da população letrada da cidade, a respeito da Faculdade, pois esse assunto circula nos jornais cotidianos. Enquanto as cadeiras ainda não preenchidas da Faculdade geram especulações e curiosidade, constam aulas de neurologia nos cursos que já estão em andamento. Isso antes de ser constituída a cadeira de Psiquiatria e Moléstias Nervosas, cujas aulas se iniciam em 1918.

Desse modo, em 1917, é publicado, na Gazeta Clinica, o Programa do Curso de Clínica Propedêutica da Faculdade de Medicina e Cirurgia de São Paulo, dado em 1916, sendo responsável o catedrático professor Rubião Meira. Esse curso contém um total de 143 aulas, sendo dadas pelos professores: Almeida Prado, Lemos Torres e Rubião Meira. Este fica com 88 dessas aulas, sendo que dessas 88, 22 aulas dizem respeito à neurologia ${ }^{961}$.

Vemos que Rubião Meira é um clínico bastante versado e com segurança em neurologia, de modo que ensina itens de propedêutica dessa área.

Em 1918, tem início o curso dado por Franco da Rocha na Faculdade de Medicina, de modo que, nesse mesmo ano, é publicada na Gazeta Clinica a inauguração das aulas de psiquiatria e moléstias nervosas, ocorrida em abril ${ }^{962}$. Após uma introdução, o professor relata que:

“Quando comecei a trabalhar pela reforma da assistencia aos alienados em S. Paulo, já lá vae um quarto de seculo, divisei claramente os dois problemas que se me antolhavam: o problema scientifico e o problema social.

O problema scientifico não podia sequer ser tentado; o meio não o permittia - não havia opportunidade. Não se força a ordem natural das coisas neste mundo. Estávamos ainda no periodo da detenção dos alienados, depois de ter passado o periodo de completa negligencia; tinhamos que entrar no periodo de tratamento. Este periodo de tratamento consta de duas partes: 0 asylamento racional e a investigação scientifica"963.

961 MEIRA, R. Programma de Clinica Propedeutica da Faculdade de Medicina e Cirurgia de S. Paulo durante o anno de 1916. Gazeta Clinica, p. 11-12, 1916.

962 ROCHA, F. Faculdade de Medicina: Inauguração do curso de psychiatria e molestias nervosas. Gazeta Clinica, p. 51-52, 1918.

963 ROCHA, F. Faculdade de Medicina: Inauguração do curso de psychiatria e molestias nervosas. Gazeta Clinica, p. 51, 1918. 
Franco da Rocha prossegue, dizendo que o asilamento racional era um programa para uma geração, e que ele lançou-se a essa tarefa, sempre contando com a ajuda do governo. Assim, ele diz que a investigação científica está para ter seu início, favorecido pela Faculdade de Medicina, que "vae ser o ponto de apoio para o surto da psychiatria scientifica em S. Paulo"964.

Vemos que o próprio Franco da Rocha não reconhece como científico, tudo que ele tem escrito e feito até esse momento.

Em 1918 encerra-se a “Universidade Livre de S. Paulo”, à qual estava ligado o Curso de Medicina vinculado à Escola de Farmácia ${ }^{965}$.

Em relação ao enfoque de nosso trabalho, não temos dados para avaliar algum aspecto referente a neurologia, psiquiatria ou psicologia no curso de medicina dessa Universidade.

A Faculdade de Medicina sofre um choque com a morte de Arnaldo Vieira de Carvalho em 1920. Com isso, passa por certa instabilidade.

Assim, em 1922, na posse de Adolpho Lindenberg como novo diretor da Faculdade de Medicina e Cirurgia de São Paulo, o professor Rubião Meira profere discurso, no qual diz que, após a morte de Arnaldo Vieira de Carvalho ${ }^{966}$, sucederam-se muito rapidamente quatro diretores e surgiram partidos, gerando divisão entre os professores. De forma grave, Meira refere que esse pode ser o fim da Faculdade. Além disso, ele diz ter suas próprias divergências com o governo do Estado, quanto à gestão da Faculdade ${ }^{967}$.

Vemos que essa instabilidade é tal, a ponto de Meira, talvez pessimista, ou talvez dramático, ou apontando uma situação real, acentuar a possibilidade de fim da instituição. Essa afirmação indica uma situação grave, em tão pouco tempo de existência da Faculdade. Essas divisões e essa instabilidade podem ter colaborado para

964 Idem.

965 GAZETA CLINICA. A Universidade de S. Paulo, p. 73, 1918.

966 A figura de Arnaldo Vieira de Carvalho era tão carismática e tão fortemente ligada à Faculdade de Medicina, que aos dez anos de sua morte, em 1930, foi feita uma romaria desde a Santa Casa, até o seu túmulo no cemitério da Consolação.

GAZETA CLINICA. Arnaldo Vieira de Carvalho: A romaria ao tumulo do illustre scientista em comemoração ao décimo anniversario de seu passamento, P. 146-148, 1930.

Isso dá uma idéia do vazio deixado na Faculdade, por sua morte.

967 FACULDADE DE MEDICINA. A posse do novo diretor. Gazeta Clinica, p. 188-191, 1922. 
o adiamento da concretização das cadeiras de Neurologia e Psiquiatria em separado, na Faculdade, bem como para a posse definitiva de um catedrático no concurso, que foi anunciado, mas acabou não ocorrendo nos anos 1920. Essa é mais uma demonstração das muitas divisões entre os médicos em todo o período de nosso trabalho.

Enquanto a Faculdade procura se acertar, após a perda da liderança que era Arnaldo Vieira de Carvalho, no mesmo ano em que Franco da Rocha se aposenta, é dado um curso no Juquery, que pode ser um novo fator nas áreas em questão.

Assim, na Gazeta Clínica, em 1923, informa-se que passou a ocorrer no Juquery um Curso de Neuropatologia, dado pelo prof. Constantino Tretiakoff, contratado pelo governo estadual para dirigir o laboratório anátomo-patológico do Hospício $^{968}$. O curso acontece sob os auspicios do diretor do estabelecimento, Antonio Carlos Pacheco e Silva. O curso destina-se aos médicos, mas também é freqüentado pelos estudantes da Faculdade de Medicina, ocorrendo nos domingos, pela manhã.

Em seguida, é explanado o extenso e detalhado programa do curso, subdividido em partes referentes a cada região do sistema nervoso, sua anatomia e suas doenças e síndromes. Na lista de aulas, não há diagnósticos psiquiátricos. Também não há referência à histeria, ou alusão direta ao termo nevroses.

Vemos assim que, em pleno Juquery, há um curso que não aborda moléstias psiquiátricas e nem mesmo as nevroses sob esse título. É como uma instalação da neurologia dentro do antigo hospício, sob o nome de neuropatologia.

Anos mais tarde, depois do período abrangido pelo nosso trabalho, neuropatologia tornou-se um termo referente apenas à parte da anatomia patológica que estuda o sistema nervoso. Conforme já vimos, por informação de Teixeira Brandão, neuropatologia era, no período de Brandão, um termo tido como abrangendo neurologia e psiquiatria. Pelo programa desse curso, vemos que neuropatologia se centraliza na neurologia; depois, anos mais tarde, restringiu-se à anatomia patológica do sistema nervoso.

No entender de Franco da Rocha, ele próprio cumpriu a parte social de estruturação do Juquery e não a parte científica (que, no entanto, já acontecia). Após Pacheco e Silva tornar-se diretor da instituição, inicia-se um processo científico mais 
visível, com o reforço de Tretiakoff. A presença de médicos e estudantes no curso, pode indicar a formação de certa “escola” de Tretiakoff seguida por Pacheco e Silva ${ }^{969}$.

Nesse mesmo ano, talvez como um sinal da instabilidade indicada por Rubião Meira, começa a ser promovida uma mudança na Faculdade.

Assim, em 1923, na Gazeta Clinica, informa-se a respeito de uma reforma realizada na organização da Faculdade de Medicina ${ }^{970}$. É citada a apresentação do Projeto n.62 de 1923 à Câmara dos Deputados de São Paulo, datado em 27 de dezembro desse ano. No projeto consta a mudança do nome da Faculdade para "Faculdade de Medicina de São Paulo”.

A nova organização do curso é descrita e nas matérias do $6^{\circ}$ ano constam: Clínica Médica; Clínica Cirúrgica; Clínica Pediátrica; Clínica Ginecológica; Clínica Neurológica; Clínica Psiquiátrica; Clinica Urológica; Medicina Legal; Higiene.

As matérias são classificadas em Matérias Fundamentais; Matérias Anexas e Matérias Complementares. As Matérias Fundamentais são lecionadas por catedráticos. As Anexas, por professores adjuntos e as Complementares, por professores auxiliares.

Também são organizados oito Departamentos: Física, Anatomia, Fisiologia, Patologia, Terapêutica, Obstetrícia, Cirurgia, Medicina.

O Departamento de Medicina inclui as matérias: Clínica Médica, Patologia Médica, Propedêutica Médica, Policlínica Médica, Clínica Dermatológica, Clínica Neurológica, Clínica Psiquiátrica.

No Departamento de Medicina, a Matéria Fundamental é a Clínica Médica. As Clínicas Neurológica e Psiquiátrica são consideradas Matérias Anexas, ou seja, com professores adjuntos.

Consta também que os internos do ano vigente (1923), e os de 1924, continuarão nos seus lugares até concluírem o curso.

Nesse mesmo ano, que é o ano da aposentadoria de Franco da Rocha, é aberto concurso para que o lugar por ele deixado seja preenchido.

969 No primeiro ano de publicação das “Memórias do Hospital do Juquery”, em 1924, dos 13 artigos publicados, 10 são de coautoria de Trétiakoff com outros autores do Juquery.

PACHECO E SILVA, A.C. A Assistência a Psicopatas no Estado de São Paulo. Oficina Gráfica de Assistência a Psicopatas, Juquery, 1945.

Também nesse sentido, na Gazeta Clinica há registro de que, em 1924, Tretiakoff tornou-se sócio da Sociedade de Medicina e Cirurgia de S. Paulo, tendo feito apresentações científicas nessa instituição.

GAZETA CLINICA. Sociedade de Medicina e Cirurgia, p. 96-98, 1924.

970 GAZETA CLINICA. Reforma da Faculdade de Medicina de S. Paulo, p. 234-238, 1923. 369 
Assim, na Gazeta Clinica, em 1923, publica-se a informação de que estão abertas as inscrições para Concurso Público, na Faculdade de Medicina, pelo prazo de quatro meses, para o lugar de "Lente Cathedratico da $5^{\text {a }}$ cadeira”, correspondente a “Clinica Psychiatrica e Molestias Nervosas”. A seguir, são listados oitenta pontos aprovados pela congregação. Todos os pontos dizem respeito a temas neurológicos e psiquiátricos; chama a atenção o fato de que um dos temas é "psychoanalyse". Como a Congregação da Faculdade aprovou essa lista de pontos, esse aspecto é digno de nota, pois comumente temos a idéia de que os médicos rejeitam a psicanálise, nesse período. A exigência dos candidatos estudarem esse tema, entre tantos outros, permite supor que esse assunto não seja tão estranho, nem tão rejeitado.

Observa-se também, nesse informe do concurso, que se trata de um concurso para a Cadeira de Psiquiatria e Moléstias Nervosas, ainda juntas e com esse nome, concomitantemente às mudanças na Faculdade, mudanças essas que constam do Projeto, no qual estariam separadas as duas cadeiras, sendo uma delas a Clínica Neurológica.

Em relação a esse concurso, obtivemos algumas informações nos “Annaes da Faculdade de Medicina de São Paulo” de 1926 (essa publicação teve início nesse mesmo ano) $)^{971}$.

Em uma seção referente ao histórico da Faculdade, registra-se que o médico Francisco Vieira de Moraes foi candidato único e foi considerado “inabilitado” em 10 de novembro de 1924.

Nesse texto há mais dados sobre esse médico. Na mesma seção sobre o histórico, na subdivisão a respeito da "Clínica de Psychiatria e Molestias Nervosas", constam os dados que relatamos a seguir.

Em 10 de abril de 1918, o médico Francisco Franco da Rocha é contratado por tempo indeterminado para "reger a cadeira de Clinica Psychiatrica e de Molestias Nervosas” ${ }^{\text {„72 }}$. Informa-se que parte do curso realiza-se no Hospício do Juquery, parte no Recolhimento de Dementes das Perdizes, no Largo das Perdizes e parte no Laboratório Anatomo-Pathologico da Santa Casa ${ }^{973}$.

971 HISTORICO DA FACULDADE DE MEDICINA. Annaes da Faculdade de Medicina de S. Paulo, p. 37-47, 1926.

972 À página 37 diz-se "para o cargo de professor".

973 Esses dados constam na página 12 dos Annaes da Faculdade, a respeito do curso, e na página 37, no histórico da Disciplina. 370 
Em 24 de abril de 1918, é nomeado o médico Francisco Vieira de Moraes como assistente dessa cadeira.

Em 1 de agosto de 1921 e 1 de agosto de 1922, Franco da Rocha entra de licença, sendo substituído por Francisco Vieira de Moraes.

Em 22 de outubro de 1923, Franco da Rocha deixa o cargo de professor (aposenta-se), sendo substituído por Francisco Vieira de Moraes.

Em 16 de novembro de 1923 são abertas as inscrições para concurso de professor dessa disciplina, sendo que o único candidato inscrito foi Francisco Vieira de Moraes (inscreveu-se em 4 de fevereiro de 1924).

O encerramento das inscrições é adiado em 27 de fevereiro e reaberto em 14 de junho. O único candidato inscrito é novamente Francisco Vieira de Moraes (em 3 de setembro de 1924). Em 31 de outubro encerram-se as inscrições depois do prazo regulamentar, em virtude de diversas vezes não ter havido quorum suficiente para a reunião da Congregação da Faculdade.

As provas ocorrem de 4 a 8 de novembro de 1924. Em 10 de novembro o candidato é considerado inabilitado para o cargo por unanimidade (18 votos).

De 1 de agosto de 1924 a 4 de março de 1925, exerce as funções de professor o médico Felício Cintra do Prado.

Em 4 de março de 1925, Francisco Vieira de Moraes exonera-se de seus cargos.

Em 4 de março de 1925 foi contratado por dois anos o médico Enjolras Vampré para o cargo de professor. A cadeira passa a funcionar na primeira enfermaria de medicina de homens da Santa Casa, onde são dadas as aulas “de Neuriatria”.

Em 8 de maio de 1925 é nomeado assistente interino o médico Adherbal Pinheiro Machado Tolosa.

Em 1 de janeiro de 1926 há uma reforma do Regulamento e a cadeira passa a chamar-se "Clinica Psychiatrica e Neuriatrica”. Em 13 de agosto de 1926 as aulas de Psiquiatria começam a ocorrer no Juquery.

Dois anos após a apresentação do projeto, em São Paulo, da nova organização da Faculdade de Medicina, é lançada uma reforma do ensino em instância federal. 
Desse modo, em 1925, é publicado na Gazeta Clinica o decreto federal de reforma do ensino no Brasil ${ }^{974}$. No texto do artigo 64, são listadas as matérias do curso médico, constando, no sexto ano, de maneira separada, as disciplinas: "VI - Clinica Neuriatrica” e “VII - Clinica Psychiatrica”.

Na estrutura do curso, os três primeiros anos são considerados como "Curso Fundamental”, os dois anos seguintes como “Curso Geral de Aplicação” e o sexto ano como "Curso Especializado de Aplicação”.

No artigo 66, são listadas as cadeiras do curso médico da Faculdade do Rio de Janeiro, que deve funcionar como um padrão, constando no item XXIX, “Clinica Neuriatrica” e no item XXX - “Clinica Psychiatrica”.

É feita a citação de alguns aspectos particulares à Faculdade do Rio de Janeiro e à Faculdade da Bahia. Cria-se também o curso de Higiene e Saúde Pública do Rio de Janeiro, bem como a cadeira de Moléstias Tropicais.

Observa-se aqui o uso do termo neuriatria, que foi usado nos anos 1920, concomitantemente à neurologia. O primeiro registro que encontramos desse termo foi no Congresso Paulista de 1916, usado pelo prof. Austregésilo. Isso indica um período de busca de uma definição, do que deve ser esse campo: Moléstias Nervosas, ou Neuriatria, ou Neurologia. Esses múltiplos nomes concomitantes acompanham a definição do “corpo neurológico”.

Enquanto isso, a Psiquiatria mantém sua designação, mesmo com várias escolas, com diferentes entendimentos. A Psicologia, conforme já dito, antes mesmo do Primeiro Congresso de Paris em fins do século XIX, tinha diversas adjetivações, diversas subdivisões.

O único campo sem nome exato, o único “corpo” indefinido, é o “corpo neurológico”. Embora haja esse descompasso com as outras duas áreas, a gradual delimitação do “corpo neurológico” permite que se estabeleçam os diagnósticos diferenciais entre essas diferentes disciplinas, colaborando na caracterização de cada uma delas, bem como em estabelecer os territórios de intersecção entre as mesmas. Nesses territórios de intersecção há confluências e conflitos.

Nesse mesmo ano, é publicado o decreto paulista (correspondente ao projeto de 1923) referente à nova organização da Faculdade de Medicina.

974 GAZETA CLINICA. Reforma do ensino, p. 109-115; 117, 1925. 
Assim, publica-se na Gazeta Clinica o Regulamento da Faculdade de Medicina de São Paulo, correspondente ao decreto n. 3874 de 11 de julho de $1925^{975}$. Por esse decreto, a faculdade passa a se chamar Faculdade de Medicina de São Paulo. Entre as cadeiras, está listada, em número 29, a “Clinica psychiatrica e neuriatrica”. Também, no sexto ano, está listada como sétima cadeira com o nome de "Clinica psychiatrica e neuriatrica”. Assim, entre o projeto de 1923 e o decreto de 1925, há a diferença de que, no primeiro, as duas áreas estão separadas; no decreto, consta uma junção das duas áreas no mesmo campo, usando-se o termo Neuriatria.

Não temos indícios do que ocorreu entre o projeto e o decreto, para que os dois campos, que já tendiam a ser separados, continuaram juntos na reforma de 1925. Assim, a tendência em separar os campos de estudo em São Paulo, tendência essa que remonta a 1900 (quando de uma tentativa para criar a faculdade), vai demorar mais dez anos para se concretizar efetivamente, apenas após a criação da Universidade de São Paulo.

A década de 1920 é um período de reformas nas faculdades brasileiras. Assim, em 1926, na Gazeta Clinica, é publicada a constituição do corpo docente da Faculdade de Medicina de Recife, após a reforma do Ensino, constando o professor Gouveia de Barros como catedrático da "Clinica Neuriatrica” e o prof. Alcides Codoceira, da “Clinica Psiquiatrica”,976. Isso demonstra que, nessa reforma, é seguida a orientação do decreto federal, fazendo uso de termo correlacionado à palavra neuriatria.

No transcorrer da década de 1930, outras mudanças acontecem, inclusive nas instalações da Faculdade. Desse modo, em 15 de março de 1931, é inaugurada a nova sede da Faculdade de Medicina de São Paulo, tendo sido mudado, antes do ato de inauguração, o nome da Avenida Municipal, onde fica o novo prédio, para Avenida Dr. Arnaldo $^{977}$.

975 GAZETA CLINICA. Regulamento da Faculdade de Medicina de S. Paulo, p. 161-168, 1925.

976 NOTAS E NOTICIAS. Como ficou constituído o corpo docente da Faculdade de Medicina de Recife. Gazeta Clinica, p. 58, 1926.

977 GAZETA CLINICA. A inauguração da nova Faculdade de Medicina, p. 60-65, 1931.

373 


\section{$\underline{4.1 .2}$ - Juquery (1913-1932)}

Em 1913, em reunião da Sociedade de Medicina e Cirurgia de S. Paulo, os médicos Vampré e Araripe Sucupira fazem uma proposta de aplauso ao ato do Secretário da Justiça, Dr. Sampaio Vidal, por ter mandado para o Hospício “todos os loucos recolhidos nos xadrezes da policia” ${ }^{\text {"78 }}$. Apesar da atitude tomada, não sabemos o quão efetiva foi essa medida. De qualquer forma, essa melhor adequação dos pacientes psiquiátricos é uma solicitação repetida por Vampré.

No transcorrer dos anos 1910, são publicados artigos a respeito de trabalhos científicos realizados no Juquery, sendo que alguns estão citados em outras seções.

Em 1923, Franco da Rocha se aposenta e passa a direção do Juquery para Antonio Carlos Pacheco e Silva ${ }^{979}$. Suas atividades de professor na Faculdade de Medicina são passadas a Vieira de Moraes, Felício Cintra do Prado ${ }^{980}$ e Enjolras Vampré.

Durante os anos 1920, algumas teses de doutoramento da Faculdade de Medicina de São Paulo são feitas no Juquery. Algumas delas são citadas em outras seções deste trabalho.

Em 1925, há uma remodelação do Hospício do Juquery (sob a direção de Pacheco e Silva) que passa a chamar Hospital do Juquery. Ocorre as seguintes nomeações de médicos: Leopoldino José dos Passos ${ }^{981}$ passa de médico interno residente do Hospício de Alienados, para o cargo de sub-diretor do Hospital; Edmundo de Souza e Silva e Bonifácio de Castro Filho ${ }^{982}$, passam para a categoria de médicos internos residentes; Artur Guimarães Junior passa de médico interno residente para médico alienista; o médico Ozório César é nomeado médico assistente do laboratório ${ }^{983}$.

978 SOCIEDADE DE MEDICINA E CIRURGIA. Revista Medica de S. Paulo, p. 35, 1913.

979 GAZETA CLINICA. Dr. Franco da Rocha, p. 69-72, 1923.

980 Felício Cintra do Prado formou-se em 1922, na Faculdade de Medicina de São Paulo, com a tese “Contribuição ao estudo clinico do syndromo pyramido-pallidal”, feita na Clinica Medica.

981 Leopoldo José dos Passos formou-se em 1919, na Faculdade de Medicina de São Paulo, com a tese "Percentagem da loucura no Estado de São Paulo", feita na Clinica Psychiatrica.

ANNAES DA FACULDADE DE MEDICINA DE SÃO PAULO, p. 58, 1926.

982 Bonifácio de Castro e Silva formou-se em 1924, na Faculdade de Medicina de São Paulo, com a tese “Adenopathias retroperitoniaes. Estudo Clinico”, feita na Clinica Medica.

983 GAZETA CLINICA. Hospício do Juquery, p. 169, 1925. 
Em 3 de abril de 1928, ocorre homenagem a Franco da Rocha no Hospital do Juquery, com a inauguração de seu busto de bronze, realizado por Pinto Coelho ${ }^{984}$.

O Diretor do Hospital, Pacheco e Silva, faz discurso sobre a vida científica do homenageado. Em seguida falam F. Marcondes Vieira e Argemiro Siqueira em nome dos médicos do estabelecimento; Virgilio C. Pacheco, em nome dos internos; Waldemar de Almeida pela Assistência Nacional aos Psicopatas, que lê também mensagem da Sociedade de Medicina Legal, Neurologia e Psychiatria do Rio de Janeiro, redigida por seu presidente, Juliano Moreira. Conforme o texto, de improviso, falou Cantídio de Moura Campos em nome da Sociedade de Medicina e Cirurgia de São Paulo.

Franco da Rocha agradece e incita seus discípulos a continuarem seu trabalho, principalmente em torno da higiene mental, da qual é entusiasta propagandista.

\section{$\underline{4.1 .3 ~-~ A s s o c i a c ̧ o ̃ e s, ~ S o c i e d a d e s, ~ L i g a s ~(1913-1932) ~}$}

Em 1918, na Gazeta Clinica, há uma nota sobre a fundação de uma Academia de Medicina em São Paulo: “a semelhança de muitos paises, onde ela se ocupa de assuntos médicos sociais e dos interesses gerais da classe”985.

Também em 1918 é fundada a Sociedade Eugênica de São Paulo, sob a presidência de Arnaldo Vieira de Carvalho ${ }^{986}$.

Em 1927 funda-se a Sociedade Brasileira de Psicanálise, com a participação de Durval Marcondes, Franco da Rocha, Osório César e artistas da Semana de Arte Moderna, como, por exemplo, Menotti Del Picchia.

Há alguns registros de reuniões dessa sociedade no periódico São Paulo Medico (esse periódico será apresentado no item sobre revistas).

Na reunião de 5 de maio de $1928^{987}$ da Sociedade Brasileira de Psychanalise é lido o trabalho de Franco da Rocha intitulado “Os mythos e lendas na loucura”, que está

984 NOTAS E INFORMAÇÕES. Homenagem ao Prof. Franco da Rocha. São Paulo Medico, p. 103-104, 1928.

985 GAZETA CLINICA. Academia de Medicina, p. 133, 1918.

986 GAZETA CLINICA. Sociedade Eugenica de S. Paulo, 1918, pp. 12-16.

Também nesse mesmo ano foi fundada a Liga Pró-Saneamento do Brasil, em algumas linhas similares à Sociedade Eugênica.

987 SOCIEDADE BRASILEIRA DE PSYCHANALYSE. São Paulo Medico, p. 358-359, 1928.

375 
publicado no primeiro número da Revista Brasileira de Psychanalise, então recentemente lançado. Em seguida, Durval Marcondes apresenta o trabalho "Um sonho de exame”, que também está publicado nessa revista.

Em seguida, nesse mesmo informe, há o registro de que ocorreu reunião no Rio de Janeiro, no Hospital Nacional de Psicopatas, presidida por Juliano Moreira, onde se tratou da unificação do movimento psicanalítico brasileiro, pela formação de núcleos filiados à Sociedade Brasileira de Psicanálise, fundada em São Paulo em 1927, com o fim de coordenar e orientar “os estudos freudianos entre nós”. A essa reunião estiveram presentes: Murillo Campos, Carneiro Ayrosa, Deodato de Moraes, Porto Carrero, Osório Cesar e Durval Marcondes. Foi decidido: dividir a sociedade em seções nos estados do Brasil, com sua sede no Rio de Janeiro; publicar revista que continuará sendo a já iniciada Revista Brasileira de Psychanalyse. Foi aclamado Juliano Moreira como presidente do núcleo do Rio de Janeiro.

Também em 1927 é fundada a Liga Paulista de Higiene Mental ${ }^{988}$, sob a presidência de Antonio Carlos Pacheco e Silva. Na terceira reunião dessa Liga, Pacheco e Silva convida o médico James Ferraz Alvim para secretário, e dá conta de mensagem entregue ao presidente do Estado de São Paulo, a respeito dos objetivos da Liga Paulista de Higiene Mental, assinada pelos professores Franco da Rocha, Enjolras Vampré, Lourenço Filho ${ }^{989}$ e Pacheco e Silva. Comunica-se, também, que foi enviada aos prefeitos de várias cidades paulistas uma circular, pedindo apoio moral e material para a criação de hospitais regionais para psicopatas ${ }^{990}$. Lê-se um relatório sobre a criação de "serviços abertos para internação voluntaria de psychopathas, de ambulatorios, dispensarios e uma clinica psychiatrica em São Paulo”991.

988 GAZETA CLINICA. Liga Paulista da Hygiene Mental, p. 111-113, 1927.

989 Conforme já referido na historiografia sobre a psicologia, Lourenço Filho não terminou o curso médico, sendo advogado e professor. Assim, Pacheco e Silva aceita outros profissionais, além dos médicos, na Liga de Higiene Mental.

990 Em nosso levantamento, o termo psicopata é mais largamente usado nos anos 1920, para se contrapor ao termo neuropata, que era o único usado para se referir a doentes psiquiátricos ou neurológicos. Assim, o aparecimento desse termo indica uma melhor delimitação entre esses dois grupos de pacientes. No entanto devemos assinalar que, como já citamos, Régis usa o termo psicopatia na primeira década do século XX.

991 ROCHA, F. Faculdade de Medicina: Inauguração do curso de psychiatria e molestias nervosas. Gazeta Clinica, p. 51-52, 1918. 
Também se comenta o júbilo do presidente da República em 16 de janeiro, ao criar a nova lei que reorganiza a assistência a alienados no Brasil, a qual faculta a criação de serviços abertos para psicopatas ${ }^{992}$.

Na primeira publicação do periódico São Paulo Medico, há um informe sobre a Liga Paulista de Hygiene Mental ${ }^{993}$, onde consta que ela tem por fim:

“a) - prevenção das doenças nervosas e mentaes pela observancia dos princípios de hygiene geral e especial do systema nervoso;

b) - protecção e amparo no meio social aos egressos dos manicomios e aos deficientes mentaes passiveis de internação;

c) - melhoria progressiva nos meios de assistir e tratar os doentes mentaes em asylos públicos, particulares ou fora delles".

Essa nota informa ainda que a Liga aceita a adesão de sócios mediante a contribuição anual de vinte mil réis, e acrescenta que os interessados devem enviar sua adesão ao tesoureiro, Dr. Fausto Guerner.

\section{1. 4. - Personagens (1913-1932)}

Em fins da década de 1920, alguns profissionais do campo neurológico, que vão se tornar lideranças acadêmicas e científicas, iniciam seus primeiros passos nessa área.

Assim, em 7 de março de 1927, na Sociedade de Medicina e Cirurgia de São Paulo, o médico Paulino Longo ${ }^{994}$ recebe o prêmio Sérgio Meira por sua tese inaugural $^{995}$. Em 1928, Vampré, A.C. Camargo e Paulino Longo apresentam à Sociedade de Medicina e Cirurgia o primeiro caso de tumor justamedular primitivamente intradural diagnosticado e operado em São Paulo e, segundo o texto, provavelmente no Brasil ${ }^{996}$. Em 1929, em Reunião na Sociedade de Medicina e Cirurgia

992 ROCHA, F. Faculdade de Medicina: Inauguração do curso de psychiatria e molestias nervosas. Gazeta clinica, p. 51-52, 1918. 993 LIGA PAULISTA DE HYGIENE MENTAL. São Paulo Medico, p. 8, 1928.

994 Paulino Watt Longo formou-se em 1925, na Faculdade de Medicina de São Paulo, com a tese "Contribuição ao estudo da esclerose lateral amyotrophica", feita na Clinica Psychiatrica e Neuriatrica. 995 SOCIEDADE DE MEDICINA E CIRURGIA. Gazeta Clinica, p. 48-55, 1927. 996 SOCIEDADE DE MEDICINA E CIRURGIA. Gazeta Clínica, p. 46-47, 1928. 377 
de São Paulo, os médicos Adherbal Pinheiro Machado Tolosa ${ }^{997}$ e Paulino Watt Longo apresentam casos neurológicos em nome de Enjolras Vampré ${ }^{998}$.

Paulino Longo torna-se catedrático de Neurologia na Escola Paulista de Medicina, após a morte de Fausto Guerner em 1938. Adherbal Tolosa assume talvez o papel mais forte na neurologia paulista depois de Enjolras Vampré, pois, entre outras coisas, tem a nomeação de um sinal semiológico com seu nome; torna-se o primeiro presidente da Academia Brasileira de Neurologia; escreve, com outros, um livro de propedêutica neurológica que adquire grande sucesso em seu campo.

O trabalho apresentado por Tolosa, na reunião de 1929, intitulado “Syndromes neuro-psychicos anemicos” - ou seja, quadros neuropsíquicos devidos à anemia -, é saudado pelo prof. Austregésilo, em reunião anterior na Academia Nacional de Medicina. O Dr. Fausto Guerner, felicitando o trabalho, diz que “somente após um acurado exame somatico negativo pode o neurologista ou o psychiatra considerar o seu caso como do dominio puro da especialidade”.

Fausto Guerner está aqui afirmando limites entre o corpo neurológico, a psiquiatria e a clínica, quando requer à especialidade um “exame clínico somático negativo”, ou seja, que não apresente nenhuma anormalidade sistêmica. Nesse exame invertido, ou às avessas, ou seja, não procurando um sinal neurológico, mas afastando sinais clínicos, Guerner aproxima neurologia e psiquiatria e sinaliza, assim, a "neuropsiquiatria”, que se inicia nos trabalhos científicos do Juquery e que passa a estar mais presente a partir dos anos 1930.

Em momento de transição da Primeira República para o Governo Getulista ${ }^{999}$, em 1930, é fundada a Associação Paulista de Medicina ${ }^{1000}$. Em 1931 são organizadas diferentes seções na Associação Paulista de Medicina. São criadas seções

997 Adherbal Tolosa forma-se na Faculdade de Medicina de São Paulo, em 1923, com a tese "Contribuição ao estudo dos pneumococos”, feita na Hygiene.

ANNAES DA FACULDADE DE MEDICINA DE SÃO PAULO, p. 65, 1926.

998 SOCIEDADE DE MEDICINA E CIRURGIA. Gazeta Clínica, p. 128-129, 1929.

999 Em 1930, foi criada a Assistência Geral a Psicopatas, pelo interventor federal em São Paulo, coronel João Alberto Lins de Barros. Essa Assistência estava subordinada à Secretaria do Interior do Estado e foi designado para seu diretor geral, o médico Pacheco e Silva. Pacheco e Silva, que neste momento estava com esse cargo ligado ao novo governo, em 1932 se colocaria ao lado dos revolucionários constitucionalistas, inclusive tendo sido detido no Rio de Janeiro.

ASSISTENCIA A PSYCHOPATAS. Gazeta Clinica, p. 329, 1930.

1000 ASSOCIAÇÃO PAULISTA DE MEDICINA. Gazeta Clinica, p. 310, 1930. 378 
especializadas $^{1001}$. Entre estas, há a Seção de “Neuro-Psychiatria”, que fica sob a coordenação de: Enjolras Vampré, presidente; James Ferraz Alvim, $1^{0}$ secretário; Durval Bellegarde Marcondes, $2^{\circ}$ secretário $^{1002}$.

\section{1. 5. - Instituições internacionais (1913-1932)}

Nesse período, os estudiosos brasileiros procuram aperfeiçoar seus conhecimentos na Europa.

Assim, em 1914, publica-se, na Gazeta Clinica, o Relatório do prof. Henrique Roxo, apresentado à Congregação da Faculdade de Medicina do Rio de Janeiro, a respeito de viagem que fez á Europa para estudos referentes à Psiquiatria ${ }^{1003}$. O autor refere-se mais à França e à Alemanha por serem as duas escolas antagônicas que mais estão trabalhando com as doenças mentais. Ele relata ter acompanhado cursos e serviços de famosos professores como Ballet, Lavastine, e outros. Em Salpêtriere teve aulas com Pierre Marie, onde teve a impressão de estar “em uma construção quase em ruínas”1004. Na Pitié achou que o prof. Babinski tinha melhores condições.

Essa impressão de Roxo também pode revelar certa admiração que os estudiosos tinham por Babinski, embora também respeitassem Pierre Marie.

Roxo admirou-se de que em todas as salas de aula "as cortinas se fecham automaticamente para a projeção de imagens” ${ }^{1005}$. Ele lembra que o prof. Teixeira Brandão, no Rio, já havia solicitado isso há tempos, mas não foi atendido porque as autoridades brasileiras acharam esse recurso muito caro.

Roxo considerou os laboratórios da França modestos, se comparados aos da Alemanha.

Na Universidade de Munich, onde ele diz estar o mais afamado centro de Psiquiatria, do professor Kraepelin, ele observou ser esse um curso bem diferente do

1001 ASSOCIAÇÃO PAULISTA DE MEDICINA. Gazeta Clinica, p. 355, 1931.

1002 Dessa seção, chegam também a fazer parte os médicos: Adherbal Tolosa, Oswaldo Lange, Paulino Longo e Fausto Guerner, que são seguidores de Vampré. Outros participantes dessa seção, vão se tornar professores de outras áreas: Renato Lochi de Anatomia e José Ribeiro de Valle, que virá a ser professor de Farmacologia na Escola Paulista de Medicina.

1003 ROXO, H. Clinica Psychiatrica; doenças mentaes e nervosas; Relatório apresentado a Congregação da Faculdade de Medicina do Rio de Janeiro. Gazeta Clinica, p. 39-41, 1914.

1004 ROXO, H. Clinica Psychiatrica; doenças mentaes e nervosas; Relatório apresentado a Congregação da Faculdade de Medicina do Rio de Janeiro. Gazeta Clinica, p. 39-41, 1914.

1005 Idem.

379 
francês. O curso alemão lhe pareceu semelhante a um sistema colegial: o professor mandava dois alunos examinarem cada caso e depois ele fazia comentários por quinze minutos. Havia aulas dos alunos mais adiantados e dos mais atrasados; a palestra científica dos primeiros era mais demorada. Quanto ao professor: "No fim de algumas aulas apresentava projecções de preparados de histologia pathologica ou fitas cinematographicas de pacientes”"1006.

O espaço que Roxo dedica a Kraepelin, em sua comunicação, dá a idéia de uma predominância desse estudioso, nesse período, em termos de psiquiatria.

Em Berlim, Roxo viu condições mais modestas. "Em qualquer das clinicas que vi, é sempre quem lecciona, que tem a seu cargo a direcção da enfermaria. A clinica da Faculdade do Rio é, infelizmente, sob este ponto de vista, uma excepção mundial”" ${ }^{1007}$. Ele notou, tanto na França como na Alemanha, que se praticava o repouso no leito, considerando-se o "individuo que soffre do cerebro como o que soffre de qualquer outra viscera”"1008. Também a relação entre o sistema nervoso e as outras vísceras era bastante pesquisada "pelos dados da psychologia e da chimica biologica" ${ }^{1009}$.

Nessa informação, Roxo dá a entender por onde caminham os estudos em psiquiatria, entre os estudos biológicos e psicológicos, devendo-se entender esses termos nesse contexto de Kraepelin.

Na Alemanha, Roxo observou acomodações semelhantes às do Rio, com uma sala de banhos para cada oito doentes. Na Grã-Bretanha, ele se admirou de seu maior estabelecimento ter uma única banheira para 36 doentes. Em Berlim observou o uso também de helioterapia e eletroterapia.

Roxo sentiu-se admirado com a precisão diagnóstica, mas não viu o mesmo empenho no tratamento, pois não se receitava quase nada, diferentemente do Brasil.

Ele acha que o trabalho de professor é mais fácil na Europa, pois sempre estão com anotações na mão, enquanto que no Brasil se têm a preocupação de esgotar completamente o assunto e ser capaz de falar tudo de cor; assim, ele dá a entender que essa é uma espécie de exigência no Brasil, de modo que o diferente disso torna-se alvo de críticas.

1006 ROXO, H. Clinica Psychiatrica; doenças mentaes e nervosas; Relatório apresentado a Congregação da Faculdade de Medicina do Rio de Janeiro. Gazeta Clinica, p. 39-41, 1914. 
Sobre o segredo da prosperidade científica na Europa, Roxo aponta para a divisão de trabalho. Ele diz que:

“O segredo da prosperidade scientifica na Europa consiste nas especializações: o auxiliar de ensino que trabalha em psychologia vive, no seu gabinete, a attender ás requisições do lente; o que está encarregado do laboratorio deste somente cuida, e assim por diante. Claro está que durante o dia podem augmentar os proventos para sua subsistencia com o exercicio clinico, mas de manhã cada qual está a postos, a viver para seu gabinete”1010.

Ao fazer observações a respeito da situação no Rio de Janeiro, ele continua se queixando da falta de divisão de funções entre os pesquisadores. Também deu a entender que a psicologia experimental era praticada junto a clínica psiquiátrica, expressando assim, nesse período, o posicionamento da psicologia médica, em relação à psiquiatria. Desse modo, Roxo diz que:

Annexa á clinica psychiatrica d'aqui ha a psychologia experimental. Com os recursos della elaborei minha these inaugural. Falta, porém auxiliar de ensino que a este serviço se dedique. Os recursos para que a reacção de Wassermann seja feita no laboratorio da clinica tem sido pedidos, improficuamente há mais de um anno pelos Professores Austregesilo e Teixeira Brandão" 1011 .

O autor acha que, no Rio, o ensino de clínica de doenças mentais e nervosas é melhor do que na Europa, pois há mais aprofundamento em cada caso; porém faltam condições técnicas, como, por exemplo, salas de projeção.

Esse artigo de Roxo dá uma idéia de como anda o ensino e pesquisa nas áreas enfocadas na Europa. Mas, concomitantemente ele revela certas condições de trabalho no Brasil, de modo que não há plena colaboração do poder político com a investigação laboratorial dos pacientes, bem como com o ensino e a pesquisa. Desse modo, Roxo frisou que o ensino no Brasil conta principalmente com a disponibilidade do material humano. Ele também passa uma noção de como anda a psicologia médica em relação à psiquiatria nesse período. Seu comentário sobre a dificuldade em realizar a reação de Wasserman e o esforço de Austregésilo e Teixeira Brandão, para superar essa dificuldade, deixa claro que, nesse momento, a sífilis é abordada tanto pela psiquiatria como pela neurologia.

1010 ROXO, H. Clinica Psychiatrica; doenças mentaes e nervosas; Relatório apresentado a Congregação da Faculdade de Medicina do Rio de Janeiro. Gazeta Clinica, p. 39-41, 1914.

1011 ROXO, H. Clinica Psychiatrica; doenças mentaes e nervosas; Relatório apresentado a Congregação da Faculdade de Medicina do Rio de Janeiro. Gazeta Clinica, p. 39-41, 1914. 


\section{2 - Revistas médicas (1912-1932)}

Em 1913, tem início o periódico Annaes Paulistas de Medicina e Cirurgia. Em seu primeiro número de agosto desse ano, seu Editorial ${ }^{1012}$ refere que a idéia de uma revista como essa foi lançada “de ha muito, em estreito circulo profissional”. Lembra-se que o periódico não tem intenções regionalistas, mas quer acolher as produções que lhe forem enviadas. Assinala-se que a publicação é estrita e rigorosamente médica. Acrescenta-se que também são aceitos trabalhos sobre assuntos que são apontados como ainda pendentes de solução como: higiene; nosografia; febres paulistas; refreamento de ancilostomose, tuberculose e lepra.

Acrescenta-se que a revista tenciona observar o cumprimento da deontologia médica, que nem sempre tem recebido a devida atenção, por causa da "intensificação da vida”, do "cosmopolitismo", pelo aumento da "população medica e pseudo-medica” e por leis “esdruxulas e eivadas do mais ferrenho sectarismo”.

O primeiro frontispício dessa publicação, a que tivemos acesso, corresponde a janeiro de $1919^{1013}$, onde consta a “Direcção Scientífica” sob: Arnaldo Vieira de Carvalho, Diretor da Santa Casa e da Faculdade de Medicina e Cirurgia; Aloysio de Castro, professor de Clinica Medica e Diretor da Faculda de Medicina do Rio de Janeiro; Diogo de Faria, Chefe de Clinica da Santa Casa e Diretor do Desinfectório Geral; Vital Brazil, Diretor do Instituto Soroterápico do Butantã.

Como "Redactores Gerentes" constam: Florêncio Gomes, assistente do Instituto Soroterápico do Butantã; Rezende Puech, chefe de Clinica Cirúrgica e Ortopédica da Santa Casa.

Como “Redactores" constam: Adolpho Lindenberg, Alex Pedroso, Ayres Netto, Benedicto Montenegro, Celestino Bourroul, Henrique Lindenberg, J. Britto, O. Pires de Campos; Olympio Portugal, Pinheiro Cintra, Raphael P. de Barros, Sergio Meira Filho.

Como “Collaboradores” há: A. Vieira Marcondes, A. Carini, Bruno R. Pestana, Clemente Ferreira, Emílio Ribas, Enjolras Vampré (como alienista do Instituto 
Paulista), Franco da Rocha (como diretor do Hospício), G. de Paula Souza, J. Aguiar Pupo, L. Campos Moura, Mathias Valladão, M. Junqueira, Rodolpho Von Ihering.

Em 1914 findam a Revista Medica de São Paulo e a Imprensa Medica.

Em 1922, é lançado o periódico Archivos da Sociedade de Medicina Legal e Criminologia de São Paulo. Esse periódico, em vez de publicar um editorial inicial, apresenta a fundação dessa sociedade em outubro e novembro de 1921, com instalação, estatuto e discursos. Franco da Rocha consta como vice-presidente dessa sociedade, mas não comparece a reuniões, onde se faz representar por Oscar Freire ou outros. Pacheco e Silva tem certa presença nessa sociedade e nesse periódico, mas contribui com pouco artigos. Não há muitos artigos referentes às áreas em questão.

Em 1924, é lançado o periódico Memorias do Hospital do Juquery ${ }^{1014}$, que publica trabalhos científicos realizados na clínicas e laboratórios do hospital, sob orientação de Pacheco e Silva (identificado na referência como neuropatologista), com pesquisas que despertam interesse na Europa e na América. Em 3 de abril de 1928 foi distribuído o volume que contém os trabalhos de 1926 e 1927, correspondente aos números 3 e 4, sendo publicado em homenagem ao Jubileu Científico de Franco da Rocha. No sumário desse volume constam os seguintes trabalhos:

1 - Espiroquetose dos centros nervosos, por Pacheco e Silva.

2 - Presença do treponema pallidum no nervo óptico, por Pacheco e Silva e J. Candido da Silva.

3 - A malarioterapia na paralisia geral, por Pacheco e Silva e Leopoldino Passos.

4 - Psamoma da dura mater, por Osório Cesar e E. Pinto Cesar.

5 - Contribuição para o estudo da constituição na demência precoce e na psicose maníaco-depressiva, por André Teixeira de Lima.

6 - Sobre um caso de amiotrofia tipo Aran-Duchenne, com perturbações mentais, por Pacheco e Silva e Fausto Guerner.

7 - Sobre dois casos de estereotipia gráfica com simbolismo sexual, por Durval Marcondes e Osório Cesar.

1014 GUERNER, F. Memorias do Hospital do Juquery. São Paulo Medico, p. 114-115, 1928. 383 
Em 1926, é lançado o periódico Annaes da Faculdade de Medicina de São Paulo $^{1015}$. Em edital datado de 14 de novembro, informa-se que serão impressos, sem época fixa de aparecimento, os Annaes da Faculdade, destinados a publicações científicas dos professores, docentes livres e auxiliares de ensino, constando de trabalhos originais, notícias, dados históricos, resumos de teses, biografias.

O editorial saúda o aparecimento dessa publicação, por considerar um importante aumento da produção científica da Faculdade, em virtude da adoção do regime de tempo integral, da limitação do número de alunos e de instalações mais apropriadas ao ensino e à pesquisa.

Os trabalhos científicos que constam nos Annaes da Faculdade, referentes às áreas em questão, são feitos mais nas áreas básicas, como Anatomia e Histologia, sendo extensos, contendo fotos, gráficos e tabelas.

Em 1928 tem início o periódico São Paulo Medico. Em seu primeiro exemplar de maio desse ano, consta o médico Fausto Guerner como "Redactor-Chefe Responsavel”. Na página ao lado dessa informação há uma foto de Franco da Rocha que ocupa a página, em provável homenagem, pois conforme consta posteriormente na revista, em abril de 1928 inaugura-se busto de Franco da Rocha no Juquery.

O editorial do primeiro exemplar informa que o jornal se destina a assuntos da ciência médica em suas várias ramificações. Saúda o grande desenvolvimento que a medicina alcançou em São Paulo, visível por suas publicações e associações científicas. Acentua que, para isso, muito concorreu a instalação do ensino oficial de medicina, em moldes modernos e progressistas. O texto assinala que, o que se produz cientificamente, é muito mais do que aquilo que vem a público, de modo que o editorial estimula os médicos patrícios a enviarem seus trabalhos, pois para isso se coloca o periódico.

Nesse periódico, em uma seção intitulada "Neurologia”, Fausto Guerner apresenta diversas resenhas de artigos internacionais com temas, como estudos a respeito do exame de líquido cefalorraquiano, ou ainda pesquisas a respeito de alterações de natureza extrapiramidal, etc.

Em 1928, é fundada a Revista Brasileira de Psicanálise, à qual não tivemos acesso.

1015 EDITORIAL. Annaes da Faculdade de Medicina de São Paulo, $1^{\circ}$ volume, p. XI-XII, 1926. 384 
Em janeiro de 1932, tem início a Revista da Associação Paulista de Medicina, sendo seus redatores Barbosa Correa e Durval Marcondes ${ }^{1016}$.

\section{3. - Temas em debate (1913-1932).}

\section{3.1 - Classificação das moléstias (1913-1932).}

Em 1913, na Revista Medica de S. Paulo, é publicado o artigo “Contribuição ao estudo clinico da catatonia de Kahlbaum" (trabalho lido em reunião da Sociedade de Medicina e Cirurgia), por Enjolras Vampré ${ }^{1017}$. O autor diz que foi motivado a escrever este artigo por ter observado que a catatonia não é uma doença única, mas sim uma síndrome, ou seja, um conjunto de sinais e sintomas secundários a diversas afecções, não apenas do sistema nervoso, mas também de outras partes do organismo. Essa condição, que foi descrita inicialmente por Kahlbaum em 1873, e depois revista por Kraepelin em 1893, embora plena de sintomatologia psiquiátrica, no entender de Vampré, baseado também em outros autores, nacionais e estrangeiros, corresponde a alterações principalmente hormonais, além de outras possibilidades. Ele exemplifica com alguns casos clínicos.

Em Paris, em 11 e 12 de outubro de 1920, ocorre uma seção decenal (a terceira), da Comissão Internacional, para rever a nomenclatura das causas de morte e das moléstias ${ }^{1018}$.

A poliomielite aguda, a meningite cerebroespinhal epidêmica e a encefalite letárgica são separadas das afecções do sistema nervoso e passam a figurar em rubrica especial (aparentemente por sua alta freqüência e pela etiologia).

Nas afecções do sistema nervoso são incluidas a embolia e trombose cerebral, que antes (desde 1910) ficavam nas afecções do aparelho circulatório. Também é criada

1016 GAZETA CLINICA. Revista da Associação Paulista de Medicina, p. 21, 1932.

1017 VAMPRÉ, E. Contribuição ao estudo clinico da catatonia de Kahlbaum. Gazeta Clinica, p. 105115, 1913.

1018 GAZETA CLINICA. Nomenclatura Nosologica, p. 31-32, 1921. 385 
a subdivisão denominada "paralisia sem causa indicada", na qual se destaca a hemiplegia, como uma síndrome incluída.

Em 1921, é publicada na Gazeta Clinica uma nova classificação a respeito da moléstia beribéri, a partir do fato de que a Conferência Internacional para a Nomenclatura, de Paris, retirou o beriberi do grupo das doenças endêmicas, epidêmicas ou infectuosas, passando-a para o grupo das doenças gerais ${ }^{1019}$. Desse modo, esse informe frisa uma conclusão da Seção de Moléstias Tropicais do Congresso Internacional de Medicina de Londres de, 1913, onde foi dito que, em vista da não infectuosidade provada do beribéri, sugeria-se que fossem abolidas as quarentenas e outras medidas restritivas ${ }^{1020}$.

Em 1922, o médico Milton Mourão de Mattos (da cidade de Cajuru, do interior paulista) publica na Gazeta Clinica artigo intitulado "Psychose maniaco-depressiva”"1021. O autor refere caso de paciente com 22 anos, sem antecedentes “de degenerescência” (conforme suas palavras), nem antecedentes familiares. $\mathrm{O}$ autor faz um relato minucioso do gradual comprometimento do paciente, com nuances detalhadas em relação a alterações de discurso e de comportamento (inclusive com uma fala do doente, em seu discurso, relativa à então recente chegada dos portugueses Sacadura e Gago no Rio). O quadro atingiu tal ponto, que o paciente chegou a ser removido para a cadeia, onde muito agitado, recebeu a camisa de força. $\mathrm{O}$ autor delineia os caminhos que foram feitos para chegar a seu diagnóstico:

“Estando ausentes os signaes clinicos de lues, a disartria, o enfraquecimento da memoria, não se trata de paralysia geral, apezar do delirio de grandeza, aliás sem absurdos nem systematização. Hystericos não são, á luz dos modernos conceitos em Neurologia, os phenomenos observados em L.C. , não só porque é rara no homem essa forma clinica, como porque somente é hysterico aquilo que se cria pela sugestão e se remove com a persuasão”1022.

1019 Ressalve-se que a idéia de que o beribéri poderia ser causado por falta de alguma substância, passou a ganhar mais força a partir de Casimir Franck que, entre 1911 e 1912, criou a palavra vitamina e divulgou o seu próprio entendimento das vitaminas.

1020 GAZETA CLINICA. O beri-beri, p., 92, 1921.

1021 MATTOS, M. M. Psychose maniaco-depressiva. Gazeta Clinica, p. 117-119, 1922.

1022 Idem.

386 
Depois o autor diz que o doente foi encaminhado ao Juquery, frisando: "aliás, era um desejo do paciente, quando na cadeia” ${ }^{1023}$ (denotaria uma boa fama do Juquery?).

Nesse artigo, o autor tem um conceito de histeria conforme a orientação de Babinski, quando fala em “modernos conceitos em Neurologia” e cita certos parâmetros. Além desse entendimento, ele usa o conceito de psicose maníacodepressiva, resultado da doutrina de Kraepelin.

Em 1926, o médico Mirandolino Caldas Filho publica artigo, referindo-se a causas da loucura que encontrou, citando o número de $\operatorname{casos}^{1024}$ : Alcoolismo, 298; sífilis, 245; herança psicopática, 219; espiritismo, 71; infecção puerperal, 55; involução orgânica, 54; emoção sexual, ou freudismo, 49; tuberculose, 44; uremia, 44; toxemia gravídica, 43; desindocrinia, 15; perturbações mentruais, 11; emoções várias, 10; cocainomania, 6; tifo, 4; morfinomania, 3; meningite, 2; traumatismo, 2; heroinomania, 1; causas ignoradas, 124.

Pode-se notar que a maioria das causas está dentro de fatores organicamente definidos. O número atribuído à herança psicopática também é alto. Chama a atenção a citação de "espiritismo" como causa de loucura, ao mesmo tempo em que diversos artigos, de médicos favoráveis ao espiritismo, são publicados nos mesmos periódicos. Também chama a atenção o termo “freudismo" para se referir a “emoção sexual”. Isso dá a entender que, de algum modo, a doutrina de Freud está entremeada nas conceituações psiquiátricas, a tal ponto de ter sido criado o neologismo "freudismo". O uso desse termo, com esse sufixo, passa até a impressão de ser uma palavra de uso corriqueiro.

Em 1927, o médico James Ferraz Alvim, identificado como diretor do Instituto Aché, de S. Paulo, publica, na Gazeta Clinica, o artigo intitulado “Algumas classificações européas das doenças mentaes” ${ }^{\text {"1025. }}$

O autor refere que a classificação européia mais conhecida é a de Kraepelin, professor da Universidade de Munich, (então recentemente falecido), considerado a “maior autoridade em Psychiatria nestes ultimos tempos e cujos methodos de estudos 
foram baseados principalmente na observação minuciosa, constante e acurada de cada entidade mental em suas diversas formas e variedades”"1026.

Desse modo, o autor passa a relatar a classificação publicada na oitava edição da obra de Kraepelin, a qual contém 17 itens, com psicoses atribuídas a diversas causas orgânicas, e outras tidas como psicógenas; a histeria está individualizada como um dos 17 itens. Alvim diz que o francês Rogues de Fursac, em 1923, adotou essa classificação, com algumas modificações.

Alvim também cita a classificação do francês Régis, de 1914, como sendo, entre as francesas, uma das menos defeituosas e mais conhecidas. Ainda conforme Alvim, este autor elaborou cinco grandes grupos, subdivididos em outros tantos subgrupos. Um desses subgrupos é denominado “nevroses”, contendo epilepsia e histeria juntas. Alvim diz que, embora essa classificação seja bastante detalhada, muitos psiquiatras franceses adotam a de Kraepelin. Régis, por sua vez, aponta a classificação do estudioso alemão como "simples enumeração nosológica".

Alvim termina dizendo que a classificação de Kraepelin serviu de base para a classificação da Sociedade de Neurologia, Medicina Legal e Psychiatria do Rio de Janeiro.

Podemos acrescentar a esse registro da influência da classificação de Kraepelin entre os psiquiatras paulistas e brasileiros, a classificação apresentada por Pacheco e Silva, em 1930, em sua publicação Cuidados aos Psychopathas. Trata-se da Classificação da Sociedade Brasileira de Neurologia, Psychiatria e Medicina Legal, organizada pelos professores Juliano Moreira, Henrique Roxo, Austregésilo e Carlos Eiras, adotada nos hospitais psiquiátricos, conforme Pacheco e Silva.

São considerados 14 grupos de "Psychoses”: “1º Psychoses infecciosas; $2^{\circ}$ Psychoses auto-toxicas; $3^{\circ}$ Psychoses hetero-toxicas (alcoolismo, morphinomania, cocainomania, etc.); $4^{\circ}$ Demencia precoce; $5^{\circ}$ Delirio systematizado allucinatorio chronico. Paraphrenia; $6^{0}$ Paranóia; $7^{0}$ Psychose maníaco-depressiva (psychose periodica), com as formas: maniaca predominante, depressiva predominante e mixta; $8^{\circ}$ psychoses de involução; $9^{\circ}$ psychoses por lesões cerebraes e demencias terminaes (arterio-esclerose, syphilis, etc); $10^{\circ}$ Paralysia geral; $11^{\circ}$ Psychose epileptica; $12^{\circ}$ Psychoses ditas nevrosicas (hysteria, neurasthenia, psychasthenia, nervosismo e 
choréa); $13^{\circ}$ Outras psychopathias constitucionaes (estados atypicos de degeneração); $14^{\circ}$ Imbecilidade e idiotia”. O autor relata eventuais concomitâncias de quadros. Ele refere-se ao mérito de Kraepelin por ter agrupado, na demência precoce, condições anteriormente denominadas catatonia, hebephrenia e síndrome paranoide ${ }^{1027}$.

Observa-se também um isolamento e enquadramento das nevroses em um único item, ainda tendo a coréia em seu grupo. Esse grupo não está muito detalhado por Pacheco e Silva, por não requerer internação em hospital psiquiátrico.

Já a paralisia geral, embora entendida como sendo causada por sífilis, continua sendo listada e lembrada, pela gravidade e amplitude do quadro, pois necessita de hospitalização. Entre as epilepsias, nessa classificação, são consideradas as, assim chamadas, “psychicas”, decorrentes de causas como sífilis, alcoolismo, lesão traumática, com quadros psicóticos associados.

\section{3. 2. - Sífilis do sistema nervoso (1912-1932)}

Durante a década de 1910, ocorre uma aplicação dos conhecimentos anteriormente obtidos sobre a sífilis, a respeito de seu agente causal, de sua detecção e , de seu tratamento. Também no início dessa década o vínculo entre sífilis e paralisia geral é definitivamente estabelecido.

Em 1913, nos Annaes Paulistas de Medicina e Cirurgia, na seção "Notas Therapeuticas” foi publicada resenha de artigo publicado na Présse Médicale (n.71, 1913), intitulada “O 606 no Congresso de Medicina de Londres”"1028. O texto se refere a um Congresso Internacional de Medicina, ocorrido nessa cidade em agosto desse ano, onde foi debatido o emprego do medicamento para sífilis, nomeado como "salvarsan" ou “606” e o "neosalvarsan” ou "914”. Comenta-se que uma das polêmicas foi a respeito da lesão do sistema nervoso pelo próprio medicamento, a melhor dosagem a ser aplicada, as contraindicações e outras questões. Embora vários pontos tenham permanecido em aberto, considerou-se que só três anos para conclusões é pouco tempo

1027 PACHECO E SILVA. A. C. Cuidados aos Psychopathas. Officinas Graphicas do Hospital de Juquery, p.11-28, 1930.

1028 NOTAS THERAPEUTICAS. O “606” no Congresso de Medicina de Londres. Annaes Paulistas de Medicina e Cirurgia, p. 166-168, 1913. 
(desde 1910), devendo-se aguardar a experiência de dez anos para melhor avaliação, sendo que, mesmo assim, considerou-se um progresso o medicamento.

Na década de 1920, embora se conheceça bastante a sífilis, seu tratamento ainda é alvo de especulações e pesquisas. No período pós-guerra, a inovação e a denominação dos medicamentos acompanham, em parte, as conseqüências da beligerância.

Assim, em 1920, é publicado na Gazeta Clinica um informe a respeito de diversas aplicações que podem ser feitas pelo "914 francês", incluindo casos de paralisia geral. O 914, ou neo-salvarsan é um aprimoramento do “606 alemão”, este também conhecido como arsenobenzol, ou salvarsan, descoberto por Erlich, para combater a sífilis. O 914 já existia antes da guerra, mas, após esta, ele foi melhorado e pareceu realmente ser um medicamento melhor do que o alemão. Adjetivado de “francês”, coincidentemente ele tem um número equivalente ao ano de início da guerra vencida pela França ${ }^{1029}$.

Em 1922, foi publicado, na Gazeta Clinica, artigo do médico Aguiar Pupo, intitulado “A syphilis em São Paulo - comunicação à Sociedade de Medicina e Cirurgia de S. Paulo" ${ }^{1030}$. O autor faz um amplo apanhado sobre tratamento e prevenção da sífilis em São Paulo.

No que diz respeito à sífilis do sistema nervoso, o autor relata que os casos de tabes e de paralisia geral estão incluídos no que é chamado de sífilis terciária. Ele acentua que esses casos eram anteriormente chamados por Fournier de "afecções parassifilíticas” ou "sífilis quaternária”.

Pupo reforça a conceituação de tabes e paralisia geral como sífilis terciária, dizendo que a reação de Wassermann é positiva no sangue e no líquido cefalorraquiano desses doentes, e que Noguchi encontrou o “spiroqueta palida de Schaudin” nos cérebros de paralíticos gerais. Cita também o fato de que o efeito favorável dos arsenicais de Erlich (derivados de arsenobenzol) não ocorre nas situações em que as células do sistema nervoso já tenham sido destruídas pelo agente causal.

1029 GAZETA CLINICA. Outras applicações do 914 francez, novo preparado, p. 23-24, 1920. 1030 PUPO, A. A syphilis em São Paulo; Comunicação à Sociedade de Medicina e Cirurgia de S. Paulo. Gazeta Clinica, p. 36-45, 1922. 
O autor reproduz, então, palavras do prof. Austregésilo, o qual diz que, conforme a escola inglesa, o conceito de Fournier estava equivocado. Fournier achava que a tabes e a paralisia geral eram apenas de “origem” sifilítica, mas não de "natureza” sifilítica (também era chamada de metassífilis de Moebius).

Conforme Pupo, Austregésilo reforçou suas considerações, citando pesquisas de Noguchi, Levaditi, Marinesco, Marie, Minea e Mário Pinheiro: todos que encontraram o treponema pálido no cérebro de paralíticos gerais, demonstrando, assim, que a "parassífilis” na verdade é a própria sífilis.

Pupo expõe então a organização de locais para atendimento desses pacientes, contando com a ajuda do Centro Acadêmico Oswaldo Cruz, da Faculdade de Medicina.

Os exames subsidiários também aprimoram as noções a respeito das moléstias. Desse modo, em 1927, foi publicado na Gazeta Clinica artigo de James Ferraz Alvim e do doutorando Nestor Solano Pereira, “interno do Instituto Aché”, intitulado "Notas sobre o liquido cephalo raqueano na Paralysia Geral”. Os autores apresentam a importância do exame de líquido cefalorraquiano para o diagnóstico de casos com comprometimento mental, que se associam a sinais sugestivos de paralisia geral. $\mathrm{O}$ autor apresenta as alterações químicas, celulares e de reações como Wasserman, entre outras.

Em 1928, Fausto Guerner publica no São Paulo Medico, resenha sobre tese de doutoramento da Faculdade de Medicina de São Paulo, de autoria de Virgilio C. Pacheco, identificado como ex-interno do Hospital do Juquery, tese essa intitulada "A malariotherapia na paralysia geral progressiva”. ${ }^{1031}$

O texto informa que esse trabalho foi feito com os resultados obtidos no emprego do “methodo de Wagner von Jauregg” em 39 doentes de paralisia geral progressiva do Hospital do Juquery.

É relatado que foram obtidas 5 remissões completas, 6 remissões incompletas; 14 melhoras; 4 doentes sem melhora; 3 faleceram após o tratamento e 7 durante o tratamento (não sabemos, nesse trabalho, a diferença entre remissão incompleta e melhora).

1031 GUERNER, F. A malariotherapia na paralysia geral progressiva; pelo Dr. Virgilio C. Pacheco. São Paulo Medico, p. 113-114, 1928. 
Informa também a resenha que o autor estuda a técnica de inoculação da malária, as indicações e contra-indicações do método, a medicação específica que deve ser associada à malarioterapia. É feita também análise dos resultados em relação aos sintomas psíquicos, ao estado geral, aos sinais neurológicos e outras modificações do organismo. Assinala-se que o autor verificou, assim como outros autores, que não há grande melhora neurológica, mesmo em casos em que as perturbações mentais desaparecem por completo. Assim, os sinais oculares não regridem, a disartria atenuase, os tremores e a disgrafia melhoram.

O texto relata as conclusões de Pacheco: no momento, a malarioterapia é o tratamento de eleição para a paralisia geral progressiva; 50\% dos doentes se beneficiam com o tratamento, em relação às melhoras psíquicas; deve-se ter atenção ao tratamento específico da malária, pelas alterações que ela causa ao organismo.

\section{3. 3. - Semiologia neurológica (1912-1932)}

Antes mais esparsos, neste período são publicados muitos artigos fazendo menção direta a um tema semiológico, ou ainda fazendo uso pormenorizado da semiologia.

Em 1913, na Imprensa Medica, é publicado artigo na seção “Neuropathologia” intitulado “Dos movimentos associados na athetose”1032 pelo Prof. Aloysio de Castro, artigo esse que corresponde a uma Comunicação feita à Academia Nacional de Medicina.

O autor refere que, apesar de terem sido feitos recentes trabalhos sobre a questão dos “movimentos associados”1033, há ainda numerosos pontos a esclarecer, tanto sob o aspecto clínico quanto fisiopatológico. Nesse sentido, ele aborda nesta comunicação o estudo desses movimentos em casos de atetose ${ }^{1034}$. Ele se refere a dois casos, a partir dos quais desenvolve sua explanação.

1032 CASTRO, A. Neuropathologia: Dos movimentos associados na athetose. Imprensa Medica, p. 2730, 1913.

1033 Os movimentos associados são assim denominados, por serem movimentos observados além daqueles que caracterizam os quadros neurológicos.

1034 Atetose: manifestação neurológica caracterizada por movimentos involuntários lentos. 392 
Assim, ele diz que a literatura tem pouco falado sobre os movimentos de sincinesia ${ }^{1035}$ nas atetoses, enquanto que as descrições mais freqüentes têm ocorrido nas hemiplegias. Ele defende a existência de sincinesias nas atetoses, reforçando-se em alguns estudiosos que cita, e diz ter dúvida se uma determinada manobra semiológica conceituada por Babinski não seria equivalente a uma sincinesia.

A seguir são apresentados três artigos de autoria de Enjolras Vampré, isoladamente ou juntamente com outro autor (inclusive um deles com Arnaldo Vieira de Carvalho). Nos três trabalhos, o detalhamento semiológico e a discussão de Vampré é tal, que não é possível resumi-lo adequadamente, de modo que fazemos apenas algumas menções aos dados registrados referentes a exame neurológico. Também queremos assinalar que, de modo geral, Vampré usa os termos “psychiatria”, "neuropathologia” e neurologia”, mas não usa o termo "neuriatria”.

Assim, em 1915, Sérgio Meira Filho e Enjolras Vampré publicam artigo nos Annaes Paulistas de Medicina e Cirurgia, intitulado "Paraplegia pareto-espasmodica por lesão traumatica da $4^{\text {a }}$ vertebra lombar - Syndroma da cauda de Cavallo Laminectomia descompressiva”, ${ }^{1036}$.

Nesse longo artigo, os autores relatam o caso de paciente com lesão traumática de medula espinhal, que foi por eles examinado e tratado por cirurgia, na Santa Casa. É provável que a parte do texto que aborda aspectos neurológicos tenha sido escrita por Vampré, enquanto que a parte que descreve os detalhes cirúrgicos tenha sido escrita por Meira Filho.

O texto que discute os aspectos semiológicos do quadro observado, bem como a literatura científica a respeito, é bastante minucioso, com muitas citações e considerações a respeito dos reflexos, da sensibilidade e de outros fenômenos neurológicos. O autor mais citado é Babinski, vindo após ele Dejerine, de cujo livro, o artigo reproduz figura anatômica, havendo também a reprodução de exame radiográfico do paciente. Outros autores que também são citados algumas vezes são Pierre Marie, Grasset e Bechterew.

1035 Sincinesia: movimento involuntário associado a movimentos voluntários, que aparece em várias condições.

1036 MEIRA FILHO, S. \& VAMPRÉ, E. Paraplegia pareto-espasmodica por lesão traumatica da $4^{\mathrm{a}}$ vertebra lombar; Syndroma da cauda de Cavallo; Laminectomia descompressiva. Annaes Paulistas de Medicina e Cirurgia, p. 30-44, 1915. 
O exame neurológico do paciente está descrito de forma sistematizada e pormenorizada, havendo também descrições de outros casos, também com detalhamento do acometimento do sistema nervoso.

Há discussão de diversos elementos tidos como certos em termos de fisiologia e de semiologia neurológica. Os pontos ainda em discussão são expostos de maneira exaustiva, citando as diversas opiniões. Há discussões sobre o entendimento mais profundo de vários reflexos, iniciando com conceituação feita por Vulpian em 1873, a respeito de "reflexos de defesa". Prosseguindo a discussão, aborda-se o sinal de Babinski. Em relação a este, chega-se ao pormenor de citar que foi descrito em 22 de fevereiro de 1896, e entra-se em outros diversos detalhamentos feitos a respeito desse sinal, seja por Babinski, ou por outros autores. É citado diagnóstico diferencial com casos de histeria, ressalvando a ausência de sinais físicos nesta condição.

Os autores consideram ter havido sucesso na cirurgia para descompressão de estruturas nervosas ligadas à coluna vertebral.

O segundo desses artigos foi publicado em 1915, nos Annaes Paulistas de Medicina e Cirurgia, sendo intitulado "Hemianesthesia e Hemiplegia cerebraes

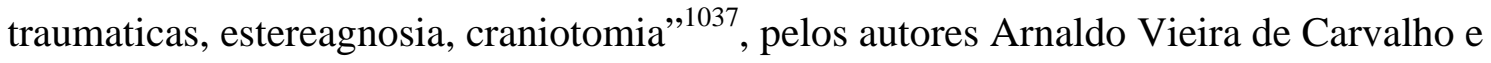
Enjolras Vampré.

O artigo descreve caso de tentativa de suicídio por tiro, atendido na Santa Casa. Inicia-se, dizendo que o ponto de penetração da bala indicava uma necessidade imperiosa do conhecimento das relações entre as circunvoluções cerebrais e a superfície craniana pelo cirurgião. Para isso os autores fizeram uso do “craneometro de Krönlein” e também do "methodo de Kocher", para traçar linhas sobre o crânio com a finalidade de localizar as regiões cerebrais. Também existe descrição e discussão a respeito de outros métodos que têm essa finalidade.

Após radiografia feita por Raphael de Barros, localizando o projétil, a paciente foi operada por Arnaldo Vieira de Carvalho, auxiliado por Ayres Netto, Zeferino do Amaral e por Casemira Loureiro, “encarregada da anesthesia”. Informa o texto que o procedimento obteve sucesso.

1037 CARVALHO, A. V.; VAMPRÉ, E. Hemianesthesia e hemiplegia cerebraes traumáticas, estereagnosia, craniotomia. Annaes Paulistas de Medicina e Cirurgia, anno III, vol. IV, n. 4, p. 73-86, 1915. 
Em seguida, o artigo adentra por longa e detalhada discussão a respeito dos dados semiológicos da paciente, fazendo-se correlações com todos os conhecimentos e explicações a respeito das estruturas do sistema nervoso.

A parte do artigo relativa ao sistema nervoso é bastante extensa e detalhada, partindo sempre dos dados semiológicos para discutir os diversos estudos a respeito das correlações entre os dados clínicos e as localizações e funções cerebrais. São acrescentados dados de outros casos, para ilustrar as explicações a serem dadas. Há a menção de alguns entendimentos citados como "novos", a partir de pesquisas então recentes. Há alguns pontos considerados como controversos ou obscuros. É assinalado diagnóstico diferencial com histeria.

O terceiro artigo, publicado em 1916, nos Annaes Paulistas de Medicina e Cirurgia, tem o título “Lesão traumatica (martellada)” ${ }^{1038}$, de autoria de Enjolras Vampré.

Este é mais um artigo de Vampré, onde aborda um caso de traumatismo de crânio, que foi operado com sucesso, e que apresenta diversas alterações neurológicas que são esmiuçadas em detalhes. Trata-se caso com amnésia, várias formas de afasia, epilepsia jacksoniana, hemianopsia e apraxia.

Mais uma vez o autor cita vários estudiosos, com diversos pontos de vista a respeito de anatomia e função do sistema nervoso, bem como de seus comprometimentos. Chama a atenção que Vampré cita uma alteração neurológica, segundo ele descrita por Freud em 1889, que ele chama de “afasia óptica de Freud”, que equivale a uma incapacidade de nomeação de objetos ao visualizá-los, mas sendo possível nomear após a palpação desses mesmos objetos.

Nesse artigo, Vampré também relata pesquisa que fez, juntamente com o professor Affonso Bovero, no laboratório de Anatomia da Faculdade de Medicina de São Paulo, com crânios preparados por esse professor, para melhor entender o caso.

O autor acrescenta fotografias de fragmentos ósseos do caso em questão, além de vários desenhos anatômicos de estruturas cerebrais reproduzidos de livros, para o entendimento do caso por ele abordado.

Pelas citações feitas, Vampré tem acesso aos registros das reuniões da Sociedade de Neurologia de Paris. Como em outros artigos, ele faz abordagem bastante

1038 VAMPRÉ, E. Lesão traumática (martellada). Annaes Paulistas de Medicina e Cirurgia, p. 10-27, 1916. 
ampla, com muitos dados, a respeito dos estudos em questão, partindo sempre dos dados semiológicos.

Em 1916, Lemos Torres publica nos Annaes Paulistas de Medicina e Cirurgia, o artigo intitulado "Um caso de Myopathia typo Landouzy-Dejerine”1039.

O autor apresenta caso de paciente com quadro de comprometimento muscular distribuído por várias partes do corpo. Ele faz descrição minuciosa do exame da musculatura e dos reflexos, e de outros componentes neurológicos, acrescentando alterações elétricas. Depois, faz considerações sobre os diagnósticos diferenciais entre diversas moléstias musculares, medulares ou de sistema nervoso periférico, de modo geral moléstias raras, e acaba concluindo pelo diagnóstico de miopatia tipo LandouzyDejerine.

Em 1916, no Congresso Paulista, ocorre explanação - pelo médico Waldemar Schiller, identificado como diretor da Casa de Saúde Dr. Eiras, e pelo médico Odilon Galloti, identificado como assistente voluntário da Clínica Neurológica da Faculdade de Medicina do Rio de Janeiro e Assistente do Serviço Neuropsiquiátrico da Casa de Saúde Dr. Eiras -, a respeito do assim chamado, fenômeno de Openheim (que é uma manobra propedêutica equivalente ao reflexo de Babinski) em termos de diagnóstico.

No caso relatado pelos autores, foi observada a ausência do reflexo de Babinski e a presença do fenômeno de Openheim, em um caso de sífilis ${ }^{1040}$.

Foi referido que alguns estudiosos acham que o fenômeno de Openheim se trata de outro reflexo, sem relação com o reflexo de Babinski.

Os autores são favoráveis ao entendimento do próprio Babinski, de que esse e outros fenômenos similares são variantes do mesmo sinal por ele descrito, que leva o seu nome. Para reforçar sua explanação, os autores citam um relatório do prof. Austregésilo, apresentado ao $1^{\circ}$ Congresso de Neurologia, Psychiatria e Medicina Legal, de 1916, intitulado “As ultimas acquisições no dominio dos reflexos”.

Essa afirmação, de que o sinal de Openheim é equivalente ao sinal de Babinski, também já havia sido feita por Enjolras Vampré em um dos artigos anteriormente relatados.

1039 TORRES, L. Um caso de Myopathia typo Landouzy-Dejerine. Annaes Paulistas de Medicina e Cirurgia, anno IV, vol. VI, n.6, p. 121-125, 1916.

1040 SCHILLER, W.; GALLOTI, O. Anomalia do signal de Babinski. Gazeta Clinica, p. 115-116, 1919. 396 
Em 1918, na Sessão de Abertura da Academia Paulista de Medicina, ocorre apresentação, feita pelo médico Campos Seabra, intitulada “Observações sobre a molestia de Friedreich" ${ }^{\text {1041 }}$. O autor apresenta três casos de irmãs com essa rara moléstia hereditária.

Na presença de Rubião Meira, presidente da Academia, o autor refere reportarse ao método ensinado por Meira para formulação de hipótese diagnóstica, baseado na exclusão. Desse modo, ele discorre longamente sobre diversas possibilidades diagnósticas no caso, excluindo-as uma a uma, e ficando com o diagnóstico de moléstia de Friedreich.

Em relação a um determinado sinal de alteração de coordenação da marcha, o autor se refere a esse sinal como sendo “a ataxia estatica dos neuropathologistas”1042. Com essa forma de expressão, Seabra dá a entender que está usando uma linguagem que não é a própria de seu grupo, mas de um outro, os “neuropathologistas” (conforme a terminologia do período).

Em 1919, foi publicada nos Annaes Paulistas de Medicina e Cirurgia, a memória apresentada por Enjolras Vampré à Academia Nacional de Medicina, intitulada "Paralysias a Distancia"1043. O autor inicia com as palavras:

“Com o desenvolvimento extraordinario da Neurologia, neste tormentosos dias de guerra, tão importantes e cheios de actualidade têm sido os estudos sobre as paralysias a distancia, as dystrophias musculares de typo myopathico, assignaladas pela primeira vez, em 11 de Outubro de 1915, na Presse Médicale por Henri Claude, A. Vigoroux e J. Lhermitte, as nevrites motoras extenso-progressivas nas lesões traumaticas dos nervos periphericos, descriptas por Mme. Athanasio Bénisty (Societé de Neurologie - Revue Neurologique, Juin 1917) - que tomamos a resolução de apresentar á douta Academia Nacional de Medicina, em obediência aos preceitos do artigo 25 de seu regimento, a observação detalhada de um curioso caso destas paralysias irracionaes e paradoxaes que tivemos a oportunidade de seguir durante mais de um anno em nossa clinica privada”1044.

1041 SEABRA, C. Observações sobre a molestia de Friedreich apresentadas á Academia Paulista de Medicina. Gazeta Clinica, 1918.

1042 Idem.

1043 VAMPRÉ, E. Paralysias a distancia. Annaes Paulistas de Medicina e Cirurgia, vol.X, n. 7, p. 145155, 1919.

1044VAMPRÉ, E. Paralysias a distancia. Annaes Paulistas de Medicina e Cirurgia, vol.X, n. 7, p. 145, 1919. 
O autor prossegue, informando que já havia apresentado esse caso em 1917 à Sociedade de Medicina e Cirurgia de S. Paulo, e diz colocar-se agora diante dos "Mestres da Neurologia brasileira”.

Segundo o autor, o quadro por ele apontado, é similar ao primeiro caso desse tipo descrito na França, e se deve a alterações em região periférica do corpo, após lesão por ferimento em local distante da sintomatologia observada, sem ter-se encontrado explicação para esses comprometimentos. Os estudiosos, Claude, Vigoroux e Lhermitte não arriscaram dizer se o quadro seria por comprometimento de músculos ou de nervos.

Vampré evoca a observação desses estudiosos e também de Babinski e Froment - que fizeram estudo sobre "paralysias reflexas" -, para explicar a "paralysia a distancia”.

O autor descreve detalhadamente o caso por ele observado, de um indivíduo que recebeu dois tiros no tórax, tendo uma bala alojada no tecido subcutâneo e outra em massa muscular, sendo que esse projétil foi de encontro às $8^{\mathrm{a}}$ e $9^{\mathrm{a}}$ vértebras. $\mathrm{O}$ quadro clínico correspondia a alterações vaso-motoras, tróficas, paresia, atrofia, hipoestesia da cintura escapular esquerda.

Vampré, repetidamente, entra em detalhes e esgota as possibilidades de se tratar de caso de histeria ou pitiatismo, ou simulação, sempre fazendo referência a Babinski e sua conceituação dessas alterações (cita o nome de Babinski mais de 15 vezes no artigo) e dando detalhes de seus estudos.

O autor refere estar diante de caso inédito em São Paulo e passa a avaliá-lo a partir dos estudos de Babinski e Froment, de 1915, sob a denominação de fenômenos de ordem reflexa.

Ele diz que as perturbações de ordem reflexa foram estudadas primeiramente por John Hunt, em 1839, e depois por Charcot e Vulpian, de 1883 a 1886. Em seguida, assinala que tais alterações “caíram no mais completo esquecimento dos neurologistas” ${ }^{1045}$. Cita então as duas razões principais para esse esquecimento, assinaladas por Babinski: uma foi o abuso do termo "reflexo" por vários autores, e outra foi a "extraordinaria dilatação do conceito da hysteria"1046.

1045 VAMPRÉ, E. Paralysias a distancia. Annaes Paulistas de Medicina e Cirurgia, vol.X, n. 7, p. 146, 1919.

1046 VAMPRÉ, E. Paralysias a distancia. Annaes Paulistas de Medicina e Cirurgia, vol.X, n. 7, p. 147, 1919. 
Assim, ele informa que, em 1915, Babinski e Froment, estudando as "noções novas adquiridas em medicina, com a guerra"1047, fizeram voltar fatos esquecidos que parecem inteiramente novos. O autor adentra, então, por reflexões, para explicar que esses quadros se devem à estimulação do sistema simpático.

Em 1919, é publicado, na Gazeta Clinica, artigo do médico Octavio Ayres, identificado como "Livre Docente de Clinica Medica da Faculdade do Rio de Janeiro", artigo esse intitulado "Da pesquiza do reflexo achilleo"1048.

O autor refere-se a uma nova proposta de pesquisa do reflexo aquileu, dentro do que ele chama de "método brasileiro", enquanto cita também os métodos de outros autores. Ayres, que não se identifica como neurologista ou psiquiatra, pode ser inserido no campo dos propedeutas interessados em neurologia:

"Procurar um novo processo de pesquiza no dominio dos reflexos, parecerá a primeira vista cousa inutil ou mesmo demonstração vaidosa em deixar um nome ligado a uma filigrana de semiologia. No emtanto quem se tenha adestrado como pesquizador em neurologia, sentirá, muitas vezes, grandes embaraços no simples acto de pesquisar um reflexo" ${ }^{1049}$.

Assim, ele propõe o novo método, incluindo-o no que chama de "neurologia indigena” 1050 , referindo-se a uma neurologia própria do Brasil: "Como temos de trazer a lume, a posição por nós aconselhada na pesquiza do mesmo reflexo, que ella fique conhecida na neurologia indigena com a denominação consoladora e humilde de methodo brazileiro"1051.

Ayres refere-se também ao método de Dejerine e ao método de Babinski, achando o deste melhor que o do primeiro. Mas, o seu próprio método, segundo ele, é ainda melhor. Assim ele descreve seu método:

“Terceira posição - 'Metodo brasileiro'- É a mais simples de todas. Eil-a: o doente fica deitado com o abdomen para baixo. Uma das pernas é flectida em angulo reto; a mão esquerda do medico repousa sobre a planta do pé do paciente; com o martello na mão direita percute-se o tendão de Achilles”1052.

1047 VAMPRÉ, E. Paralysias a distancia. Annaes Paulistas de Medicina e Cirurgia, vol.X, n. 7, p.151, 1919.

1048 AYRES, O. Da pesquiza do reflexo achilleo. Gazeta Clinica, p. 41, 1919.

1049 Idem.

1050 O adjetivo indígena é aqui usado com o sentido de próprio do Brasil, sentido esse que também era usado em outras publicações médicas, diferente, portanto, do sentido de "referente aos índios”.

1051 AYRES, O. Da pesquiza do reflexo achilleo. Gazeta Clinica, p. 41, 1919.

1052 Idem. 
A seguir o autor relata as várias vantagens desse método, para o qual ele propôs o nome de "brasileiro"1053.

Em 1923, o médico paulista Antonio de Almeida Prado, da Faculdade de Medicina de São Paulo, recebe o Prêmio Alvarenga, da Academia Nacional de Medicina, pelo seu trabalho "Syndromos Cerebellares Mixtos”"1054.

Em seu discurso na Academia Nacional de Medicina, o professor da Faculdade de Medicina da Bahia, Clementino Fraga diz que Almeida Prado cultiva uma especialidade das mais complicadas, "a neuriatria, em que os progressos actuaes, numa technologia de causar panico, referem signaes eponymicos e manobras semiologicas, que, vezes sem conta tranquillisam o diagnostico para descoroçoar a tranquillidade na therapeutica” ${ }^{\prime 1055}$.

Esse mesmo trabalho é publicado como livro em 1924, e depois traduzido e publicado na França, tendo sido alvo de elogios na Presse Medicale, fato esse assinalado por Vampré em reunião da Sociedade de Medicina e Cirurgia, em 1931.

1053Um espírito nacionalista ganha força após o início da Primeira Guerra Mundial, com a idéia de que o Brasil é uma nação fraca, diante das grandes potências. Em 1915, o discurso de Olavo Bilac, na Faculdade de Direito de S. Francisco, propondo o serviço militar obrigatório, dá início a um movimento que desencadeia a Liga de Defesa Nacional, no Rio de Janeiro, em 1916 e a Liga Nacionalista em S. Paulo, em 1917. Esse movimento tem participações políticas, artísticas, literárias, científicas. Em 1918, são fundadas a Sociedade Eugênica de S. Paulo e a Liga Pró-Saneamento, associações que têm afinidades com as anteriormente citadas.

Nessa linha, há o artigo "Saneamento do Brasil", de 1918, na Gazeta Clinica, do médico Ribeiro de Almeida. Ele relata que Monteiro Lobato, no jornal Estado de S. Paulo, publica muito sobre o saneamento rural e sua miséria, que é ignorada em virtude da "patriotada" dos escritores anteriores, que pintavam um "éden" no sertão. Diz que Lobato também critica os médicos, dizendo que, exceto Oswaldo Cruz e sua escola, ninguém estuda medicina no Brasil. Almeida diz que foram grandes os feitos de Oswaldo Cruz, mas que não foi o único, pois Emilio Ribas combateu a febre amarela antes de todos, inclusive deixandose picar pelo mosquito. Cita também Vital Brazil, que “criou no Butantã um segundo Manguinhos”. Diz que os médicos não são culpados pelas epidemias sertanejas, pois nunca foram governo, e que só em S. Paulo se faz alguma profilaxia. Após relatar alguns exemplos, conclui: "É possivel sanear o Brasil com o descaso dos nossos governantes, preoccupados unicamente com a alta politicalha pessoal e com a reforma do alistamento eleitoral?”

De LUCA, T.R. A Revista do Brasil: um diagnóstico para a (N) ação. Editora UNESP, 1998,p.40-42.

ALMEIDA, R. Saneamento do Brasil. Gazeta Clinica, p. 35-36, 1918.

1054 GAZETA CLINICA. Academia Nacional de Medicina: entrega do premio Alvarenga, p. 130-135, 1923.

1055 Idem. 


\section{3. 4. - Nevroses e neuroses (1913-1932)}

Para introduzir este assunto, nesse período, fazemos uso de uma apresentação feita por Austregésilo no Congresso Paulista de 1916, onde ele usa o termo neurose, em vez de nevrose.

No Congresso Paulista de 1916, é apresentado o tema "Debilidade Nervosa reações elementares do Sistema Nervoso” ${ }^{1056}$, pelo prof. Austregésilo ${ }^{1057}$. O autor inicia, comentando a respeito da complexidade dos quadros denominados neuroses e usa o termo neuriatria, para referir-se ao campo neurológico:

“Nas doenças de carater funcional, pela vastidão e por suas dificuldades clinicas, as neuroses se apresentam etiopatogenicamente como verdadeiros problemas. Constituem um capitulo da

Neuriatria cheio de duvidas e de opiniões heteroclitas em que as doutrinas são personalissimas e que estão ao talante do espirito filosofico observador”1058.

O autor considera a neurose como sendo uma "debilidade nervosa” que predispõe os indivíduos a apresentarem variadas manifestações clínicas.

Ele cita os principais caracteres desse quadro, que também chama de "estigmas": fatigabilidade, irritabilidade, instabilidade, emotividade exagerada, sugestionabilidade, ritmicidade, periodicidade, reações prontas, tendência aos tóxicos, hereditariedade anafilática para os mesmos, reações vasomotoras e secretoras fáceis; debilidade gastro-intestinal; sintomas para os órgãos ocos do organismo como coração, estômago, intestinos e bexiga.

A seguir ele analisa cada um desses itens. No item "Ritmicidade Periodicidade”, cita Freud:

“Ha doenças nervosas e mentaes que são essencialmente ritmicas e periodicas. Ha neurastenias e dispepsias periodicas. Ciclotimicos são cativos do ritmo, bem como maniacodepressivos. A irritabilidade emotiva, genital e toxifila obedecem não raro a períodos variantes no mez e no ano. Frequentemente os periodos se acham ligados aos do dominio genital, cuja importancia nos debeis nervosos é dominadora. Segundo Freud a histeria, a

1056 ANNAES DO CONGRESSO MEDICO DE S. PAULO. Conferencia do Professor Austregésilo na Sociedade de Medicina e Cirurgia; Primeiro Congresso Medico Paulista, p. 175-185, 1916.

1057 Na sessão inaugural desse Congresso, Austregesilo teceu elogios ao progresso e à vibração de São Paulo. Disse que a Faculdade de S. Paulo nasceu da Faculdade do Rio, mas que ele, entre os mais velhos, receberia lições de estímulo dos mais moços, para derramar o mesmo entusiasmo aos futuros médicos.

PRIMEIRO CONGRESSO MEDICO PAULISTA. Annaes do Congresso Medico de S. Paulo, p. 113114, 1916.

1058 ANNAES DO CONGRESSO MEDICO DE S. PAULO. Conferencia do Professor Austregésilo na Sociedade de Medicina e Cirurgia; Primeiro Congresso Medico Paulista, p. 176, 1916. 
neurose do medo, são estados que partem de um ponto psico-genital. A doutrina de Freud não é exata em absoluto mas frequentemente o elemento genital material e moral (ciume, erotismo mistico, choque de paixões, perversão, etc.) entram na personalidade do debil nervoso" 1059 .

Depois de fazer considerações sobre neurastenia, ele passa ao que chama de “segunda sindrome funcional do sistema nervoso” que é a histeria, que também considera como “estado” ou “sindrome histeroide”. Em comparação à neurastenia, ele considera a histeria um estado com debilidade nervosa mais acentuada. Diz que o histérico está “um grau acima da epilepsia”1060 (ou seja, um grau melhor) por não perder a consciência.

O autor insere os três quadros em uma explicação de natureza celular e química, dizendo que: “A celula do neurastenico recebe o toxico e trabalha mal; a do histerico se desagrega em sua função, mas a consciencia ainda domina a unidade psiquica; a do epileptico recebe a toxina e sua resposta é explosiva, com perda da consciencia indicando facil desagregação das funções motora e psiquica”1061.

\section{3. 4. 1. - Neurastenia e Psicastenia (1913-1932)}

Neste período, após Babinski descaracterizar a histeria como uma doença propriamente dita, considerando-a apenas uma manifestação induzida, aumentam os registros nas revistas sobre neurastenia e psicastenia. Esses quadros passam a ser cada vez mais associados às condições da vida moderna.

Nesse sentido, diversos artigos, sobre esse tema, são escritos nos periódicos paulistas, na década de 1910 .

Em 1913, o médico A. Vergely, de Jaú, escreve artigo publicado na Gazeta Clinica, intitulado "Neurasthenia” ${ }^{1062}$. O autor, após várias considerações sobre a neurastenia, conclui que os neurastênicos "podem ficar tranquilos, pois não são histericos”, já que a natureza de seus problemas localiza-se na esfera gastrointestinal, atingida por alguma alteração nervosa, devendo, portanto, receber medicamentos que atuem nessa área.

1059 Idem, p. 179.

1060 Idem.

1061 Ibidem.

1062 VERGELY, A. Neurasthenia. Gazeta Clinica, p. 66-69, 1913.

402 
Ainda no entendimento desses quadros dentro de uma linha de associar essas alterações a causas orgânicas, em 1914, na seção “Das Revistas”, da Gazeta Clinica, foi publicada uma resenha, de origem não citada, intitulada “A neurasthenia dos 50 annos 1063 . O texto compara a neurastenia da juventude com a neurastenia dos 50 anos.

No caso do jovem, são relatadas como causas: herança nevropática, astenia física, intelectual ou moral, traumatismo, infecções e intoxicações. Em qualquer dessas situações ele diz não haver substrato anatômico. O artigo considera essa condição marcada por desânimo profundo, que pode até mesmo levar a algum ato criminoso ou ao suicídio. O texto aponta que esse indivíduo cura-se com repouso físico, intelectual e moral, dieta desintoxicante, estricnina, sugestão.

No caso da neurastenia dos 50 anos, o artigo considera a possibilidade de três causas, com lesões cerebrais: arteriosclerose associada a suas complicações sistêmicas; infecções, principalmente arterite sifilítica; intoxicações lentas (venenos, chumbo, álcool, tabaco), ou experimentais (adrenalina), ou senis. Nesses casos, como os sintomas tendem a permanecer, além dos tratamentos usados nos jovens, usa-se dietas e outras medidas em relação a cada caso.

Consideramos oportuno colocarmos pontos de vista sobre neurastenia e psicastenia, que acrescentam novas influências no entendimento desses quadros, nessa mesma década. Para dialogarmos com os registros citados, dos periódicos médicos, apresentamos aqui registros dos anais do Congresso Paulista de Medicina de 1916.

Nesse congresso, Henrique Roxo fez uma palestra intitulada "Estudo Clinico da Neurastenia”1064. Ele associa sua apresentação ao fato de estar em São Paulo:

“Poderia parecer que eu buscasse fazer associação de idéias por contraste, escolhendo para thema de uma palestra - a neurasthenia - numa cidade, em que há tanta actividade e progresso. Poder-se-ia antolhar extravagante buscar ver aqui neurasthenicos, mas é que me não passou desapercebido que não há progresso sem esforço, que não há actividade sem cansaço, que a lucta pela vida exhaure o individuo e que nas grandes cidades sobejam os neurasthenicos》1065.

1063 DAS REVISTAS. A Neurasthenia dos 50 annos. Gazeta Clinica, p.89, 1914. 1064 ANNAES DO CONGRESSO MEDICO DE S. PAULO. Conferencia do Professor Roxo; Primeiro Congresso Medico Paulista, p. 225-237, 1916.

1065 ANNAES DO CONGRESSO MEDICO DE S. PAULO. Conferencia do Professor Roxo; Primeiro Congresso Medico Paulista, p. 226, 1916. 
Dizendo-se com idéias próprias sobre o assunto, ele subdivide a neurastenia em “nervosismo e psychastenia”.

No nervosismo, inclui os quadros com distúrbios sensoriais. Segundo ele, o nervosismo é encontrado nas mulheres e já foi chamado de histeria. Roxo diz que, após os estudos de Babinski, a histeria ficou limitada aos fenômenos criados por sugestão e removidos por persuasão. Ele acentua que, quando se formou em medicina, quase toda semana tinha que acudir a um caso de histeria, enquanto que agora isso é uma raridade.

Ele acha que os sintomas do nervosismo se devem a uma estase venosa no cérebro. Em relação a sintomas gastrointestinais, frisa que “as gastroenteronevroses vão abrangendo quase toda a pathologia gastrointestinal” ${ }^{1066}$. Roxo diz concordar com Dejerine, que via nas emoções a causa do nervosismo.

Roxo também diz que, depois da guerra que está em curso, diminuindo o número de homens, crescerá o número de neurastênicos, pois “as emoções violentas e demoradas determinarão uma avalanche de exgottados”1067.

O autor faz, então, menção a Freud, ao referir-se ao nervosismo:

“O nervosismo é mais frequente no sexo feminino e devo chamar a vossa atenção para um facto que a observação clinica tem me permitido constatar. É a frequencia com que o mal se verifica em doentes que praticam relações sexuais incompletas. No afan que se nota geralmente de evitar a procreação, alguns evitam ultimar o congresso sexual e a mulher fica nervosa, na ansia de um prazer que se lhe não dá. É uma applicação da doutrina de Freud que si tem demasias, diz uma grande verdade, quando attribue á sexualidade papel de grande importancia na genesis de psychoses e nevroses”1068.

Em seguida, fala da psicastenia como uma doença da vontade, e que segue Pierre Janet nesse conceito. Chama a atenção de que, pela evolução da ciência, casos que antes seriam de psicastenia, passaram a ser diagnosticados como demência precoce, psicose maníaco-depressiva e histeria.

Nesse mesmo congresso, Roxo também faz palestra intitulada "Psycasthenia”. Ele inclui nessa situação as obsessões, fobias e impulsões. Refere que há grande número de doentes com esse quadro. Diz que Janet inclui mais outros quadros, além desses três, na psicastenia. Quanto à influência da sexualidade na psicastenia, diz que: “É o pleno

1066 ANNAES DO CONGRESSO MEDICO DE S. PAULO. Conferencia do Professor Roxo; Primeiro Congresso Medico Paulista, p. 227, 1916.

1067 Idem, p. 229.

1068 Idem, p. 230.

404 
domínio da doutrina de Freud que na sexualidade busca a origem de todos os males” 1069

Em 1920, Ulysses Paranhos publica na Gazeta Clinica o artigo intitulado “Ligeiras considerações sobre o nervosismo" ${ }^{1070}$. O autor se refere à síndrome, segundo ele, “vulgarmente chamada de nervosismo”, que leva os pacientes a irem de consultório em consultório, para cura de seu mal, que consideram complicadíssimo.

Paranhos diz que entra nesse assunto porque a "pratica neurologica” que teve em 10 anos, no Instituto Jaguaribe e no consultório, o afasta "das idéias vulgarmente admitidas”. Assim, ele cita duas hipóteses para esses quadros. Uma seria por perturbação do sistema nervoso, tendo por sede a sensibilidade, a inteligência e a motilidade. Outra seria como forma frustra de neurastenia, conforme diz, de acordo com muitos autores franceses e italianos.

O autor acha que a maioria dos casos é de natureza somatogênica, e reforça essa opinião com conceituação de Gilbert Ballet, citando como exemplo os casos endocrínicos, as intoxicações e outras situações.

\section{3. 4. 2. - Histeria (1913-1932)}

Embora a conceituação de Babinski tenha feito diminuir a ênfase no diagnóstico de histeria, essa hipótese não foi totalmente abandonada, passando a ser diagnosticada, mais freqüentemente, dentro do pitiatismo, sugerido por esse estudioso.

Em 1918, Lemos Torres publica na Gazeta Clinica um artigo intitulado "Um caso de paralysia hysterica do cubital”1071. O autor descreve um caso de paralisia em região do nervo cubital, que a doente associou a uma picada de mamangava.

Torres considerou que se tratava de pessoa religiosa, obcecada pelo receio dessa moléstia poder impedí-la de fazer votos religiosos. No entanto, ele achou que, além de ser rara essa apresentação de histeria, a principal dificuldade nesse caso foi

1069 ROXO, H. Psychasthenia; (1916 - Primeiro Congresso Medico Paulista). Gazeta Clinica, p. 42-48, 1919.

1070 PARANHOS, U. Ligeiras considerações sobre o nervosismo. Gazeta Clinica, p. 128, 1920.

1071 TORRES, L. Paralysia hysterica do cubital. Gazeta Clinica, p. 69-70, 1918.

405 
encontrar a sugestão causadora da paralisia, pois, segundo o autor, esse fator é quase indispensável para o diagnóstico, “de acordo com a concepção moderna de hysteria ou melhor pithiatismo, como quer Babinski”"1072.

Desse modo, foram feitas perguntas à doente: se ela já conhecia a doença, ou se algum médico havia lhe dito sobre isso, de modo que pudesse tê-la sugestionado. Não houve qualquer indício dessas sugestões. Mesmo assim, o autor aplicou o tratamento da “contra-sugestão”. Notou melhora dos movimentos, mas sem modificar a alteração de sensibilidade. Mesmo sem a resolução desta última alteração, o autor conformou-se a seu diagnóstico inicial de pitiatismo.

Em 1921, é publicado na Gazeta Clinica artigo do médico Milton Mourão de Mattos, da cidade de Cajuru, no interior de São Paulo, intitulado "Suggestibilidade e hysteria”1073.

O autor relata o caso de uma paciente de 19 anos, com crises, as quais ele considerou sem dificuldade para caracterizar como de histeria. Baseado em Freud, concluiu tratar-se de processo ligado à sexualidade. Refere então que, lembrado dos ensinos do prof. Austregésilo, aplicou método da sugestão, mediante uso de cápsula de azul de metileno, dizendo que, "quando corasse a urina”, a doente estaria curada. Desse modo, despareceram as crises.

Mattos cita o conceito de Babinski para a histeria e considera esse quadro como sendo uma "psychose” (dentro de uma concepção genérica de alteração dos processos psíquicos), além de frisar que é suposto um elo entre a histeria e processos somáticos. Ele adverte a algum leitor, que eventualmente ridicularize seu tratamento, com uma citação de Comte, o qual chamava de veterinários, aos médicos que nenhuma atenção davam “à feição moral do doente”.

Em 1922, é publicado artigo de Américo da Veiga na Gazeta Clinica, intitulado "Um caso de astasia-abasia"1074. O autor relata caso de paciente de 62 anos, o qual sentia necessidade de ficar continuamente de cócoras, não havendo explicação orgânica para isso. Ele lembra que, às vezes, esses casos, tidos como "psycopathicos”, podem se dever à tabes.

1072 Idem.

1073 MATTOS, M.M. Suggestibilidade e hysteria. Gazeta Clinica, p. 13-14, 1921.

1074 VEIGA, A. Um caso de astasia-abasia. Gazeta Clinica, p. 99-100; 119-120, 1922. 406 
Veiga diz que tentou aplicar a "psicho-analyse” de Freud. Antes de falar a respeito da doutrina freudiana, o autor debate as conceituações do quadro em questão.

Sobre a possibilidade de associação da histeria com esse quadro, o autor acha que isso complica mais a solução do problema, pois, diz ele, a medicina ainda não consegue explicar os fenômenos histéricos, afirmando, assim, que a histeria passou ao domínio da psicologia:

“Apos o abandono das theorias de Charcot, a hysteria passou para o dominio da Psychologia; com Strumpell, Moebius, tornou-se uma desordem da representação; com Joffroy, uma forma de degeneração mental. Janet nela só encontra estigmas mentaes. Grasset cria, sem resultados, a dualidade dos psychismos; Sollier a descreve como um semisomno; e Bernheim della só aceita as crises”1075.

Por essa citação, o autor situa esses estudiosos também dentro do campo da psicologia. Por sua fala seguinte, também o próprio Babinski. A seguir relata sua própria opinião a respeito da conceituação desse estudioso:

"Foi Babinski, no meu fraco entender, quem melhor interpretou os factos clinicos constitutivos deste grande capitulo da medicina. Os stygmas, velho dogma da Salpetriere, são repudiados, pois os enfermos ainda não examinados por clinicos não os manifestam - são suggestões medicas.

As descobertas de Babinski, no tocante aos signaes proprios das doenças organicas, não volitivos, taes como: a extensão dos artelhos, o exagero dos reflexos tendinosos, a trepidação epileptoide, a imobilidade pupilar, a vertigem voltaica, a flexão combinada da coxa e do tronco, o signal do cuticular, a flexão exagerada do antebraço, etc. vieram esclarecer muitos pontos, até então obscuros.

Como nascem os stygmas? Por auto suggestão. Por suggestão e imitação. Por suggestão medica"1076.

O autor apresenta, então, quais os casos que Babinski exclui do domínio da histeria:

"Babinski elimina do dominio da hysteria as perturbações dos reflexos tendinosos, epilepsia spinal, paralysias dos nervos peryphericos, atrophia muscular com degeneração, loucura hysterica, desigualdade pupilar, perturbações vaso-motoras, hemorragias viscerais, polyurias, febre eruptiva, etc.

De acordo com estas considerações a palavra - hysteria deve ser abandonada e adoptado o termo - Pithiatismo (persuasão - curavel) (Babinski)"1077. 
Veiga refere ter seguido as orientações dadas na Clínica Pitié por Babinski. Como não obteve sucesso, achou que não se tratava de pitiatismo. A seguir ele fala sobre a teoria de Freud:

"Em contraposição com esta comcepção classica de Babinski ha uma outra theoria que pretende explicar os phenomenos hystericos.

O professor Freud (de Vienna) é o seu auctor. Para Freud nossa vida mental é governada pelas forças inconscientes que formam systemas de forças-complexas. Cada complexo contém elementos representativos, elementos motores e elementos effectivos, que são de uma importancia capital, pois que nossa energia psychica depende da somma de afectividade que possuimos. Estes complexos numerosos, e derivando uns dos outros, actuam tanto mais no nosso pensamento quanto mais são occultos e desnaturados a nossos olhos e do observador. Ora, são sempre de natureza primitivamente sexual e traduzem o instincto erotico, a fome sexual, não localizada que Freud denomina libido. Este corpo de doutrina constitui a Psychoanalyses - novo methodo de curar”1078.

Américo da Veiga explica, então, o entendimento da formação das neuroses e psicoses a partir da doutrina de Freud. Em seguida, relata ter tentado empregar a terapêutica freudiana a seu paciente. Nesse sentido, ele diferencia a sugestão indireta, própria da doutrina freudiana, da sugestão direta. Segundo ele, esta só atinge os sintomas, sem chegar à sua causa. Ele revela, então, sua preferência pelo método freudiano, chamando a "psycho-analyses” de uma "post-educação”, libertando a libido.

Em suas considerações finais, Américo da Veiga revela que o paciente em questão teve confirmado o diagnóstico de sífilis, pela reação de Wassermann. Assim, foi deixado de lado o diagnóstico de histeria e foi feito tratamento para sífilis, com bismutol e hidroterapia, tendo havido melhora. Desse modo, Veiga informou que o tratamento psicoterápico não deu resultado nesse caso.

Esse artigo, de 1922, é bastante ilustrativo de diversos conceitos transitando entre os campos de neurologia, psiquiatria e psicologia. Embora tenha citado como uma contraposição, o autor concilia as doutrinas de Freud e de Babinski, no contexto desse artigo. 
Em 1923, é publicado na Gazeta Clinica o artigo de Alberto Brochardo, identificado como "medico do manicomio Conde de Ferreira”, intitulado "O delirio hysterico” ${ }^{\prime 1079}$. Assim ele se refere a esse quadro:

“O delirio hysterico, um dos symptomas do polychromo quadro clinico da hysteria classica, o Proteu de Sydenham, capaz de simular toda a patologia, o delirio hysterico foi votado ao ostracismo pela critica rude de Babinski, como tantos outros symptomas da outrora pletorica figura nosographica. Tendo visto há já algum tempo, um interessante caso cuja etiqueta não pode ser outra senão a de hysteria, parece-me interessante trazel-o a publico"1080.

O autor se refere a alguns casos, aos quais atribuiu o diagnóstico de delírio histérico, e faz ressalvas à explicação de Babinski, o qual considera o quadro sempre proveniente de sugestão. Brochardo admite essa ocorrência em alguns casos, mas também acha possível haver certa “intoxicação dos centros nervosos”"1081, como, por exemplo, após o parto, ou após as regras. Ele acha que o diagnostico de "delirio histerico"1082 deveria constar de classificações de doenças mentais, pois considera esse quadro como fronteiriço, de transição entre a histeria e outras síndromes mentais.

\section{3. 4. 3. - Epilepsia (1913-1932)}

Em 1916, nos Annaes Paulistas de Medicina e Cirurgia, Enjolras Vampré publica o artigo "Um caso de intoxicação por cysticercus cellulosae”"1083.

O autor apresenta caso de ex-estudante de medicina que, após fazer uso de medicação vermífuga, apresentou eliminação de grande quantidade de tênias. Algum tempo depois, o doente notou nódulos superficiais espalhados pelo corpo. A partir de certo momento também passou a apresentar crises epilépticas.

Vampré diz que o paciente procurou o Dr. Camillo Negro, da Faculdade de Medicina de Turim, de quem ele reproduz, no artigo, um relatório em italiano, onde consta a hipótese de cisticercose. Após tentar tratamento nessa cidade, sem sucesso, o paciente foi a Paris, tratar-se com o professor Albert Robin, de quem Vampré também

1079 BROCHARDO, A. O delirio hysterico. Gazeta Clinica, p. 47-50, 1923.

1080 Idem.

1081 Ibidem.

1082 Ibidem.

1083 VAMPRÉ, E. Um caso de intoxicação por cysticercus cellulosae (observação). Annaes Paulistas de Medicina e Cirurgia, anno IV, vol. VI, n. 5, p. 97-103, 1916. 
reproduz o relatório, em francês, concluindo pelo mesmo diagnóstico. Nesse local, o paciente fez exames e tratamento, com alguma melhora.

Em São Paulo foi internado na Beneficência Portuguesa, onde foi examinado por Vampré e submetido a vários exames.

Vampré concluiu que o paciente teve crises epilépticas devido a uma ação tóxica dos cisticercos. Ele diz concordar com o estudioso Maurice de Fleury, para quem todos os epilépticos têm lesões anatômicas de meningo-encefalite, que, segundo diz, funciona como predisponente às crises. Agrega, a essa afirmação, dados de pesquisas internacionais.

O autor acrescenta a apresentação de outros casos similares de cisticercose cerebral e convulsões, sendo que, um deles, foi resolvido por cirurgia realizada por Meira Filho.

Em 1924, foi publicado, na Gazeta Clinica, artigo do médico Torres Vianna, com a colaboração dos médicos Acácio Pires e Gastão Cruls, intitulado "Convulsões”, que faz parte da obra "Semiotica e Therapeutica dos Estados Agudos”"1084.

Nesse artigo, os autores acham que as causas de convulsão, no adulto, são mais precisas do que nas crianças, sendo que citam essas causas: epilepsia, histeria, toxicose endógena e exógena, hipertensão intracraniana, etc. Na criança, consideram que pode haver certas predisposições ligadas ao amadurecimento do cérebro e a doenças sistêmicas, bem como a doenças dos pais, como alcoolismo, epilepsia, sífilis, histeria. Os autores fazem uma lista de causas, que são similares às do adulto, acrescentando as da infância. Eles levam em conta também a possibilidade de histeria, mas compartilham do conceito de Babinski.

Vemos aqui a histeria ainda citada juntamente com outras moléstias orgânicas, embora dentro do conceito de Babinski. Em parte isso se deve ao fato de que o fenômeno "convulsão" diz respeito, em sentido geral, ao "corpo que se debate”, podendo assim ser enquadrada também a histeria. Por outro lado, observa-se também toda uma gama de causas "sistêmicas" para as convulsões, ou seja, de quadros que comprometem o organismo em geral, de modo que o centralismo do sistema nervoso se relativiza.

1084 VIANNA, T.; PIRES, A; GASTÃO, C. Convulsões. Gazeta Clinica, p. 11-21, 1924. 


\section{3. 4. 4. - Moléstia de Parkinson (1913-1932)}

Em 1916, Enjolras Vampré publica, nos Annaes Paulistas de Medicina e Cirurgia, o artigo “Hemiplegia Parkinsoniana (duas observações)”1085.

O autor apresenta os aspectos semiológicos de dois casos de moléstia de Parkinson e informa diversos aspectos a respeito dos estudos em torno dessa doença, desde sua caracterização pela primeira vez, em 1817, por Parkinson, como paralisia agitante, até sua diferenciação completa da esclerose em placas feita por Charcot.

Ao introduzir novos estudos, Vampré desconsidera essa moléstia de ser uma nevrose:

“Considerada a principio como uma nevrose, depois como uma afecção de origem muscular, hypothese geralmente pouco acceitavel, a molestia de Parkinson é ordinariamente considerada hoje como uma afecção organica do systema nervoso, si bem que o seu substractum anatomico seja ainda obscuro" ${ }^{\mathbf{1 0 8 6}}$.

O autor passa então a discorrer a respeito de diversos estudos que tentam associar esses quadros a traumatismos, emoções violentas, auto-intoxicações dirigidas aos músculos, e outros mecanismos. Segundo ele, as duas principais teorias dizem respeito ou a uma alteração endocrínica, ou a uma lesão do sistema nervoso central.

Vampré adentra pelas duas hipóteses, sendo que, em relação à que diz respeito a comprometimento do sistema nervoso central, supõe uma lesão em alguma parte do mesencéfalo, como o locus níger ou o núcleo vermelho.

Em 1921, A. de Almeida Prado, identificado como "lente substituto de clinica medica da Faculdade de Medicina e Cirurgia de São Paulo”, publica, nos Annaes Paulistas de Medicina e Cirurgia, o artigo “Molestia de Parkinson e tabes”1087.

O autor informa que há relatos de associações da moléstia de Parkinson com várias condições como: esclerose em placas, tumores cerebrais, tabes. Questiona algumas citações que supõe serem mais "tremores symptomaticos” do que propriamente moléstia de Parkinson.

1085 VAMPRÉ, E. Hemiplegia Parkinsoniana (duas observações). Annaes Paulistas de Medicina e Cirurgia, p. 126-129, 1916.

1086 Idem, p. 127.

1087 PRADO, A.A. Moléstia de Parkinson e tabes. Annaes Paulistas de Medicina e Cirurgia, p.1-6, 1921. 
Prado descreve, então, de forma pormenorizada, caso de moléstia de Parkinson, com antecedente de sífilis manifesta oito anos antes e de quadro febril e sonolência na pandemia de gripe de 1918. No exame físico notou também o sinal de ArgyllRobertson, confirmado por um oftalmologista, e dores fulgurantes nos membros inferiores, com o que supôs o diagnóstico de tabes. Acrescenta, à descrição, o exame de líquor e reação de Wassermann.

Em seguida o autor passa a discutir a possibilidade de correlação entre tabes, moléstia de Parkinson, e o quadro febril. Cita autores que supõem um comprometimento de glândulas endocrínicas pela sífilis, de modo que estas passem a desencadear o quadro parkinsoniano. Cita também a hipótese de ser a mesma localização anatômica que ligue os dois quadros.

Prado prossegue, acentuando as, então recentes e numerosas descrições de encefalite letárgica seguida de sinais de moléstia de Parkinson, o que o faz questionar se a febre apresentada pelo doente não corresponderia a essa hipótese. Ele diz que a encefalite letárgica trouxe uma nova concepção da moléstia de Parkinson, frisando que a "velha theoria”, que incluía a paralisia agitante entre as nevroses, é repugnada pelos autores modernos. Assim, ele acentua que essa moléstia é de natureza orgânica, com suposta localização mesencéfalo-peduncular no locus níger.

Em 1922, foi publicado na Gazeta Clinica o artigo intitulado "Syphilis e afecção motora extrapiramidal - a pratica na Vanderbilt Clinic de New York”, pelo médico Oscar Clark, identificado como livre docente da Clinica Medica e assistente do prof. Rocha Faria, do Rio de Janeiro ${ }^{1088}$.

O autor se refere ao caso de um indivíduo de 26 anos, com quadro de tremor, e procura explanar como encaminhou o seu diagnóstico, passando pela hipótese de esclerose em placas, usando critérios de Charcot, e após certas considerações ficou finalmente com a hipótese etiológica de sífilis do sistema nervoso.

Clark assinala que não observou nem comprometimento do sistema piramidal e nem da sensibilidade. Ele aponta que o paciente depois passou a apresentar sinais de síndrome de Parkinson. Desse modo, faz reflexões sobre "a base anatomo-pathologica” da síndrome, dizendo que antes se pensava que “o sistema piramidal” fosse a única via

1088 CLARK, O. Syphilis e afecção motora extrapiramidal; a pratica na Vanderbilt Clinic de New York. Gazeta Clinica, p. 33-35, 1922. 
motora do sistema nervoso central. No entanto, por novos estudos, passou-se a admitir que há também “um sistema extrapiramidal”1089 que, segundo ele, tem como funções: inibir, coordenar movimentos, controlar o tônus muscular. Assim, ele descreve as associações entre lesões dos chamados gânglios da base do cérebro e as doenças do sistema extrapiramidal. No caso observado, o autor indicou o tratamento feito em New York, que consiste em administrar "soro salvarsanico no espaço subaracnoideo" ${ }^{\text {„1090. }}$

Dentro de uma visão de “corpo neurológico", vemos nesse período uma abrangência, que chegou a esclarecer quadros antes tidos dentro das "nevroses", e que passaram a ser estabelecidos com suas correlações em termos de lesões cerebrais determinadas e específicas.

\section{3. 5. - Manifestações psíquicas e neurológicas de doenças sistêmicas (1913-1932)}

Em 1914, Enjolras Vampré publica nos Annaes Paulistas de Medicina e Cirurgia o artigo “Reacção de Abderhalden nas moléstias nervosas e mentaes”1091.

O autor informa que a aplicação dessa reação ao estudo das moléstias nervosas e mentais tem sido largamente discutida na Europa. Ele acentua que "em psychiatria e neuropathologia”, a etiologia, o diagnóstico, o prognóstico e o tratamento de certas moléstias têm se beneficiado dessa reação.

Vampré diz que são complicados os métodos para execução dessa reação, pois só os bacteriologistas são capazes de executá-las. Explica que a conceituação em torno desse novo exame situa-se na então nova idéia de “anticorpo” como reação à introdução no organismo, de certas substâncias estranhas a ele. A partir desse mecanismo, informa o autor que os anticorpos atacam também “albuminas do cérebro”.

A seguir, o autor expõe diversas moléstias psiquiátricas e nervosas que apresentam essa reação positiva, como na demência precoce, na paralisia geral, além de outros órgãos concomitantemente, principalmente glândulas produtoras de hormônios.

\footnotetext{
${ }^{1089}$ O termo sistema extrapiramidal foi proposto por Samuel A. K. Wilson em 1912.

TEIVE, H.A.G. Núcleos da base, estruturas correlatas e vias extrapiramidais. In: MENESES, M.S.; Neuroanatomia aplicada, 2a Ed.Guanabara Koogan, 2006, p. 233.

Esse termo passa a ser mais usado após a Primeira Guerra Mundial.

1090 Idem.

1091 VAMPRÉ, E. Reacção de Abderhalden nas molestias nervosas e mentaes. Annaes Paulistas de Medicina e Cirurgia, 184-186, 1914.
} 
Refere ser negativa em psicose maníaco-depressiva, na histeria, "nos estados simplesmente psychopaticos”.

Assim, ele enfatiza o uso dessa reação para a facilitação do diagnóstico diferencial entre diversas moléstias. Vampré repete as palavras de um estudioso que afirma que a ciência moderna não deteve na época pasteuriana em que a causa dos processos era procurada apenas nos germes, mas também estuda o “dinamismo humoral moderno" que cconsiste na "noção de uma força de defesa".

No Congresso Paulista de 1916, foi apresentado o trabalho intitulado “Perturbações mentaes em algumas molestias infectuosas” (publicado em 1919 na Gazeta Clinica), pelos discípulos do prof. Austregésilo, Luiz José Guedes e Waldemar de Almeida, que a ele fizeram homenagem ${ }^{1092}$. Os autores discorreram a respeito de moléstias orgânicas específicas, que causavam alterações mentais, trazendo, portanto, para o terreno das causas conhecidas, os distúrbios mentais, aproximando-os da clínica, através da neurologia.

\section{3. 6. - Concepções em moléstias do sistema nervoso (1913-1932)}

Em 1918, foi publicado na Gazeta Clinica, artigo de Faustino Esponsel, identificado como livre docente da Clinica Neurológica da Faculdade do Rio e assistente do Hospital Nacional de Alienados. O título do artigo é “Apoplexia e Coma”"1093.

O autor refere-se ao comprometimento da consciência e do cérebro em vários graus e por diversas causas. Assim, ele relata como causas do coma: infecções, intoxicações, traumatismos e doenças nervosas. Entre as doenças nervosas, cita epilepsia, histeria e coréia. Portanto, deixa a histeria contada entre esses quadros responsáveis por coma.

No tratamento para essas diversas condições, o autor refere que a sangria ainda têm seu papel como tratamento, em casos de intoxicação, ou ainda em casos em que o médico perceba - pela palpação do pulso, ou pelo uso de "aparelhos medidores de pressão"-, um aumento na tensão arterial, quando, então há risco de “congestão

1092 GUEDES, L.J.; ALMEIDA, W. Perturbações mentaes em algumas molestias infectuosas. Gazeta Clinica, p. 85-90, 1919.

1093 ESPONSEL, F. Apoplexia e Coma. Gazeta Clínica, p. 203-204, 1918. 
cerebral”. O autor diz que a existência desta condição (a congestão) é duvidosa para alguns autores.

No início da década de 1920, novas conceituações provindas de observações feitas na Guerra, modificaram a idéia de centralidade do sistema nervoso.

Desse modo, em 1920 foi publicado, na Gazeta Clinica, o artigo do médico José Mendonça, intitulado “Choque traumatico”1094, a partir de conferência feita à Sociedade de Medicina dos Hospitais da Bahia. O autor refere que, após a guerra, muito se aprendeu sobre o choque, e passou-se a considerar o comprometimento do sistema nervoso, como sendo apenas uma entre outras causas desse processo. Mendonça relata várias experimentações em animais que confirmam essa hipótese.

Essa explanação expõe uma visão de ampla conexão entre os diversos sistemas do organismo. $\mathrm{O}$ autor faz menção à medida de pressão arterial, ao citar trabalhos de autores americanos que estudaram esse aspecto.

Vemos assim, que após a Primeira Guerra, o sistema nervoso reduziu a sua centralidade em relação ao organismo, entrando em foco também outros órgãos e sistemas. Esse relativismo sucedeu ao “tempo das certezas”, anterior à Guerra.

Em meio às polêmicas da década de 1920, persiste o questionamento de Pierre Marie a respeito da idéia de afasia estabelecida por Broca.

Desse modo, em 1925, foi publicado na Gazeta Clínica um artigo sem autoria, provavelmente dos editores, intitulado "Centenario de Paul Broca e o destino da localização cerebral da linguagem articulada”1095. O artigo comenta que, em 24 de junho de 1924, foi comemorado o centenário de nascimento de Pierre Paul Broca. Cita-se que “o nome desse sabio ficou ligado á anatomia cerebral e á anthropologia”"1096, frisando-se que, o que lhe deu fama mundial, foi o estudo sobre a localização cerebral da linguagem articulada em 1861. Isso permitiu, posteriormente, por exemplo, uma trepanação bem sucedida em doente atacado de abscesso no cérebro, pelo próprio Broca, inaugurando, assim, a cirurgia baseada na topografia cerebral.

1094 MENDONÇA, J. Choque traumatico. Gazeta Clinica, p. 121-124; 132-134; 141-144, 1920.

1095 GAZETA CLINICA. Centenario de Paul Broca e o destino da localização cerebral da linguagem articulada, p. 93-94, 925.

1096 Idem.

415 
Comenta-se também no artigo, que Broca chamou de afemia o que Trousseau chamou de afasia, como distúrbio da linguagem. A partir daí, Broca, associando afemia com paralisia do lado oposto do corpo, inferiu a predominância do hemisfério cerebral esquerdo na vida de relação. No entanto, o artigo da Gazeta Clinica comenta que Pierre Marie está abalando esse conceito, pois tem observado casos com afasia sem a lesão da área de Broca comprometida e vice-versa, ou seja, lesões dessa área sem afasia. Nesse sentido, o texto diz que: "a Guerra multiplicou os exemplos, demonstrando que a afasia em geral vem de outra região”1097.

No entanto, o artigo frisa que a teoria de Broca mantém seu valor, pela descrição da afasia motora, ou afasia de Broca. Cita-se que o trabalho de Broca é a pedra angular sobre a qual se assenta a localização cerebral. Comenta-se também que seu trabalho gerou acirrada luta entre espiritualistas e materialistas, entremeados entre política e religião, pois pensavam alguns que essa teoria diminuiria o valor da alma, pela associação direta que alguns faziam entre linguagem e alma.

Entre os paradigmas abalados está o que diz respeito à correlação entre tamanho do cérebro e inteligência.

Assim, em 1925, foi publicado na Gazeta Clinica o artigo do médico Nicolau Cancio, intitulado "Não importa o tamanho do cerebro humano"1098? O autor se refere a um artigo do Journal of the American Medical Association, o qual indica que o tamanho do cérebro não tem importância em relação ao talento do indivíduo. Cancio discorda dessa afirmação, argumentando com a citação do tamanho do cérebro de figuras notáveis.

Observa-se aqui uma dificuldade de aceitar novos paradigmas, aferrando-se a métodos comprobatórios de um paradigma anterior. Relativizar o tamanho do cérebro significa também relativizar a centralidade do cérebro, em relação ao organismo e ao indivíduo, desfazendo-se da certeza do peso e da medida.

Outros parâmetros científicos deveriam orientar considerações sobre capacidades cognitivas, em um período em que as observações e experimentos faziam uso de métodos mais refinados do que a mera balança.

1097 Ibidem.

1098 CANCIO, N. Não importa o tamanho do cérebro humano? Gazeta Clinica, p. 137-138, 1925. 416 
Em 1928, Fausto Guerner publica, no São Paulo Medico, resenha sobre tese de doutoramento de Edgard Pinto Cesar, identificado como ex-interno do Hospital do Juquery. A tese intitula-se "Da catatonia e das relações com os nucleos optoestriados"1099 . O texto informa que Cesar faz uso de farta bibliografia sobre a catatonia e sua correlação com os núcleos da base do cérebro, além de rever trabalhos sobre as lesões cerebrais presentes na demência precoce, sendo difusas, degenerativas, mais localizadas em região frontal e nos núcleos da base. Cesar apresenta o resultado de suas próprias investigações minuciosas sobre dez casos do Hospital do Juquery.

O autor conclui que, adotando a opinião de “autores modernos”, a síndrome catatônica participa da sintomatologia extrapiramidal.

Na transição dos anos 1920 para os anos 1930, enquanto neurologia e psiquiatria constroem um novo formato de convivência, o professor Rubião Meira continua sendo um clínico que conhece os quadros raros em neurologia.

Assim, em 1930, na Gazeta Clinica, foi publicado artigo intitulado "Paraplegia Espasmódica Familiar”, de autoria do médico Barbosa Correa, citado como $3^{\circ}$ assistente da $3^{\text {a }}$ cadeira de Clínica Médica da Faculdade de Medicina de São Paulo, assinalado como do Serviço do Prof. Rubião Meira ${ }^{1100}$. Vemos assim, os seguidores de Rubião Meira, como clínicos, publicando observações neurológicas.

\section{3. 7. - Encefalite letárgica (1913-1932)}

Nesse período também entra em cena uma moléstia que, aliada a outros fatores, propicia o estabelecimento de novos paradigmas neurológicos.

Assim, em 1920, o médico Moncorvo Filho publica artigo na Gazeta Clinica intitulado "Encefalite letargica”? ${ }^{1101}$. O autor relata caso fatal de criança de dois anos, sobre o qual ele aventou a hipótese de encefalite letárgica, considerando haver uma provável ameaça á saúde pública, por conta dessa moléstia, baseado nos relatos internacionais a esse respeito.

1099 GUEDES, F. Da catatonia e das suas relações com os nucleos opto-estriados; pelo Dr. Edgard Pinto Cesar. São Paulo Medico, p. 112-113, 1928.

1100 CORREA, B. Paraplegia Espasmodica Familiar. Gazeta Clinica, p. 85-86, 1930.

1101 MONCORVO FILHO. Encefalite letargica? Gazeta Clinica, p. 97-97, 1920. 
A partir desse período, passam a ser publicados vários artigos sobre encefalite letárgica $^{1102}$. Esse diagnóstico, em outros trabalhos, caminha com novas noções do sistema nervoso a respeito de motricidade, tornando mais complexo esse campo, entrando em cena o "sistema extrapiramidal”. Esse sistema, assim denominado por encontrar-se fora do sistema piramidal, vem esclarecer, mas também tornar mais complexa, a noção de motricidade. Enquanto ao sistema piramidal é atribuída a motricidade voluntária, o sistema extrapiramidal diz respeito a certas modulações do movimento, ou ainda à motricidade automática.

A encefalite letárgica e quadros similares chamam a atenção para um desdobramento do paradigma pasteuriano, com a conceituação de “vírus filtráveis”"1103, e também para uma maior complexidade do sistema nervoso.

Os trabalhos nessa linha de estudos continuam. Desse modo, em 1923, foi publicado na Gazeta Clinica artigo do prof. Henrique Roxo, identificado como “professor catedrático de Clinica Psiquiátrica da Universidade e Director do Instituto de Neuropathologia”, artigo esse intitulado “O estado mental na Encephalite Lethargica”1104.

O autor considera que um nome melhor para esse quadro seria encefalite epidêmica. Ele refere que alguns autores confundem esse quadro com a doença de Parkinson. Relata que esse é um dos principais assuntos das revistas médicas nos últimos três anos.

Roxo acha que tem sido dada pouca atenção ao estado mental desses casos e à diferenciação com a demência precoce, pois na encefalite há manutenção da afetividade e resposta demorada, mas lógica, diferentemente da demência.

Ele faz menção, então, a um trabalho que ele reputa como "interessantíssimo”, apresentado no último “Congresso de Psychiatria e Medicina Legal”, onde Pacheco e

1102 Entre os anos de 1917 e 1920, na Europa surgiram muitos casos de encefalite com evolução para quadros semelhantes à doença de Parkinson, cujo estudo propiciou o conhecimento das síndromes piramidais e do sistema extrapiramidal. $\mathrm{O}$ autor refere que "Em virtude de tal acontecimento, e fazendo desmoronar as antigas classificações neurológicas, é no presente capítulo que descrevemos entidades nosológicas, até estes últimos anos englobadas no grupo, que desaparece, das neuroses, tais como a enfermidade de Parkinson e a Coréia”(pp. 57-99).

RIMBAUD, L. Compêndio de Neurologia. Livraria Editora Freitas Bastos, (1938) 1940.

1103 Em 1907, a Revista Médica de S. Paulo apresenta um artigo de A. Carini sobre os vírus filtráveis (p.48-54). Nesse momento há dúvida se esses vírus são de natureza bacteriana ou protozoária, pois não se concebe outra forma de entender esse microorganismo. Algumas características dos estudos apontam para aspectos que depois serão atribuídos a um conceito de "vírus", diferenciando-o de outros germes.

1104 ROXO, H. O estado mental na Encephalite Lethargica. Gazeta Clinica, p. 145-149, 1923. 418 
Silva apresentou estudos de patologia na demência precoce, constatando lesões no núcleo lenticular, antes já aventadas por Franco da Rocha, havendo semelhança com o exame histológico da encefalite epidêmica.

Desse modo, esses estudiosos consideram encefalite e demência precoce como doenças diferentes, mas com pontos em comum na anatomia patológica.

Assinala-se aqui o uso do estudo anátomo-patológico do cérebro, que passa a ir além das afirmações clássicas e mais simples de entendimento da arquitetura cerebral, em um tempo anterior à Guerra, “no tempo das certezas”. A partir desse período, as pesquisas ampliam as noções de sistema nervoso, em vez de apenas confirmar o que já se sabia.

Observa-se também que, na medida em que as noções do corpo neurológico se expandem ao, assim chamado, sistema extrapiramidal, e moléstias antes contadas entre as nevroses passam para o quadro de moléstias bem definidas, também torna-se possível diagnosticar uma nova doença, a encefalite epidêmica, usando critérios ligados às novas noções neurológicas e também ao paradigma pasteuriano.

Henrique Roxo também se queixa de não ter sido dada a devida atenção às alterações mentais nesses quadros. Isso vem reforçar um refinamento próprio da especialidade, ficando mais distante da clínica geral.

No mesmo ano de 1923, outros artigos são publicados sobre encefalite letárgica. Nesses trabalhos registram-se síndromes parkinsonianas associadas a esses casos. Em um deles, Rubião Meira lembra que a moléstia foi descrita em 1916, e que tornou-se uma moléstia de notificação obrigatória devido a sua transmissibilidade. Observa que pouca coisa tem sido registrada sobre isso e que, em 1920, Vampré fez uma apresentação, na Sociedade de Medicina, de oito casos. Meira disse haver mais casos em São Paulo do que no Rio. 


\section{3.8 - Concepções em psiquiatria (1913-1932)}

Em 1914, publica-se nos Annaes Paulistas de Medicina e Cirurgia, artigo de Franco da Rocha intitulado "Paranoia e Syndrome Paranoide""1105.

O autor inicia fazendo uma crítica sobre o conceito de responsabilidade criminal atenuada, em certos casos psiquiátricos limítrofes, entre os quais ele inclui casos de paranóia.

Em seu texto ele faz largo uso do conceito de Kraepelin, que considera a paranóia como um quadro de “idéias delusórias”, com lenta evolução, mantendo “a clareza e a ordem no pensar, no querer e no agir”1106. Franco da Rocha cita então diversos exemplos de casos que viu, além de exemplos de Kraepelin, e exemplos da literatura universal. Ele diz que a luta pela vida, que é suportada pelas pessoas normais, desencadeia alterações no indivíduo paranóico.

Ele descreve um caso e depois cita o mérito de Freud em ter posto em relevo a influência do impulso sexual na origem das psicoses. Franco da Rocha comenta que os discípulos de Freud são acusados de exagerar na interpretação dos símbolos (acusação essa aparentemente não compartilhada por Franco da Rocha). Ele cita Gustave Le Bon, que diz ser o ciclo da vida inconsciente mais amplo do que o consciente, e que o inconsciente domina a razão.

Em 1914, na Gazeta Clínica, o médico Campos Seabra refere que, na França, o hipnotismo foi usado em situação judicial para revelar um crime. Ele frisa que o hipnotismo, sem o consentimento do paciente, é uma tirania científica, dizendo que: “o hypnotismo não pode ser a arma do carrasco”. Ele considera isso um atentado à liberdade moral ${ }^{1107}$.

Em 1918, Franco da Rocha inaugura as aulas de psiquiatria e moléstias nervosas na Faculdade de Medicina. Parte dessa aula já foi comentada em outra seção.

1105 ROCHA, F. Paranoia e Syndrome Paranoide. Annaes Paulistas de Medicina e Cirurgia, vol. II, n. 3, p. 65-75, 1914.

1106 Idem.

1107 SEABRA, C. A liberdade moral em face da medicina legal. Gazeta Clinica, p. 156-157, 1914. 420 
Ele diz que “a psychiatria é a culminação da sciencia medica”"1108 por lidar com desvios das manifestações mais elevadas na vida. Depois, cita a participação da psiquiatria em outras áreas, como Direito Criminal e Medicina Legal. Assinala que, para esse entendimento, é necessário um severo estudo de “psychologia pathologica como coroamento indispensavel de uma cultura medica philosophica” ${ }^{1109}$. Além disso, menciona também o campo pedagógico. Acentua o recente papel atribuído às autointoxicações em casos psiquiátricos e a necessidade de laboratórios de anatomia patológica e química biológica, para o esclarecimento das moléstias mentais, ressaltando o vasto campo que se abre ao estudo das perturbações endocrínicas.

O professor assinala que os fenômenos que serão estudados dependem: do sistema nervoso, das condições biológicas de todo o organismo, da herança e do meio social. Ele considera que este fator (social) distingue a área psiquiátrica das outras, de tal modo que, define-se o alienado por ser "um individuo alheio ao seu proprio meio social por motivo de afecção do cerebro" ${ }^{1110}$, sendo que alienação mental é uma expressão mais vasta do que loucura, esclarecendo que todo louco é alienado, mas nem todo alienado é louco. Assim, ele explica que:

"Toda criatura humana vive entre dois mundos: o mundo subjectivo e o mundo objectivo. Nossa concepção no mundo não resulta imediatamente do contato deste com os orgams sensoriais; é uma synthese que se faz por associações logicas, ou raciocinios, synthese que elaboramos com os materiais fornecidos pelos nossos orgãos dos sentidos. O poder de conservar mais ou menos justa a correspondencia das relações subjectivas com as relações objectivas é o que se chama de "sanidade mental"1111.

Ele explica que, nos extremos estão: de um lado o louco, de outro lado o idiota, havendo no louco um excesso de subjetivismo, e no idiota uma falta. Ressalta que as frases que são ditas por ele, não podem ser tomadas isoladamente e, assim, sobre o subjetivismo, diz:

“Assim é, que o subjectivismo do verdadeiro poeta, do literato, do artista, não é loucura; é a sublimação da realidade. É o "manto diaphano da fantasia sobre a nudez forte da verdade”, na expressão de Eça de Queiroz.

Não me refiro pois a essa sublimação fantasiosa da realidade pelo genio artistico; reporto-me ao phenomeno morbido que se tem chamado em psychiatria - "egocentrismo, autophylia,

1108 ROCHA, F. Faculdade de Medicina: Inauguração do curso de psychiatria e moléstias nervosas. Gazeta Clinica, p. 51-52, 1918.

1109 Idem.

1110 Ibidem.

1111 Ibidem. 
hipertrophia do eu”, e que num sentido talvez mais lato o prof. Breuler chamou - “autismo”. É um excesso de subjetivismo que isola o individuo do meio circumdante. Isolado do meio, torna-se elle alheio ou - alienado - que é o termo consagrado pelo uso"1112.

Refere que a emoção interfere no choque dos estados subjetivos com a dura realidade da vida. Como exemplo de uma situação, em que os estados emotivos dominam a subjetividade e a razão, Franco da Rocha cita a guerra, então em curso: "Nesta guerra, que ora flagela o mundo chamado civilisado, as batalhas são sempre uma victoria para aquelle que nos dá a noticia; a realidade, no entanto, é uma só; cada um a substitue como convem aos seus sentimentos; é a mentira sincera, de boa fé»"1113.

Ele frisa que, certos tipos de loucura, são simples exageros mórbidos de fenômenos existentes no estado normal, exemplificando: "não ha estudante reprovado que não lance a culpa no examinador”1114. Diz que essa tendência do espírito humano é o fundo do delírio de perseguição, o mais comum encontrado na clínica. Cita exemplo do Hospício, de um paciente que elaborou toda uma trama para supor que o Secretário da Justiça tinha lhe internado para que pudesse matá-lo, apresentando um discurso lógico, convincente e cheio de argumentos. Franco da Rocha conclui a aula, dizendo que, no Hospício, os alunos aprenderão detalhadamente a psiquiatria.

Assim, em 1919, é publicado, na Gazeta Clinica, artigo do prof. Henrique Roxo, intitulado "Opiomania"1115. O autor refere que essa é uma das questões de maior atualidade em Psiquiatria, pois tem crescido muito o número de indivíduos com "verdadeira obsessão" por preparados do ópio, sendo o mais freqüente o abuso de injeções de morfina, de heroína, de pantopon e de sedol. Esses quadros se iniciam com o uso dessas drogas para tratar alguma dor.

Roxo diz tratar desses casos no Hospício ou na Casa de Saúde. Ele acha ineficaz o método de somente usar a redução gradual da droga, e prefere o método de internação, com alguns medicamentos e redução gradual dos mesmos, juntamente com a redução do derivado do ópio.

1112 ROCHA, F. Faculdade de Medicina: Inauguração do curso de psychiatria e moléstias nervosas. Gazeta Clinica, p. 51-52, 1918. 
Vemos aqui uma conseqüência da dominação do corpo do doente, através das drogas, pelo psiquiatra, dentro da reflexão de Foucault. O “corpo psiquiátrico” decorrente do domínio do psiquiatra sobre o doente pelas drogas, fugiu ao controle do terapeuta e do próprio doente, quase como uma outra entidade coligada ou mesmo fabricada pela medicação, que tinha tido a função inicial de regularizar, de disciplinar a mente e o comportamento desse indivíduo, através do controle do corpo.

No despontar da década de 1920, é estabelecido um marco fundador da presença de Freud no Brasil, embora ele já fosse conhecido e comentado há vários anos.

Assim, em 1920, Franco da Rocha lança o livro O Pansexualismo na Doutrina de Freud ${ }^{1116}$. Devemos observar que, em 1919, constou na seção "Bibliographia” da Gazeta Clínica, que a revista recebeu o livro A Doutrina de Freud do professor Franco da Rocha ${ }^{1117}$. Não temos elementos para entender o vínculo entre essas duas obras, bem como o motivo desse lançamento de 1919 não ter chamado a atenção como o outro. Talvez essa obra de 1919 fosse algo como uma apostila do curso médico, que poderia ter servido de base para o outro livro, já que Franco da Rocha fazia comentários sobre Freud em artigos há anos, e em 1918 iniciou sua menção no curso médico.

No terceiro ano de suas aulas na Faculdade, Franco da Rocha adentra por temas que já dizem respeito mais aos discípulos de Freud, do que ao próprio Freud.

Desse modo, em 1920, a primeira aula da cadeira de Psiquiatria desse ano, dada por Franco da Rocha, intitula-se "Os Mitos e Lendas na Loucura”1118, publicada na Gazeta Clinica na seção “Clinica Psiquiatrica”, já grafada com "qui”, como se a “psychiatria” tivesse passado a ser já uma outra psiquiatria, mais de dez anos antes da lei de mudança ortográfica. Todo o período correspondente ao nosso trabalho se acompanha de mudanças graduais na grafia e na incorporação de neologismos, o que pode ser visto nas próprias revistas médicas.

Nessa aula, Franco da Rocha refere que a psicopatologia ensina que certas formas de loucura se apresentam como regressões degenerativas a fases anteriores de

1116 ROCHA, F. O Pansexualismo na Doutrina de Freud. Typographia Brasil de Rothschild \& Cia. São Paulo, 1920.

1117 BIBLIOGRAPHIA. Gazeta Clinica, p. 137, 1919.

1118 ROCHA, F. Clinica Psiquiatrica: Os Mitos e Lendas da Loucura. Cavaco de abertura das aulas de 1920. Gazeta Clinica, p. 19-21, 1920. 
desenvolvimento da humanidade. Ele diz que Jung considera que no "psiconevrotico", rerssurgem formas espirituais de fases passadas da humanidade.

Franco da Rocha cita também o que chama de paleopsicologia, ou "estudo dos fosseis da inteligencia humana” e trabalhos dos etnógrafos que, conforme diz, têm sido de grande auxílio ao prof. Freud e seus discípulos, como Jung, Otto Rank, Riklin, K. Abraham e outros.

A seguir, ele faz longa digressão sobre os mitos, dando grande ênfase ao mito do herói. Faz também elogios a Freud e sua doutrina. Faz analogias do "psiconevrotico" com o homem primitivo e diz que esse homem primitivo não está presente somente na infância e nos sertões, mas também: "nos centros os mais pretenciosos de progresso. Quando o desespero de uma doença ou vendaval da desgraça lhes tira a leve camada de verniz da civilização, lá vão eles, caminho da casa da cartomante, ou do curandeiro de S. Caetano"

Em 1921, o médico F. Vieira de Moraes faz conferência, na Academia Paulista de Medicina, intitulada "Historico da Psychiatria"1120. O autor inicia fazendo uso do termo "psicologia mórbida” como uma espécie de sinônimo de psiquiatria. Fala do interesse desse campo por outros profissionais, além dos médicos:

“A Psychologia morbida vai multiplicando as suas relações com as demais sciencias; já não é o apanagio de um grupo limitado de cultores. Ella interessa hoje a todos que se dedicam aos grandes problemas sociaes. Medicos, educadores, jusrisconsultos, a ella a todo momento recorrem. Posso vos falar pois da Psychiatria, da sua historia - o assumpto não vos é extranho"1121.

Assim, o expositor faz longo e detalhado histórico, dividindo sua exposição nos períodos: Antigüidade, Idade Média, Renascença e Idade Contemporânea. Após relatar a trajetória, tanto da área biológica como da psicológica, ele refere que, em neurologia, existe uma uniformidade de doutrinas, enquanto o mesmo não acontece com a psiquiatria, onde há divisões em vários grupos.

1119 ROCHA, F. Clinica Psiquiatrica. Os Mitos e Lendas da Loucura. Cavaco de abertura das aulas de 1920. Gazeta Clinica, p. 21, 1920.

1120 MORAES, F.V. Historico da Psychiatria; Conferencia na Academia Paulista de Medicina. Gazeta Clinica, p. 77-78, 1921.

1121 Idem. 
Segundo o autor, Kraepelin foi o principal responsável por essa divisão, pois "fez uma obra de Titan. Destruiu tudo para organizar de novo"1122, pelo fato de ter empreendido uma reforma da nosografia psiquiátrica. Diz Moraes que a Itália, a França, os Estados Unidos admitiram e adotaram, ao menos em parte, as idéias de Kraepelin. Relata o autor que, no Brasil, cresceu a sua aceitação e "hoje os nossos maiores cultores da psychiatria são adeptos de Kraepelin e sua escola”"1123.

Além do histórico em si, há duas coisas que chamam a atenção no artigo de Moraes. Uma é a diferença que ele faz entre o campo neurológico e o campo psiquiátrico, indicando que (em 1921) a neurologia tem um consenso, uma uniformidade de doutrinas, enquanto que a psiquiatria é dividida em vários grupos.

Essa afirmação reforça a nossa idéia da estruturação do “corpo neurológico” (de Foucault) como um elemento de consolidação desse campo científico, bem como meio indireto de caracterização de áreas correlatas como a psiquiatria e a psicologia, na medida em que esse corpo, de uma doutrina uniforme, se presta a comparações com doutrinas divididas em subgrupos, como as doutrinas psiquiátricas e as doutrinas psicológicas, mormente em diagnósticos diferenciais.

Outro aspecto que chama a atenção é que o autor conduz sua narrativa da história da psiquiatria culminando em Kraepelin, para ele um verdadeiro “titan”. Sua afirmação de que ele “destruiu tudo para organizar de novo” é a própria expressão da percepção de uma forte mudança de paradigma.

Desse modo, durante o período de nosso trabalho, o paradigma de Kraepelin acaba se impondo, mas com ressalvas de alguns, como Teixeira Brandão, que é partidário de um pensamento anterior a essa fase.

O mesmo Vieira de Moraes, em outro artigo, denota outros elementos comuns a neurologia, psiquiatria e psicologia.

Assim, em 1923, na Gazeta Clinica, publica artigo intitulado "O delirio e a logica” ${ }^{1124}$. O autor refere que “de lira” significa “fora do sulco, do trilho”. Explica que o delírio é apenas um sintoma, não uma doença, sendo a expressão de uma psicose. Diz que várias são as causas do delírio, mas sempre é necessário que o cérebro esteja 
razoavelmente preservado, para que ocorra essa manifestação. Assim, os delírios não estão presentes nas demências profundas, onde o cérebro está muito comprometido.

Moraes diz então que, na situação de delírio, a lógica e os silogismos estão comprometidos, ás vezes até mesmo em suas premissas. Ele diferencia o delírio, das alterações “psico-sensoriais”, onde ocorrem alucinações. Já no caso dos histéricos, diz que aceitam tudo que se lhes disser, porque não têm vontade própria.

No fim da década de 1920, o ambiente artístico da cidade de São Paulo também se fez sentir nos estudos psiquiátricos. Assim, em 1929, o médico Osório César publica o livro que já foi comentado em outra parte deste trabalho. A obra intitulada $A$ expressão artistica dos alienados: contribuição para o estudo dos symbolos na arte ${ }^{1125}$, é dedicada a Freitas Valle, a Alarico Silveira e a Antonio Carlos Pacheco e Silva, a quem chamou de "mestre e amigo".

Essa reverência de Osório César por Pacheco e Silva é fato notório, na medida em que este último é comumente julgado como tendo sido conservador e reacionário. Essa aparente contradição torna mais complexo o cenário de convivência entre esse professor e político e Osório César, franco simpatizante do marxismo, bem como também traz outras variáveis à nossa compreensão dos diversos fatores em jogo, no contexto abordado.

Nesse período, conviviam Higienismo, Eugenia e Higiene Mental. Pacheco e Silva apoiou a idéia xenófoba de Miguel Couto, que criticava a imigração japonesa, temendo o que chamava de "perigo amarelo",1126.

Por outro lado, Pacheco e Silva participou de um livro de 1933, organizado por intelectuais brasileiros, chamado Por que ser anti-semita?, livro esse a favor dos judeus frente à perseguição nazista. Pacheco e Silva escreveu um capítulo nesse livro, bem como Afrânio Peixoto, Menotti Del Picchia, entre outros, que escreveram seus respectivos capítulos ${ }^{1127}$. Essa publicação, ao mesmo tempo em que demonstra o acompanhamento dos intelectuais de então a respeito do que ia pelo mundo, torna mais

1125 CESAR, O. A expressão artistica nos alienados: contribuição para o estudo dos symbolos artisticos na arte. Oficinas graphicas do Juquery. São Paulo, Brasil, 1929.

1126 PICCININI, W. J. Antonio Carlos Pacheco e Silva (1898-1988). Pychiatry on Line Brazil, julho de 2004.

1127 PACHECO E SILVA. Porque não sou antisemita. In: Por que ser Anti-Semita?; um inquérito entre intellectuaes brasileiros. Civilização Brasileira S.A., Rio de Janeiro, 1933. 
complexo o entendimento de figuras como o polêmico Pacheco e Silva, ou mesmo Menotti Del Picchia que viria a ser integralista.

Osório César, por sua vez, um médico favorável à psicanálise e ao comunismo, foi discípulo de Pacheco e Silva e manteve-se ligado ao Juquery por décadas.

No início da década de 1930, dez anos após o lançamento do livro de Franco da Rocha sobre Freud, ele lança uma nova edição, agora com o nome de A doutrina de Freud. Estando aposentado de suas funções públicas, o psiquiatra paulista tem presença menos evidente no meio científico. Dois anos depois ele faz o eu parece ter sido uma das últimas, ou sua última palestra.

Assim, em dois de março de 1932, Franco da Rocha faz, na "secção de NeuroPsiquiatria” da Associação Paulista de Medicina, a palestra intitulada “A evolução do conceito de paranoia"1128. Ele inicia, dizendo que a palavra paranóia foi lançada por Hipócrates para se referir à demência. Depois cita diversos estudiosos e seus conceitos, incluindo Freud, que, especificamente sobre a paranóia, segundo Franco da Rocha, retoma conceitos de Tanzi e Riva. Sobre Kraepelin, ele diz que "quebrou os idolos da psiquiatria do passado”, tendo deixado o conceito vigente de paranóia.

\section{3. 9. - Concepções psicológicas (1913-1932)}

Em 1914 foi reproduzido na Gazeta Clinica, artigo do Correio Paulistano, de 1913, de autoria do prof. G. Dumas, de Paris, intitulado “Os milagres de Esculapio”. O autor referiu-se a recentes escavações e restaurações de antigos templos gregos, entre eles o de Esculápio. A partir daí, descreve como se supõe que tivessem ocorrido as atividades dos doentes que procuravam cura nesse local.

Ressalvou que, havendo a distância de dois mil anos, as curas referidas podem ter diversas explicações. Como o sonho era um componente importante do processo de cura, ele citou Freud, que considera os sonhos como frutos de nossos desejos e receios.

Observamos aí a presença, no Correio Paulistano, de um artigo do professor Dumas, de psicologia, e com uma referência a Freud. Assim, o público letrado, em geral,

1128 ROCHA, F. A evolução do conceito de paranoia; Secção de Neuro-Psiquiatria da Associação Paulista de Medicina. Gazeta Clinica, p. 53, 1932. 
de São Paulo, tinha acesso a esses estudiosos, e os jornais tinham interesse em publicálos. Além disso, o periódico médico teve interesse em reproduzir essa publicação ${ }^{1129}$. Também observamos uma menção aparentemente favorável, ao menos em parte, à doutrina de Freud, pelo estudioso Dumas, que era um adepto de estudos de psicologia médica de linha francesa.

Nesse mesmo ano, um trabalho publicado na Gazeta Clínica atesta um momento intermediário as áreas em estudo. Assim, em 1914, publica-se o artigo intitulado "Algumas pesquizas sobre o tempo de reacção simples nos epileptoides”"1130, de autoria da médica Olga Bovero Caporali. Essa estudiosa realizou essa pesquisa no Laboratório de Psicologia Experimental de Roma, em 1912.

A autora inicia fazendo citações de diversos estudiosos a respeito de conceitos relacionados à epilepsia. Faz grande ênfase na discordância dos autores em torno do significado de termos como: acesso epileptóide, acesso epiléptico, equivalente epiléptico, epileptoidismo. Todos esses termos dizem respeito a supostas variantes ou predisponentes do acesso epiléptico. Além disso, a autora salienta que o conceito de “caracter epileptico” é de consenso entre os estudiosos. Assim, ela diz que outro autor (De Sanctis) "ha muito tempo insiste dizendo que o caracter epiléptico póde existir em sujeitos que não têm accesso nenhum, póde existir como unico testemunho da disposição cerebral epileptica e duma nevrosis epileptica latente”"1131.

Caporali descreve então sua pesquisa, com o que é chamado de "tempo de reação simples” nos epileptoides. Aplicou testes em quatro crianças epileptoides e em duas normais. Considera sua mostra pequena, havendo dificuldade para conclusões, dizendo haver a necessidade de continuar sua pesquisa.

1129 Georges Dumas é considerado como influente entre a intelectualidade brasileira das primeiras décadas do século XX. Nesse período é uma espécie de embaixador da universidade francesa no Brasil, sendo citado por Claude Lévi-Strauss (conforme Carelli) como "cientista um tanto mistificador, animador de obras de síntese cujo amplo intento permanecia a serviço de um positivismo crítico muito decepcionante”. Ou ainda, segundo Jean Maugué (citado por Carelli), na França o “Traité de Psychologie” de Dumas “a despeito de Freud, era a Lei e os Profetas”. Dumas veio ao Rio pela primeira vez em 1908, como porta-voz do “Agrupamento das Universidades e Grandes Escolas da França”, para promover uma cooperação com o Brasil. Em 1916, trabalha para a criação do liceu francês do Rio, e pelo envio de missões universitárias a São Paulo entre 1935 e 1939.

CARELLI, M. Culturas Cruzadas: intercâmbios culturais entre França e Brasil. Papirus Editora, 1993.

1130 CAPORALI, O.B. Algumas pesquizas sobre o tempo de reacção simples nos epileptoides. Gazeta Clinica, anno XII, n. 19 e 20, p. 211-214, 1914.

1131 Idem, p. 211. 
Em 1915, é publicado, nos Annaes Paulistas de Medicina e Cirurgia, artigo do médico Frederico de Marco, de Araraquara, intitulado “A consciencia como intensidade", em uma seção da revista intitulada "Psychiatria - Psychologia Neurologia”1132. Antes de iniciar, o autor publica as respostas de Franco da Rocha e Pereira Barretto, que ele solicitou, a respeito de seu artigo.

Franco da Rocha inicia sua resposta, dizendo que suas especulações filosóficas são sempre perturbadas pela luta administrativa do grande hospital que dirige. Assim, não se sente em condições de grandes opiniões sobre o "melindroso assunto". No entanto, ele tende a concordar com o autor, o qual considera a consciência mais como um determinado grau da função psíquica, do que como uma entidade separada.

Pereira Barretto responde que, quarenta anos antes, estava interessado nessas questões. Com o tempo, ele se convenceu de que “o nosso meio social” não está preparado para assuntos abstratos. Assim, ele diz que esse trabalho interessa a meia dúzia de leitores.

A seguir o autor faz longas reflexões, citando diversos autores, para chegar à conclusão acima citada a respeito da consciência.

Em 1917, os médicos paulistas oferecem um banquete ao prof George Dumas, que visita S. Paulo ${ }^{1133}$. é dito então, que ele estudou as “doutrinas psychologicas mais em evidencia”1134, como a concepção de histeria de Pierre Janet baseada na sugestão, no estreitamento da consciência, no subconsciente e na desagregação mental; idéias que, conforme o próprio Dumas, são, em parte, do próprio Janet e da teoria "psychoasthenica” de Charcot.

Informa também o texto que Dumas explicou as questões do espiritismo pelas doutrinas de Janet, pelo desdobramento da personalidade e desagregação mental. Recordou-se também “as explosões sublimes”1135 da dialética de Dumas, ao tratar da teoria de Durkheim e da teoria de Comte, ligando o pensamento dos dois sociólogos ao de Kant, afirmando que: "a sociologia fica sendo assim a sciencia do homem, não só no

1132 MARCO, F. A Consciencia como Intensidade. Annaes Paulistas de Medicina e Cirurgia, p. 303320, 1915. 1133 GAZETA CLINICA. Prof. George Dumas, p. 94, 1917. 
conteudo de sua sensibilidade e do pensamento, mas tambem nos principios de sua logica e de sua moral”1136.

A seguir, o texto informa que o professor também ensinou sobre idéias de Bergson, de William James, sobre suas experiências psicológicas com Laignel Lavastine, e que seguiu a trilha de Claude Bernard. Após isso, orador e homenageado falaram sobre a Guerra que estava em curso na Europa.

Em 1922 foi feita uma alusão na Gazeta Clínica a respeito da visita do prof. Pierre Janet a São Paulo ${ }^{1137}$. Diz o artigo que Janet doutorou-se em Filosofia e Medicina, ocupando o lugar de professor de Psicologia Experimental no Colégio de França: “é membro da Academia de Sciencias e dirige em Paris, com o prof. George Dumas, o ‘Jornal de Psychologia Normal e Pathologica'”,1138.

Em 1922, o médico Plínio Olinto, referido como “da Assistência a Alienados do Districto Federal”, faz a conferência “O homem e a mulher - estudo psychologico”, sob os auspícios da Sociedade Brasileira de Neurologia, Psychiatria e Medicina Legal $^{1139}$. Após uma série de reflexões filosóficas, biológicas e psicológicas, o autor conclui que não há superioridade ou inferioridade entre homem e mulher, mas apenas diversidade entre os sexos.

Na década de 1920, há uma presença maior de estudiosos de psicologia em São Paulo. Desse modo, em 1923, na Sociedade de Medicina e Cirurgia de S. Paulo, o médico polonês Radwan Praglowski ${ }^{1140}$, diretor do Instituto de Psicologia Prática de Varsóvia, descreve o seu novo método de “auto-cura por auto-sugestão concentrada”, método que se baseia, segundo ele, na subconsciência do individuo, onde se encerra toda sua vida orgânica e vegetativa ${ }^{1141}$.

1136 Ibidem.

1137 GAZETA CLINICA. Prof. Pierre Janet, p. 128, 1922.

1138 Ibidem.

1139 OLINTO, P. O homem e a mulher: estudo psychologico. Gazeta Clinica, p. 155-160, 1922.

1140 Esse médico depois passará a coordenar um centro de estudos em psicologia no Estado do Rio de Janeiro.

1141 GAZETA CLINICA. Um novo método de cura, p. 229-231, 1923. 
Em 1924, na seção “Das Revistas”, foi publicada resenha sobre a obra do médico português Faria de Vasconcellos, intitulada “A psychologia diferencial escolar»1142. Foi reproduzido um trecho do trabalho, onde o autor, citando Stern e Binet, diz que essa psicologia estuda como os processos psíquicos variam de indivíduo para indivíduo. O autor também diz que esse conceito se assenta no que foi estabelecido por Darwin e Mendel. Assim, Vasconcellos considera que a diversidade entre as pessoas não está na educação, mas sim na “diversidade congenital”"1143.

Na sessão da Sociedade Brasileira de Psicanálise, de 17 de abril de 1928, em São Paulo, o professor Lourenço Filho apresenta o trabalho do professor J. Porto Carrero intitulado "O escolar segundo a psychanalyse"1144. Conforme o texto, Carrero comenta que, apesar da variedade de temperamento das crianças, a escola se mantém em sua linha antiga, exigindo que os alunos sejam inteligentes, aplicados, impecáveis, sem preferência por matéria, em atitude hierática de estátua. Ele acrescenta que "a psychologia clássica”, com Claparède, Binet, Rasmussen, etc, já havia estudado a diversidade de caracteres.

Carrero diz então que modernamente a psicanálise de Sigmund Freud abriu novos horizontes, de modo que ele, Carrero, divide os escolares em seis grupos: quietos, travessos, rebeldes, distraídos, mentirosos, medrosos. Ele estuda a evolução psicosexual na formação do caráter da criança.

Ainda conforme o texto, esse autor chega às seguintes conclusões: ao professor não basta a psicologia clássica para lidar com os alunos, necessitando estudar a psicanálise; a necessidade da educação sexual; os pais devem conhecer a teoria de Freud para evitar os conflitos emotivos, que vão constituir complexos e vão dar origem às neuroses; conforme o conceito tópico de libido, o método psicanalítico deve manejar de maneira diferenciada os diversos tipos (narcísico, oral, anal, genital).

1142 DAS REVISTAS. A psychologia diferencial escolar. Dr. Faria de Vasconcellos (Educação Social, Lisboa, 1924). Gazeta Clinica, p. 267-268, 1924.

1143 Em relação à Psicologia Escolar nesse período podemos citar o livro de A. de Sampaio Doria, publicado em 1932, intitulado "Psychologia", onde o autor refere fazer um sumário das aulas de Psicologia que professou por quase dez anos na Escola Normal de São Paulo. O autor refere não desejar entrar em debates de teorias mas em ser didático. O autor principal em que se baseia é William James.

SAMPAIO DORIA, A. Psychologia. Bibliotheca Pedagógica Brasileira, Livros Didacticos, série II, vol.VIII. Companhia Editora Nacional, S. Paulo, 1932.

1144 SOCIEDADE BRASILEIRA DE PSYCHANALISE. São Paulo Medico, p. 101-102, 1928. 


\section{3. 10. - Debates em torno de Psicologia e Espiritismo (1913-1932)}

Em artigo de 1913, publicado na Gazeta Clinica, intitulado "Phenomenos Psychicos”, o médico Carlos de Castro refere-se à publicação do jornal francês "Le Miroir” referente a sessões espíritas realizadas por “M. M. Curie, Brandly, d’Arsonval, Bergson, Mme. Curie, Charles Richet, Debierre, Yourievitch, com a presença do medio Eusapia Paladino"1145.

O autor relata uma série de fenômenos observados nesse evento, que os cientistas presentes atribuem a "um fluido nervoso especial, oriundo do corpo do medio, semelhante á electricidade”. Conforme o autor, esse fluido foi comprovado por fotografias de luz fosforescente dos dedos do médium.

Carlos de Castro e outros consideram esse tipo de conhecimento como uma forma de psicologia.

O autor considera que a fotografia é "o mais pratico e authentico meio de fixar os phenomenos psychicos e os corpos fluidos do além”.

Castro considera limitada a conclusão desses cientistas, pois o artigo francês se refere aos espíritas como supersticiosos e crentes. Ele acha que esse fluido nervoso pode se transformar em figuras humanas e revelar espíritos de mortos. Para reforçar sua afirmação, ele cita experiências feitas por celebridades mundiais, as quais, segundo ele, confirmaram essa interpretação.

A partir desse artigo, muitos outros se sucedem na Gazeta Clinica, artigos de Carlos de Castro e de outros, indo para além dos limites do período de nosso trabalho. Passa a ocorrer um aferrado debate entre médicos defensores do espiritismo, aliado a certa forma de psicologia, e os opositores, sendo o principal opositor o filósofo positivista e farmacêutico Alfredo de Araújo Lima, que argumenta, de forma entusiástica, contra os espíritas.

Araújo Lima também entra em outras polêmicas. Inicialmente adversário da homeopatia, ele passa a defendê-la, após ter sido curado por esse método. Ele faz crítica às vacinas, recebendo discórdia dos próprios editores da Gazeta Clinica, que, mesmo assim, publicam os artigos de Lima. Com grande fôlego para o debate, Araújo Lima entra na polêmica, em torno de alopatia e homeopatia, travada por outros profissionais nesse mesmo periódico. Ele foi também ferrenho opositor do tabagismo e defensor dos

1145 CASTRO, C. Phenomenos Psychicos. Gazeta Clinica, p. 104-105, 1913. 
exercícios físicos. A partir de certa altura de seus debates, ele defende que Pasteur teria sido um farsante, pois, segundo Lima, o consagrado cientista teria se apropriado das idéias do estudioso Béchamp.

A partir dos anos 1920, entra também, no debate sobre espiritismo, o médico Brasílio Machado, que teve sua tese de doutoramento, sobre espiritismo, reprovada na Faculdade do Rio de Janeiro. Também, a partir dessa década, os médicos espíritas passam a adotar uma teoria, que o cientista Charles Richet chama de "Metapsíquica”, a respeito da qual eles também se degladiam com Araújo Lima e outros.

\section{3.11 - Modernidade, sociedade, cérebro e mente (1913-1932)}

Em 1913, são publicados dois artigos na Revista Medica de São Paulo, de autoria de Faustino Esponzel, intitulados “Sobre as perturbações mentaes ligadas á arteriosclerose” ${ }^{1146}$. O autor faz extensa revisão histórica do conceito de arteriosclerose, bem como de sua localização nos vasos cerebrais, sendo que faz menção a Alzheimer e Binswanger, bem como a Juliano Moreira e ao professor Austregésilo, como estudiosos que se dedicaram a esses casos. Ele faz também a descrição de vários casos.

Como causas apontadas para a arteriosclerose, de modo geral, o autor cita as seguintes possibilidades: frio úmido; insuficiência de ar e de luz; trabalho em ambiente reduzido e com temperatura elevada; infecções agudas e crônicas; intoxicações de origem externa, como abuso de café, chá, álcool, vícios de regime alimentar, uso exagerado de carne; intoxicações de origem interna, como alterações endócrinas, fermentações intestinais, nefrite, artritismo, gota, diabetes, menopausa, estafa física. Para explicar a localização cerebral, o autor diz ser provocada pelo cansaço intelectual, as grandes emoções, as preocupações de cargos de responsabilidade, a luta pela vida.

Em linha similar, no ano de 1914, publica-se, na seção “Das Revistas” da Gazeta Clinica, uma resenha sobre os estudos do médico Ludwig Hirschstein, de Hamburgo, intitulada “A causa chimica das molestias nervosas”1147. Esse estudioso considera que as afecções nervosas, sem substrato anatômico, são causadas por

1146 ESPONZEL, F. Sobre as perturbações mentaes ligadas á arteriosclerose. Revista Medica de S. Paulo, p. 264-273; 293-303, 1913.

1147 DAS REVISTAS. A causa chimica das molestias nervosas. Gazeta Clinica, p. 226- 227, 1914. 433 
alterações químicas. Ele acha que o cerne do problema pode estar no acúmulo de ácidos no organismo. O próprio autor diz ter sido vítima de ataque nervoso e viu suas forças minguarem. Isso reforçou seu estudo. Ele considera que as causas principais da “frequencia das perturbações nervosas na civilização moderna”" ${ }^{1148}$, são, ou falta de descanso, ou excesso de alimentação albuminosa. Assim, diz que as moléstias nervosas são decorrentes de esforço insuficiente do organismo para eliminar ácidos.

No intervalo de tempo entre 1914 e 1929, artigos que tratam também dessas questões estão dispostos em outras seções, como, por exemplo, na seção que trata de neurastenia e psicastenia.

Em 1929, na Gazeta Clinica, é publicado artigo do médico Nicolau Cancio, intitulado “A Picnolexia” 1149 . Refere-se o autor a quadro descrito por Lermitte e Nicolas, que se caracteriza pela supressão da faculdade de pensar, falar e mover-se, sem alterar a consciência. Há dúvidas se esse quadro tem relação com epilepsia, narcolepsia ou histeria.

Informa o autor que o primeiro caso desse tipo foi descrito em 1915, durante a guerra, acentuando que esse foi "um tempo propicio para doenças nervosas” 1150 . Acrescenta que é uma doença própria de profissões novas: “chaufeurs de automóveis, telefonistas, ascensoristas (empregados de elevadores), aviadores” ${ }^{1151}$. Assim, ele comenta que:

“Além das novidades no campo das profissões, o medico que quiser compreender bem o estado de saúde dos seus contemporaneos deve considerar todos os fatores do meio que tem efeito deleterio sobre o systema nervoso. Sem sahirmos do nosso ambiente, nestes ultimos vinte anos o augmento do transito das ruas e o da vida nocturna (gente que se diverte e gente que é obrigada a trabalhar para os que se divertem: casas de espetaculos, de jogos, serviços de restaurants, de cafés, etc. tambem os empregados de impresa, de limpeza publica, etc) se decuplicou! E o systema nervoso devia ter se esticado dez vezes mais!”1152

1148 DAS REVISTAS. A causa chimica das molestias nervosas. Gazeta Clinica, p. 227, 1914.

1149 CANCIO, N. Picnolexia. Gazeta Clinica, p. 142-143, 1929.

1150 Idem.

1151 Ibidem.

1152 Ibidem. 


\section{4 - Práticas e procedimentos (1913-1932)}

\section{4.1 - Psicoterapia e práticas similares (1913-1932)}

Em 1914, na Gazeta Clínica, na seção “Das Revistas”, é publicada resenha a respeito do artigo "As theorias psychologicas e metapsychologicas da demencia precoce”1153, do Journal de Psychologie, n. 1, de 1914, artigo esse de autoria de A. Hesnard. O autor refere-se a Freud, mas também a Jung e aos psicanalistas de Zurich. Assim, diz o texto que:

“A. Hesnard expõe a theoria psychologica ou melhor methapsychiatrica da demencia precoce, que nasceu em Zurich sob a influencia das idéias do dr. Freude (de Vienna) difundindo-se rapidamente nos paises de lingua allemã. Os adeptos dessa doutrina applicam systematicamente aos alienados, especialmente áquelles a que põem a etiqueta de dementes precoces, o methodo de psycho-analyse de Freude, que, no sentido mais lato, comporta todas as technicas do interrogatorio, do inquerito da observação do paciente, e da historia psychica dos symptomas"1154.

Comenta-se então que, para os psicanalistas de Zurich, a assim chamada “demencia precoce” constituí a maioria de seus doentes; vemos aqui citado Jung, que tem 70 a $80 \%$ de seus doentes asilados com esse diagnóstico:

“Os doentes que serviram de edificação das theorias da escola de Zurich são ainda pouco numerosos, mas cada psycho-analyse demanda mezes, ás vezes annos... Se se considera que, dada a larguisima compreensão da sua noção de demencia precoce, essa doença constitue para os psycho-analystas a mais frequente de todas (70, 80 p. 100 dos doentes de Jung no asylo de Burghölzli) concebe-se que no seu espirito a psycho-analyse revista uma importancia capital”.

O relato fala, então, na possibilidade de uma revolução na “medicina mental”, e que Jung considera como uma nova orientação em psiquiatria. Conforme o texto, disse Hesnard:

'Se se considera, enfim, que a psycho-analyse é um methodo de psychotherapia ao mesmo tempo que de estudo das doenças mentaes, e que os seus partidarios affirmam ter melhorado senão curado dementes precoces projectando a luz do inquerito psychologico nas profundezas até então impenetraveis da sua mentalidade, comprehende-se que os medicos de

1153 DAS REVISTAS. HESNARD, A.; As theorias psychologicas e metapsychologicas da demencia precoce. Gazeta Clinica, p.73, 1914.

1154 Idem. 
Zurich não hesitem em proclamar que vão operar uma revolução na medicina mental, conduzindo-nos, segundo Jung, a uma orientação nova da psychiatria””.

Note-se que já se pode estar falando, em 1914, a respeito de uma fase da doutrina psicanalítica, após a separação entre Freud e Jung, já que o rompimento entre os dois se deu em 1911-1912 ${ }^{1155}$. A imprensa médica paulista tem, assim, acesso a acontecimentos referentes à doutrina psicanalítica, com certa proximidade no tempo, em relação ao que ocorre na Europa.

Observamos que a primeira alusão a Freud, na imprensa médica em S. Paulo, foi em 1908-1909 (além do livro de 1904 de Franco da Rocha). Conforme Jung, nos primeiros anos do século XX, "Freud era persona non grata no mundo universitário, sendo prejudicial a todo cientista de renome ter relações com ele”"1156.

Portanto, é imprecisa a idéia difundida de que, no Brasil, demorou-se mais de vinte anos para conhecer-se Freud, mormente em S. Paulo, e outro tanto tempo para ele ser aceito. Além disso, a própria aceitação de Freud na Europa também não seu deu de forma fácil e imediata.

A assim chamada demência precoce citada no artigo, depois passa a ser chamada de esquizofrenia por Bleuler (que deu esse nome à doença em 1909). É difícil sabermos se todos os casos de demência contabilizados correspondem exatamente ao mesmo número de esquizofrênicos. Pode-se estar diante de um impasse entre diferentes paradigmas em relação à linguagem usada para os mesmos, que pode corresponder ao que Thomas Kuhn chama de incomensurabilidade entre conceitos.

Esse artigo também reflete a percepção de grandes mudanças ocorrendo em termos de abordagem e conduta em psiquiatria, com a novidade da psicanálise.

Nesse mesmo ano em que a psicanálise ganha mais essa divulgação, em São Paulo é publicado um artigo advertindo a respeito do uso indiscriminado da hipnose.

Assim, em 1914, na Sociedade de Medicina e Cirurgia de S. Paulo, Enjolras Vampré fala sobre o tema "Hipnotismo"1157. Em seu discurso fala “com pesar” sobre o fato de ter ocorrido no Teatro Municipal - segundo ele "nosso mais elevado centro de

1155 JUNG, C. Memórias, Sonhos e Reflexões. Editora Nova Fronteira, (1961) 1975, p. 146-152. 1156 Idem, p. 134.

1157 VAMPRÉ, E. Hypnotismo; Sociedade de Medicina e Cirurgia de S. Paulo. Gazeta Clinica, p. 220221, 1914. 
cultura artistica” -, cenas condenadas "por todos os neurologistas em destaque”1158. Assim, ele faz um ataque veemente a sessões públicas de hipnotismo, frisando que deveriam ser banidas. Ele acha que o hipnotismo serve à pesquisa de alguns cientistas, e como fonte de rendimento a celebridades estrangeiras. Reforça sua reflexão, citando estudiosos do assunto, incluindo Babinski. Na sua fala, Vampré se coloca “como psychiatra, como hygienista”, dizendo, assim, que tem o dever de zelar pela profilaxia das moléstias do corpo, bem como das moléstias psíquicas.

Para termos uma noção da penetração do hipnotismo na sociedade, nesse período, podemos recorrer a informações presentes no livro de Medeiros e Albuquerque $^{1159}$ (1867-1934), de 1919, intitulado O Hipnotismo e suas aplicações, com prefacio do prof. Miguel Couto. Na introdução, o autor refere ter aprendido hipnotismo entre 1885 e 1889 quando era amigo de um grupo de estudantes de medicina. Segundo ele, nesse momento, o hipnotismo estava na moda e todos eles aprenderam a hipnotizar. No capítulo IV desse livro, intitulado “O Estado da sujestibilidade”, Medeiros e Albuquerque diz que:

“O hipnotismo foi algum tempo uma questão de moda. Depois, pouco a pouco, por uma série de razões que nada provam contra o seu valor, foi saindo da pratica corrente. Apenas raros especialistas o empregam com grande frequencia. A moda hoje está se voltando para a famoza escola de psico-análise do Prof. Freud de Viena. Os ensinamentos do grande neurolojista austríaco não se discutem apenas com a serenidade preciza em questões cientificas. Eles têm partidarios apaixonados e constituem, como os professores Regis e Janet já fizeram observar, uma especie de relijião ou pelo menos uma vasta seita que chega quazi a ser mística, seita que encontra seus adeptos mais fervorozos nos paises de língua alemã e nos Estados Unidos"1160.

1158 Idem.

1159 José Joaquim de Campos Costa Medeiros e Albuquerque foi um dos fundadores da Academia Brasileira de Letras. Foi jornalista, professor, político, contista, poeta, orador, romancista, teatrólogo, ensaísta e memoralista. Nasceu em Recife. Estudou com Emilio Goeldi e Silvio Romero. Participou do movimento republicano. Escreveu a letra do Hino à República. Trabalhou com a reforma ortográfica. Era irmão do médico Maurício Medeiros (também da Academia de Letras), já citado.

http://www.academia.org.br/abl/cgi/cgilua.exe/sys/start.htm?infoid=526\&sid=235 Acessado em 14 de outubro de 2006 às 22:17 hs.

Há menção de que Medeiros e Albuquerque foi o primeiro a elaborar um teste psicológico no Brasil aventado em conferência de 1921 e escrito em 1924. Isso parece estar associado a seu trabalho como professor.

GOMES, W. B. Avaliação psicológica no Brasil: Tests de Medeiros e Albuquerque. Aval. Psicol., v. 3, n.1, Porto Alegre, jun. 2004.

Em: <http://pepsic.bvs-psi.org.br/scielo> Acessado em 10 de agosto de 2007.

${ }^{1160}$ MEDEIROS E ALBUQUERQUE. O Hipnotismo e suas aplicações. Livraria Editora Leite Ribeiro \& Maurillo, Rio de Janeiro, 1919, p. 65. 
No prefácio desse livro, Miguel Couto diz que o assunto hipnotismo é mais um assunto de psicologia do que de medicina e que antes da guerra o hipnotismo se apagava na medicina e na psicologia. Além disso, no transcorrer da obra, Medeiros e Albuquerque fala que os hipnotizadores não médicos têm mais sucesso do que os médicos, nessa prática, e faz sugestões aos médicos para obterem melhor resultado.

Essas considerações dão a entender nesse momento (1919), ao mesmo tempo, uma proximidade e uma delimitação entre medicina e psicologia, tanto na prática do hipnotismo como em outras práticas psicoterápicas, conforme se depreende do texto de Medeiros e Albuquerque ao se referir a livros de psicoterapia.

Em 1914, é divulgada na Gazeta Clinica a inauguração das novas instalações do Instituto Jaguaribe (que tem sua inauguração registrada em 1905, pela Revista Medica de S. Paulo, com o nome de Instituto Psico-fisiológico), dirigido pelo médico Ulysses Paranhos. Nesse local são feitos banhos, massagens, terapia elétrica e fototerapia para quadros psíquicos diversos. Também é relatado que cerca de mil doentes de "alcoolismo e vicios" foram curados pelo hipnotismo nesse instituto ${ }^{1161}$.

O médico Ulysses Paranhos, além de ter atividades ligadas a clínica em geral, mantém atividades voltadas para o campo de psicologia médica. O fato dele ter substituído o médico Domingos Jaguaribe nesse Instituto reforça sua ligação com essa área. Paranhos é ligado à faculdade de medicina relacionada com a Escola de Pharmacia, faculdade essa que não é bem vista por muitos médicos. Não temos como estabelecer algum vínculo entre a reforma desse instituto e a posição de Paranhos em relação a ambos os cursos de medicina da cidade.

Na década de 1910 acumulam-se as referências à doutrina de Freud. O professor Roxo adapta as idéias de Freud e dá nome a um método próprio.

Assim, em 1918, Henrique Roxo publica artigo, falando do método que chama de “psychoscopia”, remetendo-se à psicanálise, a Freud, e fazendo uma espécie de adaptação dessa doutrina para esse seu método, cujo nome incorpora certa noção de “enxergar a psique”1162, conforme o sentido do neologismo por ele adotado. 
Roxo, que é do Rio de Janeiro, publica bastante em periódicos paulistas, de modo que seus trabalhos científicos, incluindo os referentes à psicanálise e a Freud, são acessíveis aos profissionais paulistas.

No tema do artigo em si, devemos notar que as idéias de Freud, nesse período, já são adaptadas à prática terapêutica, embora só anos depois se venha a considerar o emprego propriamente dito da psicanálise.

Outros artigos, que também fazem menção a uso de práticas psicoterápicas nesse período, estão selecionados em outras seções deste trabalho, de modo que eles preenchem o intervalo entre os dados de 1918 e o próximo, de 1930.

Embora os dados seguintes não façam parte de um periódico médico, eles têm especial importância, pelas informações que traz a respeito de práticas psiquiátricas vigentes no Juquery, no fim do período 1913-1932.

No início da década de 1930, com sua experiência de diretor do Juquery, Pacheco e Silva vê a necessidade de instruir os profissionais de enfermagem que cuidam de pacientes psiquiátricos, bem como os outros profissionais envolvidos com o tratamento desses pacientes. Assim, passa a enfocar a importância do conhecimento dessas pessoas, para o êxito das terapêuticas, não se restringindo, portanto, ao método terapêutico em si.

Dessa forma, em 1930, ele publica o manual Cuidados aos Psychopathas ${ }^{1163}$, destinado "aos medicos não especializados, estudantes de medicina e, sobretudo, aos enfermeiros dos phrenocomios"1164. O autor dedica o livro aos “abnegados enfermeiros do Juquery"1165 e em seu "Preambulo" diz que os enfermeiros no Brasil não têm o mesmo nível que os dos Estados Unidos por culpa dos legisladores e dos médicos que não se dedicam à instrução de seus colaboradores. Ele refere que essa é a primeira publicação em português destinada a instruir os enfermeiros dos “phrenocomios”.

Pacheco e Silva diz que o uso da camisa de força, e de outros meios violentos, foi abolido e que, nas agitações, usam-se medicações e balneoterapia. Procura-se também distrair o doente com música, diversões, esportes e trabalhos manuais. Com

1163 PACHECO E SILVA, A. C. Cuidados aos Psychopathas. Officinas Graphicas do Hospital do Juquery, S. Paulo, 1930.

1164 Idem.

1165 Ibidem.

439 
isso, cresce de importância o papel do enfermeiro de confortar e orientar os pacientes, bem como cumprir as prescrições médicas.

O autor passa a dar noções gerais de conceitos psiquiátricos, expõe a classificação adotada no Brasil pela Sociedade Brasileira de Neurologia, Psychiatria e Medicina Legal organizada por Juliano Moreira Henrique Roxo, Austregésilo e Carlos Eiras. O autor apresenta, em seguida, o questionário utilizado nas observações clínicas, no Juquery. Depois passa às condutas adotadas no Juquery, como: regime alimentar; hidroterapia; os medicamentos; os cuidados aos agitados, aos desasseados e aos epilépticos; a malarioterapia em paralisia geral.

Informa que esta última conduta foi adotada a partir de observações do prof. Von Jauregg de Viena em 1917. A paralisia geral evoluía para a morte rápida antes desse tratamento; quando esse quadro se asssociava à malária, apresentava melhor evolução. Como a malarioterapia trouxe alguma melhora nesses casos, o tratamento foi amplamente adotado.

Os pacientes tuberculosos recebem cuidados especiais, havendo no Juquery um “moderno pavilhão” para 96 doentes desses casos, com duas seções, para isolar conforme o estado mental e o grau da doença.

Também há instruções sobre as modalidades de tentativas de suicídio e como evitá-los. São passados cuidados para evitar fugas e incêndios. São dadas orientações a respeito do manicômio judiciário (cuja construção está quase pronta nesse momento).

Há comentários sobre alcoolistas e toxicomanos nos hospitais psiquiátricos. Após explicar medidas de combate ao alcoolismo, o autor acrescenta uma nota a respeito do movimento revolucionário de 3 de outubro (1930) que determinou medidas proibitivas de venda de bebidas alcoólicas. Isso causa impressão favorável em Pacheco e Silva (em 1932 ele vai se colocar do lado dos constitucionalistas).

Em seguida, são relatadas as vantagens dos serviços psiquiátricos modernos. Depois são passados os deveres e orientações do trabalho cotidiano dos enfermeiros, sendo expressamente proibidos atos violentos, ou mesmo a ridicularização das idéias ou das falas dos doentes ${ }^{1166}$.

Essa obra de Pacheco e Silva transmite a impressão de preocupação com detalhes do tratamento e do cuidado aos pacientes, tanto pelo discurso em si, como pelo

1166 PACHECO E SILVA, A.C. Cuidados aos Psychopathas. Officinas Graphicas do Hospital do Juquery, S. Paulo, 1930. 
enfoque especial dado aos profissionais de enfermagem destinados a cuidar desses pacientes. Sempre atualizado, no que diz respeito à fala científica, o autor expressa a ciência desse momento, nas indicações terapêuticas.

\section{4. 2. - Terapêutica medicamentosa (1913-1932)}

Em 1914, publica-se nos Annaes Paulistas de Medicina e Cirurgia o artigo "Sobre o tratamento da epilepsia pelo veneno de cascavel”1167, de autoria do médico Geraldo H. de Paula Souza.

O autor informa que, a partir de uma observação de um médico americano de nome Self, a respeito de um epiléptico que, após mordida de cobra não teve mais crises, o estudioso americano Spangler (em 1910) e o alemão Fackenheim (em 1911) estudaram o valor da crotalina (preparado de veneno de cobra) em vários pacientes e relataram benefícios.

Souza diz haver crotalina à venda no mercado, fabricada pela Merck. No entanto, para suas pesquisas ele preferiu solicitar a ajuda de Vital Brazil e, após autorização de Franco da Rocha, procedeu às pesquisas com pacientes do Juquery, tendo sempre ao alcance o soro anticrotálico. O autor insere no seu texto relato de Franco da Rocha, que assinala ter obtido resultado oposto ao do Dr. Self, ou seja, um indivíduo desenvolveu crises convulsivas após ser mordido por cobra.

A seguir, no artigo, o autor expõe de maneira detalhada a sua pesquisa, com relatos dos casos dos pacientes submetidos ao tratamento, acrescentando gráficos e fotos dos pacientes, nas quais observa os efeitos colaterais do uso da crotalina.

O autor comenta artigo de 1913, da Gazeta Clinica, do médico pernambucano Joaquim Loureiro, diretor do Hospital de Alienados de Recife, que descreveu bons resultados com o uso da crotalina. Souza contesta esses efeitos benéficos, pelo fato de que o seu próprio trabalho teve um seguimento por um tempo mais longo do que o de Loureiro, e também por ter controlado o efeito do veneno sobre a coagulabilidade do sangue, refinando assim sua pesquisa.

1167 SOUZA, G.H.P. Sobre o tratamento da epilepsia pelo veneno de cascavel. Annaes Paulistas de Medicina e Cirurgia, anno II, vol. II, p. 33-41, 1914. 
Souza questiona outros estudos internacionais favoráveis ao uso dessa substância para tratar epilepsia.

Em 1915, é publicado nos Annaes Paulistas de Medicina e Cirurgia o artigo de Franco da Rocha e Vital Brazil, intitulado Tratamento da Epilepsia ${ }^{1168}$. Inicialmente Franco da Rocha discorre sobre o que vem sendo feito para tratar essa moléstia, e que o mecanismo desse quadro ainda é desconhecido. Depois, fala sobre o uso de veneno de cobra usado sob formas variadas, pelo mundo afora, para tratar epilepsia, de modo que na Alemanha chegou-se a elaborar o medicamento Crotalina, à base desse veneno. Entre os vários mecanismos supostos de melhora da epilepsia a partir da propriedade do veneno de cobra, os autores fazem a suposição de que seu efeito pode-se dever a seu poder anticoagulante; assim, testaram seu uso. A conclusão é que, se o veneno funciona, não deve ser por esse mecanismo.

Em 1916, no $1^{\text {o }}$ Congresso Paulista de Medicina, o médico Philippe Aché apresenta o tema "Opotherapia - sobre a possibilidade de mais um recurso therapeutico no tratamento de algumas molestias nervosas” ${ }^{\text {1169 }}$. Nessa explanação, o autor refere ter iniciado, há três anos, experiências de tratamento de algumas moléstias nervosas por injeções de soro normal de cavalo. As moléstias nervosas a que ele se refere são: epilepsia, asma, neurastenia, tics nervosos e psicose.

Explica que essa terapia, que ele também chama de "opotherapia hormonica”, está bastante relacionada com a noção recente de ação dos hormônios como reguladores da nutrição e de outros processos fisiológicos. O autor refere que a noção trazida por modernos estudos, que relacionam o sistema nervoso às glândulas produtoras de hormônio, "abalou a doutrina corrente de que toda neuropathia ou psychopathia deve se assentar sobre uma desordem nervosa estructural”1170. Isso vem reforçar sua proposta terapêutica.

Para evitar efeitos colaterais, como o grave choque anafilático, ele solicitou a colaboração de Vital Brazil, que, conforme diz, conseguiu retirar algumas albuminas do

1168 ROCHA, F.; BRAZIL, V. Tratamento da Epilepsia. Annaes Paulistas de Medicina e Cirurgia, p. 297-306, 1915.

1169 ACHÉ, P. Opotherapia: sobre a possibilidade de mais um recurso therapeutico no tratamento de algumas molestias nervosas (Congresso Medico Paulista, 1916). Gazeta Clinica, p. 130-135, 1919.

1170 Idem. 
soro extraído de animais, deixando intactas as substâncias desejadas no tratamento. O autor, em seguida, cita casos tratados pela opoterapia.

Vemos que o autor inclui, em moléstias nervosas, a asma e a psicose. A asma está incluída entre as nevroses, nesse período, e a psicose tem um sentido de comprometimento da psique em geral, diferentemente do sentido que vai adquirir posteriormente.

Observamos também a menção a um “abalo" da doutrina que atribuía as neuropatias e psicopatias a lesões estruturais do sistema nervoso, deslocando a centralidade do organismo, atribuindo a outros fatores, como os hormônios, a possibilidade de comprometimento funcional do sistema nervoso.

No início da década de 1920, surge uma nova medicação contra a epilepsia. Desse modo, em 1921, é publicado um informe na Gazeta Clinica a respeito do medicamento recentemente descoberto de nome Gardenal, tido como de grande eficiência ${ }^{1171}$. O bom resultado do uso desse medicamento colabora para a retirada da epilepsia do grupo das nevroses, na medida em que se passa a ter uma substância química bastante eficiente na resolução desse quadro, conduzindo a hipóteses orgânicas para o entendimento do mesmo.

Ainda na linha dos estudos sobre epilepsia e manifestações similares, acumulam-se noções a respeito de como abordar as convulsões.

Assim, em 1924, são publicados, na Gazeta Clinica, diversos artigos do médico Torres Vianna, a respeito do tratamento das Convulsões ${ }^{1172}$, ocupando bastante espaço na revista. O autor entra em detalhes em relação às mais diversas causas de convulsão e de seus tratamentos, em geral, medicamentosos.

Em meio às diversas causas orgânicas, o autor inclui um item, que ele chama de "Hysteria-Pitiatismo", dentro do "tratamento dos ataques hysteriformes". Assim, ele anexa o termo lançado por Babinski (pitistismo) à palavra histeria, mas preconiza ainda orientações de Charcot para lidar com esses casos. Além disso, situa a epilepsia entre as “causas nevróticas”, ao mesmo tempo em que cita o uso do gardenal. Esse é, portanto, um momento intermediário entre paradigmas em torno de convulsões, epilepsia,

1171 GAZETA CLINICA. Tratamento da Epilepsia essencial pelo phenyl-ethyl-malonyl-urea ou Gardenal, p. 54, 1921.

1172 VIANNA, T. Convulsões. Gazeta Clinica, p. 11-21; 88-89; 104-112; 151-155; 192-199, 1924. 443 
nevroses, histeria, pitiatismo. Aparentemente, na década de 1920 alguns autores questionam a abrangência da conceituação de Babinski referente ao pitiatismo, talvez por ela não ter respondido a todas as perguntas, se usarmos o raciocínio de Kuhn para a capacidade dos paradigmas resolverem problemas. A impossibilidade do pitiatismo ter grande abrangência abre espaço para as idéias de Freud, que são, em parte, aperfeiçoamento da doutrina de Charcot.

\section{5. - Conclusões do período 1913-1932.}

Nestas conclusões, vale também a observação feita em relação aos capítulos anteriores, quanto a evitar repetições de comentários.

Neste período, chama à atenção a forma como Enjolras Vampré descreve as observações de casos neurológicos, principalmente em artigos dos Annaes Paulistas de Medicina e Cirurgia. Podemos dizer que, a partir de 1913, principalmente nesse periódico, Vampré instala a neurologia paulista, através do detalhamento do corpo neurológico. Não se trata apenas da incorporação de novos sinais, mas também da minúcia, do pormenor. Essa extensa descrição dos quadros neurológicos tem influência da passagem de Vampré pela Europa. Em seus artigos, há menções a muitos autores, mas principalmente a Babinski e seu trabalho de aprimoramento da propedêutica neurológica.

Em nossa opinião, a configuração do corpo neurológico por Babinski colabora para que a histeria passe, gradativamente, a ser considerada uma doença apenas psíquica. O refinamento desse corpo neurológico acaba favorecendo, indiretamente, a aceitação das idéias de Freud.

Em nosso levantamento, constatamos a utilização da conceituação freudiana em diagnóstico, bem como tentativas de aplicação de conceitos psicanalíticos em tratamentos, por médicos que nunca foram citados nos trabalhos que fazem menção ao início da presença da doutrina freudiana em São Paulo, ou no Brasil.

Isso sugere que não há uma recusa simples dos médicos à doutrina psicanalítica, nesse período, mas que se trata de um processo mais diversificado, com várias tendências na maneira de aceitar ou recusar essas conceituações. 
A Primeira Guerra Mundial é um marco delimitador, após o qual se tornam mais complexas as áreas enfocadas. Assim, o estabelecimento da conceituação de um sistema motor extrapiramidal traz elementos que permitem esclarecer moléstias antes tidas como obscuras e incluídas entre as nevroses. Isso modifica a interpretação do corpo neurológico, permitindo novas inferências localizatórias interligadas com o sistema estímulo-resposta.

No aspecto institucional das áreas em questão, certo caos e divisões na faculdade, que se seguiram à morte de Arnaldo Vieira de Carvalho, podem ter imfluenciado os desdobramentos em torno do estabelecimento das cadeiras de psiquiatria e neurologia, modificando ou retardando esse processo. Vieira de Moraes é uma figura obscura em um concurso para a cadeira de Psiquiatria e Neuriatria, que parece ter sido um auxiliar de primeira hora de Franco da Rocha na faculdade e que, depois da aposentadoria deste, pode ter ficado isolado entre seus pares.

Trabalhos científicos ocorrem no hospício do Juquery, tanto por conta de Franco da Rocha, quanto por outros profissionais, durante esse período, embora ele próprio não faça o devido reconhecimento dessa atividade, achando que seu trabalho tenha se restringido ao aspecto assistencial de atendimento aos pacientes psiquiátricos. A partir dos registros observados, conclui-se que a atividade científica do Juquery, anterior a Pacheco e Silva, tem sido ignorada e demanda novas pesquisas a esse respeito.

As classificações de doenças psiquiátricas, que marcam sua presença nos periódicos paulistas no primeiro período por nós abordado, muito por conta de publicações de Franco da Rocha, não aparecem tanto nos períodos seguintes, de modo que os interesses migram de discussões classificatórias, em seu sentido geral, para debates sobre pontos mais específicos, como, por exemplo, em torno da histeria e das outras nevroses. A classificação volta á cena no fim da década de 1920, mas para afirmar a aceitação plena da classificação psiquiátrica de Kraepelin.

Thomas Kuhn considera que a linguagem utilizada por determinada ciência participa do processo de mudança pelo qual ele passa. Assim, diz que: 
“O que caracteriza as revoluções (científicas), assim, é a mudança em várias das categorias taxonômicas que são pré-requisitos para descrições e generalizações científicas. Essa mudança, além do mais, é um ajuste não apenas dos critérios relevantes para a categorização, mas também do modo porque determinados objetos e situações são distribuídos entre as categorias preexistentes" ${ }^{\text {"1173. }}$

A classificação psiquiátrica de Kraepelin, a partir de determinado momento, passa a constituir um paradigma em psiquiatria, paradigma esse que se faz marcar especialmente por sua categorização das moléstias inseridas em um determinado entendimento de linguagem. Assim, “paranóia” para Kraepelin e seus seguidores tem determinadas conotações que não são aceitas por alguém como Teixeira Brandão, mas que, no entanto, são bem recebidas por seus discípulos.

A nosso ver, os médicos que passam a aceitar essa classificação, são de uma geração que acompanha outras mudanças de paradigma algo concomitantes à divulgação das sucessivas classificações de Kraepelin.

Nesse sentido, nos referimos mais especificamente ao paradigma relativo à histeria construído pelos estudos de Babinski. Assim, Babinski, indiretamente, colabora para uma reconfiguração da classificação psiquiátrica, na medida em que transforma a histeria em pitiatismo. Podemos ler então em Kuhn: “A violação ou distorção de uma linguagem científica anteriormente não-problemática é a pedra de toque para a mudança revolucionária”1174. Babinski lança um novo nome para a histeria, logo que propõe sua nova conceituação em 1901. No entanto, ele aprimora depois essas elaborações, ao mesmo tempo em que ocorre a aceitação de suas idéias.

Queremos dizer com isso que, de certa forma, Babinski prepara o terreno para a aceitação das idéias de Kraepelin. E, embora Freud e Kraepelin sejam divergentes, achamos que a conceituação de Babinski para histeria também facilite a aceitação da doutrina freudiana.

Essas divagações encontram um terreno concreto nos artigos publicados em São Paulo nos anos 1920, em que os autores relatam tentativas práticas de aplicar conceituações psicanalíticas, ao mesmo tempo em que utilizam a conceituação de Babinski para a histeria.

Assim, em São Paulo, as diferentes linhas, de Babinski, Kraepelin e Freud, convivem na conceituação e prática de alguns médicos que conciliam essas tendências.

\footnotetext{
${ }^{1173}$ KUHN, T. S. O caminho desde a estrutura. Editora UNESP, 2000, p. 42.

1174 Idem, p. 45. 
Até onde sabemos, os artigos dos periódicos médicos paulistas, que tratam de teoria e aplicação da doutrina fruediana, e que foram por nós apontados, são ignorados nos trabalhos que até o momento procuraram abordar essas questões.

Quanto às personagens deste período, entra em cena Antonio Carlos Pacheco e Silva, que tem presença ativa em todos os fatores apontados por Latour na circulação dos fatos científicos. Ele funda um laboratório no Juquery, participa de várias associações profissionais e científicas, tem laços e vínculos com o Estado, bem como com diversas instituições científicas, educacionais; tem também publicações em diversos periódicos. Em termos de construção de uma disciplina cientifica, com todos esses fatores envolvidos, mais do que o criador de uma psiquiatria em São Paulo, Pacheco e Silva é criador de uma neuropsiquiatria em São Paulo.

A psiquiatria paulista já havia se configurado em torno de Franco da Rocha. Vampré, desde o início de sua carreira, usa os termos neurologia e neurologista, mais do que os outros termos. Com Pacheco e Silva inicia-se uma leitura do passado e do presente das áreas em questão, sob a hégide da neuropsiquiatria.

Nenhum deles parece ter assumido o termo neuriatria, por algum tempo imposto por decreto federal. Isso reforça a noção de um processo formador de uma psiquiatria e de uma neurologia paulistas, bem como da neuropsiquiatria que surge dos trabalhos científicos desenvolvidos no Juquery, sob orientação de Pacheco e Silva.

Na década de 1920, o Juquery, além de ser local de trabalhos científicos, também tem toda uma atividade artística dos pacientes estudada cientificamente por Osório Cesar, mostrando um lado humano do hospício, em trabalho que ficou quase esquecido em décadas posteriores.

Ainda em termos de personagens, a presença de Durval Marcondes entre os diversos agrupamentos médicos não tem sido devidamente estudada pelos trabalhos que o enfocam como o iniciador da psicanálise, ou mesmo da psicologia. Mais pesquisas a esse respeito podem trazer mais noções sobre os processos em torno das tentativas de certa institucionalização da psicanálise, juntamente a desdobramentos e reconfigurações do campo da psicologia. 
Capítulo $5-3^{\circ}$ Período - 1933-1936.

Da Faculdade e da Escola à Universidade e às Cátedras:

O corpo neurológico delimitado no corpo paulista ferido.

Neste período final, apresentamos alguns registros de acontecimentos relevantes para o estudo, mas também assinalamos alguns artigos que nos parecem ilustrativos de alguns fatores presentes nesse momento, mas pouco visíveis ou não registrados na historiografia e que, no nosso ponto de vista permitem uma visão mais complexa do quadro então vigente.

\section{1. - Instituições (1933-1936)}

Em 15 de julho de 1933 ocorre a cerimônia de instalação da Escola Paulista de Medicina, com a presença de membros da congregação, alunos e convidados ${ }^{1175}$. O diretor da Escola, professor Octavio de Carvalho faz o discurso de abertura. Fala sobre a sucessão de acontecimentos históricos, que, segundo ele, mudaram o cenário político e social de uma época, aparentemente fazendo alusão à Revolução de 1932.

Faz elogios a São Paulo e diz que a quantidade de jovens paulistas que estudam medicina em outros estados é grande, segundo ele, 1500. Esse fato e a limitação de 119 vagas da Faculdade de Medicina, conforme Carvalho, também impulsionaram a necessidade da fundação de uma nova Escola de Medicina.

Logo em seguida, ocorre a aula inaugural de Pacheco e Silva, como "lente da Psychiatria da Escola Paulista de Medicina”. Essa designação já implica em uma cadeira de Neurologia separada da Psiquaitria; no entanto, as aulas de ambas só começam em 1938, com Fausto Guerner como responsável pela cadeira de Neurologia.

Pacheco e Silva repete os motivos de fundação da Escola elencados pelo prof. Carvalho, e enaltece São Paulo. Insiste em que o médico deve ter formação em cultura geral e filosófica, e cita diversos pensadores. Fala que é necessário aprender a fundo as ciências fundamentais, bem como estudar as especialidades - que, segundo ele, cada vez mais se subdividem -, culminando todo esse estudo dos alunos com a tese de

1175 PACHECO E SILVA, A. C. Iniciação Médica (Aula inaugural dos Cursos da Escola Paulista de Medicina proferida em 15 de julho de 1933). In: Palavras de Psiquiatria. Edições Edigraf, 1950, p. 13-34. 448 
doutoramento. Acrescenta conselhos aos estudantes, fazendo citações de outros autores e filósofos.

A aula inaugural de Pacheco e Silva, que não é uma aula de psiquiatria e sim de medicina em geral, demonstra seu prestígio no ambiente científico e acadêmico médico.

Pelos discursos feitos na inauguração da Escola Paulista de Medicina, com diversas menções a São Paulo, a derrota do Estado, na Revolução de 1932, pode ter sido mais um motivo para abrir outro curso de medicina, reforçando o orgulho ferido dos paulistas.

No ano seguinte, de modo similar, esse alento também pode ter sido mais um fator estimulador da fundação da Universidade. Assim, em 1934, na edição de janeiro da Gazeta Clinica, informa-se que foi publicado o decreto 6283, que cria a Universidade de São Paulo, pelo interventor federal Armando Salles de Oliveira ${ }^{1176}$.

Em 1935, ainda antes de ocorrerem os concursos para as cadeiras de Psiquiatria e Neurologia, a Congregação da Faculdade de Medicina decide separar as duas disciplinas, designando Vampré para Neurologia e Pacheco e Silva para Psiquiatria. Desse modo, em 23 de julho de 1935, é proferida a aula inaugural do Curso de Clínica Psiquiátrica da Faculdade de Medicina de São Paulo, por Pacheco e Silva ${ }^{1177}$. Assim, ele diz:

“É esta a primeira vez que vai esta matéria ser aqui lecionada separadamente da sua irmã gêmea - a Neurologia, com a qual esteve sempre fundida. Entendeu, entretanto, a douta Congregação desta Escola, aliás mui acertadamente, que a importância de ambas as cadeiras justificava a sua separação, para que cada qual constituísse disciplina autônoma, como acontece na maioria das faculdades nacionais e estrangeiras”1178.

1176 GAZETA CLINICA. Universidade de São Paulo, p. 25, 1934.

1177 PACHECO E SILVA, A.C. Aula inaugural do Curso de Clínica Psiquiátrica da Faculdade de Medicina de S. Paulo (proferida em 23 de julho de 1935). In: Palavras de Psiquiatria. Edições Edigraf, 1950, p. 35-51.

Também publicada em:

PACHECO E SILVA, A. C. Aula inaugural do Curso de Clinica Psiquiátrica da Faculdade de Medicina de São Paulo. Arquivos da Assistência Geral a Psicopatas do Estado de S. Paulo, p.5-14, 1936.

1178 PACHECO E SILVA, A.C. Aula inaugural do Curso de Clínica Psiquiátrica da Faculdade de Medicina de S. Paulo (proferida em 23 de julho de 1935). In: Palavras de Psiquiatria. Edições Edigraf, 1950, p. 35. 
Pacheco e Silva refere-se então à cadeira anteriormente regida por Franco da Rocha, usando a designação de "Neuro-psiquiatria”, e fazendo a mesma menção, quando cita Enjolras Vampré como substituto de Franco da Rocha.

Essa denominação dada à cadeira ocupada por Franco da Rocha, e por Vampré, parece ter sido escolhida pelo próprio Pacheco e Silva ao fazer essa fala, pois, no momento em que esses professores eram responsáveis pela cadeira, ela se denominava "Psychiatria e Molestias Nervosas". Isso corresponde à nossa observação de que a denominação "neuropsiquiatria” parece ter sido assumida nos anos 1930, talvez após a criação da seção de neuropsiquiatria pela Associação Paulista de Medicina em 1931.

Ainda na aula inaugural, Pacheco e Silva diz que a neuropatologia se divide em neurologia e psiquiatria, acrescentando que a psiquiatria trata "dos distúrbios mentais e das modificações orgânicas que lhe são inerentes”1179.

Ele frisa que a patologia mental é relegada a um segundo plano pela maioria dos médicos, que consideram os psiquiatras como poetas da medicina. Ilustra isso, contando que o autor Boucher dizia que "quando julgam terminados os seus estudos fazem os retóricos uma tragédia e os alienistas uma classificação” ${ }^{1180}$. O professor acrescenta, então, que os avanços de anatomia e fisiologia do século XIX refletiram-se sobre a psiquiatria, mudando essa idéia sobre os psiquiatras.

Ao referir-se à psicologia, Pacheco e Silva considera essa disciplina como um campo de estudo das funções cerebrais e como uma forma de aperfeiçoar as faculdades intelectuais e morais:

“O estudo das funções cerebrais, da psicologia, tornou-se apanágio não só do médico, mas de todo homem que pensa e age, buscando, pelo aperfeiçoamento contínuo das faculdades intelectuais e morais, aproveitar o máximo das suas energias, corrigindo os pequenos desvios do psiquismo, mobilizando as reservas da vontade, racionalizando todas as atividades empenhadas num determinado fim"1181.

1179 PACHECO E SILVA, A.C. Aula inaugural do Curso de Clínica Psiquiátrica da Faculdade de Medicina de S. Paulo (proferida em 23 de julho de 1935). In: Palavras de Psiquiatria. Edições Edigraf, 1950, p. 37.

1180 Idem, p. 38.

1181 Idem, p. 38.

450 
Mas, além disso, ele expande o campo da psicologia a todas as áreas do conhecimento, para além da medicina ou de áreas ligadas à saúde:

“Villa, ao delinear as tendências da Psicologia contemporânea, comenta: Não há monografia de argumento jurídico, econômico, ou histórico, e, ainda mais, não há artigo diário sobre qualquer matéria, desde o que toca à alta política até o que se refere à mais recente produção literária, que se não assente em princípios de Psicologia, que não seja calcado sobre leis psicológicas ou não envolva caracteres psicológicos”1182.

Em relação ao médico, o professor diz que mais ainda deve recorrer aos estudos da psicologia. Porém, acrescenta que o melhor caminho para conhecer a mente sã é “recorrer à observação da mente desviada do seu curso normal”"1183.

Ainda conforme Pacheco e Silva, a orientação moderna indica que mais da metade dos casos de alienação mental se originam de afecções localizadas fora do cérebro. Assim, passa a enumerar toda uma gama de exames a serem feitos em diversos órgãos, para identificar a real causa do distúrbio mental.

Refere também palavras de Henri Arthus, a respeito de doentes do corpo que ficam internados por longos períodos e sobre os quais os médicos nada sabem, em relação à sua vida psíquica e social. Assim, Pacheco e Silva valoriza a psicologia médica e a psicologia inata de certos médicos.

Pacheco e Silva refere-se também à psicoterapia como uma forma genérica de apoio ao paciente.

Essa aula inaugural de Pacheco e Silva, além de ser o ato que marca uma delimitação prática entre psiquiatria e neurologia na Faculdade de Medicina, em 1935, antes ainda dos concursos, demonstra os conceitos que alguns como Pacheco e Silva têm em relação aos campos enfocados.

Ele ainda mantém a psiquiatria e a neurologia como duas partes da neuropatologia. Usa o termo neuropsiquiatria para se referir a campos que tinham antes outras denominações. Considera a psicologia como sendo um vasto campo de conhecimento e de prática. Assim, ele apresenta certa articulação entre as três áreas em questão, ao mesmo tempo em que essas áreas ganham certa autonomia. 
Nesse mesmo ano, Enjolras Vampré submete-se ao concurso que permite a instalação da disciplina de Neurologia na Faculdade de Medicina.

Desse modo, em 1935, na edição de dezembro da Gazeta Clinica, é publicado longo artigo elogiando o prof. Vampré, por ter se submetido a concurso para a cátedra de Clínica Neurológica da Faculdade de Medicina da Universidade de São Paulo, embora já seja professor contratado há onze anos ${ }^{1184}$. É relatada, também nesse artigo, a importância de docentes de outras áreas no ensino da neurologia, sendo citados “o pesquisador do metabolismo de base, o radiologista, o anatomista (...), o embriologista (...), o neuro-otologista, o neuro-oftalmologista, o neuro-cirurgião” ${ }^{1185}$, que já colaboram com o curso existente. É citado que, em breve, haverá um anatomopatologista na Cadeira.

Pelo referido, observa-se que Vampré, na prática, já é um professor da área de neurologia, anos antes do concurso, pois já há um curso estruturado em torno da neurologia, com a colaboração de várias especialidades, dando idéia de uma interação entre várias disciplinas no curso dado por Vampré.

Em 1936, há o disputado concurso para a cadeira de Psiquiatria da Faculdade de Medicina da Universidade de São Paulo, entre Durval Marcondes e Antonio Carlos Pacheco e Silva, concurso esse vencido por este último.

Na Gazeta Clínica ${ }^{1186}$, é registrada a posse do professor Pacheco e Silva em 28 de março de 1936, com a presença do Secretário da Educação, Cantídio Moura Campos; do reitor da Universidade de São Paulo, Reynaldo Porchat; do diretor da Faculdade de Medicina, Aguiar Pupo; do diretor da Faculdade de Filosofia, Ciências e Letras, A. de Almeida Prado e do professor Enjolras Vampré. Em longo discurso, Almeida Prado acentua a carreira precoce e prolífica de Pacheco e Silva. Este, em outro discurso, ressalta a influência em sua carreira, de Sá Leite, Arthur Fajardo, Nascimento Gurgel, Miguel Couto, Lemos Monteiro, Austregésilo, Roxo, Vampré e Franco da Rocha. A

1184 GAZETA CLINICA. Prof. E. Vampré, p. 327-329, 1935.

1185 Idem.

1186GAZETA CLINICA. Faculdade de Medicina de São Paulo: A posse do Professor Pacheco e Silva, ano XXXIV, n. 3, p. 92-96, 1936.

452 
Gazeta Clínica também registra um banquete em homenagem ao concurso de Pacheco e Silva, oferecido por amigos, admiradores e colegas ${ }^{1187}$.

Em 1936, na Gazeta Clinica, é anunciado o V Curso de Neurologia e Psychiatria da Policlínica de São Paulo, realizado no mês de Julho, organizado por James Ferraz Alvim, diretor da Clínica de Neuropsiquiatria da Policlínica de São Paulo. Esse curso é composto por seções separadas de neurologia e psiquiatria, sendo que consta em psiquiatria o item psicanálise.

Observarmos assim, que há um curso em sua quinta edição, independente da Faculdade e da Escola de Medicina. Também observamos o uso desse termo “neuropsiquiatria”, como nome de um setor da Policlínica, bem como a persistência de “psychiatria”, grafada desta forma, mesmo cinco anos após o decreto da reforma ortográfica $^{1188}$. De certo modo, a alma das palavras, sua psyche, também tem seus paradigmas.

A existência desse curso de neuropsiquiatria, em concomitância com as disciplinas de neurologia e psiquiatria das faculdades, a configuração da psicologia de forma independente dão uma idéia da complexidade do fim do período abordado por nosso trabalho, em um tempo em que alguns paradigmas dessas diferentes áreas estão em situação de estabilidade.

Nesse mesmo ano, é fundada em São Paulo uma instituição, algo psicológica e algo antropológica. Assim, em 1936, o prof. Marques Junior organiza um laboratório situado à Rua Riachuelo, no palacete Santa Francisca; ele diz ter escolhido o nome de Laboratório de Antropologia, em vez de Psicologia, em virtude dos métodos de pesquisa que utiliza. No informe da Gazeta Clinica sobre essa instituição, o professor se refere a Broca como fundador da Sociedade de Antropologia de Paris em 1859, e diz que Buffon foi o fundador da Antropologia, com o seu $3^{\circ}$ volume sobre História Geral e Particular dos Animais ${ }^{1189}$. Marques Junior também relata que, em 1933, incentivado por Monteiro Lobato, Fernando Azevedo e Sud Menucci, iniciou pesquisa científica com alunos dos grupos escolares Campos Salles e Pedro II, auxiliado pelas educadoras

1187 GAZETA CLINICA. Homenagem ao Prof. Dr. Pacheco e Silva, ano XXXIV, n. 3, p. 117-118, 1936.

1188 GAZETA CLINICA. Oficializou-se a reforma orthographica, p. 180, 1931.

1189 GAZETA CLINICA. Laboratorio de Antropologia, ano XXXIV, n. 11, p. 336-337, 1936. 
Arminia Costa e Anna Kleisber, que trabalharam com desenhos pedagógicos e fichas psicológicas.

Vemos que, no fim do período estudado, a psicologia oscila entre a medicina, a pedagogia e a antropologia. Em 1934, Noemy da Silveira Rudolfer assume o curso de Psicologia Educacional na Faculdade de Filosofia, Letras e Ciências Humanas da Universidade de São Paulo.

Assim, pela primeira vez em São Paulo, a psicologia está caracterizada como uma disciplina de Ensino Superior. Noemy da Silveira Rudolfer é a primeira pessoa de São Paulo a realizar cursos nos Estados Unidos na área de psicologia, antes de integrar suas atividades ligadas à Educação do Estado de São Paulo. Em 1934, defende sua tese de cátedra intitulada “A evolução da Psicologia Educacional através de um histórico da Psicologia Moderna”"1190.

\section{2. - Revistas médicas (1933-1936)}

No que diz respeito a publicações médicas nesse período, em outubro de 1934, funda-se a Revista de Neurologia e Psychiatria de São Paulo, sendo esse o primeiro periódico dessas especialidades no Estado.

$\mathrm{Na}$ capa de seu primeiro exemplar constam os médicos que participam do periódico. O diretor é James Ferraz Alvim e o secretário geral é E. de Aguiar Whitaker.

No “conselho de direcção”, estão: A. Austregésilo, C. de Moura Campos, Durval Marcondes, E. Vampré, Flaminio Fávero, Henrique Roxo, Murillo de Campos, Neves Manta, Porto Carrero, Thomé Alvarenga.

Os “redactores” são citados por suas especialidades: Anatomia Normal e Patológica, J. Thomaz de Aquino, José Oria e Renato Locchi; Radiologia, Cássio Villaça e Paulo de Almeida Toledo; Criminologia, André Teixeira Lima; Laboratório, Oswaldo Lange; Terapêutica, Orestes Rosseto; Pediatria, J. Queiroz de Moraes e Vicente Baptista; Oftalmologia. Moacyr Álvaro; Neurologia e Psiquiatria, Paulino Longo, F. Guerner, F. de Oliveira Bastos e Mario Yahn.

1190 BAPTISTA, M.T.D.S. A constituição da identidade de alguns profissionais que atuaram como psicólogos antes de 1962 em São Paulo. In: MASSIMI, M.; GUEDES, M.C. (org.); História da Psicologia no Brasil; novos estudos, Educ - Cortez Editora, 2004, p. 153-203. 
Como “colaboradores” constam: Adherbal Tolosa, A. Silveira, Carlos Gama, Cyro A. Dorsa, E. Pinto Cesar, Fernando Fonseca, Flavio R. Dias, H. Mindlin, J. Montenegro, J. Ribeiro do Valle, M. Ottoni de Rezende, Matheus Santamaría.

Observa-se a ausência de Pacheco e Silva nos grupos da revista. Não temos elementos para saber se esse é um sinal da suposta rivalidade entre ambos. Não temos elementos para dizer qual a causa da ausência deste professor e pesquisador, mas é uma ausência que se faz notar. Não sabemos se o fato de ele ter tido o compromisso de ser membro da Assembléia Nacional Constituinte em 1934 implica nessa ausência.

A “Apresentação” da Revista expressa que:

"De facto, a neurologia e a psychiatria têm accelerado, nestes últimos annos, o rhytmo de seu progresso entre nós. No que diz respeito á pathologia e á propedeutica, alargaram-se sua fronteiras pelo campo da semiologia do liquido cefalo-rachiano, do radio-diagnostico, da anatomo-pathologia e da physio-pathologia do systema nervoso, etc.. Do ponto de vista da therapeutica e da hygiene, têm sido mobilisados os recursos mais modernos e efficientes: a neuro-cirurgia, a radiotherapia neurologica, a malariotherapia da neuro-lues, o tratamento das neuroses pela psychanalyse, a assistencia medico-pedagogica aos debeis mentaes, a campanha anti-alcoolica, etc. Nas sociedades medicas é grande a affluencia dos trabalhos neuro-psychiatricos”1191.

Conforme essa apresentação, a psicanálise é admitida regularmente pelos organizadores desse periódico. Além disso, está listada entre outras formas de tratamento consideradas modernas e eficientes. As "neuroses", em sendo tratadas pela psicanálise, e não por outros meios, dão indício de sua mudança, deixando de ser o grupo de moléstias nervosas obscuras correspondentes às “nevroses”.

Por outro lado, há um uso diversificado de nomes para as especialidades nos artigos da revista, como: neuriatria, neurologia, psiquiatria, moléstias nervosas, e também o termo alienista para um autor.

Está registrado nesse primeiro exemplar do periódico a sessão de Neurologia e Psiquiatria do Segundo Congresso Paulista de Medicina, que ocorre em novembro de $1933^{1192}$. Consta que o tema dessa seção do congresso intitula-se “A Neuro-Cirurgia em São Paulo”, sendo seu relator o professor Enjolras Vampré.

1191 APRESENTAÇÃO. Revista de Neurologia e Psychiatria de São Paulo, volume 1, n. 1, p. 1, 1934. 1192 CONGRESSO MEDICO PAULISTA. Revista de Neurologia e Psychiatria de S. Paulo, vol.1, n.1, p. 85-100, 1934. 
Conforme registra a Revista, no dia 8 de novembro de 1933, quando ocorre a primeira sessão ordinária do Congresso, com a apresentação dos trabalhos de Neurocirurgia, o Prof. Vampré interrompe a sessão para informar a morte de Franco da Rocha. Com esse fato, suspende-se a sessão e são feitas homenagens ao mestre falecido.

Em 1936, o periódico Memorias do Hospital do Juquery, fundado em 1924 por Pacheco e Silva, passa a chamar-se Arquivos da Assistência Geral a Psicopatas do Estado de São Paulo. Conforme o próprio Pacheco e Silva, isso se deve ao fato de ter sido ampliado o serviço psiquiátrico do Estado para além do Hospital e das Colônias do Juquery, passando a abranger também a Clínica Psiquiátrica e o Manicômio Judiciário. Segundo ele, deseja-se manter o periódico como expressão da escola psiquiátrica paulista fundada por Franco da Rocha ${ }^{1193}$.

Os temas do primeiro volume, de $1936^{1194}$, são: Aula Inaugural do Curso de Clinica Psiquiátrica da Faculdade de Medicina de São Paulo, por Pacheco e Silva; Evolução da Paralisia Geral Progressiva após a Malarioterapia, por Pedro Augusto da Silva; Algumas noções atuais de Endocrinologia relacionadas com a Neuropsiquiatria, por J. Ribeiro do Valle; Tumor cerebral da fossa anterior (meningeoma paramediano) em doente sexagenário, por Aníbal Silveira e Paulo Pinto Pupo; Tumor do ângulo pontocerebelar com estase papilar tardia, por Gilberto Junqueira Franco e Aníbal Silveira; A esquizofrenia em face do Direito Administrativo, por J.N. de Almeida Prado e E. Pinto Cesar; Da chamada “forma mental da criança e do adolescente”, por A. Teixeira Lima, F. Guerner e O. Bierrenbach de Castro; Em torno de uma psicose focal, por J. N. de Almeida Prado; Pseudohermafroditismo, por Argemiro Siqueira e Vicente Baptista; Contribuição para o estudo da Encefalite Letárgica, por Francisco Tancredi; Paralisia Geral e Parkinsonismo, por Pedro Augusto da Silva; Estudo sobre a ionização cálcica e iodurada e sobre a pneumoencefalografia em epilépticos, por Mário Yahn e Celso Pereira da Silva; Das vantagens do exame pneumoencefalográfico sistemático nos esquizofrênicos, por E. de Aguiar Whitaker; Leucotomia cerebral, por A. Mattos Pimenta.

Descrevemos cada um dos temas abordados nesse periódico para que possamos notar que, ao mesmo tempo em que está publicada a primeira aula da Cadeira de

1193 PACHECO E SILVA, A.C. Prólogo. Arquivos Gerais da Assistência Geral a Psicopatas do Estado de São Paulo, ano I, n. 1, p. 3, 1936.

${ }^{1194}$ ÍNDICE. Arquivos da Assistência Geral a Psicopatas do Estado de São Paulo, 1936. 456 
Psiquiatria separada da Neurologia, os assuntos tratados por essa publicação dizem respeito, em sua maioria, mais a neurologia e neurocirurgia, do que propriamente a psiquiatria. Há também temas que podem ser considerados de endocrinologia (hermafroditismo, endocrinologia e neuropsiquiatria), e também um tema que pode ser de psicologia (forma mental da criança e do adolescente).

Isso indica que, embora esteja formalizada a institucionalização da separação entre psiquiatria e neurologia, na prática as áreas convivem estreitamente nesse momento, de modo que configuram a neuropsiquiatria em voga. Esses dados também indicam que o Juquery, nesse período, abriga pacientes com variados quadros que vão além dos limites dos diagnósticos estritamente psiquiátricos, além de se prestar a ser também um local de pesquisas científicas.

\section{3 - Temas e debates (1933-1936)}

Em 1934, publica-se, na Revista de Neurologia e Psychiatria de São Paulo, o artigo de autoria do médico Adherbal Tolosa, intitulado "Dissociação do reflexo cremastérico: estudo fisiológico sobre a via centrípeta”1195. A dissociação desse reflexo torna-se conhecida como "sinal de Tolosa".

Adherbal Tolosa já havia descrito suas observações a respeito desse sinal em reunião da Seção de Neuropsiquiatria da Associação Paulista de Medicina. No artigo de 1934, Tolosa se refere também à tese inaugural de João da Fonseca Bicudo Junior, intitulada "O signal de Tolosa e as alterações da sensibilidade profunda e especialmente visceral”, pois esse médico atribui o nome do sinal ao professor, nessa tese ${ }^{1196}$. Sob orientação de Tolosa, esse aluno examina 125 indivíduos sem comprometimento neurológico.

Tolosa e Bicudo Junior agurdam, então, algum caso patológico que possa confirmar suas hipóteses. É notório que um dos pacientes, cuja lesão permite melhor esclarecimento desse estudo, é um “tenente constitucionalista” 1197 , que recebeu ferimentos de granada, os quais seccionaram seu nervo crural direito.

1195 TOLOSA, A. Dissociação do reflexo cremastérico: estudo fisiológico sobre a via centrípeta. Revista de Neurologia e Psychiatria de S. Paulo, 1: 31-40, 1934.

1196 SEÇÃO DE NEUROPSYCHIATRIA DA ASSOCIAÇÃO PAULISTA DE MEDICINA. Reunião de 5 de março de 1934. Revista de Neurologia e Psychiatria de S. Paulo, vol. 1, n.1, p. 105-107, 1934. 1197 TOLOSA, A. Dissociação do reflexo cremastérico: estudo fisiológico sobre a via centrípeta. Revista de Neurologia e Psychiatria de S. Paulo, vol.1, n.1, p. 33, 1934. 
Ora, de forma simbólica ou real, o corpo desse tenente constitucionalista é o próprio “corpo neurológico paulista”, ferido pela Revolução. Dessa derrota tira-se uma vitória científica; do entendimento de uma perda física, pelo estudo da semiologia neurológica, surge um sinal semiológico descrito pelo professor paulista, deixando uma característica própria sua, no corpo neurológico conceituado por Foucault.

Nesse mesmo ano de 1934 são publicados três artigos na Gazeta Clínica a respeito de Babinski (que morreu em 1932), sobre suas descobertas clínicas, sobre o sinal de Babinski, sobre sua visão da histeria, sobre sua importância para a ciência e para a neurologia, etc ${ }^{1198}$. Aparentemente, o meio científico se apercebe de que a neurologia está praticamente consolidada como especialidade, fazendo uma espécie de fechamento dessa consolidação, através da recordação e do estudo da obra do principal articulador da fase final desse processo. A partir daí, há algumas modificações e alguns acréscimos, como o de Tolosa, em relação ao “corpo neurológico”, mas nenhuma outra grande mudança semiológica.

No transcorrer dos anos 1930, sendo mais conhecida a doutrina de Freud, comentadores a favor e contra expressam-se nos periódicos.

Assim, em 1933, na Sociedade Medica de S. Lucas, ocorrida em 24 de outubro de 1933, o prof. Tanner de Abreu fala a respeito da doutrina freudiana ${ }^{1199}$. O autor inicia com comentários sobre “alterações meteorológicas”, como metáfora irônica à tendência de ser seguida a doutrina freudiana pelo mundo. Relata que recentemente isso tem chegado ao Brasil como sendo uma novidade, de modo que se ignora ou se desconhece tudo que já havia sido escrito sobre Freud em publicações médicas brasileiras bem antes disso, inclusive ignorando-se os livros de Franco da Rocha de 1920 e 1930 . O autor não é favorável à doutrina freudiana, embora explique alguns detalhes sobre a mesma, e considera que a psicanálise pode ser (inadequadamente) usada por advogados para inocentar criminosos, baseando-se em algum trauma passado do criminoso.

Nesse ano de 1933, morrem Franco da Rocha e Juliano Moreira. A ausência deste se faz sentir especialmente por um articulista da Gazeta Clínica.

1198 COUTINHO, E. Nota Clinica sobre o sinal de Babinski. Gazeta Clinica, p. 52-5, 1934.

LACERDA, T. Sinaes de Babinski. Gazeta Clinica, p. 140-141, 1934.

LEITÃO, G. S. Babinski foi o grande gênio da Neurologia. Gazeta Clínica, p. 316-317, 1934.

1199 ABREU, T. Discurso oficial na sessão de honra da Sociedade Medica de S. Lucas em 24 de outubro de 1933. Gazeta Clinica, p. 336-341, 1933. 
Assim, em 1933, nesse periódico, na seção intitulada "Cavacos”, o autor, que assina como “E. P.”, faz vários comentários sobre a "atualidade” então vigente. Em um deles, comenta as atitudes da moda e a imitação das novidades internacionais, como o anti-semitismo, e lamenta a morte e a falta de Juliano Moreira num momento como esse:

“A idéia de que eles são os artífices da ruína universal é de Hitler. $O$ actual chanceler allemão, nascido na Áustria, o qual, como pintor de outros tempos, deu em fazer agora decorações para o theatro mundial... Dessa sua descoberta nasceu o anti-semitismo, que se vae espalhando pelo mundo. A moda já se apoderou dessa attitude mental, e hoje ser anti-semita é uma prova de absoluto bom gosto nas rodas elegantes. (...) Grande dor foi com effeito perdermos o eminente e saudoso dr. Juliano Moreira. Mas a maior e irreparável desgraça foi desapparecer justamente num momento desses em que mais necessários se faziam os seus inestimáveis serviços”.

Essa menção a Juliano Moreira, dá a entender que ele era uma figura marcante no meio acadêmico, não só como médico, ou pesquisador, mas também como opositor das idéias de natureza racista.

Nota-se também a presença de espírito do autor E.P. de estar em dia com o que acontece em nível internacional em termos de racismo, tendo postura crítica em relação ao modismo de certas rodas nesse momento, e lembrando-se de associar toda essa questão à figura singular de Juliano Moreira, cuja ausência é mais profundamente sentida por ter tido uma postura própria diante de certas tendências.

Em linha similar, são publicados outros artigos na Gazeta Clinica.

Desse modo, em 1934, nesse periódico, é publicada uma resenha escrita pelo médico Américo da Veiga, sobre artigo da Revista Espanhola de Medicina, de autoria de Ricardo de Royo, a respeito da lei alemã de esterilização de psicopatas ${ }^{1200}$. O autor se refere ao Congresso Internacional de Higiene Mental em Roma ocorrido em 1933, em especial à fala do delegado alemão, propondo essa conduta. Veiga considera a lei de Hitler um atentado à moral e ao direito. Cita que os Estados Unidos abandonaram essa conduta e que diversas doenças mentais são curáveis. Ele admira-se que a Alemanha, tão científica, tenha feito uma lei como essa.

Em 1935, na Gazeta Clinica, o mesmo autor, Américo da Veiga, publica dois artigos, criticando a terapêutica esterilizante e o racismo nazista ${ }^{1201}$. No primeiro artigo, ele se refere negativamente à política alemã de esterilização de pessoas anormais.

1200 VEIGA, A. Revistas e Resenhas. Gazeta Clinica, p. 288-289, 1934.

1201 VEIGA, A. A terapeutica esterilizante. Gazeta Clinica, p. 23-24, 1935. 459 
Reforça sua posição com o comentário do médico Mateus de Lemos, do Corpo de Saúde do Exército, o qual disse que “muitas figuras ilustres eram anormais”, no sentido de que, portanto, os, assim ditos “anormais” devem ser respeitados. Sobre Hitler, Veiga diz que: "É tão sem critério que ele, que é moreno, de olhos negros e de cabelos crespos, advoga o tipo ideal da raça nordista (anglo-saxão) que é muito diferente do seu vulgar mestiço sem caracteres racistas". Acrescenta que "o chefe do nazismo não conseguirá fazer escola em nosso país”.

No segundo artigo de 1935, Veiga escreve uma resenha sobre outra notícia internacional, a respeito do decreto alemão de esterilização e sobre a expulsão dos judeus. O autor se diz admirado de Hitler defender o racismo, e ser a favor de uma raça à qual ele próprio não pertence. Veiga refere que Spengler, o mentor de Hitler (segundo Veiga), profetizava um grande conflito entre a raça branca e as outras raças.

Em 1935, na seção Bibliografia da Gazeta Clínica, é anunciado o lançamento do livro Psicologia Social de Raul Briquet, relatando-se que esse autor deu curso de Psicologia Social em 1923 na Escola Livre de Sociologia e Política de São Paulo, o que são indícios de outras linhas de psicologia presentes em São Paulo, que são menos aparentes.

Também a partir desse ano, diversos artigos soviéticos são traduzidos para o português e publicados na Gazeta Clinica.

Desse modo, em 1935, são publicados nesse periódico vários artigos de autoria do médico N.I. Propper intitulados “A Ciência na União Soviética”1202. O autor refere que a ciência soviética está bem avançada, se comparada ao período czarista, e diz que a clínica neuropsiquiátrica foi completamente remodelada. Diz que a neuropatologia abandonou a histopatologia e armou-se com o método fisiológico. Principalmente pela escola de Pavlov, o autor considera que a neuropatologia soviética está em primeiro lugar na ciência neurológica mundial. Informa-se que a psiquiatria soviética trabalha com terapia do trabalho e terapia cultural, e que essa psiquiatria entrou também na patologia profissional e no tratamento preventivo com a psico-higiene.

Ainda em aproximação à ciência soviética, em 1936, Pavlov é bastante saudado, por ocasião de sua morte, em uma seção de Neuropsiquiatria da Associação 
Paulista de Medicina, por J. Ferraz Alvim, que destaca estudos do cientista e refere ter conhecido Pavlov aos 86 anos, no Congresso Internacional de Neurologia de Londres ${ }^{1203}$.

Em 1936, há registros de que antigos debates continuam. Nos Annaes da Faculdade de Medicina de S. Paulo, publica-se um longo artigo denominado "Estado actual da theoria do Neuronio”"1204, de autoria do médico José Oria, identificado como $1^{\text {o }}$ assistente e docente-livre do Departamento de Histologia e Embryologia da Faculdade. Observa-se, pelo Departamento referido, que os estudos sobre esse assunto vão além dos limites das áreas de neurologia, psiquiatria e psicologia. O autor atualiza o assunto por uma série de citações, reforçando e opinando a favor das idéias de Cajal, mas citando recentes opositores dessa teoria, que ainda se debatem pela teoria reticular do sistema nervoso.

Pelos diversos aspectos citados, vemos que o processo configurador do corpo neurológico, ao mesmo tempo em que se estabelece no âmbito internacional, tem suas peculiaridades paulistas. Paralelamente à delimitação desse corpo, as neuroses passam a abarcar quadros psíquicos e se alinham com a psiquiatria. A psicologia, ao mesmo tempo em que transversaliza as diversas áreas, tende a caminhar também para uma delimitação própria.

No entanto, ao mesmo tempo em que ocorre a separação e delimitação de neurologia, psiquiatria e psicologia, também se reconfiguram as intersecções entre essas áreas, enquanto antigos debates voltam à cena, como, por exemplo, os prós e contras à teoria do neurônio, tal como visto no último artigo citado.

1203 ALVIM, J. F. Ivan Pavlov em face da Psicologia. Gazeta Clinica, p. 35-37, 1936.

${ }^{1204}$ ORIA, J. Estado actual da theoria do Neuronio. Annaes da Faculdade de Medicina de S. Paulo, vol.XII, fascículo 3, p. 357-402, 1936. 


\section{Considerações finais}

Nos diversos períodos abordados por este trabalho, a questão da modernidade e do moderno, na sociedade e na ciência, se faz presente nas falas dos autores. Não nos importa aqui se nós concordamos ou não sobre os conceitos de moderno e modernidade. O que nos importa é que eles estão presentes no entendimento que as personagens de nosso trabalho fazem dos eventos de seu próprio tempo.

Por outro lado, a conceituação de histeria, a partir de Charcot, tem a marca da visão desse estudioso em relação à beligerância entre religião e Estado, na França, em fins do século XIX. Assim, também as idéias da recente República no Brasil encontram consonância com a interpretação patológica dos fenômenos religiosos.

Após Charcot, mais e mais os autores correlacionam os estados patológicos psiquátricos e neurológicos, ou seja, tanto psíquicos quanto orgânicos, com as transformações da sociedade relacionadas com a vida urbana e seus desdobramentos associados ao que é chamado de "luta pela vida”, bem como à agitação das cidades, ao aumento da atividade psíquica e física, às preocupações e ansiedades, a invenções e novidades, etc. Enfim, a fatores tidos como modernos, aliados a outras influências, tais como alcoolismo, promiscuidade, etc.

Ao chamarmos certa atenção para o "tempo de certezas” no início do século $\mathrm{XX}$, não quisemos fazer uma oposição a outro extremo de incerteza após a Guerra, e nem estabelecer relação de causa e efeito entre o clima social e a ciência, mas antes apontar uma concomitância entre certa expectativa eufórica na ciência daqueles anos, apesar das atribuições aos males modernos, em contraste com um período mais complexo nos anos posteriores.

Esses diversos elementos encontram na cidade de São Paulo um cenário favorável ao desenrolar das correlações entre sociedade e medicina, de modo que se replicam diagnósticos similares ao descritos pelos principais estudiosos das áreas enfocadas.

Um importante intermediário e aglutinador dessas diferentes ocorrências, é o corpo neurológico, conforme conceituado por Foucault. Corpo esse que, como já dissemos, não é um achado ou algo absoluto que só aguardava ser descoberto, mas sim uma construção, uma elaboração feita por aqueles que se aplicaram no entendimento das manifestações clínicas do que foi conceituado como sistema nervoso, através do 
sistema estímulo-resposta, que também é um método de interpretação construído de maneira diferenciada do método psiquiátrico e do clínico.

Ao identificarmos no sinal de Tolosa uma marca que caracteriza o corpo neurológico em São Paulo, não queremos hiperdimensionar esse evento no contexto de então, mas assinalar e inserir esse dado na construção local desse corpo.

É notório que nos dias atuais a neurologia ainda se paute por esse sistema estímulo-resposta, embora questionamentos provindos a partir do refinamento tecnológico na abordagem aos doentes. Também persiste esse sistema, em convivência com novas configurações na intersecção entre neurologia, psiquiatria e psicologia.

Consideramos importante neste trabalho, além de fazer uso, até onde sabemos inédito, dos referidos estudos de Foucault para a abordagem que foi desenvolvida, também lançar luz sobre personagens e registros ainda não assinalados, ou esquecidos ou negligenciados, que se correlacionam com os estudos em questão.

De um modo geral, em relação ao período estudado, podemos concluir que: - A escola de Franco da Rocha estrutura-se principalmente como uma escola paulista de psiquiatria e moléstias nervosas de embasamento em Charcot-Freud-Kraepelin, mais praticada no Hospício do Juquery.

- Enjolras Vampré elabora uma escola paulista de neurologia, principalmente embasada em Babinski e sua escola de Pitié, mais praticada na Santa Casa de São Paulo.

- Pacheco e Silva e Tretiakoff criam uma escola paulista de neuropsiquiatria, embasada principalmente em Pierre Marie e sua escola de Salpêtrière, mais praticada no Hospital do Juquery.

- Uma psicologia médica transversaliza essas escolas, e a atividade de outros médicos, principalmente embasada em Dumas-Janet-Ribot.

- A citação de Freud em São Paulo, remontando a 1904, e certa presença da psicanálise entre os médicos, demandam uma nova visão sobre esse quadro, indicando um campo aberto a mais estudos a esse respeito.

- O papel de Osório Cesar, James Ferraz Alvim e Fausto Guerner, nas áreas em questão, em São Paulo, tem sido ignorado e demanda novas pesquisas.

- O processo de construção do corpo neurológico paulista configura-se principalmente com Vampré e fecha-se com Tolosa. 
Bibliografia

Fontes documentais: Periódicos e Anais de Congresso

Annaes da Faculdade de Medicina de S. Paulo - 1926 e 1936.

Annaes Paulistas de Medicina e Cirurgia - 1913-1930.

Annaes do Congresso Paulista de Medicina - 1916.

Archivos Brasileiros de Psychiatria, Neurologia e Sciencias affins - 1905.

Archivos Brasileiros de Neuriatria e Psychiatria - 1919-1936.

Archivos da Sociedade de Medicina Legal e Criminologia de São Paulo, 1922-1933.

Arquivos da Assistência Geral a Psicopatas do Estado de S. Paulo - 1935 e 1936.

Gazeta Clínica, de 1904-1936.

Imprensa Medica, de 1904-1914.

O Progresso Medico - 1877.

Revista Médica de São Paulo, 1889.

Revista Médica de São Paulo, de 1898-1914.

Revista de Neurologia e Psychiatria de São Paulo - 1934-1936.

São Paulo Médico, de 1928-1936.

464 
$\underline{\text { Fontes documentais: Livros e teses }}$

AUSTREGESILO, A. A Cura dos Nervosos. Livraria Jacintho Editora, 6ª edição, 1933.

BABINSKI, J. Sur le réflexe cutané plantaire dans certaines affections organiques du systeme nerveux central. C. R. Soc. Biol. (Paris) 3: 207-298,1896 apud TOLOSA, A.; CANELAS, H., Propedêutica Neurológica, Editora Sarvier, 1975, p. 49.

BABINSKI, J. Réflexes de défense: étude clinique. Rev. Neurol. (Paris), 29: 145-154, 1915. apud TOLOSA, A.; CANELAS, H., Propedêutica Neurológica, Editora Sarvier, 1975, p. 49.

BRANDÃO, T. Elementos fundamentaes de Psychiatria clinica e forense. Livraria Editora Leite Ribeiro \& Maurillo, Rio de Janeiro, 1918.

BREUER, J.; FREUD, S. Estudos sobre a Histeria (1895). (Coleção Obras Completas de Sigmund Freud), Imago Editora, 1995.

CHARCOT, J. M. Grande Histeria. Contra Capa Livraria, 2003, p. 21.

CESAR, O. A expressão artistica nos alienados: contribuição para o estudo dos symbolos artisticos na arte. Oficinas graphicas do Juquery, São Paulo, Brasil, 1929.

DE LASTIC, P. La pathologie mentale dans les oevres de Gustave Flaubert. Thèse pour le Doctorat en Médicine. Librairie J.-B. Baillière et Fils, Paris, 1906.

DORIA, A. S. Psychologia. Bibliotheca Pedagógica Brasileira, Livros Didacticos, série II, vol. VIII. Companhia Editora Nacional, S. Paulo, 1932.

DWELSHAUVERS, G. Traité de Psychologie. Payot, Paris, 1928.

GRASSET, J. Rapport de la psychiatrie et de la neurologie. In: MARIE, A., Traité de psychologie et pathologie. V. I,p. 11, apud BRANDÃO, T., Elementos fundamentaes de 465 
Psychiatria clinica e forense, Livraria Editora Leite Ribeiro \& Maurillo, Rio de Janeiro, 1918, p. 17.

JANET, P. As Nevroses. Livraria Garnier, Rio de Janeiro, 1924.

LAIGNEL-LAVASTINE, M. et VINCHON, J. Les maladies de l'esprit et leur médecins du XVIe au XIXe siècle: Les étapes des conaissances psychiatriques de la Renaissance à Pinel. Éditions Médicales Norbert Malone, Paris, Editions A. Chaine, 1930.

LE BON, G. As opiniões e as crenças. Companhia Brasil Editora, São Paulo, (1911) 1956.

MEDEIROS E ALBUQUERQUE. O Hipnotismo e suas aplicações. Livraria Editora Leite Ribeiro \& Maurillo, Rio de Janeiro, 1919.

MOTTA FILHO, Prefacio. In: CESAR, O., A expressão artística nos alienados: contribuição para o estudo dos symbolos na arte. Gráfica do Hospital do Juquery, São Paulo, 1929, p. XVII a XX.

PACHECO E SILVA, A. C. Cuidados aos Psychopathas. Officinas Graphicas do Hospital do Juquery, S. Paulo, 1930.

PACHECO E SILVA, A. C. Porque não sou antisemita. In: Por que ser Anti-Semita? Um inquerito entre intellectuaes brasileiros. Civilização Brasileira S.A., 1933, p. 33-37.

PACHECO E SILVA, A.C. A assistência a psicopatas no Estado de São Paulo: breve resenha dos trabalhos realizados durante o período de 1923 a 1937. Oficinas Gráficas do Hospital do Juqueri, São Paulo, Brasil, 1945.

PACHECO E SILVA, A. C. Aula inaugural do Curso de Clínica Psiquiátrica da Faculdade de Medicina de S. Paulo (proferida em 23 de julho de 1935). In: PACHECO E SILVA, A.C., Palavras de Psiquiatria. Edições Edigraf, 1950, São Paulo, p. 35-51. 
PACHECO E SILVA, A.C. Iniciação Médica (Aula inaugural dos Cursos da Escola Paulista de Medicina proferida em 15 de julho de 1933). In: PACHECO E SILVA, A.C., Palavras de Psiquiatria. Edições Edigraf, 1950, p. 13-34.

RAMOS, A. Psychiatria e Psychanalyse. Editora Guanabara Koogan, Rio de Janeiro, ano aproximado de publicação entre 1933 e 1936.

RAMOS, A. Prefácio. In: RODRIGUES, N. As collectividades Anormaes. Editado por Arthur Ramos, 1939.

RÉGIS, E. Précis de Psychiatrie. (Collection Testut) Octave Doin, Éditeur. Paris, 1906.

ROCHA, F. F. da. Das perturbações dos movimentos nas molestias mentaes. Tese de Doutoramento. Faculdade de Medicina do Rio de Janeiro, 1890.

ROCHA, F. da. Esboço de Psychiatria Forense. Typographia Laemmert \& C., São Paulo, 1904.

ROCHA, F. da. O Pansexualismo na Doutrina de Freud. Typographia Brasil de Rothschild \& Cia., S. Paulo, 1920.

ROCHA, F. da. Psicologia do Boato (1920). In: Novela e Conto. (Coleção: Obras de Amadeu Amaral, sob direção de Paulo Duarte). Editora Hucitec, 1976.

RODRIGUES, N. As collectividades anormaes (prefácio e notas de Arthur Ramos). Bibliotheca de Divulgação Scientifica, vol. 19 (dirigida pelo Prof. Arthur Ramos). Civilização Brasileira S.A. Editora, Rio de Janeiro, 1939.

TORRES-HOMEM. Molestias do Systema Nervoso. Publicado em várias lições que foram dadas a partir de 5 de julho de 1875. O Progresso Medico, 1877.

VIEIRA DE MELLO, E. J. - Hysteria no Homem. Tese apresentada à Faculdade de Medicina da Bahia. Typographia do Diario da Bahia, 1890. 


\section{Teses consultadas}

Barradas Barata, A. Hospital Psiquiátrico: Contribuição para o seu planejamento. Tese de Doutoramento apresentada ao Departamento de Prática de Saúde Pública da Faculdade de Saúde Pública da Universidade de São Paulo, 1972.

FERLA, L.A.C. Feios, sujos e malvados sob medida: do crime ao trabalho, a utopia médica do biodeterminismo em São Paulo (1920-1945). Tese de Doutorado, FFLCH, USP, 2005.

FERREIRA, L.O. O nascimento de uma instituição científica: o periódico médico brasileiro da primeira metade do século XIX. Tese de doutorado, FFLCH, USP, 1996.

GIORDANO JUNIOR, S. A persistência da higiene e a doença mental: contribuição à história das políticas de saúde mental no Estado de São Paulo. Tese de Mestrado em Medicina Preventiva, da Faculdade de Medicina da Universidade de São Paulo, 1989.

LANCMAN, S. Loucura e o espaço urbano: um estudo sobre as relações Franco da Rocha - Juqueri . Tese de Doutorado, Unicamp, 1975.

NEVES, A. C. O diagnóstico de Delirium. Tese de Doutorado. Escola Paulista de Medicina, 1993.

PONTE, C. F. Médicos, psicanalistas e loucos: uma contribuição à história da psicanálise no Brasil. Tese de Mestrado, Escola Nacional de Saúde Pública/Fiocruz, 1999. Em: <http://portalteses.icict.fiocruz.br/pdf/FIOCRUZ/1999/pontecfm/capa.pdf.> Acessado em 23 de julho de 2005.

SÁ, E.N.C. Análise de uma organização pública complexa no setor saúde: o conjunto Juqueri no Estado de São Paulo. Tese de Doutorado. Faculdade de Saúde Pública da USP, 1983. 
SILVA, M. R. B. O mundo transformado em laboratório: ensino médico e produção de conhecimento em São Paulo de 1891 a 1933. Tese de Doutorado, FFLCH, USP, 2003.

VASCONCELLOS, M. P. C. Doença mental acima de qualquer suspeita: Franco da Rocha e a prática psiquiátrica na cidade de S. Paulo, 1885-1923. Tese de Doutorado, PUC-SP, 1992.

$\underline{\text { Referências bibliográficas }}$

ABREU, J.L.N. A educação física e moral dos corpos: Francisco de Mello Franco e a medicina luso-brasileira em fins do séclo XVIII. Estudos Ibero-Americanos, PUCRGS, v. XXXII, n.2, p.65-84, dezembro 2006. Disponível em:

<http://revistaseletronicas.pucrs.br/ojs/index.php/iberoamericana/article/viewFile/1357/ 1062>. Acessado em 22 de setembro de 2007 às 21:23 hs.

ALEXANDER, Franz G. \& SELESNICK, Sheldon T. História da Psiquiatria. Ibrasa, 1966.

ANDRADE FILHO, A.S. \& SANTANA JUNIOR, P.A. Ensino da Neurologia na Bahia: aspectos históricos. In: História da Neurologia no Brasil, organizado por Rubens Reimão, Editora Lemos, 1999.

ANDRIOLO, A. A Psicologia da Arte no olhar de Osório César: leituras e escritos. Psicologia, Ciência e Profissão, 23 (4): 74-81, $2003 . \quad$ Disponível em:<http://pepsic.bvspsi.org.br/scielo.php?script=sci_arttext\&pid=S1414989320030004 00011\&lng=pt\&nrm=iso >. Acessado em 22 de fevereiro de 2007 às 22:17 hs.

ANTUNES, E.H. Raça de Gigantes: a Higiene Mental e a imigração no Brasil. In: ANTUNES, E.H., BARBOSA, L.H.S., PEREIRA, L.M.F. (Org.). Psiquiatria, Loucura e Arte. Edusp, 2002. 
ANTUNES, J.L.F. Medicina, Leis e Moral: pensamento médico e comportamento no Brasil (1870-1930), Editora UNESP, 1999.

ASSIS, J.L. A Escola Neurológica de São Paulo. In: REIMÃO, R. (org.) A História da Neurologia no Brasil, Lemos Editorial, 1999, p. 206.

AUSTREGESILO, A. Psicologia e Psicoterapia. Irmãos Pongetti Editores, Rio de Janeiro, 1951.

AZEVEDO, A. (org.). A Evolução Urbana. Vol. II da coleção A cidade de São Paulo: estudos de geografia urbana. Companhia Editora Nacional, 1958.

BAPTISTA, M. T. D. S. A constituição da identidade de alguns profissionais que atuaram como psicólogos antes de 1962 em São Paulo. In: MASSIMI, M., GUEDES, M.C., História da Psicologia no Brasil: Novos Estudos, Cortez Editora, 2004.

BAUDRILLARD, J. Esquecer Foucault. Editora Rocco, (1977) 1984.

BAUMEISTER, A.A.; HAWKINS, M.F. The Serotonin Hypothesis of Schizophrenia: a Historical Case Study on the Heuristic Value of Theory in Clinical Neuroscience. Journal of the History of the Neurosciences, 13 (n. 3): 277-291, 2004.

BENCHIMOL, J. L. Dos micróbios aos mosquitos: febre amarela e a revolução pasteuriana no Brasil. Editora Fiocruz / Editora UFRJ, 1999.

BLOCH, M. Apologia da História: ou o Ofício de Historiador. Jorge Zahar Editor, 2002.

BOGOUSSLAVSKY, J. Marcel's Proust life long tour of the Parisian Neurological intelligentsia: From Brissaud and Dejerine to Solier and Babinski. European Neurology, 57: 129-136, 2007.

BOURDIEU, P. A Economia das trocas simbólicas. Editora Perspectiva, 2005. 
BRAUDEL, F. História e Ciências Sociais. Editora Presença, 1990.

BRAUNSTEIN, J. F. \& PEWZNER, E. História da Psicologia. Instituto Piaget, 2003.

BRODAL, A. Anatomia Neurológica com Correlações Clínicas. Livraria Roca Ltda. , 1984.

BROZEK, J. \& MASSIMI, M.(orgs.). Historiografia da Psicologia Moderna: versão brasileira. Edições Loyola, 1998.

BROZEK, J. \& MASSIMI, M. Historiografia da Psicologia no Brasil. In: Historiografia da Psicologia Moderna. Edições Loyola, 1998, p. 209-221.

CANGUILHEM, G. Études D'Histoire et de Philosophie des Sciences. Librairie Philosophique J. Vrin, Paris, 1975.

CARELLI, M. Culturas cruzadas: intercâmbios culturais entre França e Brasil. Papirus Editora, 1993.

CASTEL, R. O Psicanalismo. Edições Graal, 1978.

CASTEL, R. A Gestão dos Riscos: da Antipsiquiatria à Pós-Psicanálise. Livraria Francisco Alves Editora, (1981) 1987.

CAYGILL, H. Dicionário Kant. Jorge Zahar Editor, 1995.

CAZETO, S. J. A constituição do inconsciente em práticas clínicas na França do século XIX. Editora Escuta Ltda. Fapesp, 2001.

CORADINI, O.L. Grandes famílias e elite profissional na Medicina no Brasil. História, Ciências, Saúde - Manguinhos, III (3): 425-466, 1997. 
CORRÊA, M. As Ilusões da Liberdade: A Escola Nina Rodrigues e a Antropologia no Brasil. Estudos CDAPH. Fapesp. Universidade São Francisco, 1998.

COSTA, J. F. - História da Psiquiatria no Brasil. Xenon Editora, 1989.

COSTA, A.M. da; SCHWARCZ, L.M. 1890-1914: No tempo das certezas. Companhia das Letras, 2002.

CUNHA, M. C. P. O Espelho do mundo: Juquery, a História de um Asilo. Paz e Terra, 1986.

DE LUCA, T. R. A Revista do Brasil: um diagnóstico para a (N) ação. Editora Unesp, 1998.

DECKER, H. S. The psychiatric works of Emil Kraepelin: a many-faceted Story of Modern Medicine. Journal of the History of Neurosciences, 13 (3): 248-276, 2004.

DOWBIGGIN, I. Back to the future: Valentin Magnan, French Psychiatry, and the classification of mental diseases, 1885-1925. Social History of Medicine, 9 (3): 383408, 1996.

DURKHEIM, E. Da divisão do trabalho social. Martins Fontes, (1893) 2004.

DURKHEIM, E. As Regras do Método Sociológico. Martins Fontes, (1895) 2003.

FAUSTO, B. A Revolução de 1930: Historiografia e História. Editora Brasiliense, 1972.

FEINBERG, T.E. \& FARAH, M.J. Behavioral Neurology and Neuropsychology. McGraw-Hill, 1997, p. 5-7.

FERREIRA, A. C. A epopéia bandeirante: letrados, instituições, invenção histórica (1870-1940). Editora Unesp, 2001. 
FEYERABEND, P. Contra o Método. Editora Unesp, (1992) 2003.

FINGER, S. Origins of Neuroscience: a History of Explorations into Brain Function. Oxford University Press, 1994.

FOUCAULT, M. História da Loucura na idade clássica. Editora Perspectiva (1972), 1989.

FOUCAULT, M. Microfísica do Poder. Edições Graal, (1979) 2007.

FOUCAULT, M. O nascimento da Clínica. Editora Forense Universitária, (1980) 2006.

FOUCAULT, M. As palavras e as coisas. Martins Fontes, (1966,1981) 2002.

FOUCAULT, M. O Poder Psiquiátrico. Editora Martins Fontes, (2003) 2006.

FREHSE, F. O Tempo das Ruas na São Paulo de fins do Império. Edusp, 2005.

FREITAS, F.F.P. A história da psiquiatria não contada por Foucault. História, Ciências, Saúde- Manguinhos, vol. 11 (1): 75-91, jan-abr., 2004.

GELFAND, T. How Charcot got his chair. Hist. Sci. Méd. 28 (4): 307-12, 1994

GIDDENS, A. As conseqüências da Modernidade. Editora Unesp, (1990) 1991.

GOETZ, C.G. Visual art in the neurologic career of Jean-Martin Charcot. Arch. Neurol., 48 (4): 421-5, 1991.

GOETZ, C.G. Poor Beard! Charcot's internationalization of neurasthenia, the “American disease”. Neurology, 57 (3): 510-4, 2001.

GOETZ, C.G. Charcot in contemporary literature. J. Hist. Neurosci, 15 (1): 22-30, 2006. 
GOMES, M.M. História da Neurologia no Rio de Janeiro. In: REIMÃO, R., História da Neurologia no Brasil., Editora Lemos, 1999.

GOMES, W. B. Avaliação psicológica no Brasil: Tests de Medeiros e Albuquerque. Aval. Psicol., v. 3, n.1, Porto Alegre, jun. 2004.

Em:<http://pepsic.bvs-psi.org.br/scielo> Acessado em 10 de agosto de 2007.

GUILLIN, V. Théodule Ribot's ambiguous positivism: philosophical and epistemological strategies in the founding of French scientific psychology. J Hist Behav Sci., Spring;40(2):165-81, 2004.

GUTTING, G. Michel Foucalt's “Phänomenologie des Krankengeistes”. In: PORTER, R., MICALE, M. S. (edit.), Discovering the History of Psychiatry, Oxford University Press, 1994.

HAAK, H. P. \& HAAK, C. Die Entwicklung der Psychiatrie. Disponível em $<$ www.entwicklung-der-psychiatrie.de>. Acessado em 10 de junho de 2006.

HERRNSTEIN, R. J. \& BORING, E. G. Textos Básicos de História da Psicologia, Edusp, 1971.

HUERTAS, R. El Siglo de la Clínica: para uma teoria de práctica psiquiátrica. Novalia Electronic Editions, Madrid, Espanha, 2004.

JAMES, W. Coleção Os Pensadores. Editora Nova Cultural, 1989.

JUNG, C. G. Memórias, Sonhos, Reflexões. (Reunidas e editadas por Aniela Jaffé). Editora Nova Fronteira, (1961) 1975.

KANT, I. - Crítica da Razão Pura. Martim Claret, (1781-1787) 2004. 
KRAHL, A. et al. Carl Wernicke and the concept of "elementary symptom”. History of Psychiatry, 9 (36): 503-8, 1998.

KRSTIC, K. Marko Marulic: the author of the term 'Psychology'. Acta Instituti Psychologici Universitatis Zagrabiensis, 1964, n. 36, pp 7-13. In: Classics in the History of Psychology (an internet resource developed by Christopher D. Green), York University, Toronto, Ontario, Canada, posted May 2001. Disponível em: $<$ http://psychclassics.yorku.ca/Krstic/marulic.htm>. Acessado em 10 de dezembro de 2005, às 21: 10 hs.

KOEHLER, P. About medicine and the arts. Charcot and French literature at the fin-desiècle. J. Hist. Neurosci. 10 (1): 27-40, 2001.

KUHN, T.S. A Estrutura das Revoluções Científicas. Editora Perspectiva, (1962, 1970) 2001.

KUHN, T. S. O Caminho desde A Estrutura. Editora Unesp, 2000.

LAGLER, R. The enduring mark left by Jean-Martin Charcot on rheumatology. Rev. Rhum. Engl. Ed. 64: 809-15, 1997.

LATOUR, B. A Esperança de Pandora. Editora Edusc. (1999) 2001.

LEITE NETO, A.M. A influência da Escola Neurológica Francesa na fundação da neurologia brasileira. In: REIMÃO, R. (org.), A História da Neurologia no Brasil, Lemos Editorial, 1999.

LE GOFF, J. História e Memória. Edições 70, Lisboa, 1982.

LE GOFF, J. Prefácio. In: BLOCH, M., Apologia da História: ou o Ofício de Historiador. Jorge Zahar Editor, 2003. 
LIBBRECHT, K \& QUACKELBEEN, J. On the early history of male hysteria and psychic trauma. Charcot's influence on Freudian thought. Hist. Behav. Sci., 31 (4): 37084, 1995.

LOVE, J. A locomotiva: São Paulo na federação brasileira (1889-1937). Editora Paz e Terra, 1982.

LYONS, A.S.; PETRUCELLI, R.J. Medicine: an Illustrated History. Harry N. Abrams, Inc., Publishers; Abradale Press, 1987.

MACHADO, R. et al. Danação da Norma: medicina social e constituição da psiquiatria no Brasil. Edições Graal Ltda., Rio de Janeiro, 1978.

MASSIMI, M. História da Psicologia Brasileira: da época colonial até 1934. Editora Pedagógica e Universitária Ltda., 1990.

MASSIMI, M. (org.). História da Psicologia no Brasil do século XX. Editora Pedagógica e Universitária Ltda, 2004.

MASSIMI, M.; GUEDES, M.C. (orgs.). História da Psicologia no Brasil: novos estudos. Educ / Cortez Editora, 2004.

MISKOLCI, R. Machado de Assis, o outsider estabelecido. Sociologias, 15: 352-377, 2006.

MOTA, A. Tropeços da Medicina Bandeirante: Medicina Paulista entre 1892-1920. Edusp, 2005.

NEVES, A.C. Freud antes de Freud em São Paulo. Revista Neurociências, 14 (3): 127134, 2006. 
NICOLAS, S.; SÖDERLUND, H. The Project of na International Congress of Psychology by J. Ochorowicz (1881) - International Journal of Psychology, 40: 395406, 2005.

NICOLAS, S.; CHARVILLAT, A. Introducing psychology as an academic discipline in France: Théodule Ribot and the Collège de France (1888-1901). J Hist Behav Sci. 2001 Spring;37(2):143-64.

ODA, A.M.G.R.; DALGALARRONDO, P. Juliano Moreira, um psiquiatra negro frente ao racismo científico. Revista Brasileira de Psiquiatria, 22 (4): 178-9, 2000.

OLIVEIRA, C.L.M.V. História da Psicanálise: São Paulo: 1920-1969. Editora Escuta, Fapesp, 2006.

PAIM, I. História da Psicopatologia. Editora Pedagógica e Universitária, 1993.

PAULA, E. S. Contribuição monográfica para o estudo da segunda fundação de São Paulo, 1936 apud AZEVEDO, A., (org.) A Evolução Urbana. In: A cidade de São Paulo: estudos de geografia urbana, v. II, Companhia Editora Nacional, 1958.

PEARCE, J.M.S. Romberg and his sign. European Neurology, 53: 210-213, 2005.

PEREIRA, L. M. F. Os primeiros sessenta anos da terapêutica psiquiátrica no Estado de São Paulo. In: ANTUNES, E.H.; BARBOSA, L.H.S.; PEREIRA, L.M.F.(orgs.), Psiquiatria, Loucura e Arte, Edusp, 2002.

PESSOTTI, I. Os Nomes da Loucura. Editora 34, 1999.

PICCININI, W. J. Voando sobre a História da Psiquiatria. Psychiatry on Line Brazil, 2000. Disponível em:< http://priory.com/psych/wal0800.htm>. Acessado em 30 de março de 2005. 
PICCININI, W.J. História da psiquiatria: Franco da Rocha, vida e obra. Psychiatry on line, vol.8, n.4, 2003. Acessado em 26 de abril de 2005.

PICCININI, W.J. - “Antonio Carlos Pacheco e Silva (1898-1988)”. Psychiatry on line Brazil, julho de 2004. Em:< http://www.polbr.med.br/arquivo/wal0704.htm>. Acessado em 27 de maio de 2005.

PORTER, R.; MICALE, M.S. (editores). Discovering the History of Psychiatry. Oxford University Press, 1994.

QUEIROZ, S.R.R. Política e poder público na Cidade de São Paulo:1889-1954. In: PORTA, P. (org.) História da Cidade de São Paulo, volume 3, Editora Paz e Terra, 2004.

QUINET, A. Apresentação. In: CHARCOT, J.M., Grande Histeria, Contra Capa Livraria, 2003, p. 9-10.

REIMÃO, R. (org.). História da Neurologia no Brasil. Lemos Editorial, 1999.

RIMBAUD, L. Compendio de Neurologia. Livraria Editora Freitas Bastos, (1938) 1940.

ROSSI, P. A Ciência e a Filosofia dos Modernos. Editora Unesp, (1989) 1992.

ROUDINESCO, E. O Paciente, o Terapeuta e o Estado. Jorge Zahar Editor, 2005.

SAGAWA, R. Y. Durval Marcondes. Imago Editora, 1999.

SAGAWA, R. Y. História da Psicanálise no Brasil: importação ou descoberta? In: MASSIMI, M. (org.), História da Psicologia no Brasil no século XX, E. P. U. , 2004.

SAMPAIO, G. R. Nas trincheiras da cura. Editora Unicamp, 2001. 
SCHWARCZ, L. M. Por uma história da reflexão. Apresentação à edição brasileira de Apologia da História, ou o Ofício de Historiador de Marc Bloch. Jorge Zahar Editor, 2002.

SEGAWA, H. São Paulo, veios e fluxos: 1872-1954. In: PORTA, P. (org.), História da Cidade de São Paulo, volume 3, Editora Paz e Terra, 2004.

SEVCENKO, N. Orfeu extático na Metrópole: São Paulo, sociedade e cultura nos frementes anos 20. Companhia das Letras, (1992), 2003.

SIGNORET, J.L. Creation of Charcot's chair. Rev. Neurol. (Paris), 138 (12): 887-92, 1982.

SILVA, M. R. B. Estratégias da Ciência: a história da Escola Paulista de Medicina (1933-1956). Editora Universitária São Francisco, 2003.

STRACHEY, J. Comentários e notas. In: BREUER, J.;FREUD, S., Estudos sobre a Histeria (coleção obras completas de S. Freud). Editora Imago, 1995, p. 27.

SZASZ, T. S. A fabricação da loucura: um estudo comparativo entre a Inquisição e o movimento de Saúde Mental. Zahar Editores, (1971) 1978.

TAN, S. Y.; SHIGAKI, D. Jean-Martin Charcot (1825-1893): pathologist who shaped modern neurology. Singapore Med, 48 (5): 383-384, 2007.

TARDE, G. Monadologia e Sociologia. Cosac Naify, (1895) 2007.

TEIVE, H.A.G. Núcleos da base, estruturas correlatas e vias extrapiramidais. In: MENESES, M.S.; Neuroanatomia aplicada, 2 ${ }^{\text {a }}$ Ed.Guanabara Koogan, 2006, p. 233.

TEIVE, H.A.G. et al. Professor Antonio Austregésilo: o pioneiro da neurologia e do estudo dos distúrbios do movimento no Brasil. Arquivos de Neuro-Psiquiatria, 57 (n.3B), set, 1999. 
TEIVE, H.A. et al. Charcot and Brazil. Arq. Neuropsiquiatr, 59 (2-A): 295-9, 2001.

TEIVE, H.A.G.; MUNHOZ, R.P.; BARBOSA, E.R. Little-known scientific contributions of J-M Charcot. Clinics, 62 (3), São Paulo, 2007.

TELAROLLI JUNIOR, R. Poder e Saúde: as epidemias e a formação dos serviços de saúde em São Paulo. Editora Unesp, 1996.

THOLOSA, A.; CANELAS, H. Propedêutica Neurológica. Sarvier Editora, 1975.

THOMAE, H. Abordagem social: o surgimento da Psicologia científica como disciplina independente. In: BROZEK, J.; MASSIMI, M., Historiografia da Psicologia Moderna. Edições Loyola, 1998.

VIGUIER, R. Les rapports litigieux de Janet et de Freud. Disponível em: < http://pierrejanet.com/JSarticles/2004/rv04.doc>. Acessado em março de 2006.

WEBER, M. Ciência e Política: duas vocações. Editora Cultrix, 2005.

WEINER, D.B. "Le geste de Pinel”: The History of a Psyhcatric Myth. In: PORTER, R.; MICALE, M.S., Discovering the History of Pyschiatry, Oxford University Press, 1994.

WHITE, M.B. Jean-Martin Charcot's contributions to the interface between neurology and psychiatry. Can. J. Neurol. Sci., 24 (3): 254-60, 1997.

YUDOFSKY, S.C.; HALES, R.E. Neuropsiquiatria e Neurociências na prática clínica. 4 edição, Artmed Editora, 2006. 
$\underline{\text { Outras consultas }}$

CASA DE OSWALDO CRUZ/FIOCRUZ. Dicionário Histórico e Biográfico das Ciências da Saúde no Brasil (1832-1930). Disponível em: $<$ http://www.dichistoriasaude.coc.fiocruz.br>.

DORLAND’S Ilustrated Medical Dictionary, 1994.

ACADEMIA BRASILEIRA DE LETRAS. Disponível em: $<$ http:// www.academia.org.br>.

MINISTÉRIO DA SAÚDE E FIOCRUZ. Guia de Fontes e Catálogo de Acervos e Instituições para Pesquisas em Saúde Mental e Assistência Psiquiátrica no Estado do Rio de Janeiro, 2004.

Disponível em: <http://www.ensp.fiocruz.br/eventos_novo/dados/arq423.pdf>.

SÍTIO da Disciplina de Neurologia da Universidade Federal do Paraná: Disponível em: <http://www.hc.ufpr.br/neurologia/Neuroinformacoes.htm>.

SÍTIO de Who named it. Disponível em: <http://www.whonamedit.com>.

WEBSTER'S College Dictionary, Random House, New York, 1997. 
$\underline{\text { Anexos. }}$

Anexo 1 - Decreto de 1903, a respeito de alienados. 483

Fonte: BRANDÃO, T. - Elementos fundamentaes de Psychiatria clinica e forense. Livraria Editora Leite Ribeiro \& Maurillo, Rio de Janeiro, 1918, p. 162-165.

(Consta também do livro de Franco da Rocha, Esboço de Psychiatria Forense, de 1904)

Anexo 2 - Classificações psiquiátricas 487.

Fontes: Revista Medica de São Paulo e Gazeta Clinica.

Anexo 3 - Periódicos e instituições. 493

Figura 1: Planta do Juquery publicada em 1902, juntamente com artigo de Franco da Rocha, no periódico argentino Archivos de Criminologia. Essa planta pode ter sido feita à mão pelo próprio Franco da Rocha.

Fonte: SÁ, E.N.C. Análise de uma organização pública complexa no setor saúde: o conjunto Juqueri no Estado de São Paulo. Tese de Doutorado. Faculdade de Saúde Pública da USP, 1983.

Figura 2: Instituto Psycho-physiologico do Dr. Domingos Jaguaribe (1905)

Fonte: Revista Medica de S. Paulo.

Figura 3: Primeiro exemplar do periódico São Paulo Medico (1928), com homenagem a Franco da Rocha.

Figura 4: Busto de Franco da Rocha no Juquery.

Fonte: PACHECO E SILVA, A.C. A assistência a psicopatas no Estado de São Paulo: breve resenha dos trabalhos realizados durante o período de 1923 a 1937. Oficinas Gráficas do Hospital do Juqueri, São Paulo, Brasil, 1945.

Figura 5: Capa do primeiro exemplar da Revista de Neurologia e Psychiatria de S. Paulo (1934).

Da página 496 em diante são fotos do Juquery.

Fonte: PACHECO E SILVA, A.C. A assistência a psicopatas no Estado de São Paulo: breve resenha dos trabalhos realizados durante o período de 1923 a 1937. Oficinas Gráficas do Hospital do Juqueri, São Paulo, Brasil, 1945. 
Anexo 1 Decreto $n^{\circ}$. 132, de 22 de Dezembro de 1903:

O Presidente da Republica dos Estados Unidos do Brazil:

Faço saber que o Congresso Nacional decretou e eu sancciono a resolução seguinte:

Art. $1 .^{\circ} \mathrm{O}$ individuo que, por molestia mental, congenita ou adquirida, comprometer a ordem publica ou a segurança das pessoas, será recolhido a um estabelecimento de alienados.

$\S 1 .^{\circ}$ A reclusão, porém, só se tornará effectiva em estabelecimento dessa especie, quer publico, quer particular, depois de provada a alienação.

$\S 2 .^{\circ}$ Se a ordem publica exigir a internação de um alienado, será provisoria sua admissão em asylo publico ou particular, devendo o director do estabelecimento, dentro de 24 horas, communicar ao juiz competente a admissão do enfermo e relatar-lhe todo o ocorrido a respeito, instruindo o relatorio com a observação medica que houver feita.

Art. 2..$^{\circ}$ A admissão nos asylos de alienados far-se-á mediante requisição ou requerimento, conforme a reclame autoridade publica ou algum particular.

§ 1. ${ }^{\circ}$ No primeiro caso, a autoridade juntará á requisição:

a) uma guia contendo o nome, filiação, naturalidade, idade, sexo, côr, profissão, domicilio, signaes physicos e physiognomicos do individuo suspeito de alienação ou a sua photographia, bem como outros esclarecimentos, quantos possa coligir e façam certa a identidade do enfermo;

b) uma exposição dos factos que comprovem alienação, e dos motivos que determinaram a detenção do enfermo, caso tenha sido feita, acompanhada, sempre que possível, de attestados médicos affirmativos da molestia mental;

c) o laudo do exame medico-legal, feito pelos peritos da policia quando seja esta a requisitante.

$\S 2 .^{\circ}$ No segundo caso, sendo a admissão requerida por algum particular, juntará este ao requerimento, além do que os regulamentos especiaes a cada estabelecimento possam exigir:

a) as declarações do $\S 1 .^{\circ}$, letra a, documentadas quanto possivel;

b) dous pareceres de medicos que hajam examinado o enfermo 15 dias antes, no maximo, daquelle em que for datado o requerimento, ou certidão de exame de sanidade.

Art. 3. ${ }^{\circ} \mathrm{O}$ enfermo de alienação mental poderá ser tratado em domicilio, sempre que lhe forem subministrados os cuidados necessarios. 
Paragrapho unico. Se, porém, a molestia mental exceder o periodo de dous mezes, a pessoa que tenha á sua guarda o enfermo communicará o facto á auctoridade competente, com todas as occorrencias relativas á molestia e ao tratamento empregado.

Art. $4 .^{\circ}$ Salvo o caso de sentença, na qual logo será dada curatela ao alienado, a autoridade policial providenciará, segundo as circunstancias, sobre a guarda provisoria dos bens deste, communicando o facto ao juiz competente, afim de providenciar como fôr de direito.

Art. 5. ${ }^{\circ}$ Em qualquer occasião será permittido ao individuo internado em estabelecimento publico ou particular, ou em domicilio, reclamar, por si ou por pessoa interessada, novo exame de sanidade, ou denunciar a falta dessa formalidade.

Art. 6. ${ }^{\circ}$ Salvo o caso de perigo imminente para a ordem publica ou para o proprio enfermo, não será recusada sua retirada de qualquer estabelecimento, quando pedida por quem requereu a reclusão.

Art. 7. ${ }^{\circ}$ Quando recusada, naquelle caso, a sahida, o director do estabelecimento dará, incontinenti, em relatorio, á autoridade competente, as razões da recusa, para o julgamento de sua procedencia.

Art. 8. ${ }^{\circ}$ Evadindo-se qualquer alienado de asylo publico ou particular, sómente poderá ser reinternado, sem nova formalidade, não havendo decorrido da evasão 15 dias.

Art. 9. ${ }^{\circ}$ Haverá acção penal, por denuncia do Ministerio Publico, em todos os casos de violencia e attentados ao pudor, praticados nas pessoas dos alienados.

Art. 10. É prohibido manter alienados em cadeias publicas ou entre criminosos.

Paragrapho unico. Onde quer que não exista hospicio, a autoridade competente fará alojar o alienado em casa expressamente destinada a esse fim, até que possa ser transportado para algum estabelecimento especial.

Art. 11. Emquanto não possuírem os Estados manicomios criminaes, os alienados delinquentes e os condemnados alienados sómente poderão permanecer em asylos publicos, nos pavilhões que especialmente se lhes reservem.

Art. 12. O Ministro da Justiça e Negocios Interiores, por intermédio de uma commissão composta, em cada Estado e no Districto Federal, do procurador da Republica, do curador de orphãos e de um profissional de reconhecida competencia, designado pelo Governo, fará a suprema inspecção de todos os estabelecimentos de alienados publicos e particulares existentes no paiz. 
Art. 13. Todo hospicio, asylo ou casa de saude, destinado a enfermos de molestias mentaes, deverá preencher as seguintes condições:

1. ${ }^{\circ}$ Ser dirigido por profissional devidamente habilitado e residente no estabelecimento;

2. Installar-se e funccionar em edificio adequado, situado em logar saudavel, com dependencias que permittam aos enfermos exercicios ao ar livre;

3. Possuir compartimentos especiaes para evitar a promiscuidade de sexos, bem como a separação e classificação dos doentes, segundo o numero destes e a natureza da molestia de que soffram:

4. Offerecer garantias de idoneidade, no tocante ao pessoal, para os serviços clinicos e administrativos.

Art. 14. Quem quer que pretenda fundar ou dirigir uma casa de saude destinada ao tratamento de alienados deverá requerer ao Ministro do Interior ou aos presidentes ou aos governadores dos Estados a devida autorisação.

Art. 15. O requerente annexará á sua petição:

1. Documentos tendentes a provar que o local e o estabelecimento estão nas condições do art. 13;

2. O regulamento interno da casa de saude;

3. Declaração do numero de doentes que pretenda receber;

4. Declaração de receber ou não o estabelecimento apenas alienados e de ser, no ultimo caso, o local reservado a estes inteiramente separado do destinado aos outros doentes.

Art. 16. Estando esses documentos e declarações em forma, e segundo pelo deferimento da commissão inspectora, recolherá o peticionario aos cofres publicos a quantia que arbitrar o Governo para a fiscalisação do estabelecimento, annualmente.

Art. 17. Pretendendo a direcção do estabelecimento elevar o numero primitivo de pensionistas, submetter ao Governo, devidamente informada pela commissão inspectora, uma nova planta do edificio, provando que as construcções comportam, na conformidade requerida, os novos pensionistas.

Art. 18. Os directores de asylos de alienados, publicos ou particulares, enviarão mensalmente á commissão inspectora uma relação circunstanciada dos doentes internados no mez anterior. 
Art. 19. Ao Governo da União incumbe manter a assistencia aos alienados do Districto Federal, havendo da Prefeitura do Districto a diaria dos doentes.

Paragrapho unico. A diaria dos alienados remettidos pelos Estados será paga por estes e pelos respectivos paizes a dos alienados estrangeiros.

Art. 20. O pessoal da Assistencia aos Alienados no Districto Federal compor-se-á: no Hospicio Nacional, de um director superintendendo o serviço clinico e administrativo, quatro alienistas effectivos, um adjunto, um cirurgião-gynecologista, um pediatra, um medico do pavilhão de molestias infecciosas, um ophtalmologista, um director do laboratorio anatomo-patologico, um assistente do mesmo, um chefe dos serviços kinesotherapicos, um dentista, quatro internos effectivos, um pharmaceutico, um administrador, um archivista, um primeiro, um segundo, um terceiro, um quarto escripturario, um continuo e um porteiro; e nas Colônias de alienados: de um director, que será medico, um alienista effectivo, um adjunto, um pharmaceutico, um almoxarife, um primeiro e um segundo escripturarios.

No pavilhão de admissão, onde funccionará a secção de clinica psychiatrica da Faculdade de Medicina haverá um alienista, director do mesmo pavilhão, cabendo o exercicio deste cargo ao lente da cadeira de psychiatria e de molestias nervosas.

Art. 21. Serão providos mediante concurso os cargos de alienista adjunto, de pediatra, de medico do pavilhão de molestias infecciosas, de assistente do laboratório histo-chimico, e de interno, devendo ser preferido no provimento de todos esses cargos, com excepção dos dous ultimos, o concorrente que haja exercido o cargo de assistente ou preparador das Faculdades de Medicina do paiz.

Art. 22. As infracções desta lei serão punidas com as penas de prisão até oito dias e de multa de 500\$ a 1:000\$, além das mais em que, pelas leis anteriores, incorra o infractor.

Paragrapho unico. Ao director reincidente será cassada a autorisação para funccionar o estabelecimento.

Art. 23. Revogam-se as disposições em contrario. Rio de Janeiro, 22 de Dezembro de 1903, 15 da Republica. - Francisco de Paula Rodrigues Alves - J. J. Seabra. 
$\underline{\text { Anexo } 2 \text { - Classificações psiquiátricas }}$

202 REVISTA MEDICA DE S. PAULO

Movimento do Hospicio de Alienados de Juquery

\section{Estatistica Psychiatrica}

1903

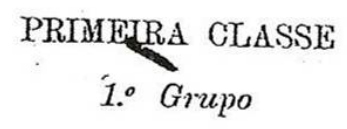

Psycho - Nevroses

Mania e excitação maniaca

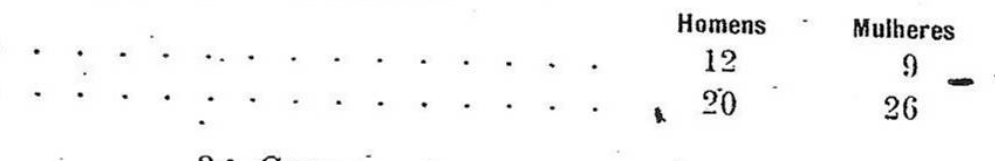

Delirio systematizado de Magnan

\section{Cerebro - Psychoses}

Loucuras periodicas, circular, intermittente, dupla forma, alternantes Loucuras consecutivas a perturbaçōes extra-cerebraes, pucrperio infecções, intoxicações etc. . . . . . . . . . alcool.-agurlo Catatonia

$$
\text { 3.० Grupo }
$$

\section{Cerebropathias}

Meningo-peri-encephalite chron. diffusa

Alcoolismo chronico

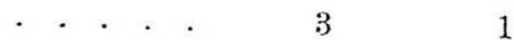

Delirio agudo

Demencia .

Syphilis cerebral

SEGUNDA CLASSE

Molestias constitucionaes devidas ao desenvolvimento incompleto do cerebro ou á degeneração hereditaria

Paranoia

77

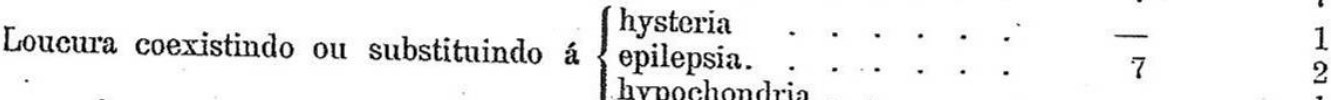

Eebephirenia ou demencia precoce

Loucura dos degenerados, delirios polymorpl........ $\cdot \quad$ -

$\cdot 11 \cdot 5$

[diotia

$\frac{1}{105} \quad \cdots \quad \frac{3}{S 8}$ 


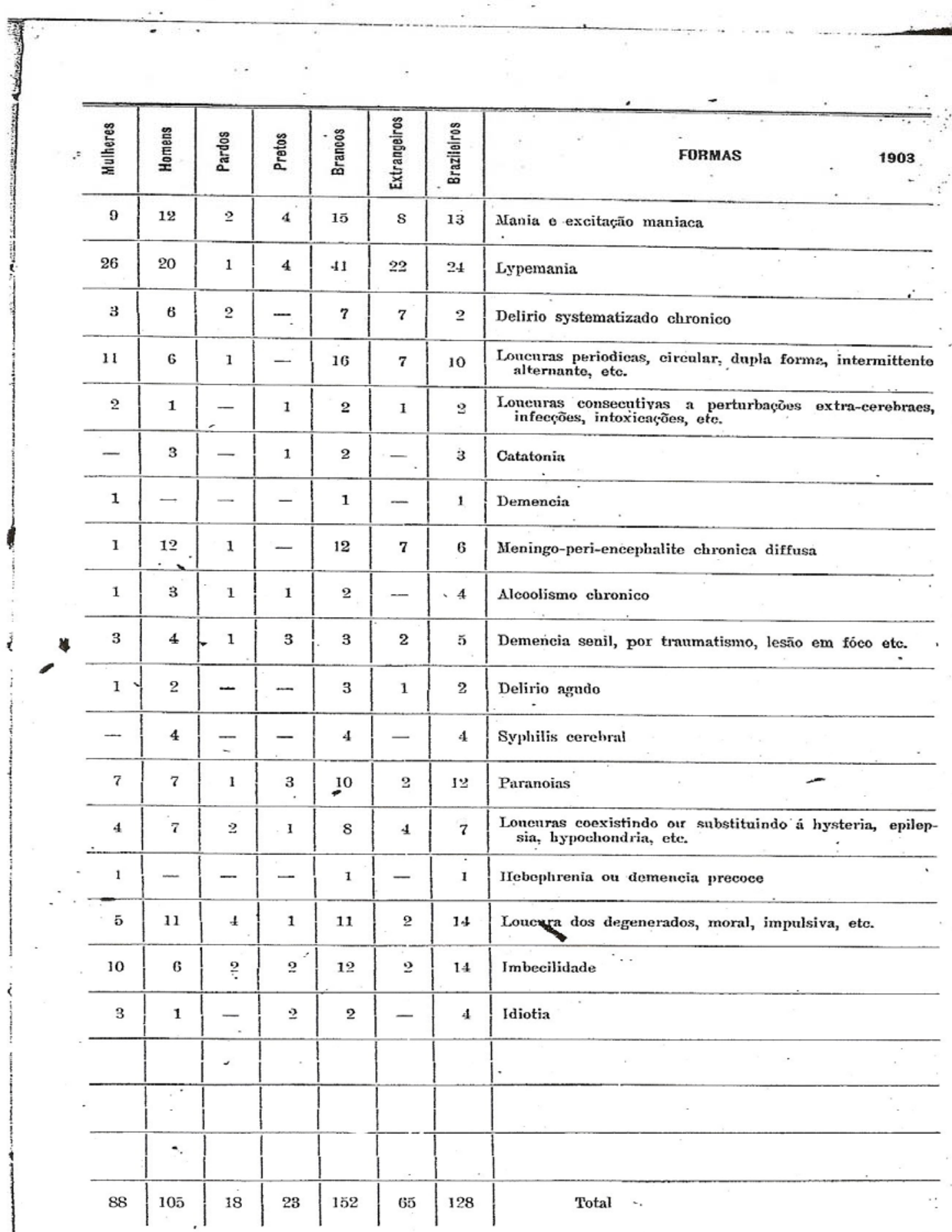




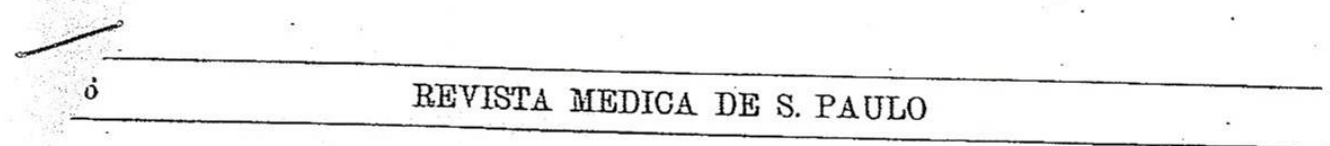

Movimento do Hospicio de Alienados do Juquery

\section{Estatistica Psychiatrica}

$1904\left(^{*}\right)$

PRIMEIRA CLASSE

1.० Grupo

Psycho - Nevroses

Mania e excitação maniaca

Lypemania

\subsection{Grupo}

Perturbacões agudas consecutivas a intoxicações de origens diversas
actuando sobre um cerebro invalido, perturbações graves da nutrição

Confusão mental allucinatoria.

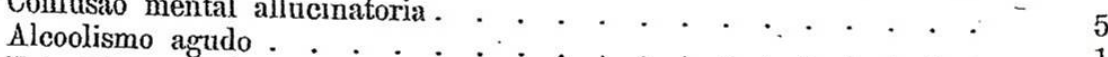

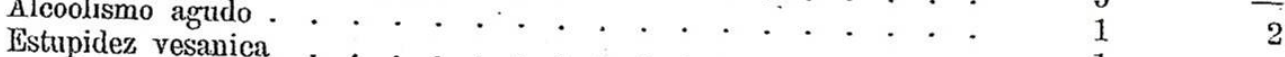

$$
\text { 3.० Grupo }
$$

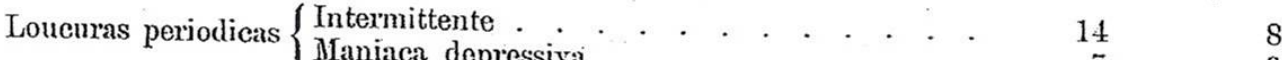

Catatonia . . .

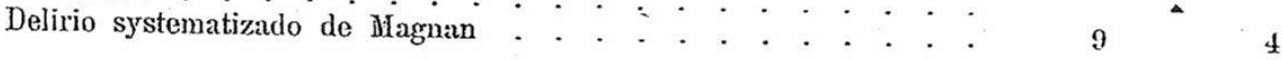

\section{SEGUNDA CLASSE}

\section{Loucuras dos cerebros francamente degenerados}

Paranoia .

Loucura moral

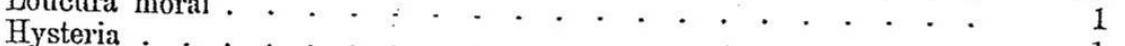

Epilepsia .

Hypochondria ..$\cdot \cdot \cdot \cdot \cdot \cdot \cdot \cdot \cdot \cdot \cdot \cdot \cdot \cdot \cdot 20$

Demencia paranoido

Hebephrenia .

Imbecilidade

Idiotia .

$\begin{array}{r}11 \\ \hline 5 \\ 6 \\ 1 \\ - \\ -14 \\ \hline\end{array}$

Grupo Demencial

\section{Lesões cerebraes grosseiras}

Peri-encephalite chronica diffusa.

Alcoolismo chronico

Syphilis cerebral

Lesões em foco (hemorrhagia).

Demencia senil.

Demencia secundaria.

Totạl

$\begin{array}{rr}17 & - \\ 3 \\ 3\end{array}-\frac{3}{7}$

${ }^{*}$ ) A presente' estatistica foi organisada de accôrdo com a classificaçāo adoptada nos eEsboços de Psychiatria Foreuse.* 


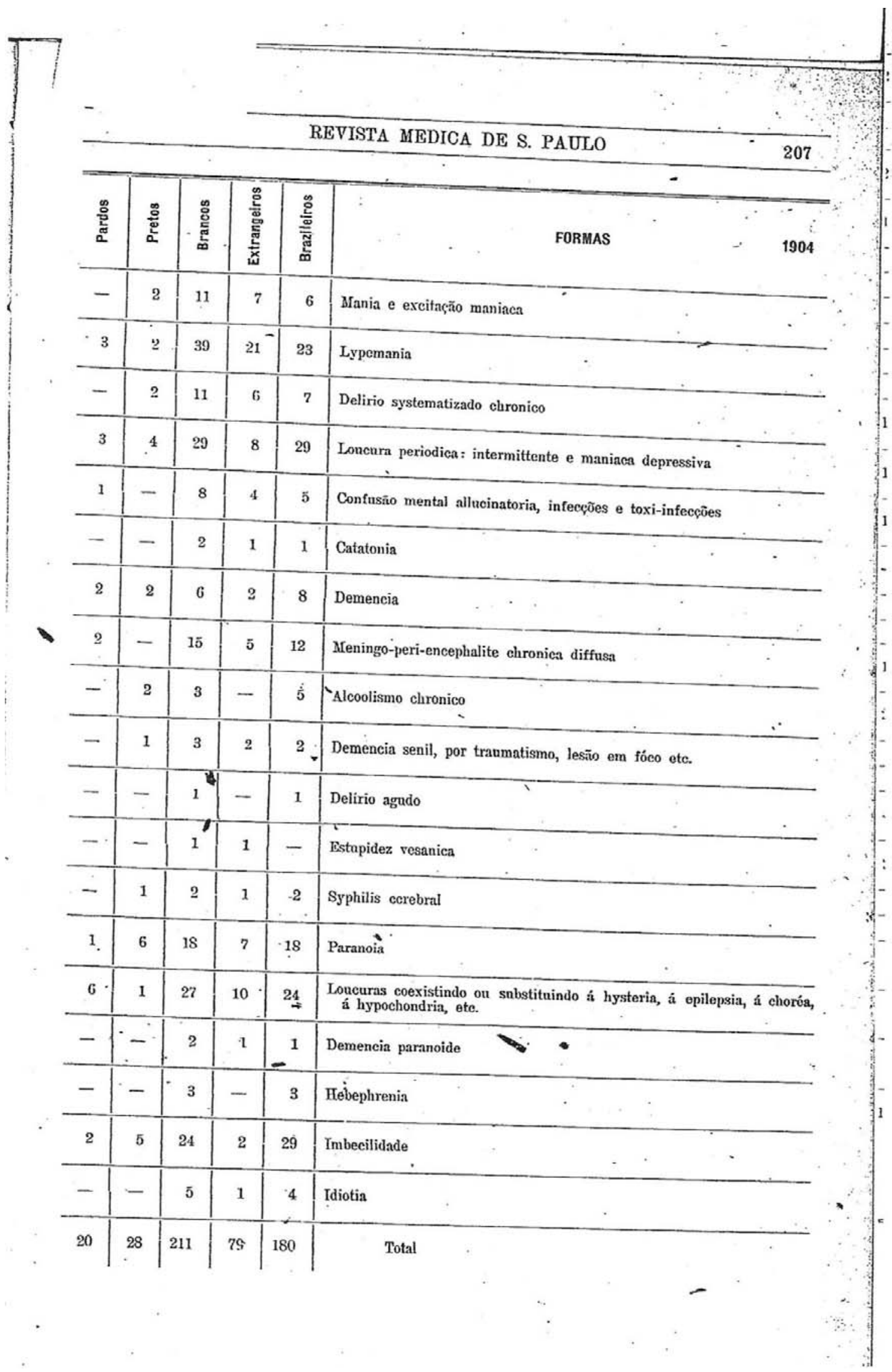


Rroactorrs: Prof. Dr. Alves de Lima o Dr. Xevier da sityesra

\section{Algumas classifieações européas das doenças mentaes \\ Pelo Dr. James Ferrax Alvim}

Director do Instituto Aché - São Paulo

Das classificaçôes curopéas a mais conhecida é a de Kraepelin, (1). protessor da Universidade de Munich. Considerado a maior autoridade em Psychiatria n'estes ultimos tempos e cujos methodos de estudos foram baseados principalment na observação minuciosa principalmente acurada de minuciosa, constante e suas diversas fórmas e variedades. A pratica diaria mostra como são communs as fórmas de transição de uma affecção mental para outra, assim como os aspectos clinicos differentes aue apresenta uma mesma psychopathia. A classificação mais recente do prof. Kraepelin é a exposta na oitava edição do seu tra balho, e constitue dezesete capitulos dos volumes dedicados a Clinica Psychiatros assim enumerados:

1.0 Psychoses traumaticas: commoçāo cerebral, delírio, epilepsia e exgottamento traumaticos.

2.0. Psychoses por lesões cerebraes: choréa de Huntington, idiotia amaurotica (Tay Sachs e Spielmeyer-Vogt), aplasia axialis extra-corticalis congenita, hemorrhagia, thrombose, etc.

3.० Intoxicaçōes agưdas e chronicas (alcoolismo, cocainismo e morphintsmo)

4.0 Psychoses infecciosas: delirrios fearis, delirios infecciosos, confusāo aguda (amentia) e estados de enfraquecimento infeccioso.

5.0 Psychoses syphiliticas: neurasthe7ia syphilitica, tumores gommosos, pseulo-paralysia syphilitica, syphilis apoplettiforme, epillepsia syphilitica, fórmas paanoides, modificaçós anatomicas, psyhoses tabidas e heredo-syphilis.

6.0 Demencia paralytica.

7:0 Psychoses sentis e pré-senis: psyhose pre-senil, arterio esclerose cereral e demencia senil.

8.0 Psychoses thyreogenas: perturrbaōes psychicas na doença Basedow, psyhose myxedematosa e cretinismo.

9.0 Demencias endogenas: demencia xrecoce e paraphrenias.

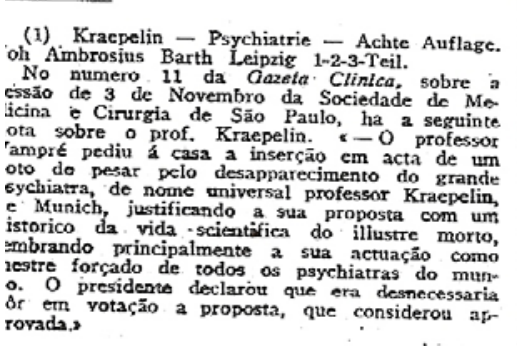

10.0 Psychose epileptica.

11.0 Psychose maniaco-depressiva,

12.0 Doenças psychogenas.

13.0 Hysteria

14.0 Paranola.

15.0 Estados morbidos originarios: nrevosismo, loucura absidente, loucura impulsiva e perversões sexuaes.

16.0 Personalidades psychopathicas : instaveis; mentirosos morbidos e fraudadores: pseudo-qurelantes tocados; antisociaes: irritaveis.

17. Paradas de desenvolvimento physico: Debilidade mental, imbecilidade e idiotia.

Rogues de Fursac (1) adopta esta clas sificação com algumas modificaçōes: ape zar de considerar na actualidade todas ellas artificiaes, pela falta de conhecimento da etiologia e pathogenia da maio ria das psychoses.

Acha entretanto que sobre todas as outras tem a superioridade de levar mais em conta a evoluç̧ăo das perturbacōes em conta a evoluç̧āo das perturbaçōes
mentacs, permittindo ùm prognostco mentaes, permittindo um prognostico
mais precoce, mais prexiso e seguro.

Fursac estabelece a seguinte ordem para o estudo das doenças mentaes:

- Psychose de exgottamento: Confusão mental: dèlirio agudo.

- Perturbaçōes psychicas ligadas as infecções agudas (ommumente chamadas psychoses infeociosas). - Delirio febril. Delirio infeccioso nåo febril. - Raiva Choréa aguda.

- Perturbaçōes psychicas ligadas as affecçōes inflammatorias do cerebro das meningeas: meningites agudas, abcessos do cerebro, encephalite epidemica. - Psychopathias de origem toxica: In toxicaçầo alcoolica (aguda e chronica) - Morphinomania - Opiomania cainomania. - Ether. - Chloral - Has chisch. Cafeinismo. - Intoxicaçāo saturnina. - Intoxicaçöes oxycarbonadas.

- Psychopathias por auto-intoxicação: Uremia delirante. Psychose polynevritica. - Psychopathias de origem thyraidiana (myxoedema, cretinismo, bocio exophtalmico).

- Hebephreno-catatonia (schizophrenia).

- Psychose systematizada allucinatoria chronicca.

- Psychopathias syphiliticas: syphilis ecundaria e terciaria.

- Perturbações mentaes na tabes. Paralysia geral.

- Psychopathias ligadas as affecções ce. rebraes ditas orrganicas e nāo consideradas como syphiliticas. - Arterio-escle. rose cerebrail. - Paralysia agillante.-Esclerose em placas. - Tumores cerebraes. - Choréa chronica.

(1) Manutel de Psychiatrie - Paris 1923. senil.

- Estados maniaco-depressivos.

- Psychose systematisada de fórma interpretativa.

- Psychopathias constitucionaes: $\mathrm{Pa}$ radas de desenvolvimento (idiotia, mibe cilidade, debilidade mental). Deswquilibrio psychico. - Psychasthenia. - Phobias e obsessões. Tícs. - Excitação psychica constitucional. - Anomalias psycho-sexuaes. - Perversões instinctivas (loucura moral).

- Delirios episodicos dos degenerados. lepsia.

Perturbaçōes mentaes ligadas a epi teria Perturbaçōes meniaes ligadas a hys-

- Psychoses traumaticas e emocionaes. Psychoses ditas commocionaes da guerra Entre as classificaçōes francezas, uma das menos defeituosas e bastante coniheciida é a de Regis, (1) professor da clinica psychiatrica da Faculdade de Medicina de Bordeaux. Keraval em seus trabalhos adoptou-a e Tolouse, o fundador da Hygiene Mental na Franç fez apreciacões sobre a mesma $N o$ estudo das doenças mentaes Régis distingue os estados psychopathicos em primitivos ou psychopathias e secundarios ou associados. Os primeiros subdividem-se em doenças e enfermidades psychicas cons tituindo dois grupos cada um delles comprehendendo as lettras $A$ e B, sendo que a primeira apresenta tres itens e a segunda um sómente. ' $\mathrm{E}^{2}$ a seguinte orientaçä́o seguida pelo prof. Régis:

Classificação methodica das psychopathias

(Estados psychopathicos primitivos!

Psychopathias - doenças ou psychoses a) - Psychoses generalisadas:

1.- Mania e melancholia.

(Loucura maniaca-depressiva).

I - Mania:

1.o Mania aguda:

a) Mania aguda typica.

b) Mania sub-aguda (excitaçāo maniaca, hypomania).

II - Melancholia ou lypemania:

1.0 Melancholia aguda:

a) Melancholia aguda typica.

b) Melancholia sub-aguda (depressão melancholica).

2.0-Mania chronica:

a) Mania chronica simples. b) Mania chronica com delirio sys ematizado secundario.

2.0 - Melancholia chronica:

a) Melancholia chronica simples.

(1) Prficis de Psychiatrie. E. Regis, Paris 1914. 
b) Melancholia chrontca com delirio Os estados psychopathicos secundarios
systematizado secundario. systematizado secundario.

II - Mania e melancholia por accessos:

1.0 Mania remittente e intermittente.

2. Melancholia remittente e intermit-.

3.0 Mania-melancholia (loucura de dupla forma).

III - Confusão mental e demencia precoce:

1. Confusão mental typica:

i) sirmples ou asthenica.

b) delírante (delirio onirico).

2.0 Confusão mental aguda:

a) estupida (estupidez).

b) agitada (confusão aguda -allucinatoria)

3.0 Confusão mental chronica.

4.0 Demencia precoce:

a) catatonica.

b) hebephrrenica.

c) paranoide.

B-Psychoses essenciaes:

1.0 Psychose systematizada progres-

siva:

1.0 Delirio hypocondriaco.

2.0 Delirio de perseguiçāo, religıoso, de ciume, erotico, etc.

$$
\text { II }
$$

Psychopathias - enfermidades ou enfermidades psychicas

A - Enfermidades psychicas de evoluçạa (Degenerescencia)

I - Desharmonias (Degenerados superiores, degenerescencia):

1.0 Falta de equilibrio.

2.0 Originalidade, excentricidade.

II - Degenerescencia (Degenerados mt .

dios ou propriamente dito).

1.0 Degenerrescencias simples;

2.0 Degerierescencia com psychoses

iII - Monstruosidades (degenerados in feriores):

1.o Imbecilidade.

2.0 Idiotia.

3.0 Cretinismo.

B - Enfermidades psychicas de involução (Decadencias)

I- - Demencia primitiva:

2.0 Demencia com psychoses. ou associados, são dispostos no seguinte

Psychopathias symptomaticas ou associadas

I - Psychopathias das exo-intoxicações. Alcoolismo.

Saturnismo.

Morphinismo.

mo, Oxy-carbonismo, etc.

II - Psychopathias das auto-intoxica-
côes. 1.0 Especiaes.

Gastro inieslinal.
Hepatica.
Renal.
Cutanea.
Genital.
Thyroidiana, Pituitaria,
Suprarenal, etc.

2.0 Geraes. .

Suprarenal, etc.

Diathéses ou ergasthnia. Surmenage.

Inanição.

Traumatismos.

Operaçōes círurgicas.

III - Psychopathias das infecções:

1.0 Agudas .

Febre typhoide.

Gitippe ou influenza.

Pneumonia.

Polynevrites.

Febres eruptivas.

Diphteria.

Erysipela.

2.0 Chronicas

Syphilis.
Tuberculose.
Cancer. IV - Psychopathias das doenças exo-
ticas:

1.0 Intoxicaçōes.

2.0 Infeç̧ōes e

Opiumismo, Haschschismo.

parasitoses. (herismo, Chloralismo, Cocainis

Paludismo.

Doença do somno.

Choléra.

Lepra.

oenças diversas: Ty.

phus exanthematico
Febremediterranea, Be ri-beri, Febre amaV - Psychopathias das doenças do systema nervoso:

1.0 Doenças Or-

ganicas.

Arterio esclerose cene bral $_{2}$ Cardiopathias Hemorrhagia e amol. lecimento.

Paralysia geral.

Tabes.

Esclerose em placas.

2.0 Nevroses. '. Doença de Parkynson Epilepsia.

Não ha duvida que a classificação ds Régis é uma das mais interessantes ap parrecidas. na França. N'ella figuram os estados psychopathicos primitivos, isto of entidades que pelos seus symptomas sãc $\cos$ typicos. São ellos que vãos clinipsychoses generalizadas isto dar as que ao lado das perturbacôes es aquellas existem as da aotividade senciaes são as psychos geral. As esbacōes são mais ou menos cujas perturr ciumscriptas.

Os estados psychopathicos secundarios, são dispostos no quadro que .já vimos em categorias similares. Apezar de ser chintras france classificaçáo muntos psylin lin, que é apontada por Régis como uma simples enumeração nosologica, sem cacaracter methodico de suas divisōes, multiplicidade de fórmas e terminologıa pouo precisa, não servindo de principio para as suas descripçōes.

No Brasil a classificacăắo do celebre prof. de Munich, serviu de base para a Sociedade de Neurologia, Medicina Legal e Psychiatria, do Rio de Janeiro.

\section{Prof. Dr Alves de Lima}

Acompanhado de sua exma. familia, deve embarcar, a 22 de Fevereiro, para a Europa o dr. J. Alves de Lima, p:ofessor da Faculdade de Medicina de S. Paulo e nosso prezado collega de redacção. 
Anexo 3 - Periódicos e instituições

Figura 1.

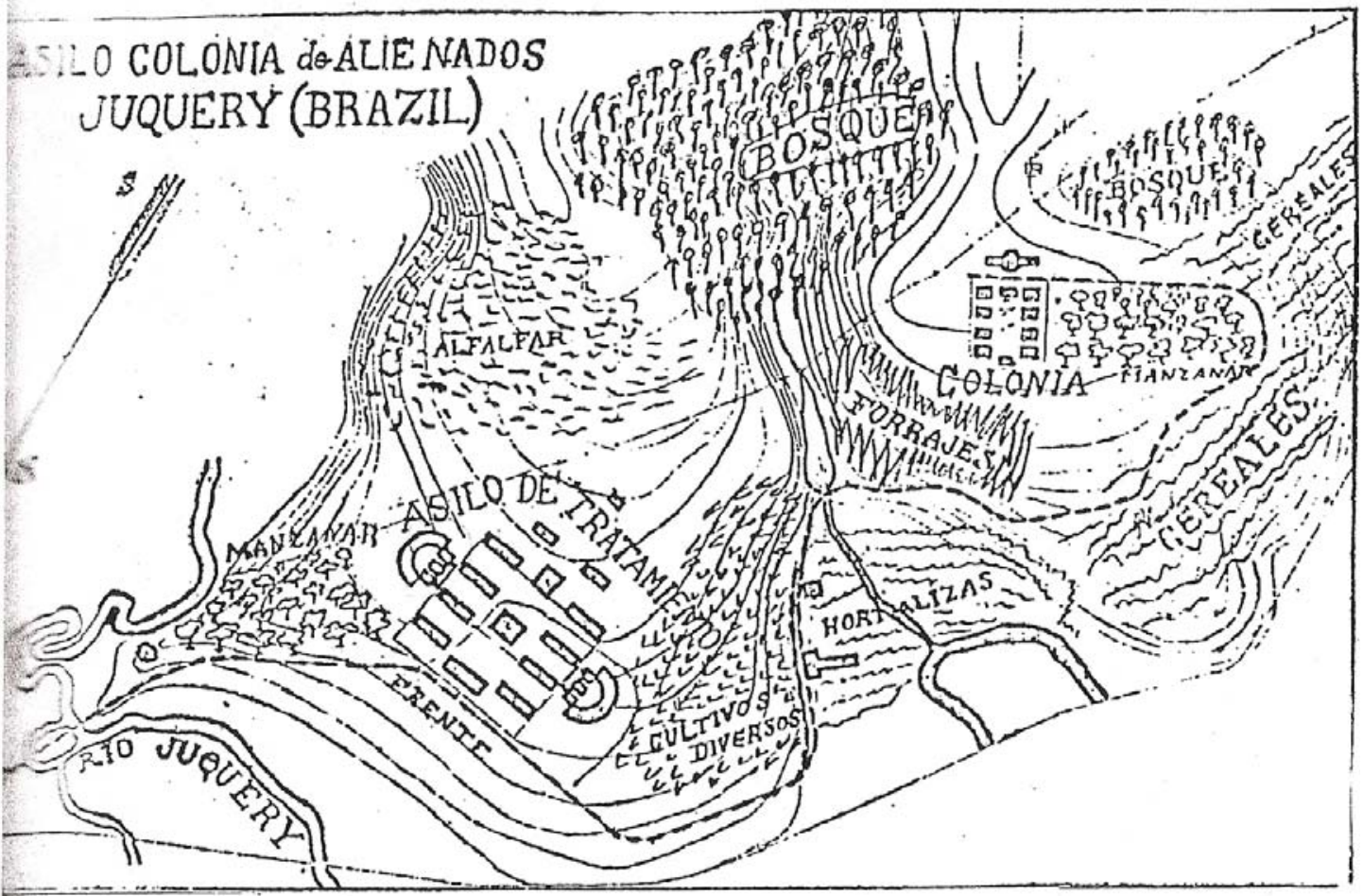

Figura 2

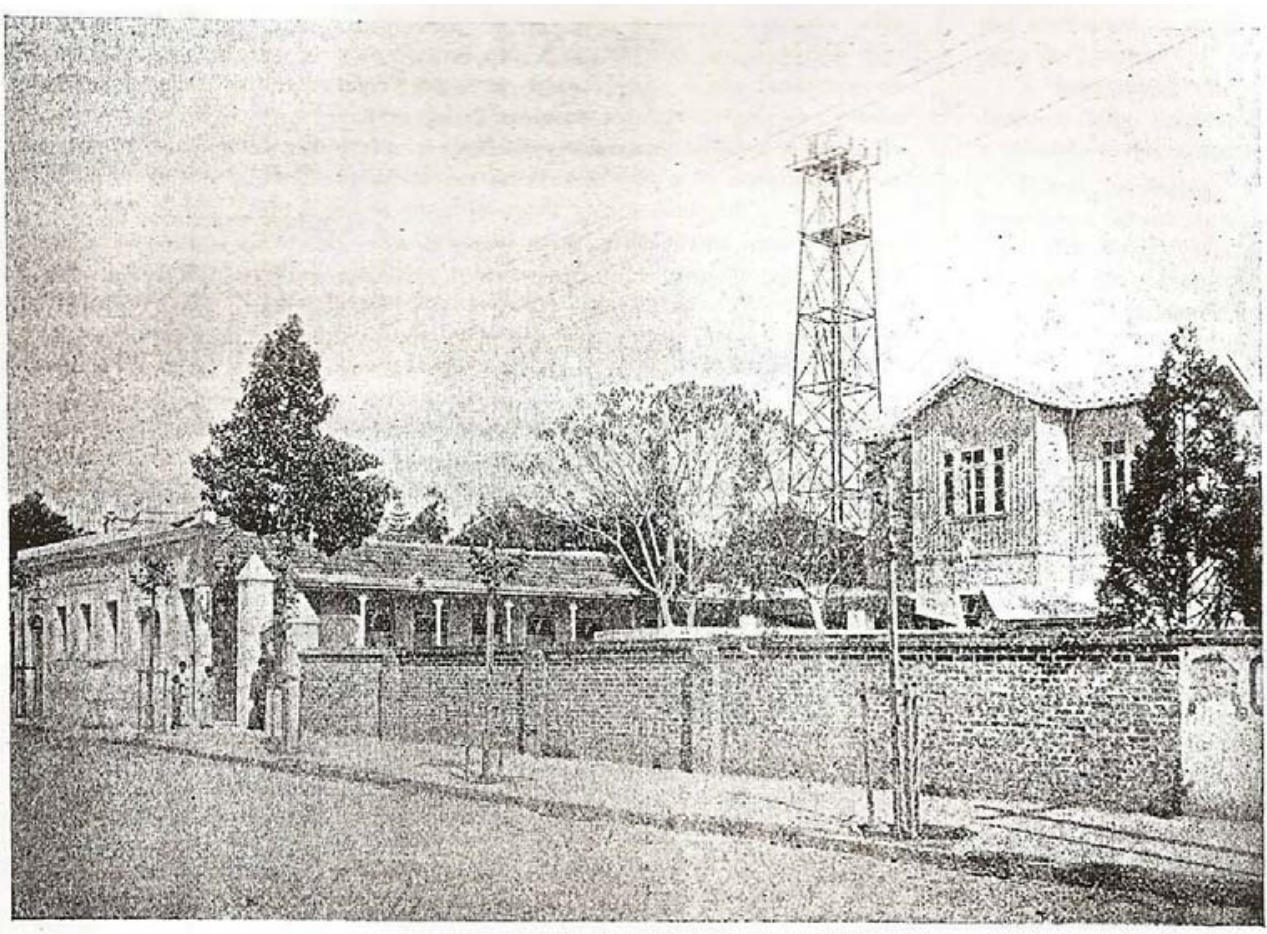

Instituto Psycho-Physiologico do DR. Doningos Jaguaribe 
Figura 3.

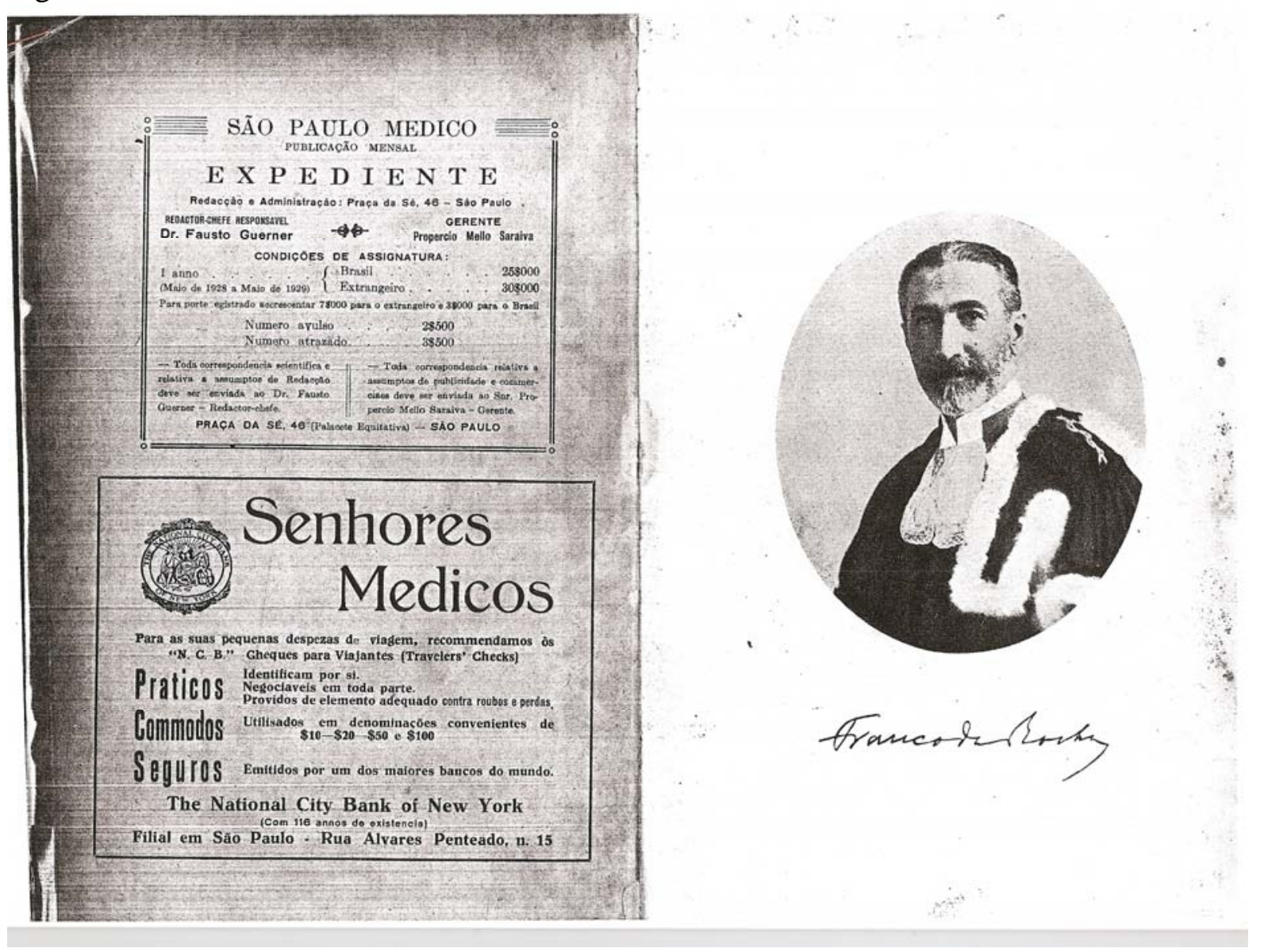

Figura 4

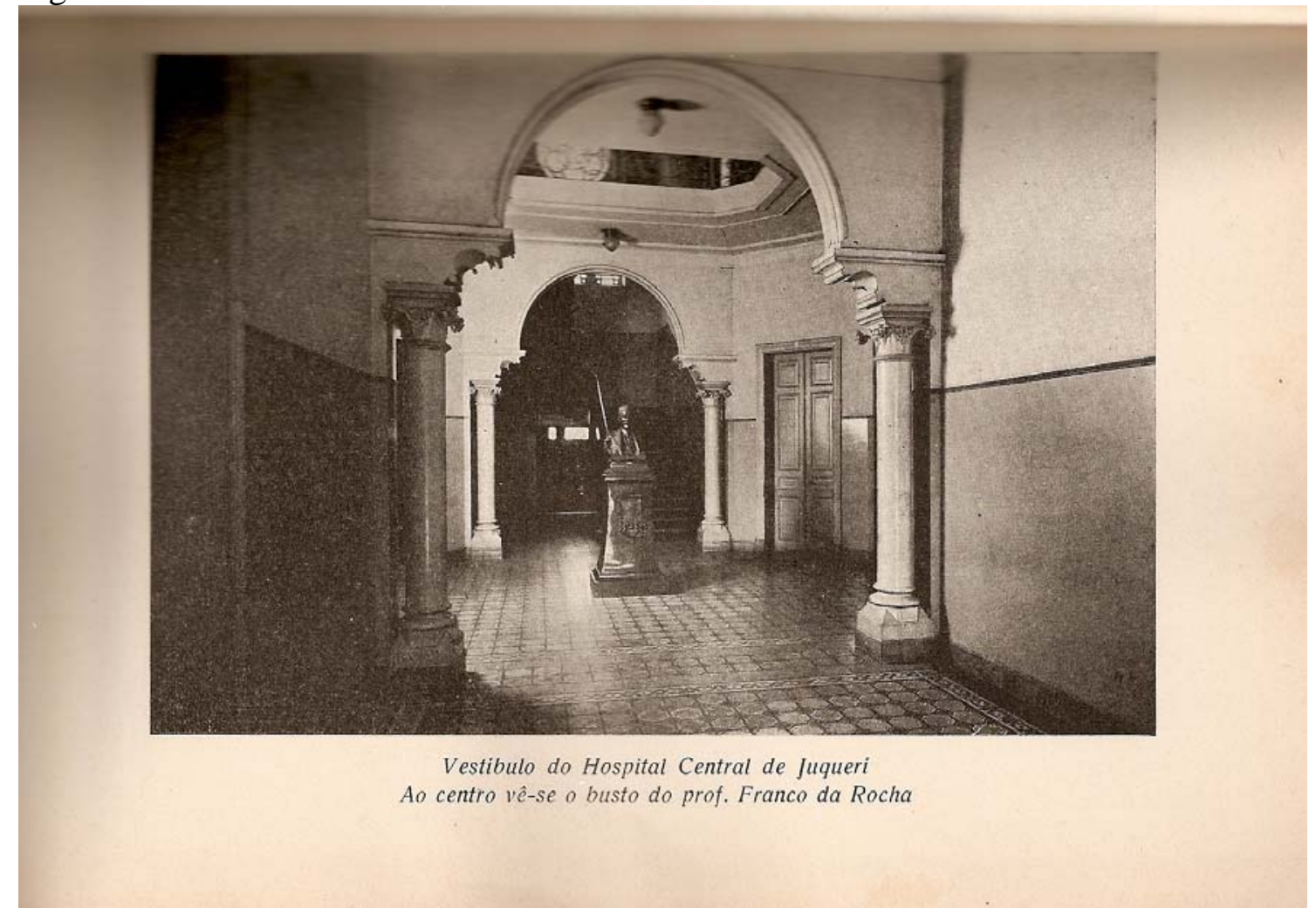




\title{
Revista de Neurologia e Psychiatria de São Paulo
}

\author{
JAMES FERRAZ ALVIM
}

\author{
SECRETARIO GERAI
}

E. de Aguiar Whitaker

A. Austregesilo CONSELHo DE DIRECÇÃo
C. de Moura Campos

E. Vampré Flaminio Favero Campos Cunha Lopes Durval Marcondes Neves Manta Murillo de Campos REDACTORES

Anatomia normal e pathologica: J. ThOMAZ DE AQUino, José Oria e Renato Locchi - Radiologia: Cassio Villaca e Paulo de Almeida Toledo-Criminologia: André Teixeira Lima - Laboratorio : Oswaldo Lange - Therapeutica : Orestes Rosseto - Pediatria: J. Queiroz de Moraes e Vicente Baptista - Ophthalmologia: Moacyr AlvaroNeurologia e Psychiatria: Paulino Longo, F. Guerner, F. de Oliveira Bastos e Mario Yahn.

COLLABORADORES

Adherbat Tolosa A Surgera Cirios Gama, Cyro A Dorsa, E. Pinto Cegar, Fernando Fonseca, Flavio R. Dias, H. Mindlin, J. Montenggro, J. Ribeiro do Valle, M. Otwoni de Rezende, Matheus Santamaria.

James Ferraz Alvim. . . . As Calcificações da Foice do Cerebro

E. Vampré e Paulino Longo A Lei de Bastian. Sua Critica e seu Valor em Face dos Traumatismos Graves da Medulla

Adherbal Tolosa ..... Dissociação do Reflexo Cremasterico. Estudo Physio-Clinico sobre a Via Centripeta

Fernando de Oliveira Bastos. Meningite Aguda Lymphocytaria Benigna.

E. de Aguiar Whitaker,

A Proposito de um Novo Caso ....

Mario Yahn e Celso P. Silva A Prova da Adrenalina (Curva da Pressão Arterial) como meio de Diagnostico em Psychiatria.

A. Teixeira Lima e

Teria sido o Delicto praticado em Estado

O. Bierrenbach de Castro. Teria sido o Delicto praticado em Estado

Theodor Goett ...... Sobre o Rachitismo Cerebral ou Demencia Rachitica . . . 66

Mario Yahn........ Infeç̧ão das Vias Biliares e Perturbações Mentaes .

Orestes Rosseto. . . . Algumas das Ultimas Acquisições Therapeuticas em Neuro-Psychiatria

(Continuação na $3 .^{\mathrm{A}}$ pagina da capa) 


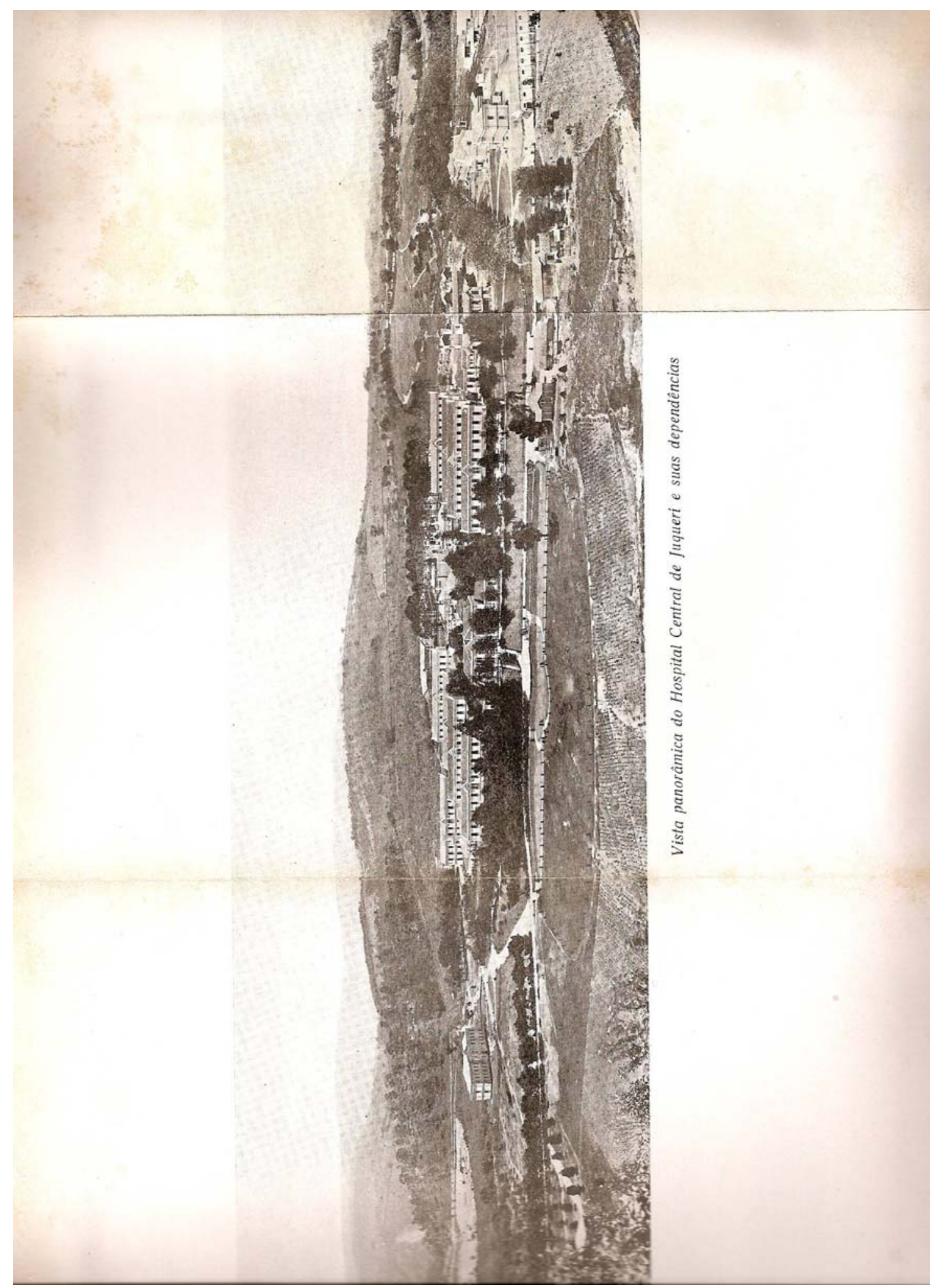




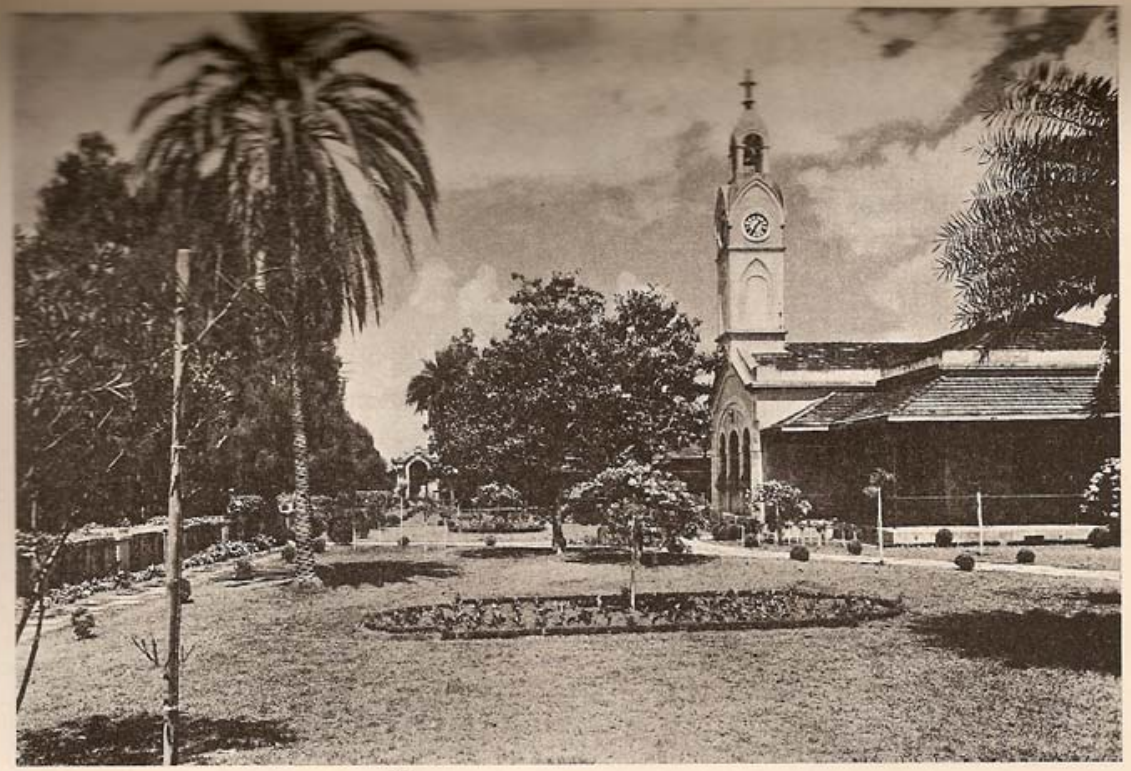

Jardins e torre do Hospital Central de Juqueri

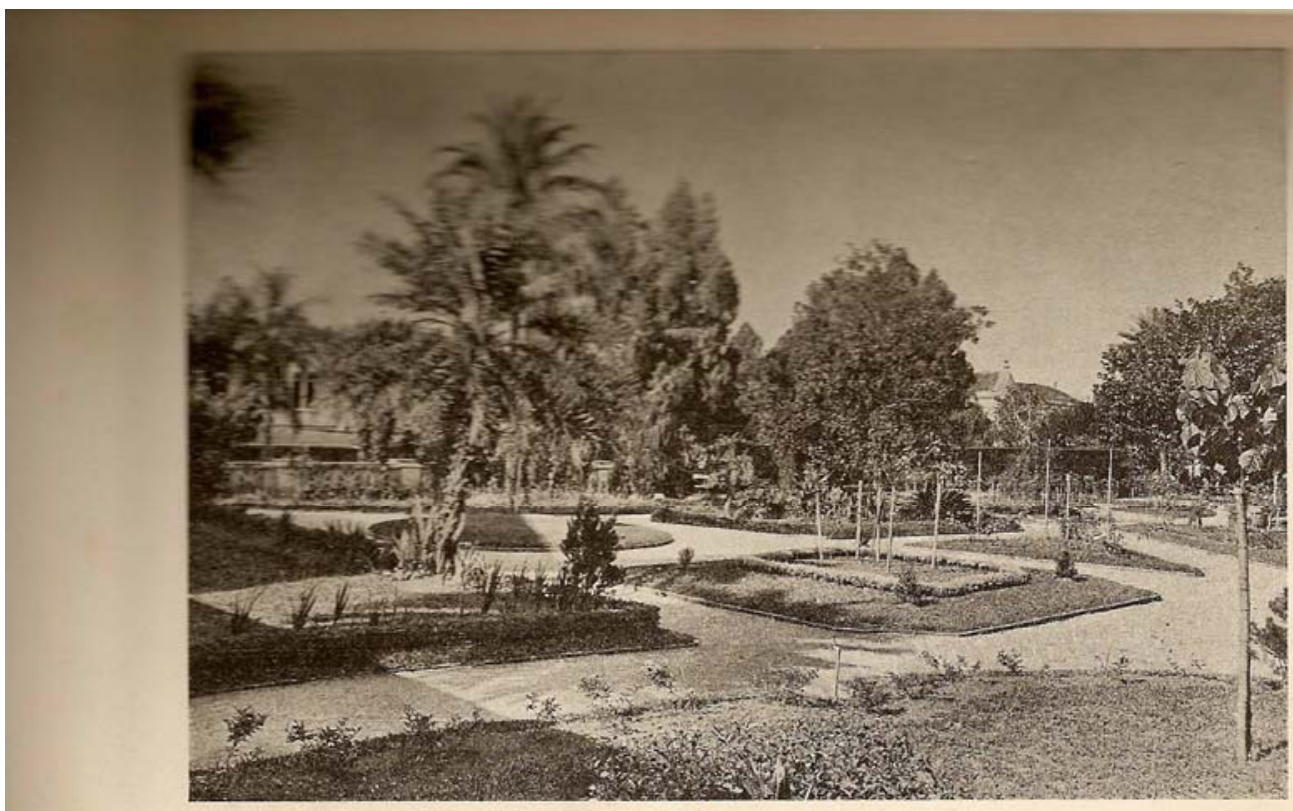

Jardins internos do Hospital Central de Juqueri 

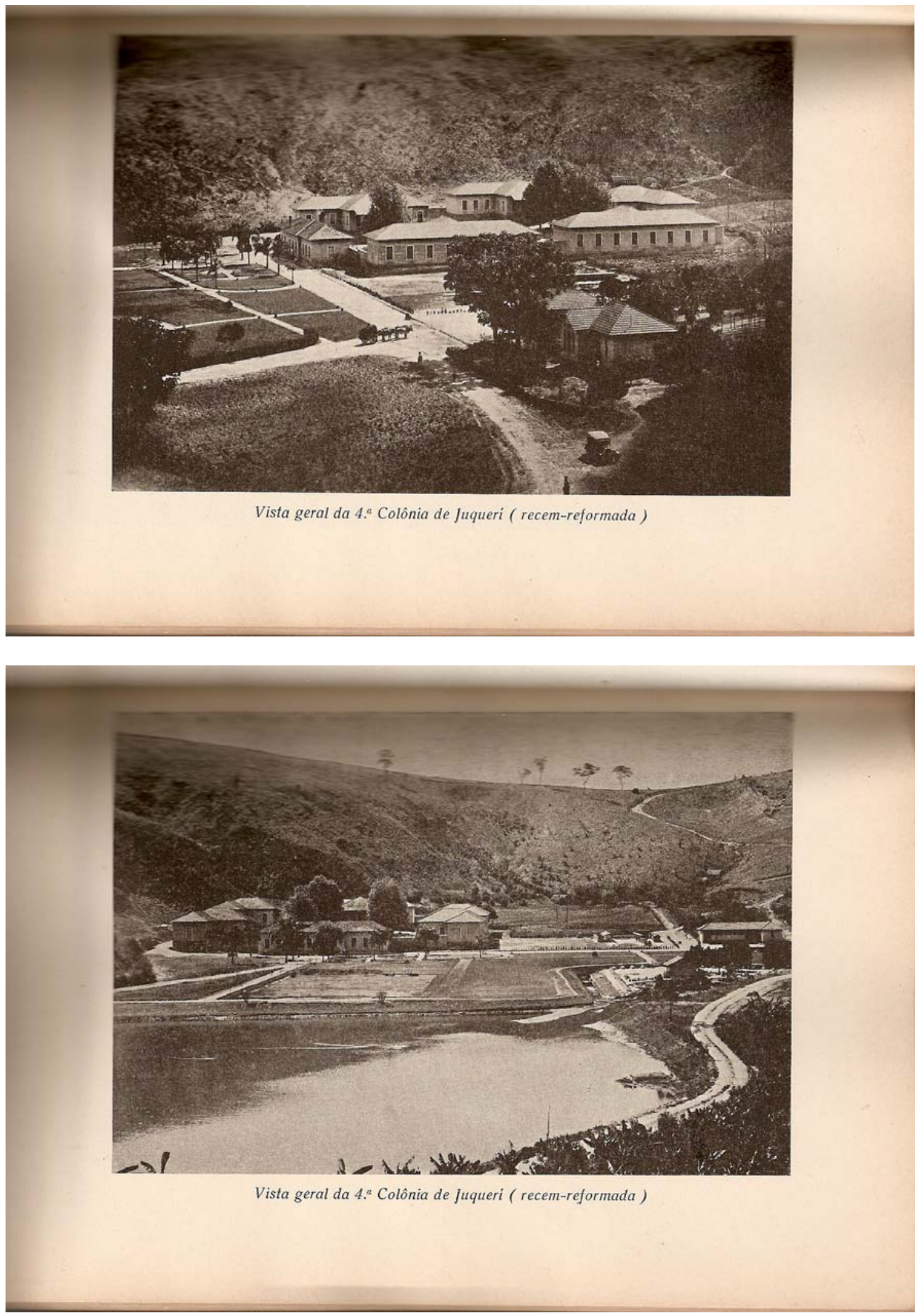

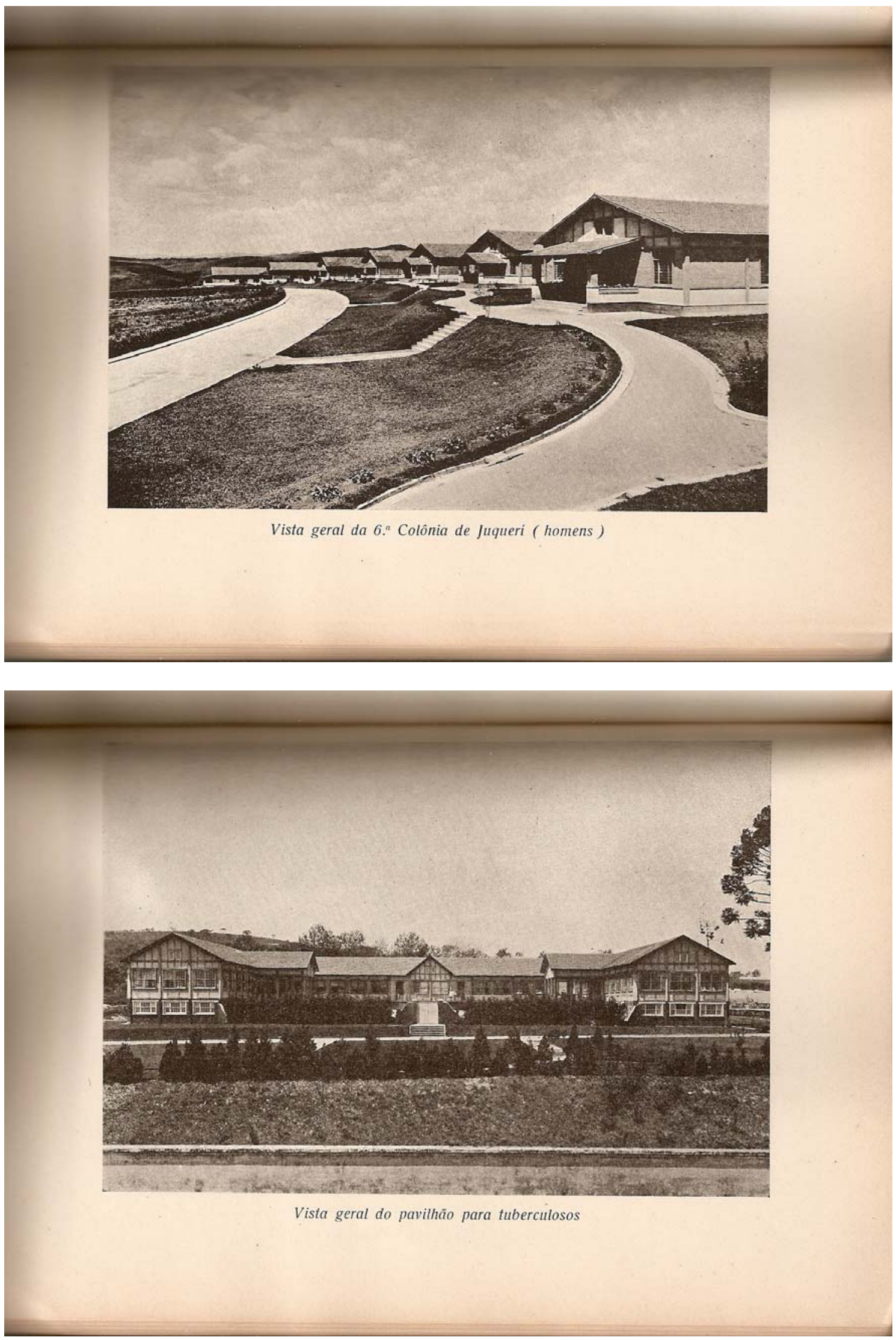


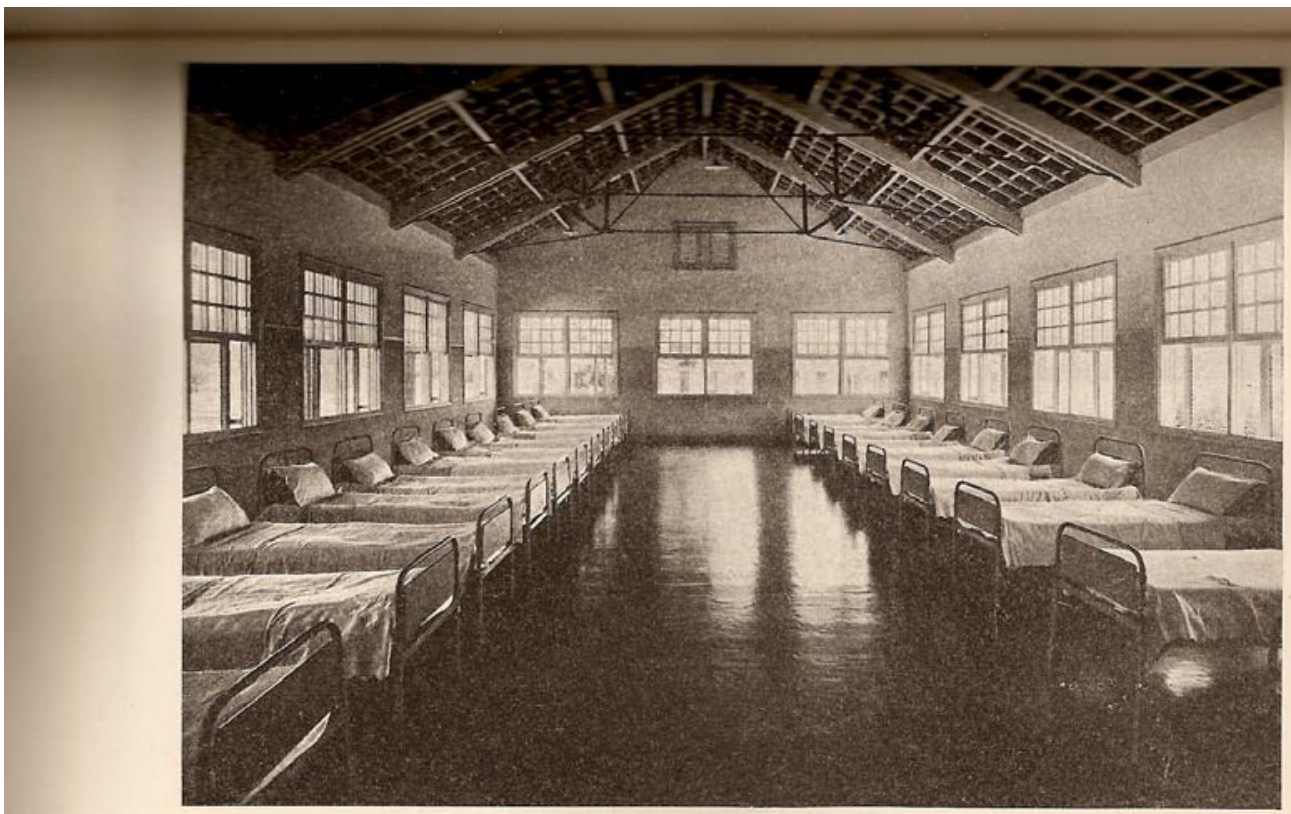

Hospital Central de Juqueri

Um dos dormitórios do pavilhão para tuberculosos

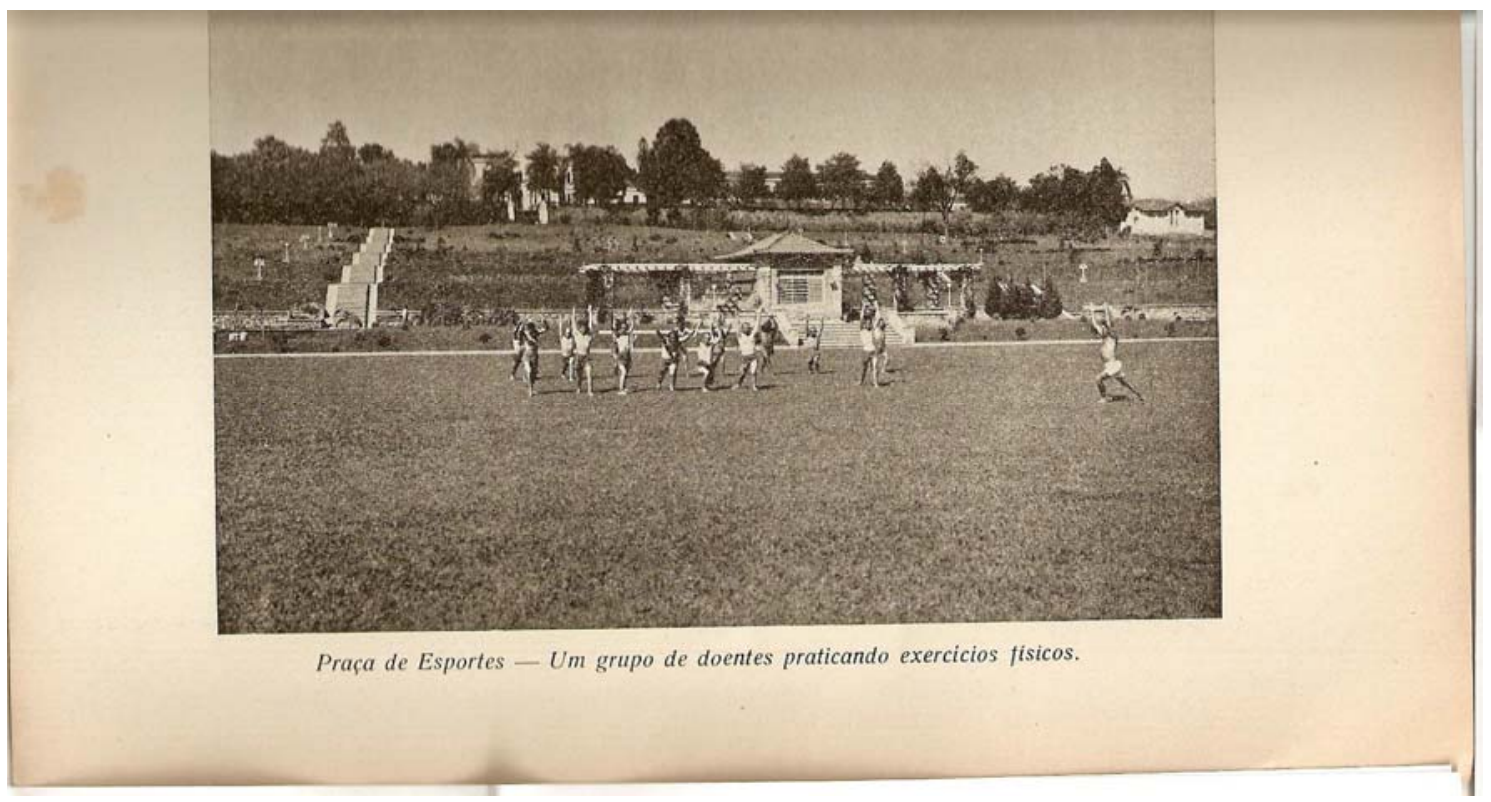




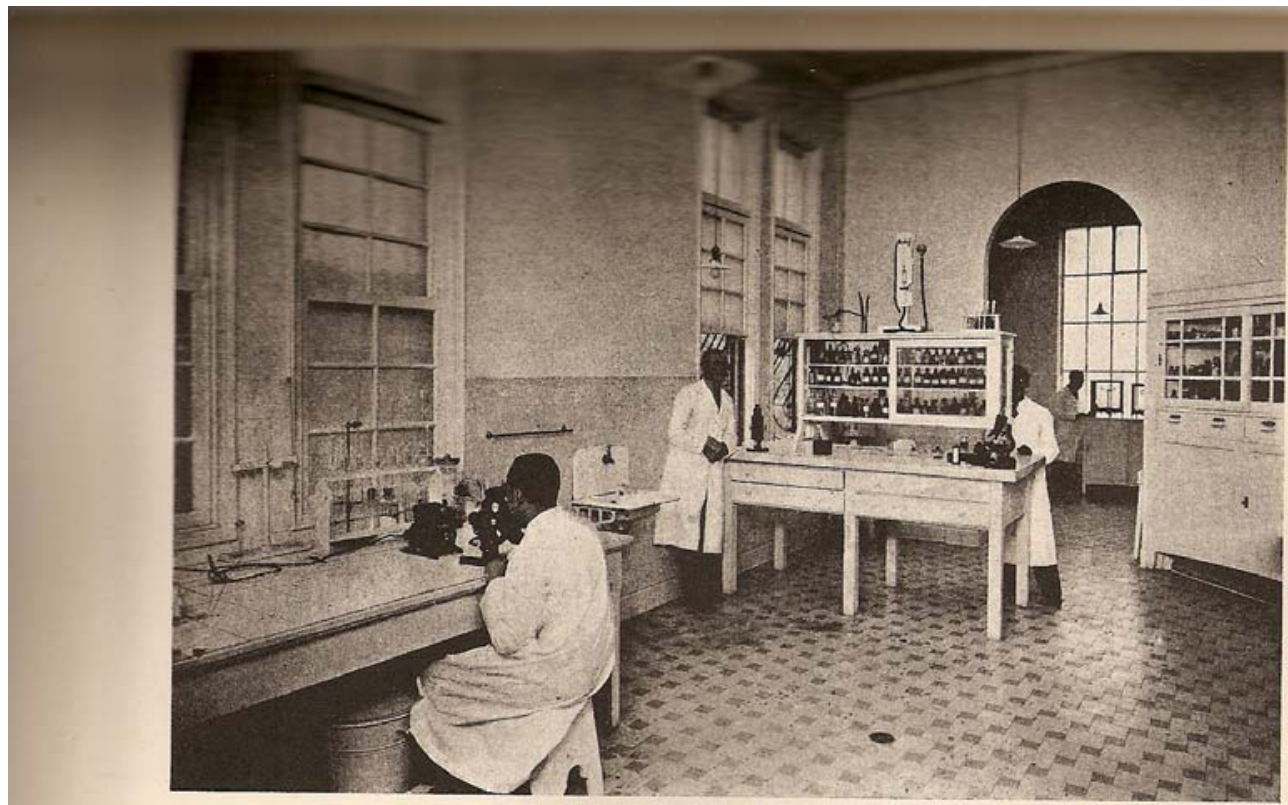

Vista interior do laboratório de biologia clinica

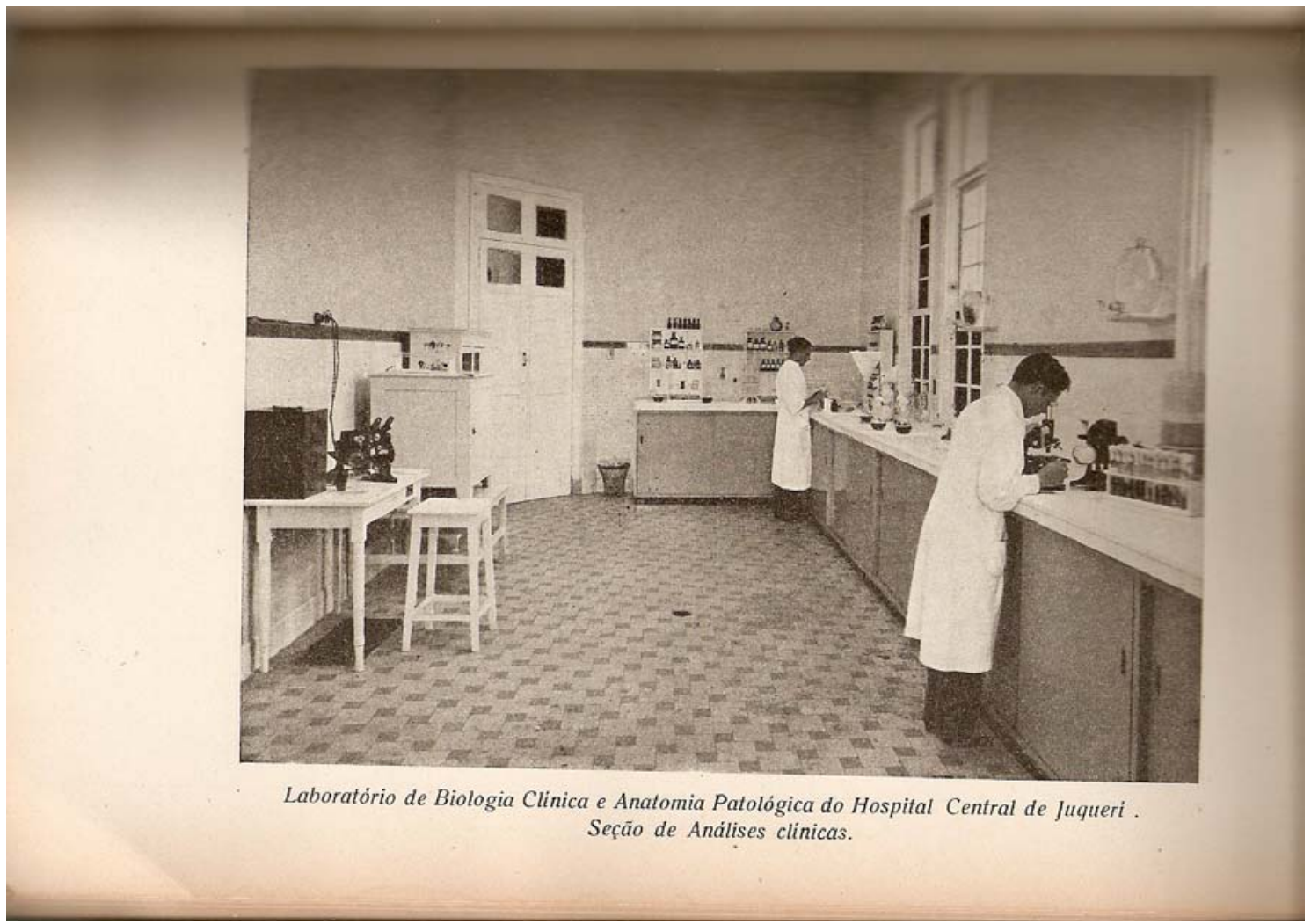




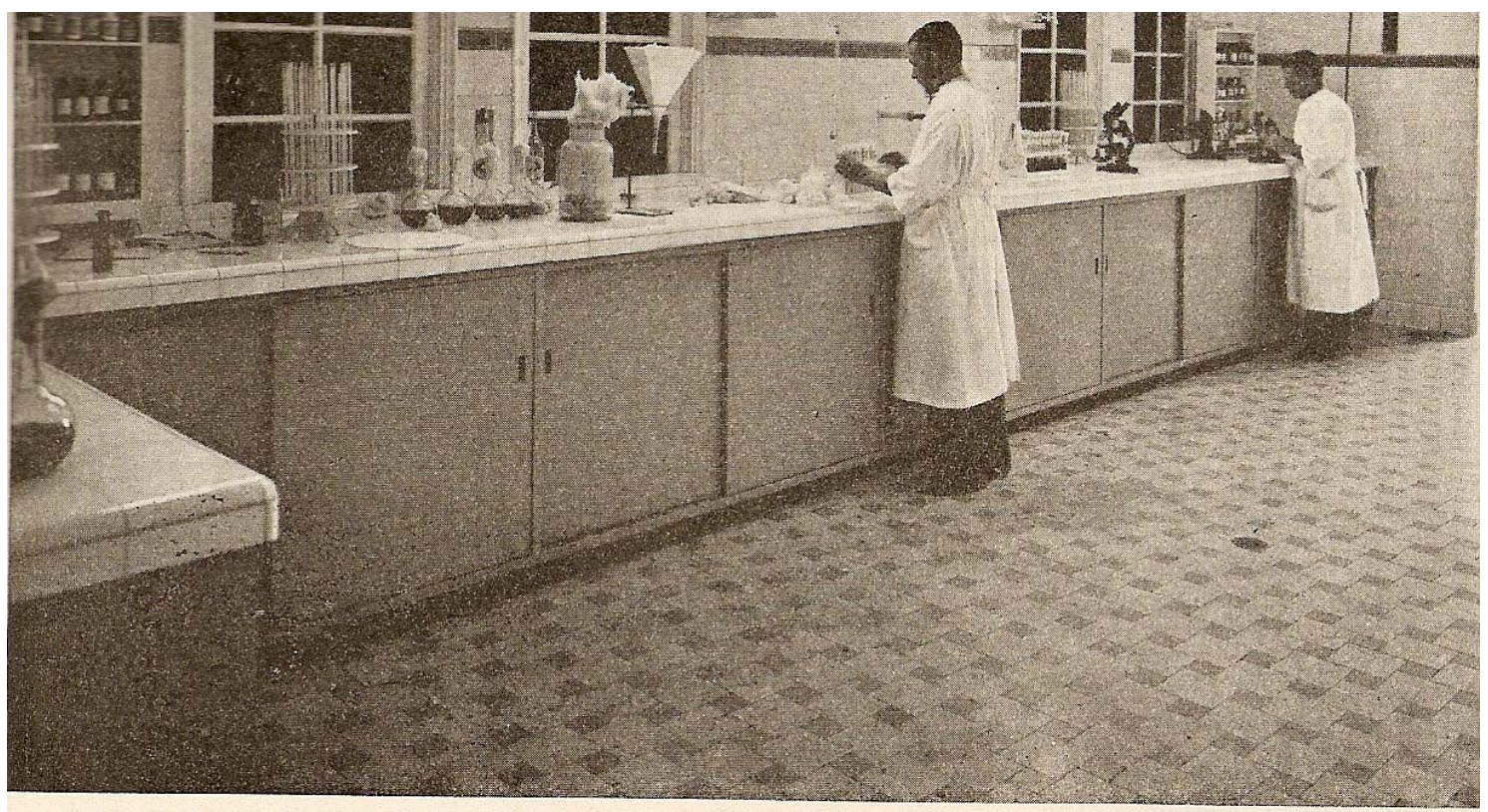

Laboratório de Biologia Clínica e Anatomia Patológica do Hospital Central de Juquerí. Seção de Análises clínicas.

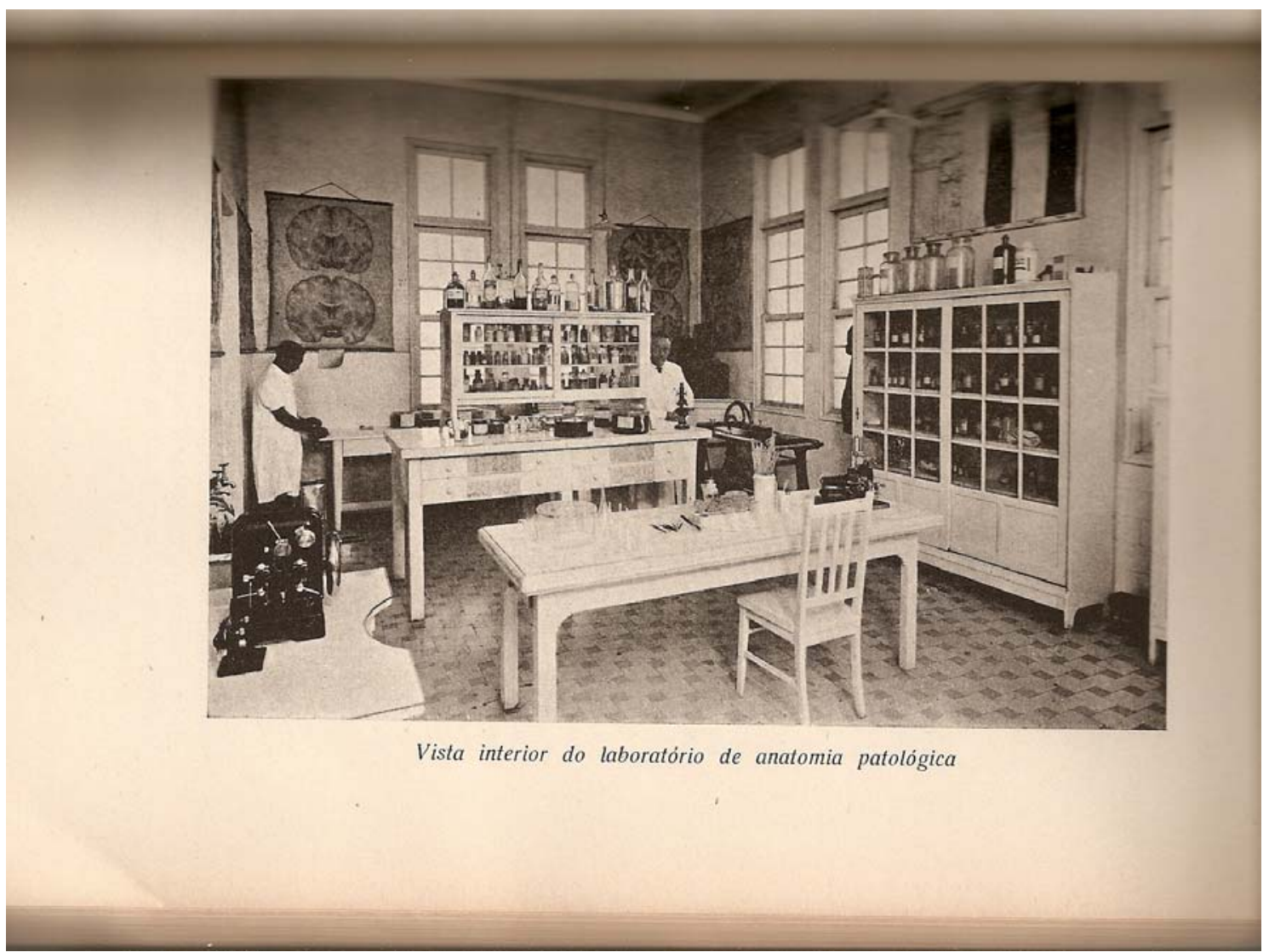



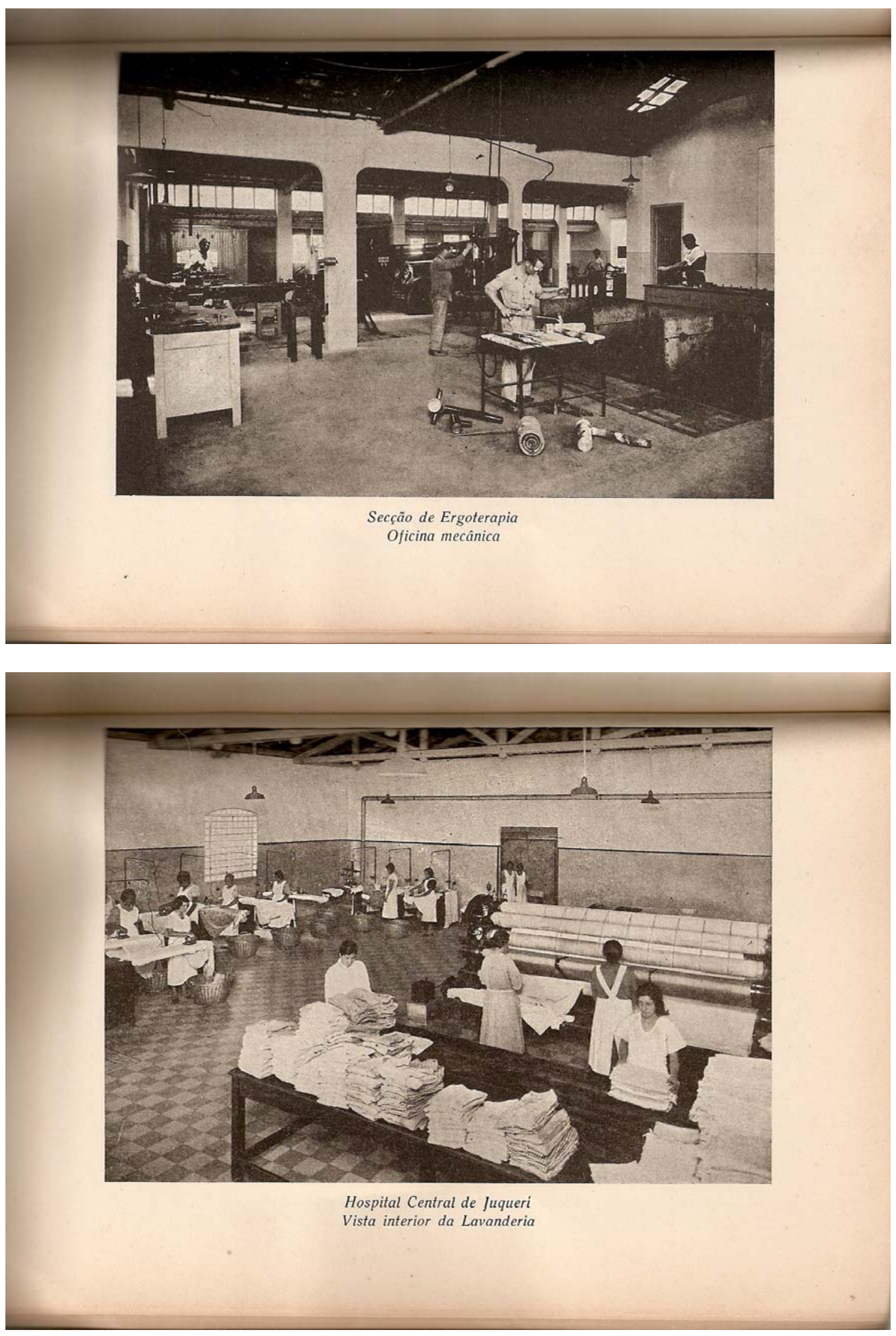


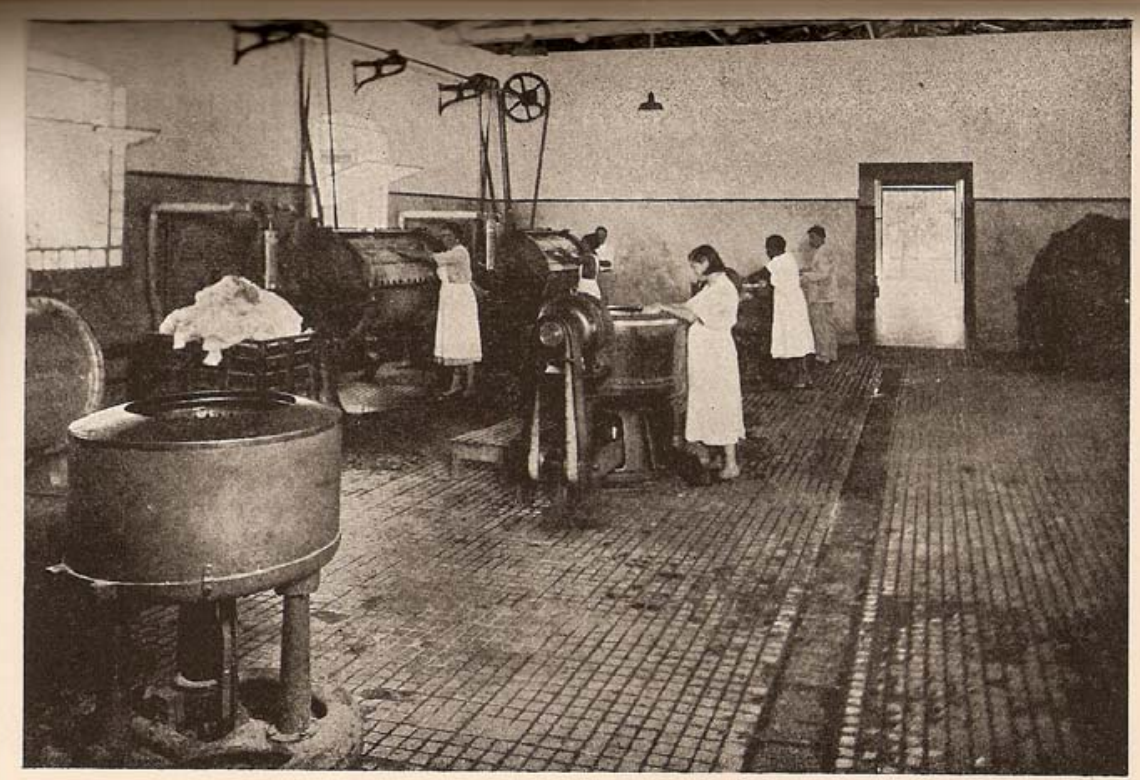

Lavanderia do Hospital Central de Juqueri

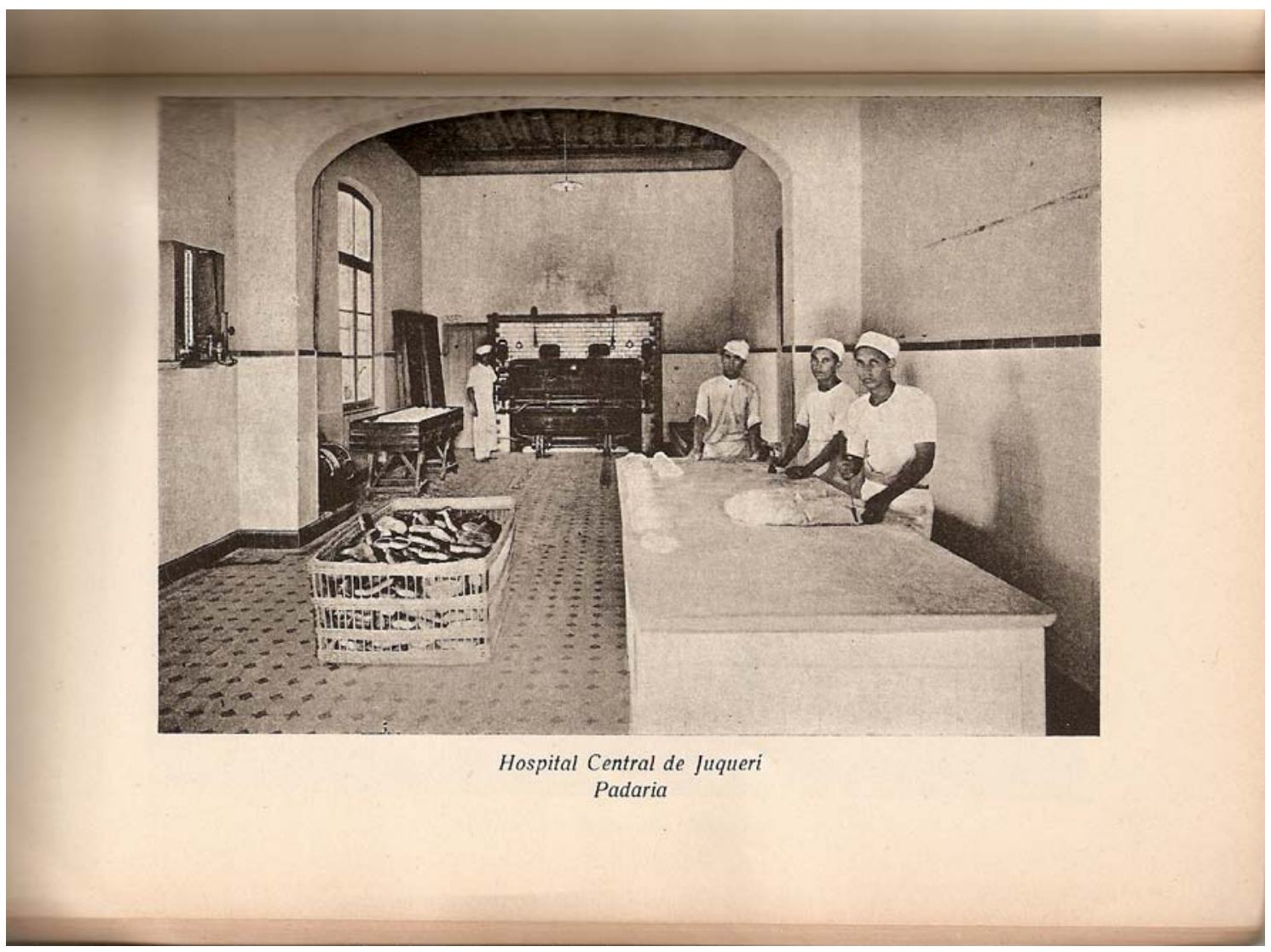



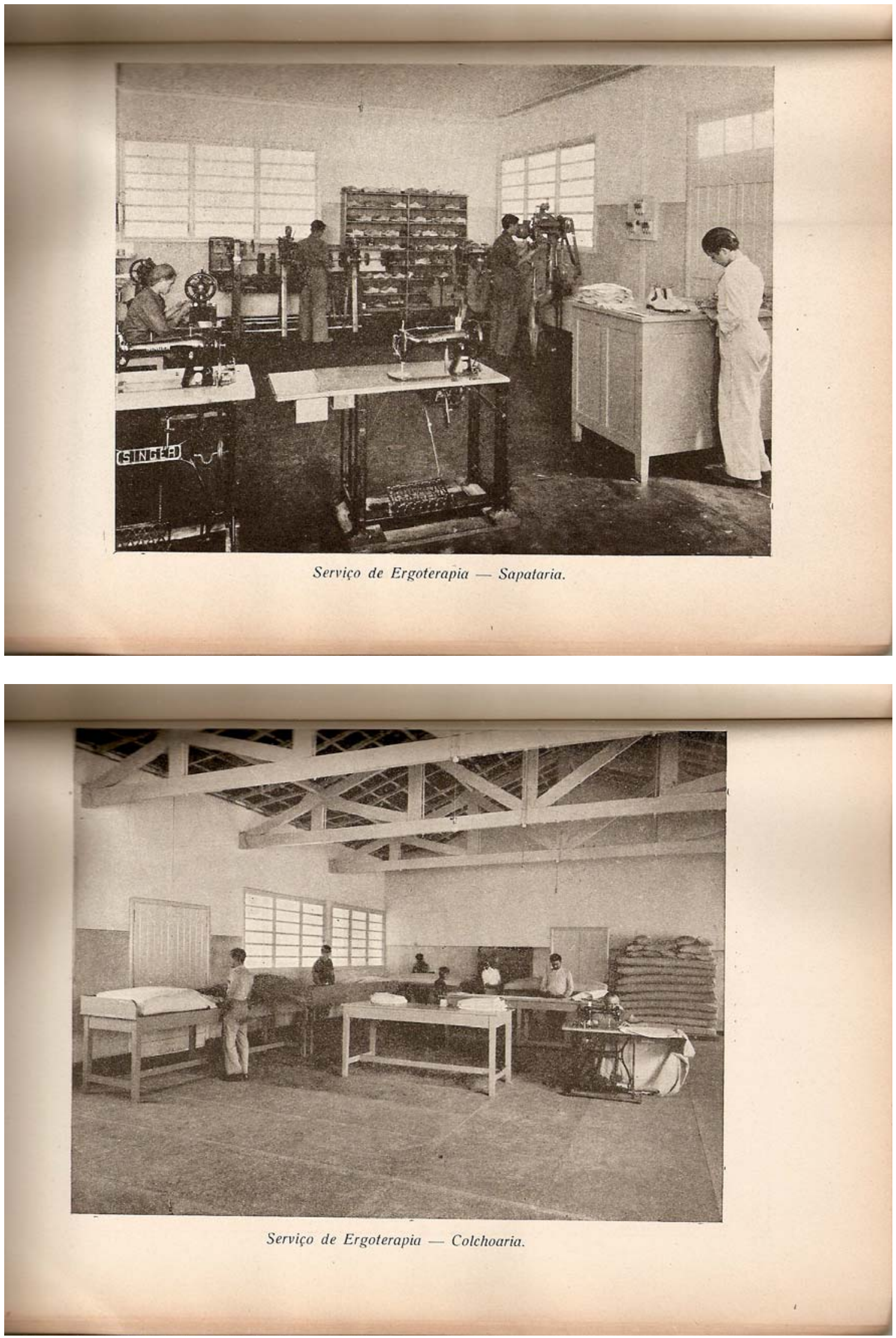


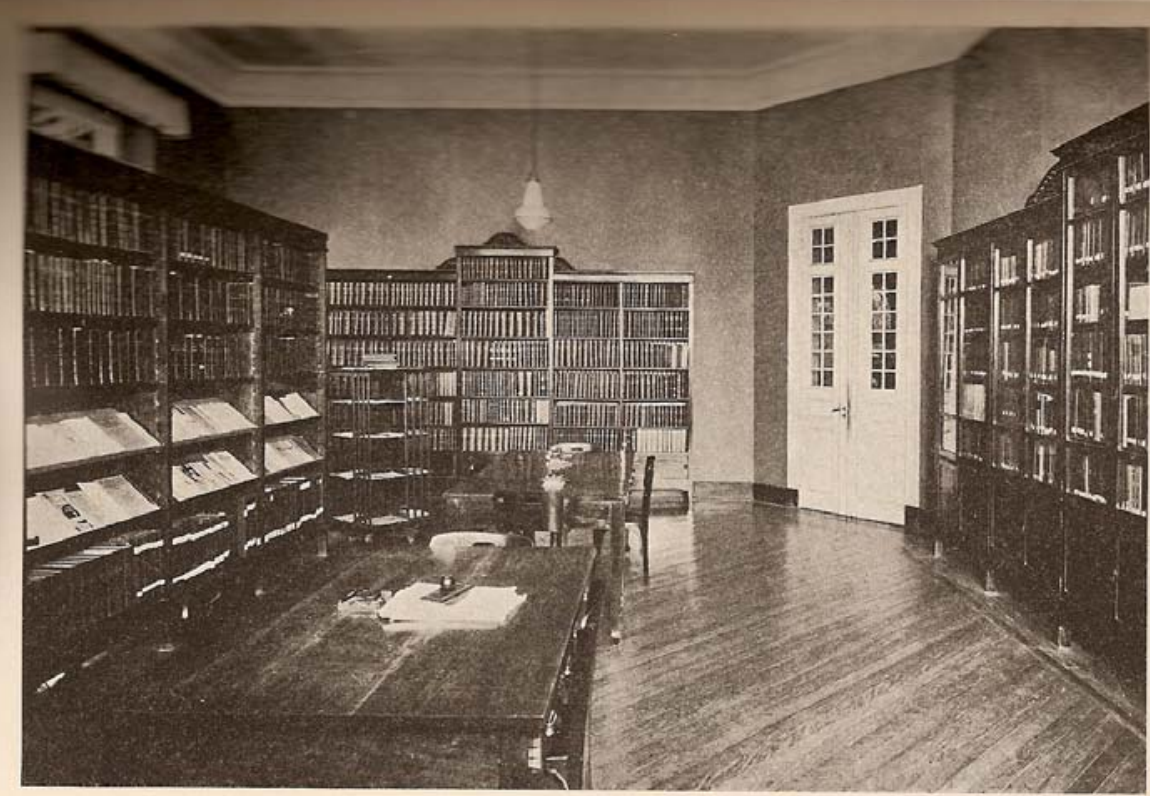

Hospital Central de Iuqueri Biblioteca

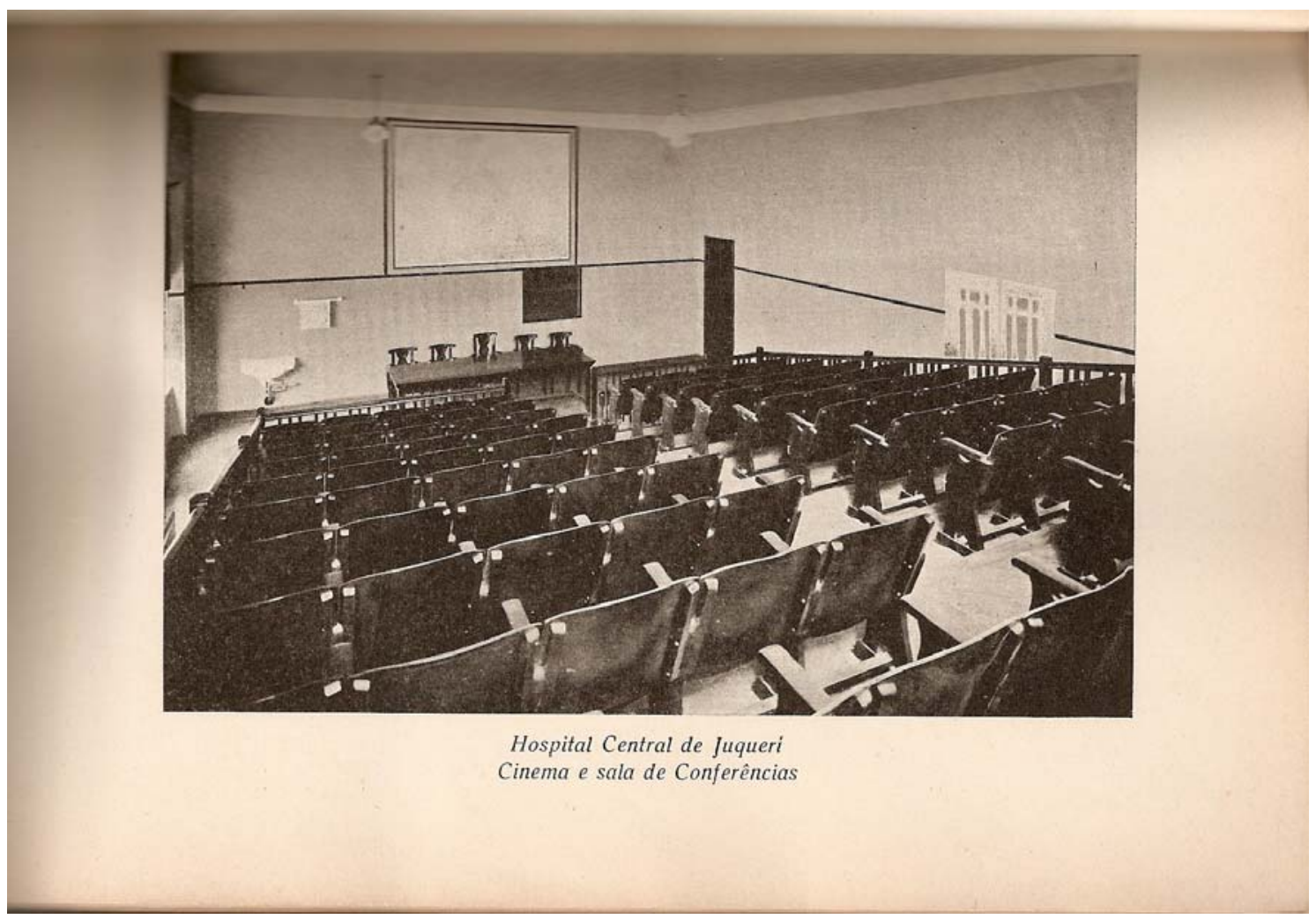




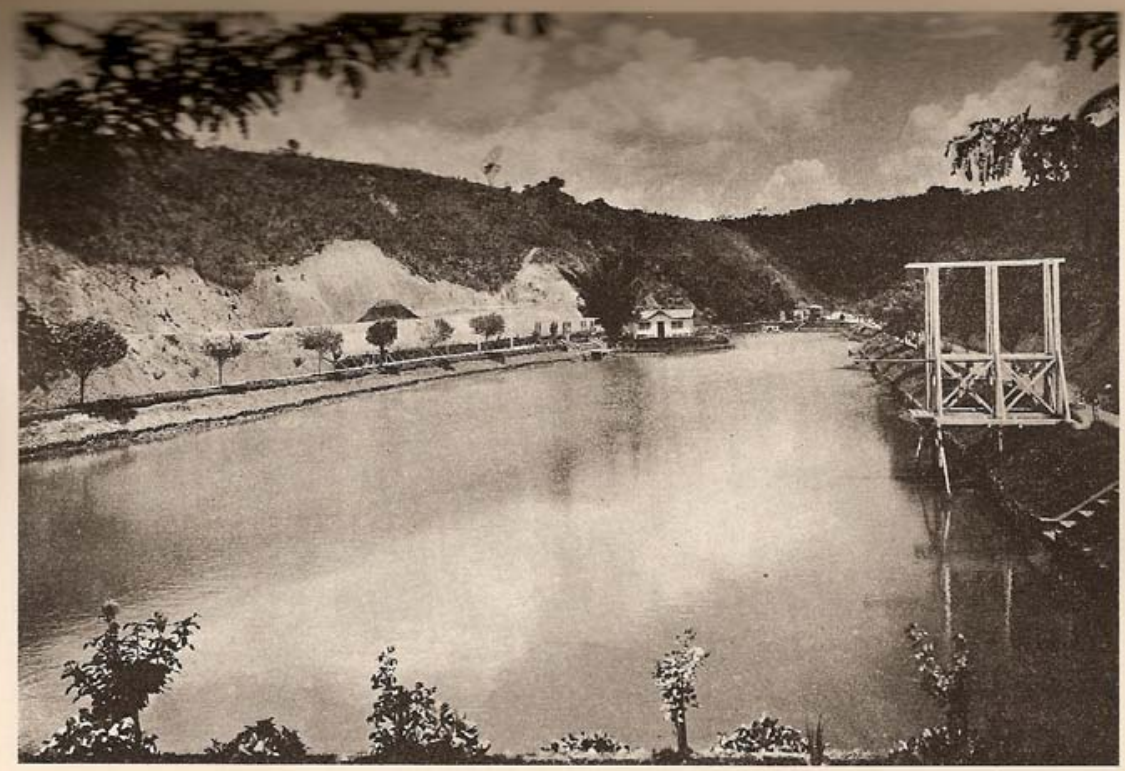

Piscina e esportes

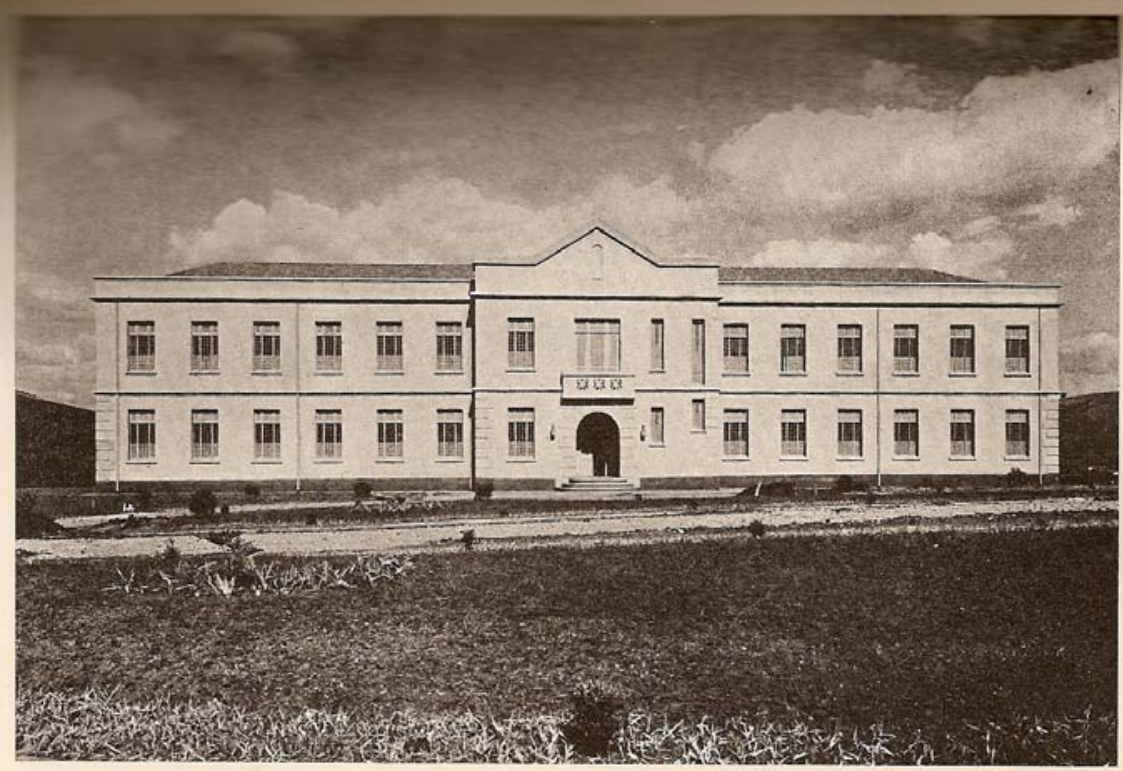

Hospital Central de Juquer

Vista de um dos pavilhôes de recepção 


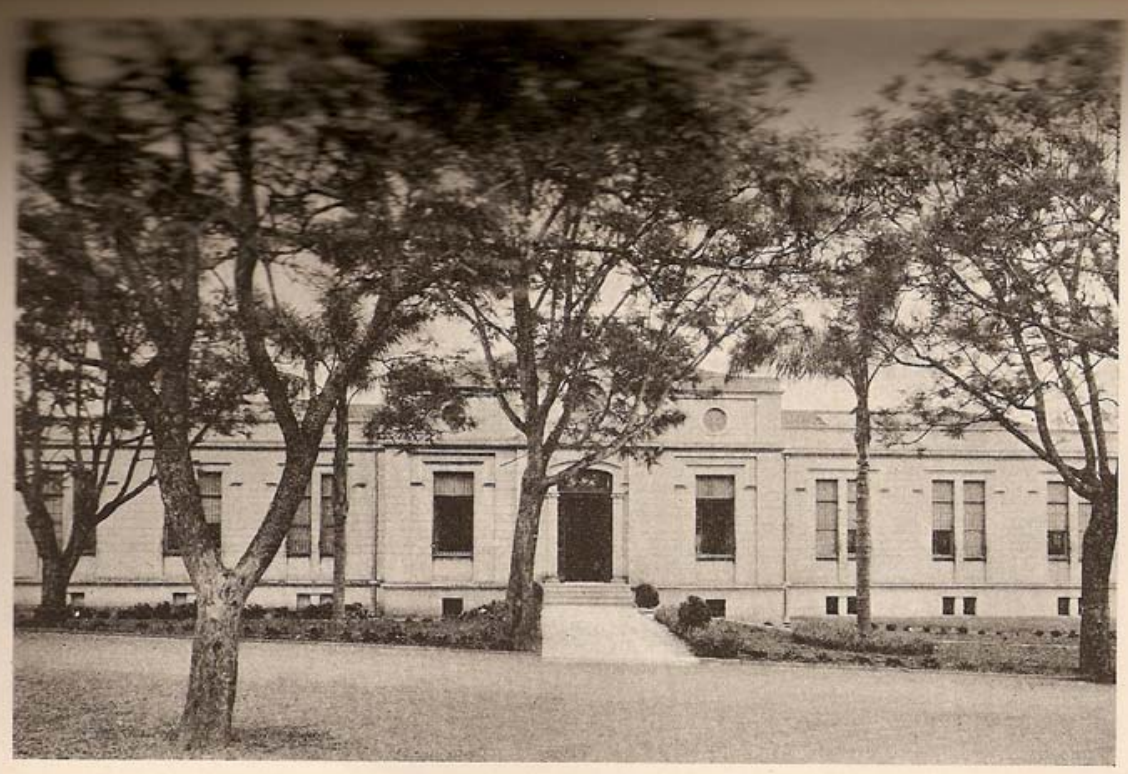

Laboratório de anatomia patológica e biologia clinica

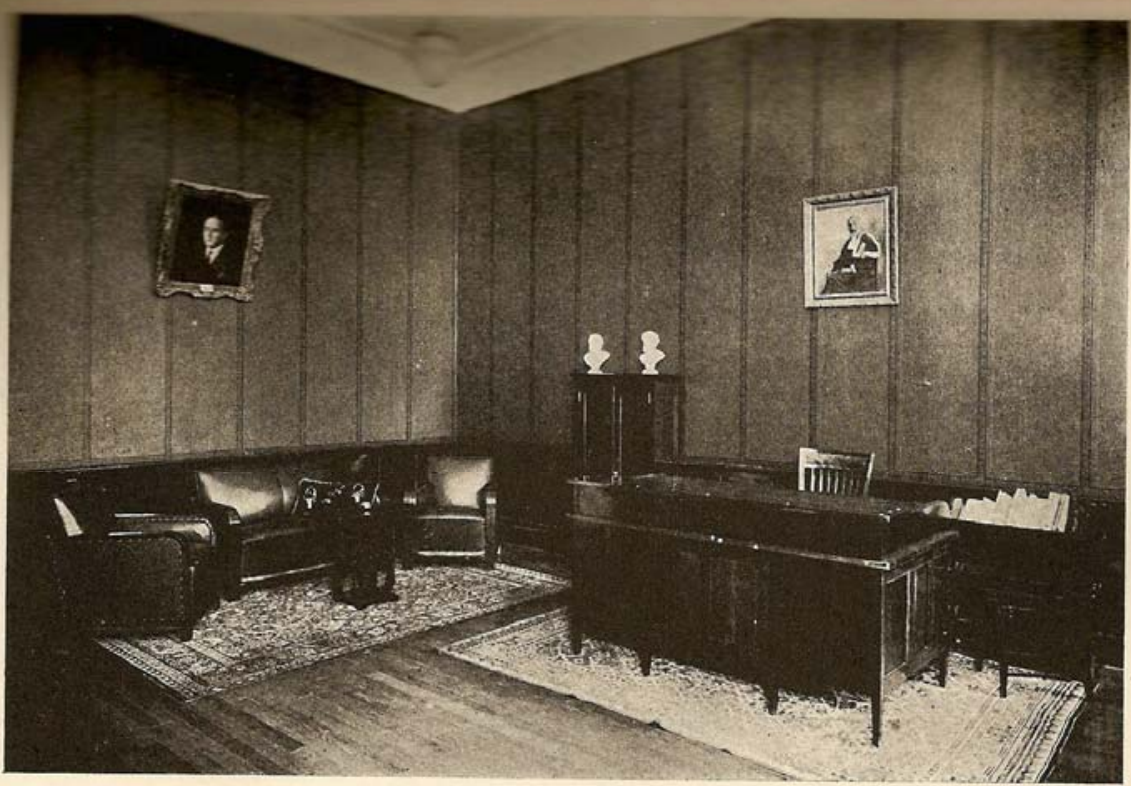

Hospital Central de Juqueri

Sala do Diretor Geral 